UNIVERSIDADE DE BRASÍLIA

FACULDADE DE TECNOLOGIA

DEPARTAMENTO DE ENGENHARIA CIVIL E AMBIENTAL

\title{
PROCESSO ANAMMOX NA REMOÇÃO DE NITROGÊNIO DE ÁGUAS RESIDUÁRIAS - AVALIAÇÃO DE SISTEMAS EM ESCALA DE BANCADA
}

\author{
GENILDA MARIA DE OLIVEIRA
}

ORIENTADORA: ARIUSKA KARLA BARBOSA AMORIM

TESE DE DOUTORADO EM TECNOLOGIA AMBIENTAL E RECURSOS HÍDRICOS

PUBLICAÇÃO: PTARH.TD - 016/2015

BRASÍLIA/DF: NOVEMBRO - 2015 


\title{
UNIVERSIDADE DE BRASÍLIA \\ FACULDADE DE TECNOLOGIA
}

DEPARTAMENTO DE ENGENHARIA CIVIL E AMBIENTAL

\author{
PROCESSO ANAMMOX NA REMOÇÃO DE NITROGÊNIO DE \\ ÁGUAS RESIDUÁRIAS - AVALIAÇÃO DE SISTEMAS EM ESCALA \\ DE BANCADA
}

\section{GENILDA MARIA DE OLIVEIRA}

TESE DOUTORADO SUBMETIDA AO DEPARTAMENTO DE ENGENHARIA CIVIL E AMBIENTAL DA FACULDADE DE TECNOLOGIA DA UNIVERSIDADE DE BRASÍLIA, COMO PARTE DOS REQUISITOS NECESSÁRIOS PARA A OBTENÇÃO DO TÍTULO DE DOUTOR EM TECNOLOGIA AMBIENTAL E RECURSOS HÍDRICOS.

APROVADA POR:

Profa. Ariuska Karla Barbosa Amorim, Doutora (ENC-UnB) (Orientadora)

Profa. Lenora Nunes Ludolf Gomes, Doutora (ENC-UnB)

(Examinadora Interna)

Prof. Marco Antonio Almeida de Souza, PhD (ENC-UnB)

(Examinador Interno)

Profa. Silvana de Queiroz Silva, PhD (ICEB-UFOP)

(Examinadora Externa)

Prof. Marcos von Sperling, PhD (DESA-UFMG)

(Examinador Externo)

BRASÍLIA/DF, NOVEMBRO DE 2015 


\section{FICHA CATALOGRÁFICA}

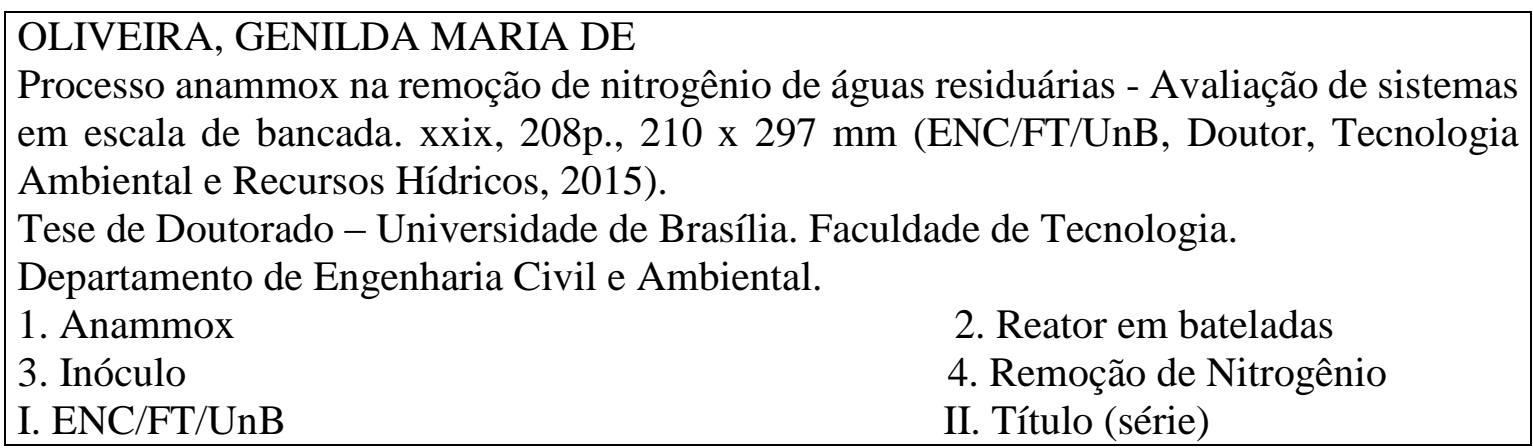

\section{REFERÊNCIA BIBLIOGRÁFICA}

OLIVEIRA, G. M. (2015). Processo anammox na remoção de nitrogênio de águas residuárias - Avaliação de sistemas em escala de bancada. Tese de Doutorado em Tecnologia Ambiental e Recursos Hídricos, Publicação DTARH.TD - 016/2015, Departamento de Engenharia Civil e Ambiental, Universidade de Brasília, Brasília, DF, 207p.

\section{CESSÃO DE DIREITOS}

AUTOR: Genilda Maria de Oliveira.

TÍTULO: Processo anammox na remoção de nitrogênio de águas residuárias - Avaliação de sistemas em escala de bancada.

\section{GRAU: Doutor}

ANO: 2015

É concedida à Universidade de Brasília permissão para reproduzir cópias desta tese de doutorado e para emprestar ou vender tais cópias somente para propósitos acadêmicos e científicos. $\mathrm{O}$ autor reserva outros direitos de publicação e nenhuma parte dessa tese de doutorado pode ser reproduzida sem autorização por escrito do autor.

\section{Genilda Maria de Oliveira}

SQSW 305 Bloco L apto 510, Sudoeste, Brasília, DF genilda@iftm.edu.br ou genilda.oliveira@ifb.edu.br 


\section{DEDICATÓRIA}

Dedico este trabalho de tese a todos os meus familiares e amigos e de uma forma especial ao meu companheiro Miron Rebis Vilarinho Segundo, pelo carinho, compreensão, amor e por tudo que deixamos de viver enquanto a tese estava em execução. 
Tudo tem o seu tempo determinado, e há tempo para todo o propósito debaixo do céu:

Há tempo de nascer, e tempo de morrer; tempo de plantar, e tempo de arrancar o que se plantou;

Tempo de matar, e tempo de curar; tempo de derrubar, e tempo de edificar;

Tempo de chorar, e tempo de rir; tempo de prantear, e tempo de dançar; Tempo de espalhar pedras, e tempo de ajuntar pedras; tempo de abraçar, e tempo de afastar-se de abraçar;

Tempo de buscar, e tempo de perder; tempo de guardar, e tempo de lançar fora;

Tempo de rasgar, e tempo de coser; tempo de estar calado, e tempo de falar;

Tempo de amar, e tempo de odiar; tempo de guerra, e tempo de paz.

Que proveito tem o trabalhador naquilo em que trabalha?

Eclesiastes 3:1-9 


\section{Agora é tempo de agradecer:}

À Deus, base da minha Força e Coragem. "Deus que faz as cruzes faz também os ombros. Ninguém o iguala na arte das proporções” (P. Prin).

À Professora Ariuska, agradeço pela confiança ao aceitar-me como sua primeira orientanda de doutorado e pela oportunidade em permitir-me desenvolver as habilidades em pesquisas e inovações, elaboração de projetos visando financiamentos, nas co-orientações de TCC e ICs. Obrigada pela compreensão nos meus momentos de incertezas.

À Professora Cristina Brandão, minha Conselheira, um exemplo de dedicação e paixão pela Academia e de moral e compromisso com a ciência de qualidade.

Ao Professor Koide, mais do que um Professor, outro exemplo de desprendimento, moral e compromisso. Aprendi muito com nossas conversas sobre a vida, o mundo administrativo da academia, sobre política e, lógico, sobre Engenharia. Obrigada por todo o apoio financeiro.

Aos membros da Banca Examinadora, à Professora Cynthia Kyaw, minha admiração e agradecimento. À Professora Lenora, agradeço pelas discussões e por descomplicar a biologia molecular. Aos Professores Silvana Queiroz, Marcos von Sperling e Marco Antonio Almeida de Souza pelas valiosas contribuições na discussão da tese.

Aos professores do PTARH, Nestor (Compromisso e Responsabilidade), Yovanka (pela amizade e discussões de métodos analíticos), Oscar (Diplomacia), Marco Antônio (pela dedicação e por abrir a sua casa para as festas tão animadas do PTARH), Ricardo Bernardes (Ciência e Filosofia), aprendi muito com cada um de vocês. Ao Carlos, Conceição e Dirceu, ainda que pelos corredores do PTARH, também fizeram parte da minha formação.

Ao amigo Leonardo Damasceno que me incentivou a buscar um Programa de PósGraduação que me faria uma profissional com verdadeira competência técnica.

Aos Órgãos Financiadores, à Coordenação de Aperfeiçoamento de Pessoal de Nível Superior (CAPES) e à Secretaria de Educação Profissional e Tecnológica pela bolsa de doutorado (Programa PIQDTEC - Edital 02/2008). Ao Conselho Nacional de Pesquisa e Desenvolvimento - CNPq (Edital MCT/CNPq No 014/2010 - Universal) e ao Decanato de Pesquisa e Pós-graduação da Universidade de Brasília (Edital DPP 09/2011), pelo apoio 
financeiro.

Ao IFTM, Campus Uberlândia, em nome dos seus Diretores Ruben Carlos Benvenhu Minussi (Gestão 2008-2012) e Ednaldo Coutinho (Gestão 2012-2015) pelo apoio e liberação para Capacitação. A Zilda Correa de Lacerda e Carlos Alberto Alves de Oliveira que foram responsáveis pelos trâmites e acompanhamento do doutorado junto ao IFTM e à CAPES.

À CAESB, representada por Cinthia Mesquita Pinke Cavalcanti e Karina Ferraz Ferro Costa, pela realização das análises de íons em cromatografia iônica.

Ao amigo José Flávio, que dividiu comigo a árdua tarefa da coleta dos lodos nos Frigoríficos São Pedro e Luciana e os “carrapatos". Ficarei devendo você para sempre. Muito obrigada.

Ao pessoal dos Frigoríficos Luciana, São Pedro e Mataboi pela cessão dos inóculos utilizados nos experimentos.

Aos amigos e colaboradores do Laboratório de Análise de Águas do Departamento de Engenharia Civil e Ambiental da UnB, Junior (pelas idas e coletas de chorume no aterro Jockey Clube e pelas soluções no desenvolvimento experimental), Marcilene (não teria conseguido terminar sem a sua ajuda, muito obrigada!), Carla (pelo carinho e ajuda na otimização do espaço e discussão sobre as análises de biologia molecular), ao Dênio e Sara (pela ajuda nas análises de cromatografia iônica), ao Antônio (Boy) e ao James pelo convívio e ajuda no laboratório.

Ao meu irmão Gilson Peixoto de Oliveira que ajudou a projetar e desenvolveu os reatores imprescindíveis para os experimentos. Aos meus pais, Valdemar e Maria do Rosário, que adaptaram suas rotinas para tornar minhas idas e vindas a Brasília mais fáceis. A minha irmã Gislene A. de Oliveira Arantes pela revisão do texto. Ao meu marido, Miron Rebis Vilarinho Segundo, que também ajustou sua rotina para me ajudar no deslocamento em Brasília, pelas inúmeras vezes que me fez companhia no laboratório (LAA) nos finais de semana e feriados, pelo alívio nos afazeres de casa. Às amigas Orlandina e Ana Maria Mota pelo companheirismo e ajuda nas análises de biologia molecular.

Aos amigos que se fizeram no PTARH: Bruna, Elisa, Jackeline, Marcilene, Carla, Olga, Arthur, Eduardo, Larissa, Aline, Lucas, Janícia, Welliton, também não teria conseguido sem vocês, obrigado pelo companheirismo e pelos inúmeros momentos de descontração. Aos amigos de Uberlândia, Marilda, Luciana Pinto, Sérgio, Firmino, Letícia, Deborah, Antônio 
Cesar, Reginaldo, Zilda, Carlos DJ por ajudarem a manter-me firme nos meus ideais de Escola.

À minha família Oliveira \& Vilarinho, sem o apoio, torcida e carinho de vocês não teria forças e razões para lutar. Amo vocês. 


\title{
RESUMO
}

\section{PROCESSO ANAMMOX NA REMOÇÃO DE NITROGÊNIO DE ÁGUAS RESIDUÁRIAS - AVALIAÇÃO DE SISTEMAS EM ESCALA DE BANCADA}

\author{
Autora: Genilda Maria de Oliveira \\ Orientadora: Ariuska Karla Barbosa Amorim \\ Programa de Pós-Graduação em Tecnologia Ambiental e Recursos Hídricos \\ Brasília, 06 de novembro de 2015.
}

O controle e tratamento de águas residuárias são os principais mecanismos para evitar o aporte de nitrogênio aos ecossistemas aquáticos. Esse nutriente em altas concentrações ocasiona problemas ambientais e de saúde pública. O processo anammox, realizado por bactérias anaeróbias que oxidam a amônia usando o nitrito como aceptor final de elétrons, apresenta-se com potencial promissor para a remoção de nitrogênio de águas residuárias, devido à redução dos custos comparado ao processo convencional de tratamento, composto pelas etapas de nitrificação e desnitrificação heterotrófica. No Brasil, deve-se buscar fontes de inóculos e estudar as condições para o estabelecimento do processo anammox para quando esse mecanismo de remoção de nitrogênio tornar-se uma alternativa de tratamento viável tecnicamente. Nesse sentido, foram objetivos desse trabalho fornecer informações sobre fontes de inóculos, enriquecimento de micro-organismos e ativação de biomassa para partida de sistemas em bateladas visando remoção biológica de amônia pelo processo anammox. Foram testadas 6 fontes de inóculos, oriundas de lodos de sistemas tratando efluentes de abatedouros de bovinos e suínos, sedimentos do Lago Paranoá e da lagoa de acumulação de chorume do aterro controlado Jóckey Clube de Brasília DF, em reatores operados por bateladas em escala de bancada, usando água residuária sintética acrescida de concentrações crescentes dos substratos amônia e nitrito. Durante 120 dias, os sistemas foram ajustados para promoção do enriquecimento da biomassa anammox. Posteriormente testaram-se os sistemas para avaliação da atividade anammox. Sugere-se a presença de micro-organismos anammox, verificados por PCR e por sequenciamento dos fragmentos amplificados dos genes para o RNAr 16S, nas biomassas provenientes do sedimento do lago Paranoá, Brasília DF, dos lodos das lagoas anaeróbia e facultativas tratando efluentes de abatedouros. Ocorreu o aumento da concentração de cópias de fragmentos do gene para RNAr 16S, avaliados por PCRq após os 120 dias, indicando o enriquecimento da biomassa 
anammox. As condições estabelecidas para os sistemas biológicos parecem selecionar o mesmo grupo de bactérias anammox, independentemente da origem da biomassa, possivelmente havendo substituição de dominância dos grupos de bactérias anammox inicialmente presentes. Os índices de similaridades, calculados por comparações entre as sequências de nucleotídeos obtidas nesse estudo com aquelas de candidatas espécies anammox depositadas no Genbank utilizando o BLAST, indicam que os micro-organismos presentes nos sistemas testados pertencem à Ordem Brocadiales. Limitação de nitrito pode interferir no sucesso do processo, uma vez que as bactérias anammox têm menor afinidade por esse substrato do que as nitratantes e heterotróficas desnitrificantes. Em todos os sistemas biológicos testados o metabolismo anammox não foi exclusivo, uma vez que não foram atingidos os índices estequiométricos esperados. Nos sistemas biológicos ocorreu a concomitância dos processos metabólicos anammox, nitritação, nitratação e desnitrificação heterotrófica. Os inóculos utilizados e/ou as condições estabelecidas nesse estudo não favoreceram a redução do tempo de partida nos sistemas biológicos, sendo necessários mais de 200 dias de operação para enriquecimento e estabilidade do processo anammox.

\section{Palavras-Chaves: Anammox, fonte de inóculos, culturas em bateladas, tempo de partida, nitrogênio.}




\title{
ABSTRACT
}

\section{ANAMMOX PROCESS IN NITROGEN REMOVAL FROM WASTEWATER - EVALUATION OF SYSTEMS IN BENCH SCALE}

\author{
Author: Genilda Maria de Oliveira \\ Supervisor: Ariuska Karla Barbosa Amorim \\ Graduate Program in Environmental Technology and Water Resources \\ Brazil, Brasilia, November 2015.
}

The control and treatment of wastewater are the main mechanisms to prevent the nitrogen supply to aquatic ecosystems. This nutrient in high concentrations causes environmental and public health problems. The anammox process, carried out by anaerobic bacteria that oxidize ammonia using nitrite as a final electron acceptor, is presented with promising potential for the removal of nitrogen from wastewater, due to its reduced costs compared to the conventional treatment process, which is composed of nitrification and heterotrophic denitrification stages. In Brazil, one must seek sources of inoculum and study the conditions for the establishment of anammox process when this nitrogen removal mechanism becomes a technically viable treatment alternative. In this sense, the objectives of this study were to provide information on sources of inoculum, enrichment of microorganisms and activation of biomass for the startup of batch systems targeting biological removal of ammonia by anammox process. Six sources of inoculum were tested, derived from sludge systems treating wastewater from cattle and pig slaughterhouses, sediments from Paranoa Lake and from the leachate accumulation lake of the controlled landfill Jockey Club of Brasilia DF, in reactors operated by batch in bench scale, using synthetic wastewater together with increasing concentrations of substrates ammonia and nitrite. For 120 days, the systems were adjusted for promoting the enrichment of anammox biomass. Afterwards, the systems for evaluation of anammox activity were tested. It is suggested the presence of anammox microorganisms, checked by PCR and sequencing of the amplified fragments of the genes for 16S rRNA from biomass in the lake Paranoa sediment, Brasilia DF, the sludge of anaerobic and facultative lagoons treating effluent from slaughterhouse. There was an increase in the concentration of copies of gene fragments for 16S rRNA, evaluated by PCRq after 120 days, indicating enrichment of anammox biomass. The conditions developed for the biological systems seem to select the same group of anammox bacteria, regardless of 
their biomass origin, possibly having replacement of the anammox bacteria groups initially present. The levels of similarity, calculated by comparing the nucleotide sequences obtained in this study with those of candidate species anammox deposited in Genbank using the BLAST, indicate that microorganisms present in the tested systems belong to the Order Brocadiales. Limitation of nitrite may interfere with the success of the process, since the anammox bacteria has lower affinity for this substrate than nitrite oxidiziers and heterotrophic denitrifiers. In all the biological systems that were tested, anammox metabolism was not unique, since the expected stoichiometric ratio was not achieved. In the biological systems, there was the concurrence of anammox metabolic processes, nitritation, nitration and heterotrophic denitrification. The inoculum used and / or the conditions established in this study did not favor the reduction of the startup time of biological systems, requiring more than 200 days of operation for enrichment and stability of the anammox process.

Keywords: Anammox, source of inoculum, batch cultures, startup time, nitrogen. 


\section{SUMÁRIO}

RESUMO IX ix

ABSTRACT

SUMÁRIO X Xiii

LISTA DE TABELAS $\quad$ XV

LISTA DE FIGURAS C Xvii

LISTA DE SÍMBOLOS, NOMENCLATURAS E ABREVIAÇÕES $\quad$ xxiii

1. INTRODUÇÃ

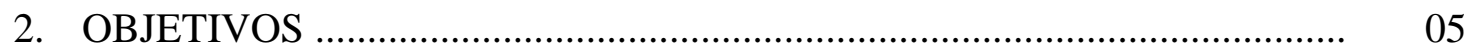

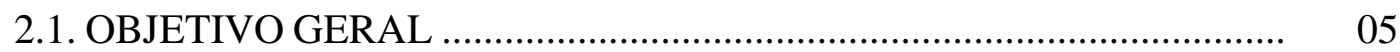

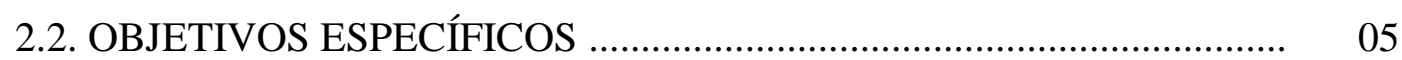

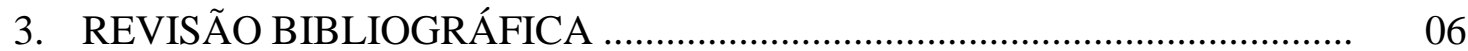

3.1. PROCESSOS BIOLÓGICOS PARA REMOÇÃO DE NITROGÊNIO ... 06

3.2. INÓCULOS PARA PROCESSO ANAMMOX …................................... 16

3.3. MICRO-ORGANISMOS ENVOLVIDOS NA REMOÇÃO DE NITROGÊNIO …...................................................................... 25

3.4. PARÂMETROS DE CONTROLE PARA O PROCESSO ANAMMOX 41

3.5. DETECÇÃO DOS MICRO-ORGANISMOS …..................................... 49

4. MATERIAIS E MÉTODOS …............................................................... 57

4.1. DESCRIÇÃO DOS MATERIAIS ....................................................... 58

4.1.1. Reatores: concepção e desenvolvimento ....................................... $\quad 58$

4.1.2. Água Residuária Sintética e Substratos ........................................... 61

4.1.3. Fonte dos inóculos ......................................................................... 63

4.2. DESENVOLVIMENTO EXPERIMENTAL ….................................... 69

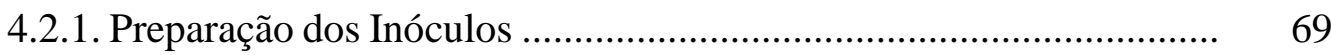

4.2.2. ETAPA 1: Aclimatação e Enriquecimento de Micro-Organismos ... 69

4.2.2.1. Coleta de Biomassa para análises de biologia molecular ....... $\quad 73$

4.2.3. ETAPA 2: Comportamento de Conversão dos Compostos Nitrogenados

73

4.2.3.1. Coleta de Biomassa para análises de biologia molecular ........ 73

4.3. MÉTODOS ANALÍTICOS ............................................................. 76

4.3.1. Preparação e conservação das amostras do licor misto para análises e cromatografia iônica .

4.3.2. Análises dos componentes nitrogenados e de outros íons .............. 77

4.3.3. Análises de biologia molecular para avaliação dos microorganismos

4.3.3.1. Da extração do DNA Genômico ........................................... 78

4.3.3.2. Análises PCR convencional e Sequenciamento ..................... $\quad 79$

4.3.3.3. Análises de PCR quantitativa ................................................ $\quad 82$

4.4. TRATAMENTO DOS DADOS .......................................................... 85

5. RESULTADOS E DISCUSSÃO …….................................................... 93

5.1. CARACTERIZAÇÃO DOS SISTEMAS AMBIENTAIS UTILIZADOS 
5.3. AVALIAÇÃO DA ATIVIDADE DOS MICRO-ORGANISMOS 105 ANAMMOX NAS ETAPAS 1 E 2

5.3.1. Etapa 1 - enriquecimento dos micro-organismos responsáveis pelo processo anammox

5.3.1.1. Comportamento de conversão dos íons nitrogenados ............ 106

5.3.1.2. Variações do $\mathrm{pH}$ do licor dos sistemas biológicos ................. 114

5.3.1.3. Comportamento da biomassa quanto aos íons sulfato e fosfato

5.3.1.4. Caracterização da biomassa nos sistemas biológicos após 120 dias

5.3.1.5. Afiliações filogenéticas por comparações às sequências anammox depositadas no GenBank

5.3.2. Etapa 2 - comportamento de conversão dos compostos nitrogenados

5.3.2.1. Avaliação dos sistemas biológicos operados em duplicatas ...

5.3.2.2. Comportamento de conversão dos íons amônia $\left(\mathrm{NH}_{4}{ }^{+}\right)$, nitrito $\left(\mathrm{NO}_{2}{ }^{-}\right)$e nitrato $\left(\mathrm{NO}_{3}\right)$ pela comparação à relação estequiométrica pelo processo anammox

5.3.2.3 Teste de Kruskal-Wallis comparando as relações estequiométricas anammox obtidas nos sistemas biológicos

5.3.2.4. Variações do $\mathrm{pH}$ do licor misto durante a $2^{\mathrm{a}}$ etapa

5.3.2.5. Análises de biologia molecular da biomassa nos sistemas biológicos após 180 dias (final da $2^{\mathrm{a}}$ etapa)

6. CONCLUSÕES E RECOMENDAÇÕES

REFERÊNCIAS BIBLIOGRÁFICAS

APÊNDICE I

APÊNDICE II

APÊNDICE III

APÊNDICE IV

APÊNDICE V

CD

APÊNDICE VI 


\section{LISTA DE TABELAS}

Tabela 3.1: Custo estimado ( $\mathrm{R} \$ / \mathrm{Kg} \mathrm{N})$ para remoção de nitrogênio amoniacal de águas residuárias por meio de diferentes processos

Tabela 3.2: Inóculos e sistemas usados para enriquecimento e atividade anammox

Tabela 3.3: Situação do sequenciamento de genes codificadores do RNAr 16S de bactérias anammox para inferências filogenéticas

Tabela 3.4: Caracterização de bactérias anammox em sistemas biológicos para remoção de nitrogênio, com base no RNAr $16 \mathrm{~S}$

Tabela 3.5: Condições que promovem a ocorrência dos processos biológicos relacionados ao ciclo do nitrogênio

Tabela 3.6: Primers desenhados com base nos genes para o RNAr 16S utilizados nas técnicas moleculares de amplificação do material genético dos organismos anammox

Tabela 3.7: Razão estequiométrica entre amônia, nitrito e nitrato durante atividade anammox em sistemas biológicos

Tabela 4.1: Soluções de macro e micronutrientes da água residuária sintética utilizada nas etapas experimentais

Tabela 4.2: Soluções com os substratos utilizados nas etapas experimentais

Tabela 4.3: Inóculos usados nos experimentos em bateladas para enriquecimento de organismos anammox

Tabela 4.4: Parâmetros e metodologias usadas para caracterização nas diferentes amostras inoculadas nas culturas em bateladas para enriquecimento anammox

Tabela 4.5: Conjunto de pares de primers utilizados para detecção de microorganismos anaeróbios (anammox) e aeróbios (nitritantes e nitratantes) oxidadores de amônia

Tabela 4.6: Condições de amplificações utilizadas com os pares de primers para detecção de micro-organismos aeróbios (nitritantes) e anaeróbios (anammox) oxidadores de amônia

Tabela 4.7: Primers utilizados e temperatura de anelamento adotados nas análises de PCR quantitativa 
Tabela 4.8: Combinações de comparações realizadas entre as amostras de DNA genômico dos sistemas biológicos por analise de PCR quantitativa

Tabela 5.1: Amostras de lodo utilizadas como inóculos nos experimentos de enriquecimento e atividade anammox

Tabela 5.2: Avaliação das características químicas dos ambientes utilizados como fonte de inóculos nos experimentos para enriquecimento e atividade anammox

Tabela 5.3: Composição dos sólidos nos lodos e sedimentos utilizados nos sistemas biológicos testados

Tabela 5.4: Avaliação do rendimento do DNA genômico extraído da biomassa dos seis inóculos utilizados nos sistemas biológicos para enriquecimento anammox

Tabela 5.5: Resultados das amplificações por PCR das biomassas obtidas a partir do inóculos testados nos sistemas biológicos

Tabela 5.6: Comparação das duplicatas A e B dos sistemas biológicos na conversão dos íons amônia, nitrito e nitrato pelos testes estatísticos: 1) teste $t$ para amostras dependentes para $\mathrm{p}<0,05$ e 2) teste não paramétrico de Wilcoxon de Postos com Sinais para $\mathrm{p}<0,05$

Tabela 5.7: Resultados de amplificações por PCR usando par de primers Pla 46F e Amx 820R, nos diferentes lodos antes e após o período para enriquecimento anammox

Tabela 5.8: Análise dos sistemas biológicos A e B para verificação da igualdade estatística entre duplicata na conversão dos íons nitrogenados

Tabela 5.9: Correlações entre produção de nitrato_N (mM) com a redução concomitante das concentrações de nitrito_N (mM) nos sistemas biológicos, dada pelo valor de $\mathrm{R}^{2}$ calculado

Tabela 5.10: Resultados das amplificações para fragmentos de DNA por PCR para bactérias anammox, nitritantes como Nitrosomonas e nitratantes como Nitrobacter

Tabela 5.11: Ciclos de quantificação obtidos por PCR quantitativa para os sistemas biológicos aos 120 dias relativos às condições de operação da etapa 1 e aos 180 dias relativos às condições de operação da etapa 2, destinadas ao enriquecimento e atividade dos organismos anammox 


\section{LISTA DE FIGURAS}

Figura 3.1: Fluxograma mostrando o processo de nitrificação parcial seguido por desnitrificação

Figura 3.2: Fluxograma mostrando a conversão desejada de amônia por meio do processo SHARON

Figura 3.3: Fluxograma mostrando que no processo CANON em um único reator a amônia pode ser convertida em nitrogênio gasoso e nitrato

Figura 3.4: Fluxograma mostrando que o processo $\mathrm{NO}_{\mathrm{x}}$ é ativado pela presença de pequenas concentrações de óxidos de nitrogênio

Figura 3.5: Fluxograma do sistema patenteado (US007267764B2) para remoção das formas nitrogenadas e carbonáceas de águas residuária

Figura 3.6: A) Grânulos da biomassa com as bactérias aeróbias oxidantes de amônia, as anaeróbias oxidantes de amônia e as desnitrificantes. B) Grânulos com diâmetro médio de 5mm (Wang et al., 2010)

Figura 3.7: Fluxograma mostrando o processo DEAMOX. Adaptado de Bagchi et al. (2012)

Figura 3.8: Fluxograma mostrando o processo BABE. Adaptado de Bagchi et al. (2012)

Figura 3.9: Fluxograma mostrando que numa relação molar aproximada de 1:1 entre amônia e nitrito por meio do processo ANAMMOX é possível a oxidação anaeróbia da amônia

Figura 3.10: Principais estados de oxidação do nitrogênio e processos biológicos possíveis para a oxidação e/ou redução

Figura 3.11: Ciclagem do nitrogênio conduzida por micro-organismos por catabolismo (setas pontilhadas) e anabolismo (setas cheias)

Figura 3.12: Oxidação da amônia e fluxo de elétrons em bactérias oxidadoras de amônia

Figura 3.13: Oxidação de nitrito a nitrato por bactérias nitrificantes

Figura 3.14: Árvore filogenética da Classe Planctomycetia dividida em duas prováveis ordens, baseada na sequência dos genes que codificam o RNAr 16S, Fonte: Jogler et al., 2012

Figura 3.15: A: Micrografia de células em forma de cocos presentes nas 
culturas enriquecidas anammox. B: Micrografia eletrônica de biomassa suspensa de micro-organismos anammox .....

Figura 3.16: Ultraestrutura da bactéria anammox "Candidatus Kuenenia stuttgartiensis"

Figura 3.17: Mecanismos metabólicos possíveis e localização celular do sistema de enzimas envolvido na oxidação anaeróbia de amônia

Figura 3.18: Catabolismo Hipotético e a reversão na cadeia transportadora de elétrons no anamoxossomo, estrutura celular das bactérias anammox

Figura 3.19: Árvore Filogenética de organismos relacionados ao ciclo do nitrogênio baseada em sequências de genes do RNA ribossomal $16 \mathrm{~S}$ (Vlaeminck et al., 2011)

Figura 4.1: Desenho experimental do trabalho

Figura 4.2: A) reator desenvolvido para estabelecimento dos sistemas biológicos B) sistema composto por dois reatores (1: com água para dissolução de gases e 2: biomassa, meio sintético e substratos nitrogenados)

Figura 4.3: A) Localização das válvulas de alimentação e descarte dos reatores; B) Componentes utilizados na produção dos reatores; C) Válvula para escape dos gases produzidos nos sistemas biológicos

Figura 4.4: A) Reator para dissolução dos gases com canículo afogado e mangueira conexão dos sistemas; b) válvula stopflow para manobras de controle durante operação dos sistemas

Figura 4.5: Lagoa anaeróbia tratando efluente de abatedouro de suínos. A) vista da lagoa anaeróbia. B) Aspecto do lodo coletado no fundo da lagoa anaeróbia

Figura 4.6: Lagoa de acumulação de chorume localizada no aterro Jockey Club de Brasília, DF

Figura 4.7: Reatores inoculados com diferentes biomassas acoplados com os vasos para dissolução dos gases e na base agitadora em sala climatizada

Figura 4.8: Operação dos sistemas biológicos em bateladas sequencias na ETAPA 1, destinada à aclimatação e enriquecimento de micro-organismos anammox

Figura 4.9: Sistema composto por duas peças para verificação e quantificação dos gases 
Figura 4.10: Operação dos sistemas biológicos em bateladas sequencias na ETAPA 2, destinada a avaliação das conversões dos compostos nitrogenados

Figura 4.11: Configuração da placa do PCR quantitativo utilizada para cada par de iniciadores (primers) testados

Figura 5.1: Correlação entre o ciclo de quantificação e a concentração de cópias dos genes de interesse quando obtidos os Cq pela análise de PCRq ........ Figura 5.2: Ciclo de quantificação $(\mathrm{Cq})$ obtidos pela análise de PCR quantitativos, testando quatro pares de primers

Figura 5.3. Desempenho dos sistemas biológicos com inóculo proveniente de sedimentos do lago Paranoá, Brasília/DF (Par) na conversão dos compostos nitrogenados durante a etapa 1 visando o enriquecimento de micro-organismos anammox

Figura 5.4: Desempenho dos sistemas biológicos com inóculo proveniente de lodo de lagoa anaeróbia tratando efluente de frigorífico 1, Araguari/MG (AnF1) na conversão dos compostos nitrogenados durante a etapa 1 visando o enriquecimento de micro-organismos anammox

Figura 5.5: Desempenho dos sistemas biológicos com inóculo proveniente de lodo de lagoa facultativa tratando efluente de frigorífico 1, Araguari/MG (FaF1) na conversão dos compostos nitrogenados durante a etapa 1 visando o enriquecimento de micro-organismos anammox

Figura 5.6: Desempenho dos sistemas biológicos com inóculo proveniente de lodo de lagoa facultativa tratando efluente de frigorífico 2, Uberlândia/MG (FaF2) na conversão dos compostos nitrogenados durante a etapa 1 visando o enriquecimento de micro-organismos anammox

Figura 5.7: Desempenho dos sistemas biológicos com inóculo proveniente de lodo reator UASB tratando efluente de frigorífico 2, Uberlândia/MG (UaF2) na conversão dos compostos nitrogenados durante a etapa 1 visando o enriquecimento de micro-organismos anammox

Figura 5.8: Desempenho dos sistemas biológicos com inóculo proveniente da lagoa de acumulação de chorume do aterro controlado Jockey Clube, Brasília, $\mathrm{DF}$ (Cho) na conversão dos compostos nitrogenados durante a etapa 1 visando o enriquecimento de micro-organismos anammox

Figura 5.9: Variação do pH dos sistemas biológicos ao longo das bateladas 
durante a etapa 1 visando o enriquecimento da biomassa anammox

Figura 5.10: Concentrações dos íons sulfato e fosfato nos sistemas biológicos com inóculo proveniente do sedimento do lago Paranoá, Brasília, DF (Par) durante a etapa 1 visando o enriquecimento de micro-organismos anammox ...

Figura 5.11: Concentrações dos íons sulfato e fosfato nos sistemas biológicos com inóculo proveniente do lodo da lagoa anaeróbia tratando efluente do frigorífico 1, Araguari, $\mathrm{MG}(\mathrm{AnF} 1)$ durante a etapa 1 visando o enriquecimento de micro-organismos anammox

Figura 5.12: Concentrações dos íons sulfato e fosfato nos sistemas biológicos com inóculo proveniente do lodo da lagoa facultativa tratando efluente do frigorífico 1, Araguari, $\mathrm{MG}(\mathrm{FaF} 1)$ durante a etapa 1 visando o enriquecimento de micro-organismos anammox

Figura 5.13: Concentrações dos íons sulfato e fosfato nos sistemas biológicos com inóculo proveniente do lodo da lagoa facultativa tratando efluente do frigorífico 2, Uberlândia, $\mathrm{MG}(\mathrm{FaF} 2)$ durante a etapa 1 visando o enriquecimento de micro-organismos anammox

Figura 5.14: Comportamento dos íons sulfato e fosfato nos sistemas biológicos com inóculo proveniente do reator UASB tratando efluente do frigorífico 2, Uberlândia (MG) (UaF2) durante a etapa 1 visando o enriquecimento de micro-organismos anammox

Figura 5.15: Comportamento da biomassa quanto aos íons sulfato e fosfato nos sistemas biológicos com inóculo proveniente da lagoa de acumulação de chorume do aterro controlado Jockey Clube de Brasília, DF durante a etapa 1 visando o enriquecimento de micro-organismos anammox

Figura 5.16: Abundância de cópias dos genes de micro-organismos de interesse, usando quatro pares de primers, para levantamento do número de cópias de DNA de organismos relacionados ao Domínio Bacteria, bactérias anammox, oxidadoras aeróbias de nitrito e amônia, dados em escala logarítmica e empilhados

Figura 5.17: Concentrações de cópias de DNA relacionadas ao RNAr 16S de bactérias anammox nos sistemas biológicos antes e após o período de 120 dias com condições ajustadas para o desenvolvimento de micro-organismos anammox 
Figura 5.18: Dendrograma comparativo da similaridade filogenética das biomassas obtidas a partir dos inóculos e dos sistemas biológicos após 120 dias em condições ajustadas para ocorrência do enriquecimento dos microorganismos anammox

Figura 5.19: Concentrações de cópias de DNA relacionadas ao RNAr 16S de bactérias como Nitrobacter nos sistemas biológicos antes e após o período de 120 dias com condições ajustadas para o desenvolvimento de microorganismos anammox

Figura 5.20: Dendrograma mostrando a afiliação filogenética das sequências obtidas a partir da biomassa dos inóculos e dos sistemas biológicos após 120 dias em condições ajustadas para ocorrência do enriquecimento dos microorganismos anammox com sequências depositadas no GenBank a partir dos códigos para as candidatas a espécies anammox

Figura 5.21: Dendrograma mostrando a afiliação filogenética das sequências obtidas a partir da biomassa dos inóculos e dos sistemas biológicos após 120 dias em condições ajustadas para enriquecimento dos micro-organismos anammox com sequências depositadas no GenBank a com similaridades elevadas dada por comparações usando BLAST

Figura 5.22: Indicadores descritivos para o comportamento de conversão concomitante dos íons nitrito e amônia comparada à relação estequiométrica dada pelo processo anammox, usando-se os dados de 10 bateladas e 5 diferentes intervalos de tempo dentro de cada batelada

Figura 5.23: Indicadores descritivos para o comportamento de formação de nitrato a partir da redução concomitante dos íons nitrito e amônia comparada à relação estequiométrica dada pelo processo anammox, usando-se os dados de 10 bateladas e 5 diferentes intervalos de tempo dentro de cada batelada ....... Figura 5.24: Relação estequiométrica entre a formação de nitrato a partir da redução concomitante dos íons nitrito e amônia comparada à relação estequiométrica dada pelo processo anammox, usando-se os dados de 10 bateladas e 5 diferentes intervalos de tempo dentro de cada batelada Figura 5.25: Relações estequiométrica entre as reduções concomitantes de nitrito e amônia nos intervalos de tempo A) T0_T1 (0 a 24 horas), B) T0_T2 ( 0 a 48 horas) e C) T0_T3 (0 a 72 horas) durante as 10 bateladas conduzidas 
na etapa 2 visando a atividade anammox

Figura 5.26: Relações estequiométrica entre a produção de nitrato com reduções concomitantes de nitrito e amônia nos intervalos de tempo A) T0_T1 (0 a 24 horas $),$ B) T0_T2 (0 a 48 horas $)$ e C) T0_T3 (0 a 72 horas) durante as 10 bateladas conduzidas na etapa 2 visando a atividade anammox

Figura 5.27: Variação do $\mathrm{pH}$ (em valores médios, $\mathrm{n}=10$ ) nos sistemas biológicos ao longo das bateladas de 72 horas durante a $2^{\mathrm{a}}$ etapa experimental Figura 5.28: Valores médios do $\mathrm{pH}$ inicial (0 horas) e final (72 horas) do licor dos sistemas biológicos ao longo das bateladas com duração de 72 horas realizados na $2^{\mathrm{a}}$ etapa experimental

Figura 5.29: Abundância de cópias dos genes de micro-organismos de interesse nos inóculos utilizados nos sistemas biológicos ajustados para permitir o enriquecimento e atividade de bactérias anammox

Figura 5.30: Concentrações de cópias de DNA relacionadas ao RNAr 16S de bactérias anammox nos sistemas biológicos aos 120 dias destinados ao enriquecimento e após o período de 180 dias destinados à atividade de microorganismos anammox 


\section{LISTA DE SÍMBOLOS, NOMENCLATURAS E ABREVIAÇÕES:}

ANAMMOX: Anaerobic Ammonium Oxidation (reação de oxidação da amônia, sob condições anóxicas, tendo o nitrito como aceptor final de elétrons).

BABE: Bio-Augmentation Batch Enhanced

BOA: bactérias aeróbias oxidantes de amônia.

BON: bactérias aeróbias oxidantes de nitrito.

CANON: Completely Autotrophic Nitrogen removal Over Nitrite (Remoção autotrófica de nitrogênio sob nitrito).

Chorume: lixiviado oriundo da decomposição de resíduos sólidos urbanos em aterros sanitários e/ou controlados.

DEAMOX: Denitrifying Ammonia Oxidation (Desnitrificação pela oxidação da amônia)

DGGE: eletroforese em gel por gradiente desnaturante.

dNTP: desoxirribonucleotídeos trifosfatos

E0': é potencial redutor, tendência inerente (medida em volts) de um composto doar elétrons.

E0’ corresponde ao potencial redutor em condições padrões.

FISH: hibridação in situ com sondas fluorescentes.

HPLC: High performance liquid chromatography (Cromatografia líquida de alta eficiência)

$\mathbf{K}_{\mathbf{s}}$ : constante de afinidade pelo substrato

$\mathbf{N}_{2}$ : gás nitrogênio

$\mathbf{N}_{2} \mathbf{H}_{4}$ : hidrazina

$\mathbf{N}_{2} \mathrm{O}$ : óxido nitroso.

$\mathbf{N H}_{2} \mathrm{OH}$ : hidroxilamina

NH3: amônia livre

$\mathbf{N H}_{4}^{+}$: íon amônio

NO: óxido nítrico.

$\mathrm{NO}_{2}^{-}$: nitrito

$\mathrm{NO}^{-}:$nitrato

OD: oxigênio dissolvido

OLAND: Oxigen-Limited Autotrophic Nitrogen Removal (Remoção autotrófica de nitrogênio com limitação de oxigênio).

PCR: reação polimerase em cadeia.

PCRq: reação polimerase em cadeia, quantitativa. 
PRIMER: são sequências iniciadoras no processo de síntese e correspondem a curtas cadeias de nucleotídeos complementares à região inicial (primer forward - direto) e região final (primer reverse - reverso) da sequência alvo do DNA que se deseja amplificar.

RBC: Rotating biological contactors (discos biológicos rotativos).

RBS: Reator em bateladas sequenciais.

SHARON: Single reactor High activity Ammonium Removal Over Nitrite (Reator para alta atividade de remoção de amônia sob nitrito).

SNAD: Simultaneous partial Nitrification, Anammox and Denitrification process (Processo simultâneo de nitrificação parcial, anammox e desnitrificação).

SNAP: Single-stage Nitrogen removal using Anammox and Partial nitritation (Remoção de nitrogênio num único estágio usando anammox e nitritação parcial).

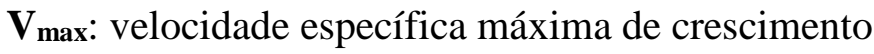

$\Delta \mathbf{G}^{\circ}$ ': corresponde à energia livre em condições padrões.

$16 S$ rDNA: Ácido desoxirribonucleico, ou gene, que codifica o ácido ribonucleico ribossomal 16S encontrado na subunidade menor da região ribossômica 30S dos organismos procariotos.

16S rRNA: Ácido ribonucleico ribossomal 16S componente da subunidade menor da região ribossômica $30 \mathrm{~S}$ dos organismos procariotos. 


\section{1 - INTRODUÇÃO}

O nitrogênio é um nutriente essencial para os seres vivos e deve estar presente nos ecossistemas em concentrações equilibradas com as necessidades biológicas dos organismos e, quando em excesso, nos ambientes aquáticos torna-se um problema ambiental.

O aporte do nitrogênio aos mananciais pode se dar em diferentes formas e estados de oxidação sendo as espécies mais comuns e, portanto, mais importantes devido ao seu potencial poluidor, o nitrogênio orgânico, o nitrogênio amoniacal $\left(\mathrm{NH}_{3} / \mathrm{NH}_{4}{ }^{+}\right)$, o nitrito $\left(\mathrm{NO}_{2}^{-}\right)$e o nitrato $\left(\mathrm{NO}_{3}^{-}\right)$.

A amônia livre $\left(\mathrm{NH}_{3}-\mathrm{N}\right)$ é muito tóxica devido ser permeável pelas membranas celulares de peixes, pequenos vertebrados e invertebrados. A amônia pode ser acumulada nos tecidos desses animais levando a efeitos secundários como alterações do metabolismo, tais como a perda de equilíbrio, hiper-excitabilidade, aumento da atividade respiratória, aumento de batimentos cardíacos, bloqueio das funções vitais, danos ao fígado e rins, etc (Boardman et al., 2004).

O nitrogênio, juntamente com o fósforo, pode estimular o florescimento das algas nos mananciais em que são lançados. Esse superflorescimento promove a eutrofização desses mananciais (Hasler e Swenson, 1967). Também, o nitrogênio na forma amoniacal apresenta demanda por oxigênio durante o processo de nitrificação para as formas oxidadas (nitrito e nitrato), dessa maneira contribui para redução do oxigênio dissolvido das águas (Metcalf e Eddy, 1991; Wang et al., 2010).

Sob o ponto de vista de saúde pública, nitrato e nitrito podem ser responsáveis pelo desencadeamento de várias doenças. O nitrato, íon nitrogenado mais estável, é a principal forma dispersa em águas e consumida pelos humanos. No entanto, somente após o nitrato ser reduzido a nitrito, no interior do corpo humano, é que os problemas de saúde são iniciados. O nitrito na corrente sanguínea está relacionado com a oxidação da hemoglobina saudável $\left(\right.$ com $\mathrm{Fe}^{2+}$ ) para com $\mathrm{Fe}^{3+}$, originando a metahemoglobina. $\mathrm{O} \mathrm{Fe}^{3+}$ não permite o transporte de oxigênio, reduzindo assim, as trocas gasosas no organismo humano (WHO, 2011). O nitrito ainda pode se combinar com aminas secundárias, formando nitrosaminas com poder mutagênico e carcinogênico (Bitton, 2005; WHO, 2011). 
O nitrogênio pode ser inserido nos mananciais por meio de despejos ilegais de águas residuárias não tratadas, ricas com as formas nitrogenadas, por lançamentos de águas residuárias tratadas com concentrações residuais de nitrogênio acima das recomendadas pela legislação (BRASIL, 2011) e, também, por entradas difusas por processos de carreamento superficial nas bacias hidrográficas (Hasler e Swenson, 1967; Porto, 1995).

Como exemplos de águas residuárias com grandes concentrações de nitrogênio pode-se citar os líquidos de fossas sépticas, chorumes de aterros sanitários, efluentes dos processos agroindustriais de frigoríficos, abatedouros e curtumes, efluentes de indústrias alimentícias e de fertilizantes e os efluentes formados a partir de dejetos animais, criados intensivamente, como suínos, bovinos e aves (van Hulle et al., 2010).

A remoção de nitrogênio de águas residuárias é uma maneira efetiva para redução do seu aporte aos mananciais e, geralmente, a remoção é realizada em sistemas de tratamento baseados em processos físico-químicos e biológicos.

Os processos físico-químicos, dependendo das características da água residuária, removem eficientemente os compostos nitrogenados, no entanto, são dispendiosos. Os custos dos processos químicos estão associados aos produtos químicos usados na precipitação, oxidação, adsorção e stripping da amônia (Liang e Liu, 2007). Os processos térmicos necessitam de energia para elevação da temperatura à de evaporação. A utilização de processos de filtração, como a osmose reversa, depende de energia e das membranas que são geralmente caras e rapidamente desgastadas (IRAR, 2008; Liang e Liu, 2008).

A remoção biológica das formas nitrogenadas de águas residuárias é comumente realizada pelo processo convencional de nitrificação autotrófica e desnitrificação heterotrófica. Nos sistemas de lodos ativados, comumente utilizados, tem-se custos associados tais como gasto de energia para promover aeração no sistema, fontes externas de carbono inorgânico para manutenção da alcalinidade e de carbono orgânico para os organismos desnitrificantes heterotróficos.

Torna-se importante buscar e combinar processos biológicos que removam as diferentes formas nitrogenadas presentes nas águas residuárias e que reduzam os custos associados aos processos biológicos convencionais de nitrificação e desnitrificação e aos processos físicoquímicos. 
Dessa forma, o processo biológico, conhecido como anammox, realizado por bactérias capazes de oxidar anaerobicamente a amônia usando o nitrito como aceptor final de elétrons, apresenta-se com potencial promissor para a remoção de nitrogênio de águas residuárias em estações de tratamento, uma vez que não demanda as etapas de aeração e de introdução de fonte de carbono orgânico (Mulder, 1992; Strous et al., 1998; Kuenen, 2008).

Desde a descoberta do processo anammox, no início dos anos 90, que estudos são realizados visando a sua aplicação em estações de tratamento de águas residuárias (Kuenen, 2008). No entanto, ainda que os estudos estejam se consolidando, permanecem desafios básicos para implementação do processo em escala plena. Entre eles, a definição dos limites quanto às concentrações dos substratos e oxigênio, diretrizes para controle e monitoramento do processo e fontes de inóculos para partidas dos sistemas (van der Star et al., 2007; Park et al., 2010; Terada et al., 2011; Kartal et al., 2012; Jenni et al., 2014).

Vale ressaltar que quase todos os projetos de tratamento, em escala plena, envolvendo remoção de nitrogênio de águas residuárias pelo processo anammox encontram-se localizados na Europa e Ásia. Conforme discutido por Sánchez et al. (2014), poucos estudos sobre a aplicação do processo anammox e a habilidade de inóculos em zonas tropicais têm sido desenvolvidos, e é particularmente importante que se mude esta estatística dada a diversidade dessa região. No Brasil, deve-se buscar fontes de inóculos e estudar as condições para o estabelecimento do processo anammox quando esse mecanismo de remoção de nitrogênio tornar-se uma alternativa de tratamento tecnicamente viável.

É, portanto, foco desse trabalho fornecer informações, resultantes de pesquisas experimentais, sobre fontes de inóculos para partida de sistemas anammox, enriquecimento de micro-organismos anammox em culturas em bateladas e ativação de biomassa para partida de sistemas em bateladas visando à remoção biológica de amônia pelo processo anammox.

Além do mais, a aplicação das técnicas de biologia molecular para o conhecimento das comunidades biológicas de reatores tratando águas residuárias tem auxiliado no entendimento dos vários processos biológicos permitindo a varredura de uma diversidade de habitats e o monitoramento dos sistemas ajustados para a atividade anammox (Jetten et al., 2005; Sanz e Kochling, 2006; Bae et al., 2010; Hu et al., 2010; Sánchez et al., 2014). 
Esse trabalho insere-se dentro da linha de pesquisa remoção biológica de nitrogênio de águas residuárias por meio de processos não convencionais articulada ao grupo de Pesquisa Aplicada à Engenharia Ambiental do Departamento de Engenharia Civil e Ambiental, Faculdade de Tecnologia da Universidade de Brasília. Vários aportes financeiros foram aplicados a essa pesquisa, os diretos como os recursos do Edital MCT/CNPq No 014/2010 Universal para aquisição de um reator tipo BioFlo 115, do Edital DPP/UnB 09/2011 para aquisição de reagentes para análises moleculares e os indiretos como dos projetos vinculados Águas - Pro Centro-Oeste/ 2010 financiado pelo Ministério de Ciência e Tecnologia, por meio do FINEP, CNPQ, CAPES e FAPDF (processo 193.000.489/2011 FAP-DF) e do CAPES PRODOC/PNPD 02815/09-5) na aquisição de reagentes e suprimentos para as análises moleculares e iônicas. 


\section{2 - OBJETIVOS}

\section{1 - OBJETIVO GERAL}

Avaliar o desempenho de sistemas biológicos ajustados para enriquecimento e atividade dos micro-organismos responsáveis pelo processo anammox visando compreensão de características que favorecem a partida de reatores e o estabelecimento do processo anammox.

\section{2 - OBJETIVOS ESPECÍFICOS}

* Investigar diferentes fontes de inóculos provenientes de sistemas naturais e/ou de estações de tratamento de águas residuárias, caracterizando-os quimicamente e quanto à presença de bactérias quimiolitoautotróficas, sendo elas as oxidadoras anaeróbias de amônia e as nitrificantes.

× Definir condições físico químicas e operacionais para enriquecimento de biomassa com micro-organismos anammox para partida dos reatores visando à remoção de amônia pelo processo anammox.

× Avaliar alterações na composição das comunidades bacterianas ao longo do período de desenvolvimento e enriquecimento da biomassa por meio de técnicas de biologia molecular.

* Avaliar a utilização e conversão das formas nitrogenadas nos sistemas biológicos para avaliação dos processos metabólicos predominantes.

× Comparar os sistemas biológicos com os diferentes inóculos quanto à predominância do processo anammox para indicação de inóculos para uso em partidas de reatores visando a remoção de nitrogênio pelo processo anammox. 


\section{3 - REVISÃO BIBLIOGRÁFICA}

\section{1 - PROCESSOS BIOLÓGICOS PARA REMOÇÃO DE NITROGÊNIO}

O processo de nitrificação para remoção de nitrogênio de águas residuárias começou a ser utilizado na primeira metade do século 20 , com o objetivo de reduzir a demanda por oxigênio nos rios usados como corpos receptores e eliminar o efeito tóxico da amônia sobre as espécies aquáticas, conforme discutido por Henze et al. (2008). Dessa forma, os filtros biológicos foram os primeiros sistemas de tratamento para remoção de cargas orgânicas e de nitrogênio em cidades dos Estados Unidos, Europa e África do Sul. Posteriormente o processo de desnitrificação heterotrófica, para remoção de nitrito e nitrato, foi favorecido com suplementação dos sistemas com fontes de carbono orgânico pelo uso do metanol (Henze et al., 2008).

Desde então a remoção biológica de nitrogênio por meio de uma etapa de nitrificação aeróbia e outra de desnitrificação anóxica ficou conhecida como processo convencional para remoção de nitrogênio de água residuárias. Atualmente, esse processo é combinado nos mais variados tipos de reatores (Alvarez-Vazques et al., 2004; Ahn, 2006), como em reatores de leito fluidizado (Mulder et al., 1995); gás-lift (Dapena-Mora et al., 2004); bateladas sequenciais (Callado e Foresti, 2000; Ganigué et al., 2007), entre outros (Chen et al., 2009; Kim et al., 2006).

Geralmente, em estações de tratamento de águas residuárias, a primeira etapa para a remoção biológica do nitrogênio é o processo de nitrificação. Esse processo ocorre com a participação de dois grupos de bactérias quimiolitoautotróficas aeróbias, o primeiro grupo de bactérias oxida a amônia e a converte em nitrito e o segundo grupo de bactérias oxida o nitrito e o converte em nitrato (Mulder et al., 1995; Sliekers et al., 2005). Em sequência, o processo de desnitrificação é promovido pelas bactérias heterotróficas que usam o carbono orgânico como fonte de carbono e energia e os óxidos de nitrogênio $\left(\mathrm{NO}_{\mathrm{x}}^{-}\right)$como aceptores de elétrons.

Nos sistemas de tratamento é possível arranjos no posicionamento dos reatores de forma a permitir a ocorrência da pré-desnitrificação seguida da nitrificação. Nesse caso, é necessária a recirculação do efluente do reator de nitrificação para o de desnitrificação (Dapena-Mora 
et al., 2004). Há também a possibilidade dos processos de nitrificação/desnitrificação ocorrer em um único reator, bastando haver alternância de períodos e/ou zonas óxicas e anóxicas (Mulder et al., 1995).

As condições necessárias para que a nitrificação e a desnitrificação ocorram eficientemente são oferta de oxigênio para permitir a nitrificação por bactérias quimiolitoautotróficas aeróbias e fonte de carbono orgânico para as bactérias heterotróficas anaeróbias facultativas responsáveis pelo processo de desnitrificação. É ainda necessário que se garanta a alcalinidade do meio para que a nitrificação ocorra com bom desempenho (Ganigué et al., 2007).

No processo convencional de nitrificação autotrófica e desnitrificação heterotrófica, os gastos com energia para aeração e com fonte externa de carbono são estimados em 2,8 kWh. $\mathrm{N} \mathrm{kg}^{-1}$ e $3 \mathrm{~kg}$ metanol. $\mathrm{N} \mathrm{kg}^{-1}$, respectivamente. Nesse processo tem-se ainda como inconveniente a grande produção de lodo, em torno de $1 \mathrm{SSV} \mathrm{kg.} \mathrm{N} \mathrm{kg}^{-1}$ (Suneethi e Joseph, 2011).

A busca por processos biológicos e/ou arranjos de sistemas de tratamento que reduzam os custos e que apresentem boa eficiência na remoção das cargas nitrogenadas é cada vez mais intensa. Várias das novas propostas tecnológicas de remoção de nitrogênio já se encontram patenteadas (Li et al., 2008; Bagchi et al., 2012). Alguns desses novos processos biológicos e arranjos para remoção de nitrogênio das águas residuárias são discutidos a seguir, de acordo com revisões publicadas por Schmidt et al. (2003), Ahn (2006) e Bagchi et al. (2012).

O processo de nitrificação parcial é a oxidação da amônia até nitrito, inibindo-se a oxidação subsequente do mesmo (Figura 3.1). Há vários mecanismos para inibir a oxidação do nitrito a nitrato. Entre eles tem-se o uso da diferença de energia de ativação para oxidação da amônia e do nitrito $\left(68 \mathrm{~kJ} \mathrm{~mol}^{-1} \mathrm{e} 44 \mathrm{~kJ} \mathrm{~mol}^{-1}\right.$, respectivamente). A maior energia de ativação necessária para a oxidação da amônia torna esse processo mais dependente da temperatura. Em outro mecanismo, opera-se com menor concentração de oxigênio em meio com excesso de amônia. Também, pode-se usar de concentrações inibitórias de amônia livre e óxido nitroso para as bactérias oxidadoras de nitrito (Anthoniesen et al., 1976). Todos esses mecanismos dificultam o crescimento dos organismos oxidadores de nitrito e tendem a favorecer os oxidadores de amônia. 


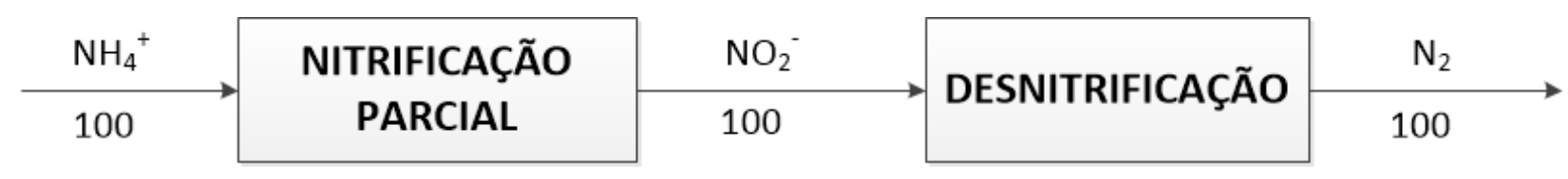

Figura 3.1: Fluxograma mostrando o processo de nitrificação parcial seguido por desnitrificação. Os números representam as concentrações idealizadas das formas nitrogenadas em percentuais.

O sistema SHARON (Single reactor High activity Ammonium Removal Over Nitrite), faz uso da diferença entre as taxas de crescimento dos organismos oxidadores de amônia e nitrito em temperaturas em torno de $35^{\circ} \mathrm{C}$ (Hellinga et al., 1998). Nas informações constantes em registros de patentes para aplicação desse processo, a água residuária deve ser tratada em tanques com agitação contínua sem retenção do lodo e com tempo máximo de detenção hidráulica de 1,5 dias (Dijkman e Strous, 1999). Portanto, os principais parâmetros operacionais são os tempos de detenção hidráulica e de retenção do lodo que devem ser inferiores às taxas de crescimento dos micro-organismos oxidadores de nitrito (Hellinga et al., 1998). Ainda, citam-se o pH do licor entre 7,5 a 8,0, concentrações de oxigênio dissolvido e de substratos como parâmetros importantes (Li et al., 2008; Bagchi et al., 2012)

Em outro registro de patente, com base no processo SHARON, observa-se a razão de 1 entre amônia e bicarbonato para manter a estabilidade do $\mathrm{pH}$ do licor e garantir a oxidação de $50 \%$ da amônia presente na água residuária por nitritação em um reator específico a essa finalidade (van Loosdrescht e Jetten, 1997) (Figura 3.2).

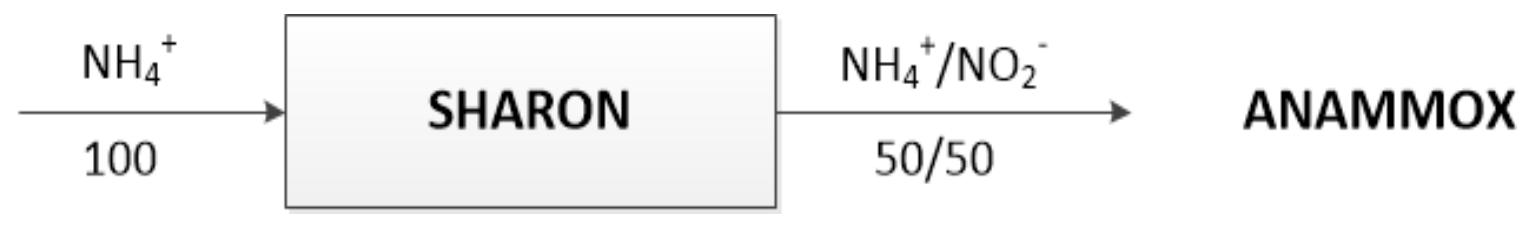

Figura 3.2: Fluxograma mostrando a conversão desejada de amônia por meio do processo SHARON. Os números representam as concentrações idealizadas das formas nitrogenadas em percentuais.

Jetten et al. (1999) sugeriram a combinação dos processos SHARON e ANAMMOX (Anaerobic Oxidation of Ammonium), em reatores separados, para tratamento de águas 
residuárias ricas em amônia. Essa combinação é ideal para remover nitrogênio de efluentes com concentrações altas de amônia (>0,5 gN.L $\left.\mathrm{L}^{-1}\right)$.

Em situações onde há limitação de oxigênio o processo de nitrificação é desfavorecido, podendo ocorrer apenas a conversão parcial da amônia para nitrito devido a inibições da biomassa presente. No entanto, tem-se utilizado da limitação permanente de oxigênio, em determinadas estações de tratamento de águas residuárias para conseguir limitar a conversão do nitrito para nitrato. Buscam-se com isso os processos conhecidos como completa remoção autotrófica de nitrogênio sob nitrito $(\mathrm{CANON})$ e remoção autotrófica de nitrogênio com limitação de oxigênio (OLAND) (Kuai e Verstraete, 1998; Sliekers et al., 2005).

O sistema CANON (Completely Autotrophic Nitrogen removal Over Nitrite) pode ser definido como a combinação do processo de nitritação parcial e do processo anaeróbio de oxidação da amônia (anammox) em um único reator aerado (Figura 3.3). Refere-se também à cooperação entre dois grupos de bactérias: as oxidadoras aeróbias de amônia consomem o oxigênio e criam condições anóxicas para que as bactérias anaeróbias oxidadoras de amônia atuem (Sliekers et al., 2002). Os parâmetros operacionais, oxigênio dissolvido, carga de nitrogênio aplicável, espessura do biofilme e temperatura devem ser bem ajustados (Ahn, 2006; Bagchi et al., 2012). Um arranjo do sistema para combinação desses dois processos biológicos foi patenteado por Dijkman e Strous (1999), ajustando condições para desenvolvimento de grânulos que permite a convivência simbiótica entre bactérias aeróbias e anaeróbias oxidadoras de amônia.

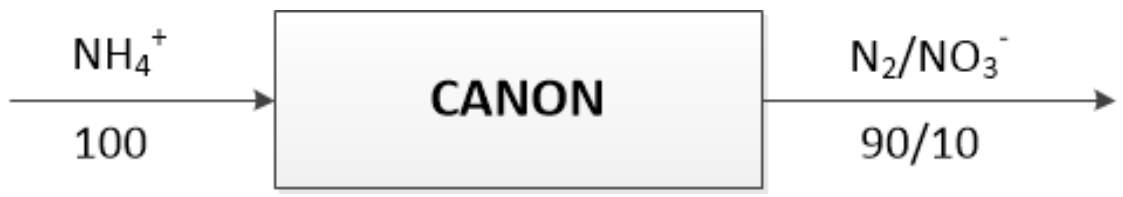

Figura 3.3: Fluxograma mostrando que no processo CANON, em um único reator, a amônia pode ser convertida principalmente em nitrogênio gasoso e nitrato. Os números representam as concentrações idealizadas das formas nitrogenadas em percentuais.

$\mathrm{O}$ processo conhecido como $\mathrm{NO}_{\mathrm{x}}$ ocorre quando se controla e estimula a atividade de desnitrificação por organismos como Nitrosomonas, adicionando-se óxidos de nitrogênio em forma gasosa (Figura 3.4). Nesse processo tem-se demandas menores por oxigênio 
dissolvido (50\%) pois o nitrito é usado como aceptor de elétrons, e por carbono orgânico (80\%), quando comparado ao processo convencional de nitrificação e desnitrificação. A quantidade de $\mathrm{NO}_{\mathrm{x}}$ introduzida é somente em concentrações traços servindo como indutores do processo.

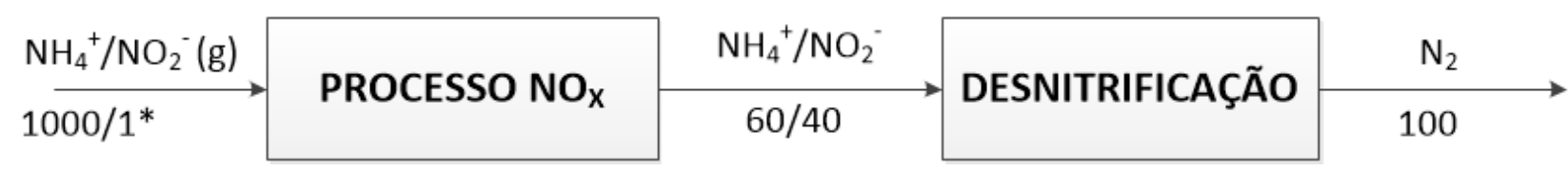

Figura 3.4: Fluxograma mostrando que o processo $\mathrm{NO}_{\mathrm{x}}$ é ativado pela presença de pequenas concentrações de óxidos de nitrogênio. Os números representam as concentrações idealizadas das formas nitrogenadas em percentuais. $(\mathrm{g}=$ gasoso $)$.

O sistema OLAND (Oxigen-Limited Autotrophic Nitrification and Denitrification) é uma variante do sistema CANON e nesse sistema a remoção de amônia pode ocorrer em um ou dois estágios, sem adição de fonte externa de carbono e em concentrações de oxigênio dissolvido inferiores a 0,2 mg OD.L ${ }^{-1}$ (Ahn, 2006). Esse sistema possui semelhanças operacionais com o CANON e $\mathrm{NO}_{\mathrm{x}}$ (Schmidt et al., 2003). Adota-se os discos biológicos rotativos para o desenvolvimento do sistema OLAND em um estágio e os biorreatores de membranas para OLAND em dois estágios. As etapas de nitrificação e desnitrificação são conduzidas principalmente pelas bactérias aeróbias e anaeróbias oxidadoras de amônia (Kuai e Verstraete, 1998; Bagchi et al., 2012). A vantagem desse sistema é manter-se estável em condições de temperatura oscilando entre 22 e $30^{\circ} \mathrm{C}$ ( $\mathrm{Li}$ et al., 2008).

Objetivando a remoção de todas as formas nitrogenadas e da matéria orgânica carbonácea em águas residuárias, desenvolveu-se um sistema utilizando o processo de oxidação anaeróbia da amônia (ANAMMOX) no retorno do efluente para um tanque de desnitrificação, tendo sido patenteado o arranjo de três reatores, onde um distribuidor encaminha uma parte do fluxo para o reator de nitritação e outra parte para o reator de desnitrificação e os fluxos efluentes desses dois reatores são destinados para o reator ANAMMOX com posterior retorno do efluente desse para o reator de desnitrificação (Figura 3.5) (Isaka e Sumino, 2007). 


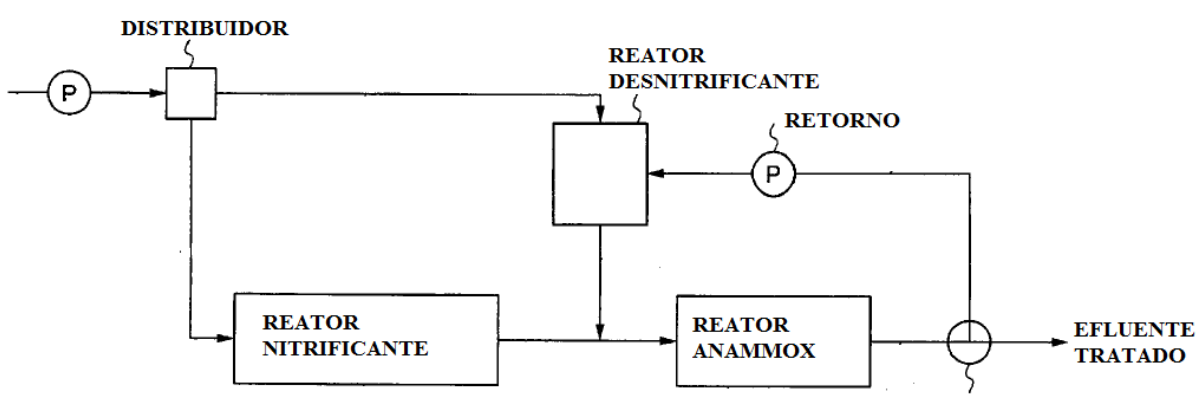

Figura 3.5: Fluxograma do sistema patenteado (US007267764B2) para remoção das formas nitrogenadas e carbonáceas de águas residuária.

Adaptado de Isaka e Sumino (2007)

No entanto, de maneira a otimizar sistemas para redução de custos no tratamento de águas residuárias com altas cargas de nitrogênio, alguns autores sugeriram ainda a simultaneidade de vários processos em um único reator, sistema conhecido como SNAD. Chen et al. (2009) conseguiram boa eficiência de remoção de nitrogênio e carbono orgânico operando discos biológicos rotativos (RBC) em escala experimental.

O sistema SNAD (Simultaneous partial Nitrification, Anaerobic Ammonium oxidation and Desnitrification) é conduzido pela coexistência de bactérias nitrificantes, anammox e bactérias desnitrificantes heterotróficas em um mesmo reator. As grandes vantagens desse sistema são remoção de todas as formas de nitrogênio presentes numa água residuária e também reduzir o carbono orgânico necessário à desnitrificação clássica (Wang et al., 2010; Lan et al., 2011). Os grânulos que se desenvolvem em sistemas SNAD apresentam-se com diâmetro de $5 \mathrm{~mm}$ e coloração vermelha, indicativa da atividade anammox (Figura 3.6).
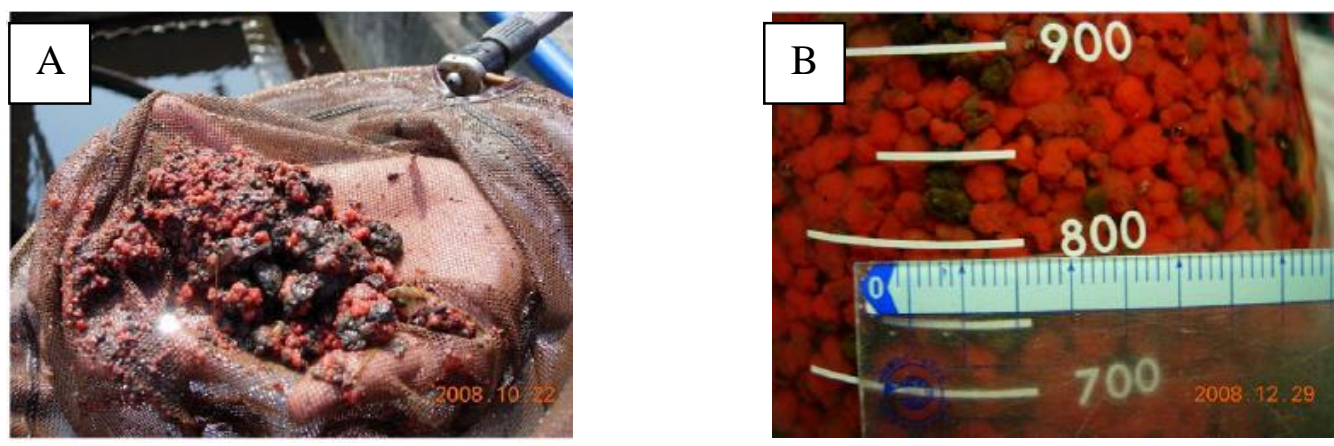

Figura 3.6: A) Grânulos da biomassa com as bactérias aeróbias oxidantes de amônia, as anaeróbias oxidantes de amônia e as desnitrificantes. B) Grânulos com diâmetro médio de $5 \mathrm{~mm}$ (Wang et al., 2010). 
Ocorrem, ainda, duas variantes de processos para remoção de nitrogênio combinando-se a nitritação, a oxidação anaeróbia da amônia e/ou desnitrificação autotrófica, sendo eles o DEAMOX (DEnitrifying AMmonium OXidation) e BABE (Bio-Augmentation Batch Enhanced) (Bagchi et al., 2012). No DEAMOX não é requerida a etapa da nitritação parcial, pois é introduzida a redução do nitrato $\left(\mathrm{NO}_{3}{ }^{-}\right)$a nitrito usando o sulfeto como doador de elétrons conforme equação 3.1. Esse processo é recomendado para o tratamento de águas residuárias com concentrações de nitrogênio e de sulfetos, como exemplo os efluentes dos processos industriais de produção de fermentos (Kalyuzhnyi e Gladchenko, 2009). Esse processo tecnológico é proposto num arranjo de três reatores (Figura 3.7).

$$
\mathrm{NO}_{3}^{-}+0,25 \mathrm{HS}^{-} \rightarrow \mathrm{NO}_{2}^{-}+0,25 \mathrm{SO}_{4}^{-}+0,25 \mathrm{H}^{+}
$$

(Equação 3.1)

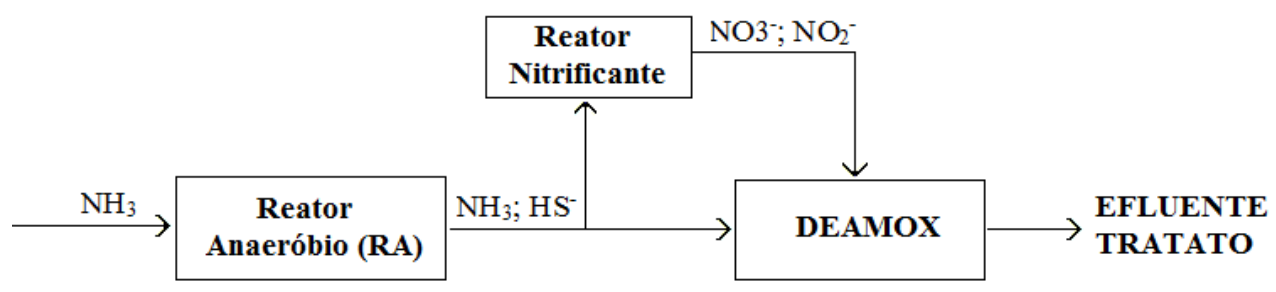

Figura 3.7: Fluxograma mostrando o processo DEAMOX. Adaptado de Bagchi et al. (2012).

No arranjo tecnológico proposto, um afluente rico em amônia $\left(\mathrm{NH}_{4}\right)$ e enxofre (S orgânico) é usado para alimentar um reator anaeróbio que, após o tempo necessário de detenção hidráulica, converte o enxofre orgânico em sulfetos. O efluente do reator anaeróbio é dividido para duas linhas que alimentam cada qual um reator nitrificante convencional responsável pela conversão da amônia em nitrito e nitrato e o reator DEAMOX. Nesse último reator, que também recebe o efluente do reator nitrificante, tem-se a combinação dos substratos necessários $\left(\mathrm{NH}_{4}{ }^{+}\right.$e $\left.\mathrm{NO}_{2}^{-}\right)$à reação anammox (Kalyuzhnyi e Gladchenko, 2009).

O processo BABE baseia-se na utilização de um reator, na linha de recirculação do lodo, no qual se promove o desenvolvimento dos micro-organismos nitritantes (bio-amplificação) e concomitantemente a acumulação de nitrito que retorna para o reator anaeróbio e garante a razão estequiométrica necessária para o processo de oxidação anaeróbia da amônia (Figura $3.8)$. 


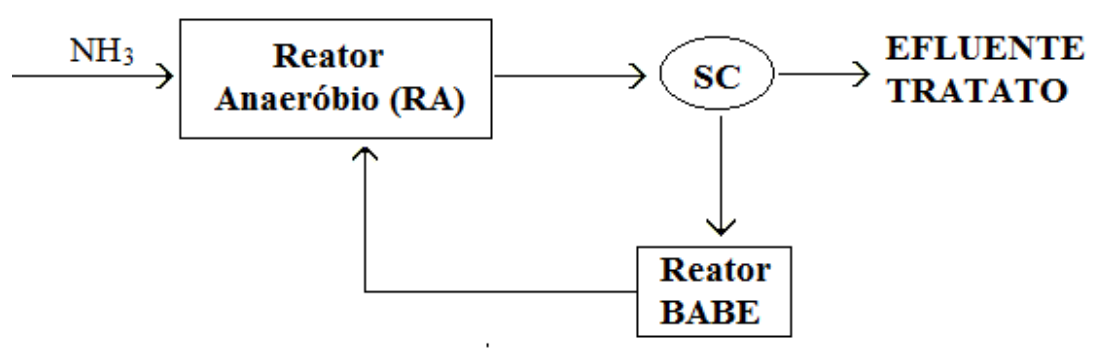

Figura 3.8: Fluxograma mostrando o processo BABE. Adaptado de Bagchi et al. (2012).

Como apresentado anteriormente, vários sistemas como SHARON, CANON, OLAND, SNAD, DEAMOX e BABE são projetados para permitir o desenvolvimento de um grupo de micro-organismos capazes de oxidar a amônia tendo o nitrito como aceptor de elétrons.

Portanto, no processo ANAMMOX (Anaerobic Oxidation of Ammonium), ocorre a oxidação da amônia para gás nitrogênio usando o nitrito como aceptor de elétrons (Figura 3.9). Para cada mol de amônia a ser convertida é necessário 1,32 mol de nitrito (Strous et al., 1998) e, por isso, as concentrações de amônia e nitrito no afluente devem ter relação de 1:1 (Ahn, 2006). Essa rota metabólica havia sido considerada termodinamicamente possível por Broda em 1977. No entanto, a primeira descrição da ocorrência da oxidação anaeróbia da amônia em sistemas de tratamento de águas residuárias foi realizada por Mulder et al. (1995).

Os micro-organismos responsáveis por esse processo metabólico pertencem ao grupo dos Planctomycetes (Strous et al., 1998; Strous et al., 1999). Com essa descoberta obteve-se uma melhor compreensão do ciclo do nitrogênio (Vlaeminck et al., 2011), apresentando mais um mecanismo da oxidação da amônia e consequente remoção de nitrogênio de águas residuárias.

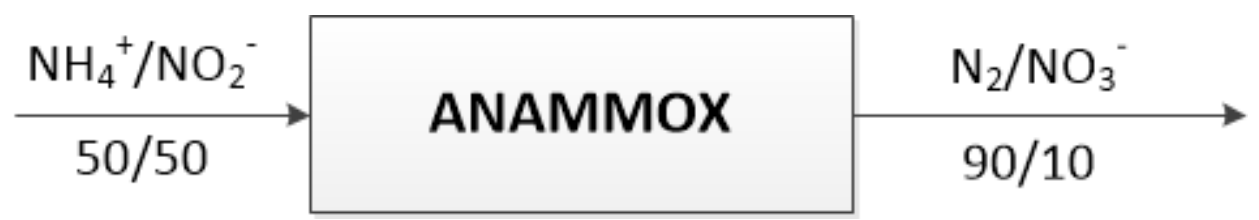

Figura 3.9: Fluxograma mostrando que numa relação molar aproximada de 1:1 entre amônia e nitrito por meio do processo ANAMMOX é possível a oxidação anaeróbia da amônia. Os números representam as concentrações idealizadas das formas nitrogenadas em percentuais. 
Vislumbrando a utilização da rota metabólica anammox no tratamento de águas residuárias, foi patenteada a aplicação do processo de desnitrificação autotrófica combinada com o íon amônio, tendo-se como vantagens a redução do oxigênio e carbono orgânico aplicados no sistema (Mulder, 1992).

No primeiro registro de patente utilizando-se o processo ANAMMOX para remoção de amônia de águas residuárias julgava-se que o íon oxidante fosse preferencialmente o nitrato (Mulder, 1992). Posteriormente, ficou comprovado que o processo anammox ocorria preferencialmente com o nitrito como aceptor de elétrons (Strous et al., 1998).

A principal limitação para utilização efetiva do processo ANAMMOX em sistemas de tratamento para remoção de nitrogênio é o tempo requerido para a partida dos reatores, ainda que todas as condições estejam ajustadas ao desenvolvimento dos micro-organismos responsáveis pelo processo. Esse tempo de partida está associado às taxas lentas de crescimento das bactérias anammox (Strous et al., 1998) e, por isso, exigindo sistemas com eficiente retenção celular (Schmid et al., 2005). As configurações de reatores como os de lodos ativados (Mulder, 1992), leito fixo (Mulder, 1992; Strous et al., 1997), leito fluidizado (Mulder, 1992; van de Graaf et al., 1996), bateladas sequenciais (Strous et al., 1998; DapenaMora et al., 2004; Ganigué et al., 2007; Kartal et al., 2011), reatores de gás-lift (DapenaMora et al., 2004), discos rotativos (van de Graaf et al., 1996; Egli et al., 2003; Windey et $a l ., 2005)$ foram utilizados com sucesso para desenvolvimento dos micro-organismos anammox.

Os desafios para aplicação desse processo em sistemas plenos são justamente a estratégia de partida de reatores visando reduzir o tempo de emergência da atividade e a estabilização da eficiência do processo anammox (Terada et al., 2011). A eficiência na remoção de nitrogênio pelo processo anammox depende do enriquecimento das bactérias, as quais requerem um período entre 180 a 280 dias nos reatores para representarem entre 70 a $80 \%$ da comunidade microbiana (Kartal et al., 2012).

Vale ressaltar que quase todos os projetos de tratamento, em escala plena, envolvendo remoção de nitrogênio de águas residuárias pelo processo anammox encontram-se localizados na Europa, Ásia e, recentemente nos Estados Unidos (Munõz et al., 2007; Bagchi et al., 2012; Lackner et al., 2014). No Brasil, devem-se buscar fontes de inóculos a serem adotados para quando esse processo se tornar uma alternativa de tratamento tecnicamente viável. Além do mais, as temperaturas mesófilas, ocorrentes durante quase todo o ano no 
Brasil, favorecem a aplicação dessa tecnologia em escala plena (Aiyuk et al., 2006; Sánchez et al., 2014).

Os trabalhos já realizados no Brasil testaram inóculos para partidas de reatores anammox oriundos de lagoa de estabilização tratando efluente de abatedouro de frangos e suínos (Reginatto et al., 2005), de sistemas de lodos ativados tratando esgotos domésticos (Reginatto et al., 2005; Araújo et al., 2010), de sistemas de tratamento de dejetos suínos (Kunz, 2007; Schierholt Neto, 2007), de reatores nitrificantes/desnitrificantes tratando efluentes de indústria produtora de aminoácidos e UASB tratando efluente de abatedouro de aves (Martins, 2007), de lagoas de polimento, wetlands plantados e não plantados e de reator UASB tratando esgotos domésticos (Costa, 2013a), de diversas partes do sistema de tratamento de efluentes de refinaria de petróleo, composto por lagoas aeradas, discos rotativos e lagoa de estabilização (Costa, 2013a). Em todos esses estudos, somente após 200 dias de operação dos reatores, é que foram atingidas eficiências significativas de remoção de nitrogênio pelo processo anammox, mas em sistemas operados com baixas cargas de nitrogênio aplicadas.

A partir desses estudos, confirma-se a ubiquidade dos micro-organismos anammox (Kartal et al., 2012; Bagchi et al., 2012), no entanto, o tempo gasto requerido para efetivação do processo anammox demonstra a necessidade de continuar a busca por inóculos e condições que acelerem a partidas dos sistemas visando a remoção anaeróbia das formas nitrogenadas.

Existem vantagens econômicas e ambientais significativas para adoção do processo anammox como forma de tratamento de águas residuárias para remoção de nitrogênio, sendo elas: redução de $90 \%$ dos custos operacionais devido à redução da aeração e aporte de carbono orgânico nos sistemas e menor área requerida para instalação de reatores anammox (Vives et al., 2007; Gao et al., 2011). Tem-se, ainda, menor produção de lodos devido à baixa velocidade de duplicação das bactérias anammox (Kim et al., 2006; Jetten et al., 2009; Wang et al., 2010). Além do mais, a vantagem ambiental da diminuição, em média, de $90 \%$ das emissões de gases relacionados ao efeito estufa, pois, o processo não emite $\mathrm{N}_{2} \mathrm{O}$ e ainda consome o $\mathrm{CO}_{2}$ (Abma et al., 2010; Kartal et al., 2012).

No estudo de Munoz et al. (2007) é apresentada a estimativa de custo para remoção do nitrogênio amoniacal de águas residuárias por diferentes sistemas (Tabela 3.1). 
Tabela 3.1: Custo estimado $(\mathrm{R} \$ / \mathrm{kg} \mathrm{N})$ para remoção de nitrogênio amoniacal de águas residuárias por meio de diferentes processos.

\begin{tabular}{lc}
\hline \hline \multicolumn{1}{c}{ Processo } & $\begin{array}{c}\text { Custo estimado } \\
(\mathbf{R} \$ \mathbf{~ / ~ k g ~ N )}\end{array}$ \\
\hline Sharon $^{1}$ & $5,27^{3}$ \\
Anammox $^{2}$ & 2,44 a $3,86^{4}$ \\
Sharon-Anammox $^{4}$ & 3,89 a $4,64^{5}$ \\
Nitrificação/Desnitrificação convencionais & 8,08 a $15,80^{6}$ \\
Tratamentos físico-químicos & 15,80 a $39,68^{6}$ \\
\hline \hline
\end{tabular}

${ }^{1}$ Single reactor High activity Ammonium Removal Over Nitrite; ${ }^{2}$ Reação de oxidação da amônia, sob condições anóxicas, tendo o nitrito como aceptor de elétrons; ${ }^{3}$ Fonte: Fundação Stowa (2001). Estimativa dos custos para uma unidade de ETE com capacidade de tratamento de 500.000 habitantes. ${ }^{4}$ Fonte: Centro avançado de tratamento de águas residuárias da Universidade de Queensland na Austrália (2005). ${ }^{5}$ Fonte: Grontmij Nederland (2004); ${ }^{6}$ Fonte: Fundação Stowa (2001) adaptado de Munõz et al., 2007. A conversão de moedas foi realizada de acordo com a cotação do Banco Central do Brasil em 30/06/2015: 1 EURO/EUR (978) = 3,5080 REAL BRASIL/BRL (790).

Em recente publicação, levantaram-se pelo menos 100 estações de tratamento, em escala plena, utilizando da combinação de nitritação parcial e anammox para a remoção de amônia de águas residuárias, confirmando-se o processo anammox como solução biotecnológica para remoção de nitrogênio (Lackner et al., 2014).

Ressalta que entre essas estações de tratamento, destacam-se os sistemas com reatores em bateladas sequenciais (RBS) como a tecnologia mais empregada, em mais de 50\% dos casos. Entre todas as instalações configuram-se os sistemas de um estágio (88\%) e tratando especialmente esgotos urbanos (75\%) (Lackner et al., 2014).

\section{2 - INÓCULOS PARA PROCESSO ANAMMOX}

Desde a descoberta da atividade anammox em reatores de nitrificação/desnitrificação em uma estação de tratamento de águas residuárias na Holanda por Mulder et al. (1995), vários estudos foram desenvolvidos buscando o conhecimento dos micro-organismos envolvidos, os aspectos operacionais dos reatores para favorecer a atividade anammox, entre outros. De acordo com alguns estudos, que revisaram a maioria das publicações científicas sobre esse processo, indicam os desafios para área, sendo principalmente a estratégia de partida de 
reatores visando reduzir o tempo de emergência da atividade, estabilização e eficiência do processo anammox (Terada et al., 2011; Bagchi et al., 2012, Jenni et al., 2014).

A composição do inóculo parece ser determinante no tempo de partida de reatores com atividade anammox e está relacionada com a origem do inóculo (Terada et al., 2011). Tsushima et al. (2007b) demonstraram que a abundância de organismos anammox e a relação carbono e nitrogênio $\left(\mathrm{C} / \mathrm{N}_{\text {total }}\right)$ do inóculo influenciam no tempo de estabelecimento da atividade anammox e na taxa de remoção de nitrogênio. Assim, quanto maior o número de cópias de genes relacionados a micro-organismos anammox, comprovando a maior abundância desses organismos e menor valor na relação $\mathrm{C} / \mathrm{N}_{\text {total }}$, mais rapidamente consegue-se a partida de reatores visando a atividade anammox.

Diferentes inóculos foram testados buscando-se avaliar o tempo de partida de reatores visando a atividade anammox pelas bactérias autotróficas do grupo Planctomycetes. Vives et al. (2007) utilizaram uma mistura de biomassas oriundas de sistemas de lodos ativados, de estação de tratamento de chorume e de esgoto municipal e registraram estabilidade do processo anammox somente após 225 dias. Em outro estudo foi utilizado lodo proveniente de um sistema convencional de lodos ativados que trata esgoto doméstico da cidade de Belo Horizonte (MG), para enriquecimento de bactérias anaeróbias oxidadoras de amônia, e verificou-se o aumento na abundância de tais micro-organismos anammox com a consequente atividade anammox após 125 dias (Araújo et al., 2010).

Chamchoi e Nitisoravut (2007) testaram inóculos a partir de lodos de UASB, lodos ativados e lodo de digestão anaeróbia em reatores em bateladas sequenciais (RBS) para enriquecimento de micro-organismos anammox. Após 4 meses de operação registraram atividade anammox com eficiência na remoção de amônia em torno de $80 \%$ para todos os inóculos testados quando afluente cerca de $90 \mathrm{mg} . \mathrm{L}^{-1}$ nitrogênio total. No entanto, o RBS inoculado com lodo de UASB apresentou uma menor população anammox, quando comparado aos outros reatores inoculados com os demais lodos.

Também, foram testados inóculos a partir de biomassas oriundas de estações de tratamento com altas cargas de nitrogênio. Martins (2007) utilizou biomassa de reator nitrificante / desnitrificante de uma estação de tratamento de água residuária de indústria produtora de aminoácidos e de lodo granular de reator UASB de abatedouro de aves, ambos localizados no Brasil. No entanto, as condições de operação dessas estações não favoreciam os micro- 
organismos anammox.

Nos estudos visando a remoção de nitrogênio pelo processo anammox, a biomassa passa por estágios durante a partida dos reatores, até que apresente eficiência na remoção da amônia. Esses estágios são conhecidos como crescimento e enriquecimento (Tao et al., 2013). Ao longo da partida dos reatores diferentes parâmetros operacionais devem ser adotados a fim de que não ocorram inibições devido às concentrações das diferentes formas de nitrogênio e de outras substâncias.

Em várias pesquisas, usando diferentes inóculos, foram obtidos resultados diferenciados no tempo de partida e na estabilização do processo anammox. Na maioria dos estudos, o início da detecção de atividade anammox só foi registrado a partir de 60 dias da inoculação nos sistemas.

Os estágios de partida dos reatores, crescimento e enriquecimento, são geralmente longos. Vives et al. (2007) detectaram atividade anammox em um reator de batelada sequencial a partir do sexagésimo dia do início da operação do reator e gastaram mais 145 dias no estágio de enriquecimento. Araújo et al. (2007) relataram que em um RBS, utilizando-se inóculo proveniente de sistemas de lodos ativados, foram necessários 25 dias para cessar a atividade desnitrificante por bactérias heterotróficas e mais 62 dias para a etapa de enriquecimento.

Martins (2007), operando quimiostatos, registrou que após cerca de 136 dias as concentrações dos parâmetros analisados amônia, nitrito e nitrato apresentaram padrões que demonstravam início da estabilização do processo anammox. Mas somente a partir de 272 dias de operação foi que o pesquisador observou eficiências em torno de $70 \%$ na remoção de amônia e nitrito.

O modo de crescimento da biomassa, se suspensa ou imobilizada, pode contribuir para acelerar a partida de reatores. Chamchoi e Nitisoravut (2007) desenvolveram seus experimentos com biomassa suspensa em reatores de bateladas sequenciais e conseguiram, após quatro meses, obter eficiência na remoção de amônia acima de 70\%. Van de Graaf et al. (1996), trabalhando com um reator de leito imobilizado, obtiveram remoção de amônia acima de $70 \%$ somente após sete meses de operação. Em sistemas com biomassa suspensa ocorre uma melhor distribuição do substrato e consequentemente redução no tempo de partida. 
A utilização de biomassa já enriquecida com micro-organismos do grupo Planctomycetes não é garantia para a rápida partida de sistemas anammox. Dapena-Mora et al. (2004) realizaram experimentos para avaliação da atividade anammox usando biomassa já enriquecida, oriunda de um RBS em escala de bancada, e conseguiram remover amônia e nitrito partir da montagem do sistema. No entanto, quando se utilizou biomassa oriunda do reator que se detectou pela primeira vez a atividade anammox, na Holanda, ou seja, com micro-organismos aclimatados, demorou-se mais de 90 dias para se obter eficiência na remoção de amônia (Jetten et al., 1999).

Tsushima et al. (2007a) estudaram o sucesso de enriquecimento de culturas anammox em sistema de semi-bateladas. Água residuária sintética, com os substratos amônia e nitrito, foi usada para alimentar as culturas. O sucesso no enriquecimento e remoção dos compostos nitrogenados só foram obtidos após o $340^{\circ}$ dia. Depois desse período de aclimatação, foi determinado o tempo de duplicação para essas culturas como sendo de 4,3 dias. A biomassa utilizada nas culturas foi oriunda de discos rotativos submersos, em escala de bancada, operados para avaliar o efeito da relação $\mathrm{C} / \mathrm{N}$ na distribuição espacial de micro-organismos nitrificantes e heterotróficos no biofilme (Okabe et al., 1995).

Estudos realizados para avaliar a remoção de nitrogênio de águas residuárias ou de meios sintéticos por processo anammox e que obtiveram eficiências de remoção superiores a 95\% do nitrogênio total usaram biomassa aclimatada às condições ótimas para as bactérias anammox por mais de 3 anos (Jetten et al., 1999, Dapena-Mora et al., 2004).

Em um estudo, usando inóculos a partir de lagoa aerada tratando efluente de refinaria de petróleo e de wetland construído tratando esgoto doméstico em biofiltros anaeróbios, em escala de bancada, foi possível atingir eficiências acima de $98 \%$ para remoção de nitrogênio pelo processo anammox após 300 dias, com cargas aplicadas de 0,550 e 0,350 kg N.m ${ }^{-3} \mathrm{dia}^{-}$ ${ }^{1}$ de amônia e nitrito, respectivamente (Costa, 2013a; Costa et al., 2014).

A detecção de micro-organismos e atividade anammox em amostras de ambientes naturais combinada com as informações das condições ambientais pode facilitar a procura por outras fontes de biomassa para serem usadas como inóculos em reatores em escala de bancada, piloto e plena (Schmid et al., 2005). As interfaces óxicas/anóxicas de muitos sedimentos naturais e ambientes antropizados mostram-se como habitats ideais para os microorganismos oxidadores anaeróbios de amônia (Jetten et al., 1999). 
Costa (2013a) registrou a presença de micro-organismos anammox, por análise de biologia molecular, em 23 amostras de lodos extraídos em sistemas de tratamento de esgotos, tais como lagoas de polimento, reatores UASB, wetlands construídos plantados (Typha latifolia) e não plantados e, ainda, em sistemas de tratamento de efluentes de refinaria de petróleo composto por lagoa aerada, biodiscos e lagoas de polimento localizados no Brasil.

Dessa forma, utilizar biomassas oriundas de ecossistemas naturais ou artificiais, onde ocorre a presença de altas concentrações de nitrogênio amoniacal e onde os fatores ambientais favoreçam o desenvolvimento de micro-organismos anammox pode reduzir o período de tempo gasto na partida de reatores visando a atividade anammox. Tsushima et al. (2007b) demonstram que quanto menor a relação carbono/nitrogênio nos inóculos melhor é a resposta de enriquecimento e atividade anammox. Da mesma maneira, concentrações de amônia e nitrito e a ausência de oxigênio são condições para a ocorrência do processo de oxidação anaeróbia da amônia pelo mecanismo anammox (Jetten et al., 1999). Alguns outros aspectos ambientais, tais como alto potencial redox e baixas concentrações de sulfetos são importantes em inóculos para o desenvolvimento dos organismos anammox (SànchezMelsió et al., 2009).

Sànchez-Melsió et al. (2009) demonstraram que bactérias como "Candidatus Brocadia anammoxidans" foram detectadas em várias culturas para enriquecimento anammox cujos inóculos foram coletados em diversos ambientes com condições variando nas concentrações de nitrito, amônia, salinidade, sulfeto de hidrogênio, entre outros fatores.

Conforme indicado, os micro-organismos anammox são espécies ubíquas (Bagchi, et al. 2012; Kartal et al., 2012) e, dessa forma, os ambientes naturais como os mangues nas regiões costeiras brasileiras e as veredas do cerrado reúnem condições que podem abrigar os organismos anammox. Também, sistemas de tratamento de efluentes de frigoríficos/abatedouros e lagoas de chorume, devido às características dessas águas residuárias, podem oferecer boas condições para o desenvolvimento dos organismos anammox. Nas regiões tropicais, sedimentos de lagos e lagoas que recebem contribuições de nutrientes por carreamento das bacias hidrográficas podem também servir de habitats para o desenvolvimento de micro-organismos anammox.

Em mangues, as atividades microbiológicas são processos chaves para a alta produtividade desses ecossistemas (Li et al., 2010). Espécies de arqueias e bactérias foram descritas em 
mangues e identificadas como as principais no processo de oxidação de amônia nesses ambientes. Foram investigadas a diversidade filogenética, a distribuição e abundância de arqueias e bactérias oxidadoras de amônia, relacionando com a presença de árvores de mangue e com a profundidade no sedimento. A concentração de amônia $\left(\mathrm{NH}_{4}\right)$ foi o fator principal na distribuição das arqueias oxidadoras de amônia, enquanto a distância da vegetação do mangue e a salinidade foram os fatores mais importantes para a distribuição das bactérias oxidadoras de amônia. Também, a coexistência de bactérias anammox apresentou correlação positiva com as arqueias oxidadoras de amônia (Li et al., 2010).

Foi investigada a resposta de sedimentos e lodos de diferentes origens ao enriquecimento das bactérias anammox em sistemas de culturas em bateladas. Sànchez-Melsió et al. (2009) avaliaram a atividade e os organismos anammox presentes em culturas em bateladas oriundas de 13 diferentes inóculos testados: sedimentos a partir de ambientes lacustres, lagoas salobras, ambientes costeiros, wetlands construídos e lodos de digestores anaeróbios (3 inóculos) e de SBR anóxicos (6 inóculos). Pela análise da relação estequiométrica anammox, somente 6 culturas, provenientes de dois inóculos de SBR anóxicos, de lagoa salobra, de wetland construído e de dois inóculos de digestores anaeróbios, apresentaram respostas em termos de atividade anammox.

Schierholt Neto (2007) testaram dois inóculos provenientes de sistemas de tratamento de dejetos de suínos em reatores tubulares com meio suporte, em escala de bancada, para atividade anammox. A seleção desses inóculos baseou-se no fato que biomassa adaptada a tratamento de efluentes com altas cargas de nitrogênio, como é o caso dos dejetos suínos

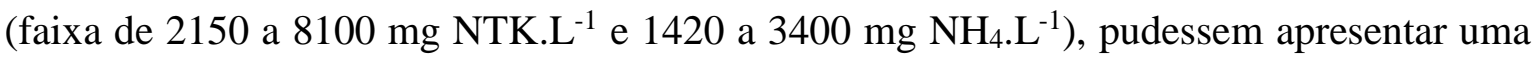
diversidade de micro-organismos anammox e assim desenvolver-se em sistemas visando a atividade anammox.

A origem dos inóculos utilizados por Schierholt Neto (2007) foi o lodo biológico de uma lagoa experimental desativada onde se desenvolvia um sistema de aeração intermitente e o lodo de um decantador secundário de uma estação de tratamento de dejetos de suínos localizadas no Brasil. Esses inóculos passaram por uma etapa de aclimatação (63 dias) de forma a lavar e eliminar o máximo possível de microrganismos competidores ou substâncias que pudessem prejudicar o desenvolvimento dos micro-organismos anammox.

Schierholt Neto (2007) avaliaram a atividade anammox por meio dos coeficientes 
estequiométricos globais encontrados a partir da avaliação dos produtos efluentes dos reatores testados. Esses autores encontraram razões estequiométricas muito próximas às citadas na literatura para a atividade anammox $\left(1 \mathrm{~mol} \mathrm{NH}_{4}^{+}\right.$e $1,31 \mathrm{~mol} \mathrm{NO}_{2}^{-}$consumidos para 1,05 mol de $\mathrm{N}_{2}$ e 0,22 mol $\mathrm{NO}_{3}{ }^{-}$produzidos) (Strous et al. 1998). A confirmação dos micro-organismos anammox ocorreu com os resultados obtidos por análises de biologia molecular. Ainda, o reator inoculado com lodo proveniente da lagoa desativada apresentou melhor desenvolvimento para a atividade anammox removendo maiores cargas de nitrogênio [em torno de $290 \mathrm{mg}$ N.L dia ${ }^{-1}$ ].

Para o desenvolvimento dos organismos anammox deve-se observar as relações simbióticas, ou seja, como as bactérias anammox interagem com outros micro-organismos, a exemplo das bactérias aeróbias nitritantes (Sànchez-Melsió et al., 2009). Portanto, compreender as relações que ocorrem entre uma comunidade de micro-organismos é chave para o sucesso da aplicação dos mesmos nos sistemas de tratamento de águas residuárias (Tao et al., 2013).

Destaca-se que as bactérias nitrificantes apresentam boa adaptação às baixas concentrações de oxigênio nas interfaces óxicas-anóxicas. Em ambientes anóxicos, podem reduzir nitrito para $\mathrm{N}_{2} \mathrm{O}$ e $\mathrm{N}_{2}$ quando o piruvato e o hidrogênio atuam como doadores de elétrons. No entanto, as bactérias anammox apresentam taxa específica de oxidação anaeróbia 50 vezes mais rápida dos que as bactérias aeróbias oxidadoras de amônia (Sliekers et al., 2005).

Na Tabela 3.2 é apresentada uma sistematização de algumas pesquisas com microorganismos e atividade anammox que testaram biomassas oriundas de inóculos de habitats naturais e antropizados, adotaram reatores como modelos de sistemas, avaliaram tempo para início e estabilização da atividade anammox, definiram parâmetros operacionais e que obtiveram sucesso no estabelecimento do processo anammox avaliado pelas taxas de remoção de nitrogênio. Em todos os experimentos, apresentados na Tabela 3.2, foi utilizada água residuária sintética nos sistemas biológicos testados. 
Tabela 3.2: Inóculos e sistemas usados para enriquecimento e atividade anammox.

\begin{tabular}{|c|c|c|c|c|c|}
\hline Origem do Inóculo / Sistema & $\begin{array}{l}\text { Tipo de } \\
\text { sistema } \\
\text { testado }\end{array}$ & $\begin{array}{l}\text { Início da atividade } \\
\text { anammox }\end{array}$ & $\begin{array}{c}\text { Estabilização da } \\
\text { atividade anammox }\end{array}$ & 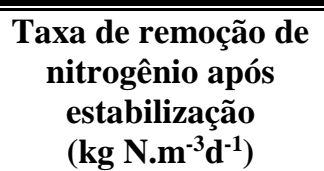 & Referência \\
\hline $\begin{array}{l}\text { × Lagoa de sedimentação tratando efluente de usina de } \\
\text { processamento de cana de açúcar }{ }^{(1)}\end{array}$ & $\operatorname{RBS}^{(2)}$ & $35-60$ dias & 90 dias & 2,1 & Sánchez et al., 2014 \\
\hline $\begin{array}{l}\times \text { Lagoa aerada tratando efluente de refinaria de petróleo } \\
\times \text { Wetland construído tratando esgoto doméstico } \\
{ }^{(3)}\end{array}$ & $\begin{array}{l}\text { Biofiltros } \\
\text { anaeróbios }\end{array}$ & $\begin{array}{l}50 \text { a } 300 \text { dias } \\
55 \text { a } 145 \text { dias }\end{array}$ & $\begin{array}{l}300 \text { dias } \\
210 \text { dias }\end{array}$ & $\begin{array}{l}0,550 \\
0,350\end{array}$ & $\begin{array}{c}\text { Costa, 2013a } \\
\text { Costa } \text { et al., } 2014\end{array}$ \\
\hline$\times$ Tanque anóxico tratando esgoto doméstico ${ }^{(1)}$ & $\begin{array}{l}\text { Bioreator com } \\
\text { membranas }\end{array}$ & 80 dias & 175 dias & 0,800 & Tao et al., 2013 \\
\hline $\begin{array}{l}\times \text { Reator anaeróbio tratando efluente de indústria processamento } \\
\text { vegetais }{ }^{(1)}\end{array}$ & $\begin{array}{l}\text { Frascos com } \\
\text { culturas em } \\
\text { bateladas }\end{array}$ & 71 dias & 130-140 dias & NA & $\begin{array}{l}\text { Suneethi e Joseph, } \\
2011\end{array}$ \\
\hline $\begin{array}{l}\text { × Bioreator com membranas testado com água residuária } \\
\text { sintética }(2)\end{array}$ & $\mathrm{RBS}^{(2)}$ & 49 dias & $60-90$ dias & NA & Wang et al., 2011 \\
\hline$\times$ Lodos ativados tratando esgotos domésticos ${ }^{(1)}$ & $\mathrm{RBS}^{(2)}$ & 87 dias & 125 dias & NA & Araújo et al., 2010 \\
\hline $\begin{array}{l}\times \text { RBS aeróbio tratando efluentes de abatedouros e de dejetos }{ }^{(1)} \\
\times \text { Sistema A2O tratando esgoto doméstico }\end{array}$ & $\begin{array}{l}\text { Frascos com } \\
\text { culturas em }\end{array}$ & 35 dias & 70 dias & 0,140 & Bae et al., 2010 \\
\hline A) reator anaeróbio & bateladas & 35 dias & 70 dias & 0,140 & \\
\hline B) reator anóxico & & 35 dias & 70 dias & 0,140 & \\
\hline C) reator óxico & & 50 dias & & & \\
\hline$\times$ Discos rotativos tratando dejetos animais ${ }^{(1)}$ & & $\mathrm{ND}^{(5)}$ & ND ${ }^{(5)}$ & & \\
\hline $\begin{array}{l}x \text { Reator bateladas sequenciais anóxico tratando esgotos } \\
\text { domésticos }\end{array}$ & $\begin{array}{l}\text { Frascos com } \\
\text { culturas em }\end{array}$ & 90 dias & - & NA & $\begin{array}{l}\text { Sànchez-Melsió et } \\
\text { al., } 2009\end{array}$ \\
\hline × Lodo de lagoas salobras & bateladas & 365 dias & - & & \\
\hline × Lodo de wetlands construídos tratando esgotos domésticos & & 365 dias & - & & \\
\hline$\times$ Reator anaeróbio tratando esgoto doméstico ${ }^{(1)}$ & & 365 dias & - & & \\
\hline $\begin{array}{l}\times \text { Lagoa desativada tratando dejetos suínos } \\
\times \text { Decantador secundário tratando dejetos suínos }\end{array}$ & $\begin{array}{c}\text { Reatores } \\
\text { tubulares com } \\
\text { meio suporte }\end{array}$ & - & $\begin{array}{l}100 \text { dias } \\
82 \text { dias }\end{array}$ & 0,290 & $\begin{array}{l}\text { Schierholt Neto, } \\
2007\end{array}$ \\
\hline 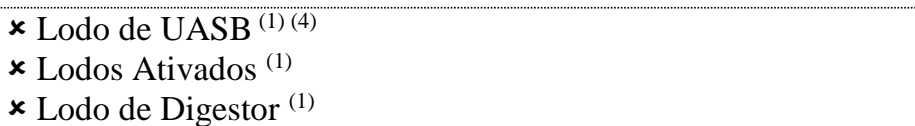 & $\mathrm{RBS}^{(3)}$ & 90 dias & 120 dias & NA & $\begin{array}{l}\text { Chamchoi e } \\
\text { Nitisoravut, } 2007\end{array}$ \\
\hline
\end{tabular}


Continuação Tabela 3.2: Inóculos e sistemas usados para enriquecimento e atividade anammox.

\begin{tabular}{|c|c|c|c|c|c|}
\hline Origem do Inóculo / Sistema & $\begin{array}{l}\text { Tipo de } \\
\text { sistema } \\
\text { testado }\end{array}$ & $\begin{array}{c}\text { Início da atividade } \\
\text { anammox }\end{array}$ & $\begin{array}{c}\text { Estabilização da } \\
\text { atividade anammox }\end{array}$ & 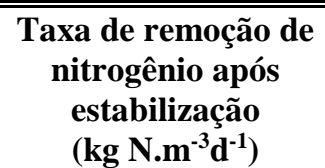 & Referência \\
\hline $\begin{array}{l}\text { × Lodos Ativados tratando efluente combinado de esgoto e } \\
\text { chorume }\end{array}$ & RBS $^{(3)}$ & 70 dias & 225 dias & NA & Vives et al., 2007 \\
\hline $\begin{array}{l}\text { × Discos Rotativos Submersos testando água residuária sintética } \\
\text { (2) }\end{array}$ & $\begin{array}{c}\text { Semi- } \\
\text { bateladas }\end{array}$ & - & 340 dias & 0,700 & $\begin{array}{l}\text { Tsushima et al., } \\
\text { 2007a }\end{array}$ \\
\hline $\begin{array}{l}x \text { Reator nitrificante / desnitrificante tratando efluente indústria } \\
\text { de aminoácidos }(1)\end{array}$ & Quimiostato & 136 dias & 274 dias & 0,043 & Martins, 2007 \\
\hline x Lodo de UASB tratando efluente de abatedouro de aves ${ }^{(4)}$ (1) & & 136 dias & 274 dias & 0,043 & \\
\hline$\times$ Reatores com membranas tratando esgoto doméstico ${ }^{(3)}$ & Frascos com & $\mathrm{ND}^{(5)}$ & $\mathrm{ND}^{(5)}$ & $\mathrm{ND}^{(5)}$ & Tsushima et al., \\
\hline$\times$ Bacia de desnitrificação tratando esgoto doméstico ${ }^{(1)}$ & culturas em & 223 dias & - & 0,032 & $2007 \mathrm{~b}$ \\
\hline$\times$ Discos rotativos nitrificantes tratando chorume ${ }^{(1)}$ & bateladas & 171 dias & - & 0,004 & \\
\hline x Valas de Oxidação tratando esgoto doméstico ${ }^{(1)}$ & & 64 dias & - & 0,054 & \\
\hline$\times$ Bacia de desnitrificação tratando esgoto doméstico ${ }^{(1)}$ & & 143 dias & - & 0,044 & \\
\hline$\times$ Valas de Oxidação tratando esgoto doméstico ${ }^{(1)}$ & & 203 dias & - & 0,026 & \\
\hline$\times$ Digestor Anaeróbio tratando esgoto doméstico ${ }^{(1)}$ & & 107 dias & - & 0,039 & \\
\hline$\times$ Tanque de Aeração tratando lodo de fossas ${ }^{(1)}$ & & 54 dias & - & 0,058 & \\
\hline$\times$ Bacia de desnitrificação tratando lodo de fossas ${ }^{(1)}$ & & 69 dias & - & 0,048 & \\
\hline$\times$ Discos rotativos tratando esgoto doméstico ${ }^{(1)}$ & & $\mathrm{ND}^{(5)}$ & $\mathrm{ND}^{(5)}$ & $\mathrm{ND}^{(5)}$ & \\
\hline$\times$ Bacia de desnitrificação tratando esgoto doméstico ${ }^{(1)}$ & & 37 dias & 100 dias & 0,083 & \\
\hline
\end{tabular}

(1) EPL: escala plena; ${ }^{(2)}$ EBA: escala bancada; ${ }^{(3)}$ EPI: escala piloto; ${ }^{(4)}$ UASB: Reator Anaeróbio de Manta de Lodo e Fluxo Ascendente; ${ }^{(5)}$ ND: Não Detectado; ${ }^{(6)}$ NA: Não Apresentado 
Portanto, tendo-se o conhecimento das condições e parâmetros operacionais que resultaram em sucesso na estabilização da atividade anammox e das condições limitantes ao desenvolvimento e crescimento das populações de micro-organismos anammox pode contribuir para novas pesquisas buscando inóculos em habitats naturais ou antropizados. $\mathrm{O}$ Brasil, devido à sua extensão territorial e diversidade de condições ambientais, permite a ocorrência de uma grande diversidade biológica e, assim, testar a viabilidade de diferentes inóculos para a atividade anammox é importante para quando essa alternativa de tratamento se tornar predominante. Dessa forma, sedimentos de lagos, sistemas anaeróbios e facultativos para tratamento de efluentes de abatedouros e lagoas de acumulação de chorume parecem reunir condições para o estabelecimento e crescimento de micro-organismos anammox.

Além do mais, o estudo da viabilidade de novos inóculos para aplicação em processos biológicos visando a atividade anammox pode ampliar o espectro genético, ecológico e de micro-organismos existentes e pode auxiliar no monitoramento dos sistemas de tratamentos de águas residuárias.

\section{3 - MICRO-ORGANISMOS ENVOLVIDOS NA REMOÇÃO DE NITROGÊNIO}

As biomassas constituintes dos sistemas de tratamentos biológicos para remoção de nitrogênio são compostas por uma diversidade de micro-organismos, principalmente dos Domínios Bacteria e Archaea, que podem interagir em relações simbióticas e competitivas.

Os micro-organismos são empregados no tratamento de águas residuárias, pois podem utilizar uma série dos componentes presentes nesses efluentes como substratos para os seus processos metabólicos. O nitrogênio, um dos principais poluentes em águas residuárias, pode apresentar-se em diferentes estágios de oxidação, favorecendo a oxidação e/ou redução por processos diferentes (Figura 3.10). 


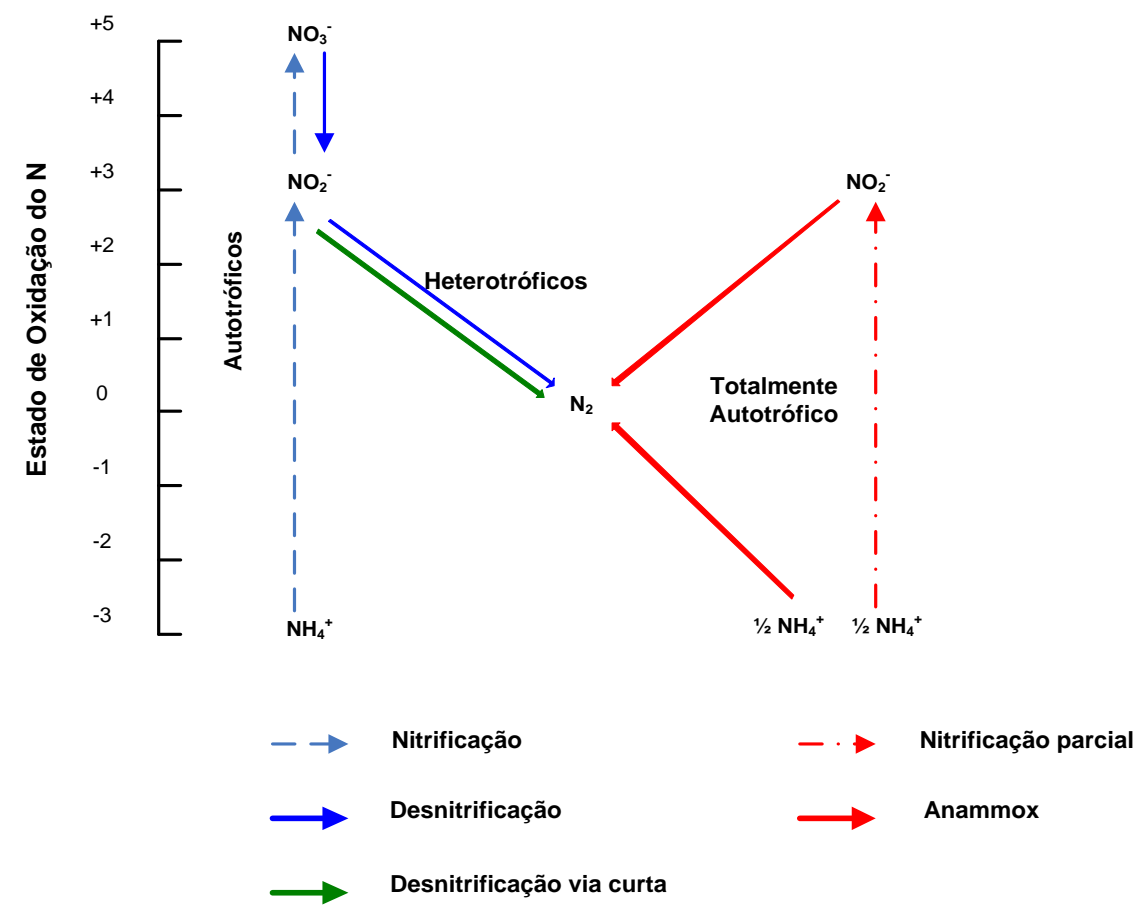

Figura 3.10: Principais estados de oxidação do nitrogênio e processos biológicos possíveis para a oxidação e/ou redução. Fonte: Adaptado de http://www.aresta.jawnet.pl/ (acesso em 10 de março de 2011).

Os diferentes organismos realizam os seus processos metabólicos pelas mais diversas rotas metabólicas (Tortora et al., 2005; Madigan et al., 2010). Essa diferenciação quanto ao tipo de substrato necessário e a forma de obtenção de energia é que torna tão importante a presença de uma comunidade de micro-organismos atuando nos processos de tratamento. Diferentes rotas metabólicas e enzimas envolvidas na ciclagem de nitrogênio por microorganismos estão apresentados na Figura 3.11, conforme proposto por Vlaeminck et al. (2011).

Há três grupos principais de bactérias quimiolitoautotróficas que podem ser utilizadas para remoção de nitrogênio de águas residuárias: as bactérias aeróbias oxidadoras de amônia (BOA), as bactérias aeróbias oxidadoras de nitrito $(\mathrm{BON})$ e as bactérias anaeróbias oxidadoras de amônia (Schmidt et al., 2003). Todas obtêm energia para o crescimento microbiano a partir de compostos inorgânicos de nitrogênio. Destaca-se a possibilidade de nitrificação por outros grupos de bactérias e Archaea heterotróficas e mixotróficas. 


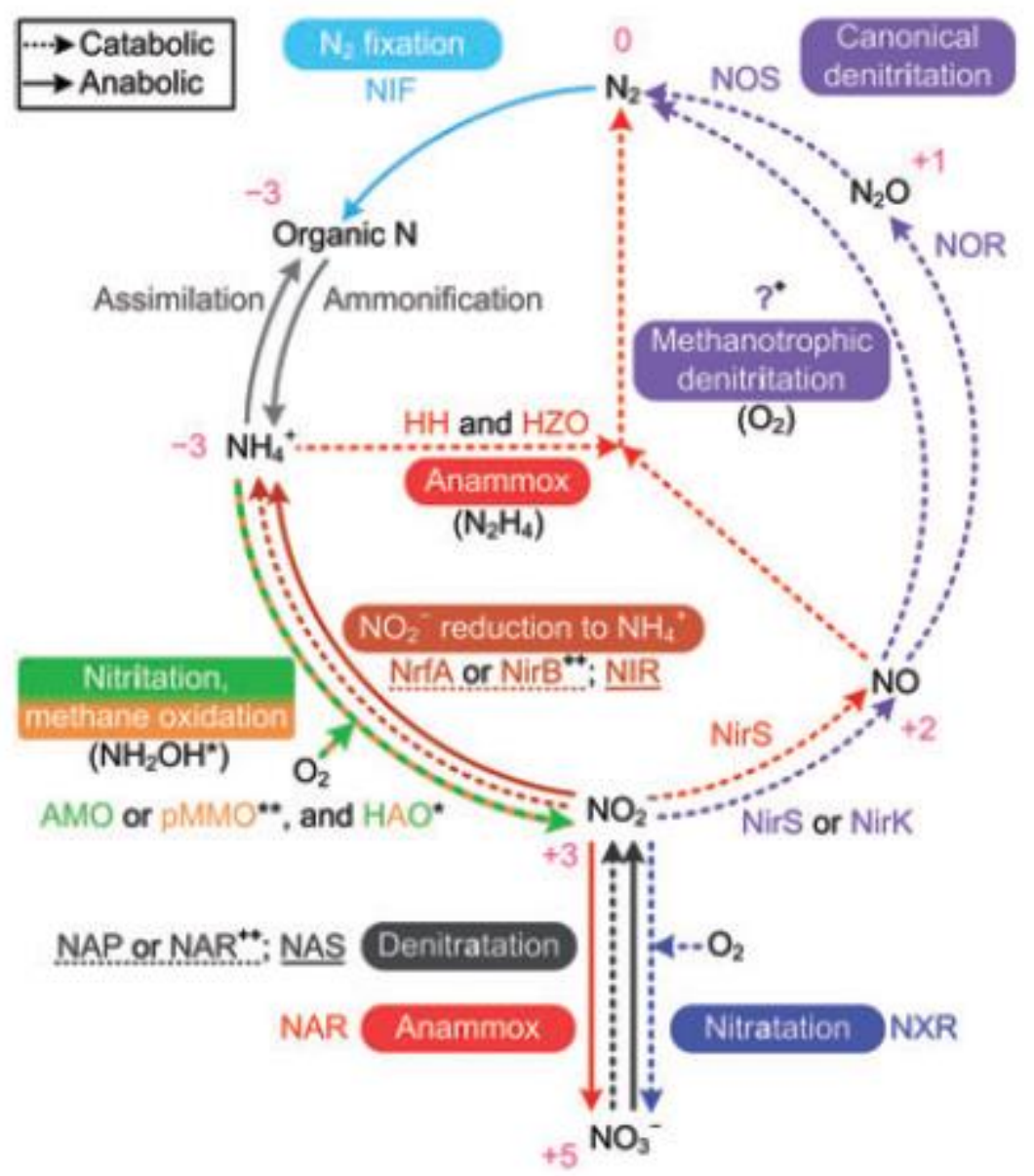

Figura 3.11: Ciclagem do nitrogênio conduzida por micro-organismos por catabolismo (setas pontilhadas) e anabolismo (setas cheias). Os estágios de oxidação do nitrogênio são indicados em rosa e os estágios intermediários entre parênteses. AMO (amônia monooxigenase); HAO (hidroxilamina oxiredutase); HH (hidrazina hidrolase); HZO (hidrazina oxiredutase); NAP (nitrato redutase periplasmatica); NAR (nitrato redutase em membrana); NAS (nitrato redutase citoplasmática); NIF (nitrogenase); NIR e NirB (nitrito retudases); NirK (nitrito redutase contendo $\mathrm{Cu}$ ); NirS (nitrito redutase citocromo $c d_{1}$ );

NOR (oxido nítrico redutase); NOS (oxido nitroso redutase); NrfA (nitrito redutase citocromo $c$ ); NXR (nitrito oxiredutase); pMMO (metano mono-oxigenase particulado). Fonte: Vlaeminck et al. (2011).

As reações químicas conduzidas pelos organismos quimiolitoautotróficos que usam os compostos de nitrogênio são apresentadas abaixo, bem como a energia livre oriunda de cada uma dessas reações. Nas equações 3.2 e 3.3 têm-se as reações possíveis para as bactérias aeróbias oxidadoras de amônia. Na equação 3.4 a reação conduzida por bactérias aeróbias oxidadoras de nitrito e em 3.5 a reação conduzida por bactérias anaeróbias oxidadoras de amônia (Strous et al., 1998). 


$$
\begin{aligned}
& \mathrm{NH}_{4}^{+}+1,5 \mathrm{O}_{2} \rightarrow \mathrm{NO}_{2}^{-}+2 \mathrm{H}^{+}+\mathrm{H}_{2} \mathrm{O} \\
& {\left[\Delta \mathrm{G}^{\circ}, 275 \mathrm{~kJ} \mathrm{~mol}^{-1}\right] \text { (Equação 3.2) }} \\
& \mathrm{NH}_{4}^{+}+\mathrm{N}_{2} \mathrm{O}_{4} \rightarrow 0,33 \mathrm{NO}_{2}^{-}+1,33 \mathrm{H}^{+}+0,33 \mathrm{~N}_{2}+2 \mathrm{NO}+1,33 \mathrm{H}_{2} \mathrm{O} \\
& {\left[\Delta \mathrm{G}^{\circ}, 295 \mathrm{~kJ} \mathrm{~mol}^{-1}\right] \text { (Equação 3.3) }} \\
& \mathrm{NO}_{2}^{-}+0,5 \mathrm{O}_{2} \rightarrow \mathrm{NO}_{3}^{-} \\
& {\left[\Delta \mathrm{G}^{\circ},-74 \mathrm{~kJ} \mathrm{~mol}^{-1}\right] \text { (Equação 3.4) }} \\
& \mathrm{NH}_{4}^{+}+1,32 \mathrm{NO}_{2}^{-}+0,066 \mathrm{HCO}_{3}^{-}+0,13 \mathrm{H}^{+} \\
& \rightarrow 1,02 \mathrm{~N}_{2}+0,26 \mathrm{NO}_{3}^{-}+0,066 \mathrm{CH}_{2} \mathrm{~N}_{0,15}+2,03 \mathrm{H}_{2} \mathrm{O} \\
& {\left[\Delta \mathrm{G}^{\circ} \text { - } 357 \mathrm{~kJ} \mathrm{~mol}^{-1}\right] \text { (Equação 3.5) }}
\end{aligned}
$$

As reações de oxidação aeróbia e anaeróbia da amônia são as que apresentam maiores liberações de energia livre, demonstrado pela variação da energia de Gibbs. Quanto maior a possibilidade de oxidação de um substrato, maior será a liberação de energia da reação que poderá ser convertida para os processos de síntese celular (Comeau, 2008).

As bactérias aeróbias oxidadoras de amônia formam dois grupos monofiléticos: $\gamma$ Proteobacteria (Nitrosococcus) e $\beta$ Proteobacteria (Nitrosomonas e Nitrosospira) (Schmidt et al., 2003). Ahn (2006), ainda cita as bactérias Nitrosovibrio e Nitrosolobus, pertencentes à $\beta$ Proteobateria, como organismos com essa habilidade. Ainda que sejam consideradas como quimiolitoautotróficas, tem sido registrado o uso por elas de compostos orgânicos como fonte de carbono e energia. Além das bactérias litoautotróficas, tem-se citado bactérias heterotróficas e fungos como organismos capazes de oxidar biologicamente a amônia a nitrito (Udert et al., 2005).

Schmidt et al. (2003), relataram a presença conjunta de diferentes gêneros como Nitrosomonas, Nitrosospira, Nitrosococcus, Nitrosovibrio em estações de tratamento de águas residuárias em estações de tratamento de águas residuárias na Europa.

As enzimas envolvidas e os locais celulares onde ocorre o processo de oxidação aeróbia da amônia pelas bactérias nitritantes são apresentados na Figura 3.12. 


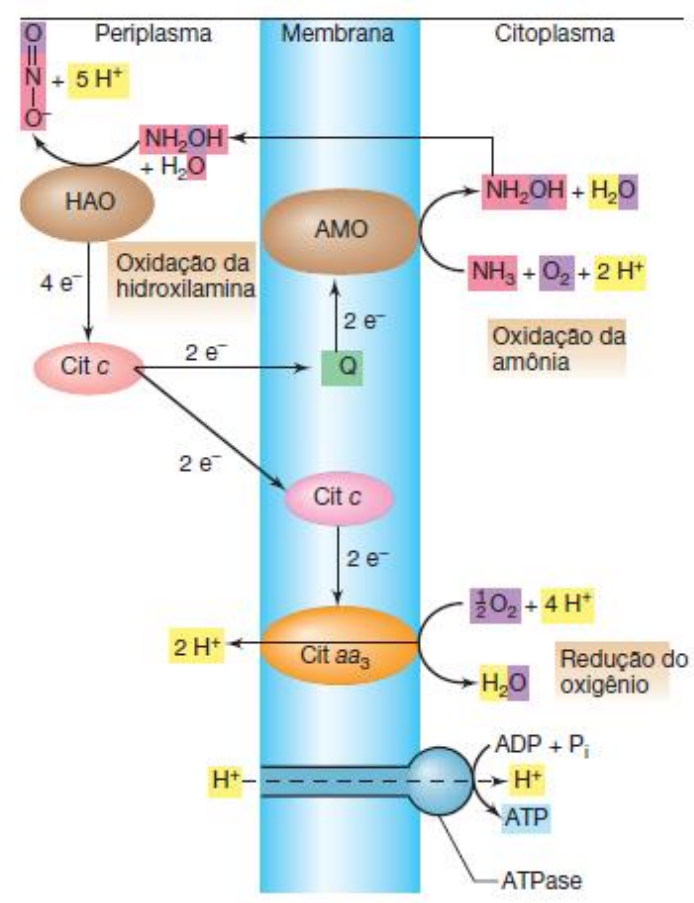

Figura 3.12: Oxidação da amônia e fluxo de elétrons em bactérias oxidadoras de amônia. Os reagentes e produtos dessa série de reações encontram-se destacados. AMO: enzima amônia mono-oxigenase; HAO: enzima hidroxilamina oxidoredutase; Q: ubiquinona (Madigan et al., 2004).

A oxidação biológica do nitrito é realizada principalmente pelas bactérias quimiolitoautotróficas e, adicionalmente, por alguns micro-organismos heterotróficos (Udert et al., 2005). Entre os organismos quimiolitoautotróficos destaca-se as bactérias aeróbias Nitrobacter e Nitrococcus pertencentes ao grupo $\alpha$ Proteobacteria (Schmidt et al., 2003). Nitrospira, também bactérias aeróbias oxidadora de nitrito, estão em uma divisão isolada, Nitrospirae (Youssef, 2014). Nitrospira é o oxidador de nitrito mais especializado. Os demais grupos são mais versáteis, podendo atuar como autotróficos facultativos e anaeróbios, sendo capazes de crescer em substratos ricos em carbono. Incluem-se as bactérias Nitrospina (Nitrospinae) e Nitrocystis como oxidadores de nitrito (Ahn, 2006). As enzimas envolvidas e os locais celulares onde ocorre o processo de oxidação aeróbia do nitrito pelas bactérias nitrificantes são apresentados na Figura 3.13.

A forma de utilização de substrato por Nitrosomonas (BOA) e Nitrobacter (BON) fazem com que essas bactérias sejam classificadas como r-estrategistas, pois apresentam baixa afinidade ao substrato, mas têm taxas altas de reação em concentrações altas de substrato. Enquanto, Nitrosospira (BOA) e Nitrospira (BON) são classificadas como organismos $k$ estrategistas, tendo alta afinidade pelo substrato, mas baixa taxa de reação em concentrações 
altas de substrato (Kim et al., 2006; Park et al., 2010).

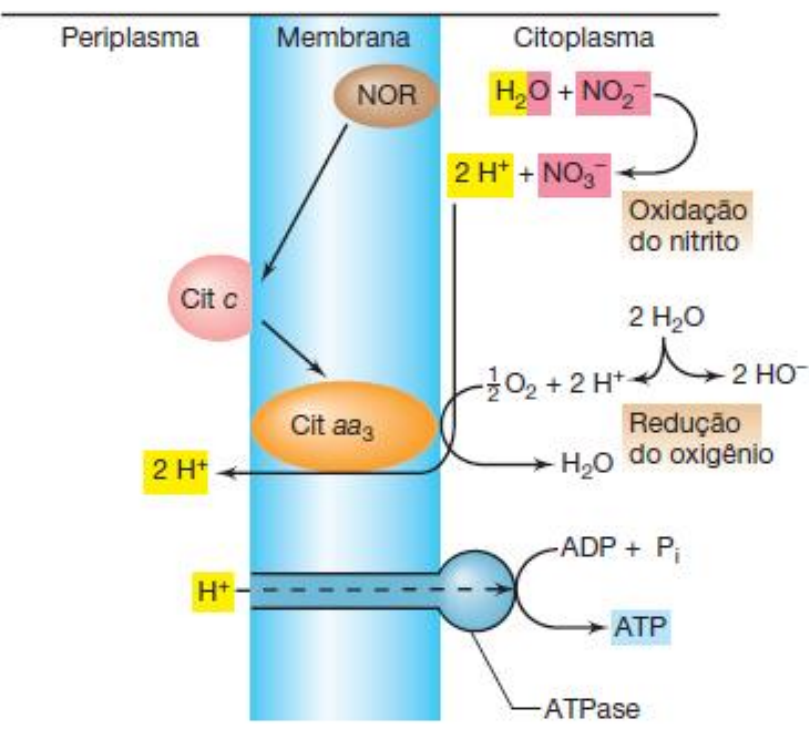

Figura 3.13: Oxidação de nitrito a nitrato por bactérias nitrificantes. Os reagentes e produtos dessa série de reações encontram-se destacados. NOR: enzima nitrito oxiredutase (Madigan et al., 2004).

Os micro-organismos capazes de oxidar anaerobicamente a amônia usando o nitrito como aceptor de elétrons são conhecidos como bactérias anammox devido justamente à essa habilidade metabólica. Na mais recente classificação biológica tem-se as bactérias anammox pertencentes ao Domínio Bacteria; Filo Planctomycetes; Classe Planctomycetia; Ordem Brocadiales; Família Candidatus Brocadiaceae e os Gêneros "Candidatus Brocadia", "Ca. Kuenenia", “Ca. Scalindua”, “Ca. Anammoxoglobus” e "Ca. Jettenia” (Jetten et al. 2011; Ludwig et al., 2011).

Os micro-organismos anammox com os seus gêneros "Candidatus Brocadia", "Ca. Kuenenia" e "Ca. Scalindua" (Schmid et al., 2005); "Ca. Anammoxoglobus" (Kartal et al., 2007) e "Ca. Jettenia" (Quan et al., 2008) formam um ramo monofilético que os distancia dos demais micro-organismos agrupados no mesmo filo, diferindo-os na ordem Brocadiales (Ludwig et al., 2011).

Reconhecem-se 18 bactérias como candidatas a espécies desse grupo anammox, sendo "Candidatus Brocadia anammoxidans” (Schmid et al., 2001), "Ca. Brocadia fulgida” (Kartal 
et al., 2004), "Ca. Brocadia sinica" (Hu et al., 2010), “Ca. Brocadia brasiliensis" (Araújo et al., 2011), “Ca. Brocadia carolinensis" (Vanotti et al., 2011; Rothrock et al., 2011) "Ca. Kuenenia stuttgartiensis" (Schmid et al., 2001; Strous et al., 2006), “Ca. Scalindua wagneri” (Schmid et al., 2003), “Ca. Scalindua brodae" (Schmid et al., 2003), “Ca. Scalindua sorokinii" (Kuypers et al., 2003), "Ca. Scalindua arabica" (Woebken et al., 2008), "Ca. Scalindua profunda" (van de Vossenberg et al., 2008), “Ca. Scalindua marina” (Brandsma et al., 2011), "Ca. Scalindua richardsii" (Fuchsman et al., 2012), "Ca. Scalindua pacifica" (Dang et al., 2013), “Ca. Anammoxoglobus propionicus” (Kartal et al., 2007), “Ca. Jettenia asiatica" (Quan et al., 2008). Sendo também citadas "Ca. Scalindua sinoiilfied", "Ca. Scalindua zhenghe" num estudo realizado por Sonthiphand et al. (2014).

Ocorre a hipótese que os Planctomycetes sejam uma linhagem antiga e, assim, houve tempo para evoluir formando gêneros individuais bem separados filogeneticamente (Schmid et al., 2005). Supõe-se que a biodiversidade genética e molecular desse grupo seja muito maior que de Proteobacteria (Schmidt et al., 2003; Kartal et al., 2012). Um arranjo do Filo Planctomycetes apresentando as distâncias filogenéticas baseadas em sequências de DNA que codificam o RNAr $16 \mathrm{~S}$ entre os grupos de micro-organismos sem (Ordem Planctomycetales) e com habilidade para a oxidação anaeróbia da amônia (Ordem Brocadiales) é mostrado na Figura 3.14 (Ludwig et al., 2011; Jogler et al., 2012;).

Atualmente toda a sistemática dos micro-organismos está baseada no Manual Bergey de Sistemática Bacteriológica que considera as identificações por análises de sequências genéticas. Considerando o filo Planctomycetes, as análises comparativas de sequências de genes para RNAr $16 \mathrm{~S}$ mostram uma divergência maior que $15 \%$ entre as bactérias anammox (Brocadiales) e as demais da ordem Planctomycetales (Jetten et al., 2011). Schmid et al. (2000), destacaram que a similaridade entre as sequências desses dois grupos de bactérias é em torno de $79 \%$.

De acordo com Jetten et al. (2011), o valor limiar tipicamente usado para separar espécies é de 3\% de divergência entre as sequências de DNA obtidas pela amplificação dos genes que codificam o RNAr 16S. Para os micro-organismos anammox quando obtidos índices de similaridades, entre genes para RNAr 16S, inferiores a 95\% tem-se agrupados em gêneros diferentes. Assim, por exemplo, as sequências de DNA considerando o RNAr 16S dos gêneros " $C a$. Brocadia" e " $C a$. Kuenenia" são similares em apenas 90,5\% (Schmid et al., 2000). 


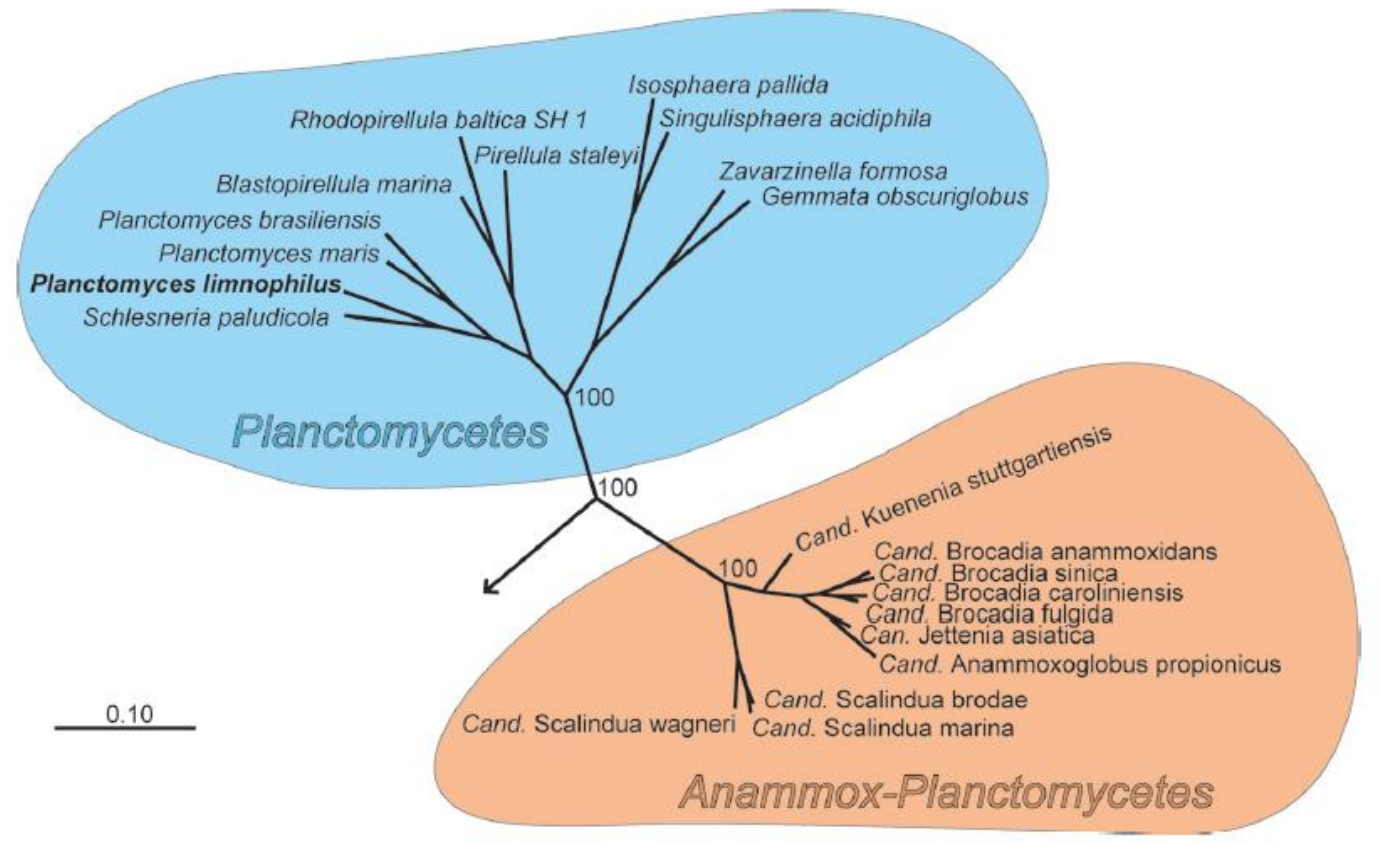

Figura 3.14: Árvore filogenética da Classe Planctomycetia dividida em duas prováveis ordens, baseada na sequência dos genes que codificam o RNAr 16S. Escherichia coli foi escolhida como outgroup. A barra representa 10\% de divergência nas sequências (Jogler et al., 2012).

Atualmente, para todas as candidatas a espécies do grupo anammox, encontram-se disponíveis, em bibliotecas genômicas, o sequenciamento completo ou parcial dos genes codificadores para RNAr 16S, espaço intergênico 16S-23S, RNAt e RNAr 23S permitindose a realização de inferências filogenéticas entre sequências de DNA obtidas em pesquisas que buscam micro-organismos e atividade anammox (Tabela 3.3).

Em análise de amostras de lodos, provenientes de diferentes tipos de reatores e de águas residuárias, por técnicas de biologia molecular usando o RNAr 16S, têm-se detectado predominantemente bactérias anammox próximas, relacionadas filogeneticamente, a "Candidatus Brocadia" e " $\mathrm{Ca}$. Kuenenia" independentemente da localidade e do tempo de atividade anammox (Tabela 3.4). Os micro-organismos relacionados à " $C a$. Scalindua" são citados por desempenharem papel fundamental no ciclo do nitrogênio em ambientes subóxicos marinhos e em estuários, mas raramente são registrados em estações de tratamento (Schmid et al., 2005). O estudo de Sonthiphand et al. (2014) corrobora para a hipótese de especificidade de habitats para os diferentes grupos anammox. 
Pelo fato de não se ter conseguido, ainda, o isolamento das bactérias pertencentes ao grupo anammox, permanece o prefixo Candidatus para todas as espécies classificadas até o momento, de acordo com as regras do Código Bacteriológico, LPSN (Strous et al., 1999a; Jetten et al., 2011; Kartal et al., 2012; Youssef et al., 2014).

Tabela 3.3: Situação do sequenciamento de genes codificadores do RNAr 16S de bactérias anammox para inferências filogenéticas.

\begin{tabular}{|c|c|c|c|}
\hline $\begin{array}{l}\text { Gene / situação } \\
\text { sequenciamento }\end{array}$ & Micro-organismos & $\begin{array}{l}\text { Número } \\
\text { acesso } \\
\text { NCBI** }\end{array}$ & Referência \\
\hline \multirow[t]{6}{*}{ - RNAr 16S (completo) } & Ca. Brocadia anammoxidans* & AF375994 & Schmid et al., 2001 \\
\hline & Ca. Brocadia sinica* & AB565477 & Oshiki et al., 2011 \\
\hline & $\mathrm{Ca}$. Brocadia caroliniensis & JF487828 & $\begin{array}{l}\text { Vanotti et al., 2011; } \\
\text { Rothrock et al., } 2011\end{array}$ \\
\hline & Ca. Kuenenia stuttgartiensis* & AF375995 & Schmid et al., 2001 \\
\hline & Ca. Jettenia asiatica* & DQ301513 & Quan et al., 2008 \\
\hline & $\begin{array}{l}\mathrm{Ca} \text {. Anammoxoglobus } \\
\text { propionicus* }\end{array}$ & EU478694 & Woebken et al., 2008 \\
\hline \multirow[t]{6}{*}{ - RNAr 16S (parcial) } & $\mathrm{Ca}$ Brocadia fulgida* & EU478693 & Woebken et al., 2008 \\
\hline & $\mathrm{Ca}$. Brocadia brasiliensis & GQ896513 & Araújo et al., 2011 \\
\hline & $\mathrm{Ca}$. Scalindua wagneri* & EU478692 & Woebken et al., 2008 \\
\hline & Ca. Scalindua brodae & AY254883 & Schmid et al., 2001 \\
\hline & $\mathrm{Ca}$. Scalindua sorokinii & AY257181 & Kuypers et al., 2003 \\
\hline & Ca. Scalindua marina & EF602039 & Brandsma et al.,2011 \\
\hline
\end{tabular}

*Espécies com o sequenciamento completo ou parcial para os genes que codificam o espaço intergênico 16S23S, RNAt e RNAr 23S. ** http://www.ncbi.nlm.nih.gov/

As bactérias anammox apresentam-se como células cocóides (Figura 3.15A) gram-negativas e possuem uma morfologia irregular incomum, conforme apresentado na Figura 3.15B (Jetten et al., 1999).
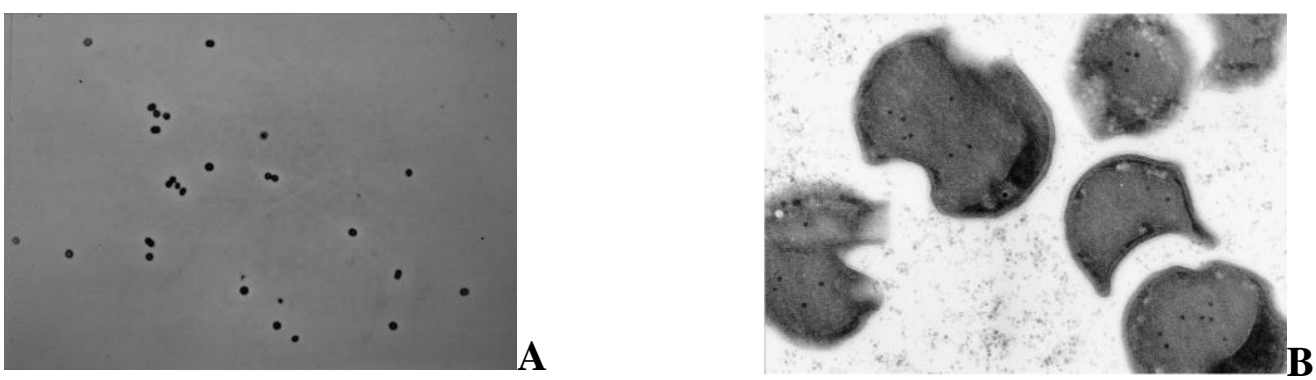

Figura 3.15: A: Micrografia de células em forma de cocos presentes nas culturas enriquecidas anammox. B: Micrografia eletrônica de biomassa suspensa de microorganismos anammox. Jetten et al., 1999. 
Tabela 3.4: Caracterização de bactérias anammox em sistemas biológicos para remoção de nitrogênio, com base no RNAr 16S.

\begin{tabular}{|c|c|c|c|c|c|}
\hline Origem inóculo $^{1}$ & $\begin{array}{l}\text { Tipo de } \\
\text { análise }\end{array}$ & $\begin{array}{c}\text { Filogenia } \\
(\% \text { de similaridade }) \\
\end{array}$ & $\begin{array}{c}\text { Tempo } \\
\text { experimento }\end{array}$ & $\begin{array}{c}\text { Sistema } \\
\text { experimento }\end{array}$ & $\begin{array}{c}\text { Cidade, País } \\
\text { Autores }\end{array}$ \\
\hline Tanque aeração ${ }^{2}$ - chorume & FISH, PCRq & $\begin{array}{l}\text { Ca. Kuenenia }(99 \%) \\
\text { Ca. Brocadia }(93 \%) \\
\text { Ca. Jettenia }(92 \%)\end{array}$ & 200 dias & $\mathrm{UASB}^{3}-\operatorname{ars}^{5}$ & $\begin{array}{l}\text { Jhinan, China } \\
\text { Ni et al. } 2011\end{array}$ \\
\hline $\begin{array}{l}\text { Lagoa sedimentação }{ }^{2} \text { usina de } \\
\text { açúcar }\end{array}$ & FISH, PCR & $\begin{array}{l}\text { Ca. Kuenenia } \\
\text { Ca. Brocadia }\end{array}$ & 100 dias & $\mathrm{RBS}^{4}-\operatorname{ars}^{5}$ & $\begin{array}{l}\text { Valle del Cauca, Colômbia } \\
\text { Sánchez et al., } 2014\end{array}$ \\
\hline Tanque aeração ${ }^{2}$ - chorume & FISH, PCR & $\begin{array}{l}\text { Ca. Kuenenia }(99 \%) \\
\text { Ca. Brocadia }(93 \%) \\
\text { Ca. Jettenia }(92 \%)\end{array}$ & 100 dias & $\begin{array}{l}\text { Tanques aeração } \\
\left(0,3 \text { mg OD.L }{ }^{-1}\right) \\
\text { - chorume }\end{array}$ & $\begin{array}{c}\text { Taiwan, China } \\
\text { Wang et al., } 2010\end{array}$ \\
\hline Lodo anammox Austria ${ }^{3}$ & $\begin{array}{l}\text { PCR, PCRq, } \\
\text { DGGE e } \\
\text { Sequenc. }\end{array}$ & $\begin{array}{l}\text { Ca. Kuenenia stuttgartiensis e Ca. } \\
\text { Brocadia fulgida (antes) para Ca. } \\
\text { Brocadia sp } 40 \text { (depois) }\end{array}$ & 380 dias & $\mathrm{RBS}^{4}-\mathrm{eda}^{6}$ & $\begin{array}{l}\text { Nova York, EUA } \\
\text { Park et al., } 2010\end{array}$ \\
\hline Lodos Ativados ${ }^{2}$ - esgoto & & Ca. Brocadia sp40 & 380 dias & Canon $^{4}-\mathrm{eda}^{6}$ & \\
\hline Discos rotativos submersos ${ }^{4}$ & $\begin{array}{l}\text { FISH, PCRq; } \\
\text { PCR, } \\
\text { Clonagem } \\
\text { RNAr 16S e } \\
\text { Sequenc. }\end{array}$ & $\begin{array}{l}\text { Ca. Brocadia anammoxidans }(92 \%) \\
\text { Planctomycete KSU-1 }(95 \%)\end{array}$ & 390 dias & $\begin{array}{c}\text { Culturas semi } \\
\text { bateladas }{ }^{4}-\operatorname{ars}^{5}\end{array}$ & $\begin{array}{c}\text { Sapporo, Japão } \\
\text { Tsushima et al., 2007a }\end{array}$ \\
\hline Sedimento rio & $\begin{array}{l}\text { PCR, } \\
\text { Clonagem } \\
\text { RNAr 16S e } \\
\text { Sequenc. }\end{array}$ & $\begin{array}{l}\text { Planctomycete KSU-1 }(95 \%)-15 \\
\text { bibliotecas clônicas } \\
\text { Ca. Brocadia fulgida }(98 \%)-1 \\
\text { biblioteca clônica }\end{array}$ & 360 dias & $\mathrm{UASB}^{4}-\operatorname{ars}^{5}$ & $\begin{array}{l}\text { Shangai, China } \\
\text { Quan et al., } 2008\end{array}$ \\
\hline Valos de Oxidação - esgoto & \multirow{5}{*}{$\begin{array}{l}\text { PCR, } \\
\text { Clonagem } \\
\text { RNAr 16S e } \\
\text { Sequenc. }\end{array}$} & Ca. Brocadia sp40 $(99 \%)$ & 134 dias & \multirow{5}{*}{$\begin{array}{c}\text { Culturas em } \\
\text { bateladas }-\operatorname{ars}^{5}\end{array}$} & Tucson, Arizona, EUA \\
\hline Retorno lodos ativados - esgoto & & Ca. Brocadia sp40 $(99 \%)$ & 50 dias & & Tucson, Arizona, EUA \\
\hline Retorno lodos ativados - esgoto & & Ca. Kuenenia $(99 \%)$ & 204 dias & & Valencia, Califórnia, EUA \\
\hline Retorno lodos ativados - esgoto & & Ca. Kuenenia $(99 \%)$ & 204 dias & & San Jose, Califórnia, EUA \\
\hline $\begin{array}{l}\text { Bioreator de membranas - } \\
\text { esgoto }\end{array}$ & & Ca. Kuenenia $(99 \%)$ & 134 dias & & $\begin{array}{l}\text { Lancaster, Califórnia, EUA } \\
\text { Sun et al., } 2011\end{array}$ \\
\hline
\end{tabular}

Continuação da tabela 3.4 na próxima página 
Continuação da Tabela 3.4: Caracterização de bactérias anammox em sistemas biológicos para remoção de nitrogênio, com base no RNAr 16S.

\begin{tabular}{|c|c|c|c|c|c|}
\hline Origem inóculo $^{1}$ & $\begin{array}{c}\text { Tipo } \\
\text { Analise } \\
\end{array}$ & Filogenia & $\begin{array}{c}\text { Tempo } \\
\text { experimento }\end{array}$ & $\begin{array}{c}\text { Sistema } \\
\text { experimento }\end{array}$ & $\begin{array}{c}\text { Cidade, País } \\
\text { Autores } \\
\end{array}$ \\
\hline $\mathrm{RBS}^{2}$ - esgoto e dejetos animais & \multirow[b]{2}{*}{$\begin{array}{l}\text { PCR, PCRq, } \\
\text { Clonagem } \\
\text { RNAr } 16 \mathrm{~S} \text { e } \\
\text { Sequenc. }\end{array}$} & \multirow[b]{2}{*}{$\begin{array}{l}\text { Planctomycete KSU-1 }(99 \%) \\
\text { Possíveis novos candidatos a gêneros } \\
\text { anammox ( } 79,8 \% \text { com as atuais } \\
\text { candidatas anammox) }\end{array}$} & \multirow[b]{2}{*}{$\begin{array}{l}\text { Avaliação do } \\
\text { inóculo - } \\
0 \text { dia }\end{array}$} & \multirow[b]{2}{*}{$\begin{array}{c}\text { Culturas em } \\
\text { bateladas -ars }{ }^{5}\end{array}$} & \multirow[b]{2}{*}{$\begin{array}{l}\text { Seul, Coreia do Sul } \\
\text { Bae et al., } 2010\end{array}$} \\
\hline $\begin{array}{l}\text { Sistema } \mathrm{A} 2 \mathrm{O}^{2} \text { - anaeróbico - } \\
\text { esgoto } \\
\text { Sistema } \mathrm{A} 2 \mathrm{O}^{2} \text { - anóxico -esgoto } \\
\text { Sistema } \mathrm{A} 2 \mathrm{O}^{2} \text { - óxico - esgoto } \\
\text { Discos biológicos rotativos }{ }^{2}- \\
\text { dejetos animais }\end{array}$ & & & & & \\
\hline Digestor anaeróbio - glu mons ${ }^{7}$ & \multirow{8}{*}{$\begin{array}{l}\text { PCR, PCRq, } \\
\text { Clonagem } \\
\text { RNAr } 16 S \text { e } \\
\text { Sequenc. }\end{array}$} & $\begin{array}{l}\text { Ca. Brocadia sinica }(100 \%) ; C a . \\
\text { Anammoxoglobus }\end{array}$ & 900 dias & $\begin{array}{c}\mathrm{CSTR}^{8}-\mathrm{glu} \\
\text { mons }^{7}\end{array}$ & \multirow{7}{*}{$\begin{array}{c}\text { China } \\
\text { Hu et al., } 2010\end{array}$} \\
\hline $\begin{array}{l}\text { Mix anaeróbio e nitrificação - } \\
\operatorname{ars}^{5}\end{array}$ & & Ca. Kuenenia stuttgartiensis (98\%) & 540 dias & $\mathrm{UBF}^{9}-\operatorname{ars}^{5}$ & \\
\hline Reator $\mathrm{CSTR}^{8}-\operatorname{ars}^{5}$ & & Ca. Brocadia (97-99\%) & 540 dias & $\begin{array}{l}\text { Leito expandido } \\
- \text { ars }^{5}\end{array}$ & \\
\hline Digestor anaeróbio - ars 5 & & Ca. Brocadia $(97-99 \%)$ & 420 dias & UASB - $\operatorname{ars}^{5}$ & \\
\hline Digestor anaeróbio - ars ${ }^{5}$ açúcar & & Ca. Brocadia; Ca. Anammoxoglobus & 420 dias & $\begin{array}{l}\text { UASB - ars }{ }^{5}+ \\
\text { açúcar }\end{array}$ & \\
\hline Digestor anaeróbio - ars 5 & & Ca. Kuenenia stuttgartiensis (98\%) & 420 dias & UASB - ars ${ }^{5}$ & \\
\hline Digestor anaeróbio - $\operatorname{ars}^{5}$ & & Ca. Brocadia $(97-99 \%)$ & 600 dias & $\begin{array}{l}\text { Leito expandido } \\
- \text { ars }^{5}\end{array}$ & \\
\hline Sistema nitrificação - ars ${ }^{5}$ & & Ca. Brocadia $(97-99 \%)$ & 360 dias & UASB - ars ${ }^{5}$ & \\
\hline Tanque anóxico ${ }^{2}$ - esgoto & \multirow{3}{*}{$\begin{array}{l}\text { PCR, PCRq, } \\
\text { T-RFLP; } \\
\text { FISH }\end{array}$} & \multirow{3}{*}{ Ca. Kuenenia stuttgartiensis } & \multirow{3}{*}{175 dias } & \multirow{3}{*}{$\mathrm{MBBR}^{10}-\operatorname{ars}^{5}$} & \multirow{3}{*}{$\begin{array}{l}\text { Harbin e Beijing, China } \\
\text { Tao et al., } 2013\end{array}$} \\
\hline $\begin{array}{l}\text { Tanque anóxico }{ }^{2} \text { com lavagens - } \\
\text { esgoto }\end{array}$ & & & & & \\
\hline $\begin{array}{l}\text { Tanque anóxico }{ }^{2} \text { - esgoto + } \\
\text { biomassa anammox UASB }{ }^{3} \\
\text { com Kuenenia stuttgartiensis }\end{array}$ & & & & & \\
\hline
\end{tabular}


A morfologia irregular incomum das células dos micro-organismos anammox observada em microscopia eletrônica por Jetten et al. (1999), está associada à uma estrutura celular intracitoplasmática, definida e exclusiva para os organismos anammox, o anamoxossomo. Essa estrutura tem uma delicada membrana impermeável devido aos lipídeos ladderane que a compõe (Lindsay et al., 2001) e é nela que ocorre parcialmente o catabolismo anammox (Kuenen, 2008; Kartal et al., 2012). Numa revisão apresentada por Schmidt et al. (2003), pode-se melhor observar essa estrutura por uma imagem de microscopia eletrônica, como mostrado na Figura 3.16.

Essa estrutura, o anamoxossomo, permite a realização de estimativas do número de células anammox em comunidades microbianas antes e após períodos destinados ao enriquecimento, pela sua observação em microscopia eletrônica (Jetten et al., 1999).

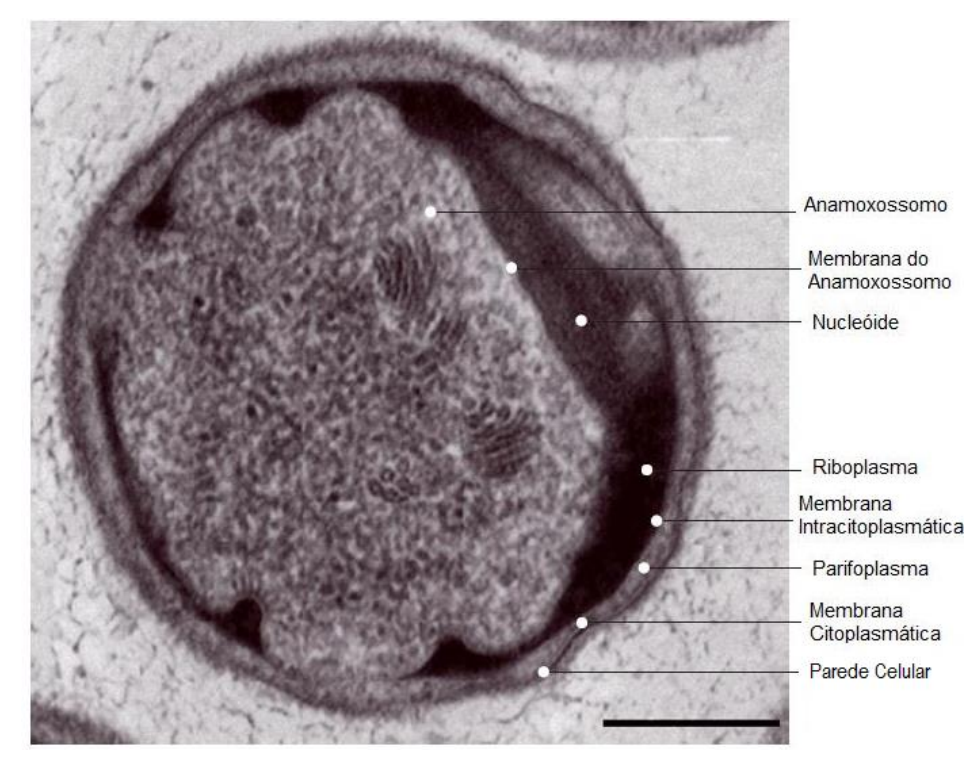

Figura 3.16: Ultraestrutura da bactéria anammox Candidatus 'Kuenenia stuttgartiensis'. Escala da barra representa 200nm (Schmidt et al., 2003; Kuenen, 2008).

As taxas de crescimento das bactérias que realizam o processo anammox são extremamente lentas, resultando na necessidade de tempos elevados de detenção celular (Schmid et al., 2005). Jetten et al. (1999) calcularam o tempo gasto para duplicação das bactérias em reatores de leito fixo e em bateladas sequenciais, obtendo 29 e 11 dias, respectivamente. Essa diferença foi devida a uma detenção celular mais eficiente e distribuições mais 
homogêneas de substratos, produtos e biomassa no reator em bateladas sequenciais.

No entanto, tem-se registrado tempos de duplicação significativamente menores para esses micro-organismos dependendo dos sistemas e parâmetros de controle operacionais adotados. Tsushima et al. (2007a) obtiveram tempos de duplicação de 3,6 a 5,4 dias em culturas enriquecidas, após 400 dias em modo de culturas em bateladas escala bancada, com inóculos provenientes de um reator com discos rotativos submersos. Tanto no reator que originou o inóculo, quanto nas culturas em bateladas, utilizou-se água residuária sintética com adição dos substratos necessários.

O tempo médio de duplicação de bactérias anammox em sistema anaeróbio em bateladas com lodo granular após 150 dias e em reator CANON utilizando-se de biomassa fixa após 100 dias de operação foram de 5,3 e 8,7 dias, respectivamente. A diferença foi atribuída à limitação no transporte de substratos ocorrida no sistema com biofilme (Park et al., 2010).

Bae et al. (2010), utilizando-se da análise de PCR quantitativa, estimaram o tempo de duplicação de 1,12 dias para culturas em bateladas após 70 dias de enriquecimento, tendo sido usada biomassa originária da mistura de três inóculos, sendo lodo de reator aeróbio em bateladas tratando dejetos animais, lodos de sistemas anaeróbios e anóxicos tratando esgotos domésticos.

É provável que o tempo de duplicação de bactérias anammox diferencie entre espécies candidatas, sobre as condições operacionais e tipos de reatores testados e, também, como resultado dos métodos de cálculos adotados tais como rendimento teórico de biomassa obtido pela taxa de remoção de nitrogênio, estimativas de crescimento populacional feitos por FISH (hibridização fluorescente in situ) e PCRq (reação em cadeia de polimerase quantitativa) (Tsushima et al., 2007a).

A rota metabólica utilizada pelas bactérias anammox é considerada rara devido à produção de hidrazina $\left(\mathrm{N}_{2} \mathrm{H}_{4}\right)$ como composto intermediário. Os mecanismos atuantes no metabolismo anammox ainda não estão totalmente definidos (Bagchi et al., 2012; Kartal et al., 2012). Jetten et al. (1999), haviam proposto mecanismos possíveis para o processo metabólico anammox. Durante a oxidação da amônia a hidroxilamina seria usada como aceptor de elétrons, formando hidrazina. A conversão de hidrazina para gás nitrogênio geraria elétrons equivalentes para reduzir o nitrito para hidroxilamina (Figura 3.17). 
Uma enzima similar a hidroxilamina oxidoredutase (HAO) presente nos organismos nitrificantes aeróbios poderia ser a responsável pelo processo de conversão da hidrazina para gás nitrogênio pelos organismos anammox. De acordo com Jetten et al. (1999), a enzima responsável pela conversão da hidrazina apresenta massa molecular menor do que a dos nitrificantes aeróbios, sequência única de aminoácidos em determinados fragmentos e possui vários citocromos tipo c.
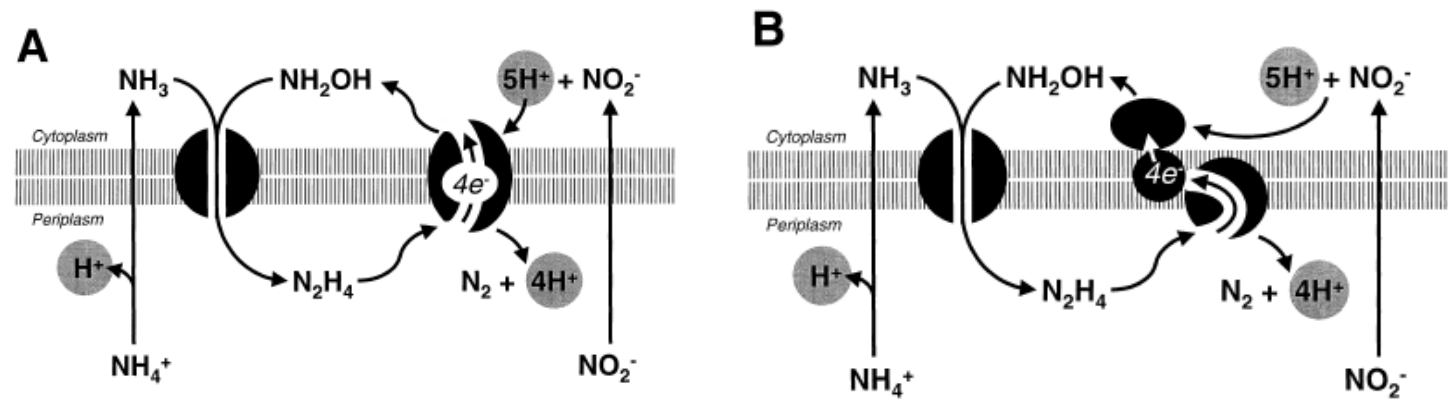

Figura 3.17: Mecanismos metabólicos possíveis e localização celular do sistema de enzimas envolvido na oxidação anaeróbia de amônia (Jetten et al., 1999).

Posteriormente, com a identificação dos genes que codificavam as supostas enzimas relacionadas ao metabolismo anammox, foram postulados dois novos modelos para explicar o fluxo de energia e a formação de hidrazina conforme apresentado na Figura 3.18 (Kuenen, 2008).

No primeiro modelo, durante a oxidação da amônia usando o nitrito como aceptor de elétrons criar-se-ia uma força próton motriz (FPM) sobre a membrana do anamoxossomo (Figura 3.18a). O nitrito $\left(\mathrm{NO}_{2}{ }^{-}\right)$é reduzido para óxido nítrico (NO) que se combinaria com a amônia $\left(\mathrm{NH}_{4}{ }^{+}\right)$para gerar a hidrazina $\left(\mathrm{N}_{2} \mathrm{H}_{4}\right)$, com o consumo de quatro elétrons de baixa energia. A redução da hidrazina para nitrogênio gasoso $\left(\mathrm{N}_{2}\right)$ renderia quatro elétrons de alta energia que fluiriam através de um complexo enzimático formado pela Quinona e o citocromo $\mathrm{bc}_{1}$ translocador de $\mathrm{H}^{+}$formando assim uma força próton motriz positiva (FPM). A FPM energizaria o complexo ATPase translocador de próton para produção de ATP no riboplasma. Os elétrons seriam reciclados pelo grupo Quinona e citocromo oxidoredutase durante a reação de formação da hidrazina. 
No segundo modelo, sugere-se uma rota metabólica na qual durante o processo catabólico a força próton motriz (FPM) comandaria a reversão na cadeia transportadora de elétrons ao combinar-se com a ação da enzima nitrato redutase para gerar ferrodoxina usada na redução do dióxido de carbono na via metabólica acetil-CoA (Figura 3.18b). Esse mecanismo seria possível porque a hidrazina doaria elétrons de alta energia para a ferrodoxina e esses não seriam reciclados, dessa forma, seria necessário à oxidação do nitrito a nitrato pela enzima nitrato redutase compensando essa perda de elétrons. Os elétrons de baixa energia seriam “energizados" pela FPM durante a oxidação anaeróbia da amônia.
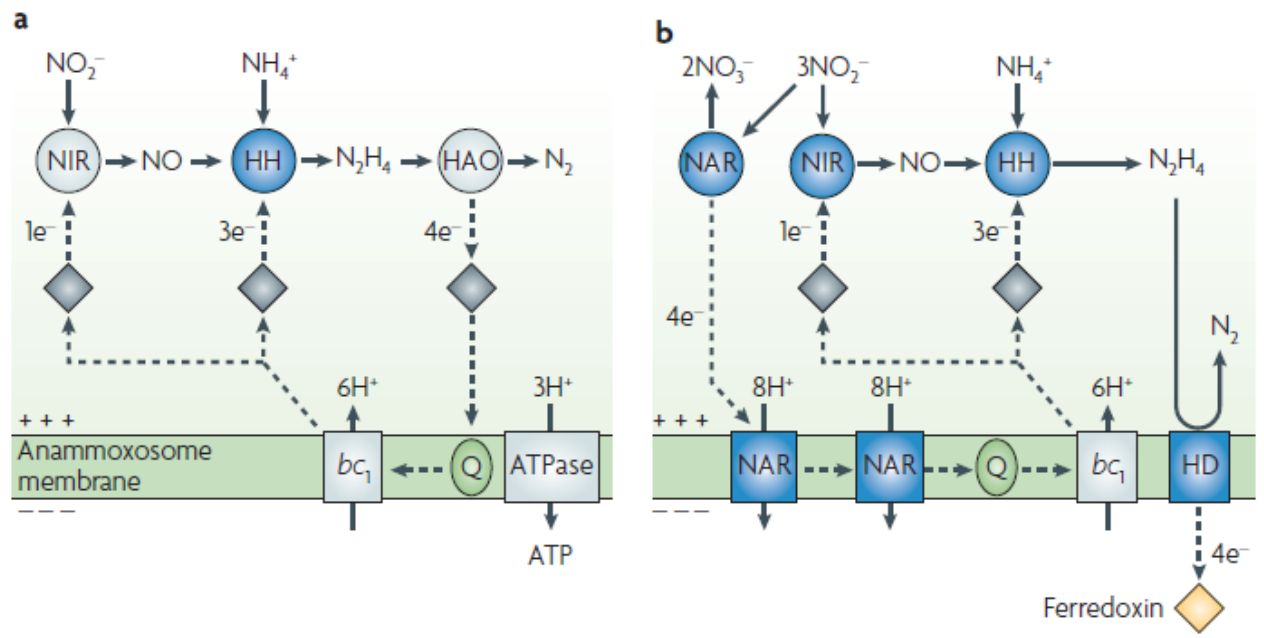

Figura 3.18: Catabolismo Hipotético e a reversão na cadeia transportadora de elétrons no anamoxossomo, estrutura celular das bactérias anammox. HAO: enzima hidrazina oxidoredutase; HD: enzima hidrazina dehidrogenase; HH: enzima hidrazina hidrolase; NIR: enzima nitrito oxidoredutase; NAR: enzima nitrato redutase (Kuenen, 2008).

Tem-se, ainda, participando do ciclo do nitrogênio os micro-organismos desnitrificantes heterotróficos facultativos (quimiorganotróficos) e agrupam-se principalmente entre os gram-negativos das Classes $\alpha$ e $\beta$ das Proteobacteria, sendo os mais comuns Pseudomonas, Alcaligenes, Paracoccus, Thiobacillus. Há bactérias gram-positivas, como o gênero Bacillus, e algumas arqueias halofilíticas como Halobacterium (Ahn, 2006). Existe a possibilidade da desnitrificação sendo realizada por bactérias litoautotróficas, fototróficas e por fungos. Nesse mecanismo os desnitrificantes utilizam compostos inorgânicos de enxofre, hidrogênio, amônia e nitrito como aceptores de elétrons (Ahn, 2006). 
A versatilidade metabólica desses micro-organismos permite a eles que em determinadas situações aeróbias realizem a desnitrificação atuando com metabolismo autotrófico, citandose as espécies de Paracoccus, Magnetospirillum e algumas cepas de Pseudomonas (Ahn, 2006).

Com o objetivo de demonstrar a estrutura filogenética dos grupos de micro-organismos envolvidos nos processos de oxidação dos compostos de nitrogênio é apresentada na Figura 3.19 a árvore filogenética partindo do último ancestral em comum (LUCA) conforme hipotetizado por Vlaeminck et al. (2011).

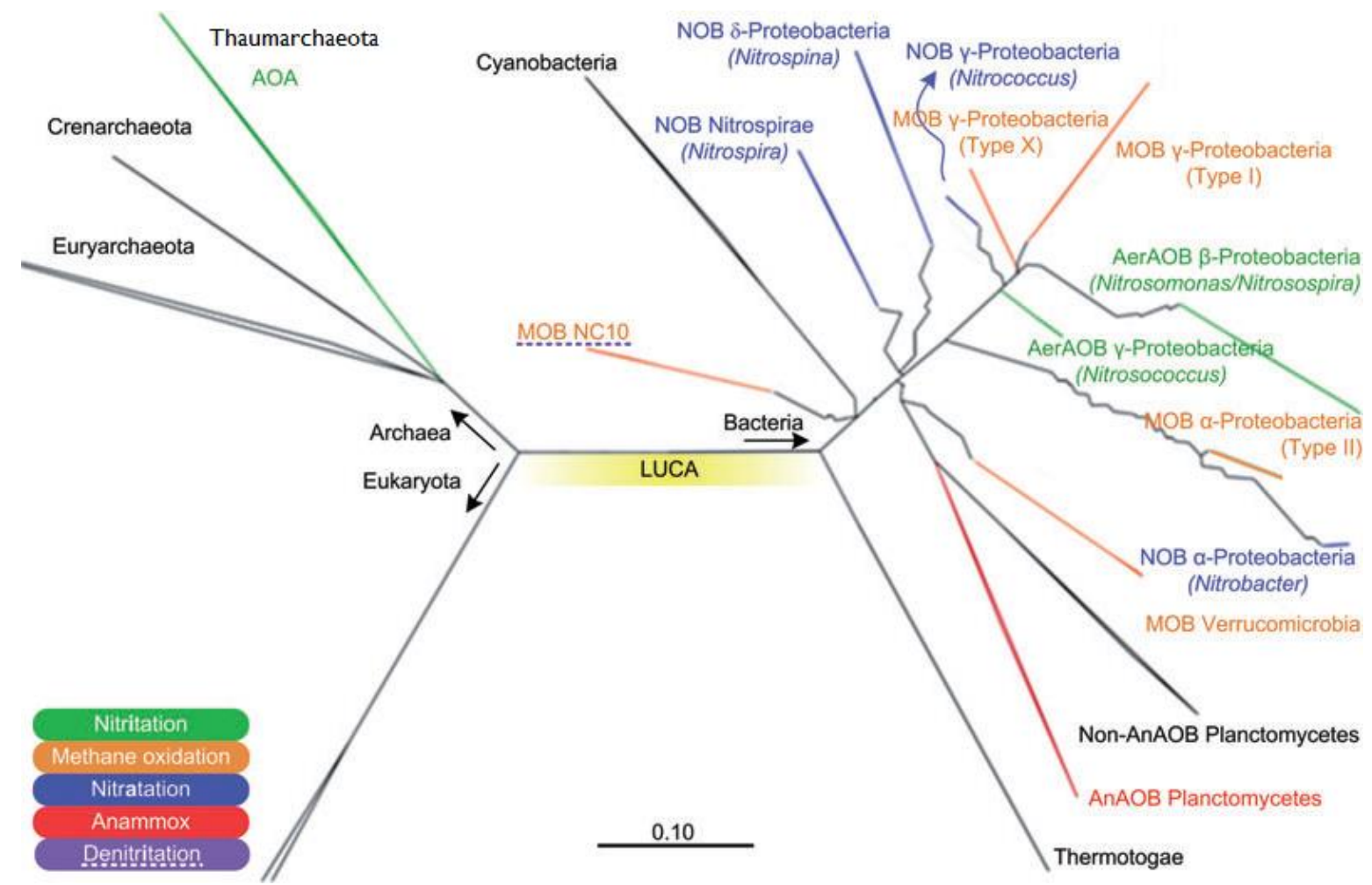

Figura 3.19: Árvore Filogenética destacando os organismos relacionados ao ciclo do nitrogênio baseada em sequências de genes do RNA ribossomal 16S (Vlaeminck et al., 2011). 


\section{4 - PARÂMETROS DE CONTROLE PARA O PROCESSO ANAMMOX}

Em todos os novos arranjos de processos e sistemas biológicos para remoção de nitrogênio, o processo anammox é essencial e, portanto, torna-se necessário o desenvolvimento de biomassa, com os micro-organismos responsáveis pelo processo, enriquecida e adaptada à remoção dos compostos nitrogenados de águas residuárias.

Para o desenvolvimento e adaptação da biomassa deve-se buscar conhecer os limites dos vários parâmetros operacionais e identificar condições para conferir vantagens competitivas às bactérias anammox dentro dos sistemas biológicos. Durante o período de partida dos sistemas visando a atividade anammox ocorrem interações interespecíficas na comunidade microbiana interferindo no sucesso de estabelecimento das bactérias oxidadoras anaeróbias de amônia. Vários grupos de bactérias que atuam no ciclo do nitrogênio estão presentes nos inóculos e as condições estabelecidas para os sistemas são determinantes para o sucesso de um ou mais grupos.

Vários parâmetros operacionais são importantes para ocorrência exclusiva e/ou simultânea dos processos biológicos em reatores, sendo eles: $\mathrm{pH}$, temperatura, concentração de oxigênio dissolvido, tipos e concentrações de substratos, configurações de reatores, tempo de detenção hidráulica e de retenção de lodo, estratégias de alimentação, cargas de nitrogênio aplicadas (Ganigué et al., 2007).

Os principais processos biológicos que concorrem nos sistemas visando atividade anammox são a nitritação, nitratação, desnitrificação heterotrófica e degradação de carbono por bactérias heterotróficas mesófilas e a seguir é apresentado um quadro resumo das faixas de parâmetros que podem promover a ocorrência dos processos biológicos, em especial, o anammox (Tabela 3.5).

Nos sistemas biológicos visando a atividade anammox é desejável a formação de nitrito pelas bactérias aeróbias oxidadoras de amônia (BOA) e a restrição da oxidação do nitrito a nitrato pelas bactérias aeróbias oxidadoras de nitrito (BON). Dessa maneira, as concentrações de oxigênio dissolvido são determinantes para atuação de BOA e BON. 
Tabela 3.5: Condições que promovem a ocorrência dos processos biológicos relacionados ao ciclo do nitrogênio.

\begin{tabular}{|c|c|c|c|c|c|}
\hline Parâmetro & 胥 & 苞 & 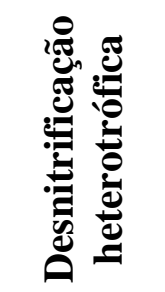 & 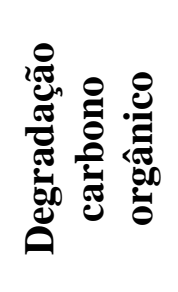 & 畹 \\
\hline OD & $>0,2$ & $>1,0$ & $<1,0$ & $>0,5$ & $<1,0$ \\
\hline Temperatura & $>25^{\circ} \mathrm{C}$ & & & & $20 \mathrm{a} 43^{\circ} \mathrm{C}$ \\
\hline $\mathrm{pH}$ & $\approx 7$ & & & & 6,7 a 8,3 \\
\hline Carbono orgânico & - & - & presente & presente & - \\
\hline Nitrito & & & & & $<98,0$ \\
\hline $\mathrm{NH}_{3}$ livre* & $<250,0$ & $<1,0$ & & & - \\
\hline Alcalinidade & $\begin{array}{l}4,05 \mathrm{mg} \\
\mathrm{CaCO}_{3} . \\
\mathrm{mg}^{-1} \mathrm{NH}_{4}\end{array}$ & $\begin{array}{l}3,02 \mathrm{mg} \\
\mathrm{CaCO}_{3} . \\
\mathrm{mg}^{-1} \mathrm{NO}_{2}\end{array}$ & & & - \\
\hline
\end{tabular}

Concentrações em mg.L $\mathrm{L}^{-1}$.

Uma das condições para que ocorra o processo competitivo entre as bactérias nitrificantes é a limitação de oxigênio dissolvido (Sliekers et al., 2005). As bactérias aeróbias oxidadoras de amônia apresentam maior afinidade por oxigênio $\left(V_{\max } / K_{s}\right)$ e em reatores com baixas concentrações de oxigênio pode ocorrer o acúmulo de nitrito. Concentrações reduzidas de oxigênio dissolvido são, também, importantes para garantir a contínua atividade dos organismos anammox.

O oxigênio dissolvido e as concentrações de amônia são fatores chaves determinando a eficiência do processo de nitritação parcial e, portanto, podem ser usados para controlá-lo. Liang e Liu (2008), registraram perturbações temporárias na estabilidade de um reator de nitritação parcial quando aumentos nas cargas de amônia e de oxigênio dissolvido ocorriam. Esses pesquisadores variaram gradualmente cargas de 0,27 a $1,2 \mathrm{~kg} \mathrm{~N}-\mathrm{NH}_{4} \cdot \mathrm{m}^{-3} \mathrm{dia}^{-1}$ e ajustes de oxigênio dissolvido de 0,8 a 2,3 mg.. $\mathrm{L}^{-1}$.

Sliekers et al. (2002), desenvolveram uma estratégia para operação de um reator em bateladas sequenciais (RBS), em escala de bancada, visando a remoção de nitrogênio pelo sistema CANON, ou seja, atuação combinada dos micro-organismos aeróbios e anaeróbios oxidadores de amônia. Para estabilização da etapa de nitritação, a concentração de oxigênio dissolvido foi mantida abaixo de $0,2 \mathrm{mg} . \mathrm{L}^{-1}$. Em outros dois estudos, visando a remoção das 
formas nitrogenadas pela combinação dos processos nitritação parcial, anammox e desnitrificação heterotrófica (SNAD), foram operados reatores de discos rotativos para remoção de nitrogênio mantendo o oxigênio dissolvido numa faixa de 0,5 a 0,7 mg. $\mathrm{L}^{-1}$ (Chen et al., 2009) e reatores em bateladas sequencias com concentrações de oxigênio dissolvido mantidas entre de 0,5 a 1 mg.L $\mathrm{L}^{-1}$ (Lan et al., 2011).

Registra-se, também, que a versatilidade metabólica das bactérias aeróbias oxidadoras de amônia permite que as mesmas estejam presentes em condições anóxicas, no entanto, só efetuam a nitritação quando o oxigênio é oferecido ao sistema. Esses organismos nitrificantes podem, inclusive, efetuar oxidação anaeróbia da amônia, mas em taxas 25 vezes menores do que aquelas observadas para biomassa anammox (Jetten et al., 1999).

Conclui-se que em condições limitantes de oxigênio pode-se oferecer um ambiente adequado para uma interação estável entre micro-organismos aeróbios como as Nitrosomonas e bactérias anaeróbias como as do grupo Brocadiales, oxidadoras de amônia (Sliekers, et al., 2002; Wang et al., 2010).

A temperatura e o pH são importantes parâmetros para as bactérias anammox que podem atuar numa faixa de 20 a $43^{\circ} \mathrm{C}$, tendo seu ótimo a $40^{\circ} \mathrm{C}$ e $\mathrm{pH}$ na faixa de 6,7 a 8,3 com ótimo a 8 (Jetten et al., 1999). A temperatura e o $\mathrm{pH}$, definidos para os sistemas, pode auxiliar na exclusão de determinados processos devido à promoção de formação de substâncias inibidoras.

A temperatura influencia na taxa de oxidação da amônia e dessa maneira na acumulação de nitrito. Ou seja, quanto maior a temperatura, maior será a eficiência de remoção de amônia (Liang e Liu, 2007). No entanto, deve-se observar que em temperaturas elevadas $\left( \pm 35^{\circ} \mathrm{C}\right)$ promove-se a formação de amônia livre (Anthoniesen et al., 1976).

As bactérias aeróbias oxidadoras de amônia (BOA) têm seu metabolismo inibido pela amônia livre e pelo ácido nitroso. A toxicidade da amônia livre e do ácido nitroso depende do $\mathrm{pH}$ e da temperatura do licor do sistema. De acordo com Anthonisen et al. (1976), o pH e a temperatura são os fatores que determinam as concentrações de amônia livre em equilíbrio com $\mathrm{NH}_{4}{ }^{+}-\mathrm{N}$. A faixa de inibição da amônia livre para as bactérias aeróbias oxidadoras de amônia (BOA) é muita ampla, com registros de concentrações variando entre 10 e 150 mg.L - $^{-1}$ (Kim et al., 2006). No entanto, em meios com temperatura de $30{ }^{\circ} \mathrm{C}$, pH 8,6 e concentrações de amônia livre e ácido nitroso oscilando entre 160-260 mg. $\mathrm{L}^{-1}$ e 0,007- 
0,019 mg. $\mathrm{L}^{-1}$, respectivamente, não provocaram inibição às bactérias nitritantes (Liang e Liu, 2008).

De acordo com Anthoniesen et al. (1976) as concentrações de amônia livre e de ácido nitroso são calculadas como funções do $\mathrm{pH}$, temperatura e amônia/nitrito totais utilizando as Equações 3.6 a 3.9 .

$$
\begin{gathered}
\text { Amônia livre }\left(\mathrm{mg}^{-1} \mathrm{~L}^{-1}\right)=\frac{\text { Amônia total }}{1+\left(1^{-p H} / K_{e}^{N H}\right)} \\
\text { Acido nitroso }\left(\mathrm{mg}^{-1} \mathrm{~L}^{-1}\right)=\frac{\text { Nitrito total }}{1+\left(\mathrm{K}_{e}^{N O} / 1^{-p H}\right)} \\
K_{e}^{N H}=e^{-6344 /(273+T)} \\
K_{e}^{N O}=e^{-2300 /(273+T)}
\end{gathered}
$$

(Equação 3.8)

(Equação 3.9)

As bactérias aeróbias oxidadoras de nitrito (BON) são sensíveis até mesmo a baixas concentrações de amônia livre. Concentrações de 0,1 a 1 mg.L $\mathrm{L}^{-1}$ são suficientes para causar inibição ao metabolismo das bactérias oxidadoras de nitrito (Kim et al., 2006). O nitrito é um substrato que se pretende acumular, pois é necessário para bactérias anammox como aceptores de elétrons (Liang e Liu, 2007).

Ressalta-se que a combinação de bactérias aeróbias oxidadoras de amônia com bactérias anammox limita a geração de subprodutos, tais como os óxidos nítricos e nitrosos (Sliekers et al., 2005).

Em condições ótimas para Nitrosomonas (BOA) e Nitrobacter (BON) tem-se rendimento em biomassa de $0,15 \mathrm{mg}$ células. $\mathrm{mg}^{-1} \mathrm{NH}_{4}-\mathrm{N}$ e $0,02 \mathrm{mg}$ células. $\mathrm{mg}^{-1} \mathrm{NO}_{2}{ }^{-}$, respectivamente, para taxas de consumo oxigênio de $3,16 \mathrm{mg} \mathrm{O} \cdot \mathrm{mg}^{-1} \mathrm{NH}_{4}-\mathrm{N}$ e $1,11 \mathrm{mg} \mathrm{O}_{2} \cdot \mathrm{mg}^{-1} \mathrm{NO}_{2}^{-}-\mathrm{N}$ e, ainda, um consumo de alcalinidade em ordem de 4,05 mg CaCO $3 . \mathrm{mg}^{-1} \mathrm{NH}_{4}-\mathrm{N}$ para a nitritação e de 3,02 mg CaCO $3 \cdot \mathrm{mg}^{-1} \mathrm{NO}_{2}-\mathrm{N}$ (Ahn, 2006). 
Dessa forma, por meio da manutenção do $\mathrm{pH}$ entre 7,5 e 8,5, temperatura em torno de $32^{\circ} \mathrm{C}$, concentrações de amônia entre 100 e 1000 mg.L ${ }^{-1}$ e de amônia livre em até 250 mg.L $\mathrm{L}^{-1}$, promove-se o crescimento de organismos oxidadores de amônia e inibe-se o desenvolvimento das bactérias aeróbias oxidadoras de nitrito. Para as bactérias nitritantes, em baixas concentrações de oxigênio dissolvido, a temperatura deve estar acima de $25^{\circ} \mathrm{C}$ e o pH próximo ao neutro (Egli et al., 2003; Aslan et al., 2009).

No desenvolvimento da biomassa anammox, as bactérias desnitrificantes heterotróficas são importantes competidores, pois atuam em condições anaeróbias consumindo o substrato nitrito. No entanto, esses micro-organismos dependem de carbono orgânico no meio para realizarem o metabolismo. Assim, em sistemas de tratamento de águas residuárias pelo processo convencional é necessária introdução de fonte externa de carbono e ou recirculações para completar a etapa de desnitrificação heterotrófica (Dapena-Mora et al., 2004; Ganigué et al., 2007; Liang \& Liu, 2007).

Na busca por um mecanismo ótimo de remoção de nitrogênio, o carbono orgânico presente nas águas residuárias deve ser consumido pelas bactérias desnitrificantes heterotróficas que o usará como fonte de carbono e energia (Wang et al., 2010). É interessante ajustar a ocorrência de desnitrificação, em condições sub-óxicas, para ocorrer concomitantemente com a nitritação em reatores destinados a condicionar à agua residuária à relação molar de 1:1,32 mol entre amônia $\left(\mathrm{NH}_{4}\right)$ e nitrito $\left(\mathrm{NO}_{2}\right)$ necessária à reação anammox. Geralmente, nesses sistemas recircula o efluente do reator anammox de volta para o reator de nitritação/desnitrificação para consumo do nitrato pelas bactérias desnitrificantes.

Também, concorrendo nos sistemas de tratamento para remoção de nitrogênio, tem-se as bactérias heterotróficas mesófilas que estabilizam os compostos orgânicos presentes nas águas residuárias e disputam o oxigênio dissolvido com as BOA e o carbono orgânico com as bactérias desnitrificantes (Kim et al., 2006; Tao et al., 2013). Dessa maneira, para o tratamento de determinadas águas residuárias com altas concentrações de matéria orgânica por processos combinados de nitritação e anammox deve-se aumentar a concentração de oxigênio dissolvido disponível. No estudo realizado por Liang e Liu (2007), tratando chorume em reatores de fluxo ascendente e de leito fixo, quando as cargas aplicadas de amônia foram maiores que $0,5 \mathrm{Kg} \mathrm{NH}_{4}-\mathrm{N} \cdot \mathrm{m}^{-3} \mathrm{~d}^{-1}$ e a proporção entre $\mathrm{C} / \mathrm{N}$ ficou entre 1 e 2 foi necessário ajustar as concentrações de oxigênio dissolvido para 1,8 a 2,3 mg. $\mathrm{L}^{-1}$. 
Ressalta-se que o oxigênio dissolvido inibe o processo anammox, mas em baixas concentrações é um inibidor reversível. Jetten et al. (1999) operando um reator em bateladas e introduzindo oxigênio ao sistema de forma intermitente, sendo 2 horas óxicas e 2 horas anóxicas, verificaram atividade anammox quando o reator se encontrava anóxico.

Para a efetividade da atuação dos micro-organismos anammox em sistemas biológicos é, ainda, necessário considerar alguns outros parâmetros, tais como a estratégia de alimentação minimizando acúmulo de substâncias inibidoras, as cargas de amônia aplicáveis e o tipo de reator para sucesso na retenção de biomassa.

Condições adequadas devem ser ajustadas para que também as bactérias anaeróbias oxidadoras de amônia atuem em conjunto com as bactérias aeróbias oxidadoras de amônia na remoção de nitrogênio nos sistemas. Constataram-se que sistemas CANON, em bateladas alimentadas e sequenciais, foram eficientes na remoção de nitrogênio a uma taxa de $0,12 \mathrm{~kg}$ N.m ${ }^{-3} \mathrm{dia}^{-1}$ quando garantidos concentrações contínuas de amônia sob baixas concentrações de oxigênio (<0,24 mg. $\left.\mathrm{L}^{-1}\right)$ (Third et al., 2001). Da mesma maneira, Vives et al. (2007), demonstraram que a estratégia de alimentação ao longo de toda a fase de reação resultou em melhor estabilidade tratando chorume com concentração de amônia de $2500 \mathrm{mg} \mathrm{N}-\mathrm{NH}_{4} \cdot \mathrm{L}^{-1}$, do que a estratégia de alimentação somente no início da fase de reação.

No entanto, a combinação desses dois processos biológicos apresenta alguns inconvenientes tais como: a) devem ser conduzidos em altas temperaturas $\left( \pm 35^{\circ} \mathrm{C}\right)$ e, assim, consequente gasto de energia; b) controle das concentrações de ácido nitroso e amônia livres para evitar situações de inibição dos processos metabólicos das bactérias autotróficas no reator de nitrificação parcial e c) o crescimento lento das bactérias anammox é um importante entrave durante o período de partida dos reatores (Vives et al., 2007).

Vale destacar que as temperaturas registradas nas regiões tropicais favorecem a aplicação de tecnologias de tratamento de águas residuárias por processos biológicos dependentes de temperaturas mesófilas $\left( \pm 35^{\circ} \mathrm{C}\right)$ (Aiyuk et al., 2006; Sánchez et al., 2014).

Tem-se, também, que a eficiência da nitritação é fortemente dependente de alcalinidade disponível. Teoricamente, o licor no sistema deve apresentar uma relação molar entre $\mathrm{HCO}_{3}{ }^{-}$ e $\mathrm{NH}_{4}{ }^{+}$de aproximadamente 1,14. Vives et al. (2007) mostraram que a estratégia de alimentação, ao longo de toda a fase de reação em um reator de bateladas, manteve a relação molar estável e garantiu um efluente com a composição desejável de $0,77 \mathrm{~mol} \mathrm{de} \mathrm{NH}_{4}{ }^{+}$para 
$1 \mathrm{~mol} \mathrm{de} \mathrm{NO}_{2}^{-}$.

Quando se combinam vários processos num único sistema, como o caso do SNAD, os processos anammox e desnitrificação heterotrófica podem produzir alcalinidade suficiente para manter constante o $\mathrm{pH}$ da solução, mesmo ocorrendo o consumo pela nitritação parcial (Wang et al., 2010).

Ainda, a estratégia de alimentação pode auxiliar no controle das concentrações de várias fontes inibitórias ao processo anammox, tais como concentrações dos substratos, matéria orgânica, salinidade, metais pesados, fosfatos e sulfetos (Jin et al., 2012). Jetten et al. (1999), apresentaram uma lista de substâncias que podem ter efeito inibidor para a atividade anammox, sendo elas: 2,4-dinitrofenol, cianeto de carbonila-clorofenilhidrazona, cloreto de mercúrio, oxigênio, fosfato e concentrações altas de nitrito.

Concentrações elevadas de nitrito, um dos substratos da reação, causam inibição da atividade anammox (Strous et al., 1999b; Jetten et al., 1999; Dapena-Mora et al., 2004; Liang e Liu, 2008). A concentração inibitória citada por Strous et al. (1999b) é de $98 \mathrm{mg}$. L ${ }^{-1}$ de nitrito. Em reatores em bateladas sequenciais visando a desnitrificação por processo anammox operados por Vives et al. (2007), e de leito fixo operado Liang e Liu (2008), foram verificadas inibições do processo anammox quando o nitrito atingiu concentrações acima de $90 \mathrm{mg} . \mathrm{L}^{-1}$. Ressalta-se que o afluente ao sistema anammox deve apresentar uma relação molar entre amônia e nitrito de 1,3 (Strous et al. 1998).

No entanto, em um reator de gás-lift somente em concentrações de nitrito próximas a 200 mg. $L^{-1}$ é que ocorreu a desestabilização do processo anammox. Nesse caso, o acúmulo de nitrito foi resultado da perda de biomassa devido à sua flotação ocasionada por bolhas de gases no interior dos grânulos. A flotação da biomassa ocorreu devido à sobrecarga de nitrogênio afluente que excedeu a atividade específica anammox da biomassa (Dapena-Mora et al., 2004).

A carga de amônia é, também, um parâmetro importante que influencia a estabilidade da remoção de nitrogênio por organismos anammox. Cargas de amônia superiores a 0,12 kg $\mathrm{NH}_{4} \cdot \mathrm{m}^{-3} \mathrm{~d}^{-1}$ resultaram em diminuição na taxa de remoção de nitrogênio em um reator de leito fixo operado para favorecer o processo anammox (Liang e Liu, 2008). No entanto, em vários estudos citados em Dapena-Mora et al. (2004) ficou demonstrado que é possível tratar cargas de nitrogênio entre 1,0 a 2,4 kg N.m ${ }^{-3} \mathrm{dia}^{-1}$ pelo processo anammox. 
A carga específica de nitrogênio aplicada está fortemente relacionada à concentração da biomassa no reator e ao valor máximo da atividade específica anammox $\left(1 \mathrm{gN} \mathrm{g}^{-1}\right.$ biomassa $\left.\mathrm{dia}^{-1}\right)$ (Dapena-Mora et al., 2004).

As bactérias anammox tem crescimento lento que é atribuído à conversão lenta do substrato, sendo $\mathrm{V}_{\max }$ de $55 \mathrm{nmol} \cdot \mathrm{min}^{-1} \cdot \mathrm{mg}^{-1}$ proteína. Assim, o rendimento para esse grupo foi estimado em 0,07 mol de carbono fixado. $\mathrm{mol}^{-1}$ de amônia oxidada (Khin e Annchhatre, 2004).

Reatores em bateladas sequenciais fornecem um bom modelo experimental para cultivar micro-organismos anammox (Strous et al., 1998). Esse tipo de reator retém eficientemente a biomassa, proporciona distribuição homogênea do substrato, produtos e dos flocos da biomassa e permite otimizar condições para as bactérias anammox (Jetten et al., 1999). São citados como parâmetros fisiológicos importantes ao adotar esse modelo do sistema: rendimento da biomassa, taxa máxima específica de consumo de amônia e taxa máxima de crescimento específica. Outra vantagem para a adoção dos reatores em bateladas é que há menores possibilidades de acumulação de nitrito em concentrações inibitórias ao processo anammox (Dapena-Mora et al., 2004).

Em sistemas usando reatores de leito fixo, leito fluidizado e gás-lift pode-se, também, conseguir uma boa retenção de biomassa (Dapena-Mora et al., 2004; Liang e Liu, 2008).

Dapena-Mora et al. (2004) demonstraram que a estabilidade da estrutura dos grânulos nos sistemas é um dos fatores importantes para a eficiência do processo anammox. Quanto maior a densidade dos grânulos, maiores as forças de coesão entre as bactérias e, consequentemente, redução da possibilidade de acumulação de gases no interior dos grânulos, redução de lise celular e, ainda, redução das perdas de substratos intermediários importantes para os micro-organismos anammox.

Mediante o conjunto de parâmetros operacionais e condições físico-químicas apresentados que permitem o desenvolvimento dos micro-organismos anammox e que possibilitam a combinação com outras bactérias consorciadas do ciclo do nitrogênio tem-se os seguintes exemplos.

Wang et al. (2010), definiram condições para ocorrência simultânea dos processos nitritação parcial, anammox e desnitrificação em um único sistema em tanques aerados, escala plena, 
tratando chorume. As condições usadas para ocorrência conjunta desses processos biológicos foram: 1,6 dias de tempo de detenção hidráulica; 12 a 18 dias de retenção de lodo; concentrações de 2110 e 1505 mg.L L $^{-1}$ de sólidos suspensos totais e voláteis, respectivamente; concentração de oxigênio dissolvido em $0,3 \mathrm{mg} . \mathrm{L}^{-1}$, $\mathrm{pH}$ mantido em torno de 7,4 e temperatura oscilando entre 30 e $33^{\circ} \mathrm{C}$. As concentrações médias afluentes de carbono orgânico e amônia foram de 554 e $634 \mathrm{mg} . \mathrm{L}^{-1}$, respectivamente. Os resultados de eficiência de remoção de carbono orgânico e amônia foram de $28 \%$ e $80 \%$, respectivamente (Wang et al., 2010).

A remoção de nitrogênio pelo processo SNAD também foi obtida usando um RBS tratando água residuária sintética (Lan et al., 2011). As condições usadas foram temperatura a $35^{\circ} \mathrm{C}$, pH entre 7 e 8 , concentração de oxigênio dissolvido entre 0,5 e 1,0 mg. $\mathrm{L}^{-1}$, alcalinidade de 250-300 mg $\mathrm{CaCO}_{3} \cdot \mathrm{L}^{-1}$. O diferencial nesse trabalho foi avaliar o tempo de detenção hidráulica necessária para remover amônia e carbono em concentrações de 200 mg.L $\mathrm{L}^{-1}$ e 100 mg. $\mathrm{L}^{-1}$, respectivamente. A remoção de $96 \%$ de $\mathrm{NH}_{4}{ }^{+}$e de $86 \%$ de COD foi obtida quando as cargas aplicadas foram de $44 \mathrm{gN} \cdot \mathrm{m}^{-3} \mathrm{dia}^{-1}$ e $22 \mathrm{gC} \cdot \mathrm{m}^{-3} \mathrm{dia}^{-1}$ equivalendo a período de detenção hidráulica de 4,5 dias.

\section{5 - DETECÇÃO DOS MICRO-ORGANISMOS}

Até poucas décadas, as técnicas microbiológicas convencionais foram as únicas ferramentas possíveis para investigação das comunidades microbianas. Estas baseavam-se na obtenção de culturas puras a partir de meios seletivos e de enriquecimento. No entanto, a falta de informações sobre fisiologias, interações simbióticas e sintróficas dificultavam a obtenção de culturas in vitro (Sanz e Kochling, 2006). Acredita-se que, na maioria absoluta (99\%), as células dos micro-organismos de amostras ambientais não sejam recuperadas em cultura puras usando metodologias de plaqueamento e por estimativas do número mais provável (Gao et al., 2011; Youssef et al., 2014).

A aplicação das técnicas de biologia molecular para o conhecimento das comunidades biológicas de reatores para tratamento de águas residuárias tem auxiliado no entendimento dos vários processos biológicos (Sanz e Kochling, 2006; Sánchez et al., 2014). 
A abordagem baseada nos genes que codificam o RNAr 16S tem sido amplamente adotada pela comunidade científica e utilizada para estudos de diversidade microbiana por meio da sistemática de micro-organismos (Krieg et al., 2011; Ludwig et al., 2011; Yossef et al., 2014). O RNAr 16S é uma molécula encontrada na pequena subunidade ribossomal dos procariotos e é considerada um cronômetro evolutivo, pois foi altamente conservada ao longo da evolução, apresenta regiões extremamente variáveis e está presente abundantemente em todos os seres vivos (Madigan et al., 2010). Mais recentemente, os genes que codificam o espaço intergênico e o RNAr 23S têm sido também adotados nos estudos (Jetten et al., 2011).

Tem-se, ainda, utilizados genes específicos, ou seja, que codificam proteínas enzimáticas únicas e específicas para cada grupo de organismos. De acordo com Hirsch et al. (2011), o uso das ferramentas moleculares, tendo como alvo os genes funcionais, têm aumentando a detecção e compreensão da diversidade microbiológica envolvendo o ciclo do nitrogênio.

As principais técnicas moleculares atualmente utilizadas para estudar os micro-organismos em sistemas de tratamento de águas residuárias são Reação em Cadeia de Polimerase (PCR) convencional e quantitativa, Eletroforese em Gradiente de Gel Desnaturante (DGGE), Hibridização Fluorescente in situ (FISH), Clonagem e Sequenciamento dos genes (Sanz e Kochling, 2006).

Os estudos com resultados mais consistentes baseiam-se no uso combinado das várias técnicas de biologia molecular. Em estudos de comunidades microbianas advindas de estações de tratamento de águas residuárias, a técnica de DGGE tem sido aplicada em conjunto com hibridização fluorescente in situ (FISH) que, além de confirmar a presença de determinado grupo detectado pelo DGGE, permite uma análise quantitativa (Sanz e Kochling, 2006). Os estudos tratando dos micro-organismos relacionados ao ciclo do nitrogênio têm adotado as técnicas moleculares disponíveis como segue.

Araújo et al. (2010), utilizaram as técnicas moleculares de PCR e FISH para identificar e quantificar a biomassa de um reator operado em bateladas sequenciais com meio sintético visando a atividade anammox.

Martins (2007) utilizou-se de DGGE para avaliar mudanças na estrutura dos consórcios presentes em quimiostatos operados para enriquecimento de bactérias anammox e com a técnica de FISH confirmou a presença desses organismos nos consórcios microbianos. 
Wang et al. (2010), usando primers e sondas específicas para grupos anammox utilizaramse das técnicas de PCR e FISH, com a finalidade de avaliar a presença desse grupo em tanques de aeração onde os processos de nitritação parcial, anammox e desnitrificação ocorriam concomitantemente.

O uso de PCR quantitativa vem ganhando destaque nas avaliações de sistemas de tratamento visando processos de remoção de nitrogênio. Hu et al. (2010) identificaram e quantificaram bactérias anammox em oito reatores para remoção de nitrogênio. Esses autores avaliaram a diversidade e abundância de bactérias anammox observando-se configuração de reatores, idade do lodo e fonte dos inóculos usando as técnicas de análise de PCR quantitativa e FISH. Outra vantagem da PCR quantitativa é permitir acompanhar o aumento do número de cópias de DNA dos genes de interesse ao longo do tempo em sistemas biológicos e, com isso, ter uma eficiente metodologia para estimar o tempo de duplicação de bactérias (Tsushima et al., 2007a; Bae et al., 2010; Park et al., 2010).

Bae et al. (2010) usaram clonagem e sequenciamento do gene para o RNAr 16S para construção de árvores filogenéticas avaliando a diversidade de clones relacionados ao Filo Planctomycetes em 5 inóculos diferentes visando partidas de reatores anammox, tendo sido registradas uma variedade de unidades taxonômicas operacionais (OTU) nos inóculos testados, indicando grande diversidade principalmente para aqueles inóculos provenientes de sistemas ambientais anaeróbios e anóxicos tratando águas residuárias ricas em nitrogênio. A técnica PCR quantitativa foi também utilizada para avaliação dos enriquecimentos visando atividade anammox. Park et al. (2010) utilizaram-se das técnicas de PCR quantitativa, PCR convencional e DGGE para avaliarem o impacto dos tipos de inóculos nas taxas de crescimento dos micro-organismos, na velocidade de utilização dos substratos, no efeito das condições de operação em comunidades anammox em biorreatores.

Os iniciadores ou primers, utilizados nas técnicas moleculares, para a detecção de bactérias aeróbias e anaeróbias oxidadoras de amônia são baseados no gene de RNAr 16S e/ou em genes específicos como amoA, que codificam a subunidade catalítica $\alpha$ da enzima amônia monoxigenase (Li et al., 2010) e para o gene hzo, responsável pela enzima que sintetiza a hidrazina, molécula indicadora da atividade das bactérias anammox (Hirsh et al., 2010; Schmid et al., 2008).

Jetten et al. (2005) recomendam o uso das técnicas moleculares, tal como o PCR e FISH, 
específicos para a ordem Brocadiales na análise ambiental de habitats em que potencialmente ocorre o processo anammox. Dessa forma, alguns estudos utilizam-se das técnicas de biologia molecular para realizarem varreduras de sistemas ambientais naturais e antropizados como as estações de tratamentos de esgotos domésticos e efluentes agroindustriais ricos em cargas de nitrogênio, procurando pelos micro-organismos anammox, visando indicar biomassas para partidas mais rápidas de sistemas anammox (Sànchez-Melsió et al., 2009; Bae et al., 2010; Hu et al., 2010; Costa, 2013a).

A técnica de FISH tem sido muito utilizada na obtenção de dados qualitativos e quantitativos de bactérias anammox em amostras ambientais (Schmid et al., 2005). A sonda S-P-Planc0046-a-A-18 (Pla46) que hibridiza com o gene do RNAr 16S é muito recomendada para experimentos iniciais visando a identificação e quantificação da maioria dos Planctomicetales, hibridizando também com o grupo Brocadiales (Jetten et al., 2011). A sonda S-D-Bact-0338-d-A-18 é indicada para identificar o gene RNAr 16S de Isosphaera que não é detectável com a sonda Pla46 (Schmid et al., 2005).

É importante selecionar e combinar primers específicos para esses micro-organismos a fim de comparações e construções de árvores filogenéticas. Existem alguns primers que oferecem uma boa resposta na amplificação dos micro-organismos anammox e a combinação de alguns oferece uma boa especificidade para determinados grupos de organismos anammox (Schmid et al., 2005). Os primers mais utilizados para a amplificação dos genes baseados no RNAr 16S por meio da técnica de PCR são apresentados na Tabela 3.6. Inicialmente a maior parte dos primers foram desenhados visando "Candidatus Brocadia anammoxidans", mas registrou-se o iniciador S-*-Amx-820-a-A-22 (Amx 820) hibridizando com "Candidatus Kuenenia stuttgartiensis" (Jetten et al., 2011).

É muito efetiva a combinação do primer S-P-Planc-0046-a-A-18 (direto) com o primer reverso S-*-Amx-0368-a-A-18 para detecção da maioria dos micro-organismos anammox conhecidos (Schmid et al., 2005; Jetten et al., 2011). Foi com o uso desses primers que Sànchez-Melsió et al. (2009) confirmaram a presença de “Ca. Brocadia anammoxidans” em seis inóculos testados para enriquecimento anammox. 
Tabela 3.6: Primers desenhados com base nos genes para o RNAr 16S utilizados nas técnicas moleculares de amplificação do material genético dos organismos anammox.

\begin{tabular}{|c|c|c|}
\hline Nome referência & Especificidade & Sequência 5'-3' \\
\hline S-P-Planc-0046-a-A-18 (Pla46) & Planctomycetes & GACTTGCATGCCTAATCC \\
\hline S-P-Planc-0886-a-A-19 (Pla886) & $\begin{array}{l}\text { Isosphaera, Gemmata, Pirellula, } \\
\text { Planctomyces }\end{array}$ & GCCTTGCGACCATACTCCC \\
\hline S-D-Bact-0338-b-A-18 (Eub3381I) & $\begin{array}{l}\text { Linhagens de bactérias não abrangidas } \\
\text { pelas sondas EUB338 e EUB3381Ia }\end{array}$ & GCAGCCACCCGTAGGTGT \\
\hline S-D-Bact-0338-d-A-18 (Eub3381V) & $\begin{array}{l}\text { Linhagens de bactérias não abrangidas } \\
\text { pelas sondas EUB338 e EUB3381Ia e } \\
\text { EUB111 }\end{array}$ & GCAGCCTCCCGTAGGAGT \\
\hline S-*-Amx-0368-a-A-18 & Todos os organismos anammox & CCTTTCGGGCATTGCGAA \\
\hline L-*-Amx-1900-a-A-21 & Gênero " $C a$. Brocadia" e " $C a$. Kuenenia" & CATCTCCGGCTTGAACAA \\
\hline S-*-Amx-0820-a-A-22 (Amx820) & Gênero "Ca. Brocadia" e "Ca. Kuenenia" & AAAACCCCTCTACTTAGTGCCC \\
\hline S-G-Sea-1309-a-A-21 & Gênero " $C a$. Scalindua" & TGGAGGCGAATTTCAGCCTCC \\
\hline S-*-Seabr-1114-a-A-22 & "Ca. Scalindua brodae" & CCCGCTGGTAACTAAAAACAAG \\
\hline S-*-BS-820-a-A-22 & $\begin{array}{l}\text { "Ca. Scalindua wagneri" } \\
\text { "Ca. Scalindua sorokinii" }\end{array}$ & TAATTCCCTCTACTTAGTGCCC \\
\hline S-S-Kst-0157-a-A-18 & "Ca. Kuenenia stuttgartiensis" & GTTCCGATTGCTCGAAAC \\
\hline S-S-Kst-1275-a-A-20 & "Ca. Kuenenia stuttgartiensis" & TCGGCTTTATAGGTTTCGCA \\
\hline S-S-Ban-0162(B.anam.)-a-A-18 & "Ca. Brocadia anammoxidans" & CGGTAGCCCCAATTGCTT \\
\hline S-*-Amx-0156-a-A-18 & "Ca. Brocadia anammoxidans" & CGGTAGCCCCAATTGCTT \\
\hline S-*-Amx-0223-a-A-18 & "Ca. Brocadia anammoxidans" & GACATTGACCCCTCTCTG \\
\hline S-*-Amx-0432-a-A-18 & "Ca. Brocadia anammoxidans" & CTTAACTCCCGACAGTGG \\
\hline S-*-Amx-0613-a-A-22 & "Ca. Brocadia anammoxidans" & CCGCCATTCTTCCGTTAAGCGG \\
\hline S-*-Amx-0997-a-A-21 & "Ca. Brocadia anammoxidans" & TTTCAGGTTTCTACTTCTACC \\
\hline S-*-Amx-1015-a-A-18 & "Ca. Brocadia anammoxidans" & GATACCGTTCGTCGCCCT \\
\hline S-*-Amx-1154-a-A-18 & "Ca. Brocadia anammoxidans" & TCTTGACGACAGCAGTCT \\
\hline S-*-Amx-1240-a-A-23 & "Ca. Brocadia anammoxidans" & TTTAGCATCCCTTTGTACCAACC \\
\hline I-*-Ban-0071(B.anam.)-a-A-18 & "Ca. Brocadia anammoxidans" & CCCTACCACAAACCTCGT \\
\hline I-*-Ban-0108(B.anam.)-a-A-18 & "Ca. Brocadia anammoxidans" & TTTGGGCCCGCAATCTCA \\
\hline I-*-Ban-0222(B.anam.)-a-A-19 & "Ca. Brocadia anammoxidans" & GCTTAGAATCTTCTGAGGG \\
\hline I-*-Ban-0389(B.anam.)-a-A-18 & "Ca. Brocadia anammoxidans" & GGATCAAATTGCTACCCG \\
\hline I-*-Kst-0031(K.stutt.)-a-A-18 & "Ca. Kuenenia stuttgartiensis" & ATAGAAGCCTTTTGCGCG \\
\hline I-*-Kst-0077(K.stutt.)-a-A-18 & "Ca. Kuenenia stuttgartiensis" & TTTGGGCCACACTCTGTT \\
\hline I-*-Kst-0193(K.stutt.)-a-A-19 & "Ca. Kuenenia stuttgartiensis" & CAGACCGGACGTATAAAAG \\
\hline I-*-Kst-0288(K.stutt.)-a-A-20 & "Ca. Kuenenia stuttgartiensis" & GCGCAAAGAAATCAAACTGG \\
\hline $\operatorname{An} 7 F^{2}$ & Todos os organismos anammox & GGCATGCAAGTCGAACGAGG \\
\hline An1388R 2 & Todos os organismos anammox & GCTTGACGGGCGGTGTG \\
\hline
\end{tabular}

Fonte: Schmid et al. (2005); ${ }^{2}$ Penton et al. (2006) 
Araújo et al. (2010) usaram a combinação do primer direto Pla46F formando par com os seguintes primers reversos Amx820R, Amx 1240R e Amx667R e, também, o par An7F An1388R na técnica de PCR para detecção e confirmação da presença das bactérias anammox no lodo do inóculo proveniente de um sistema de lodos ativados e, ao longo do enriquecimento usando reator em bateladas sequenciais.

Park et al. (2010), fizeram uso dos primers Pla46F e do Amx667R desenvolvidos por van der Star et al. (2007), para avaliarem como o tipo de inóculo e o modo de operação interferiram na ecologia microbiana das comunidades anammox de biorreatores.

Sànchez-Melsió et al. (2009), melhoraram a detecção de bactérias anammox como as do grupo "Candidatus Brocadia” ao aumentar a especificidade do primer, usando o Amx368 na posição forward (direto) e Amx820 na posição reversa.

Na utilização de PCR quantitativa para avaliação de número de cópias relacionadas aos genes que codificam o RNAr 16S do grupo de micro-organismos anammox utiliza-se da combinação de primers que resultem em fragmentos mais curtos, tais como os pares Amx694F e Amx960R desenvolvidos por Ni et al. (2010), do Amx809F com Amx1066R e do Amx818F com Amx1066R desenvolvidos por Tsushima et al. (2010).

Existe, ainda, técnicas para detecção de micro-organismos não baseadas em análises moleculares, tais como microscopia, avaliação da atividade por estequiometria, pela produção de hidrazina e por verificação da mudança de coloração da biomassa.

Uma vez que as células das bactérias anammox apresentam uma morfologia irregular incomum, pode-se valer dessa característica para uma avaliação quantitativa de consórcios microbianos com anammox por meio da técnica de microscopia eletrônica. Jetten et al. (1999), estimaram 64\% de células anammox após 177 dias em sistemas biológicos ajustados para enriquecimento anammox comparados aos $16 \%$ antes do período de enriquecimento. Wang et al. (2011), também, usaram a microscopia eletrônica de varredura (MEV) observando a morfologia e estrutura interna da biomassa das amostras de lodos para verificação da presença de micro-organismos anammox.

Quando se têm culturas enriquecidas anammox, a biomassa apresenta-se com coloração avermelhada, devido à presença de proteínas como citocromo do tipo c que é observável no espectro visível a $468 \mathrm{~nm}$ (Jetten et al., 1999). Assim, outra estratégia para avaliação da 
atividade anammox é monitorar o aumento do sinal observado a $468 \mathrm{~nm}$ em espectrofotômetro à medida que um consórcio se enriquece com micro-organismos anammox.

Um mecanismo alternativo para verificar a ocorrência do processo anammox é pela avaliação estequiométrica dos reagentes e produtos nitrogenados da reação anammox, conforme a equação 3.10, desenvolvida por Strous et al. (1998).

$$
\begin{aligned}
\mathrm{NH}_{4}^{+}+1,32 \mathrm{NO}_{2}^{-}+0,066 \mathrm{HCO}_{3}^{-}+0,13 \mathrm{H}^{+} \\
\quad \rightarrow 1,02 \mathrm{~N}_{2}+0,26 \mathrm{NO}_{3}^{-}+0,066 \mathrm{CH}_{2} \mathrm{~N}_{0,15}+2,03 \mathrm{H}_{2} \mathrm{O}
\end{aligned}
$$

Equação 3.10

Ressalta-se que todos os trabalhos que analisaram a atividade anammox, em sistemas visando esse processo para remoção de amônia, utilizaram-se da avaliação estequiométrica. Foram reunidos alguns estudos que calcularam a atividade anammox pela equivalência da estequiometria conforme proposto por Strous et al. (1998), sendo 1 mol de $\mathrm{NH}_{4}{ }^{+}$e 1,32 mol de $\mathrm{NO}_{2}{ }^{-}$consumidos para cada 0,26 mol de $\mathrm{NO}_{3}{ }^{-}$produzido (Tabela 3.7).

Tabela 3.7: Razão estequiométrica entre amônia, nitrito e nitrato em sistemas biológicos

\begin{tabular}{|c|c|c|c|c|c|}
\hline Sistema & Origem Inóculo & $\mathrm{NH}_{4}{ }^{+}$ & $\mathrm{NO}_{2}^{-}$ & $\mathrm{NO}_{3}^{-}$ & Referência \\
\hline Reator de gás-lift & Lodo granular anammox & 1 & 1,28 & 0,26 & \multirow{2}{*}{ Dapena-Mora et al., 2004} \\
\hline Reator bateladas & Lodo granular anammox & 1 & 1,11 & 0,20 & \\
\hline Culturas bateladas & $\begin{array}{l}\text { Discos rotativos } \\
\text { submersos }\end{array}$ & 1 & 1,38 & 0,29 & Tsushima et al., 2007 \\
\hline \multirow{4}{*}{ Culturas bateladas } & SBR aeróbio & 1 & 0,91 & 0,45 & \multirow{4}{*}{ Bae et al., 2010} \\
\hline & Reator anaeróbio & 1 & 0,77 & 0,31 & \\
\hline & Reator anóxico & 1 & 0,80 & 0,30 & \\
\hline & Discos rotativos & 1 & 1,04 & 0,13 & \\
\hline \multirow{4}{*}{$\begin{array}{l}\text { Biorreatores com } \\
\text { membranas em } \\
\text { diferentes concentrações } \\
\text { de biomassa }\end{array}$} & \multirow[t]{4}{*}{ Reator anóxico } & 1 & 1,32 & 0,37 & \multirow[t]{4}{*}{ Tao et al., 2013} \\
\hline & & 1 & 1,62 & 0,44 & \\
\hline & & 1 & 1,37 & 0,26 & \\
\hline & & & & & \\
\hline
\end{tabular}
anammox 
Para a detecção da atividade anammox pode-se também utilizar amônia e nitrito com isótopo do nitrogênio marcado $\left({ }^{15} \mathrm{~N}\right)$ (Schmid et al., 2005). Assim foi utilizado $\mathrm{NaNO}_{2}$ com ${ }^{15} \mathrm{~N}$ para verificar a diferença entre a produção percentual de gás $\mathrm{N}_{2}$ pelas combinações ${ }^{14-14} \mathrm{~N}_{2} ;{ }^{15-}$ ${ }^{15} \mathrm{~N}_{2}$ e a ${ }^{14-15} \mathrm{~N}_{2}$ que é atribuída à atividade anammox (Tsushima et al., 2007a).

As bactérias anammox apresentam um grupo de lipídeo único, devido à cadeia ladderane, que pode ser usado como um biomarcador indicando a presença de células anammox numa amostra, por meio de cromatografia líquida de alta eficiência - HPLC (Sànchez-Melsió et al., 2009).

A avaliação da conversão de hidroxilamina em hidrazina, por meio de suas concentrações, pode ser utilizada para detecção de organismos anammox, pois são os únicos organismos a catalisar essa reação (Schmid et al., 2005; Suneeth e Joseph, 2011). 


\section{4 - MATERIAIS E MÉTODOS}

Com a finalidade de responder aos objetivos propostos neste trabalho de doutorado, seguese o detalhamento do desenho experimental, com os materiais utilizados, as descrições das etapas experimentais, as metodologias analíticas físico-químicas e de biologia molecular, o tratamento dos dados brutos obtidos e os testes estatísticos utilizados para verificação dos processos biológicos ocorrentes nos sistemas biológicos estudados.

Os experimentos e as análises dos parâmetros físico-químicos e PCRq (Reação em Cadeia de Polimerase por avaliação e quantificação em tempo real) foram desenvolvidos no Laboratório de Análise de Água (LAA) do Departamento de Engenharia Civil e Ambiental da Universidade de Brasília. As análises de biologia molecular por PCR convencional foram realizadas no Laboratório de Microbiologia do Departamento de Biologia Celular da Universidade de Brasília em parceria com a Profa. Dra. Cynthia Maria Kyaw. A determinação das sequências de nucleotídeos (sequenciamento), dos fragmentos amplificados por PCR, foi obtida pela contratação do serviço EZ-Seq da Macrogen na Coreia do Sul.

O estudo iniciou-se com a concepção e desenvolvimento dos reatores utilizados e com a definição e coleta dos lodos de sistemas ambientais, posteriormente inoculados nos sistemas biológicos desse estudo. Após a montagem dos sistemas biológicos, o trabalho experimental foi dividido em 2 etapas, sendo elas: desenvolvimento da biomassa visando enriquecimento de micro-organismos responsáveis pelo processo anammox e avaliação do comportamento de conversão dos compostos nitrogenados, estabelecidas as condições de operação dos sistemas biológicos (Figura 4.1). 


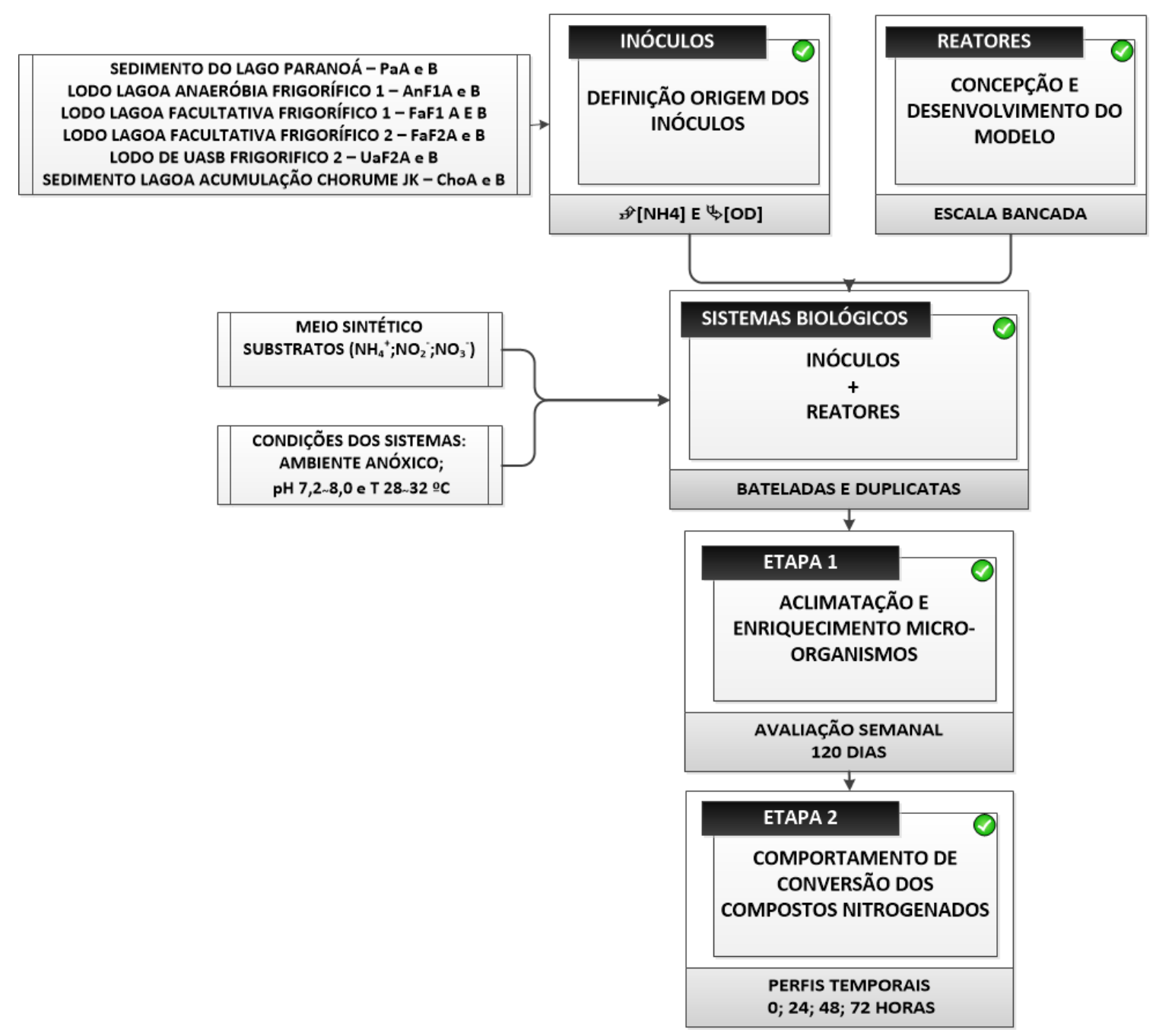

Figura 4.1: Desenho experimental do trabalho.

\section{1 - DESCRIÇÃO DOS MATERIAIS}

\subsection{1 - Reatores: Concepção e Desenvolvimento}

Para maior controle dos processos biológicos concebeu-se um sistema de reatores, em escala de bancada, para serem operados em bateladas sequenciais.

Foram projetados reatores buscando-se conseguir um sistema estável onde as condições anaeróbias fossem predominantes. Os reatores foram desenvolvidos usando tubos de acrílico de diâmetro interno de $90 \mathrm{~mm}$ e parede com espessura de $5 \mathrm{~mm}$, com volume total de 1600 mL, capazes de resistir a uma pressão de 2,24 Kgf.cm² (Figura 4.2A) (Tubos DE 100 mm; DI 90 mm; Parede 5 mm; Comprimento 200 mm, Acrílicos Brasil Ltda., BR). 
A capacidade útil $(1000 \mathrm{~mL})$ dos reatores foi determinada pela estimativa do número e volume de alíquotas do licor misto necessárias à condução das análises físico-químicas durante a fase de avaliação dos perfis temporais, de modo a remover, ao final de cada batelada, no máximo $10 \%$ do volume do sistema, minimizando modificações das concentrações de substratos por redução do volume do sistema.

Foram confeccionados 24 reatores para funcionarem num sistema composto por 2 peças, sendo um responsável por conter a mistura biomassa e água residuária sintética, e o outro para conter água para dissolução dos gases formados no primeiro reator e para avaliar a produção de gases pelo deslocamento da massa de água, conforme proposto por Suneethi e Joseph (2011) (Figura 4.2B).
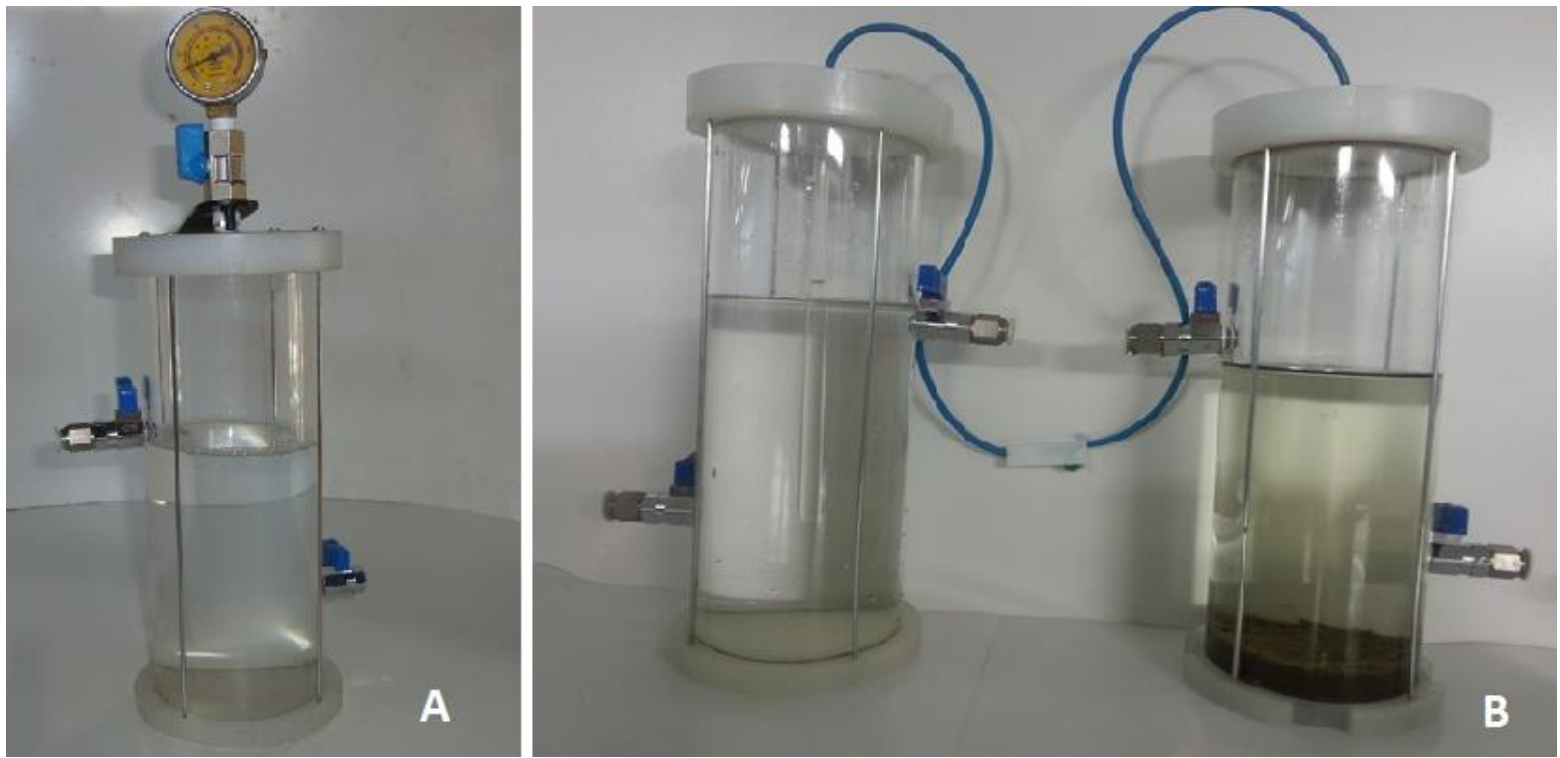

Figura 4.2: A) reator desenvolvido para estabelecimento dos sistemas biológicos B) sistema composto por dois reatores (1: com água para dissolução de gases e 2: biomassa, meio sintético e substratos nitrogenados)

Os reatores projetados possuíam sistemas de entrada para alimentação e descarte dos efluentes por válvulas de esfera 1/8" npt (GE, Brasil), com acoplamento de conexão de engate rápido 1/8" (Pro-S, Brasil), localizadas nas paredes laterais dos reatores facilitando o manuseio dos mesmos e, assim, diminuindo o tempo de perturbações aos sistemas. As tampas inferiores e superiores foram moldadas em tarugos de nylon, com mecanismos de suporte para oringes e encaixes de aperto, garantindo vedação aos sistemas (Figura 4.3 A, 
B). Na tampa superior foi instalado um adaptador de rosca 1/4" com engate rápido de 2,5 mm (4-5/32", Pro-S, Brasil) para remoção dos gases produzidos pelo metabolismo dos micro-organismos (Figura $4.3 \mathrm{C}$ ).

Nos reatores com $25,2 \mathrm{~cm}$ de altura, a válvula de descarte na lateral do sistema foi instalada a 5,6 cm da base do reator mantendo-se um volume de $350 \mathrm{ml}$ dentro do sistema e, assim, a conservação da biomassa no sistema após a sedimentação do licor misto. A válvula de alimentação foi instalada a $15,7 \mathrm{~cm}$ da base do reator para permitir a introdução do meio sintético acrescido dos substratos e realizar a troca volumétrica de 65\% (4.3 A).

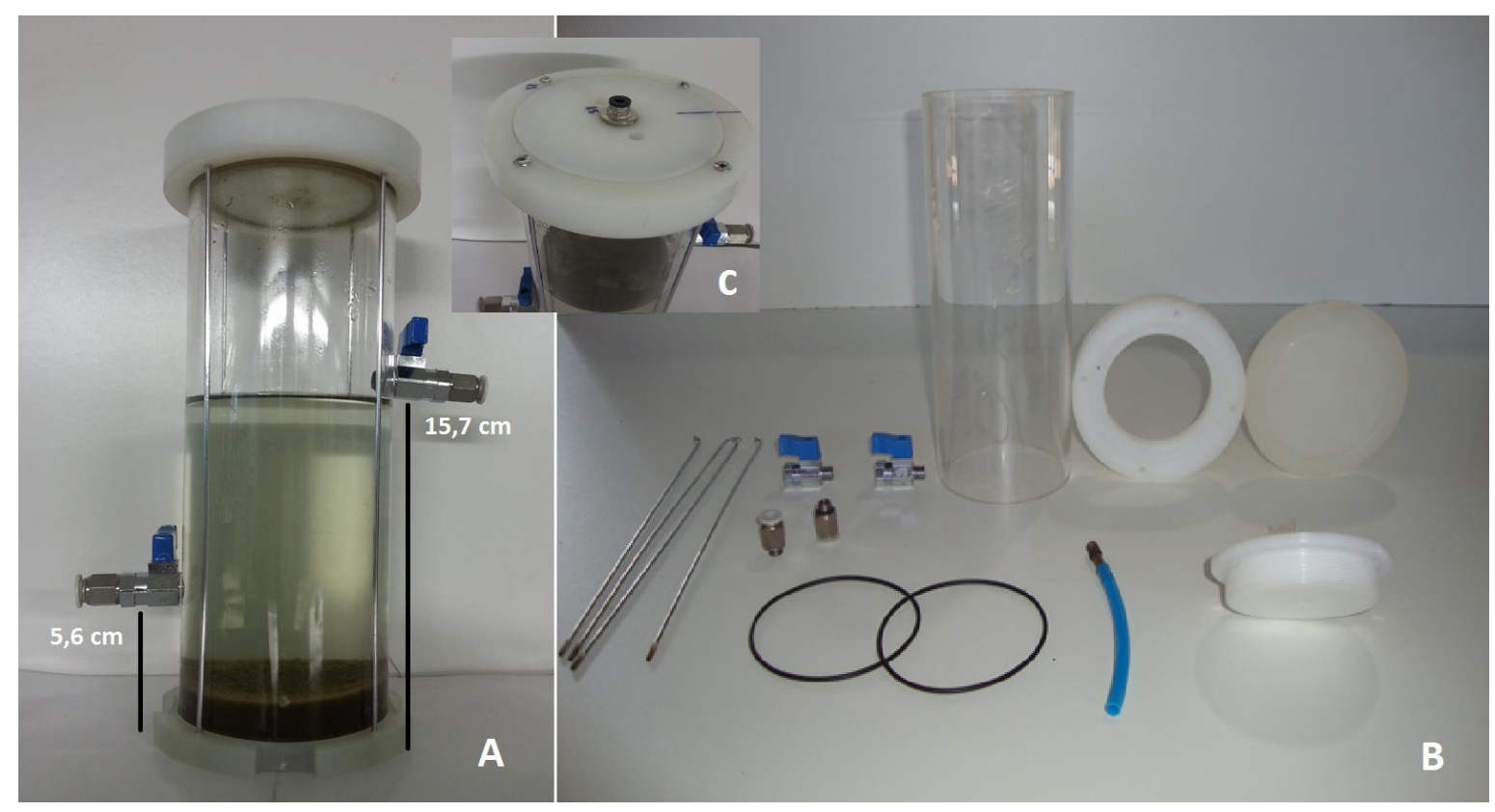

Figura 4.3: A) Localização das válvulas de alimentação e descarte dos reatores; B) Componentes utilizados na produção dos reatores; C) Válvula para escape dos gases produzidos nos sistemas biológicos.

Nas peças utilizadas para reter os gases produzidos nos sistemas biológicos foi encaixado um tubo de acrílico (canículo), com $15 \mathrm{~cm}$ de comprimento e $0,5 \mathrm{~cm}$ de diâmetro, preso ao adaptador fixo à tampa superior. A saída desse canículo ficou submersa na água de preenchimento da peça do sistema de reatores utilizada para a dissolução dos gases (Figura 4.4 A).

A conexão entre os dois reatores, utilizados para compor os sistemas biológicos durante as fases de aclimatação, desenvolvimento e enriquecimento da biomassa, foi feita por 
mangueira flexível de poliuretano (Urethane 4 GHM, Werk Schott, Brasil) com $35 \mathrm{~cm}$ de comprimento e diâmetro de 2,5 mm (Figura 4.4 A). Uma válvula stopflow foi usada na extensão da mangueira de conexão entre os dois reatores para facilitar manobras de operação (Figura 4.4 B). Mangueiras (Urethane, 8 SHM, Werk Schott, Brasil) e seringas cirúrgicas descartáveis (10 e $60 \mathrm{~mL}$, com bicos de rosca e cateter) foram utilizadas para realizar as coletas de alíquotas e inserir os substratos durante os intervalos de tempo dentro das bateladas.
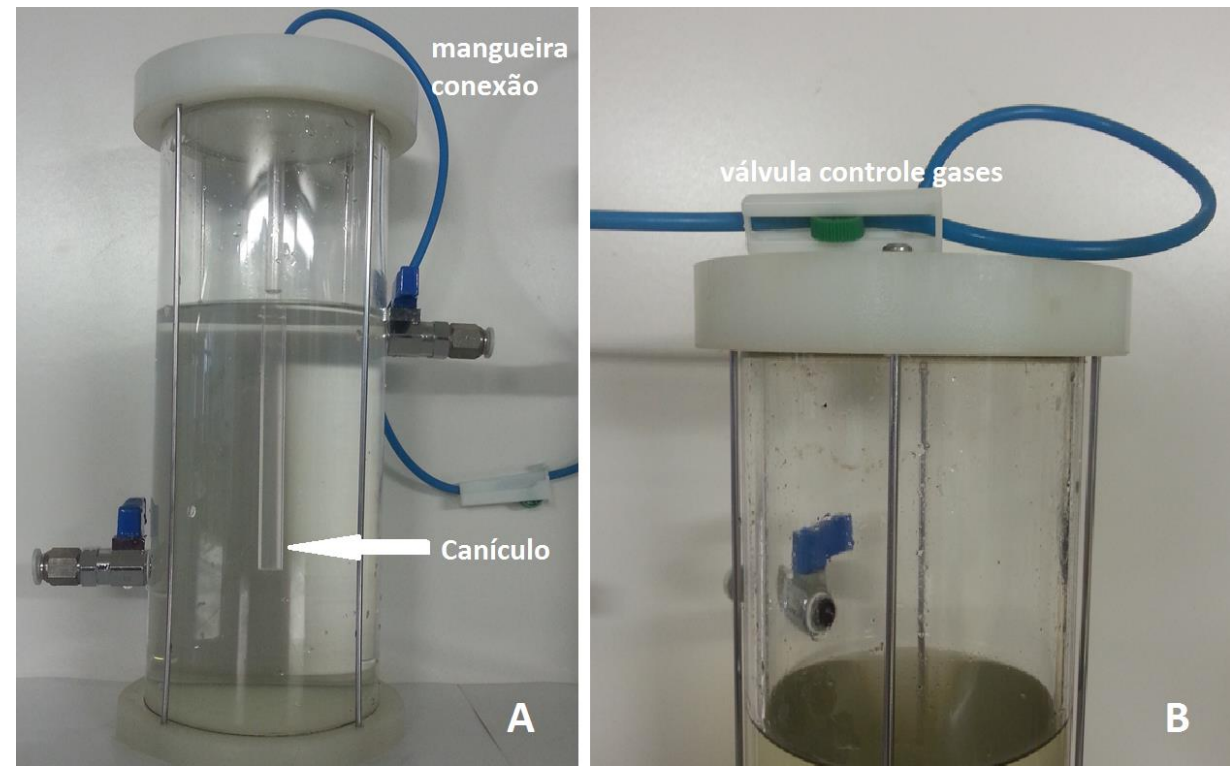

Figura 4.4: A) Reator para dissolução dos gases com canículo afogado e mangueira de conexão dos sistemas; b) válvula stopflow para manobras de controle durante operação dos sistemas.

\subsection{2 - Água Residuária Sintética e Substratos}

A água residuária sintética utilizada foi a proposta por Sànchez-Melsió et al. (2009) que realizaram uma adaptação ao meio de Van de Graaf et al. (1996), conforme apresentado na Tabela 4.1. Essa água sintética apresenta características para permitir o desenvolvimento dos micro-organismos anammox tais como salinidade de $32 \mathrm{ppt}, \mathrm{pH}$ de 8,25, alcalinidade total de $580 \mathrm{mg} . \mathrm{L}^{-1}$, sendo alcalinidade a bicarbonato e ácidos voláteis de $530 \mathrm{mg} . \mathrm{L}^{-1} \mathrm{e}$ alcalinidade a ácidos orgânicos de $50 \mathrm{mg} \cdot \mathrm{L}^{-1}$. A água residuária sintética não apresentou fonte de carbono orgânico e, portanto, após a fase de aclimatação dos micro-organismos nos sistemas biológicos os processos conduzidos por micro-organismos heterotróficos foram reduzidos. 
A água residuária sintética foi preparada anteriormente às trocas volumétricas após a finalização de cada batelada nas duas etapas experimentais. Dessa maneira, a água residuária sintética introduzida esteve sempre com as suas propriedades químicas conservadas.

A solução de elementos traços, importante para o pleno metabolismo dos micro-organismos, foi a proposta por Van de Graaf et al. (1996), que a desenvolveu para o enriquecimento de micro-organismos anammox (Tabela 4.1). A solução estoque de elementos traços foi preparada no volume de $1 \mathrm{~L}$ e mantida sob armazenamento a $4^{\circ} \mathrm{C}$ sendo substituída à medida que se esgotava. Utilizou-se água ultrapura para preparação da água residuária sintética e para a solução estoque de elementos traços (Gradient Milli-Q, Millipore, DE).

O oxigênio dissolvido presente no meio sintético foi removido por deslocamento com nitrogênio gasoso conforme metodologia proposta por Wang et al. (2011) e com o uso de uma sonda de OD, a remoção do oxigênio foi acompanhada até que o visor do equipamento indicasse uma concentração máxima de $0,03 \mathrm{mg} \cdot \mathrm{L}^{-1}$ de OD (55 DO - 12 FT, YSI Incorporated, USA).

Tabela 4.1: Soluções de macro e micronutrientes da água residuária sintética utilizada nas etapas experimentais.

\begin{tabular}{|c|c|c|c|}
\hline \multicolumn{2}{|c|}{$\begin{array}{c}\text { ÁGUA RESIDUÁRIA SINTÉTICA (pH: 7,2 a } \\
\qquad 7,4)^{1}\end{array}$} & \multicolumn{2}{|c|}{ SOLUÇÃO DE ELEMENTOS TRAÇOS ${ }^{2}$} \\
\hline Substâncias ${ }^{3}$ & Quantidade (mg.L $\left.{ }^{-1}\right)$ & Substâncias ${ }^{3}$ & Quantidade (mg.L $\left.{ }^{-1}\right)$ \\
\hline $\mathrm{NaHCO}_{3}$ & 1050 & EDTA & 15000 \\
\hline $\mathrm{KH}_{2} \mathrm{PO}_{4}$ & 25 & $\mathrm{ZnSO}_{4} \cdot 7 \mathrm{H}_{2} \mathrm{O}$ & 430 \\
\hline $\mathrm{CaCl}_{2} .2 \mathrm{H}_{2} \mathrm{O}$ & 300 & $\mathrm{CoCl}_{2} \cdot 6 \mathrm{H}_{2} \mathrm{O}$ & 240 \\
\hline $\mathrm{MgCl}_{2} \cdot 6 \mathrm{H}_{2} \mathrm{O}$ & 165 & $\mathrm{MnCl}_{2} \cdot 4 \mathrm{H}_{2} \mathrm{O}$ & 990 \\
\hline $\mathrm{FeSO}_{4} .7 \mathrm{H}_{2} \mathrm{O}$ & 12 & $\mathrm{CuSO}_{4} .5 \mathrm{H}_{2} \mathrm{O}$ & 250 \\
\hline EDTA. $2 \mathrm{H}_{2} \mathrm{O}$ & 7 & $\mathrm{NaMoO}_{4} \cdot 2 \mathrm{H}_{2} \mathrm{O}$ & 220 \\
\hline \multirow[t]{3}{*}{ Solução de elementos traços } & $1,25 \mathrm{ml} \cdot \mathrm{L}^{-1}$ & $\mathrm{NiCl}_{2} \cdot 6 \mathrm{H}_{2} \mathrm{O}$ & 190 \\
\hline & & $\mathrm{Na}_{2} \mathrm{SeO}_{3}$ & 90 \\
\hline & & $\mathrm{H}_{3} \mathrm{BO}_{3}$ & 14 \\
\hline
\end{tabular}

Fonte: ${ }^{1}$ Sànchez-Melsió et al. (2009) e ${ }^{2}$ Van de Graaf et al. (1996). ${ }^{3}$ Reagentes químicos, grau analítico PA. 
Os substratos nitrogenados utilizados foram amônia $\left(\mathrm{NH}_{4}^{+}\right)$; nitrito $\left(\mathrm{NO}_{2}{ }^{-}\right)$e nitrato $\left(\mathrm{NO}_{3}{ }^{-}\right)$, e para tanto foram preparadas soluções concentradas de $\mathrm{NH}_{4} \mathrm{Cl} ; \mathrm{NaNO}_{2}$ e $\mathrm{NaNO}_{3}$ com 5000 mg. $L^{-1}$ dos íons de interesse (Tabela 4.2). Devido à instabilidade das formas nitrogenadas em solução, as soluções concentradas com os substratos utilizados nas etapas experimentais foram preparadas anteriormente à introdução nos sistemas a cada batelada, para evitar ocorrência de oxidações externas aos sistemas biológicos. As soluções foram preparadas com água ultrapura (Gradient Milli-Q, Millipore, DE).

Tabela 4.2: Soluções com os substratos utilizadas nas etapas experimentais.

\begin{tabular}{|c|c|c|}
\hline \multicolumn{3}{|c|}{ SOLUÇÕES COM OS SUBSTRATOS NITROGENADOS } \\
\hline Substância ${ }^{1}$ & $\begin{array}{l}\text { Quantidade composto } \\
\text { químico em g.L }{ }^{-1}\end{array}$ & $\begin{array}{l}\text { Quantidade íon interesse } \\
\text { Em g.L } \mathbf{L}^{-1}\end{array}$ \\
\hline $\mathrm{NH}_{4} \mathrm{Cl}$ & 14,8 & 5 \\
\hline $\mathrm{NaNO}_{2}$ & 7,51 & 5 \\
\hline $\mathrm{NaNO}_{3}$ & 6,85 & 5 \\
\hline
\end{tabular}

${ }^{1}$ Reagentes químicos com grau Analítico PA.

Soluções de $\mathrm{Hl}, \mathrm{NaOH}$ e $\mathrm{Na}_{2} \mathrm{CO}_{3}$ a $1 \mathrm{M}$ foram preparadas para ajuste do $\mathrm{pH}$ dos sistemas biológicos dentro da faixa das condições ambientais estabelecidas nas etapas experimentais.

\subsection{3 - Fonte dos Inóculos}

Para verificar a presença de micro-organismos e atividade anammox nos inóculos escolhidos, procurou-se obtê-los a partir de locais propícios ao seu desenvolvimento. As interfaces óxicas/anóxicas de muitos sedimentos naturais e ambiente antropizados mostramse como habitats ideais para os micro-organismos oxidadores anaeróbios de amônia (Jetten et al., 1999; Kartal et al., 2012).

Desta forma, buscou-se inóculos a partir de: 


\section{a) Sedimento do Lago Paranoá, Brasília:}

O Lago Paranoá formado a partir do barramento do rio Paranoá no ano de 1959, também represou as vazões de várias micro bacias contribuintes sendo as águas do Riacho Fundo, Ribeirão do Gama, Ribeirão do Torto, Ribeirão Banana e dos córregos Acampamento, Taquari, e Ribeirão Cabeça de Veado (Liporoni, 2012). Apresenta uma extensão superficial de $38 \mathrm{Km}^{2}$ com um volume de $441 \times 10^{6} \mathrm{~m}^{3}$, com uma profundidade máxima de $38 \mathrm{~m}$ junto à barragem e média de 12,42 m, com tempo de detenção hidráulica de 299 dias (CAESB, 2003; CEB, 2010).

O lago Paranoá recebe várias descargas de poluição com concentrações de nitrogênio oriundas de fontes pontuais e difusas. Como exemplos de fontes pontuais tem-se as contribuições de esgotos sanitários da população urbana do DF proveniente de três Estações de Tratamento de Esgoto da CAESB (Companhia de Água e Esgoto de Brasília) Norte, Sul e Riacho Fundo, no entanto todas as estações possuem, desde 1994, a etapa de tratamento terciário para remoção de nutrientes como o nitrogênio e o fósforo (CAESB, 2003). Tem-se, também, o escoamento superficial das bacias urbanas da cidade de Brasília como importantes fontes difusas contribuindo com o aporte de nutrientes para o Lago Paranoá (Costa, 2013b; Souza, 2014). Ainda assim, o Lago Paranoá é considerado Oligotrófico (Philomeno, 2007; GDF, 2012a; GDF, 2012b).

As amostras de sedimento do lago Paranoá foram coletadas durante o desenvolvimento do projeto Águas - Pro Centro Oeste e foram armazenadas a $4^{\circ} \mathrm{C}$, no Laboratório de Análise de Águas da UnB. A biomassa inoculada nos sistemas biológicos foi resultante da composição de amostras de sedimentos de 3 pontos de coleta no lago Paranoá localizados próximos à ponte do Bragueto, à Estação de Tratamento de Esgoto Norte (ETE Norte, CAESB) e à ponte Juscelino Kubitschek.

\section{b) Lodos de sistemas de tratamento de efluentes de abatedouros de suínos e bovinos nos municípios de Uberlândia e Araguari, Minas Gerais:}

A escolha desse tipo de ecossistema deve-se ao fato dos mesmos reunirem várias condições que os qualificam como habitats propícios ao desenvolvimento de micro-organismos anammox. Isso ocorre devido às cargas de nitrogênio que esses recebem e às baixas ou nulas 
concentrações de oxigênio dissolvido.

Os efluentes gerados em unidades de abate de animais e processamento de carnes caracterizam-se principalmente pela alta carga orgânica, devido à presença de sangue, gorduras, estercos, conteúdo estomacal e intestinal não digeridos; pelas flutuações de pH em função do uso de agentes de limpeza ácidos e básicos; os altos conteúdos de nitrogênio, fósforo e sais e pelas flutuações de temperatura (Pacheco \& Yamanaka, 2006).

Nos abatedouros, é comum os efluentes líquidos serem divididos em duas linhas de tubulações: a linha "verde", que contém os efluentes líquidos gerados em áreas sem presença de sangue (por exemplo, recepção - lavagens de pátios, caminhões, currais ou pocilgas, "seringa", bucharia e triparia) e a linha "vermelha", com os efluentes que contêm sangue (das áreas do abate e processamento das carnes). Isto é feito para facilitar e melhorar o tratamento primário (físico-químico), que é feito separadamente, permitindo remover e segregar mais e melhor os resíduos em suspensão destes efluentes, de forma a facilitar e aumentar possibilidades para sua destinação adequada (Pacheco \& Yamanaka, 2006).

O sangue tem a DQO mais alta de todos os efluentes líquidos gerados no processamento de carnes. O sangue líquido bruto tem uma DQO em torno de 400 g.L $\mathrm{L}^{-1}, \mathrm{DBO}_{5}$ de 200 g.L $\mathrm{L}^{-1} \mathrm{e}$ de nitrogênio de aproximadamente 30 g.L $\mathrm{L}^{-1}$. Dessa maneira, é comum a separação do sangue puro precedendo a estação de tratamento de efluentes com a finalidade de evitar a contribuição dessa carga ao efluente a ser tratado.

Nos abatedouros, geralmente, o tratamento secundário ocorre em lagoas de estabilização, especialmente as anaeróbias. Há, também, outras possibilidades de processos biológicos anaeróbios, citando-se: processos anaeróbios de contato, filtros anaeróbios e digestores anaeróbios de fluxo ascendente. Com relação a processos biológicos aeróbios, podem-se ter processos aeróbios com biofilme (filtros biológicos e biodiscos) e processos aeróbios de biomassa dispersa (lodos ativados convencionais e de aeração prolongada, que inclui os valos de oxidação). Também é bastante comum observar o uso de lagoas fotossintéticas na sequência do tratamento com lagoas anaeróbias (Pacheco \& Yamanaka, 2006).

O tratamento terciário é por vezes requerido como "polimento" final dos efluentes líquidos provenientes do tratamento secundário, promovendo remoção suplementar de sólidos, de nutrientes (nitrogênio, fósforo) e de organismos patogênicos. Podem ser utilizados sistemas associados de nitrificação-desnitrificação, filtros e sistemas biológicos ou físico-químicos 
(ex.: uso de coagulantes para remoção de fósforo) (Pacheco \& Yamanaka, 2006).

Assim, as lagoas de estabilização anaeróbias e facultativas presentes em abatedouros de bovinos e suínos, devido às cargas de nitrogênio que recebem e às condições de anaerobiose, possuem condições para que se estabeleçam micro-organismos anammox.

Os municípios de Uberlândia e Araguari são polos agroindustriais e possuem dezenas de abatedouros e frigoríficos registrados para processamento de carnes.

O primeiro abatedouro/frigorífico que cedeu lodos para o estudo, designado Frigorífico 1, está localizado dentro do perímetro urbano de Araguari (MGO. Esse frigorífico abate cerca de 2000 cabeças de gado.dia ${ }^{-1}$. Possui um sistema de tratamento composto por etapas primária e secundária, sendo essa última composta por lagoa anaeróbia, lagoa aerada, lagoa facultativa, sequencialmente. Escolheram-se lodos da lagoa anaeróbia e da lagoa facultativa para constituírem-se em inóculos para os sistemas biológicos.

O outro abatedouro/frigorífico, designado de Frigorífico 2, de onde foram removidos lodos para os experimentos, encontra-se localizado na zona rural de Uberlândia. Nesse abate-se cerca de 400 cabeças de gado.dia ${ }^{-1}$ e 300 cabeças de suínos.dia ${ }^{-1}$. Possui um sistema de tratamento de efluente separado em linha verde e vermelha. Após todo o tratamento primário composto de gradeamento, separador de gorduras, peneiras, queimador de sangue, o efluente segue para um filtro biológico e depois para um UASB para remoção da carga orgânica. Finalmente, após o UASB, segue para uma sequência de 3 lagoas facultativas para polimento. Escolheram-se lodos do UASB e da $2^{\text {a }}$ lagoa facultativa para constituírem-se em inóculos para os sistemas biológicos.

Foi ainda coletado lodo de uma lagoa anaeróbia de um abatedouro de suínos, designado Frigorífico 3, localizado na zona rural de Uberlândia. Abate-se cerca de 400 suínos.dia $^{-1}$ nesse abatedouro e, o mesmo possui um sistema de tratamento dos efluentes composto por uma etapa de gradeamento e separação de gorduras e, outra etapa biológica, em lagoas anaeróbias (Figura 4.5).

Assim, foram coletadas amostras de lodos nesses três frigoríficos, observando-se as condições das lagoas e grau de tratamento pelo quais os efluentes já haviam passado. 


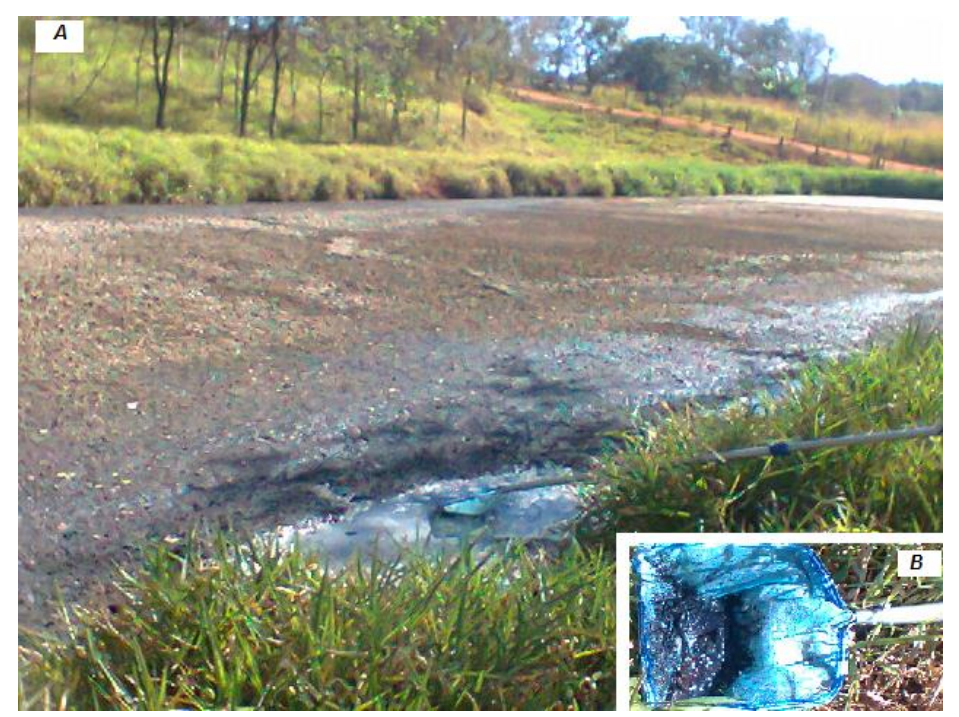

Figura 4.5: Lagoa anaeróbia tratando efluente de abatedouro de suínos. A) vista da lagoa anaeróbia. B) Aspecto do lodo coletado no fundo da lagoa anaeróbia.

c) Sedimento da lagoa de acumulação de chorume do aterro controlado Jockey Club de Brasília:

Esse sedimento caracteriza-se por acúmulo de sólidos advindos junto com o chorume das células do aterro e biomassa adaptada às condições desse ambiente. Como a concentração média de amônia no chorume é alta, espera-se que no sedimento dessa lagoa ocorra o desenvolvimento de micro-organismos anammox (Figura 4.6).

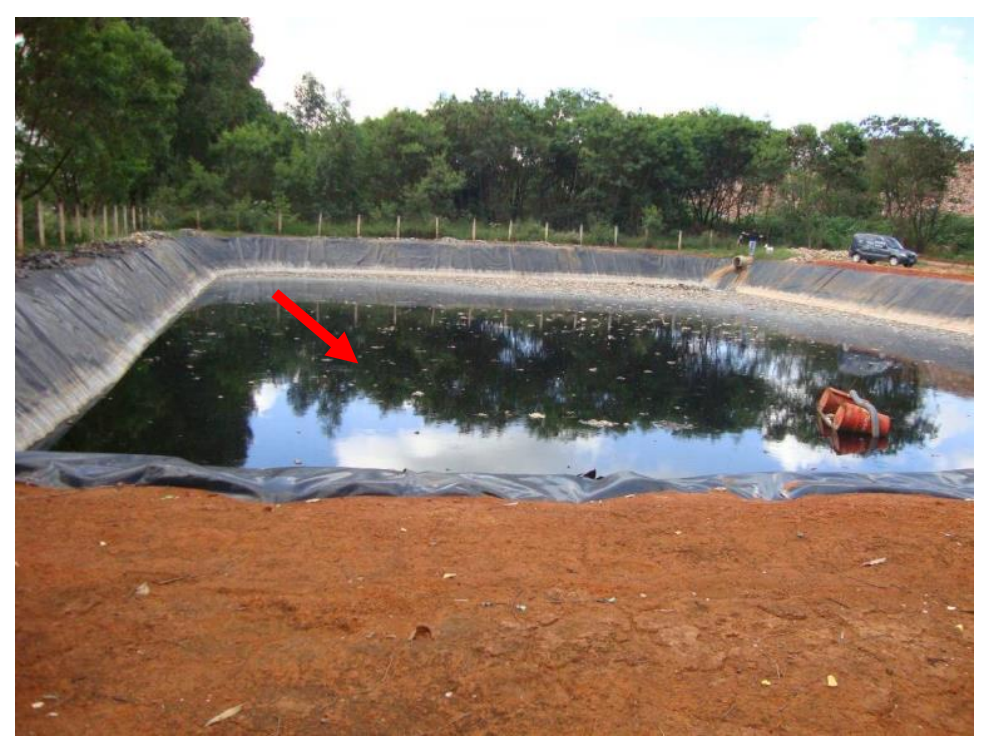

Figura 4.6: Lagoa de acumulação de chorume localizada no aterro controlado Jockey Club de Brasília, DF. 
Em todos os ambientes/habitats de onde os inóculos foram coletados, à exceção do Lago Paranoá, fez-se as seguintes avaliações das variáveis ambientais, in situ: temperatura e pH utilizando equipamentos manuais de campo.

Para cada um dos lodos e sedimentos foi criado um código do inóculo, observando-se a origem do ponto de coleta, a etapa do tratamento, as condições in situ e, assim, dispostos na Tabela 4.3. Os micro-organismos, dadas as condições dos ambientes de onde se coletaram os inóculos, apresentavam metabolismo anaeróbio.

Tabela 4.3: Inóculos usados nos experimentos em batelada para enriquecimento de organismos anammox.

\begin{tabular}{|c|c|c|c|c|c|}
\hline Inóculo & $\begin{array}{l}\text { Código } \\
\text { Inóculo }\end{array}$ & Origem & $\begin{array}{c}\text { Etapa/tipo do } \\
\text { Tratamento }\end{array}$ & pH & $\begin{array}{c}\text { Temperatura } \\
\left({ }^{\circ} \mathbf{C}\right)\end{array}$ \\
\hline Sedimento & Par & Lago Paranoá/ Brasília & - & - & - \\
\hline Lodo & AnF1 & $\begin{array}{l}\text { Lagoa anaeróbia tratando } \\
\text { efluente de frigorífico }\end{array}$ & $\begin{array}{c}\text { Início/ } \\
\text { Biológico }\end{array}$ & 6,40 & 26 \\
\hline Lodo & FaF1 & $\begin{array}{l}\text { Lagoa facultativa } \\
\text { tratando efluente de } \\
\text { frigorífico }\end{array}$ & $\begin{array}{l}\text { Final - pós } \\
\text { lagoa aerada/ } \\
\text { Biológico }\end{array}$ & 6,85 & 28 \\
\hline Lodo & FaF2 & $\begin{array}{l}\text { Lagoa facultativa } \\
\text { tratando efluente de } \\
\text { frigorífico }\end{array}$ & $\begin{array}{c}\text { Final - pós } \\
\text { UASB/ } \\
\text { Biológico }\end{array}$ & 7,50 & 25 \\
\hline Lodo & UaF2 & $\begin{array}{l}\text { Reator UASB tratando } \\
\text { efluente de frigorífico }\end{array}$ & $\begin{array}{c}\text { Intermediário/ } \\
\text { Biológico }\end{array}$ & 6,76 & 26 \\
\hline Lodo & AnF3 & $\begin{array}{c}\text { Lagoa anaeróbia tratando } \\
\text { efluente de abatedouro } \\
\text { suíno }\end{array}$ & $\begin{array}{l}\text { Intermediário/ } \\
\text { Biológico }\end{array}$ & 6,54 & 28 \\
\hline Sedimento & Cho & $\begin{array}{l}\text { Lagoa de detenção de } \\
\text { chorume aterro Jockey } \\
\text { Clube }\end{array}$ & - & 8,38 & 26 \\
\hline
\end{tabular}




\section{2 - DESENVOLVIMENTO EXPERIMENTAL}

\subsection{1 - Preparação dos Inóculos}

Os diferentes inóculos foram caracterizados usando-se os parâmetros e métodos de análise apresentados na Tabela 4.4. Os inóculos foram preparados pela mistura do lodo (sólido) e sobrenadante (líquido) conforme coletados.

Tabela 4.4: Parâmetros e metodologias usadas para caracterização das diferentes amostras inoculadas nos sistemas em bateladas para enriquecimento anammox.

\begin{tabular}{lc}
\hline \hline Parâmetro & Método* $^{*}$ \\
\hline $\mathrm{pH}$ & Potenciométrico \\
Temperatura & Potenciométrico \\
Sólidos Totais & Gravimétrico \\
Sólidos Voláteis & Gravimétrico \\
Sólidos Fixos & Gravimétrico \\
Nitrogênio Total Kjeldahl & Digestão/Espectrofotométrico \\
Nitrogênio amoniacal & Potenciométrico \\
Nitrito & Cromatografia iônica \\
Nitrato & Cromatografia iônica \\
DQO & Digestão/Espectrofotométrico \\
\hline \hline
\end{tabular}

\subsection{2 - ETAPA 1: Aclimatação e Enriquecimento de Micro-organismos}

A metodologia de culturas em bateladas foi utilizada para o processo de aclimatação e desenvolvimento da biomassa, buscando-se o enriquecimento dos micro-organismos anammox, pois permite uso de sistemas simples, otimização experimental e o tempo requerido é relativamente curto (Sànchez-Melsió et al., 2009).

Os reatores projetados, conforme modelo apresentado no item 4.1.1, foram preenchidos cada com 25 g de lodo centrifugado dos inóculos testados $(\approx 25 \mathrm{~mL})$ e $975 \mathrm{~mL}$ de água residuária sintética com os substratos nitrogenados, livre de OD, perfazendo os $1000 \mathrm{~mL}$ de volume reacional, e mantidos em condições anaeróbias. Os sistemas biológicos com cada lodo foram montados em duplicatas. A quantidade de lodo inserido nos reatores (25g) foi determinada visando ter uma concentração inicial de biomassa em torno de 1,5 a 2 g.L $\mathrm{L}^{-1}$ de sólidos 
suspensos voláteis (Kuai e Verstraete, 1998; Schierholt Neto, 2007; Wang et al., 2011). Os reatores foram encaixados em uma base com agitação equivalente a 100 rpm (Shaker 2540, FANEM, BR) e colocados em sala climatizada, com temperatura oscilando entre 28 a $32{ }^{\circ} \mathrm{C}$ (Figura 4.7) (HN 500 CEMAR, BR). O parâmetro pH, dentro de uma faixa de 7,2 a 8,0, foi mantido com o uso de soluções de $\mathrm{HCl}, \mathrm{NaOH}$ e $\mathrm{Na}_{2} \mathrm{CO}_{3}$ a $1 \mathrm{M}$.

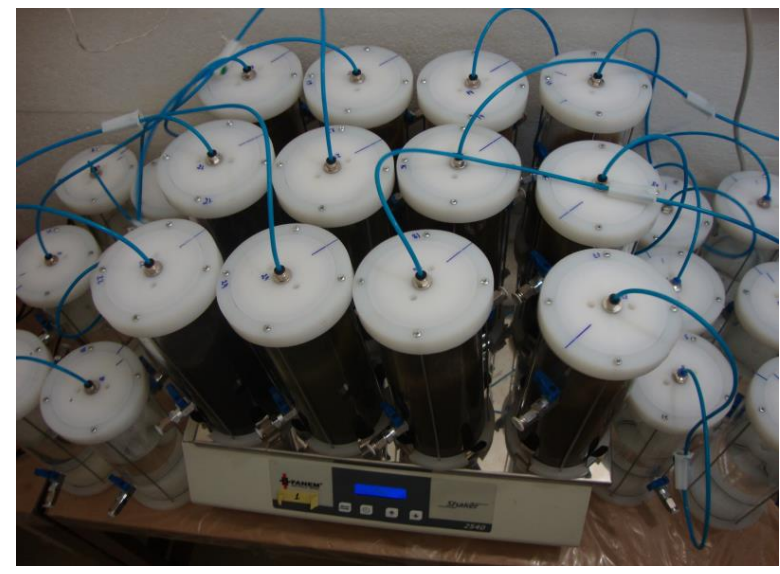

Figura 4.7: Reatores inoculados com diferentes inóculos de lodos e sedimentos acoplados com os vasos para dissolução dos gases, conforme metodologia discutida no item 4.1.1, e na base agitadora em sala climatizada.

O suprimento dos substratos amônia e nitrito foi garantido pela adição das soluções de $\mathrm{NH}_{4} \mathrm{Cl} / \mathrm{NaNO}_{2}$ introduzidos semanalmente ao início das bateladas (Figura 4.8). O aumento das concentrações de amônia e nitrito no meio ocorreu gradativamente, iniciando com concentrações de $20 \mathrm{mg} . \mathrm{L}^{-1}$ para ambos componentes e fazendo incrementos de $5 \mathrm{mg} . \mathrm{L}^{-1} \mathrm{a}$ cada batelada, até atingir a concentração de $60 \mathrm{mg} . \mathrm{L}^{-1}$ (Sànchez-Melsió et al., 2009). A alimentação de cada sistema biológico foi realizada pela válvula localizada na lateral do reator posicionada a 15,7 cm da base do reator, no nível de $1000 \mathrm{~mL}$ (Figura 4.8).

Foi adicionado nitrato nos sistemas biológicos, em concentrações de 20 a $30 \mathrm{mg} . \mathrm{L}^{-1}$, nas 3 primeiras bateladas para evitar consumo de nitrito e formação de gás sulfídrico decorrentes dos processos metabólicos resultantes da presença de bactérias heterotróficas desnitrificantes e das bactérias sulfato redutoras responsáveis pela formação de gás sulfídrico. Esse procedimento também foi adotado em outros trabalhos (Tsushima et al., 2007b; Sànchez-Melsió et al., 2009; Suneethi e Joseph, 2011). 
A água residuária sintética foi reposta periodicamente, a cada 15 dias, para evitar problemas ocasionados por acumulação ou consumo de substâncias que inibissem o desenvolvimento dos micro-organismos anammox (Tsushima et al., 2007b; Sànchez-Melsió et al., 2009; Suneethi e Joseph 2011). Quando da substituição da água residuária sintética, os reatores foram removidos da base agitadora e aguardou-se uma hora para deposição do lodo no fundo dos reatores abaixo do nível da válvula de descarte $(350 \mathrm{~mL})$ (Figura 4.8). As válvulas de descarte, localizadas na lateral dos reatores (conforme Figura 4.3), foram abertas para o descarte do meio sintético sobrenadante. Dessa forma, os reatores com capacidade útil de $1000 \mathrm{~mL}$, funcionaram com $350 \mathrm{~mL}$ de volume mínimo, e com $650 \mathrm{~mL}$ de troca volumétrica, equivalendo a uma razão de troca de 65\% (Figura 4.8).

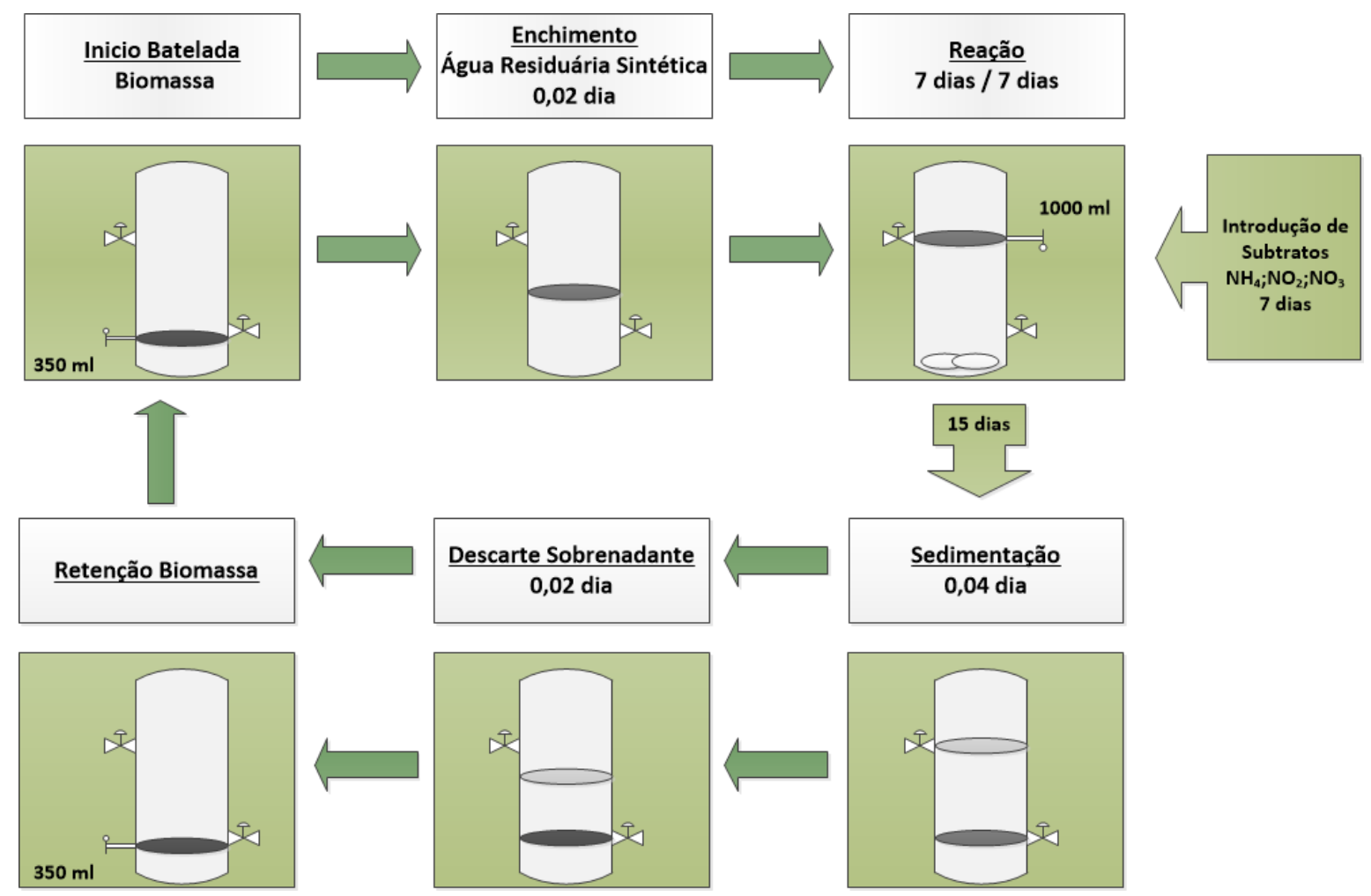

Figura 4.8: Operação dos sistemas biológicos em bateladas sequencias na ETAPA 1, destinada à aclimatação e enriquecimento de micro-organismos anammox.

Alíquotas do licor misto $(20 \mathrm{~mL})$ para cada sistema biológico foram coletadas no início das bateladas (T0) (consideradas quando da inserção de novas concentrações de substratos) e após períodos compreendidos entre 5 e 7 dias (T1) para avaliar as conversões de amônia, 
nitrito e nitrato, bem como dos íons aniônicos fosfato e sulfato presentes no meio. $\mathrm{O}$ pH do licor misto, quando das retiradas das alíquotas, foi acompanhado e ajustado quando necessário para a faixa de 7,2 a 8,0.

Na parte superior do reator, uma válvula fez o controle de escape dos gases produzidos que foram capturados por dissolução em água destilada, para quantificação dos gases produzidos medidos pelo deslocamento da massa de água, conforme proposto por Suneethi e Joseph (2011) (Figura 4.9).

Definiu-se uma metodologia para equilibrar os sistemas compostos pelos reatores como as diferentes biomassas e água residuária sintética (P2) com seus respectivos reatores para recepção dos gases (P1) e assim quantificar o volume dos gases produzidos por cada sistema (Figura 4.9). Os reatores $\mathrm{P} 1$ e $\mathrm{P} 2$, com headspace à pressão atmosférica, foram conectados e, após a válvula de descarte do reator P1 foi aberta expulsando cerca de $8 \mathrm{ml}$ de água e cessando a vazão pois o sistema entrava em equilíbrio. Qualquer novo deslocamento de água a partir do reator P1 só ocorreu devido à introdução e ou formação de gases no sistema. Dessa maneira, foi possível encontrar uma equivalência entre os gases produzidos em P2 e o deslocamento de água em P1. Assim, um dado volume de água deslocado em P1 corresponde igual volume de gás produzido em P2.

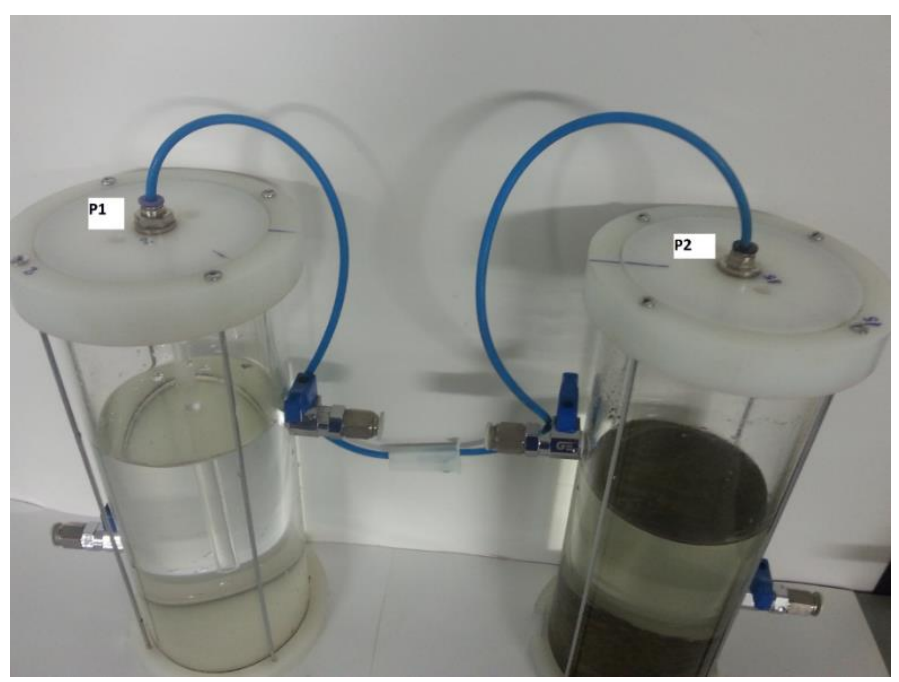

Figura 4.9: Sistema composto por duas peças para verificação e quantificação dos gases. 


\subsubsection{1 - Coleta de biomassa para análises de biologia molecular - Etapa 1}

Para detecção e quantificação dos grupos de micro-organismos relacionados ao ciclo de nitrogênio foram recolhidas alíquotas dos lodos e sedimentos antes da inoculação e do licor dos sistemas biológicos, contendo a biomassa, após 120 dias do período ajustado para o enriquecimento de micro-organismos anammox. As técnicas de biologia molecular utilizadas foram PCR convencional, PCR quantitativa e sequenciamento dos fragmentos de DNAr 16S obtidos em PCR para o grupo de micro-organismos anammox, as quais tem suas metodologias detalhadas no tópico 4.3.3 sobre Análises de biologia molecular para avaliação dos micro-organismos.

\subsection{3 - ETAPA 2: Comportamento de Conversão dos Compostos Nitrogenados}

Para avaliação do comportamento de conversão de nitrogênio, nas formas de amônia $\left(\mathrm{NH}_{4}^{+}\right)$, nitrito $\left(\mathrm{NO}_{2}{ }^{-}\right)$e nitrato $\left(\mathrm{NO}_{3}{ }^{-}\right)$, nos sistemas que foram destinados ao enriquecimento e verificados atividade anammox foi desenvolvida a seguinte metodologia, adaptada da operação em bateladas sequenciais.

Os reatores com a biomassa, resultante da etapa 1, foram alimentados com o mesmo tipo de água residuária sintética acrescida com concentrações dos substratos de amônia e nitrito. Para esses ensaios foram inseridos $650 \mathrm{~mL}$ de água residuária sintética com concentrações crescentes de amônia e nitrito a nova cada batelada. As concentrações de amônia e nitrito iniciaram em $30 \mathrm{mg} . \mathrm{L}^{-1}$ e $40 \mathrm{mg} . \mathrm{L}^{-1}$, respectivamente, com acréscimo crescentes de $5 \mathrm{mg} . \mathrm{L}^{-}$ ${ }^{1}$, até atingir concentrações de $60 \mathrm{mg} \mathrm{NH}_{4} \cdot \mathrm{L}^{-1}$ e $80 \mathrm{mg} \mathrm{NO}_{2} \cdot \mathrm{L}^{-1}$. Dessa forma, os reatores com volume reacional de $1000 \mathrm{~mL}$ funcionaram com $350 \mathrm{~mL}$ de volume mínimo, e com 650 $\mathrm{ml}$ de troca volumétrica, equivalendo a uma razão de troca de $65 \%$. Informa-se que os sistemas biológicos com cada inóculo testado encontravam-se representados em duplicatas (Figura 4.10).

Nos reatores, as condições de anaerobiose foram mantidas por remoção do oxigênio dissolvido do meio sintético por deslocamento com gás $\mathrm{N}_{2}$, até concentrações $<0,04 \pm 0,02$ mg.L $\mathrm{L}^{-1}$ de OD. Um headspace de $600 \mathrm{~mL}$ à pressão atmosférica foi deixado em cada um dos sistemas para acúmulo dos gases gerados pelo sistema. A alimentação e o descarte do efluente proveniente das bateladas foram feitos pelas duas válvulas nas laterais dos reatores. 
Nessa etapa não foram acompanhados os volumes dos gases produzidos.

Alíquotas com $10 \mathrm{~mL}$ do licor misto de cada sistema biológico foram coletadas ao longo das bateladas nos tempos T0 (zero hora); T1 (24 horas); T2 (48 horas) e T3 (72 horas) para avaliar as conversões de amônia, nitrito e formação de nitrato, bem como de outros íons aniônicos (fosfato e sulfato) presentes no meio. Para essa etapa experimental foram realizadas 10 bateladas de 72 horas para todos os sistemas testados. $\mathrm{O}$ pH do licor misto, quando das retiradas das alíquotas, foi monitorado para verificar as modificações do mesmo ao longo das bateladas e, portanto, não foram feitas correções de $\mathrm{pH}$ durante a batelada.

Dessa maneira, as bateladas constituíram-se em: 15 minutos para alimentação, 72 horas em reação com sedimentação de 30 minutos a cada 24 horas de reação para coleta de alíquotas do licor, 2 horas de sedimentação ao final, para permitir completa sedimentação da biomassa para realização da troca da água ressudaria sintética e reduzir a perda de biomassa (Figura 4.10).

O volume final removido para as amostragens ao longo do período de avaliação não ultrapassou $10 \%$ do volume reacional dos reatores definido em $1000 \mathrm{~mL}$.

A avaliação da conversão das formas nitrogenadas foi realizada pela observação dos índices estequiométricos da reação anammox, pois os sistemas foram ajustados para que o metabolismo anammox fosse predominante nos sistemas biológicos, conforme a equação 4.1 .

$$
\begin{aligned}
\mathrm{NH}_{4}^{+}+1,32 \mathrm{NO}_{2}^{-}+0,066 \mathrm{HCO}_{3}^{-}+0,13 \mathrm{H}^{+} \\
\rightarrow 1,02 \mathrm{~N}_{2}+0,26 \mathrm{NO}_{3}^{-}+0,066 \mathrm{CH}_{2} \mathrm{~N}_{0,15}+2,03 \mathrm{H}_{2} \mathrm{O}
\end{aligned}
$$

Equação 4.1 


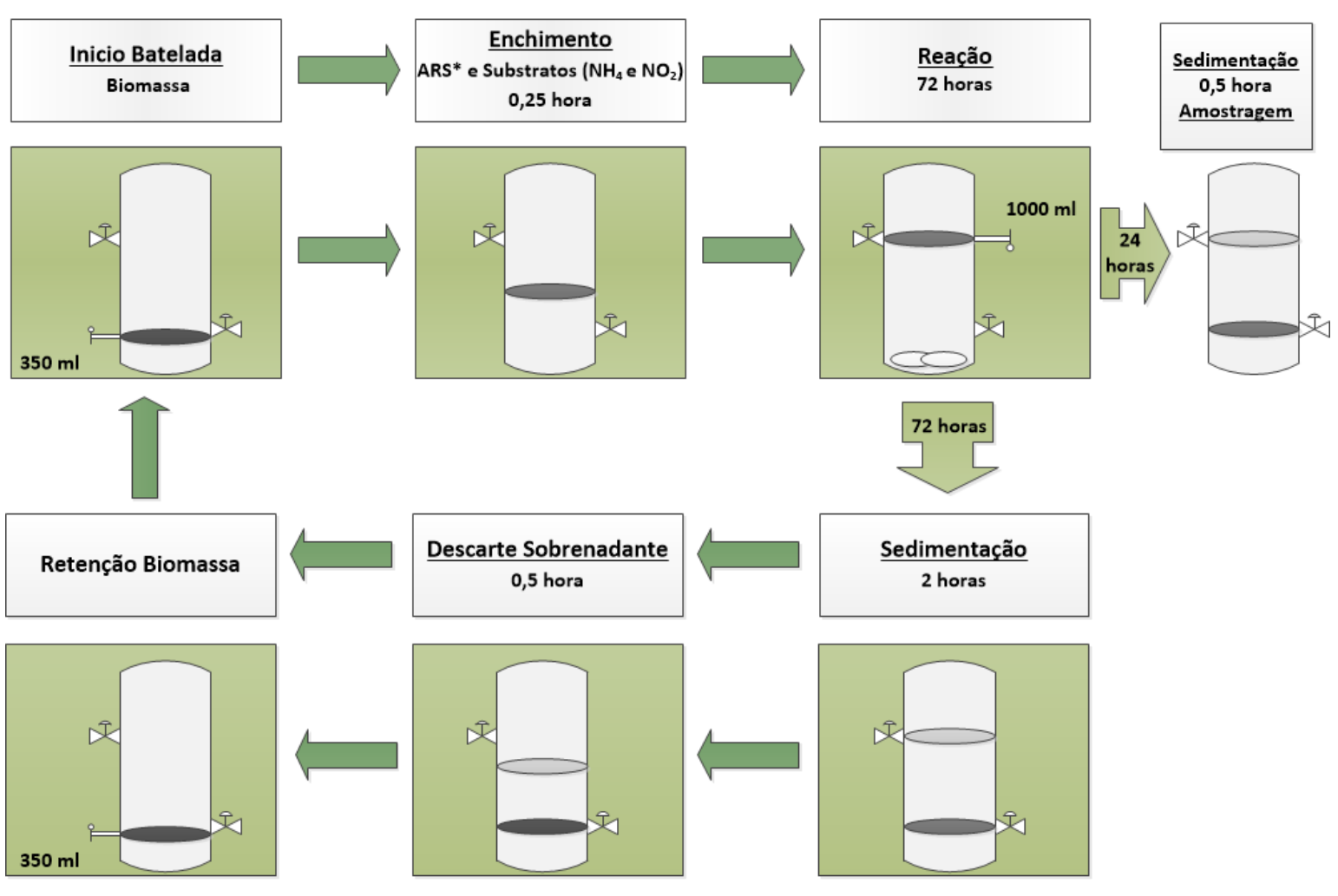

*ARS = Água Residuária Sintética

Figura 4.10: Operação dos sistemas biológicos em bateladas sequencias na ETAPA 2, destinada a avaliação das conversões dos compostos nitrogenados.

\subsubsection{1 - Coleta de biomassa para análises de biologia molecular - Etapa 2}

Para verificação e quantificação dos grupos de micro-organismos relacionados ao ciclo de nitrogênio foram recolhidas alíquotas do licor dos sistemas biológicos, contendo a biomassa, ao final dos experimentos da $2^{\mathrm{a}}$ etapa (180 dias após a inoculação dos lodos/sedimentos nos sistemas biológicos). As técnicas de biologia molecular utilizadas foram PCR convencional, PCR quantitativa para os grupos de micro-organismos relacionados ao ciclo do nitrogênio, as quais tem suas metodologias detalhadas no tópico 4.3.3 sobre Análises de biologia molecular para avaliação dos micro-organismos. 


\section{3 - MÉTODOS ANALÍTICOS}

Os métodos analíticos adotados para avaliação dos procedimentos experimentais seguiram as metodologias descritas Standard Methods for the Examination of Water and of Wastewater (APHA, 2005).

\subsection{1 - Preparação e conservação das amostras do licor misto para análises em cromatografia iônica}

As alíquotas coletadas foram imediatamente passadas em uma sequência de filtros por sistema de vácuo, iniciando pelo filtro analítico de fibra de vidro com $1 \mu \mathrm{m}$ de poro (AP40, $47 \mathrm{~mm}$ ), membrana em ésteres de celulose (nitrato $75-80 \%$ e acetato) com $0,45 \mu \mathrm{m}$ poro (HA, 47mm) e em membrana em éster de celulose com $0,22 \mu \mathrm{m}$ poro (GS, $47 \mathrm{~mm}$ ) (Filtros e Membranas da Millipore Indústria e Comércio Ltda., BR).

As amostras da $1^{\text {a }}$ etapa experimental, após serem filtradas na membrana de $0,45 \mu \mathrm{m}$ de poro, tiveram um tratamento diferenciado para redução do carbono orgânico. Esse filtrado foi colocado em contato com uma pequena quantidade de carvão ativado $(10 \mathrm{mg}$ por $10 \mathrm{~mL}$ de amostra) (Carvão Analítico PA, Merck) para adsorção do material orgânico. Essa mistura foi submetida à sonicação (Modelo USC 5000 - Ultrasonic Cleaner, Unique) durante 20 minutos para aumentar a eficiência de adsorção da matéria orgânica carbonácea ao carvão (Barbosa, 2010). Após um período de repouso as amostras foram filtradas em membranas de ésteres de celulose com 0,22 $\mu \mathrm{m}$ poro (GS, 47mm, Millipore Indústria e Comércio Ltda., BR) e separadas em triplicatas, em alíquotas de $5 \mathrm{~mL}$, para posterior utilização para as análises de ânions e cátions.

As amostras das etapas 1 e 2, quando necessário, foram armazenadas em tubos com alíquotas de $5 \mathrm{~mL}$ e estocadas sobre congelamento a $-20{ }^{\circ} \mathrm{C}$ como, também, realizado por outros pesquisadores (Martins, 2007; Barbosa, 2010; Costa, 2013a; Sánchez et al., 2014). 


\subsection{2 - Análises dos componentes nitrogenados e de outros íons}

A determinação das concentrações das formas nitrogenadas, sendo elas amônia $\left(\mathrm{NH}_{4}^{+}\right)$, nitrito $\left(\mathrm{NO}_{2}{ }^{-}\right)$e nitrato $\left(\mathrm{NO}_{3}{ }^{-}\right)$foi realizada por meio da cromatografia iônica, bem como dos íons aniônicos fosfato $\left(\mathrm{PO}_{4}{ }^{3-}\right)$ e sulfato $\left(\mathrm{SO}_{4}{ }^{3-}\right)$. Esses últimos íons foram também avaliados devido as colunas de separação de ânions e as soluções padrões disponíveis permitirem que os mesmos fossem quantificados. O cromatógrafo utilizado foi o ICS 900-DCR Dionex (Thermo Fisher Scientific, USA).

Na configuração do ICS 900 para análise dos ânions, utilizou-se a coluna de separação Dionex IonPac AS23 RFIC Analytical (4 x $250 \mathrm{~mm}$ ), a coluna guarda Dionex IonPac AS23 RFIC Guard (4 x $50 \mathrm{~mm})$ e a supressora Dionex AMMS 300 MicroMembrane $4 \mathrm{~mm}$ (Thermo Fisher Scientific, USA). O eluente utilizado na fase móvel foi a solução de carbonato de sódio $\left(\mathrm{Na}_{2} \mathrm{CO}_{3}\right)$ a 4,5 mM com bicarbonato de sódio $\left(\mathrm{NaHCO}_{3}\right)$ a $0,8 \mathrm{mM}$. O regenerante para recuperação da supressora foi o ácido sulfúrico a $36 \mathrm{mM}$. O sistema foi operado com a condutividade da linha base a $23 \mu \mathrm{S}$, velocidade do fluxo de $1,0 \mathrm{~mL} \cdot \mathrm{min}^{-1} \mathrm{e}$ pressão da bomba a \pm 1950 psi, com volume de injeção de $100 \mu \mathrm{L}$ e loop de amostragem de $10 \mu \mathrm{L}$. O tempo de corrida para separação dos ânions foi de 22 minutos. As alíquotas foram aplicadas manualmente com utilização de seringas descartáveis de $1 \mathrm{~mL}$ acoplada ao filtro millex com membrana de PVDF 0,22 $\mu$ m de poro (Millex, GV 13mm, Millipore Indústria e Comércio Ltda.). Para realização das curvas de padrões foi utilizado a solução de 7 Ânions da Dionex contendo os seguintes ânions fluoreto, cloreto, nitrito, brometo, nitrato, fosfato e sulfato (Dionex Seven Anion Standard II, Thermo Fisher Scientific, USA).

Na configuração do ICS 900 para análise dos cátions, utilizou-se a coluna de separação Dionex IonPac CS12A RFIC Analytical (4 x $250 \mathrm{~mm}$ ), a coluna guarda Dionex IonPac CG12A RFIC Guard (4 x $50 \mathrm{~mm}$ ) e a supressora Dionex CMMS 300 MicroMembrane $4 \mathrm{~mm}$ (Thermo Fisher Scientific, USA). O eluente da fase móvel da análise de cátions foi a solução de ácido metanossulfônico $\left(\mathrm{CH}_{3} \mathrm{SO}_{3} \mathrm{H}\right)$ a $20 \mathrm{mM}$ e o regenerante do sistema de supressão foi o hidróxido de tetrabutilamônio, (TBAOH - $\left.\left(\mathrm{C}_{4} \mathrm{H}_{9}\right)_{4} \mathrm{NOH}\right)$ a $100 \mathrm{mM}$. O ácido metanossulfônico, ao invés do ácido sulfúrico, foi adotado como eluente porque permite uma melhor separação dos íons sódio e amônia devido a diferenciação nos tempos de detenção pela coluna de separação. $O$ sistema foi operado com a condutividade da linha base de 2,0 a 3,0 $\mu \mathrm{S}$, velocidade do fluxo de 1,0 mL.min ${ }^{-1}$ e pressão da bomba a \pm 1350 psi, com volume 
de injeção de $100 \mu \mathrm{L}$ e loop de amostragem de $10 \mu \mathrm{L}$. O tempo de corrida para separação dos cátions foi de 14 minutos. As alíquotas foram aplicadas manualmente com utilização de seringas descartáveis de $1 \mathrm{~mL}$ acoplada ao filtro millex com membrana de PVDF 0,22 $\mu \mathrm{m}$ de poro (Millex, GV 13mm, Millipore Indústria e Comércio Ltda.). Para realização das curvas de padrões foi utilizado a solução de 6 cátions da Dionex contendo os seguintes íons lítio, sódio, amônia, potássio, magnésio e cálcio (Dionex Six Cation II Standard, Thermo Fisher Scientific, USA).

Todos os reagentes químicos utilizados para a preparação das soluções eluentes e regenerantes apresentaram grau de pureza PA.

A quantificação dos íons foi por meio de ajuste de variáveis (escolha dos íons, ajuste das concentrações das curvas padrões, calibração dos tempos de detecção dos picos para cada íon, calibração dos limites de quantificação de acordo com as curvas padrões e linha base, com coeficientes de correlação entre 0,965 a 0,999$)$ do método de quantificação do programa Chromeleon versão 6.8 (Thermo Fisher Scientific, USA).

\subsection{3 - Análises de biologia molecular para avaliação dos micro-organismos}

\subsubsection{1 - Da extração do DNA Genômico}

Para avaliação da presença e quantificação dos micro-organismos de interesse nos inóculos e nas biomassas desenvolvidas nos sistemas biológicos, após a operação das etapas experimentais 1 e 2, foram feitas extrações de DNA total dos organismos presentes usando kit de extração de DNA Genômico, conforme as recomendações do fabricante (PowerSoil DNA Isolation Kit, MoBio Laboratories, Inc., USA).

A qualidade e quantidade do DNA genômico, extraído de cada amostra dos inóculos coletados nos diferentes habitats, bem como das amostras das biomassas desenvolvidas após as etapas experimentais 1 e 2, foram verificadas por meio de eletroforese em gel de agarose (1\%) corado com brometo de etídeo $\left(1 \mu \mathrm{g} \cdot \mathrm{mL}^{-1}\right)$, usando marcador de massa molecular, High

DNA Mass Ladder (Invitrogen, USA). As estimativas das quantidades de DNA genômico das amostras dos lodos (em $\eta \mathrm{g}$ ) foram realizadas pela comparação da intensidade do sinal do marcador e das amostras, tendo sido padronizados das alíquotas do extrato contendo o 
DNA genômico e do marcador aplicados nos géis de agarose.

\subsubsection{2 - Análises PCR convencional e Sequenciamento}

As análises de PCR convencional foram realizadas para verificação da presença de bactérias anammox, das nitrificantes aeróbias oxidadoras de nitrito e de nitrato, utilizando pares de primers cujos genes alvos foram aqueles que codificam para porções do RNAr 16S e os específicos para enzima hidrazina (bactérias anammox) e hidroxilamina (bactérias aeróbias oxidadoras de amônia) (Tabela 4.5).

As condições de PCR para cada um dos pares primers foram estabelecidas com base em literatura, cujos pesquisadores obtiveram sucesso nas amplificações quando da utilização de DNA genômico de amostras ambientais não cultivadas. As condições para amplificações dos genes encontram-se na Tabela 4.6.

Os termocicladores utilizados para as análises de PCR foram um PTC-100 (MJ Research, Inc, USA) e PTC 1148 (MJ Mini Personal Thermal Cycler, BioRad, USA). O volume das reações em cada microtubo foi de $25 \mu \mathrm{L}$ contendo Tampão $1 \mathrm{X}, \mathrm{MgCl}_{2}$ 1,5 mM, Taq Dna Polimerase 1U a 1,5U (Taq DNA Polymerase Recombinant, Invitrogen, USA), dNTPs 200 $\mu \mathrm{M}$ (Invitrogen, USA), os primers $200 \eta \mathrm{M}$ de cada um dos pares (direto e reverso) e $10 \mu \mathrm{l}$ de DNA Genômico $\left(0,5 \eta \mathrm{g} \cdot \mu \mathrm{L}^{-1}\right)$. A avaliação dos fragmentos amplificados ocorreu por eletroforese em gel de agarose (1\%) corado com brometo de etídeo $\left(1 \mu \mathrm{g} \cdot \mathrm{mL}^{-1}\right)$, usando os marcadores para determinação dos tamanhos de fragmentos de $1 \mathrm{~Kb}$ e $100 \mathrm{bp}(1 \mathrm{~Kb}$ Plus Ladder da Invitrogen, USA e 1Kb e 100 bp Dna Ladder Axigen, USA) (Figura 4.12).

Todas as amplificações foram realizadas no mínimo duas vezes, em eventos distintos de PCR. Em todas elas foram realizadas os controles negativos das reações. Por não dispor de amostras de DNA controle para os micro-organismos estudados nessa pesquisa, os controles positivos para as PCRs não foram aplicados. 
Tabela 4.5: Conjunto de pares de primers utilizados para detecção de micro-organismos anaeróbios (anammox) e aeróbios (nitritantes e nitratantes) oxidadores de amônia.

\begin{tabular}{|c|c|c|c|}
\hline $\begin{array}{l}\text { Pares } \\
\text { Primers }\end{array}$ & Sequência 5' -3' & Especificidade & Referência \\
\hline $\begin{array}{l}\text { Pla } 46 \mathrm{~F} \\
\text { Amx } 820 \mathrm{R}^{1}\end{array}$ & $\begin{array}{c}\text { GGATTAGGCATGCAAGTC } \\
\text { AAAACCCCTCTACTTAGTGCCC }\end{array}$ & $\begin{array}{l}\text { Planctomicetos/Ca. } \\
\text { Brocardia e Kuenenia }\end{array}$ & $\begin{array}{c}\text { Neef et al., } 1998 \\
\text { Schmid } \text { et al., } \\
2000\end{array}$ \\
\hline $\begin{array}{l}\text { Pla } 46 \mathrm{~F} \\
\text { Amx } 368 \mathrm{R}^{1}\end{array}$ & $\begin{array}{l}\text { GGATTAGGCATGCAAGTC } \\
\text { CCTTTCGGGCATTGCGAA }\end{array}$ & $\begin{array}{c}\text { Planctomicetos/Bactérias } \\
\text { Anammox }\end{array}$ & $\begin{array}{c}\text { Neef et al., } 1998 \\
\text { Schmid et al., } \\
2005\end{array}$ \\
\hline $\begin{array}{l}\text { Amx } 368 \mathrm{~F} \\
\text { Amx } 820 \mathrm{R}^{1}\end{array}$ & $\begin{array}{c}\text { TTCGCAATGCCCGAAAGG } \\
\text { AAAACCCСТCTACTTAGTGCCC }\end{array}$ & $\begin{array}{c}\text { Planctomicetos/Bacterias } \\
\text { Anammox }\end{array}$ & $\begin{array}{l}\text { Sànchez-Melsió, } \\
\text { et al. } 2019\end{array}$ \\
\hline $\begin{array}{l}\text { Ana-hzo1F } \\
\text { Ana-hzo2R }\end{array}$ & $\begin{array}{l}\text { TGTGCATGGTCAATTGAAAG } \\
\text { ACCTCTTCWGCAGGTGCAT }\end{array}$ & $\begin{array}{c}\text { Detecção do gene } \\
\text { hzoA/hzoB Anammox }\end{array}$ & Quan et al., 2008 \\
\hline $\begin{array}{l}\text { Hzoc11F1 } \\
\text { Hzoc11R22 }\end{array}$ & $\begin{array}{l}\text { TGYAAGACYTGYCAYTGG } \\
\text { ACTCCAGATRTGCTGACC }\end{array}$ & $\begin{array}{c}\text { Detecção do gene } \\
\text { hzoA/hzoB Anammox }\end{array}$ & $\begin{array}{l}\text { Schmid et al., } \\
2008\end{array}$ \\
\hline $\begin{array}{l}\text { AmoA-1F } \\
\text { AmoA-2R }\end{array}$ & $\begin{array}{c}\text { GGGGTTTCTACTGGTGGT } \\
\text { CCCCTCKGSAAAGCCTTCTTC }\end{array}$ & $\begin{array}{c}\text { Detecção do gene amoA } \\
\text { - Bactérias aeróbias } \\
\text { oxidadoras de amônia }\end{array}$ & Egli, 2003 \\
\hline $\begin{array}{l}\text { NTSPA F } \\
\text { NTSPA R }^{1}\end{array}$ & $\begin{array}{l}\text { CGCAACCCCTGCTTTCAGT } \\
\text { CGTTATCCTGGGCAGTCCTT }\end{array}$ & $\begin{array}{c}\text { Nitrospira } \\
\text { Bactérias aeróbias } \\
\text { oxidadoras de nitrito }\end{array}$ & $\begin{array}{l}\text { Kindaichi et } \\
\text { al.,2006 }\end{array}$ \\
\hline $\begin{array}{l}\text { NITRO } 1198 \mathrm{~F} \\
\text { NITRO } 1423 \mathrm{R}^{1}\end{array}$ & $\begin{array}{c}\text { ACCССТAGCAAATCTCAAAAAACCG } \\
\text { CTTCACCCCAGTCGCTGACC }\end{array}$ & $\begin{array}{c}\text { Nitrobacter } \\
\text { Bactérias aeróbias } \\
\text { oxidadoras de nitrito }\end{array}$ & $\begin{array}{l}\text { Graham et al., } \\
\quad(2007)\end{array}$ \\
\hline $\begin{array}{l}1055 \mathrm{~F} \\
1392 \mathrm{R}^{1}\end{array}$ & $\begin{array}{c}\text { ATGGCTGTCGTCAGCT } \\
\text { ACGGGCGGTGTGAC }\end{array}$ & Universal RNAr 16S & $\begin{array}{l}\text { Ferris et al. } \\
\quad(1996)\end{array}$ \\
\hline
\end{tabular}

Iniciadores sintetizados: ${ }^{1}$ (IDT, Integrated DNA Techonologies, USA) e ${ }^{2}$ (Invitrogen, USA).

Tabela 4.6: Condições de amplificação utilizadas com os pares de primers escolhidos para detecção de micro-organismos aeróbios e anaeróbios oxidadores de amônia e nitrito.

\begin{tabular}{|c|c|c|c|c|c|c|}
\hline \multirow{2}{*}{$\begin{array}{l}\text { Primers/ } \\
\text { Referência }\end{array}$} & \multicolumn{6}{|c|}{ Condições da Amplificação (Temperatura ${ }^{\circ} \mathrm{C}$ e tempo) } \\
\hline & D. Inicial ${ }^{1}$ & $\mathbf{N}^{0} \operatorname{ciclos}^{2}$ & Desn. $^{3}$ & Anel. $^{4}$ & Ext. $^{5}$ & E.Final $^{6}$ \\
\hline \multirow{2}{*}{$\begin{array}{l}\text { Pla 46F e Amx820R (Araújo et } \\
\text { al., 2011) }\end{array}$} & $94^{\circ} \mathrm{C}$ & \multirow{2}{*}{35} & $94^{\circ} \mathrm{C}$ & $56^{\circ} \mathrm{C}$ & $72^{\circ} \mathrm{C}$ & $72^{\circ} \mathrm{C}$ \\
\hline & $4 \min$ & & $45 \mathrm{seg}$ & $50 \mathrm{~s}$ & $1 \mathrm{~min}$ & $7 \mathrm{~min}$ \\
\hline \multirow{2}{*}{$\begin{array}{l}\text { Pla 46F e Amx368R (Sànchez } \\
\text { - Melsió et al., 2009) }\end{array}$} & $94^{\circ} \mathrm{C}$ & \multirow{2}{*}{35} & $94^{\circ} \mathrm{C}$ & $58^{\circ} \mathrm{C}$ & $72^{\circ} \mathrm{C}$ & $72^{\circ} \mathrm{C}$ \\
\hline & $5 \mathrm{~min}$ & & $45 \mathrm{seg}$ & $1 \mathrm{~min}$ & $1 \mathrm{~min}$ & $7 \mathrm{~min}$ \\
\hline \multirow{2}{*}{$\begin{array}{l}\text { Amx 368F e Amx 820R } \\
\text { (Sànchez - Melsió et al., 2009) }\end{array}$} & $94^{\circ} \mathrm{C}$ & \multirow{2}{*}{35} & $94^{\circ} \mathrm{C}$ & $62{ }^{\circ} \mathrm{C}$ & $72^{\circ} \mathrm{C}$ & $72^{\circ} \mathrm{C}$ \\
\hline & $5 \mathrm{~min}$ & & $45 \mathrm{seg}$ & $1 \mathrm{~min}$ & $1 \mathrm{~min}$ & $7 \mathrm{~min}$ \\
\hline \multirow{2}{*}{$\begin{array}{l}\text { Ana-hzo1F e Ana-hzo2R } \\
\text { (Quan et al., 2008) }\end{array}$} & $94^{\circ} \mathrm{C}$ & \multirow{2}{*}{30} & $94^{\circ} \mathrm{C}$ & $53^{\circ} \mathrm{C}$ & $72^{\circ} \mathrm{C}$ & $72^{\circ} \mathrm{C}$ \\
\hline & $2 \min$ & & $1 \mathrm{~min}$ & $1 \mathrm{~min}$ & $1 \mathrm{~min}$ & $10 \mathrm{~min}$ \\
\hline \multirow{2}{*}{$\begin{array}{l}\text { Hzoc11F1 e Hzoc11R2 } \\
\text { (Schmid } \text { et al., 2008) }\end{array}$} & $94^{\circ} \mathrm{C}$ & \multirow{2}{*}{30} & $94^{\circ} \mathrm{C}$ & $50^{\circ} \mathrm{C}$ & $72^{\circ} \mathrm{C}$ & $72^{\circ} \mathrm{C}$ \\
\hline & $5 \mathrm{~min}$ & & $1 \mathrm{~min}$ & $1 \mathrm{~min}$ & $1 \mathrm{~min}$ & $7 \mathrm{~min}$ \\
\hline \multirow{2}{*}{$\begin{array}{l}\text { AmoA-1F e AmoA-2R (Egli, } \\
\text { 2003) }\end{array}$} & $95^{\circ} \mathrm{C}$ & \multirow{2}{*}{35} & $95^{\circ} \mathrm{C}$ & $60^{\circ} \mathrm{C}$ & $72^{\circ} \mathrm{C}$ & $72{ }^{\circ} \mathrm{C}$ \\
\hline & $4 \min$ & & $1 \mathrm{~min}$ & $45 \mathrm{seg}$ & $1 \mathrm{~min}$ & $3 \mathrm{~min}$ \\
\hline \multirow{2}{*}{$\begin{array}{l}\text { Ntspa F e Ntspa R } \\
\text { (Kindaichi et al., 2006) }\end{array}$} & $94{ }^{\circ} \mathrm{C}$ & \multirow{2}{*}{40} & $94^{\circ} \mathrm{C}$ & $60^{\circ} \mathrm{C}$ & $72^{\circ} \mathrm{C}$ & $72^{\circ} \mathrm{C}$ \\
\hline & $5 \mathrm{~min}$ & & $30 \mathrm{seg}$ & $45 \mathrm{seg}$ & $40 \mathrm{seg}$ & $10 \mathrm{~min}$ \\
\hline \multirow{2}{*}{$\begin{array}{l}\text { Nitro 1198F e Nitro 1423R } \\
\text { (Graham et al., 2007) }\end{array}$} & $95^{\circ} \mathrm{C}$ & \multirow{2}{*}{35} & $95^{\circ} \mathrm{C}$ & $53^{\circ} \mathrm{C}$ & $72^{\circ} \mathrm{C}$ & $72^{\circ} \mathrm{C}$ \\
\hline & $10 \mathrm{~min}$ & & $20 \mathrm{seg}$ & $1 \mathrm{~min}$ & $1 \mathrm{~min}$ & $7 \mathrm{~min}$ \\
\hline
\end{tabular}

\footnotetext{
${ }^{1}$ Desnaturação Inicial; ${ }^{2}$ Número de ciclos; ${ }^{3}$ Desnaturação; ${ }^{4}$ Anelamento; ${ }^{5}$ Extensão; ${ }^{6}$ Extensão final.
} 
Os produtos de amplificação por PCR para os micro-organismos anammox, das amostras dos inóculos e das biomassas dos sistemas após 120 dias, usando os primers Pla46F e Amx 820R, foram enviados à empresa Macrogen em Seul na Coreia do Sul, para o sequenciamento dos pares de bases, contratando-se o serviço EZ-seq. A modalidade EZ-seq tratou-se da aquisição antecipada do serviço de sequenciamento junto à Empresa, na qual se obteve códigos de barra para serem afixados nos microtubos que tiveram as amostras sequenciadas. As amostras foram preparadas fazendo-se uma mistura dos produtos de PCR purificados e os primers utilizados nas concentrações e volumes especificados. $\mathrm{O}$ sequenciador utilizado foi o 3730XL (Applied Biosystems 3730xl DNA Analyzer, Life Technologies, USA) que se baseia na metodologia de Sanger.

Os produtos da amplificação, sendo eles fragmentos com aproximadamente $774 \mathrm{pb}$, enviados à Macrogem, foram preparados usando-se kit de purificação de DNA a partir de produtos de PCR segundo protocolo disponibilizado pelo fabricante (AxyPrep PCR Clean up Kit, AXIGEN, USA). Cada amostra purificada foi acondicionada em um microtubo (500 $\mu \mathrm{L}$ ) com volume de $20 \mu \mathrm{l}\left(50 \eta \mathrm{g} . \mu \mathrm{L}^{-1}\right)$ combinada com $10 \mu \mathrm{L}\left(5\right.$ pmole. $\left.\mu \mathrm{L}^{-1}\right)$ de cada primer, conforme os procedimentos recomendados para o sequenciamento de amostras a partir de produtos de PCR.

O envio das amostras de fragmentos de DNA, obtidos a partir da amplificação por PCR, à Macrogen na Coreia do Sul foi autorizado pelo IBAMA/Brasil por meio da CITES, licença de exportação e importação de material biológico (fragmentos de DNA) n 13BR010345/DF.

$\mathrm{Na}$ análise de sequenciamento objetivou-se avaliar a similaridade das sequências obtidas dos produtos de PCR para genes que codificam para o RNAr 16S usando-se primers (Pla46F e Amx 820R) com sequências de fragmentos de micro-organismos anammox depositadas no GenBank (<http://www.ncbi.nlm.nih.gov/>). Ainda que os fragmentos de DNA amplificados representem um mix dos genes para o RNAr $16 \mathrm{~S}$ de bactérias anammox originados de células diferentes dentro da amostra ambiental, pode-se buscar o sequenciamento direto quando utilizados procedimentos e equipamentos que apresentem alto rendimento (Youssef et al., 2014). Tem-se também registrado o predomínio de um único gênero anammox em amostras de sistemas biológicos em que ocorre o processo de oxidação anaeróbia de amônia (Hu et al., 2010; Tao et al., 2013) podendo-se esperar que o sequenciamento resultará na obtenção de sequências com bons padrões de qualidade para comparações filogenéticas. 
A avaliação da qualidade das sequências de bases de DNA obtidas pelo sequenciamento foi analisada usando os softwares CodonCode Aligner versão demo 4.1.1 (CodonCode Corporation, Massachusetts, USA) e o Sequence Scanner versão 1.0 (Applied Biosystems, USA). As aproximações filogenéticas das sequências de DNA obtidas, para o RNAr 16S de bactérias anammox, foram realizadas por comparações com sequências de microorganismos relacionados depositadas no GenBank da NCBI (National Center for Biotechnology Information) usando o BLAST - Basic Local Alignment Search Tool. A construção das árvores filogenéticas entre as sequências obtidas nesse estudo e as depositadas no GenBank, tendo-se usado as sequências de referência para as candidatas anammox, foram realizadas usando o software Clustal Multiple Sequence Alignment versão ômega, por análise de bootstrap (reamostragem) usando o método de Neighbor-Joing (Sierver et al., 2011). No entanto, a geração das árvores filogenéticas com as relações evolutivas foi feita utilizando o programa MEGA 4.1 - Molecular Evolutionary Genetics Analysis (Tamura et al., 2007). O dendrograma foi gerado pelo método Neighbor-Joining e as distâncias evolutivas foram calculadas usando o método Maximum Composite Likelihood e estão apresentadas em unidades de números de substituições de bases por sítio, sendo realizado uma estimativa simultânea dos parâmetros para todos os pares de sequências (Tamura et al., 2007). As posições contendo espaços e dados faltantes nos alinhamentos foram eliminadas em comparações de sequências (por pares) usando a opção pairwise deletion. Análise de bootstrap contendo 1000 réplicas foram realizadas para estimar a confiabilidade e o arranjo das árvores.

\subsubsection{3 - Análises de PCR quantitativa}

A análise de PCR quantitativa foi realizada para comparações relativas entre o número de cópias dos genes dos micro-organismos do Domínio Bacteria (Universal, Anammox, Nitritantes e Nitratantes) usando primers para os genes alvos RNAr 16S e o específico amoA conforme combinações propostas por Park et al. (2010) (Tabela 4.7). A partir da análise conjunta das biomassas antes e após cada etapa experimental foi possível realizar uma quantificação relativa para cada amostra de DNA genômico extraído para comparações entre grupos de micro-organismos dominantes em cada etapa e entre as biomassas de cada sistema (Tabela 4.8). 
Tabela 4.7: Primers utilizados e temperatura de anelamento adotados nas análises de PCR quantitativa.

\begin{tabular}{lcc}
\hline \hline \multicolumn{1}{c}{ Gene Alvo } & Primers $^{1}$ & $\begin{array}{c}\text { Temperatura de Anelamento } \\
\left({ }^{\circ} \mathrm{C}\right)\end{array}$ \\
\hline Universal RNAr 16S & $1055 \mathrm{~F}-1392 \mathrm{R}$ & 53 \\
\hline Anammox RNAr 16S & Pla 46 F - Amx667 R & 55 \\
\hline Nitrobacter RNAr 16S & Nitro 1198 F - Nitro 1423 & 58 \\
\hline Nitrosomonas amoA & $\mathrm{R}$ & 57 \\
\hline \hline
\end{tabular}

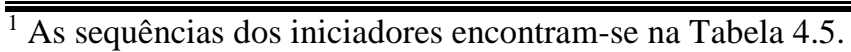

Tabela 4.8: Combinações de comparações realizadas entre as amostras de DNA genômico dos sistemas biológicos testados por análise de PCR quantitativa.

\begin{tabular}{llcccc}
\hline \hline \multirow{2}{*}{$\begin{array}{l}\text { Origem do DNA } \\
\text { Genômico }\end{array}$} & $\begin{array}{l}\text { Período } \\
\text { extração }\end{array} \quad$ do & \multicolumn{2}{c}{ Grupos de micro-organismos testados } \\
& DNA & Universal & Anammox & Nitrobacter & Nitrosomonas \\
\hline Biomassa obtida & Pai1 & $\checkmark$ & $\checkmark$ & $\checkmark$ & $\checkmark$ \\
sedimento Paranoá & PaA e B e1 & $\checkmark$ & $\checkmark$ & $\checkmark$ & $\checkmark$ \\
\hline Biomassa obtida lodo & PaA e B e2 & $\checkmark$ & $\checkmark$ & $\checkmark$ & $\checkmark$ \\
lagoa anaeróbia & AnF1i & $\checkmark$ & $\checkmark$ & $\checkmark$ & $\checkmark$ \\
Frigorífico 1 & AnF1A e B e1 & $\checkmark$ & $\checkmark$ & $\checkmark$ & $\checkmark$ \\
\hline Biomassa obtida lodo 2 & $\checkmark$ & $\checkmark$ & $\checkmark$ & $\checkmark$ \\
lagoa facultativa & FaF1i & $\checkmark$ & $\checkmark$ & $\checkmark$ & $\checkmark$ \\
Frigorífico 1 & FaF1A e B e1 & $\checkmark$ & $\checkmark$ & $\checkmark$ & $\checkmark$ \\
\hline Biomassa obtida lodo & FaF1A e B e2 & $\checkmark$ & $\checkmark$ & $\checkmark$ & $\checkmark$ \\
lagoa facultativa & FaF2i & $\checkmark$ & $\checkmark$ & $\checkmark$ & $\checkmark$ \\
Frigorífico 2 & FaF2A e B e1 & $\checkmark$ & $\checkmark$ & $\checkmark$ & $\checkmark$ \\
\hline \multirow{2}{*}{ Biomassa obtida lodo } & FaF2A e B e2 & $\checkmark$ & $\checkmark$ & $\checkmark$ & $\checkmark$ \\
UASB Frigorífico 2 & UaF2i & $\checkmark$ & $\checkmark$ & $\checkmark$ & $\checkmark$ \\
\hline Biomassa obtida & UaF2A e B e1 & $\checkmark$ & $\checkmark$ & $\checkmark$ & $\checkmark$ \\
Sedimento lagoa & Choi & $\checkmark$ & $\checkmark$ & $\checkmark$ \\
acumulação Chorume & ChoA e B e1 & $\checkmark$ & $\checkmark$ & $\checkmark$ & $\checkmark$ \\
\hline \hline
\end{tabular}

$\overline{{ }_{1}}=$ inicial; ${ }^{2} \mathrm{e}_{1}=$ após etapa 1 (120 dias); ${ }^{3} \mathrm{e}_{2}=$ após etapa 2 (180 dias)

As análises de PCR quantitativa foram realizadas usando um termociclador específico para acompanhamento das amplificações em tempo real (C1000 Touch Thermal Cycler - 
BioRad, USA), com placas de 96 poços seladas (Hard-Shell 96 Well WHT/CLR e Microseal 'B' Film, BioRad, USA). Utilizou-se um mix com os reagentes necessários à amplificação dos fragmentos, contendo a enzima de polimerização (Taq), dNTPs, tampão, cloreto de magnésio e a sonda hidrolítica contenho o fluoróforo SYBR Green, para otimização das reações (SsoAdvanced ${ }^{\mathrm{TM}}$ SYBR Green Supermix, BIO-RAD). O volume final das reações foi de $20 \mu \mathrm{L}$, sendo $10 \mu \mathrm{L}$ do mix, $0,4 \mu \mathrm{L}$ de cada primer $(20 \mu \mathrm{M}), 3 \mu \mathrm{L}$ do DNA template $\left(0,5 \eta \mathrm{g} . \mu \mathrm{L}^{-1}\right)$ e água ultrapura estéril para completar o volume.

A curva de referência quantitativa foi realizada por diluições da amostra de DNA genômico extraído da biomassa a partir do sedimento do Lago Paranoá (quando da inoculação nos sistemas biológicos) com objetivo de um valor de referência (Bustin et al., 2009). As diluições do DNA genômico obtido a partir da extração da biomassa presente no sedimento do Lago Paranoá (Pa inicial) utilizadas para realização das curvas foram de 0,$5 ; 1,5 ; 3,75$; 7,5 e $15\left(\eta g . \mu \mathrm{L}^{-1}\right)$. Ressalta-se essa metodologia para construção da curva permite apenas uma comparação relativa e que seriam preferíveis controles positivos com DNA dos grupos de micro-organismos para construção da curva de calibração, garantindo a comparação inequívoca do número de cópias de DNA.

Na Figura 4.11 é apresentada a configuração da placa do PCR quantitativa adotada para avaliar a quantidade relativa de DNA para cada par de primers testados das diferentes biomassas nos diferentes tempos experimentais. Todas as amostras de DNA genômico foram aplicadas em duplicatas.

\begin{tabular}{|c|c|c|c|c|c|c|c|c|c|c|c|c|}
\hline 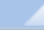 & 1 & 2 & 3 & 4 & 5 & 6 & 7 & 8 & 9 & 10 & 11 & 12 \\
\hline & Std & Std & Unk & Unk & Unk & Unk & Unk & Unk & Unk & Unk & Unk & Unk \\
\hline A & $5,00 \mathrm{E}-01$ & $5,00 \mathrm{E}-01$ & $\begin{array}{c}\text { SYBR } \\
\mathrm{Pai}\end{array}$ & $\begin{array}{c}\text { SYBR } \\
\mathrm{Pai}\end{array}$ & $\begin{array}{c}\text { SYBR } \\
P a A \in 1\end{array}$ & $\begin{array}{c}\text { SYBR } \\
P a A \in 1\end{array}$ & $\begin{array}{c}\text { SYBR } \\
\mathrm{PaB} \in 1\end{array}$ & $\begin{array}{c}\text { SYBR } \\
\mathrm{PaB} \in 1\end{array}$ & $\begin{array}{l}\text { SYBR } \\
\mathrm{PaA} \in 2\end{array}$ & $\begin{array}{c}\text { SYBR } \\
\mathrm{PaA} e 2\end{array}$ & $\begin{array}{c}\text { SYBR } \\
\mathrm{PaB} \in 2\end{array}$ & $\begin{array}{c}\text { SYBR } \\
\mathrm{PaB} e 2\end{array}$ \\
\hline & Std & Std & Unk & Unk & Unk & Unk & Unk & Unk & Unk & Unk & Unk & Unk \\
\hline B & $1,50 E+00$ & $1,50 E+00$ & $\begin{array}{l}\text { SYBR } \\
\text { AnF1i }\end{array}$ & $\begin{array}{l}\text { SYBR } \\
\text { AnF1i }\end{array}$ & $\begin{array}{c}\text { SYBR } \\
\text { AnF1A } \in 1\end{array}$ & $\begin{array}{c}\text { SYBR } \\
\text { AnF1A } \in 1\end{array}$ & $\begin{array}{c}\text { SYBR } \\
\text { AnF1B } 1\end{array}$ & $\begin{array}{c}\text { SYBR } \\
\text { AnF1B } 11\end{array}$ & $\begin{array}{c}\text { SYBR } \\
\text { AnF1A } \in 2\end{array}$ & $\begin{array}{c}\text { SYBR } \\
\text { AnF1A } e 2\end{array}$ & $\begin{array}{c}\text { SYBR } \\
\text { AnF1B e2 }\end{array}$ & $\begin{array}{c}\text { SYBR } \\
\text { AnF1B e2 }\end{array}$ \\
\hline & Std & Std & Unk & Unk & Unk & Unk & Unk & Unk & Unk & Unk & Unk & Unk \\
\hline C & $3,75 \mathrm{E}+00$ & $3,75 \mathrm{E}+00$ & $\begin{array}{l}\text { SYBR } \\
\text { FaF1i }\end{array}$ & $\begin{array}{l}\text { SYBR } \\
\text { FaF1i }\end{array}$ & $\begin{array}{c}\text { SYBR } \\
\text { FaF1A } 1\end{array}$ & $\begin{array}{c}\text { SYBR } \\
\text { FaF1A e1 }\end{array}$ & $\begin{array}{c}\text { SYBR } \\
\text { FaF1B e1 }\end{array}$ & $\begin{array}{c}\text { SYBR } \\
\text { FaF1B } 11\end{array}$ & $\begin{array}{c}\text { SYBR } \\
\text { FaF1A } e 2\end{array}$ & $\begin{array}{c}\text { SYBR } \\
\text { FaF1A } e 2\end{array}$ & $\begin{array}{c}\text { SYBR } \\
\mathrm{FaF} 1 \mathrm{~B} e 2\end{array}$ & $\begin{array}{c}\text { SYBR } \\
\mathrm{FaF} 1 \mathrm{~B} \mathrm{e2}\end{array}$ \\
\hline & Std & Std & Unk & Unk & Unk & Unk & Unk & Unk & Unk & Unk & Unk & Unk \\
\hline D & $7,50 \mathrm{E}+00$ & $7,50 \mathrm{E}+00$ & $\begin{array}{l}\text { SYBR } \\
\text { FaF2i }\end{array}$ & $\begin{array}{l}\text { SYBR } \\
\text { FaF2i }\end{array}$ & $\begin{array}{c}\text { SYBR } \\
\text { FaF2A } 11 \\
\end{array}$ & $\begin{array}{c}\text { SYBR } \\
\text { FaF2A } \in 1\end{array}$ & $\begin{array}{c}\text { SYBR } \\
F a F 2 B \in 1\end{array}$ & $\begin{array}{c}\text { SYBR } \\
\mathrm{FaF} 2 \mathrm{~B} \in 1\end{array}$ & $\begin{array}{c}\text { SYBR } \\
\text { FaF2A } e 2 \\
\end{array}$ & $\begin{array}{c}\text { SYBR } \\
\text { FaF2A } e 2 \\
\end{array}$ & $\begin{array}{c}\text { SYBR } \\
\text { FaF2B } e 2\end{array}$ & $\begin{array}{c}\text { SYBR } \\
\mathrm{FaF2B} \in 2 \\
\end{array}$ \\
\hline & Std & Std & Unk & Unk & Unk & Unk & Unk & Unk & Unk & Unk & Unk & Unk \\
\hline $\mathrm{E}$ & $1,00 \mathrm{E}+01$ & $1,00 \mathrm{E}+01$ & $\begin{array}{l}\text { SYBR } \\
\text { UaF2i }\end{array}$ & $\begin{array}{l}\text { SYBR } \\
\text { UaF2i }\end{array}$ & $\begin{array}{c}\text { SYBR } \\
\text { UaF2A e1 }\end{array}$ & $\begin{array}{c}\text { SYBR } \\
\text { UaF2A e1 }\end{array}$ & $\begin{array}{c}\text { SYBR } \\
\text { UaF2B e1 }\end{array}$ & $\begin{array}{c}\text { SYBR } \\
\text { UaF2B } \in 1\end{array}$ & \begin{tabular}{|c|} 
SYBR \\
UaF2A $\in 2$ \\
\end{tabular} & $\begin{array}{c}\text { SYBR } \\
\text { UaF2A } e 2 \\
\end{array}$ & $\begin{array}{c}\text { SYBR } \\
\text { UaF2B } e 2\end{array}$ & $\begin{array}{c}\text { SYBR } \\
\text { UaF2B } e 2 \\
\end{array}$ \\
\hline & Std & Std & Unk & Unk & Unk & Unk & Unk & Unk & Unk & Unk & Unk & Unk \\
\hline $\mathrm{F}$ & $1,50 \mathrm{E}+01$ & $1,50 \mathrm{E}+01$ & $\begin{array}{l}\text { SYBR } \\
\text { Choi } \\
\end{array}$ & $\begin{array}{l}\text { SYBR } \\
\text { Choi } \\
\end{array}$ & $\begin{array}{c}\text { SYBR } \\
\text { ChoA e1 }\end{array}$ & $\begin{array}{c}\text { SYBR } \\
\text { ChoA e1 }\end{array}$ & $\begin{array}{c}\text { SYBR } \\
\text { ChoB e1 }\end{array}$ & $\begin{array}{c}\text { SYBR } \\
\text { ChoB e1 } \\
\end{array}$ & $\begin{array}{c}\text { SYBR } \\
\text { ChOA } e 2\end{array}$ & $\begin{array}{c}\text { SYBR } \\
\text { ChOA e2 } \\
\end{array}$ & $\begin{array}{c}\text { SYBR } \\
\text { ChoB e2 }\end{array}$ & $\begin{array}{c}\text { SYBR } \\
\text { ChoB e2 }\end{array}$ \\
\hline G & & & & & & & & & & & & \\
\hline H & & & & & & & & & $\begin{array}{c}\text { NTC } \\
\text { SYBR } \\
\text { Branco } \\
\end{array}$ & $\begin{array}{c}\text { NTC } \\
\text { SYBR } \\
\text { Branco }\end{array}$ & $\begin{array}{c}\text { NTC } \\
\text { SYBR } \\
\text { Branco } \\
\end{array}$ & $\begin{array}{c}\text { NTC } \\
\text { SYBR } \\
\text { Branco }\end{array}$ \\
\hline
\end{tabular}

Figura 4.11: Configuração da placa do PCR quantitativo utilizada para cada par de primers testados. 
$\mathrm{Na}$ quantificação relativa determina-se o número de cópias da porção do gene de interesse entre amostras comparadas pelo uso dos parâmetros: Ciclo de quantificação (Cq) e Quantidade inicial (SQ) de DNA calculado pelas concentrações oferecidas para construir a curva padrão. O ciclo de quantificação marca o ponto no qual a amostra entra na fase exponencial de amplificação e, dessa forma, quanto maior a concentração inicial do gene de interesse numa amostra mais rapidamente obter-se-á o Cq. A quantidade inicial (SQ) é um escore obtido no momento que se obtém o Cq comparando-se com quantidades informadas da curva de referência. Os valores de Cq e SQ foram utilizados para comparar as amostras de DNA das biomassas nos diferentes tempos das etapas experimentais.

Os parâmetros Cq e SQ foram obtidos utilizando-se o software CFX fornecido pelo fabricante do termociclador utilizado (BIO-RAD, USA). Utilizou-se, também, de outros parâmetros apresentados pelo software como a curva da temperatura de meeting (Tm) que indica a especificidade dos primers pela ocorrência ou não da formação de dímeros e outras amplificações não específicas, bem como, os parâmetros eficiência de amplificação, coeficiente de correlação e o slope da curva de amplificação para avaliação do sucesso das análises de acordo com as recomendações do The MIQE Guidelines: Minimum Information for Publication of Quantitative Real Time PCR experiments (Bustin et al., 2009).

\section{4 - TRATAMENTO DOS DADOS}

Os dados obtidos nos experimentos foram tabelados usando o Excel 2013 (Office 365 University). Para o tratamento estatístico dos dados utilizou-se o software IBM SPSS Estatistic 22 (Código Licença - Autorização da Versão para Teste).

Os dados brutos de concentrações dos íons envolvidos na estequiometria da reação anammox, sendo eles amônia $\left(\mathrm{NH}_{4}{ }^{+}\right)$, nitrito $\left(\mathrm{NO}_{2}^{-}\right)$e nitrato $\left(\mathrm{NO}_{3}^{-}\right)$foram convertidos de mg. $\mathrm{L}^{-1}$ para $\mathrm{mM}$ de $\mathrm{N}-\mathrm{NH}_{4}{ }^{+} ; \mathrm{N}^{-\mathrm{NO}_{2}}{ }^{-}$e $\mathrm{N}-\mathrm{NO}_{3}{ }^{-}$.

Na etapa 1 foram realizadas 12 bateladas para todos os 12 sistemas biológicos estudados (a partir de 6 inóculos de origens diferentes $\times 2$ repetições), tendo sido verificadas as concentrações dos íons nos tempos T0 (início das bateladas - 0 hora) e em T1 (intervalos de 5 7 dias após o início das bateladas). Com os resultados das concentrações dos íons (N- 
$\mathrm{NH}_{4}{ }^{+}, \mathrm{N}-\mathrm{NO}_{2}{ }^{-}, \mathrm{N}_{-} \mathrm{NO}_{3}{ }^{-}$em $\mathrm{mM}$ ) nesses tempos foram obtidas as conversões dessas formas nitrogenadas pelas diferenças nas concentrações entre os intervalos de tempo T0_T1.

Para a etapa 2 foram realizadas 10 bateladas para todos os 12 sistemas biológicos estudados (a partir dos sistemas montados para a etapa 1 com 6 inóculos de origens diferentes $\mathrm{x} 2$ repetições) tendo sido verificadas as concentrações dos íons nos tempos T0 (início das bateladas - 0 hora); T1 (24 horas depois do início das bateladas); T2 (48 horas depois do início das bateladas) e T3 (72 horas depois do início das bateladas). Com os resultados das concentrações dos íons ( $\mathrm{N}-\mathrm{NH}_{4}{ }^{+}, \mathrm{N}_{-} \mathrm{NO}_{2}{ }^{-}, \mathrm{N}_{-} \mathrm{NO}_{3}{ }^{-}$em mM) nesses tempos foram obtidas as conversões dessas formas nitrogenadas pelas diferenças nas concentrações entre os intervalos de tempo T0_T1 (0 a 24 horas); T1_T2 (24 a 48 horas); T0_T2 (0 a 48 horas); T2_T3 (48 a 72 horas) e T0_T3 (0-72 horas).

De forma a aumentar o poder das variáveis comparativas entre os sistemas biológicos testados durante a etapa 2 construiu-se variáveis de ordens secundária e terciária pela agregação das variáveis primárias. A variável de ordem secundária foi a relação entre as diferenças entre as concentrações de $\mathrm{N}^{-\mathrm{NO}_{2}}{ }^{-}(\mathrm{mM})$ e N-NH${ }_{4}{ }^{+}(\mathrm{mM})$ entre os intervalos de tempo dentro de cada batelada, conforme equação 4.3.

$$
R_{-} N i A m_{-} N_{t i t j}=\left[\frac{N O_{2_{t i}}^{-}-N O_{2_{t j}}^{-}}{N H_{4_{t i}}^{+}-N H_{4_{t j}}^{+}}\right]
$$

Sendo:

$\mathrm{R} \_N i A m \_\mathrm{N}_{\text {titj }}=$ Relação molar entre as concentrações de $\mathrm{N}-\mathrm{NO}_{2}{ }^{-}(\mathrm{mM})$ e $\mathrm{N}^{-N_{H}}{ }^{+}(\mathrm{mM})$ entre o intervalo de tempos considerados.

$\mathrm{t}_{\mathrm{i}}=$ Tempo anterior do intervalo considerado para o cálculo

$\mathrm{t}_{\mathrm{j}}=$ Tempo posterior do intervalo considerado para o cálculo

$\mathrm{NO}_{2}^{-}$e $\mathrm{NO}_{2_{t j}}^{-}=$Concentração molar de $\mathrm{N}^{-N}{ }_{2}^{-}$no tempo anterior e posterior do intervalo considerado para o cálculo.

$\mathrm{NH}_{4 t i}^{+}$e $\mathrm{NH}_{4 t j}^{+}=$Concentração molar de $\mathrm{N}-\mathrm{NH}_{4}{ }^{+}$no tempo anterior e posterior do intervalo considerado para o cálculo. 
A variável de ordem terciária foi estruturada pela relação entre a diferença entre concentrações de $\mathrm{N}^{-\mathrm{NO}_{3}}{ }^{-}(\mathrm{mM})$ com a diferença entre as concentrações conjuntas de $\mathrm{N}^{-\mathrm{NO}_{2}}{ }^{-}$ $(\mathrm{mM})$ e $\mathrm{N}-\mathrm{NH}_{4}{ }^{+}(\mathrm{mM})$ entre os intervalos de tempo dentro de cada batelada, conforme equação 4.4 .

$$
R_{-} N a_{-} N i A m_{-} N_{t i t j}=\left[\frac{N O_{3_{t j}}^{-}-N O_{3_{t i}}^{-}}{\left(N H_{4_{t i}}^{+}-N H_{4_{t j}}^{+}\right)+\left(N O_{2_{t i}}^{-}-N O_{2_{t j}}^{-}\right)}\right]
$$

Sendo:

R_Na_NiAm_N $\mathrm{N}_{\text {titj }}=$ Relação molar entre as concentrações de $\mathrm{NO}_{3}{ }^{-} \_\mathrm{N}(\mathrm{mM})$ sob a conversão conjunta das concentrações de $\mathrm{N}_{-\mathrm{NO}_{2}}^{-}(\mathrm{mM})$ e $\mathrm{N}-\mathrm{NH}_{4}{ }^{+}(\mathrm{mM})$ entre o intervalo de tempos considerados.

$\mathrm{t}_{\mathrm{i}}=$ Tempo anterior do intervalo considerado para o cálculo

$\mathrm{t}_{\mathrm{j}}=$ Tempo posterior do intervalo considerado para o cálculo

$\mathrm{NO}_{2}^{-}$e $\mathrm{NO}_{2_{t j}}^{-}=$Concentração molar de $\mathrm{N}^{-N} \mathrm{O}_{2}^{-}$no tempo anterior e posterior do intervalo considerado para o cálculo.

$\mathrm{NH}_{4 t i}^{+}$e $\mathrm{NH}_{4 t j}^{+}=$Concentração molar de $\mathrm{N}-\mathrm{NH}_{4}{ }^{+}$no tempo anterior e posterior do intervalo considerado para o cálculo.

$\mathrm{NO}_{3_{t j}}^{-}$e $\mathrm{NO}_{3}^{-}=$Concentração molar de $\mathrm{N}_{t i} \mathrm{NO}_{3}{ }^{-}$no tempo posterior e anterior do intervalo considerado para o cálculo.

No entanto, para análise dos dados de normalidade e homogeneidade para os testes estatísticos de comparações entre os sistemas realizou-se a transformação dos dados obtidos nessas relações estequiométricas porque ocorreram diferenças grandes entre as reduções das concentrações de amônia e nitrito, bem como na produção de nitrato que resultaram em distribuições de frequências dos escores com muitos valores atípicos e extremos. Dessa maneira, realizou-se a transformação dos dados usando o logaritmo na base $10\left(\log _{10}\left(\mathrm{X}_{\mathrm{i}}\right.\right.$ +2)). Adicionou-se uma constante igual a 2 ao escore obtido da relação entre as reduções das concentrações de $\mathrm{N}^{-\mathrm{NO}_{2}}{ }^{-}(\mathrm{mM})$ e N-NH${ }^{+}(\mathrm{mM})$. O objetivo do acréscimo da constante igual a 2 foi evitar os escores iguais a zero e negativos visto que os mesmos não podem ser obtidos na escala logarítmica (Field, 2009). Portanto procedeu-se a análise de sensibilidade da 
seguinte forma conforme as equações 4.5 e 4.6:

$$
\begin{gathered}
T_{-} N i A m_{-} N_{t i t j}=\log _{10}\left(\left[\frac{N O_{2_{t i}}-N O_{2_{t j}}}{N H_{4_{t i}}-N H_{4_{t j}}}\right]+2\right) \quad \text { Equação } 4.5 \\
T_{-} N a_{-} N i A m_{-} N_{t i t j}=\log _{10}\left[\left(\frac{N O_{3_{t j}}-N O_{3_{t i}}}{\left(N H_{4 t i}-N H_{4_{t j}}\right)+\left(N O_{2_{t i}}-N O_{2_{t j}}\right)}\right)+2\right] \text { Equação } 4.6
\end{gathered}
$$

Sendo:

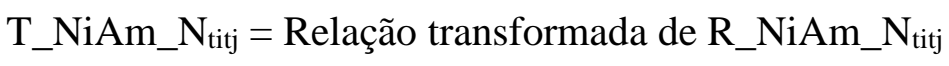

T_Na_NiAm_Nt $t_{i t j}=$ Relação transformada de R_Na_NiAm_N titj

A relação estequiométrica ideal entre nitrito e amônia pela reação anammox é igual a 1,32 e com a transformação torna-se 0,521. Enquanto, a relação estequiométrica ideal entre nitrato com a redução concomitante de amônia e nitrito pela reação anammox é 0,28 e com a transformação torna-se 0,358 .

Os escores obtidos pelas diferenças nas concentrações dos íons $\mathrm{N}-\mathrm{NO}_{3}{ }^{-} ; \mathrm{N}^{-} \mathrm{NO}_{2}{ }^{-}$e $\mathrm{N}_{-} \mathrm{NH}_{4}{ }^{+}$ $(\mathrm{mM})$ e pela realização das relações entre variáveis primárias consolidadas em variáveis secundária e terciária entre os diferentes intervalos de tempo dentro de cada batelada para as etapas 1 e 2 foram avaliados quanto à sua distribuição normal e homogeneidade das amostras.

Para testar se as distribuições dos dados desviaram de uma distribuição normal utilizaramse os testes de Kolmogorov-Smirnov (D) e de Shapiro-Wilk (D), que comparam escores de uma amostra a uma distribuição normal modelo de mesma média e variância dos valores encontrados nas amostras. No entanto, optou-se pelas significâncias obtidas com os testes de Shapiro-Wilk (D), que representam maior robustez quando o número de amostras é pequeno (Field, 2009). Nesse estudo, para cada condição testada o tamanho das amostras foi igual a 12 (Etapa 1) e 10 (Etapa 2). Quando o teste não foi significativo (p > 0,05), inferiuse que os dados das amostras não diferiram significativamente de uma distribuição normal. 
Por outro lado, quando o teste foi significativo $(\mathrm{p} \leq 0,05)$ a distribuição em questão foi significativamente diferente de uma distribuição normal.

A homogeneidade entre as amostras foi testada na etapa 1 e 2 considerando-se a variância entre as duplicatas de cada sistema biológico A e B. Para a etapa 2, também, foram realizados testes de homogeneidade das amostras entre os intervalos de tempos estudados, ou seja, verificou-se as variâncias entre os intervalos de tempos T0_T1; T1_T2; T0_T2; T2_T3; T0_T3 (que foram as variáveis comparadas) distorciam igualmente da média entre os intervalos para cada sistema.

Para essa avaliação de homogeneidade utilizou-se o teste de Levene (F). Esse teste verificou a hipótese de que a variância nos grupos foi a mesma (isto é, se a diferença entre as variâncias foi zero). Dessa forma, o teste de Levene foi significativo quando $\mathrm{p} \leq 0,05$, concluindo-se que a hipótese nula estava incorreta e que as variâncias foram significativamente diferentes. No entanto, quando o teste de Levene não foi significativo (isto é, p > 0,05), aceitou-se a hipótese nula de que as diferenças entre as variâncias foi zero, ou seja, as variâncias foram estatisticamente iguais.

Essas avaliações de normalidade e homogeneidade foram realizadas para definição dos testes estatísticos utilizados. Os usos de testes estatísticos paramétricos pressupõem que os dados sigam uma distribuição normal e tenham variâncias homogêneas.

$\mathrm{Na}$ etapa 1 , como os escores obtidos entre a diferença das concentrações dos íons $\mathrm{N}^{-\mathrm{NO}_{3}}{ }_{3}$; $\mathrm{N}-\mathrm{NO}_{2}{ }^{-}$e $\mathrm{N}_{-} \mathrm{NH}_{4}{ }^{+}(\mathrm{mM})$ nos tempos T0_T1 dos sistemas biológicos resultaram em distribuições normais e homogêneas para todos os sistemas biológicos testados e íons avaliados definindo-se por realizar um Teste $t$ Dependente para comparar se as médias das concentrações dos íons nos sistemas biológicos A e B inoculados com o mesmo lodo foram estatisticamente semelhantes e, portanto, como duplicatas.

Dada a natureza das amostras e os resultados das avaliações da normalidade e homogeneidade dos dados para cada sistema durante a etapa 2, definiu-se pela utilização dos testes estatísticos não-paramétricos de Wilcoxon (T) de Postos com Sinais para comparar se as duplicatas de cada sistema biológico inoculado com o mesmo lodo comportaram, em termos de conversões para as formas nitrogenadas, estatisticamente semelhantes. Considerase no teste que $\mathrm{H}_{0}$ : Sistema $\mathrm{A}=$ Sistema $\mathrm{B}$ e $\mathrm{H}_{1}$ : Sistema $\mathrm{A} \neq$ Sistema $\mathrm{B}$ e, para tanto, os sistemas A e B foram considerados como variáveis dependentes. 
Para verificar se houve diferenças entre os sistemas biológicos nas conversões das formas nitrogenadas $\mathrm{N}-\mathrm{NO}_{3}{ }^{-} ; \mathrm{N}^{-\mathrm{NO}_{2}}{ }^{-}$e N-NH${ }_{4}{ }^{+}(\mathrm{mM})$, dadas pelas variáveis obtidas pelas relações entre os íons, também, o teste não paramétrico de Kruskal-Wallis $(\mathrm{H})$ que permite avaliar se existe diferenças entre vários grupos independentes. O Teste de Kruskal-Wallis foi uma alternativa ao ANOVA independente de um fator.

O Teste $t$ é, em resumo, a razão da variação sistemática no experimento para a variação não sistemática (Field, 2009).

No Teste de Wilcoxon (T) de Postos com Sinais calculou-se a diferença entre as observações de cada amostra (teste e tempo) das duas variáveis dependentes, nesse caso sistema A e sistema B e, depois essas diferenças foram transformadas em postos, mas o sinal da diferença (se positiva ou negativa) foi atribuído a cada posto. Ao final, separou-se os postos com sinais negativos e positivos e, obteve-se a soma dos postos com mesmos sinais. A estatística desse teste $(\mathrm{T})$ foi utilizar o menor dos dois valores obtidos na soma dos postos com sinais diferentes (valor T).

A significância do teste foi obtida com o cálculo da média $\bar{T}$, do erro padrão do teste $\left(\mathrm{EP}_{\mathrm{T}}\right)$ e do cálculo de $Z$, onde n é o tamanho das amostras dos sistemas testados, de acordo com as equações 4.7, 4.8 e 4.9:

$$
\begin{gathered}
\bar{T}=\frac{n(n+1)}{4} \\
E P_{T}=\sqrt{\frac{n(n+1)(2 n+1)}{24}} \\
Z=\frac{T-\bar{T}}{E P_{T}}
\end{gathered}
$$

O Teste de Kruskal-Wallis $(\mathrm{H})$ tem como base os postos de valores. Iniciou-se ordenando os escores do menor para o maior, ignorando-se o grupo ao qual o escore pertencia. Após a ordenação, retornaram-se os escores aos grupos as quais eles pertenciam inicialmente e somaram-se os postos atribuídos a cada escore para cada grupo. A soma dos postos de cada grupo foi representada por $\mathrm{R}_{\mathrm{i}}$ (i representa cada um dos grupos testados). A estatística $\mathrm{H}$ foi 
calculada usando a equação 4.10:

$$
H=\frac{12}{N(N+1)} \sum_{i=1}^{k} \frac{R_{i}^{2}}{n_{i}}-3(N-1)
$$

Sendo:

$\mathrm{R}_{\mathrm{i}}=$ soma dos postos para cada grupo

$\mathrm{N}=$ total da amostra (somatório de $\mathrm{n}_{\mathrm{i}}$ de cada grupo testado)

$\mathrm{n}_{\mathrm{i}}=$ tamanho amostral de cada um dos grupos testados

$\mathrm{k}=$ graus de liberdade (número de grupos menos um)

Essa estatística teste tem um tipo especial de distribuição conhecida como Qui-Quadrado e, para isso, essa distribuição possui um parâmetro denominado graus de liberdade, que é o número de grupos menos um (k-1).

As análises post hoc para o teste de Kruskal-Wallis, que buscaria quais os sistemas que foram responsáveis pelas diferenças entre as relações nos tempos testados, não foram realizadas pois as opções seriam os testes de Mann-Witney que faz comparação em pares. Nesse caso o tratamento estatístico compararia 7 sistemas duplas e aumentaria a possibilidade de incorrer no erro tipo I (quando aceita um efeito que na verdade não existe).

Para reduzir as chances de cometer o erro tipo I, deve-se aplicar a correção de Bonferroni que divide o valor crítico de significância de 0,05 pelo número de comparações a serem feitas. Na situação em estudo equivaleria a serem realizadas 20 comparações, que para serem significativamente diferentes teriam que apresentar $\mathrm{p}<2,5.10^{-3}$.

Outra opção de teste post hoc tem semelhanças com o de Mann-Witney, por fazer comparações entre duplas do fator de grupo em estudo, no entanto, envolveria tomar a diferença entre as médias dos postos dos diferentes grupos comparadas com um valor $\mathrm{Z}$ (corrigido pelo número de comparações sendo feitas) e uma constante baseada no tamanho amostral total e nos tamanhos amostrais dos dois grupos sendo comparados, dada pela equação 4.11: 


$$
\left|\bar{R}_{u}-\bar{R}_{v}\right| \geq \sqrt[z_{\alpha / k(k-1)}]{\frac{N(N+1)}{12}\left(\frac{1}{n_{u}}+\frac{1}{n_{v}}\right)}
$$

Onde:

$\left|\bar{R}_{u}-\bar{R}_{v}\right|=$ diferença em módulos entre a média dos postos para os dois grupos comparados $\mathrm{k}=$ número de grupos

$\mathrm{N}=$ tamanho total da amostra

$\mathrm{n}_{\mathrm{u}}=$ tamanho da amostra no grupo 1

$\mathrm{n}_{\mathrm{v}}=$ tamanho da amostra no grupo 2

$Z \alpha_{k(k-1)}=$ valor da curva normal para o qual somente $\alpha / k(k-1)$, dos demais valores $Z$ são maiores.

A quantidade de comparações (20) a serem realizadas, produziriam valores de significância maiores que $\mathrm{p}=2,5.10^{-3}$ (aplicado a correção de Bonferroni), resultando em comparações par a par não significantes e, portanto, não discriminantes dos sistemas.

Com o objetivo de discriminar os sistemas biológicos testados quanto à aproximação de um comportamento metabólico ideal, que seria os sistemas que se aproximassem das relações estequiométricas previstas pela reação anammox, utilizaram-se critérios para comparação tendo-se como referências o número de cópias dos genes relacionados aos micro-organismos envolvidos na ciclagem do nitrogênio esperando-se: 1) Maior número de cópias do gene do RNAr 16S específicos para os micro-organismos anammox obtidos pelo uso dos iniciadores Pla46 F e Amx667 R; 2) Menor número de cópias do gene amoA específicos para os microorganismos nitritantes obtidos pelo uso dos iniciadores amoA $\mathrm{F}$ e amoA $\mathrm{R}$ e do gene do RNAr 16S específicos para os micro-organismos nitratantes obtidos pelo uso dos primers Nitro 1198 F e Nitro 1423 R; 3) Proporção comparada entre número de cópias do gene do RNAr 16S específicos para os micro-organismos do domínio Bacteria obtidos pelo uso dos iniciadores Universal 1055 F e Universal 1392 R e o número de cópias dos genes dos grupos envolvidos nas conversões das formas nitrogenadas. 


\section{5 - RESULTADOS E DISCUSSÃO}

$\mathrm{Na}$ descrição dos resultados e discussões que se seguem utilizam-se códigos de letras e números para referir-se aos sistemas biológicos conforme a origem dos inóculos inseridos nos sistemas, bem como as letras A e B para diferenciar as duplicatas de cada sistema biológico conforme descrito na Tabela 5.1.

Tabela 5.1: Amostras de lodos e sedimentos utilizados como inóculos nos sistemas biológicos para enriquecimento e atividade anammox.

\begin{tabular}{|c|c|c|}
\hline "Inóculo utilizado no sistema & Local de coleta do Inóculo & $\begin{array}{c}\text { Sigla Sistema } \\
\end{array}$ \\
\hline 1) Sedimento do lago & Lago Paranoá, Brasília/DF & Par A e B \\
\hline $\begin{array}{l}\text { 2) Lodo de lagoa anaeróbia tratando } \\
\text { efluente de abatedouro/frigorífico de } \\
\text { bovinos }\end{array}$ & Frigorífico 1, Araguari/MG & AnF1 A e B \\
\hline $\begin{array}{l}\text { 3) Lodo de lagoa facultativa tratando } \\
\text { efluente de abatedouro/frigorífico de } \\
\text { bovinos }\end{array}$ & Frigorífico 1, Araguari/MG & FaF1 A e B \\
\hline $\begin{array}{l}\text { 4) Lodo de lagoa facultativa tratando } \\
\text { efluente de abatedouro de bovinos e } \\
\text { suínos }\end{array}$ & Frigorífico 2, Uberlândia/MG & FaF2 A e B \\
\hline $\begin{array}{l}\text { 5) Lodo de reator UASB tratando efluente } \\
\text { de abatedouro de bovinos e suínos }\end{array}$ & Frigorífico 2, Uberlândia/MG & UaF2 A e B \\
\hline $\begin{array}{l}\text { 6) Sedimento de lagoa de acumulação de } \\
\text { chorume de aterro de resíduos sólidos }\end{array}$ & $\begin{array}{l}\text { Aterro controlado Jockey } \\
\text { Clube, Brasília/DF }\end{array}$ & Cho A e B \\
\hline
\end{tabular}

\section{1 - CARACTERIZAÇÃO DOS SISTEMAS AMBIENTAIS UTILIZADOS COMO FONTE DE INÓCULOS}

As características químicas dos sistemas ambientais, tais como as concentrações de amônia e carbono podem interferir na composição da comunidade microbiana a ser desenvolvida nos sistemas biológicos testados, limitando o sucesso dos micro-organismos responsáveis pelo processo anammox. Essas substâncias provocam inibição ao metabolismo dessas bactérias (Tsushima et al., 2007; Jin et al., 2012), além das elevadas concentrações de carbono favorecerem o desenvolvimento de micro-organismos heterotróficos que competem por substratos com os organismos anammox (Ni et al., 2012; Tao et al., 2013; Jenni et al., 2014). Espera-se mais sucesso no enriquecimento de micro-organismos anammox em 
sistemas biológicos quando em presença de menores concentrações de carbono e menor relação C/N (Wang et al., 2011; Li-Dong et al., 2012). No entanto, em recente pesquisa, discute-se a adequabilidade de se tratar efluentes com elevada razão $\mathrm{C} / \mathrm{N}$ pelo processo anammox, desde que a fonte de carbono orgânico possa ser também consumida por algumas bactérias responsáveis pelo processo anammox que possuem habilidade para oxidar acetato, propionato com a redução do nitrato (Jenni et al., 2014).

Os sistemas ambientais de onde foram retirados os inóculos (Tabela 5.1) apresentaram diferenças em suas características físico-químicas resultantes das condições de cada habitat escolhido (Tabela 5.2). Os lodos e sedimentos coletados foram bem homogeneizados para avaliação dos parâmetros químicos.

Os sistemas de tratamento de águas residuárias de abatedouros de bovinos e suínos apresentaram elevadas concentrações de nitrogênio e de carbono (Tabela 5.2). Essas elevadas concentrações são decorrentes do tipo de água residuária tratada com presença de sangue e gorduras oriundos do abate e do processamento das carnes e do estrume dos animais abatidos. Ainda, no sedimento da lagoa de armazenamento de chorume do aterro controlado do Jóckey Club de Brasília, também, apresentou altas concentrações de nitrogênio e carbono resultantes dos processos de estabilização dos resíduos sólidos depositados no aterro.

O sedimento coletado a partir do Lago Paranoá, como esperado pelas características de sua origem, apresentou concentrações de nitrogênio e carbono bem menores do que as dos sistemas de tratamento de águas residuárias (Tabela 5.2). No entanto, as elevadas concentrações nitrato no sedimento do Lago Paranoá indicam que esse manancial recebe contribuições de cargas difusas de poluição, especialmente relatadas nos estudos de contribuição da drenagem urbana para a poluição do Lago Paranoá (Costa, 2013b) O pH variou de acordo com os sistemas ambientais de coleta, sendo mais ácido ( $\mathrm{pH} \mathrm{5,73)} \mathrm{no}$ sedimento do lago Paranoá e mais alcalino ( $\mathrm{pH} 8,38)$ no sedimento da lagoa de acumulação de chorume. $\mathrm{O} \mathrm{pH}$ dos sistemas de tratamento de águas residuárias de abatedouros de bovinos e suínos variaram entre 6,63 a 7,91. A temperatura em todos os habitats encontravase em faixa mesofílica $\left(25\right.$ a $\left.28^{\circ} \mathrm{C}\right)$.

A relação entre carbono orgânico dissolvido, lido como DQO filtrada, e nitrogênio (DQO/N) foi variante entre os diferentes ambientes selecionados como fontes de inóculos (Tabela 5.2). Somente no sedimento proveniente do lago Paranoá (Par) e no lodo da lagoa anaeróbia do 
Frigorífico 1 (AnF1) é que houve razão DQO/N menor que 0,6. Nos lodos das lagoas facultativas do Frigorífico $1(\mathrm{FaF} 1)$ e do Frigorífico $2(\mathrm{FaF} 2)$ e do reator UASB do Frigorífico 2 (UaF2) a razão DQO/N calculada foi de 1,02 e 1,42, enquanto na lagoa de chorume do aterro Jockey Clube de Brasília (Cho) a razão DQO/N foi maior do que 2. Temse discutido a utilização do tratamento de águas residuárias ricas em amônia e com baixa razão C/N pelo processo anammox, ou seja $<0,5 \mathrm{~g} \mathrm{COD} \cdot \mathrm{g}^{-1} \mathrm{~N}$. A remoção de nitrogênio pelo processo biológico convencional de desnitrificação heterotrófica requer $1,72 \mathrm{~g} \mathrm{COD} \cdot \mathrm{g}^{-1} \mathrm{~N}$ (Ahn, 2006). Jenni et al. (2014) demonstraram a adequabilidade de efluentes com razão entre 0,5 e 1,72 $\mathrm{g} \mathrm{de} \mathrm{COD} \mathrm{N}^{-1}$ para serem tratados pelos processos de nitritação e anammox.

Tabela 5.2: Avaliação das características químicas dos ambientes utilizados como fonte de inóculos nos experimentos para enriquecimento e atividade anammox.

\begin{tabular}{|c|c|c|c|c|c|c|}
\hline \multirow[t]{2}{*}{ Parâmetros } & \multicolumn{6}{|c|}{ Origem Lodo/Sedimento ${ }^{1}$} \\
\hline & Par & AnF1 & $\overline{\text { FaF1 }}$ & FaF2 & $\overline{\mathrm{UaF} 2}$ & Cho \\
\hline NTK (mg.L $\left.\mathbf{L}^{-1}\right)$ & 6,38 & 236,25 & 168,75 & 215,6 & 717,0 & 860 \\
\hline NTotal $\left(\mathrm{mg} . \mathrm{L}^{-1}\right)^{2}$ & 138,2 & 517,75 & 351,25 & 599,6 & 1724,0 & 914,0 \\
\hline $\mathrm{NH}_{4}\left(\mathrm{mg} . \mathrm{L}^{-1}\right)$ & 5,1 & 173,3 & 168,30 & 203,4 & 705,0 & 824,0 \\
\hline $\mathrm{NO}_{2}\left(\mathrm{mg} . \mathrm{L}^{-1}\right)$ & 24 & 100,0 & 60,0 & 160,0 & 540,0 & 18,0 \\
\hline $\mathrm{NO}_{3}\left(\mathrm{mg} . \mathrm{L}^{-1}\right)$ & 107,8 & 181,5 & 122,5 & 224,0 & 479,0 & 36,0 \\
\hline DQO $\left(\mathrm{mg} \mathrm{L}^{-1}\right)^{3}$ & 64,0 & 305,0 & 355,0 & 610,0 & 2455,00 & 1878,0 \\
\hline Razão DQO/N & 0,46 & $\mathbf{0 , 5 9}$ & 1,01 & 1,02 & 1,42 & 2,05 \\
\hline
\end{tabular}

1 Par: Lago Paranoá, Brasília/DF; AnF1: lagoa anaeróbia do Frigorífico 1, Araguari/MG; FaF1: lagoa facultativa do Frigorífico 1, Araguari/MG; FaF2: lagoa facultativa do Frigorífico 2, Uberlândia, MG; UaF2: lodo de reator UASB do Frigorífico 2, Uberlândia/MG; Cho: lagoa de acumulação de chorume do aterro controlado Jockey Club/DF.

${ }^{2} \mathrm{~N}$ total $=\left[\mathrm{NTK}+\mathrm{NO}_{2}+\mathrm{NO}_{3}\right] ;{ }^{3} \mathrm{DQO}$ filtrada

Pelas características químicas, especialmente a razão $\mathrm{C} / \mathrm{N}$, presentes nos sedimentos do Lago Paranoá (Par) e nos lodos das lagoas dos frigoríficos (AnF1, FaF1, FaF2) esperava-se que os sistemas biológicos inoculados com biomassas dessas origens apresentassem melhor performance para o desenvolvimento dos micro-organismos, visto que as concentrações de tais componentes químicos são determinantes para o sucesso no estabelecimento da atividade anammox. 
Outra característica importante a ser apresentada é a composição dos sólidos em cada um dos lodos e sedimentos dos sistemas ambientais selecionados. O sedimento do lago Paranoá (Par), da lagoa facultativa do Frigorífico $2(\mathrm{FaF} 2)$ e da lagoa de acumulação de chorume do aterro Jockey Club de Brasília (Cho) constituía-se de muita matéria inorgânica (areias, argilas e siltes) típicas das condições de onde foram coletados, ou seja, a partir de sedimentos (Tabela 5.3). Essa constituição pode interferir na sedimentabilidade da biomassa nos sistemas biológicos testados. A argila, o principal constituinte desses sedimentos, devido ao pequeno diâmetro de suas partículas - em torno de 0,002 mm, apresenta velocidade de sedimentação baixa ainda que esteja agregada a micro-organismos e moléculas orgânicas (Tomaz, 2013). Observou-se que a sedimentação das biomassas proveniente dos sedimentos foi mais lenta quando comparados às biomassas oriundas dos lodos dos sistemas ambientais da lagoa anaeróbia do Frigorífico 1 (AnF1); lagoa facultativa do Frigorífico 1 (FaF1) e do reator UASB do Frigorífico 2 (UaF2), que se apresentavam em forma de flocos.

Tabela 5.3: Composição dos sólidos nos lodos e sedimentos utilizados nos sistemas biológicos testados.

\begin{tabular}{lcccc}
\hline \hline $\begin{array}{l}\text { Origem } \\
\text { Inóculo }^{1}\end{array}$ & $\begin{array}{c}\text { Sólidos Fixos } \\
(\% \mathrm{em} \mathrm{lg})\left(\mathrm{mgSF} . \mathrm{g}^{-1}\right)\end{array}$ & $\begin{array}{c}\text { Sólidos Voláteis } \\
(\% \mathrm{em} \mathrm{lg})\left(\mathrm{mg} \mathrm{SV} \cdot \mathrm{g}^{-1}\right)\end{array}$ & $\begin{array}{c}\text { Sólidos Totais } \\
(\% \mathrm{em} \mathrm{1g})\left(\mathrm{mg} \mathrm{ST} . \mathrm{g}^{-1}\right)\end{array}$ & $\begin{array}{c}\text { Biomassa } \\
\text { inserida } \\
\left(\mathrm{g} . \mathrm{L}^{-1}\right)\end{array}$ \\
\hline Par & $(40,89)(0,409)$ & $(6,91)(0,069)$ & $(47,80)(0,478)$ & 1,73 \\
AnF1 & $(1,81)(0,018)$ & $(5,77)(0,058)$ & $(7,58)(0,076)$ & 1,44 \\
FaF1 & $(5,02)(0,050)$ & $(6,87)(0,069)$ & $(11,89)(0,119)$ & 1,72 \\
FaF2 & $(21,09)(0,211)$ & $(8,38)(0,084)$ & $(29,47)(0,295)$ & 2,10 \\
UaF2 & $(1,79)(0,018)$ & $(8,95)(0,089)$ & $(10,73)(0,107)$ & 2,24 \\
Cho & $(33,51)(0,335)$ & $(6,65)(0,066)$ & $(40,16)(0,402)$ & 1,66 \\
\hline \hline
\end{tabular}

1 Par: Lago Paranoá, Brasília/DF; AnF1: lagoa anaeróbia do Frigorífico 1, Araguari/MG; FaF1: lagoa facultativa do Frigorífico 1, Araguari/MG; FaF2: lagoa facultativa do Frigorífico 2, Uberlândia, MG; UaF2: lodo de reator UASB do Frigorífico 2, Uberlândia/MG; Cho: lagoa de acumulação de chorume do aterro controlado Jockey Club/DF.

A sedimentabilidade da biomassa nos sistemas biológicos em bateladas é importante para garantir a permanência dos micro-organismos nos sistemas, principalmente, daqueles de crescimento lento como são as bactérias que realizam o processo anammox. Além do mais, discute-se que o crescimento de micro-organismos heterotróficos pode também colaborar para a redução da sedimentabilidade da biomassa, uma vez que, devido ao rápido 
crescimento dos organismos heterotróficos, os flocos formados são pequenos e, portanto, mais lentos para decantar (Jenni et al., 2014).

Nas duas etapas do desenvolvimento desse trabalho promoveram-se longos períodos de sedimentação, tendo sido 1 e 2 horas para as etapas 1 e 2 , respectivamente, na operação das bateladas sequenciais. O objetivo desse período longo foi justamente garantir a permanência da biomassa desenvolvida dentro dos sistemas biológicos.

Ocorreram grandes diferenças entre os sólidos fixos e totais dos diferentes sedimentos e lodos utilizados nos sistemas biológicos testados. No entanto, a concentração de sólidos voláteis foi relativamente próxima, oscilando entre 5,77\% a 8,95\% dos sólidos totais (Tabela 5.3). Dessa maneira, a concentração de biomassa inserida nos sistemas biológicos foi aproximadamente entre 1,44 a 2,24 g. $\mathrm{L}^{-1}$ obtida pelos percentuais de sólidos voláteis nas amostras. Em estações de tratamento em escala plena, adotando-se os reatores em bateladas sequencias, tem-se utilizado conteúdo de sólidos voláteis entre aproximadamente 1 a 4,5 g.L1 , inferindo-se a biomassa a partir dos sólidos voláteis (Lackner et al., 2014).

Os reatores utilizados nos experimentos de enriquecimento e atividade anammox, conforme descrito no Capítulo Materiais e Métodos, foram inoculados com $25 \mathrm{ml}$ (=25 g) de lodo e $975 \mathrm{~mL}$ de água residuária sintética e substratos.

Conforme discutido por Ni et al. (2012), em sistemas biológicos onde podem ser acumuladas substâncias poliméricas extracelulares, materiais inertes residuais, produtos solúveis decorrentes do metabolismo microbiano podem significativamente influenciar a composição da comunidade microbiana em um sistema ajustado para atividade anammox. Além do mais, Tsushima et al. (2007) mencionam que os compostos orgânicos e/ou tóxicos aderidos originalmente no inóculo podem inibir a atividade de bactérias anammox.

Alguns pesquisadores têm realizado a lavagem dos inóculos, antes da inserção nos sistemas, com a água residuária teste buscando evitar que substâncias presentes nos inóculos interfiram no sucesso do enriquecimento de micro-organismos (Schierholt Neto, 2007; Lidong et al, 2012; Costa, 2013). No entanto, como realizado nos experimentos desse trabalho de tese, muitas pesquisas também introduzem os inóculos sem prévia manipulação e lavagem dos mesmos, visando a compreensão dos resultados para aplicação posterior em projetos em escalas piloto e plena, quando tais procedimentos seriam inviáveis, bem como avaliar os efeitos da competição entre micro-organismos heterotróficos e anammox e da concentração 
de determinadas substâncias no sucesso da atividade anammox (Quan et al., 2008; SànchezMelsió et al., 2009; Bae et al., 2010; Hu et al., 2010; Park et al., 2010; Wang et al., 2011; Ni et al., 2012). Tendo inclusive pesquisa que avaliou o efeito da manipulação do inóculo antes de sua inserção nos sistemas biológicos. A pré-lavagem do lodo promoveu uma redução do carbono orgânico e de bactérias heterotróficas e consequentemente uma maior abundância de micro-organismos anammox. No entanto, comprovou-se que maior riqueza e equidade entre espécie são determinantes para rápida partida de reatores, pois favorece a funcionalidade do sistema sobre stress seletivo (Tao et al., 2013).

\section{2 - CARACTERIZAÇÃO DOS INÓCULOS}

Para a caracterização da biomassa dos diferentes inóculos testados foi realizado a extração de DNA genômico para aplicação em técnicas de biologia molecular. Para tanto foi avaliado o rendimento obtido com as extrações do DNA a partir de $0,5 \mathrm{~g}$ dos inóculos usando o kit PowerSoil tendo-se um volume final de $100 \mu \mathrm{L}$ às diferentes concentrações de DNA genômico para cada biomassa presente nos inóculos (Tabela 5.4) (Apêndice I-CD).

Após extração do DNA genômico da comunidade microbiana presente nos inóculos, a realização de eletroforeses em gel de agarose $1 \%$ corado com brometo de etídeo $\left(1 \mu \mathrm{g} . \mathrm{mL}^{-}\right.$

${ }^{1}$ ), demonstraram que as biomassas nos inóculos provenientes do sedimento do lago Paranoá, Brasília, DF (Par), dos sistemas de lagoa anaeróbia e facultativa do frigorífico 1, Araguari, MG (AnF1 e FaF1) e lagoa facultativa do frigorífico 2, Uberlândia (FaF2) apresentaram padrões de bandas de DNA genômico satisfatórios quando comparados com High Mass Ladder. Esses resultados indicam como o DNA genômico apresentava-se em quantidade e qualidade, sem rastros indicativos de fragmentação do DNA (Tabela 5.4). Por outro lado, o DNA genômico proveniente das primeiras tentativas de extrações de DNA das biomassas nos inóculos do reator UASB tratando água residuária do frigorífico 2, Uberlândia, MG (UaF2) e da lagoa de acumulação de chorume do aterro Jockey Clube, Brasília, DF (Cho) não resultaram em concentrações detectáveis. O licor misto do UASB tratando água residuária de abatedouro de bovinos e suínos e da lagoa de chorume provavelmente apresentam características complexas com presença de substâncias que interagiram com os componentes do kit de extração de DNA PowerSoil da MoBio, dificultando a obtenção de DNA genômico. 
Devido à complexidade das águas residuárias do UASB tratando efluente de abatedouro de bovinos e suínos do frigorífico 2, Uberlândia, $\mathrm{MG}(\mathrm{UaF} 2)$ e da lagoa de chorume do aterro controlado Jockey Clube de Brasília, DF (Cho) pode-se esperar a ocorrência de substâncias inibidoras e, assim, uma maior toxicidade selecionando bactérias mais resistentes no pool genômico das amostras de lodos desses ambientes. Shen et al. (2012) também citam a complexidade e biotoxicidade de águas residuárias provenientes de indústria produtora de glutamato monossódico e de chorume, mas lograram sucesso, após um ano, no enriquecimento de micro-organismos anammox na biomassa tendo utilizado inóculos provenientes de estações de tratamento dessas águas residuárias.

Foram feitas outras tentativas para melhorar a qualidade e quantidade de DNA Genômico obtidos a partir da biomassa nos inóculos do UaF2 e Cho, usando-se de estratégias de lavagens com água residuária sintética e uso diferenciado de massas de lodos. No entanto, não houve melhorias significativas na quantidade de DNA genômico para as extrações realizadas com o inóculo proveniente da lagoa de acumulação de chorume do aterro controlado Jóckey Clube de Brasília, DF (Tabela 5.4).

Tabela 5.4: Avaliação do rendimento do DNA genômico extraído da biomassa dos seis inóculos utilizados nos sistemas biológicos para enriquecimento anammox.

\begin{tabular}{lc}
\hline \hline \multicolumn{1}{c}{ Inóculo } & Quantidade estimada $\left(\eta g . \mu l^{-1}\right)$ \\
\hline Par & 56 \\
\hline AnF1 & 22 \\
\hline FaF1 & 44 \\
\hline FaF2 & 8 \\
\hline UaF2 1 ext. $^{\text {a }}$ & $<D^{*}$ \\
\hline UaF2 0,25 g. & 56 \\
\hline UaF2 0,5g & 30 \\
\hline Cho 1 ${ }^{\mathbf{a}}$ ext. & $<\mathrm{LD}$ \\
\hline Cho 0,25g & 5 \\
\hline Cho 0,5g & 4 \\
\hline \hline
\end{tabular}

Par: sedimento do lago Paranoá, Brasília/DF; AnF1: lodo da lagoa anaeróbia tratando efluente do Frigorífico 1, Araguari/MG; FaF1: lodo da lagoa facultativa tratando efluente do Frigorífico 1, Araguari/MG; FaF2: lagoa facultativa tratando efluente do Frigorífico 2, Uberlândia, MG; UaF2: lodo de reator UASB tratando efluente do Frigorífico 2, Uberlândia/MG; Cho: sedimento da lagoa de acumulação de chorume do aterro controlado Jockey Clube, Brasília/DF. * LD: limite de detecção. 
A avaliação do potencial dos inóculos para partidas de sistemas biológicos, visando a atividade anammox, pode ser realizada pela verificação da presença dos micro-organismos capazes de realizar a oxidação anaeróbia da amônia usando o nitrito como aceptor de elétrons. A verificação foi realizada pela detecção de fragmentos amplificados por PCR convencional e pela quantificação do número de cópias dos genes que codificam para porções alvos do RNAr $16 \mathrm{~S}$ ( $\eta$ g cópias. $\mu \mathrm{L}^{-1}$ ) por PCR quantitativa utilizando primers específicos ao grupo de micro-organismos Planctomycetes e dos grupos de microorganismos nitrificantes aeróbios, para entendimento dos processos metabólicos predominantes nos sistemas biológicos testados.

A realização de análises de PCR, tendo como moldes fragmentos de DNA genômico obtidos a partir das biomassas presentes nos lodos e sedimentos, amplificando genes alvos de bactérias anammox em diferentes ecossistemas aumenta o conhecimento do espectro genético e ecológico desse grupo de micro-organismos e ajuda a melhorar o monitoramento desses organismos em sistemas de tratamento de águas residuárias (Quan et al., 2008; Kartal et al., 2012; Costa, 2013; Sánchez et al., 2014).

Dessa maneira, usando-se a combinação dos primers Pla 46F e Amx 820R, específicos para amplificação de fragmento do gene que codifica RNAr $16 \mathrm{~S}$ de organismos relacionados aos gêneros "Candidatus Brocadia" e "Ca. Kuenenia", nas condições testadas por Araújo et al. (2010), foi possível obter amplicons de tamanhos aproximados de 774 pb a partir do DNA Genômico obtido das biomassas antes do enriquecimento, à exceção do DNA Genômico obtido da biomassa presente no inóculo do sedimento da lagoa de acumulação de chorume (Cho) (Tabela 5.5) . No entanto, a ausência de amplificações anammox na biomassa do sedimento de chorume não exclui a possibilidade desses organismos estarem originalmente nesse ambiente. Sànchez-Melsió et al. (2009) não conseguiram amplificar fragmentos de DNA anammox antes do enriquecimento em 13 lodos usados como inóculos, dado os limites de quantificação pela técnica de PCR, mas após o período de um ano de enriquecimento foi registrada a presença de bactérias anammox em todos os sistemas, pela análise das amplificações em PCR, mas fazendo uso da combinação dos primers Pla46F e Amx 368R, que permite a detecção de todos os organismos anammox presentes. Costa (2013) não conseguiu resultados de amplificações para amostras obtidas em algumas câmaras de reatores UASB, wetland plantado (amostra a $50 \mathrm{~cm}$ de profundidade) e de lagoa de polimento tratando esgotos. Cita-se a combinação dos primers Amx 368F e Amx 820R como 
eficientes para a detecção de todos os organismos Planctomycetales (Schmid et al., 2003).

Alguns pesquisadores também obtiveram resultados positivos característicos de amplificações anammox a partir das biomassas coletadas para avaliação de inóculos que serviriam para experimentação visando atividade anammox, tendo usado os primers $\mathrm{Pla} 46 \mathrm{~F}$ e Amx 820R. Assim, foram registradas amplificações de fragmentos de DNA para inóculos provenientes de sistema convencional de lodos ativados da estação de tratamento de esgotos em Belo Horizonte, MG (Araújo et al., 2010), de lagoa aerada, biodiscos, lagoa de polimento, caixas de sistemas de distribuição por bombas em sistemas de tratamento para águas residuárias oriundas de refinaria de petróleo e de lagoas de polimento, wetlands plantados e não plantados e para alguns reatores UASB tratando esgotos (Costa, 2013), de lagoa de sedimentação em usina de processamento de cana de açúcar (Sánchez et al., 2014).

Tabela 5.5: Resultados das amplificações por PCR das biomassas obtidas a partir dos inóculos testados nos sistemas biológicos.

\begin{tabular}{lcccc}
\hline \hline & & Primers / especificidade & \\
Inóculos & $\begin{array}{c}\text { Pla46F e } \\
\text { Amx820R RNA } \\
\text { testados } \\
\text { 16S “Ca. Brocadia } \\
\text { e Kuenenia” }\end{array}$ & $\begin{array}{c}\text { Ana-hzo1F e- } \\
\text { hzo2R } \\
\text { Gene hzo }\end{array}$ & $\begin{array}{c}\text { AmoAF e AmoAR } \\
\text { Nitrosomonas }\end{array}$ & $\begin{array}{c}\text { Nitro1198F e Nitro } \\
1423 \mathrm{R}- \\
\text { Nitrobacter }\end{array}$ \\
Par & + & - & + & + \\
AnF1 & $+/-$ & - & + & + \\
FaF1 & $+/-$ & - & + & + \\
FaF2 & + & - & $+/-$ & + \\
\hline UaF2 & $+/-$ & - & + & + \\
\hline Cho & - & - & + \\
\hline \hline
\end{tabular}

(+) Resultados positivos para os produtos amplificados na PCR visualizados em gel de agarose; (+/-) Resultados positivos com fragmentos amplificados visualizados sem nitidez em gel de agarose. Par: sedimento do lago Paranoá, Brasília/DF; AnF1: lodo da lagoa anaeróbia tratando efluente do Frigorífico 1, Araguari/MG; FaF1: lodo da lagoa facultativa tratando efluente do Frigorífico 1, Araguari/MG; FaF2: lagoa facultativa tratando efluente do Frigorífico 2, Uberlândia, MG; UaF2: lodo de reator UASB tratando efluente do Frigorífico 2, Uberlândia/MG; Cho: sedimento da lagoa de acumulação de chorume do aterro controlado Jockey Clube, Brasília/DF (Apêndice I).

Quando usados os conjuntos de primers específicos para os genes que codificam a enzima hidrazina oxigenase, exclusiva aos micro-organismos anammox, não se obteve sucesso nas amplificações de fragmentos observáveis em gel de agarose após PCR e eletroforese (Tabela 5.5). Costa (2013) também registrou resultados negativos para 7 amostras de inóculos 
provenientes de diferentes partes de sistemas de tratamento de esgoto (lagoas de polimento, wetlands plantados, UASB), mas obteve resultados positivos para 6 amostras de águas residuárias de refinaria de petróleo (lagoas aeradas, biodiscos, lagoas de polimento e em caixas de distribuição com bombas) e de wetlands em sistemas de esgotos. Quando se obtém resultados positivos de amplificações utilizando primers para os genes que codificam enzimas específicas anammox confirma-se a presença de micro-organismos anammox visto que as amplificações ocorridas com primers para os genes RNAr 16S podem resultar em amplificações de organismos de todo o grupo Planctomycetes, dos quais alguns não são classificados com habilidade anammox (Hirsch et al., 2010). Portanto, somente o sequenciamento dos fragmentos de 774 bp obtidos a partir de genes RNAr 16S poderão indicar, por análise de similaridade, o grupo pertencente.

Os micro-organismos nitrificantes aeróbios representam potenciais parceiros e/ou competidores com as bactérias anammox, visto que utilizam os substratos amônia e nitrito, e, por isso, a presença desses grupos foi inferida a partir de amplificações positivas em análise de PCR. O primeiro grupo inferido foi o de bactérias aeróbias oxidadoras de amônia, representadas por bactérias como Nitrosomonas, por meio da utilização do par de primers amoA direto e reverso (Egli, 2003), amplificando fragmentos de aproximadamente $650 \mathrm{pb}$ em todas as amostras analisadas (Tabela 5.5), ainda que as condições iniciais nos locais de amostragem dos inóculos não promovessem a atividade metabólica do grupo. Jetten et al. (1999) discutiram que devido à sua versatilidade metabólica podem estar presentes em grande abundância em condições anóxicas. Importante destacar que condições limitantes de oxigênio podem oferecer um ambiente adequados para uma interação estável entre os microorganismos aeróbios como Nitrosomonas e anaeróbios como as bactérias anammox (Sliekers et al., 2002; Wang et al., 2010).

O segundo grupo inferido foi o de bactérias aeróbias oxidadoras de nitrito, representadas por bactérias como Nitrobacter, por meio da utilização os primers Nitro 1198 direto e Nitro 1423 reverso (Graham et al., 2007), amplificando fragmentos de tamanho aproximado de $225 \mathrm{pb}$ (Tabela 5.5). Foram registradas amplificações em todos os inóculos coletados nos vários sistemas ambientais escolhidos, ainda que as condições ambientais não devessem favorecer esse grupo de bactérias, visto que os inóculos foram coletados em locais com concentrações baixas e/ou nulas de oxigênio (Tabela 5.5). Esse grupo de micro-organismos pode tornar-se 
um competidor efetivo pelo uso do nitrito, tornando esse substrato limitante em sistemas visando a remoção da amônia tendo o nitrito como aceptor de elétrons.

A avaliação dos resultados da análise de PCR quantitativa (PCRq) permitiu sugerir a representatividade de cada um dos três grupos de micro-organismos: os anammox, os oxidadores aeróbios de amônia (como Nitrosomonas) e os oxidadores aeróbios de nitrito (como Nitrobacter) no total do DNA genômico extraído a partir de cada um dos inóculos.

O ciclo de quantificação $(\mathrm{Cq})$ foi um dos parâmetros utilizados para realização de uma comparação relativa entre os diferentes inóculos e entre os grupos de micro-organismos de interesse usando os conjuntos de primers específicos. A partir dos resultados de Cq obtidos na análise de PCRq inferiu-se que quanto menor o valor de Cq maior o número de cópias iniciais do gene em análise (Figura 5.1). Na Figura 5.2 são demonstrados os resultados obtidos pela avaliação dos inóculos por PCR quantitativa para vários grupos de microorganismos.

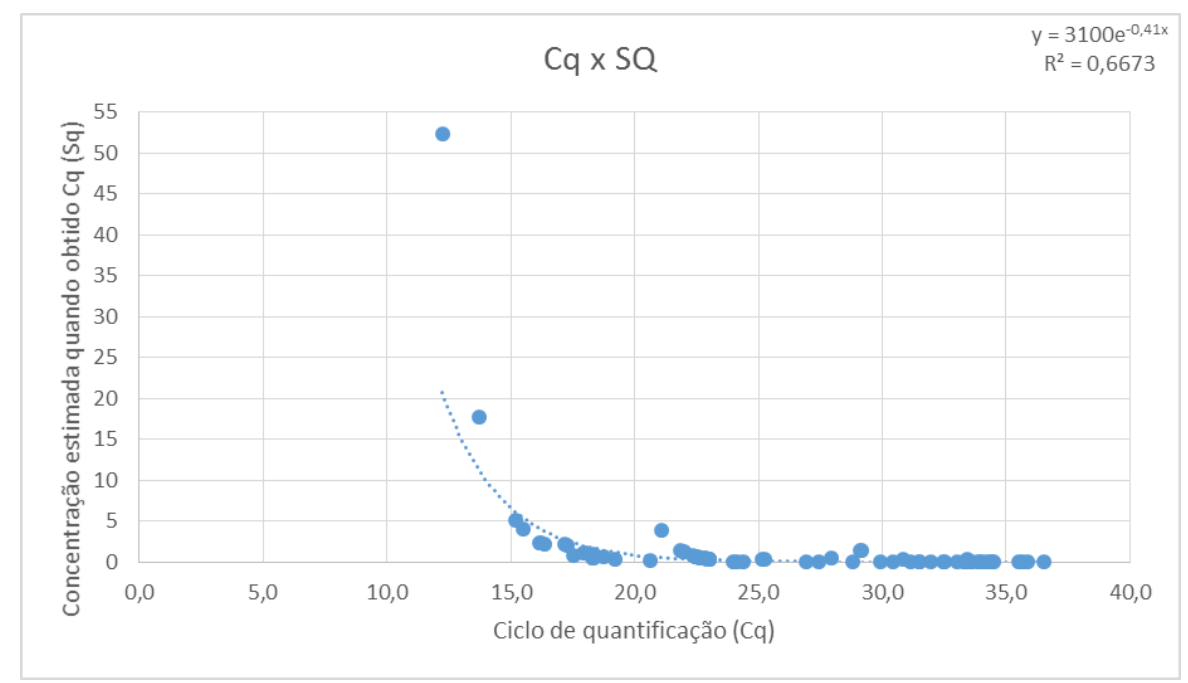

Figura 5.1: Correlação entre o ciclo de quantificação e a concentração de cópias dos genes de interesse quando obtidos os Cq pela análise de PCRq.

Os inóculos provenientes do lodo do reator UASB tratando efluente do frigorífico 1, Uberlândia, MG (UaF2) e do sedimento da lagoa de acumulação de chorume do aterro controlado de Brasília, DF (Cho) apresentaram uma menor quantidade de cópias dos genes relacionado ao RNAr 16S das bactérias anammox do que os demais inóculos, sendo o Cq para esses inóculos de 33,04 e 30,44, respectivamente (Figura 5.2). Da mesma forma, 
verificou-se que para UaF2 e Cho, o ciclo de quantificação $(\mathrm{Cq})$ foi maior para a amplificação dos genes relacionado ao RNAr $16 \mathrm{~S}$ das bactérias anammox do que os $\mathrm{Cq}$ obtidos para o gene RNAr $16 \mathrm{~S}$ relacionados com Nitrobacter, sugerindo uma maior densidade de cópias do gene RNAr 16S para os oxidadores aeróbios de nitrito do que as bactérias anammox (Figura 5.2).

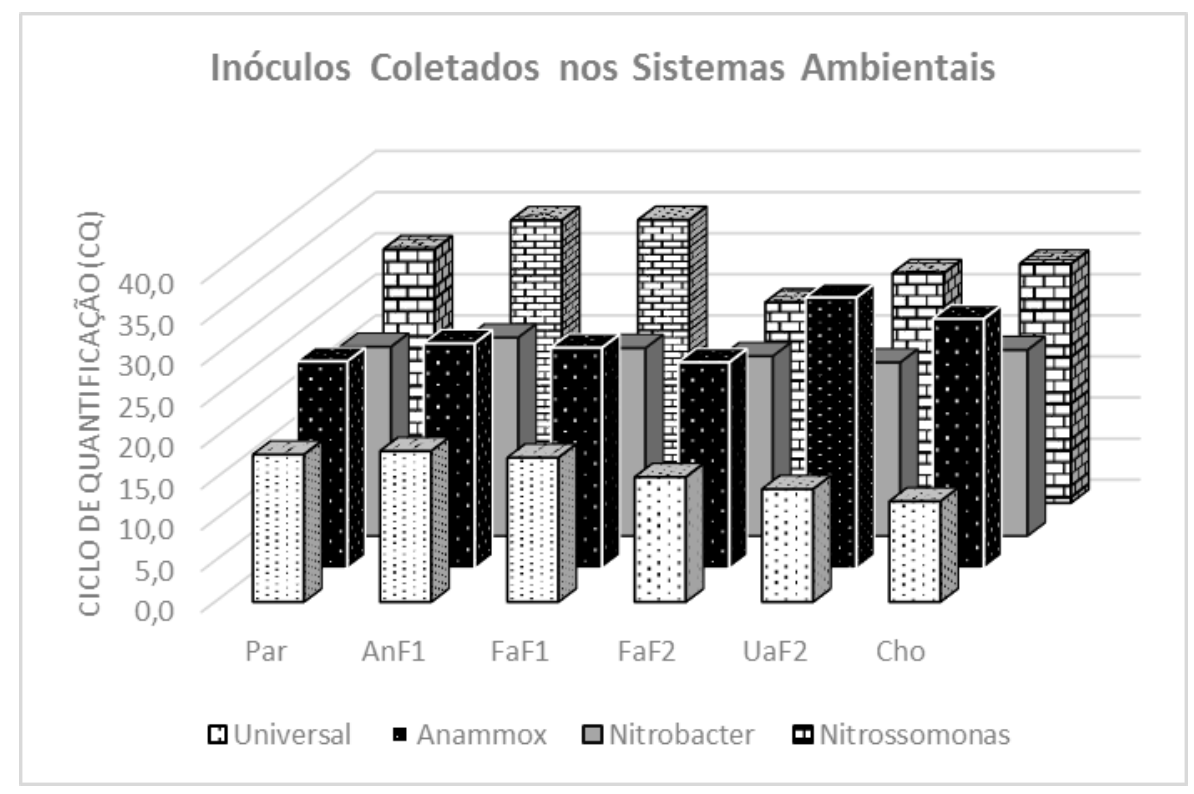

Figura 5.2: Ciclo de quantificação $(\mathrm{Cq})$ obtidos pela análise de PCR quantitativos, testando quatro pares de primers, para levantamento do número de cópias de organismos relacionados ao Domínio Bacteria, as bactérias anammox, as oxidadoras aeróbias de nitrito e as oxidadoras aeróbias de amônia. Par: sedimento do lago Paranoá, Brasília/DF; AnF1: lodo da lagoa anaeróbia tratando efluente do Frigorífico 1, Araguari/MG; FaF1: lodo da lagoa facultativa tratando efluente do Frigorífico 1, Araguari/MG; FaF2: lodo de lagoa facultativa tratando efluente do Frigorífico 2, Uberlândia, MG; UaF2: lodo de reator UASB tratando efluente do Frigorífico 2, Uberlândia/MG; CHOR: sedimento da lagoa de acumulação de chorume do aterro controlado Jockey Clube, Brasília, DF.

Para as biomassas dos outros inóculos (Par, AnF1, FaF1 e FaF2), a partir dos DNA genômicos extraídos, apresentaram $\mathrm{Cq}$ próximos para as amplificações dos genes relacionados ao RNAr 16S para os micro-organismos anammox e os aeróbios oxidadores de nitrito (Figura 5.2). Observa-se que para todos os inóculos a densidade de cópias do gene relacionado à enzima amônia mono-oxigenase foi baixa, dados os valores altos de $\mathrm{Cq}$ obtidos, ou seja, é necessário um maior número de ciclos de amplificações para se obter uma estimativa de quantificação (Figura 5.2). 
Numa análise global, utilizando de primers universais para os genes que codificam o RNAr 16S para o Domínio Bacteria, observa-se que os inóculos UaF2 e Cho apresentaram maiores densidade de cópias para o RNAr 16S devido os ciclos de quantificação $(\mathrm{Cq})$ terem sido os menores do que os apresentados pelos demais inóculos, fazendo supor uma maior diversidade genética e de micro-organismos responsáveis por vários outros processos metabólicos (Figura 5.2)

A concentração de biomassa relativa ao grupo anammox é extremamente importante para definição das cargas volumétricas aplicadas em sistemas e consequentemente para a eficiência de remoção de nitrogênio (Dapena-Mora et al., 2004; Lackner et al., 2014). No entanto, ficou demonstrado que para o sucesso da atividade anammox, além da concentração de organismos anammox, é necessário que ocorra equitabilidade nas densidades dos grupos que formam as comunidades microbianas relacionadas ao ciclo do nitrogênio (Tao et al., 2013).

Não há uma relação direta entre os parâmetros físico-químico e microbiológicos para distinção dos inóculos quanto ao possível desempenho anammox. No entanto, acredita-se que os inóculos provenientes do sedimento do Lago Paranoá (Par) e dos lodos das lagoas anaeróbia e facultativa dos Frigoríficos (AnF1, FaF1 e FaF2) demonstram apresentar maior potencial para sucesso em enriquecimento e atividade anammox devido às características químicas dos ambientes de onde foram coletados (Tabela 5.2) e dos resultados inferidos pelas análises de PCR convencional e quantitativa (Tabela 5.5 e Figura 5.2).

\section{3 - AVALIAÇÃO DA ATIVIDADE DOS MICRO-ORGANISMOS ANAMMOX NAS ETAPAS 1 E 2}

Foram usadas as seguintes evidências para inferir a ocorrência do processo anammox nos sistemas biológicos: 1) avaliação estequiométrica do consumo concomitante de amônia e nitrito numa razão de 1,32 com consequente formação de nitrato numa razão de 0,26 (Strous et al., 1998; Sun et al., 2011); 2) aumento no valor do pH do licor dos sistemas biológicos, uma vez que a reação anammox produz alcalinidade (Lackner et al., 2012; Li et al., 2012); 3) presença de micro-organismos anammox nas biomassas avaliadas por análises de PCR 
convencional, PCR quantitativa e sequenciamento dos fragmentos de DNA obtidos por PCR (Bae et al., 2010; Hu, et al., 2010; Park et al., 2010; Sun et al., 2011).

\subsection{1 - Etapa 1: Enriquecimento dos micro-organismos anammox}

\subsubsection{1 - Comportamento de conversão dos íons nitrogenados $\left(\mathrm{NH}_{4}{ }^{+}, \mathrm{NO}_{2}{ }^{-} \mathrm{e} \mathrm{NO}_{3}{ }^{-}\right)$}

A avaliação da conversão dos compostos nitrogenados foi interpretada pelas observações de redução das concentrações de amônia e nitrito e aumento das concentrações de nitrato nos diferentes sistemas biológicos utilizados nos experimentos. Verificou-se a normalidade e homogeneidade dos dados obtidos para cada um dos sistemas biológicos ao longo do tempo dos experimentos por meio dos testes de Shapiro-Wilk e Levene, respectivamente, para $\mathrm{p}<$ 0,05, concluindo-se que, para quase todos os sistemas, os íons de interesse apresentaram distribuição normal e as variâncias entre as duplicatas foram as mesmas. Os sistemas biológicos para os quais os dados obtidos não apresentaram distribuição normal ( $\mathrm{p}<0,05)$ foram amônia para os sistemas AnF1A e B, nitrato para os sistemas FaF1A e B e amônia e nitrato para o par UaF2A e B (Apêndice II - CD).

Dos sistemas biológicos que se obteve a distribuição normal e homogênea dos íons aplicouse um teste estatístico de diferenças de médias, o teste $t$ para amostras dependentes para verificar se os sistemas biológicos A e B, montados com o mesmo inóculo, apresentaram comportamentos de conversão semelhantes (Tabela 5.6). Para os sistemas biológicos que apresentaram resultados para os dados de alguns íons com distribuição não normal aplicouse o teste não paramétrico de Wilcoxon de Postos com Sinais, buscando-se comparar as duplicatas A e B dos sistemas biológicos (Tabela 5.6) (Apêndice II - CD).

Com base nos testes estatísticos realizados considerou-se que as duplicatas A e B, para os sistemas biológicos que tiveram como biomassa o mesmo inóculo, apresentaram comportamentos semelhantes de conversão dos íons amônia, nitrito e nitrato e, portanto, os resultados que se seguem são os valores médios obtidos a partir das duplicatas A e B dos sistemas biológicos testados. 
Tabela 5.6: Comparação das duplicatas A e B dos sistemas biológicos na conversão dos íons amônia, nitrito e nitrato pelos testes estatísticos: 1) teste $t$ para amostras dependentes para $\mathrm{p}<0,05$ e 2) teste não paramétrico de Wilcoxon de Postos com Sinais para $\mathrm{p}<0,05$.

\begin{tabular}{lccccc}
\hline \multicolumn{1}{c}{$\begin{array}{c}\text { Sistemas } \\
\text { Biológicos }\end{array}$} & \multicolumn{2}{c}{$\begin{array}{c}\text { Amônia } \\
\text { Teste } t\end{array}$} & Wilcoxon & Nitrito & \multicolumn{2}{c}{ Nitrato } \\
& Teste $t$ & Teste $t$ & Wilcoxon \\
\hline ParA e ParB & $=$ & & $=$ & $=$ & \\
AnF1A e AnF1B & & $=$ & $=$ & $=$ & $=$ \\
FaF1A e FaF1B & $=$ & & $=$ & & $=$ \\
FaF2A e FaF2B & $=$ & & $=$ & $=$ & \\
UaF2A e UaF2B & & $=$ & $=$ & & $=$ \\
ChoA e ChoB & $=$ & & $=$ & $=$ & \\
\hline \hline
\end{tabular}

Os sistemas biológicos com biomassa proveniente do lago Paranoá (Par) apresentaram comportamento de conversão dos compostos nitrogenados diferenciados dos demais sistemas (Figura 5.3), com a redução nas concentrações de amônia e nitrito e com aumento nas concentrações de nitrato, desde o início dos experimentos.

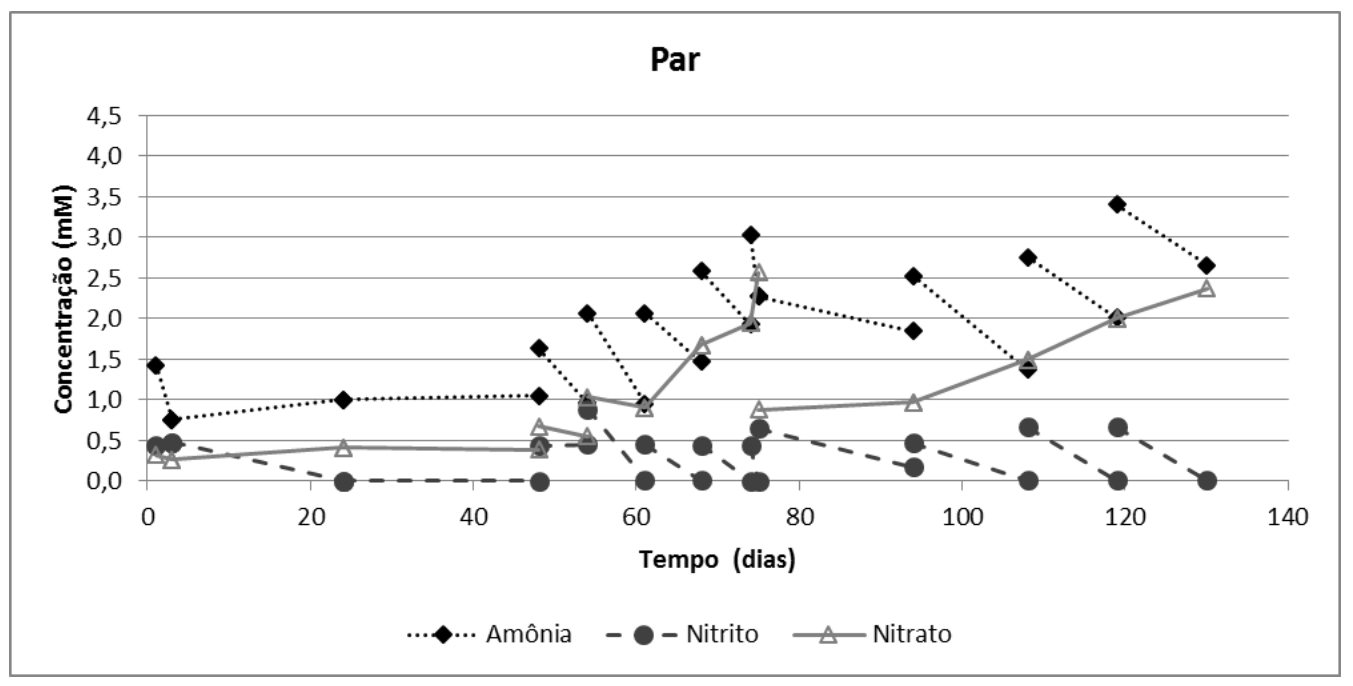

Figura 5.3. Desempenho dos sistemas biológicos com biomassa proveniente de sedimentos do lago Paranoá, Brasília/DF (Par) na conversão dos compostos nitrogenados durante a etapa 1 visando o enriquecimento de bactérias anammox.

Por razões de ajustes experimentais não foram realizadas as adições de substratos nos sistemas biológicos entre os $24^{\circ}$ e $48^{\circ}$ dias e, por isso, foi possível constatar que, devido a ausência do nitrito no meio não ocorreu nenhuma conversão de amônia e as concentrações 
de nitrato permaneceram constantes (Figura 5.3). Deixou-se de inserir nitrato nesses sistemas biológicos, após 60 dias, uma vez que o mesmo não estava sendo consumido pelo processo de desnitrificação heterotrófica. Infere-se, portanto que, para esses sistemas biológicos (Par) o processo biológico conduzido por micro-organismos anammox prevaleceu após 60 dias, sendo necessária a presença de ambos os substratos amônia e nitrito para modificações das concentrações das formas nitrogenadas no licor misto. A avaliação dos índices estequiométricos das conversões das formas nitrogenadas comparada aos índices esperados quando do predomínio do processo biológico anammox foi realizada, sendo que a razão média $( \pm s)$ entre $\left[\mathrm{NO}_{2}{ }^{-}\right] /\left[\mathrm{NH}_{4}{ }^{+}\right]$foi de $0,73(s=0,26)$ e entre $\left[\mathrm{NO}_{3}{ }^{-}\right] /\left[\mathrm{NO}_{2}{ }^{-}+\mathrm{NH}_{4}{ }^{+}\right]$foi de $0,39(s=0,20)$, sendo que quanto mais próximas estiverem dos valores 1,32 e 0,28 , respectivamente, é um indicativo do metabolismo anammox prevalecendo no sistema.

Nos demais sistemas biológicos foi observada, possivelmente, a conversão da amônia pelo processo anammox conjuntamente com a ocorrência da desnitrificação heterotrófica, uma vez que todo o nitrito e nitrato inseridos e, possivelmente, produzidos nos sistemas foram totalmente removidos (Figuras 5.4 a 5.8). As concentrações iniciais de carbono orgânico nos sistemas quando da montagem dos sistemas biológicos, inferidas pelos resultados obtidos nas análises de DQO, permitiram o estabelecimento do metabolismo de micro-organismos desnitrificantes heterotróficos.

Tem-se também que as modificações do ambiente, ou seja, após a inserção dos inóculos nos sistemas biológicos, os micro-organismos presentes nas biomassas passam a estar expostos ao meio autotrófico e condições anaeróbias gerando a lise de células das bactérias que não se adaptam a essas novas e diferentes condições operacionais. De acordo com Bae et al. (2010), ocorreram reduções nas concentrações de SSV em sistemas em bateladas, visando atividade anammox, depois do enriquecimento, possivelmente, devido à lise de bactérias que não se propagaram nas condições estabelecidas nos sistemas.

Ni et al. (2012) discutiram as interações entre bactérias anammox e heterotróficas em biofilmes anammox e demonstraram que as razões encontradas entre produção de nitrato e consumo de amônia foram significativamente inferiores à razão proposta por Strous et al. (1998), sendo ela igual a 0,28. Esses autores sugeriram que quantidades significativas de nitrato foram usadas como aceptores de elétrons por bactérias heterotróficas quando as mesmas utilizavam outros produtos orgânicos solúveis. 
Nos sistemas com lodo da lagoa anaeróbia tratando efluente do frigorífico 1, Araguari/MG $(\mathrm{AnF} 1)$, a razão média $( \pm s)$ entre $\left[\mathrm{NO}_{2}{ }^{-}\right] /\left[\mathrm{NH}_{4}{ }^{+}\right]$foi de $0,57(s=0,31)$. Como todo o nitrato inserido e produzido foi removido do sistema, não foi possível calcular o índice estequiométrico dado pela razão entre $\left[\mathrm{NO}_{3}{ }^{-}\right] /\left[\mathrm{NO}_{2}{ }^{-}+\mathrm{NH}_{4}{ }^{+}\right]$(Figura 5.4).

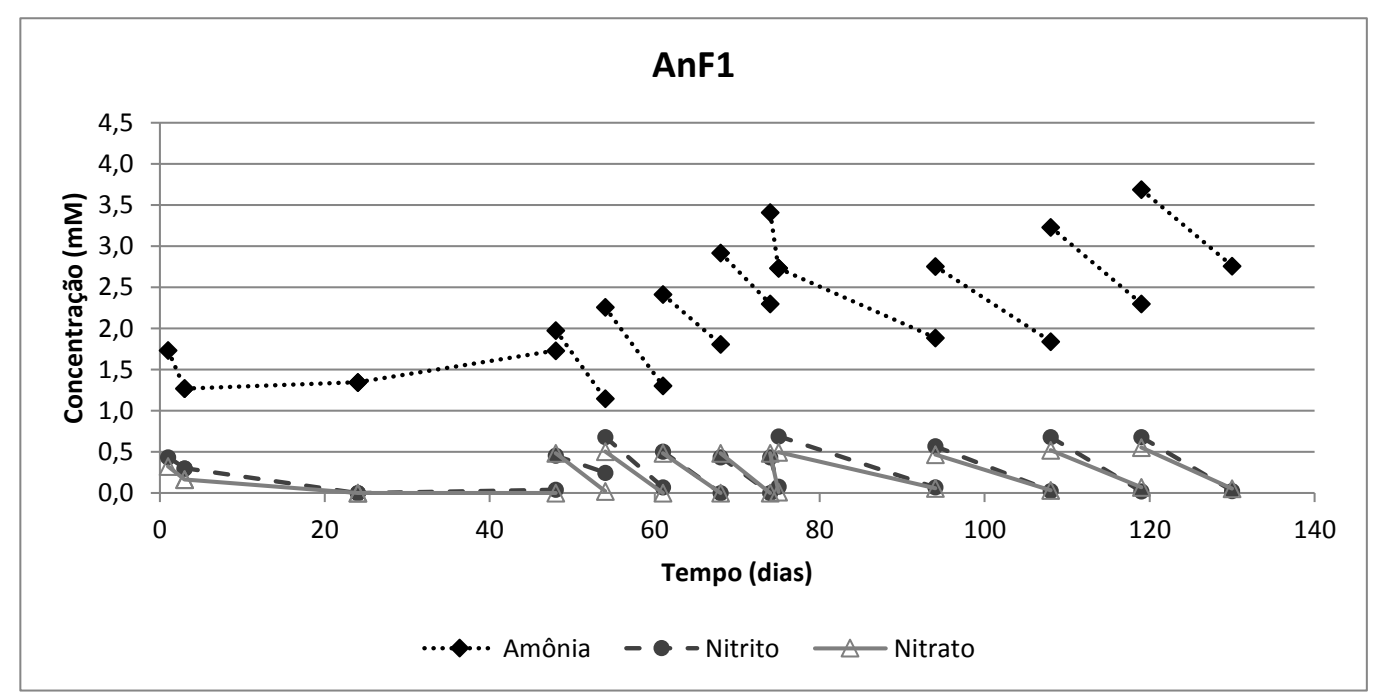

Figura 5.4: Desempenho dos sistemas biológicos com biomassa proveniente de lodo de lagoa anaeróbia tratando efluente de frigorífico 1, Araguari/MG (AnF1) na conversão dos compostos nitrogenados durante a etapa 1 visando o enriquecimento de bactérias anammox.

Da mesma maneira comportaram-se os sistemas biológicos com biomassa proveniente da lagoa facultativa tratando efluente do Frigorífico 1, Araguari/MG (FaF1), tendo ocorrido possivelmente as conversões das formas nitrogenadas pelos processos anammox e desnitrificação heterotrófica, visto que ocorreram reduções nas concentrações de amônia, nitrito e nitrato (Figura 5.5). Nos sistemas com lodo da lagoa facultativa a razão média $( \pm s)$ entre $\left[\mathrm{NO}_{2}{ }^{-}\right] /\left[\mathrm{NH}_{4}{ }^{+}\right]$foi de $0,73(s=0,87)$. A desnitrificação heterotrófica foi responsável pela remoção do nitrato do sistema e, por isso, não foi possível realizar cálculo do índice estequiométrico dado pela razão entre $\left[\mathrm{NO}_{3}{ }^{-}\right] /\left[\mathrm{NO}_{2}{ }^{-}+\mathrm{NH}_{4}{ }^{+}\right]$.

Nos sistemas biológicos com biomassa proveniente da lagoa facultativa do Frigorífico 2, Uberlândia/MG (FaF2) observou-se o acúmulo de nitrato a partir do $60^{\circ}$ dia do início do desenvolvimento da biomassa indicando que, possivelmente, o processo anammox passa a predominar sobre o processo de desnitrificação heterotrófica (Figura 5.6). A partir desse momento cessou-se a introdução do substrato nitrato nos sistemas, uma vez que a finalidade da inserção foi reduzir a competição por substratos entre micro-organismos responsáveis 
pelos metabolismos anammox e desnitrificação heterotrófica. Os índices estequiométricos dados pelas razões médias $( \pm s)$ entre $\left[\mathrm{NO}_{2}^{-}\right] /\left[\mathrm{NH}_{4}{ }^{+}\right]$e entre $\left[\mathrm{NO}_{3}{ }^{-}\right] /\left[\mathrm{NO}_{2}{ }^{-}+\mathrm{NH}_{4}{ }^{+}\right]$foram de $0,73(s=0,87)$ e $0,40(s=0,20)$, respectivamente, e quanto mais próximos estiverem dos valores 1,32 e 0,28, respectivamente, melhor eficiência de conversão das formas nitrogenadas pelo metabolismo anammox.

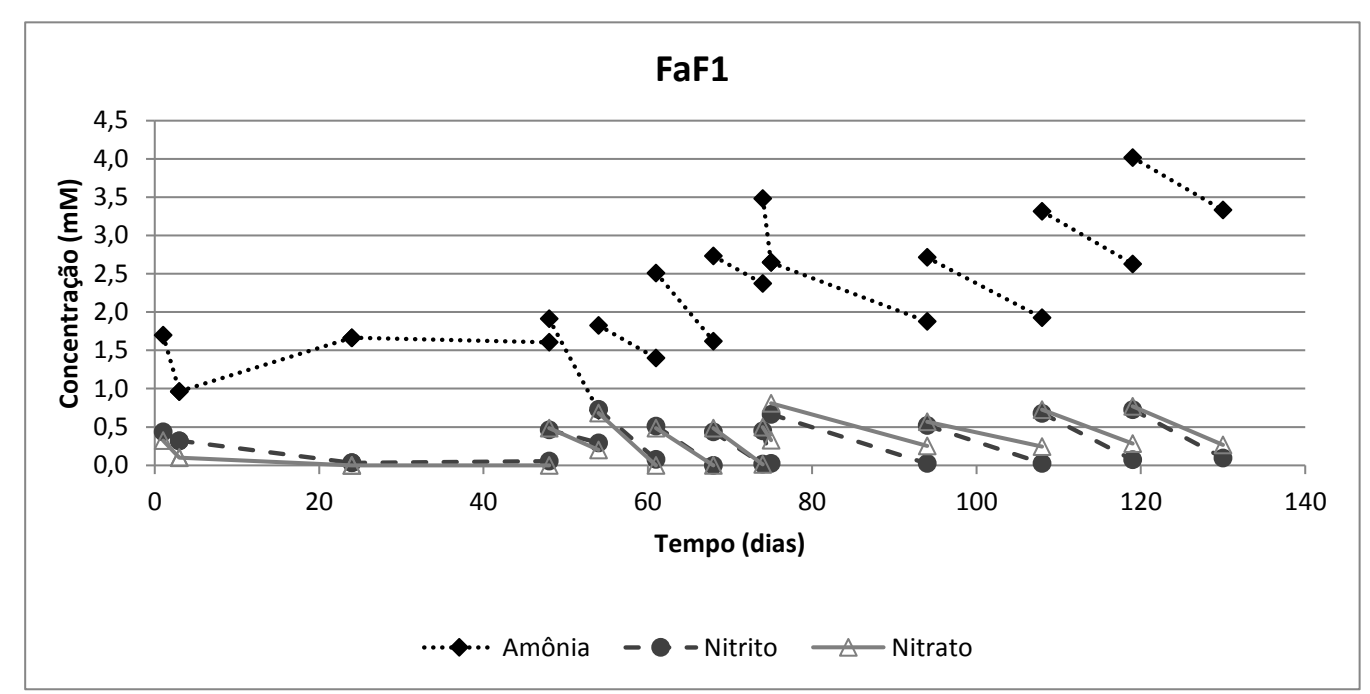

Figura 5.5: Desempenho dos sistemas biológicos com biomassa proveniente de lodo de lagoa facultativa tratando efluente de frigorífico 1, Araguari/MG (FaF1) na conversão dos compostos nitrogenados durante a etapa 1 visando o enriquecimento de bactérias anammox.

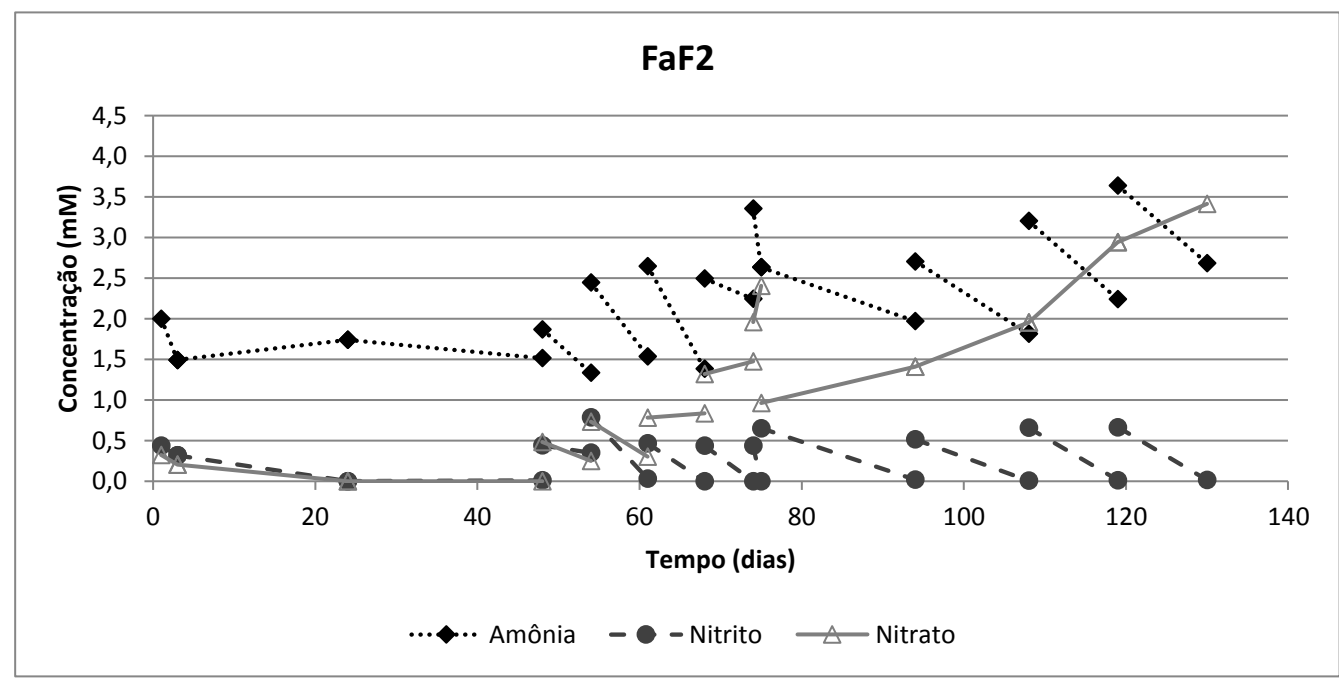

Figura 5.6: Desempenho dos sistemas biológicos com biomassa proveniente de lodo de lagoa facultativa tratando efluente de frigorífico 2, Uberlândia/MG (FaF2) na conversão dos compostos nitrogenados durante a etapa 1 visando o enriquecimento de bactérias anammox. 
Os sistemas biológicos montados com biomassa proveniente do reator UASB tratando efluente do frigorífico 2, Uberlândia/MG (UaF2) apresentaram a concomitância dos metabolismos conduzidos por micro-organismos responsáveis pelos processos anammox e de desnitrificação heterotrófica devido às reduções nas concentrações dos substratos amônia, nitrito e nitrato, tendo sido as formas nitrogenadas oxidadas removidas dos sistemas, dadas as concentrações abaixo do limite de detecção do método de análise (Figura 5.7). Dessa maneira, foi possível apenas calcular o índice estequiométrico dado pela razão $( \pm s)$ entre $\left[\mathrm{NO}_{2}^{-}\right] /\left[\mathrm{NH}_{4}^{+}\right]$, sendo de $0,72(s=0,73)$.

Os sistemas biológicos montados com biomassa proveniente do sedimento da lagoa de acumulação de chorume do aterro controlado Jockey Clube de Brasília/DF (Cho) também se comportaram de forma semelhante aos sistemas biológicos AnF1, FaF1, UaF2 restringindose às comparações das conversões das formas nitrogenadas. Os processos anammox e a desnitrificação heterotrófica se destacaram dadas as reduções nas concentrações dos substratos amônia, nitrito e nitrato (Figura 5.8). Devido à utilização do substrato nitrato pelas bactérias desnitrificantes heterotróficas não foi possível calcular a razão entre $\left[\mathrm{NO}_{3}{ }^{-}\right] /\left[\mathrm{NO}_{2}{ }^{-}\right.$ $+\mathrm{NH}_{4}{ }^{+}$] para comparação com o índice estequiométrico dado pela reação anammox. No entanto, calculou-se a razão entre o consumo concomitante de nitrito e amônia por meio de $\mathrm{NO}_{2}{ }^{-} / \mathrm{NH}_{4}{ }^{+}$, sendo de $0,49(s=0,32)$.

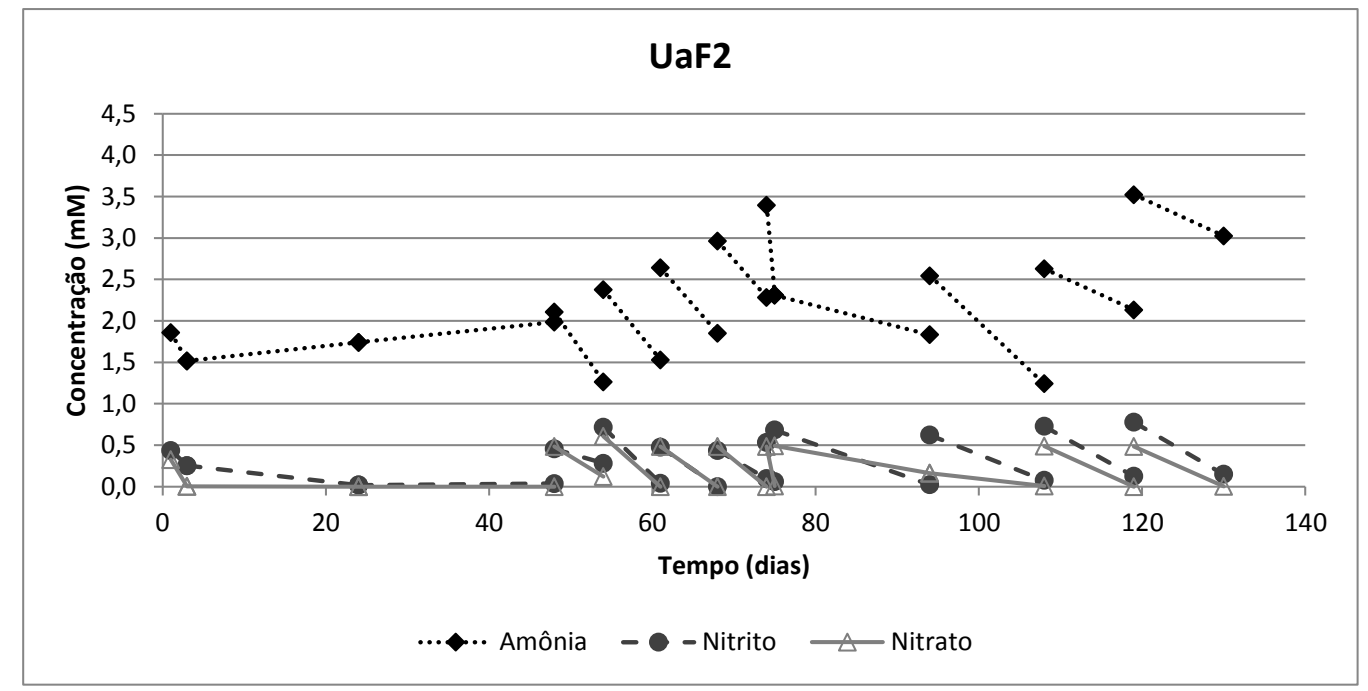

Figura 5.7: Desempenho dos sistemas biológicos com biomassa proveniente de lodo reator UASB tratando efluente de frigorífico 2, Uberlândia/MG (UaF2) na conversão dos compostos nitrogenados durante a etapa 1 visando o enriquecimento de bactérias anammox. 


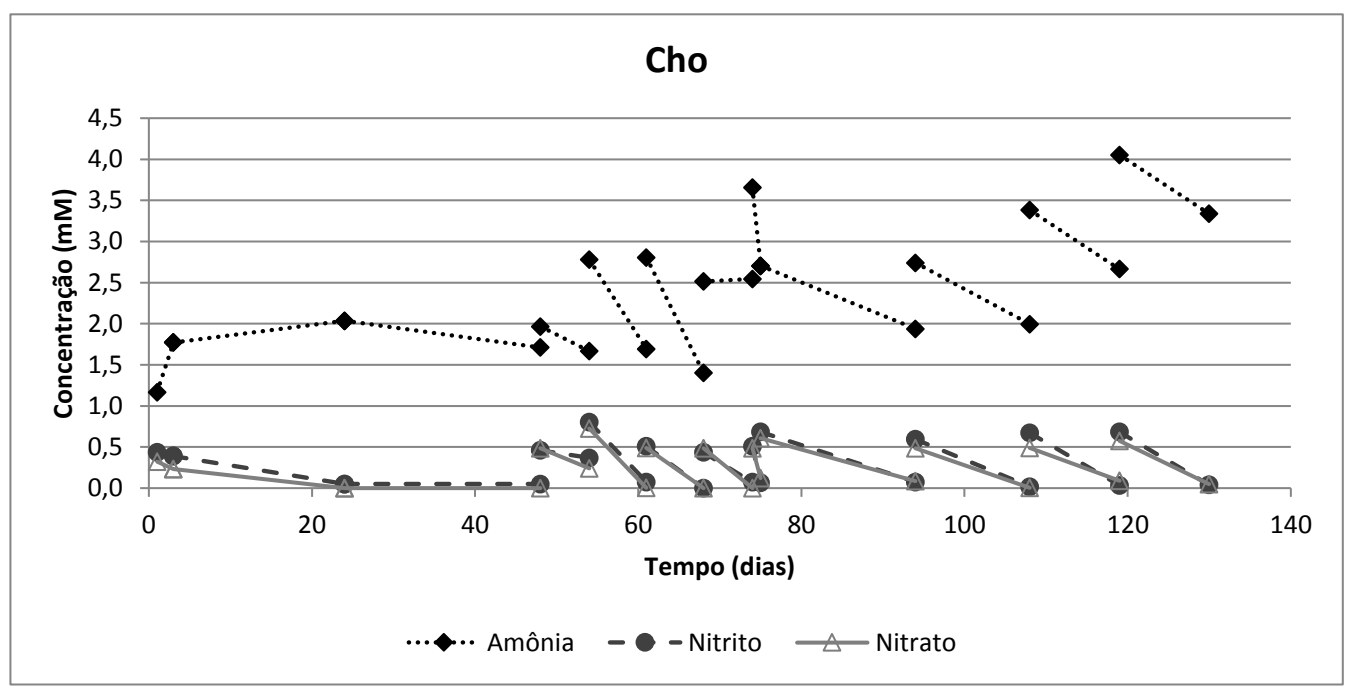

Figura 5.8: Desempenho dos sistemas biológicos com biomassa proveniente da lagoa de acumulação de chorume do aterro controlado Jockey Clube, Brasília, DF (Cho) na conversão dos compostos nitrogenados durante a etapa 1 visando o enriquecimento de bactérias anammox.

A presença do carbono orgânico, quando da inserção dos inóculos, favoreceu grupos de bactérias heterotróficas, em especial as desnitrificantes, que demonstraram sua participação na remoção de nitrito e nitrato, em todos os sistemas biológicos testados e de forma acentuada naqueles sistemas inoculados com lodo do reator UASB tratando água residuária de abatedouro de bovinos e suínos do frigorífico 2, Uberlândia, MG (UaF2). Provavelmente, a redução do sulfato com formação de sulfetos para os sistemas biológicos (UaF2) tenha interferido no metabolismo dos micro-organismos anammox. Os sulfetos formados são considerados substâncias inibidoras aos micro-organismos responsáveis pelo processo anammox (Jin et al., 2012).

A desnitrificação heterotrófica inibe o processo anammox devido às alterações das concentrações dos substratos presentes no licor e no balanço químico modificando o tamponamento do licor $(\mathrm{pH})$, além do mais as bactérias heterotróficas utilizam das formas oxidadas de nitrogênio competindo por nitrito com as bactérias anammox (Ni et al., 2012).

De acordo com Tao et al. (2013), as bactérias anammox apresentam desvantagens competitivas com as bactérias heterotróficas, pois a reação anammox é termodinamicamente menos viável do que a reação de desnitrificação heterotrófica. Também, a síntese celular das bactérias heterotróficas é quase cinco vezes maior do que das anammox (Shen et al., 2011). 
Vários pesquisadores relataram o processo de desnitrificação heterotrófica predominando inicialmente nos sistemas para enriquecimento anammox devido à atmosfera anaeróbica e à presença de carbono e das formas oxidadas de nitrogênio necessárias para o metabolismo das bactérias desnitrificantes (Sànchez-Melsió et al., 2009; Araújo et al. 2010; Suneethi e Joseph. 2011; Wang et al. 2011).

Araújo et al. (2010), usando inóculo a partir de sistema de lodos ativados, registraram que a atividade desnitrificante foi exclusiva durante os primeiros 25 dias e concomitante ao processo anammox até o $87^{\circ}$ dia, predominando então o processo anammox. Wang et al. (2011) usaram 3 fontes de inóculos para enriquecimento anammox em RBS e obtiveram sucesso apenas com o inóculo proveniente de um biorreator de membranas tratando água residuária sintética, com baixa relação $\mathrm{C} / \mathrm{N}$. Nos primeiros 19 dias apenas atividade desnitrificante foi registrada e permaneceu de forma menos acentuada até o dia $59^{\circ}$. O processo anammox ficou estável e predominante a partir do $60^{\circ}$ dia. No trabalho desenvolvido por Sànchez-Melsió et al. (2009) apenas um inóculo, de 13 testados, demonstrou potencial atividade anammox depois de 3 meses. A atividade desnitrificante foi o único processo observado em todos os demais sistemas até um ano de monitoramento. Suneethi \& Joseph (2011), usando lodo anaeróbio proveniente de biodigestor tratando resíduos de indústria de processamento de vegetais, registraram atividade anammox somente após 70 dias de cultivo, sendo que a estabilização do processo só foi verificada a partir de 140 dias.

Os sistemas biológicos Par e FaF2, cujas biomassas foram provenientes de sedimentos do lago Paranoá, Brasília, DF e de lodo de lagoa facultativa do Frigorífico 2, Uberlândia, MG, demonstraram potencial atividade anammox observando-se os registros de conversão dos compostos nitrogenados nos sistemas em bateladas e pela verificação de amplificações positivas, em análise de PCR, sugerindo a presença de organismos anammox. Nesses sistemas a atividade heterotrófica desnitrificante cessou rapidamente. As características da biomassa do sistema biológico Par com concentrações de carbono e relação $\mathrm{C} / \mathrm{N}$ baixas devem ter favorecido as bactérias anammox desde o início do enriquecimento. No entanto, para os sistemas biológicos FaF2 somente após 60 dias é que se estabeleceu e predominou a atividade anammox. A diferença entre os dois sistemas, Par e FaF2, deve-se provavelmente às características químicas apresentadas pelos sistemas ambientais de onde foram coletados esses inóculos. 
5.3.1.2 - Variações do pH do licor nos sistemas biológicos

De acordo com Li et al. (2012), a elevação no valor do pH de efluentes de reatores biológicos, ou seja, tornando-se mais básico, é um indicador efetivo do desempenho dos micro-organismos anammox.

As variações do $\mathrm{pH}$ do licor misto nos sistemas biológicos auxiliam no entendimento dos processos metabólicos predominantes, uma vez que os processos de nitritação e nitratação consomem alcalinidade (Ahn, 2006) enquanto os processos anammox e de desnitrificação heterotrófica produzem alcalinidade (Sun et al., 2011; Li et al., 2012; Lackner et al., 2012). Para cada 1,0 mg de nitrogênio amoniacal oxidado pela nitrificação aeróbia são necessários 7,07 mg de alcalinidade (Ahn, 2006), expressa como carbonato de cálcio $\left(\mathrm{CaCO}_{3}\right)$. A ocorrência conjunta de vários processos metabólicos pode assegurar uma menor oscilação do $\mathrm{pH}$ permitindo uma maior estabilidade dos sistemas biológicos garantindo com que este parâmetro operacional permaneça constante e dentro da faixa ótima para os microorganismos responsáveis pelas conversões dos diferentes substratos.

As variações do $\mathrm{pH}$ ao longo das bateladas realizadas durante a etapa 1 visando o enriquecimento de micro-organismos anammox estão apresentadas na Figura 5.9. As correções de $\mathrm{pH}$ ocorreram apenas quando da substituição do meio sintético ou quando atingiam valores menores do que 7 , mas permanecendo sempre dentro da faixa ótima para a atividade anammox, entre 7,0 a 8,2. Em todos os sistemas biológicos durante os primeiros 60 dias, o pH do licor misto reduziu dos valores ajustados ao início das bateladas indicando o consumo da alcalinidade por processos metabólicos como nitrificação, redução de sulfato e consumo de carbono orgânico por bactérias heterotróficas (Figura 5.9 A a F). Ao final do período destinado ao enriquecimento da biomassa anammox (120 dias) registra-se uma menor oscilação dos valores de $\mathrm{pH}$ ajustados ao início das bateladas com uma tendência à elevação, provavelmente devido à predominância de processos metabólicos produtores de alcalinidade (Figura 5.9 A a F). O decaimento dos valores de $\mathrm{pH}$ foi mais acentuado nos sistemas biológicos com lodo proveniente do reator UASB (UaF2) tratando efluente do frigorífico 2 (Figura 5.9 E) provavelmente devido à redução do sulfato, detectada pela formação de fortes odores de gás sulfídrico (sulfetos) e pela remoção das concentrações de sulfato do licor misto. 


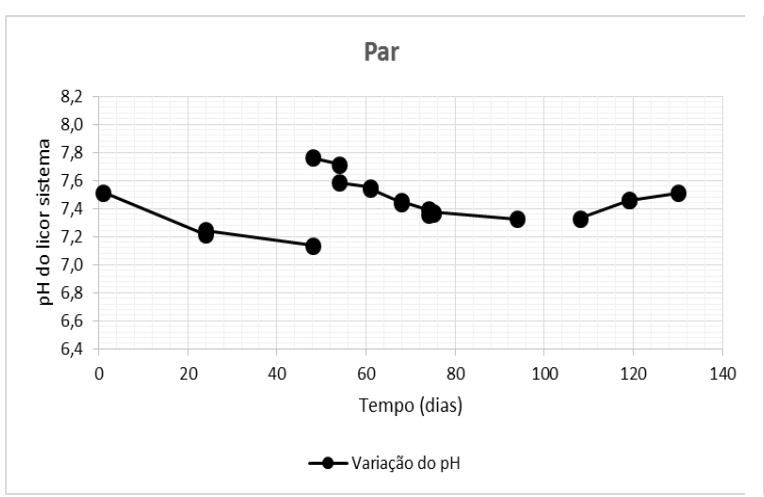

A

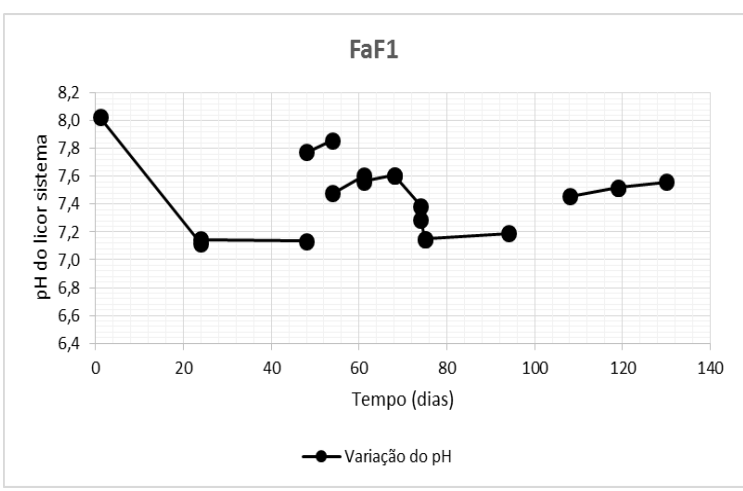

C

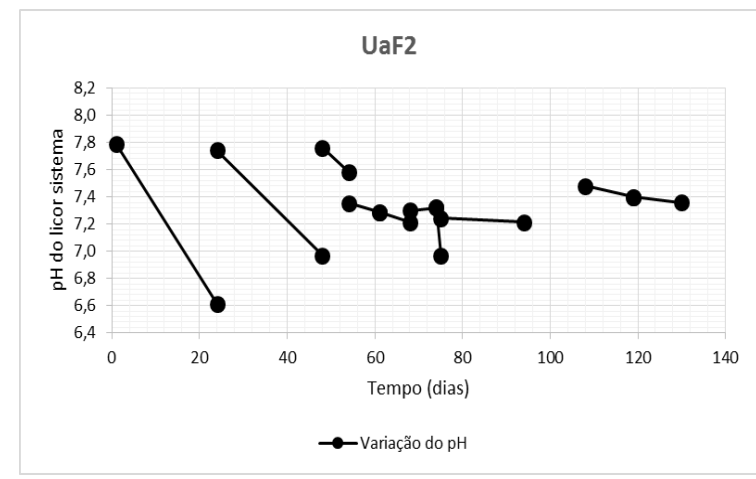

$\mathbf{E}$

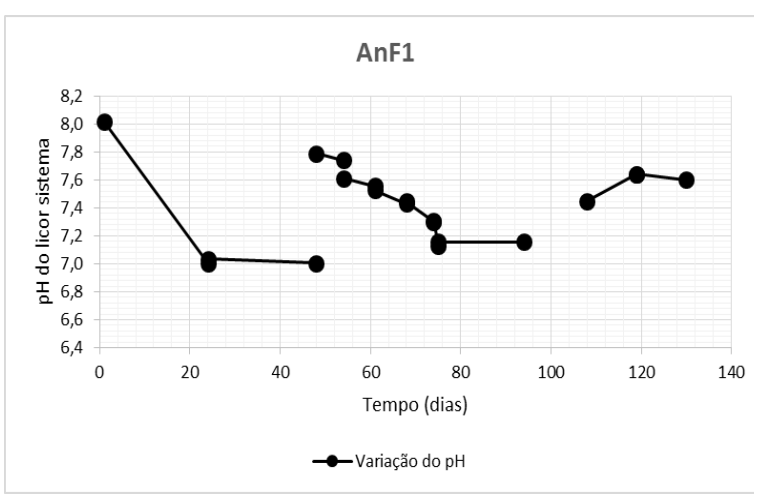

B

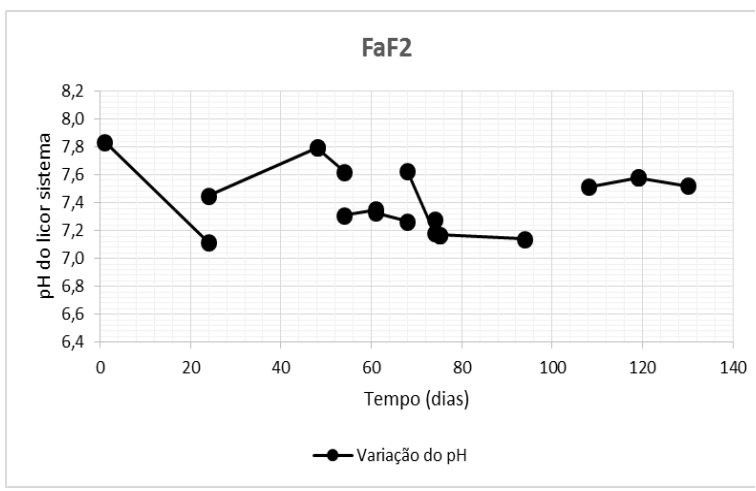

D

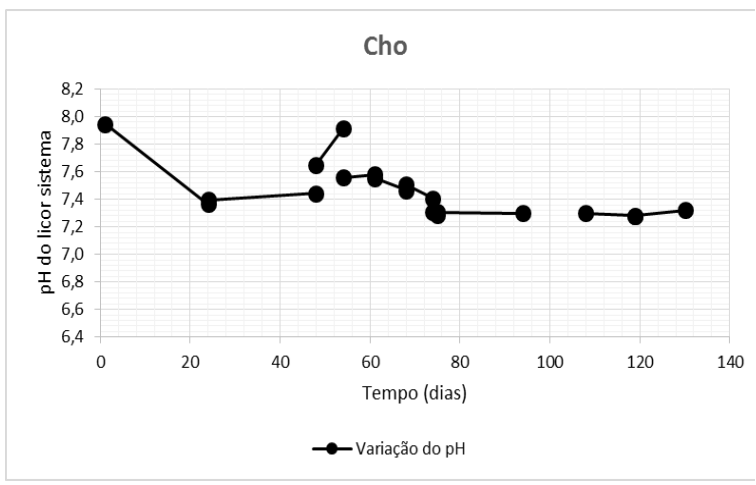

$\mathbf{F}$

Figura 5.9: Variação do $\mathrm{pH}$ dos sistemas biológicos ao longo das bateladas durante a etapa

1 visando o enriquecimento da biomassa anammox. A) Par: sedimento do lago Paranoá, Brasília/DF; B) AnF1: lodo da lagoa anaeróbia tratando efluente do Frigorífico 1, Araguari/MG; C) FaF1: lodo da lagoa facultativa tratando efluente do Frigorífico 1, Araguari/MG; D) FaF2: lodo de lagoa facultativa tratando efluente do Frigorífico 2, Uberlândia, MG; E) UaF2: lodo de reator UASB tratando efluente do

Frigorífico 2, Uberlândia/MG; F) CHOR: sedimento da lagoa de acumulação de chorume do aterro controlado Jockey Clube, Brasília, DF. 
5.3.1.3 - Comportamento da biomassa quanto aos íons sulfato e fosfato

Dadas as concentrações iniciais de sulfato $\left(4,2 \mathrm{mg} . \mathrm{L}^{-1}\right)$ e de fosfato $\left(17,5 \mathrm{mg} . \mathrm{L}^{-1}\right)$ inseridas nos sistemas biológicos a cada substituição do meio sintético, ocorreram comportamentos diferenciados na utilização desses componentes iônicos até 80 dias do início dos experimentos, sendo que os sistemas biológicos testados, à exceção daqueles inoculados com biomassa proveniente do reator UASB do Frigorífico 2, Uberlândia, MG (UaF2), consumiram o fosfato presente e produziram sulfato, dados os processos metabólicos predominantes nos sistemas (Figuras 5.10 a 5.14).

Nos sistemas biológicos com biomassa a partir do sedimento do lago Paranoá, Brasília, DF (Par), ocorreu um aumento considerável das concentrações de sulfato ao longo das bateladas, quase 10 vezes maior o valor originalmente inserido no meio sintético. $\mathrm{O}$ fosfato é quase totalmente consumido nos primeiros 75 dias, quando a partir desse período as concentrações de fosfato e sulfato permanecem constantes (Figura 5.10).

A produção de sulfato sugere ocorrência de oxidação de sulfetos que pode promover consequências positivas para os sistemas biológicos visando a atividade anammox, primeiro porque reduz a presença de sulfetos que são inibitórios ao processo anammox (Jin et al., 2012) e, segundo, porque consome oxigênio reduzindo a possibilidade deste ser utilizado na oxidação aeróbia de amônia e nitrito por bactérias aeróbias nitrificantes.

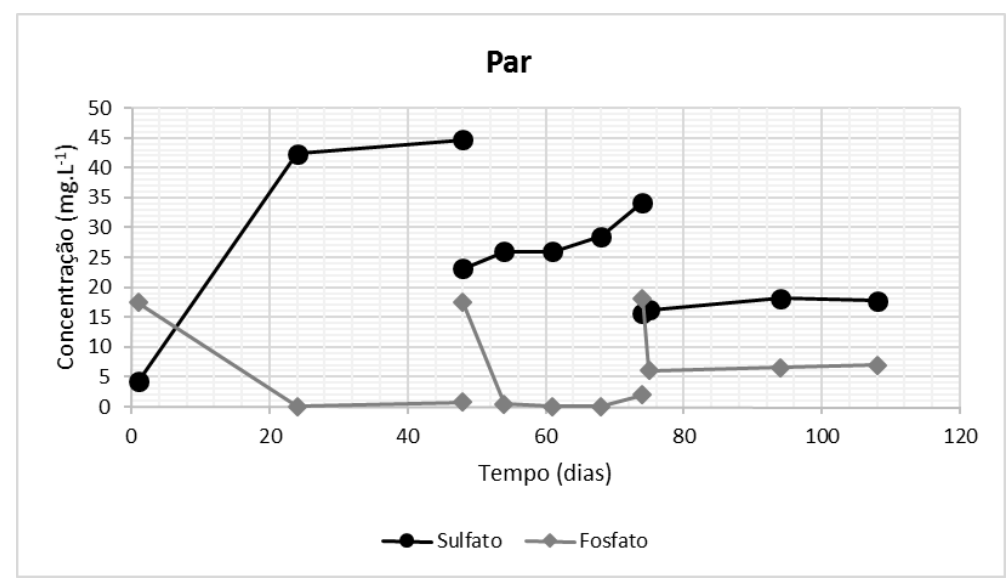

Figura 5.10: Concentrações dos íons sulfato e fosfato nos sistemas biológicos com biomassa proveniente do sedimento do lago Paranoá, Brasília, DF (Par) durante a etapa 1 visando o enriquecimento de micro-organismos anammox. 
Nos sistemas biológicos, com biomassa provenientes dos lodos das lagoas anaeróbia e facultativa tratando efluente do frigorífico 1, Araguari, MG (AnF1 e FaF1), e da lagoa facultativa tratando efluente do frigorífico 2, Uberlândia, $\mathrm{MG}(\mathrm{FaF} 2)$ as concentrações de sulfato aumentaram ao longo das bateladas, tendo variações de acordo com os sistemas em análise, atingindo concentrações 20 vezes maiores para os sistemas AnF1 e de 10 vezes maiores para os sistemas $\mathrm{FaF} 1$ e FaF2, do que aquelas introduzidas nesses sistemas quando da substituição da água residuária sintética. O fosfato foi, inicialmente, todo consumido pela biomassa em todos os sistemas em análise, sendo que após o período de 80 dias de enriquecimento, as suas concentrações permaneceram relativamente constantes, em torno de $10 \mathrm{mg} . \mathrm{L}^{-1}$. O sulfato, mesmo após um período maior de tempo, continuou sendo produzido, elevando-se para patamares entre 25 mg. $\mathrm{L}^{-1}\left(\mathrm{FaF} 1\right.$ e FaF2) e $45 \mathrm{mg} . \mathrm{L}^{-1}$ (AnF1) (Figuras 5.11 a 5.13).

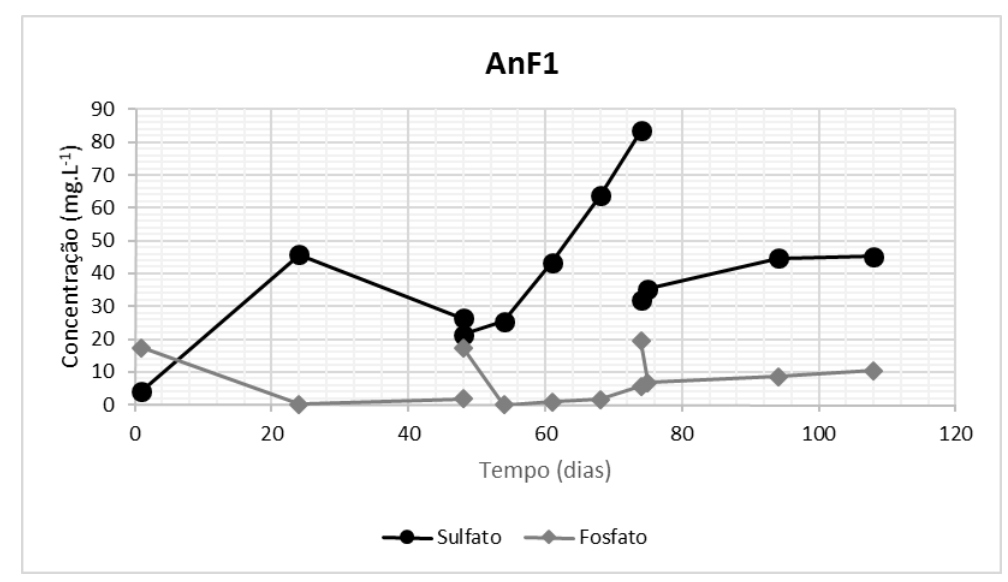

Figura 5.11: Concentrações dos íons sulfato e fosfato nos sistemas biológicos com biomassa proveniente do lodo da lagoa anaeróbia tratando efluente do frigorífico 1, Araguari, MG (AnF1) durante a etapa 1 visando o enriquecimento de micro-organismos anammox. 


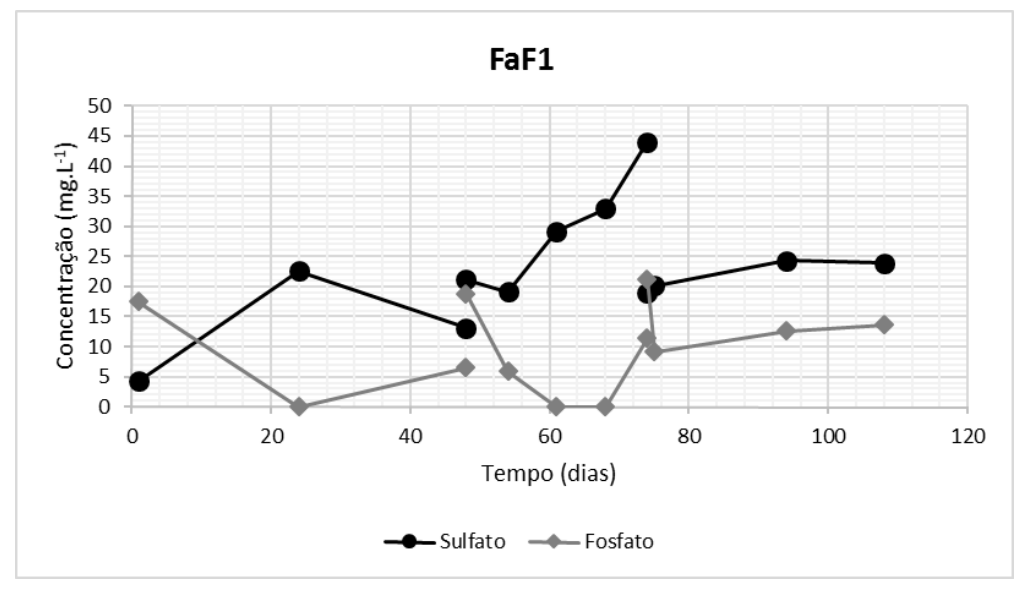

Figura 5.12: Concentrações dos íons sulfato e fosfato nos sistemas biológicos com biomassa proveniente do lodo da lagoa facultativa tratando efluente do frigorífico 1, Araguari, $\mathrm{MG}(\mathrm{FaF} 1)$ durante a etapa 1 visando o enriquecimento de micro-organismos anammox.

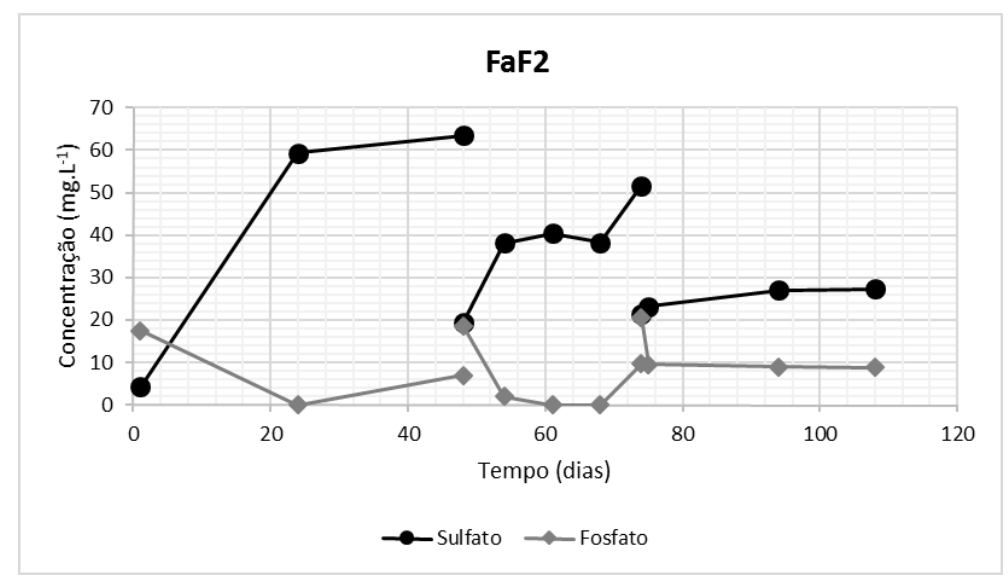

Figura 5.13: Concentrações dos íons sulfato e fosfato nos sistemas biológicos com biomassa proveniente do lodo da lagoa facultativa tratando efluente do frigorífico 2 , Uberlândia, $\mathrm{MG}(\mathrm{FaF} 2)$ durante a etapa 1 visando o enriquecimento de micro-organismos anammox.

Nos sistemas biológicos com biomassa a partir do lodo proveniente do reator UASB tratando efluente do frigorífico 2, Uberlândia/MG (UaF2) foi possível constatar a ocorrência de processos metabólicos conduzidos por bactérias redutoras de sulfato, dado a formação de gases sulfídricos $\left(\mathrm{H}_{2} \mathrm{~S}\right)$ detectados pelos odores quando da operação dos sistemas. As concentrações de sulfato presentes no meio sintético foram significativamente reduzidas pela ocorrência desse processo metabólico redutor de sulfato (Figura 5.14). 


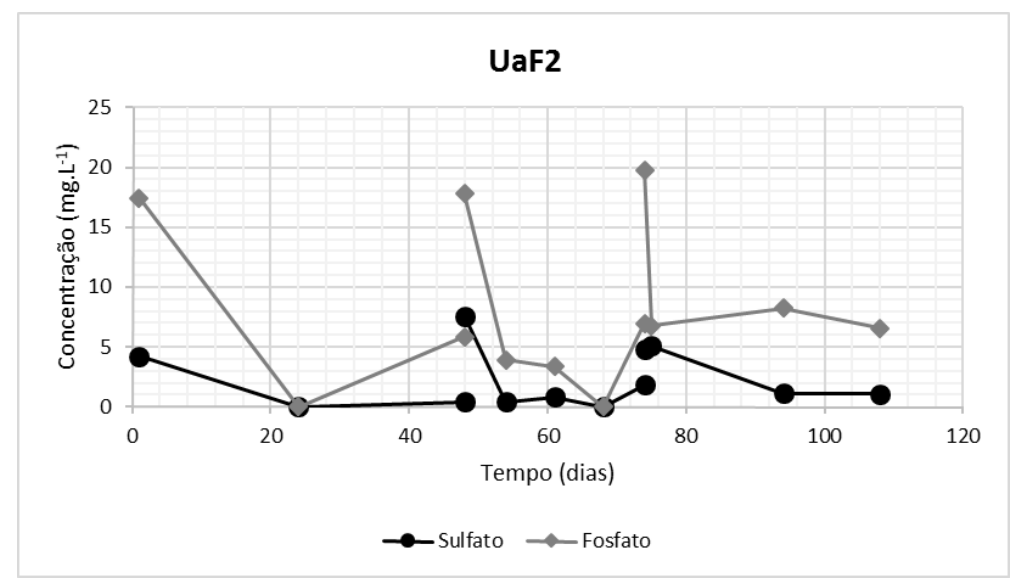

Figura 5.14: Concentrações dos íons sulfato e fosfato nos sistemas biológicos com biomassa proveniente do reator UASB tratanto efluente do frigorífico 2, Uberlândia, MG

(UaF2) durante a etapa 1 visando o enriquecimento de micro-organismos anammox.

De acordo com Fdz-Polanco et al. (2001), as bactérias redutoras de sulfato, em condições anaeróbias, usam esse ânion como aceptor final de elétrons para degradação de compostos orgânicos e hidrogênio com formação de sulfetos dissolvidos no licor e ou liberação de gases sulfídricos. Foi demonstrado, experimentalmente, que sulfato em condições anaeróbias, juntamente com o nitrito, nitrato e propionato, pode ser um oxidante adequado para conversão anaeróbia da amônia conduzida por micro-organismos como as bactérias do grupo Planctomycetales, sendo sugerido como responsável "Candidatus Anammoxoglobus sulfate" (Liu et al., 2008). A conversão anaeróbia da amônia tendo o sulfato como aceptor de elétrons ocorre com formação do intermediário nitrito e assim, os substratos amônia e nitrito estão disponíveis para a oxidação da amônia a nitrogênio gasoso (Li et al., 2008). Esse processo de remoção anaeróbia da amônia tendo o sulfato como aceptor final de elétrons havia sido previsto por Fdz-Polanco et al. (2001).

Ocorreram reduções nas concentrações de fostato do licor misto, tendo sido pronunciadas as reduções nas bateladas conduzidas até 70 dias, sem detecção de fosfato dissolvido no licor misto dos sistemas biológicos (UaF2). Após esse período inicial, registra-se a redução das concentrações próximas a $20 \mathrm{mg} . \mathrm{L}^{-1}$ para $7,5 \mathrm{mg} . \mathrm{L}^{-1}$ permanecendo-se constante nessa faixa.

Os sistemas biológicos inoculados com sedimento proveniente da lagoa de acumulação de chorume do aterro Jockey Clube de Brasília, DF (Cho) também se diferenciaram dos demais sistemas devido à maior produção de sulfato durante as bateladas que ocorreram entre os dias 45 e 65, tendo atingindo concentrações 24 vezes maiores do que as inseridas nos 
sistemas quando da substituição da água residuária sintética, tendo continuado a produção nas bateladas seguintes até os 120 dias de monitoramento, relativos à fase inicial de enriquecimento da biomassa para atividade anammox. Nesses sistemas biológicos, o consumo total de fósforo também foi observado, mesmo para períodos maiores do que os primeiros 80 dias (Figura 5.15).

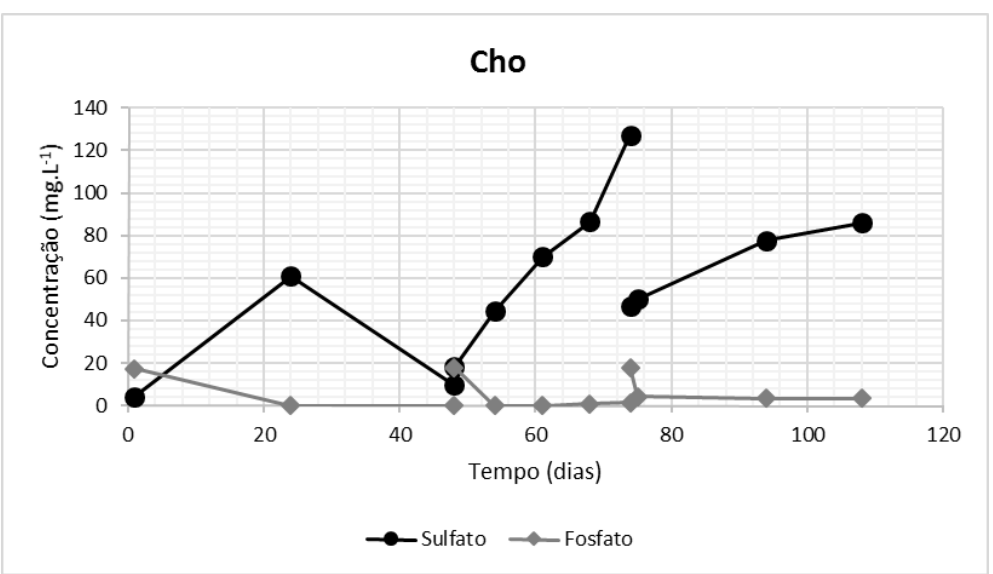

Figura 5.15: Concentração dos íons sulfato e fosfato nos sistemas biológicos com biomassa proveniente da lagoa de acumulação de chorume do aterro controlado Jockey Clube de Brasília, DF (Cho) durante a etapa 1 visando o enriquecimento de micro-organismos anammox.

Registra-se que nos demais sistemas biológicos como Par, AnF1, FaF1 e FaF2 as concentrações de fosfato, após o período de 80 dias do início dos experimentos, permaneceram relativamente constantes, em torno de $10 \mathrm{mg} . \mathrm{L}^{-1}$.

Outras substâncias iônicas presentes no meio podem também interferir para o sucesso da biomassa presente. A sedimentação do lodo em sistemas de tratamento pode ser favorecida quando a água residuária tratada apresenta concentrações elevadas de cloreto de sódio, como demonstrado por Férnandez et al. (2008). Dessa maneira, devido às características da água residuária sintética utilizada nos sistemas biológicos testados, as concentrações de cloreto de sódio foram sempre maiores do que $200 \mathrm{mg} . \mathrm{L}^{-1}$, o que pode ter ajudado a garantir a manutenção da biomassa anammox nos sistemas. 
5.3.1.4 - Caracterização da biomassa nos sistemas biológicos após 120 dias

Avaliou-se a biomassa dos sistemas biológicos, por PCR convencional e quantitativa, utilizando primers específicos ao grupo Planctomycetales e aos nitrificantes aeróbios, após um período de 120 dias do início dos experimentos, tendo os sistemas sido operados conforme as condições estabelecidas para a $1^{\mathrm{a}}$ etapa. A amplificação positiva de fragmentos de DNA de tamanhos esperados sugere a presença dos micro-organismos de interesse e, assim, a inferência dos processos metabólicos predominantes nos sistemas biológicos testados.

Após extração do DNA da biomassa, realizou-se eletroforese em gel de agarose $1 \%$ corado com brometo de etídeo $\left(1 \mu \mathrm{g} \cdot \mathrm{mL}^{-1}\right)$ e estimou a concentração total do DNA genômico usando-se o marcador molecular High Mass Ladder (Invitrogen, USA), obtendo-se um volume final de $100 \mu \mathrm{L}$ em concentrações entre $5 \eta g \mathrm{~L}^{-1}$ a $35 \eta \mathrm{g} \mu \mathrm{L}^{-1}$ (Apêndice III - CD).

Nas análises por PCR usando os mesmos primers para os genes que codificam o RNAr 16S de bactérias anammox e as mesmas condições anteriormente testadas para os inóculos, foi possível observar amplificações positivas para fragmentos de aproximadamente 774 pb nos sistemas biológicos, à exceção dos sistemas UaF2 (Tabela 5.7) (Apêndice III - CD).

Para os primers Pla 46F e Amx 820R, os sistemas com lodos provenientes do sedimento do lago Paranoá (Par) e da lagoa facultativa do frigorífico 2 (FaF2) resultaram em melhores respostas de amplificação antes e depois do período destinado para enriquecimento (Tabela 5.7). Ocorreu amplificação positiva usando esse conjunto de primers para a biomassa dos sistemas biológicos com sedimento da lagoa de acumulação de chorume de Brasília, DF (Cho), indicando que a falta de amplificação no início do experimento pode ser devida às concentrações iniciais e limite de detecção da técnica de análise, bem como a mudança de dominância das espécies presentes. A ausência de resultados positivos nas amplificações para os sistemas biológicos com lodo do reator do UASB do frigorífico 2, Uberlândia, MG (UaF2), após o período destinado ao enriquecimento, pode indicar a exclusão de algumas espécies candidatas anammox do sistema. Pode-se também supor que o conjunto de primers utilizados (Pla 46F e Amx 820R), desenhados para amplificações de fragmentos de genes que codificam o RNAr 16S para organismos relacionados à "Candidatus Brocadia" e "Ca. Kuenenia", não foi satisfatório para amplificação de outras bactérias presentes pertencentes ao grupo de anammox. 
Tabela 5.7: Resultados de amplificações por PCR usando par de primers Pla 46F e Amx 820R, nos diferentes lodos antes e após o período para enriquecimento anammox.

\begin{tabular}{lcc}
\hline \hline Sistema & Inóculo & Após 120 dias \\
\hline Par & + & + \\
AnF1 & $+/-$ & $+/$ \\
FaF1 & $+/-$ & + \\
FaF2 & + & + \\
UaF2 & $+/-$ & - \\
Cho & - & $+/-$ \\
\hline \hline
\end{tabular}

(+) Resultados positivos para os produtos amplificados na PCR visualizados no gel de agarose $1 \%$; $(+/-)$ Resultados positivos com fragmentos amplificados visualizados sem nitidez no gel de agarose. Sistemas: Par: sedimento do lago Paranoá, Brasília/DF; AnF1: lodo de lagoa anaeróbia tratando do Frigorífico 1, Araguari/MG; FaF1: lodo da lagoa facultativa tratando efluente do Frigorífico 1, Araguari/MG; FaF2: lodo da lagoa facultativa do Frigorífico 2, Uberlândia/MG; UaF2: lodo de reator UASB tratando de efluente do Frigorífico 2, Uberlândia/MG; Cho: sedimento de lagoa de acumulação de chorume do aterro controlado Jockey Club/DF. Apêndices I e III

Da mesma maneira, utilizando-se da análise de PCR, foi levantada a possibilidade da presença de micro-organismos nitrificantes aeróbios pois representam potenciais parceiros e/ou competidores das bactérias anammox, visto que utilizam os substratos amônia e nitrito. O primeiro grupo analisado foi das bactérias aeróbias oxidadoras de amônia, representadas por bactérias como Nitrosomonas, por meio da utilização do par de primers amoA direto e reverso (Egli, 2003). As ocorrências de fragmentos de aproximadamente $650 \mathrm{pb}$ esperados para essa amplificação foram apenas para os sistemas biológicos com inóculo proveniente da lagoa de acumulação de chorume do aterro controlado Jóckey Clube de Brasília, DF (Cho A e B), tendo ocorrido também a formação de fragmentos não específicos para os demais sistemas (Apêndice III - CD).

O segundo grupo analisado foi das bactérias aeróbias oxidadoras de nitrito, representadas por bactérias como Nitrobacter, por meio da utilização dos primers Nitro 1198 direto e Nitro 1423 reverso (Graham et al., 2007), formando fragmentos de aproximadamente $225 \mathrm{pb}$ em todos os sistemas biológicos testados. Ainda que as condições estabelecidas nos sistemas não devessem favorecer esse grupo de bactérias, supõe-se que elas mantiveram ao longo do período para enriquecimento anammox e provavelmente atuaram como competidoras pelo substrato nitrito com as bactérias anammox (Apêndice III - CD).

A avaliação dos resultados da PCR quantitativa permitiu indicar a representatividade de cada um dos três grupos de micro-organismos: os anammox, os nitrificantes aeróbios de amônia (como Nitrosomonas) e os nitrificantes aeróbios de nitrito (como Nitrobacter) no total do 
DNA genômico extraído a partir da biomassa de cada um dos sistemas biológicos A concentração de cópias de DNA do fragmento amplificado usando os primers específicos, no momento que se tem o valor de $\mathrm{Cq}$, foi o parâmetro de medida utilizado para comparações das comunidades biológicas dos sistemas. Esse parâmetro é construído pela estimativa comparada e relativa das concentrações de DNA de cada amostra a uma curva referência (Bustin et al., 2009). Os resultados foram apresentados como concentração de cópias em

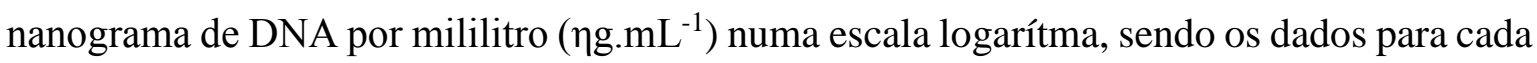
grupo de micro-organismo colocados empilhados e após a diminuição das proporções de densidades de cópias de DNA dos envolvidos no ciclo do nitrogênio do total calculado para o Domínio Bacteria.

Os micro-organismos como Nitrobacter destacam-se nas amostras de DNA genômico de todos os sistemas ambientais (Figura 5.16). Quando da inoculação nos sistemas biológicos, na avaliação da densidade do número de cópias, os micro-organismos anammox e os nitratantes aeróbios como Nitrobacter apresentavam-se em densidades próximas para os sistemas Par, AnF1, FaF1 e FaF2 (Figura 5.16). A densidade do número de cópias obtida com o uso do primer universal, para amplificação de fragmentos de genes para o RNAr 16S do Domínio Bacteria, resultou em aumento significativo na densidade total para os sistemas Par, AnF1, FaF1 quando comparadas à biomassa dos inóculos (Figura 5.16).

Os inóculos utilizados para compor os sistemas biológicos divergiram em concentrações de cópias de DNA para o Domínio Bacteria, sendo que as maiores concentrações de cópias registradas foram em ordem crescente para os inóculos provenientes da lagoa de acumulação de chorume do aterro JK, Brasília, DF (Cho) e dos provenientes do reator UASB tratando efluente do Frigorífico 2, Uberlândia, MG (UaF2) (Figura 5.16). Os demais inóculos utilizados nos sistemas biológicos apresentaram concentrações de cópias de DNA de 1 a 2 ordens de grandeza menor do que os inóculos Cho e UaF2. Sendo, em sequência, aqueles com maior concentração de cópias: lodo de lagoa facultativa tratando efluente do frigorífico 2, Uberlândia, $\mathrm{MG}(\mathrm{FaF} 2)$; lodos provenientes da lagoa facultativa ( $\mathrm{FaF} 1)$ e lagoa anaeróbia (AnF1) tratando efluente do frigorífico 1, Araguari e MG sedimento do lago Paranoá, Brasília, DF (Pa) (Figura 5.16). 


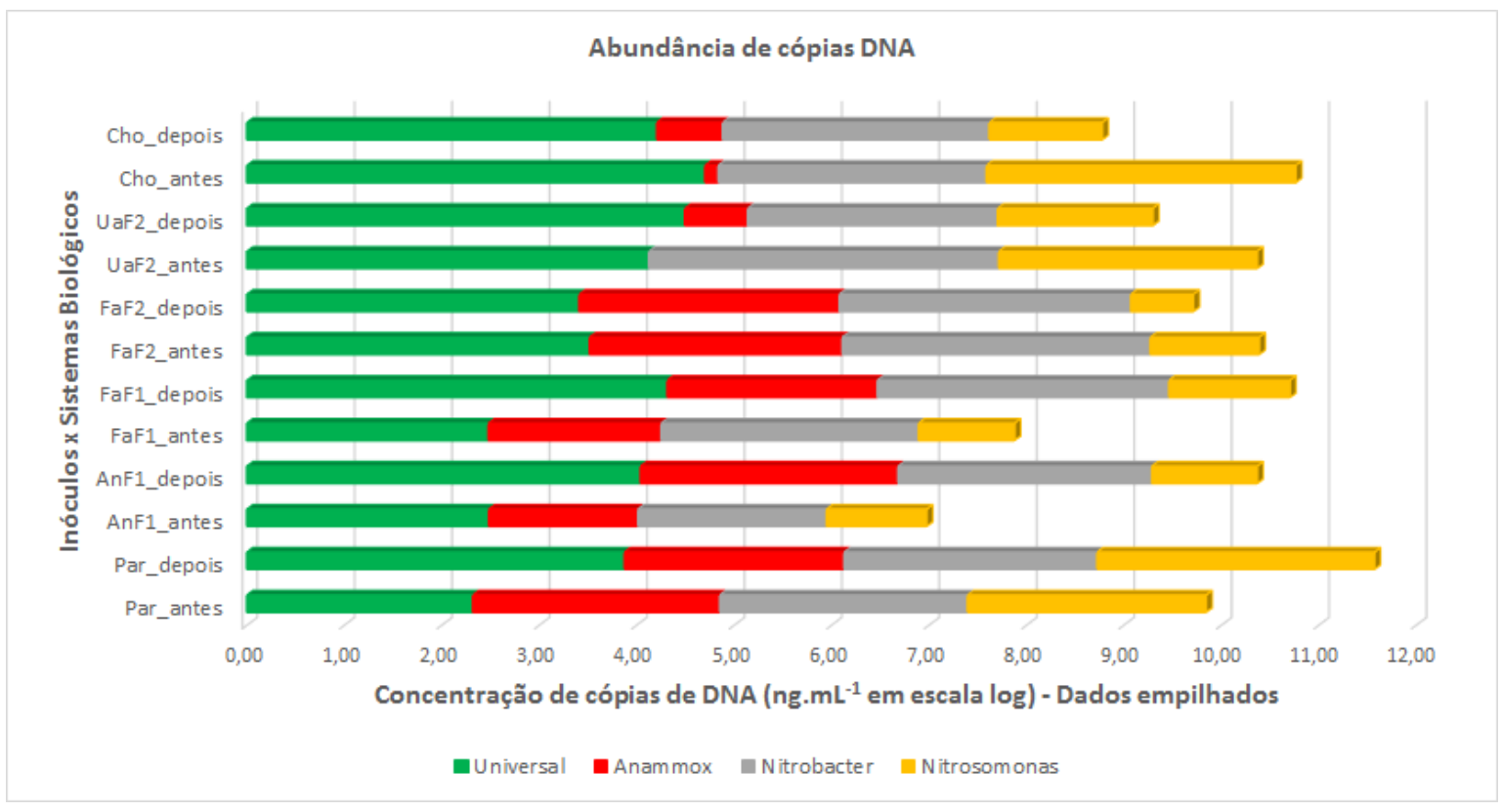

Figura 5.16: Abundância de cópias dos genes de micro-organismos de interesse, usando quatro pares de primers, para levantamento do número de cópias de DNA de organismos relacionados ao Domínio Bacteria, bactérias anammox, oxidadoras aeróbias de nitrito e amônia, dados em escala logarítmica e empilhados. Par: sedimento do lago Paranoá, Brasília/DF;

AnF1: lodo da lagoa anaeróbia tratando efluente do Frigorífico 1, Araguari/MG; FaF1: lodo da lagoa facultativa tratando efluente do Frigorífico 1, Araguari/MG; FaF2: lodo de lagoa facultativa tratando efluente do Frigorífico 2, Uberlândia, MG; UaF2: lodo de reator UASB tratando efluente do Frigorífico 2, Uberlândia/MG; CHOR: sedimento da lagoa de acumulação de chorume do aterro controlado Jockey Clube, Brasília, DF.

Observa-se que os inóculos provenientes do sedimento lago Paranoá, Brasília, DF (Pa) e dos lodos provenientes de lagoas facultativas tratando efluente de frigoríficos (FaF1 e FaF2), apresentaram uma distribuição mais equitativa entre os grupos de bactérias relacionadas ao ciclo do nitrogênio, podendo resultar em melhor equilíbrio competitivo entre as bactérias para consumo dos íons nitrogenados presentes (Figura 5.16).

Constata-se que a abundância do número de cópias das bactérias analisada pelo uso dos primers universais para o gene RNAr 16S do Domínio Bacteria aumentou em ordem de 1 a 2 grandezas para os sistemas biológicos provenientes do sedimento do Lago Paranoá (Par), do lodo da lagoa anaeróbia e facultativa do Frigorífico 1 (AnF1, FaF1). Nos demais sistemas, a abundância do número de cópias permaneceu constante, na mesma unidade de grandeza (Figuras 5.16). As condições estabelecidas para operação dos sistemas biológicos, em modo de culturas em bateladas ajustadas para o enriquecimento de organismos anammox, determinaram os micro-organismos que permaneceram nos sistemas. As condições definiram variações na abundância de cada um dos grupos de micro-organismos em 
decorrência da eficiência competitiva em situações de limitação dos substratos, especialmente de fonte externa de carbono orgânico e nitrito, necessários ao metabolismo das bactérias.

A partir da análise dos resultados obtidos pela PCRq, para a primeira etapa experimental (120 dias), observou-se aumento nas concentrações de cópias de DNA para os microorganismos anammox nos AnF1A e FaF1, bem como nos sistemas UaF2 e Cho (Figura 5.17). Depreende-se que processos metabólicos como os de desnitrificação heterotrófica, oxidação de sulfetos, redução de sulfatos e nitrificação, bem como o tempo necessário para aclimatação dos micro-organismos podem ter contribuído para o relativo aumento nas concentrações de cópias das bactérias anammox, visto que, o consumo de substratos e formação de substâncias inibidoras limitam o seu desenvolvimento.

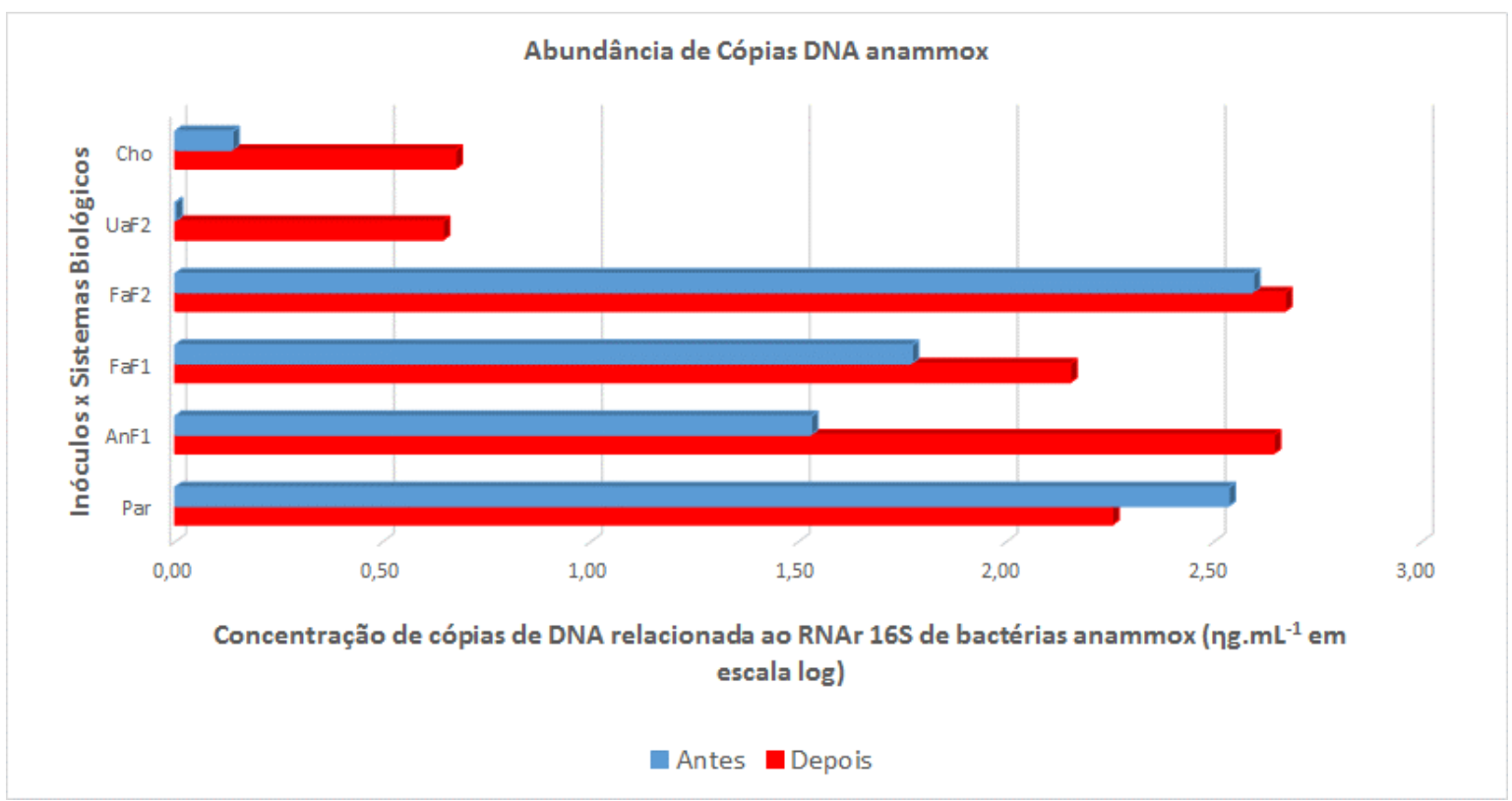

Figura 5.17: Concentrações de cópias de DNA relacionadas ao RNAr 16S de bactérias anammox nos sistemas biológicos antes e após o período de 120 dias com condições ajustadas para o desenvolvimento de micro-organismos anammox.

Outra possível explicação para a concentração do número de cópias de fragmentos dos genes relacionados ao RNAr 16S para bactérias anammox terem permanecidas relativamente constantes é a substituição de dominância da espécie anammox originalmente presentes nos inóculos por outra espécie candidata dadas as condições estabelecidas para os sistemas e, 
também, devido a interações competitivas e cooperativas com outros grupos de bactérias, constatação também feita por Hu et al. (2010). Park et al. (2010) registraram a substituição de dominância de espécie, após o período de enriquecimento, daquelas bactérias originalmente presentes nos inóculos.

Em observações prévias em comunidades de biorreatores notaram a mudança na dominância de "Ca. Kuenenia" para “ $C a$. Scalindua" depois de 360 dias para o enriquecimento em meio com altas concentrações de sais (Kartal et al., 2006). Em sistemas com variações nas concentrações de nitrito ocorreram mudanças nas comunidades biológicas, inicialmente com dominância de " $\mathrm{Ca}$. Brocadia" para " $\mathrm{Ca}$. Kuenenia" devido às diferenças na afinidade por $\mathrm{NO}_{2}^{-}$(van der Star et al., 2008). Da mesma forma, Nakajima et al. (2008) registraram modificações de dominância de comunidade de biorreatores, tendo-se "Ca. Scalindua" substituída por "Ca. Brocadia” e "Ca. Kuenenia”.

As análises das sequências do DNA dos fragmentos obtidos utilizando-se os pares de primers Pla46F e Amx820R indicam que as espécies de bactérias anammox presentes na biomassa antes e após o período destinado ao enriquecimento diferiram significativamente (Figura $5.18)$.

Há uma divergência menor do que $2 \%$ entre as sequências de DNA relacionadas ao RNAr $16 \mathrm{~S}$ para o grupo anammox comparando-se as biomassas dos diferentes inóculos mesmo sendo estes de origens bastante distintas. As condições ambientais nos habitats de onde foram coletados os inóculos, tais como baixas concentrações de oxigênio dissolvido, temperatura mesofílicas, $\mathrm{pH}$ próximos a 7 , sugerem que interações entre os membros das comunidades microbiológicas não sejam significativamente diferentes (Figura 5.18). Além do mais, os fragmentos de DNA amplificados e sequenciados a partir dos primers Pla46F e Amx820R podem ser resultado da espécie dominante nos sistemas. Divergências menores que $2 \%$ podem indicar espécies dentro do mesmo gênero (Rosselló-Mora e Amann, 2001; Kartal et al., 2007).

A partir da análise do dendrograma constata-se que as sequências de nucleotídeos dos fragmentos de DNA para as bactérias anammox presentes originalmente nos inóculos divergiram em quase $10 \%$ em posições dos nucleotídeos quando comparadas com as sequências obtidas a partir dos DNAs para as bactérias anammox nas biomassas dos sistemas biológicos, após 120 dias de operação, com condições ajustadas para o enriquecimento do 
grupo anammox (Figura 5.18). De acordo com Kartal et al. (2007) ocorrem grandes diferenças nas distâncias filogenéticas entre distintas espécies membros dos Planctomycetales. Dessa maneira, os resultados obtidos até essa etapa experimental sugerem a substituição das populações de bactérias anammox, estabelecidas as condições operacionais dos sistemas biológicos que foram diferentes das condições ambientais dos habitats de onde os inóculos foram coletados. Dessa forma, pressupõe-se que concentrações de cópias de DNA, relacionadas ao RNAr 16S para o grupo anammox, permaneceram relativamente constantes devido à essa substituição de espécies anammox. São necessários períodos longos de tempo, sob dadas condições, para que ocorra o estabelecimento das populações em abundância para sobreporem-se nas comunidades biológicas e, assim apresentarem vantagens competitivas sobre espécies de micro-organismos concorrentes por substratos.

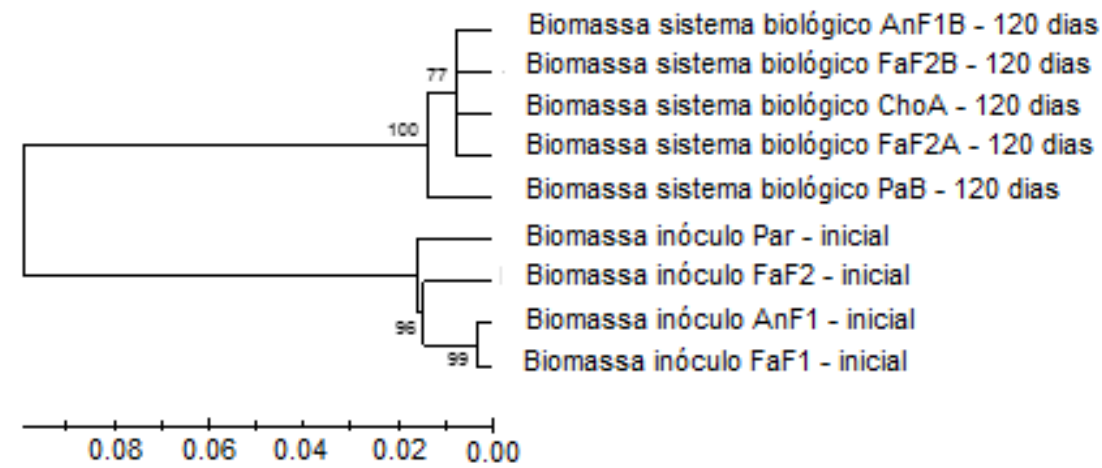

Figura 5.18: Dendrograma comparativo da similaridade filogenética das biomassas obtidas a partir dos inóculos e dos sistemas biológicos após 120 dias em condições ajustadas para ocorrência do enriquecimento dos micro-organismos anammox. O dendrograma foi gerado usando fragmentos de $720 \mathrm{pb}$ do gene RNAr 16S, usando os primers Pla46F e Amx820R. Os valores presentes nos nós da árvore indicam a porcentagem de vezes que os ramos se repetiram em 1000 análises de re-amostragens (Bootstrap). A barra de escala representa a diferença estimada nas posições dos nucleotídeos entre as sequências (Apêndice IV - CD).

Independentemente da origem dos inóculos, ocorreu uma convergência das candidatas espécies anammox entre os sistemas biológicos, sugerindo que a pressão seletiva imposta pelas condições operacionais estabelecidas foi determinante para a prevalência de dada candidata (Figura 5.18). As sequências obtidas para os sistemas biológicos com biomassas provenientes das lagoas facultativas tratando efluentes dos frigoríficos 1 e $2(\mathrm{FaF} 1)$ e $(\mathrm{FaF} 2)$, 
da lagoa anaeróbia tratando efluente do frigorífico 1 (AnF1) e da lagoa de acumulação de chorume do aterro JK (Cho) apresentaram similaridades maiores do que $99 \%$ e as sequências obtidas a partir do DNA da biomassa dos sistemas biológicos proveniente do sedimento do lago Paranoá, Brasília, DF (Pa) diferiram apenas em 0,5\% destas sequências obtidas nos sistemas FaF1, FaF2, AnF1 e Cho (Figura 5.18).

A avaliação da abundância de cópias de DNA, relacionada ao RNAr 16S, para os microorganismos como Nitrobacter foi realizada porque esse grupo é um importante competidor pelo substrato nitrito (Figura 5.19). As concentrações de cópias de DNA para os organismos como Nitrobacter reduziram nos sistemas biológicos com biomassa do reator UASB tratando efluente do frigorífico 2, Uberlândia, MG (UaF2) após o período de 120 dias (Figura 5.19). No sistema biológico UaF2 as concentrações de carbono orgânico, originalmente presentes no inóculo, favoreceram grupos de micro-organismos heterotróficos, visto que, todo o nitrito e nitrato inicialmente inseridos nos sistemas foram rapidamente consumidos. Dessa maneira, a limitação de substrato nitrito aliada às concentrações baixas de oxigênio dissolvido podem ter determinado as reduções nas concentrações de cópias de DNA para Nitrobacter (Figura 5.19). Deve-se analisar a utilização de determinadas fontes de carbono orgânico para partidas de sistemas visando atividade anammox pois apresenta-se como estratégia na redução das concentrações das bactérias como Nitrobacter dos sistemas.

Diferentemente, os sistemas biológicos montados com biomassa proveniente do sistema de tratamento de efluentes do frigorífico 1, Araguari, MG (AnF1 e FaF1) resultaram num aumento das concentrações de cópias de DNA relacionadas aos micro-organismos como Nitrobacter (Figura 5.19). Esse acréscimo significa uma maior população de microorganismos nitratantes aeróbios competindo pelo substrato nitrito e, tornando-o limitante nos sistemas para a atividade anammox. 


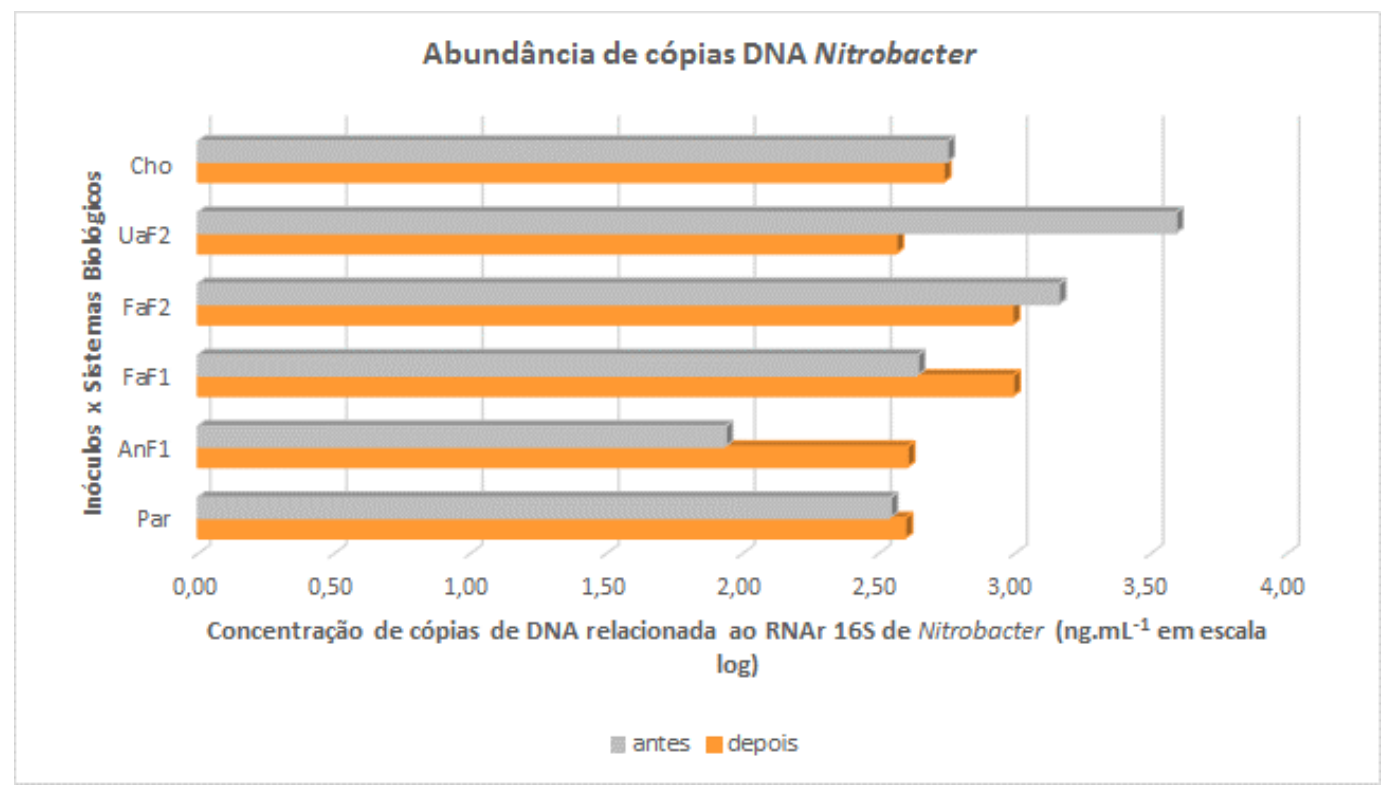

Figura 5.19: Concentrações de cópias de DNA relacionadas ao RNAr 16S de bactérias como Nitrobacter nos sistemas biológicos antes e após o período de 120 dias com condições ajustadas para o desenvolvimento de micro-organismos anammox.

5.3.1.5 - Afiliações filogenéticas por comparações às sequências anammox depositadas no GenBank

Foram realizadas afiliações filogenéticas entre as sequências de DNA obtidas da biomassa dos inóculos provenientes do sedimento do lago Paranoá, Brasília, DF (Par), dos lodos das lagoas anaeróbia e facultativas tratando efluente de Frigorífico 1 e 2 (AnF1, FaF1 e FaF2) e da biomassa dos sistemas biológicos Par (sedimento lago Paranoá); AnF1 (lodo da lagoa anaeróbia), FaF2 (lodo da lagoa facultativa) e Cho (lagoa acumulação de chorume), após 120 dias do início das bateladas com sequências das candidatas a espécies anammox depositadas no GenBank. Comparou-se, também, com grupos externos tais como aqueles representantes da Ordem Planctomycetales que não possuem habilidade metabólica de oxidar a amônia usando o nitrito como aceptor de elétrons e com uma espécie pertencente ao Filo Verrucomicrobia (Figura 5.20).

Os fragmentos utilizados para o sequenciamento e posteriores comparações filogenéticas foram obtidos pela amplificação dos genes relacionados ao RNAr 16S usando-se os primers Pla46F (Neef et al., 1998) e Amx 820R (Schmid et al., 2000). As sequências utilizadas nas comparações foram somente as decorrentes dos inóculos e/ou sistemas biológicos que 
resultaram em sequências com boa qualidade avaliadas pelo Sequence Scanner (Applied Biosystems, USA), visto que, como não foi realizada clonagem, buscou-se pela qualidade resultante do sequenciamento (Apêndice IV - CD).

As sequências resultantes dos fragmentos de DNA amplificados da biomassa dos inóculos e dos sistemas biológicos após 120 dias diferiram em aproximadamente 12,5\% formando dois ramos filogeneticamente diferentes (Figura 5.20), sugerindo a substituição da espécie antes dominante no inóculo para outra espécie com o estabelecimento das condições operacionais dos sistemas. Da mesma maneira, esses dois clusters diferiram do cluster associado ao grupo das bactérias candidatas anammox, ou seja, apresentando apenas 87,5\% de similaridades entre as sequências de nucleotídeos comparados.

As diferenças registradas entre as sequências das candidatas a espécies anammox também são consideráveis. Diferenças em torno de 5\% resultam em vários clusters e, assim separados em diferentes gêneros anammox (Figura 5.20). Diferenças filogenéticas acentuadas têm sido consideradas como ocorrentes entre os membros pertencentes aos Planctomycetales (Kartal et al., 2007; Bae et al., 2010). De acordo com Rosselló-Mora e Amann (2001), a análise de sequências dos genes que codificam o RNAr $16 \mathrm{~S}$ é útil para quando se pretende definir ordens de agrupamentos superiores à espécie, apresentando que sequências com similaridade acima de $95 \%$ podem ser definidas dentro do mesmo gênero.

Constata-se dois ramos dentro das candidatas anammox que se diferenciaram em mais de 8\% separando os "Candidatus Kuenenia e Scalindua" de "Ca. Brocadia, Jettenia e Anammoxoglobus" (Figura 5.20). Dessa maneira, tendo as distâncias filogenéticas obtidas por comparações dos genes para o RNAr 16S como critério para agrupamento conforme discutido por Rosselló-Mora e Amann (2001), sugere-se que as sequências obtidas nesse estudo apresentam similaridade suficiente $(88,5 \%)$ com as sequências das candidatas anammox e, por isso foram consideradas como possíveis membros da Ordem dos microorganismos capazes de oxidar a amônia sob condições anóxicas. Bae et al. (2010), reuniram 26 clones como um cluster de supostas anammox, visto que apresentaram em média 79,5\% de similaridade com " $\mathrm{Ca}$. Jettenia asiatica", " $\mathrm{Ca}$. Brocadia fulgida", " $\mathrm{Ca}$. Brocadia anammoxidans", “ $\mathrm{Ca}$. Kuenenia stuttgartiensis", “ $\mathrm{Ca}$. Anammoxoglobus propionicus” e "Ca. Scalindua brodae". 


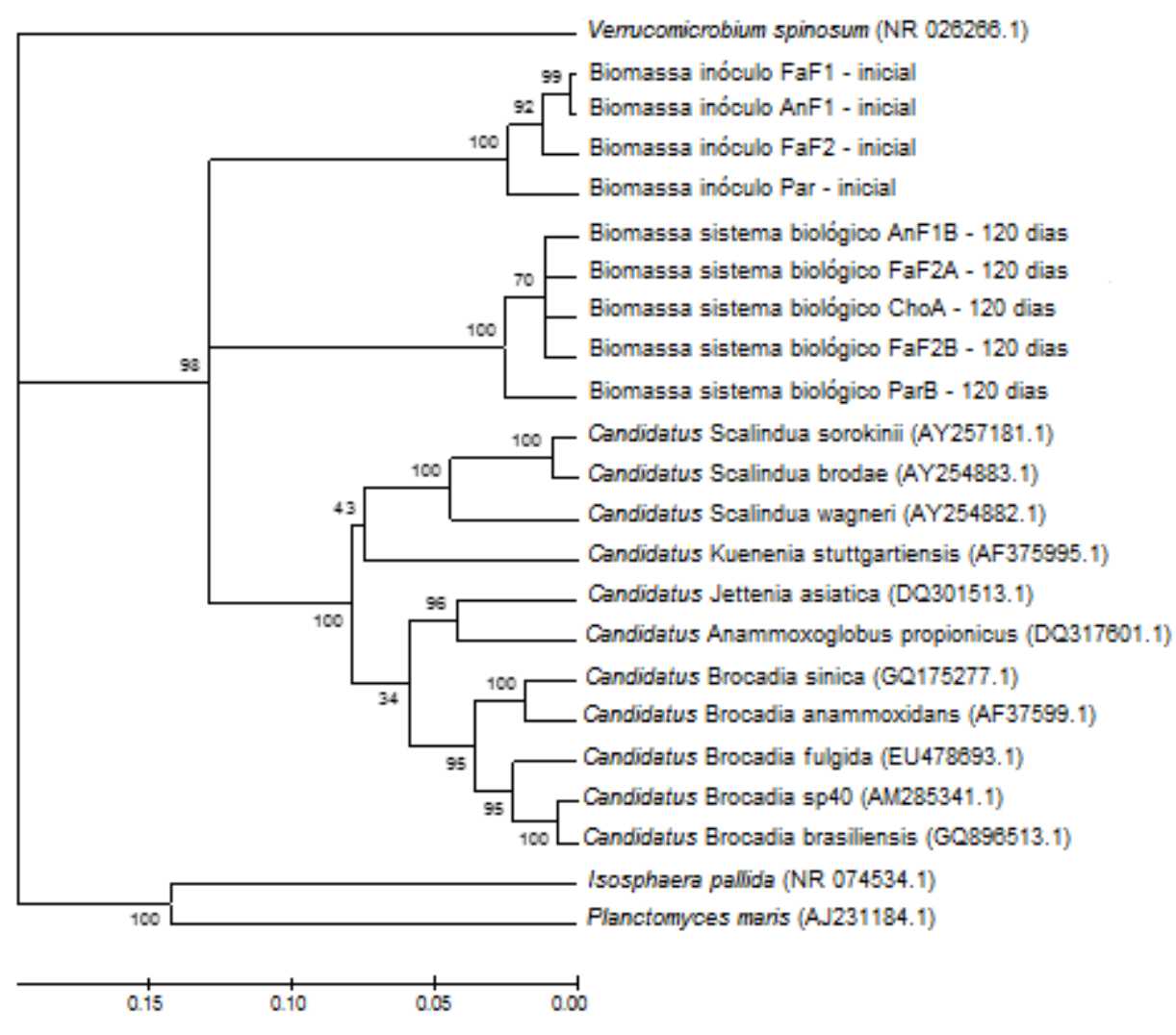

Figura 5.20: Dendrograma mostrando a afiliação filogenética das sequências obtidas a partir da biomassa dos inóculos e dos sistemas biológicos após 120 dias com sequências depositadas no GenBank a partir dos códigos para as candidatas a espécies anammox. O dendrograma foi gerado usando fragmento de $720 \mathrm{pb}$ do gene RNAr 16S, usando os iniciadores Pla46F e Amx820R. Os valores presentes nos nós da árvore indicam a \% de vezes que os ramos se repetiram em 1000 análises de re-amostragens. A barra de escala representa a diferença estimada nas posições dos nucleotídeos entre as sequências.

Foi proposto classificar as bactérias anammox, capazes de oxidar a amônia usando o nitrito como aceptor de elétrons, na Ordem Candidatus Brocadiales separando-as daquelas bactérias sem habilidade anammox pertencentes à Ordem Planctomycetales (Schmid et al., 2001; Kuypers et al., 2003; Schmid et al., 2003; Woebken et al, 2008; Quan et al., 2008; Kartal et al., 2007; Hu et al., 2010; Araújo et al., 2011).

Quando comparadas as sequências com aquelas das espécies pertencentes a ordem Planctomycetales, tais como Isosphaera pallida e Planctomyces maris, tanto as sequências obtidas nesse estudo quanto aquelas relacionadas às espécies candidatas ao grupo anammox tiveram, igualmente, uma similaridade de apenas 80\% (Figura 5.20). Assim, sugere-se que os clusters formados pelas sequências desse estudo estão mais relacionados ao cluster do 
grupo das candidatas às espécies anammox do que das espécies sem a habilidade metabólica de oxidar anaerobicamente a amônia, pertencentes à ordem Planctomycetales.

Foi realizada uma avaliação das afiliações filogenéticas comparando-se cada sequência desse estudo com sequências depositadas no GenBank que tiveram similaridades elevadas (Max. Ident. e Query Coverage acima de $95 \%$ ) calculadas pela ferramenta BLAST. Dessa maneira, selecionou-se um conjunto de 13 sequências que foram originadas de estudos em vários países (Sànchez-Melsió et al., 2009; Kalyuzhnyi et al., 2010; Park et al., 2010; e outras ainda não publicadas em artigos). Utilizou-se a sequência de Candidatus Brocadia brasilensis (GQ896513.1) como referência no Brasil, dado que foi obtida a partir de enriquecimento de biomassa com inóculo proveniente de sistemas de lodos ativados da ETE Arrudas de Belo Horizonte, MG (Campos, 2012).

Ocorreu a formação de 3 clusters separando as sequências em: a) aquelas geradas a partir de DNA de amostras de sistemas ambientais sob condições sub-óxicas; b) a pertencente à sequência de "Candidatus Brocadia brasilensis" e c) aquelas geradas a partir de DNA de amostras de sistemas de tratamento de efluentes e/ou de sistemas biológicos ajustados para atividade e/ou enriquecimento anammox (Figura 5.21).

Os clusters formados pelas sequências obtidas a partir do DNA da biomassa dos inóculos antes de serem inseridos nos sistemas apresentaram maior similaridade com a sequência referência "Candidatus Brocadia brasilensis" (88\%) do que com as sequências obtidas a partir do DNA das biomassas dos sistemas biológicos (86\%).

As sequências obtidas a partir do DNA das biomassas antes de serem inseridas nos sistemas biológicos apresentaram similaridades elevadas (maiores que 97\%) com sequências relacionadas às biomassas de sistemas ambientais em condições sub-óxicas, permitindo inferir que bactérias proximamente relacionadas se estabelecem nesses tipos de ecossistemas (Figura 5.21). A salinidade é o fator determinante para o padrão de distribuição global de bactérias anammox, tendo sido registrado espécies similares quando as condições ambientais são semelhantes (Sonthiphand et al., 2014).

Da mesma maneira, as sequências obtidas de fragmentos de DNA da biomassa dos sistemas biológicos, após 120 dias do início da operação ajustadas as condições para enriquecimento anammox, apresentaram similaridades elevadas (maiores que 99\%) com sequências de sistemas de tratamento pelo processo anammox (Figura 5.21). Todas as sequências, 
depositadas no GenBank e utilizadas para comparações, foram reconhecidas como biomassas com atividade anammox e, portanto, como sequência de possíveis candidatas anammox (Sànchez-Melsió et al., 2009; Kalyuzhnyi et al., 2010; Park et al., 2010, Sonthiphand et al., 2014). Conforme conclusão apresentada por Sonthiphand et al. (2014) ocorre uma partição de habitats entre as candidatas espécies anammox, separando as comunidades anammox em ecossistemas naturais daquelas em ambientes antropizados como as ETEs.

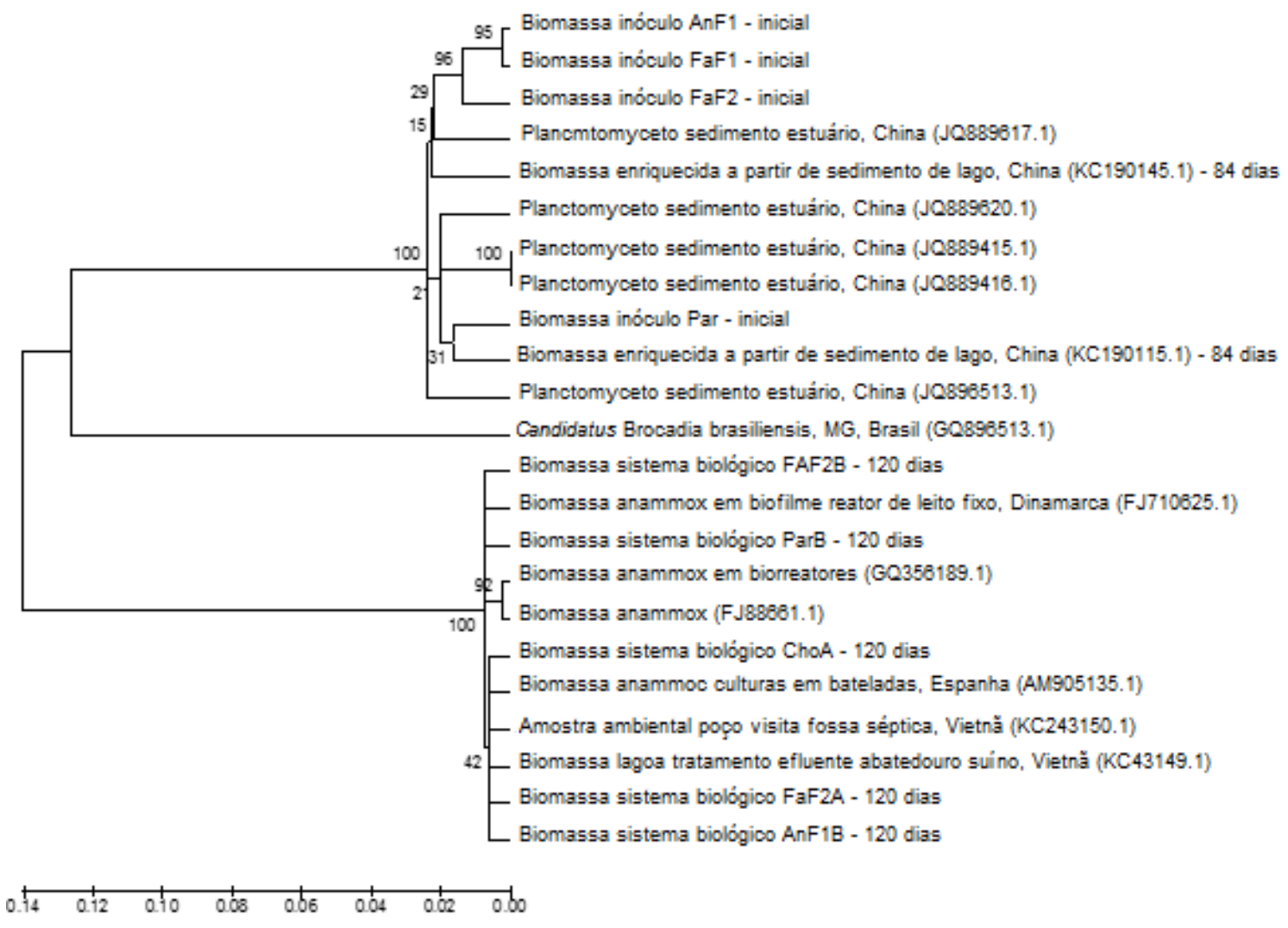

Figura 5.21: Dendrograma mostrando a afiliação filogenética das sequências obtidas a partir da biomassa dos inóculos e dos sistemas biológicos após 120 dias com sequências depositadas no GenBank a com similaridades elevadas dada por comparações usando BLAST. O dendrograma foi gerado usando fragmento de $720 \mathrm{pb}$ do gene RNAr 16S relacionado ao grupo anammox. Os valores presentes nos nós da arvore indicam a porcentagem de vezes que os ramos se repetiram em 1000 análises de re-amostragens. A barra de escala representa a diferença estimada nas posições dos nucleotídeos entre as sequências. 
A partir dessas comparações, é possível sugerir que as condições operacionais estabelecidas para desenvolvimento da atividade anammox provocou a mudança de dominância das bactérias anammox daquelas originalmente presentes nos inóculos (Figura 5.21), conforme a partição de habitats entre bactérias anammox proposta por Sonthiphand et al. (2014).

A mudança de dominância das espécies anammox quando estabelecidas as condições para enriquecimento e atividade pode ser a resposta para os elevados tempos de partidas de sistemas que visam a remoção da amônia pelo processo anammox, uma vez que a duplicação da biomassa é lenta devido às baixas taxas de crescimento desses micro-organismos.

Modificações na comunidade anammox, antes e após o período destinado ao enriquecimento, foram relatadas em outros estudos que também discutiram quais as forças seletivas dirigindo essas alterações. Park et al. (2010) acompanharam o estabelecimento da comunidade anammox em dois sistemas de reatores (RBS e reator com meio suporte) inoculados com biomassas diferentes e alimentados com efluente de um digestor anaeróbio de uma ETE em Nova York, EUA, tendo ao final predominado, em ambos sistemas, clones relacionados à “ $C a$. Brocadia sp. 40”. Durante o desenvolvimento experimental avaliou-se que a biomassa originária de um reator anammox, escala plena, na cidade de Strass na Áustria com clones relacionados à “ $C a$. Kuenenia stuttgartiensis”, modificou-se para clones relacionados à " $\mathrm{Ca}$. Brocadia fulgida" quando em reator anammox, escala piloto, e para clones relacionados à " $\mathrm{Ca}$. Brocadia sp. 40" quando em reator anammox em escala de bancada (Park, et al. 2010).

Date et al. (2009) observaram a dominância de " $\mathrm{Ca}$. Brocadia anammoxidans" em sistema de 3 reatores tubulares de fluxo contínuo e biomassa imobilizada inoculados diferentemente com biomassa a partir de uma estação de tratamento de esgoto, de um digestor anaeróbio e de um tanque de nitrificação tratando dejetos suínos e alimentando com água residuária sintética. Registrou-se também clones de " $\mathrm{Ca}$. Brocadia fulgida" no reator inoculado com lodo de estação de tratamento de esgoto. Esses autores sugerem que o modo de operação dos reatores promove a dominância de uma das espécies originalmente presente no inóculo (Date et al., 2009).

Com os resultados obtidos nesse trabalho e os da literatura, pode-se inferir que as alterações de dominância ocorridas nas comunidades anammox, ao longo do período para enriquecimento, são responsáveis pelo tempo gasto na partida de sistemas que visam a 
remoção de nitrogênio pelo processo anammox. A espécie que torna dominante precisa passar por períodos sucessivos de duplicação até que atinja abundância suficiente para que prevaleça nos sistemas e resulte em eficiente remoção de amônia. Além do mais, independentemente da origem do inóculo, parece existir uma convergência da espécie anammox dominante que se estabelece nos sistemas ajustados às mesmas características operacionais. Sugere-se que o inóculo venha a contribuir para o rápido start-up dos sistemas quando apresenta alta dominância original da espécie que se estabelecerá nos sistemas dadas as condições operacionais.

\subsection{2 - Etapa 2: Comportamento de conversão dos compostos nitrogenados}

Na etapa 2 os sistemas biológicos, com biomassas resultantes da etapa 1, foram submetidos às bateladas com duração de 72 horas com troca volumétrica de $65 \%$ da água residuária sintética, após sedimentação da biomassa, com introduções crescentes dos substratos amônia e nitrito. Essas condições de operação foram estabelecidas para todos os sistemas biológicos, independentemente do sucesso de enriquecimento dos micro-organismos anammox na $1^{\mathrm{a}}$ etapa.

Nessa etapa foram realizadas avaliações das concentrações dos íons nitrogenados e dos valores de $\mathrm{pH}$ em intervalos de 24 horas, caracterizando os perfis temporais de 0-24 horas; 24-48 horas; 0-48 horas; 48-72 horas; 0-72 horas. Os resultados obtidos para as concentrações dos íons foram transformados em relações molares para obtenção dos índices estequiométricos e comparação aos índices alcançados quando ocorre o predomínio da reação anammox nos sistemas biológicos (Equações 5.1 e 5.2).

$$
\begin{gathered}
\frac{\left[\mathrm{NO}_{2}^{-}\right]}{\left[\mathrm{NH}_{4}^{+}\right]}=1,32 \\
\frac{\left[\mathrm{NO}_{3}^{-}\right]}{\left[\mathrm{NH}_{4}^{+}+\mathrm{NO}_{2}^{-}\right]}=0,28
\end{gathered}
$$




\subsubsection{1 - Avaliação dos sistemas biológicos em duplicatas}

Como realizado para a $1^{a}$ etapa, foi verificado se os sistemas biológicos operados em duplicata apresentaram comportamentos similares de conversões das formas nitrogenadas. Devido às adaptações dos micro-organismos às condições estabelecidas nos sistemas, verificadas pelas substituições de dominância das supostas bactérias anammox, antes e após o período ajustado para ocorrência de enriquecimento, pode-se esperar que os sistemas biológicos venham a se comportar diferentemente dadas pequenas variações das condições entre os sistemas A e B.

Tendo-se os dados das concentrações dos íons amônia, nitrito e nitrato (mM) foram realizados os testes de Kolmogorov-Smirnov (D) e de Shapiro-Wilk (D) para verificar a normalidade dos dados considerando $\mathrm{p}<0,05$. O teste de Levene $(\mathrm{F})$ foi realizado para testar a homogeneidade das amostras com $\mathrm{p}<0,05$.

Para realização dos testes foram utilizados os dados brutos de redução das concentrações de amônia e nitrito e acréscimo de nitrato em mM, obtidas pela diferença entre os tempos de coleta de amostras dentro de cada batelada. Dessa maneira, como os intervalos de tempo se configuraram como variáveis interferindo nas concentrações dos íons em análise, fez-se uma avaliação da distribuição normal e homogeneidade entre as duplicatas considerando esse fator.

$\mathrm{Na}$ análise utilizou-se a comparação de normalidade e homogeneidade do comportamento dos íons (amônia, nitrito, nitrato em $\mathrm{mM}$ ) para cada intervalo de tempo dado o início de cada batelada, sendo eles (T0_T1 $\Leftrightarrow 0 \_24$ horas; T1_T2 $\Leftrightarrow 24 \_48$ horas; T0_T2 $\Leftrightarrow$ 0_48 horas; T2_T3 $\Leftrightarrow 48 \_72$ horas; T0_T3 $\Leftrightarrow 0 \_72$ horas). Os dados utilizados foram os obtidos em 10 bateladas para cada sistema biológico componente das duplicatas (A e B). A homogeneidade foi avaliada usando a comparação da variância de um dado íon, se igual ou diferente entre os sistemas A e B, mas observando-se a variância dentro de cada intervalo de tempo foi homogênea ou heterogênea para cada sistema componente da duplicata.

Os resultados dos testes para avaliação da normalidade dos dados de concentrações dos íons nitrogenados por Kolmogorov-Smirnov (D) e de Shapiro-Wilk (D) e para avaliação da homogeneidade pelo teste Levene (F) demonstraram que deveriam ser aplicados testes não paramétricos para comparação da igualdade das duplicatas (Apêndice V-CD). 
As modificações das concentrações dos íons são dependentes do tempo dentro de cada batelada, uma vez que implicam na velocidade de utilização dos substratos para cada grupo de micro-organismos presente, influenciando na disponibilidade futura dos íons. Além do mais, devido ao longo tempo experimental as biomassas nos sistemas biológicos adaptamse e aumentam as concentrações dos grupos de micro-organismos que melhores se ajustam às condições estabelecidas.

As conversões das formas nitrogenadas dependem das densidades dos grupos de microorganismos nos sistemas biológicos, das concentrações dos substratos limitantes e das concentrações de substâncias inibitórias a cada grupo de micro-organismos.

Adotou-se o teste não paramétrico dos Postos com Sinais de Wilcoxon (F) para comparação entre os sistemas em duplicatas A e B. Buscou avaliar se os mesmos continuaram a agir como duplicatas na conversão dos compostos nitrogenados. Para tanto realizou-se o levantamento das hipóteses, sendo: $\mathrm{H}_{0}=\mathrm{F}\left(\right.$ Sistema A) $=\mathrm{F}\left(\right.$ Sistema B) e $\mathrm{H}_{1}=\mathrm{F}($ Sistema A) $\neq \mathrm{F}$ (Sistema B) (Apêndice V - CD).

No teste não existe uma previsão de qual sistema apresenta maior ou menor conversão, considera-se apenas as igualdades e desigualdades entre os valores lidos de conversão para amônia, nitrito e nitrato e, portanto, a análise bilateral. Os sistemas foram considerados variáveis dependentes e, dessa maneira, os dados para os sistemas A e B foram colocados como emparelhados.

No teste de Postos com Sinais de Wilcoxon calculou-se a diferença entre as observações de cada amostra (teste e tempo) das duas variáveis dependentes, nesse caso sistema A e sistema B. As diferenças foram transformadas em postos adicionando os sinais positivo ou negativo, de acordo com o cálculo. Ao final separou-se os postos com sinais negativos e positivos e obteve-se a soma dos postos com mesmos sinais. A estatística desse teste (T) é utilizar o menor dos dois valores obtidos na soma dos postos com sinais diferentes.

Os resultados obtidos nos testes de Postos com Sinais de Wilcoxon para todos os conjuntos de duplicatas foram analisados e resultaram na conclusão que apenas os sistemas biológicos de duplicatas com inóculos provenientes dos lodos da lagoa facultativa $(\mathrm{FaF} 2)$ e do reator Uasb (UaF2) tratando efluente do Frigorífico 2, Uberlândia, MG permaneceram com comportamentos similares na conversão dos compostos nitrogenados ( $\mathrm{p}<0,05)$ (Tabela 5.8) (Apêndice $\mathrm{V}-\mathrm{CD}$ ). 
Tabela 5.8: Análise dos sistemas biológicos A e B para verificação da igualdade estatística entre duplicata na conversão dos íons nitrogenados.

\begin{tabular}{llcccccc}
\hline \hline \multirow{2}{*}{$\begin{array}{c}\text { IONS (mM) / } \\
\text { Intervalo tempo }\end{array}$} & $\begin{array}{c}\text { ParA } \\
\text { ParB }\end{array}$ & $\begin{array}{c}\text { AnF1A } \\
\text { AnF1B }\end{array}$ & $\begin{array}{c}\text { FaF1A } \\
\text { FaF1B }\end{array}$ & $\begin{array}{c}\text { FaF2A } \\
\text { FaF2B }\end{array}$ & $\begin{array}{c}\text { UaF2A } \\
\text { UaF2B }\end{array}$ & $\begin{array}{c}\text { ChoA e } \\
\text { ChoB }\end{array}$ \\
\hline \multirow{2}{*}{ T0_T1 (0 a 24 horas) } & Não & $\checkmark$ & Não & $\checkmark$ & $\checkmark$ & $\checkmark$ \\
\hline T1_T2 (24 a 48 horas) & $\checkmark$ & Não & Não & $\checkmark$ & $\checkmark$ & Não \\
\hline T0_T2 (0 a 48 horas) & $\checkmark$ & $\checkmark$ & $\checkmark$ & $\checkmark$ & $\checkmark$ & Não \\
\hline T2_T3 (48 a 72 horas) & $\checkmark$ & Não & $\checkmark$ & $\checkmark$ & $\checkmark$ & $\checkmark$ \\
\hline T0_T3 (0 a 72 horas) & $\checkmark$ & Não & Não & $\checkmark$ & $\checkmark$ & Não \\
\hline T0_T1 (0 a 24 horas) & $\checkmark$ & $\checkmark$ & $\checkmark$ & $\checkmark$ & $\checkmark$ & $\checkmark$ \\
\hline T1_T2 (24 a 48 horas) & Não & Não & $\checkmark$ & Não & $\checkmark$ & $\checkmark$ \\
\hline T0_T2 (0 a 48 horas) & $\checkmark$ & Não & $\checkmark$ & $\checkmark$ & $\checkmark$ & Não \\
\hline T2_T3 (48 a 72 horas) & Não & $\checkmark$ & $\checkmark$ & $\checkmark$ & $\checkmark$ & $\checkmark$ \\
\hline T0_T3 (0 a 72 horas) & $\checkmark$ & Não & $\checkmark$ & $\checkmark$ & $\checkmark$ & $\checkmark$ \\
\hline T0_T1 (0 a 24 horas) & $\checkmark$ & $\checkmark$ & $\checkmark$ & $\checkmark$ & $\checkmark$ & $\checkmark$ \\
\hline T1_T2 (24 a 48 horas) & $\checkmark$ & $\checkmark$ & $\checkmark$ & $\checkmark$ & $\checkmark$ & $\checkmark$ \\
\hline T0_T2 (0 a 48 horas) & $\checkmark$ & $\checkmark$ & $\checkmark$ & $\checkmark$ & $\checkmark$ & Não \\
\hline T2_T3 (48 a 72 horas) & Não & $\checkmark$ & $\checkmark$ & $\checkmark$ & $\checkmark$ & $\checkmark$ \\
\hline T0_T3 (0 a 72 horas) & $\checkmark$ & Não & Não & $\checkmark$ & $\checkmark$ & $\checkmark$ \\
\hline Desigualdades & $\mathbf{4}$ & $\mathbf{7}$ & $\mathbf{4}$ & $\mathbf{1}$ & $\mathbf{0}$ & $\mathbf{5}$ \\
\hline Igualdade estatística & & & & SIM & SIM & \\
\hline \hline
\end{tabular}

Significados: Não = duplicatas diferiram no íon e tempo considerados; $\checkmark$ = duplicatas não diferiram no íon e tempo considerados; $\mathrm{Sim}=$ Sistemas que não foram significativamente diferentes, apresentando comportamento similares nas concentrações dos íons nitrogenados (Apêndice $\mathrm{V}-\mathrm{CD}$ ).

Com base nos resultados do Teste de Wilcoxon de Postos com Sinais foram apresentados todos os resultados como tendo-se 12 diferentes sistemas biológicos, mas fazendo-se uma comparação entre os sistemas que tiveram a mesma origem da biomassa inoculada. Ainda que os sistemas biológicos FaF2A - FaF2B e UaF2A - UaF2B demonstraram comportamentos em conversões dos íons nitrogenados semelhantes estatisticamente, optouse em apresentar os resultados de cada sistema ao invés do valor médio para as duplicatas A e B. 
5.3.2.2 - Comportamento de conversão dos íons amônio $\left(\mathrm{NH}_{4}{ }^{+}\right)$, nitrito $\left(\mathrm{NO}_{2}^{-}\right)$e nitrato $\left(\mathrm{NO}_{3}\right)$ pela comparação à relação estequiométrica pelo processo anammox

A relação entre a redução concomitante de nitrito e amônia pela estequiometria da reação do processo anammox é de 1,32. No entanto, para análise dos dados e testes de comparações entre os sistemas realizou-se a transformação dos dados obtidos devido às grandes diferenças entre as reduções das concentrações de amônia e nitrito que resultaram distribuições de frequências dos escores com muitos valores atípicos e extremos (Field, 2009). Dessa maneira, realizou-se a transformação dos dados usando $\left(\log _{10}\left(X_{i}+2\right)\right)$. Nessa condição, com os dados transformados, a relação estequiométrica entre nitrito e amônia pelo processo anammox é de 0,521 (Figura 5.22).

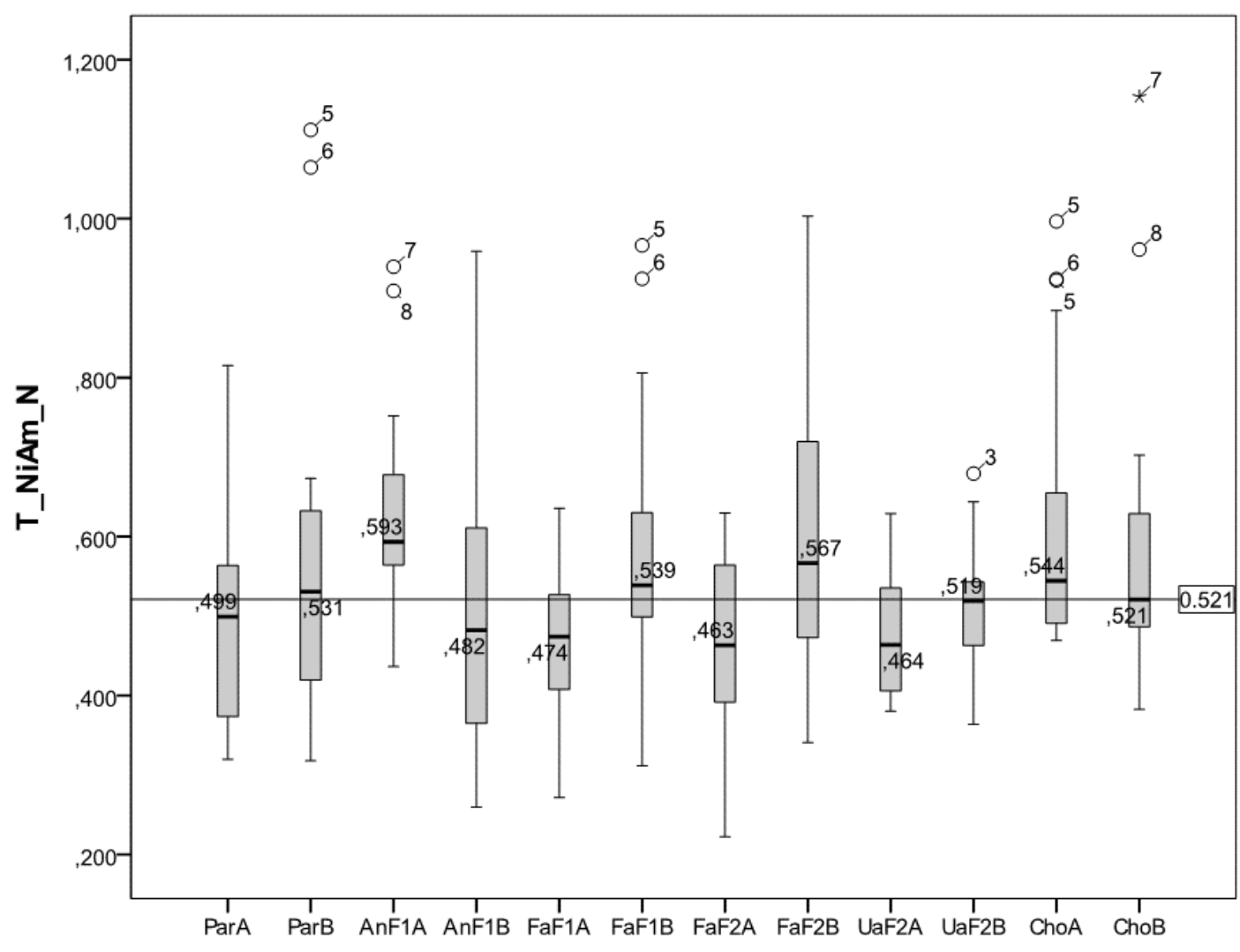

Sistemas testados

Figura 5.22: Indicadores descritivos para o comportamento de conversão concomitante dos íons nitrito e amônia comparada à relação estequiométrica dada pelo processo anammox, usando-se os dados de 10 bateladas e 5 diferentes intervalos de tempo dentro de cada batelada. Os indicadores descritivos tratam-se da mediana, $1^{\circ}$ e $2^{\circ}$ quartis, desvio padrão, valores atípicos e extremos. A linha traçada indica o valor obtido quando se obtém uma relação estequiométrica perfeita unicamente pelo processo anammox de 0,521 . No eixo das ordenadas indica-se que T_NiAm_N é a relação transformada por $\left(\left(\log _{10}\left(X_{i}+2\right)\right)\right)$ entre nitrito e amônia em forma de nitrogênio em mM. 
Verificou-se uma variação acentuada nas concentrações iônicas realizando-se a avaliação da conversão concomitante dos íons nitrito e amônia para todos os sistemas biológicos testados, indicando que até essa etapa experimental não ocorreu estabilização do processo anammox nos sistemas. Portanto, as conversões de nitrito e amônia podem ser decorrentes da combinação de vários processos metabólicos passíveis de ocorrerem nos sistemas, como a nitritação, nitratação e desnitrificação. No entanto, ressalta-se que nessa avaliação considerou-se a combinação dos dados obtidos em todas as bateladas e em todos os intervalos de tempo dentro de cada batelada.

Destacam-se os sistemas biológicos com biomassa oriunda do reator UASB do frigorífico 2, Uberlândia, MG (UaF2 A e B), que apresentaram uma menor variação e tiveram a maior parte dos seus dados próximos a 0,521 para a relação entre nitrito e amônia dada pelo processo anammox.

Da mesma maneira, foi avaliada a combinação dos dados obtidos pela formação de nitrato com redução concomitante de nitrito e amônia para todos os sistemas biológicos testados. Essa relação estequiométrica pelo processo anammox é de 0,28 . No entanto, para análise dos dados e testes de comparações entre os sistemas, realizou-se a transformação dos dados obtidos devido às grandes diferenças entre as reduções das concentrações de amônia e nitrito, bem como da produção de nitrato que resultaram distribuições de frequências dos escores com muitos valores atípicos e extremos (Field, 2009). Dessa maneira, realizou a transformação dos dados usando $\left(\log _{10}\left(\mathrm{X}_{\mathrm{i}}+2\right)\right)$ resultando no valor de 0,358 para essa relação (Figura 5.23).

Na relação entre a produção de nitrato com a redução concomitante de nitrito e amônia obteve-se uma variação acentuada para todos os sistemas biológicos testados, confirmando a não estabilização do processo anammox até essa etapa experimental. Para essa análise, considerou a combinação dos dados obtidos em todas as bateladas e em todos os intervalos de tempo dentro de cada batelada (Figura 5.23). Discute-se que a estabilização do processo anammox seja atingida quando a sua estequiometria é preponderante (consumo de 1 mol de $\mathrm{NH}_{4}$ e 1,32 mol de $\mathrm{NO}_{2}$ e formação de 0,26 mol de $\mathrm{NO}_{3}$ ) (Dapena-Mora et al., 2004; Tsushima et al., 2017; Bae et al., 2010; Tao et al., 2013).

Destacam-se novamente o comportamento dos sistemas biológicos com biomassa oriunda do reator UASB tratando efluente do frigorífico 2, Uberlândia, MG (UaF2 A e B), que 
resultaram numa relação entre formação de nitrato com redução concomitante de nitrito e amônia significativamente inferior a esperada pela reação anammox. Interpreta-se que processo de desnitrificação heterotrófica permaneceu atuante nesses sistemas (Figuras 5.23 e 5.24). No entanto, ainda que a ocorrência concomitante do metabolismo heterotrófico nos sistemas biológicos tenha sido considerada não desejável devido à competição pelo substrato, sugere-se que a sua ocorrência nos sistemas UaF2 possa ter favorecido as bactérias anammox.

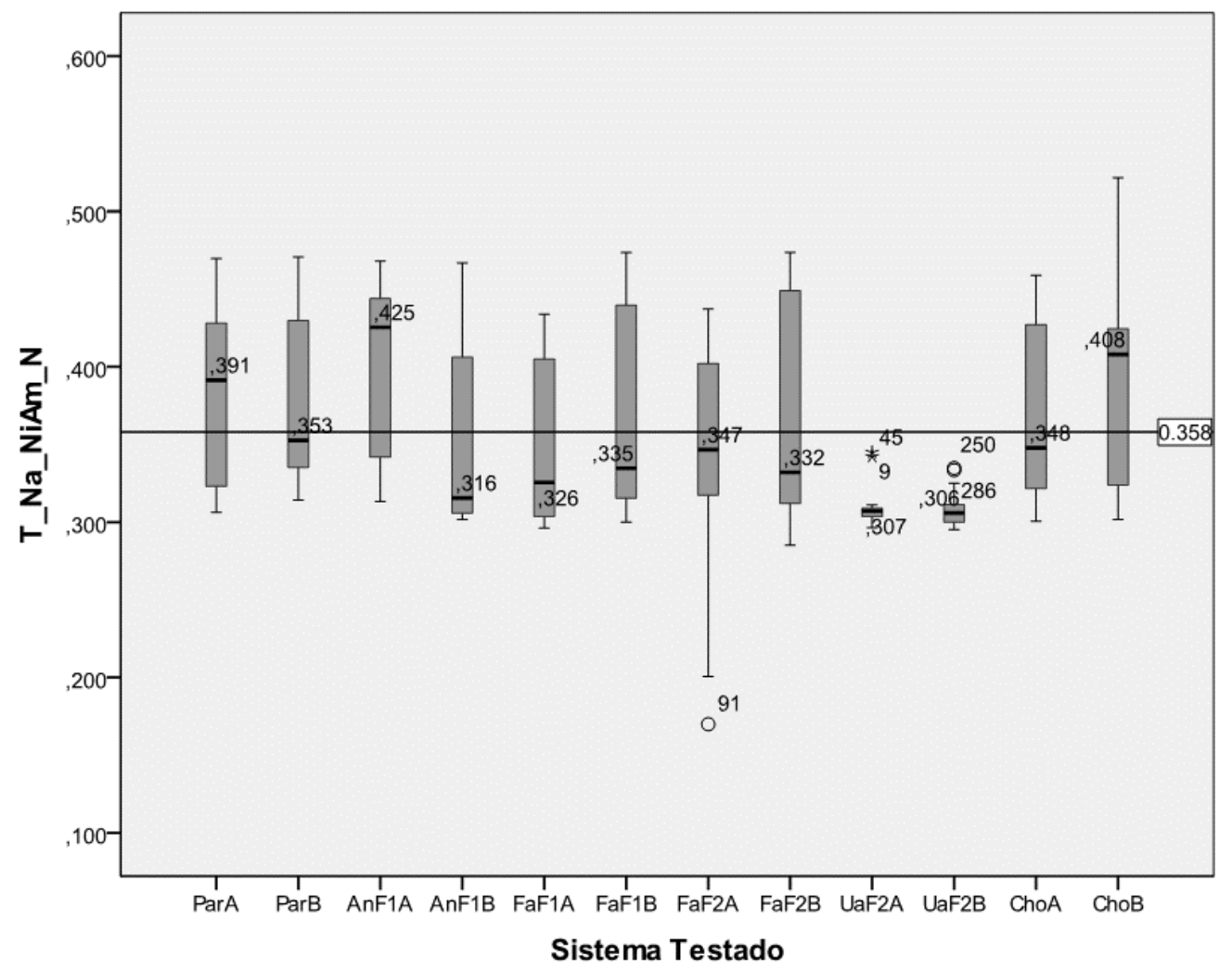

Figura 5.23: Indicadores descritivos para o comportamento de formação de nitrato a partir da redução concomitante dos íons nitrito e amônia comparada à relação estequiométrica dada pelo processo anammox, usando-se os dados de 10 bateladas e 5 diferentes intervalos de tempo dentro de cada batelada. Os indicadores descritivos tratam-se da mediana, $1^{\circ}$ e $2^{\circ}$ quartis, desvio padrão, valores atípicos e extremos. A linha traçada indica o valor obtido quando se obtém uma relação estequiométrica perfeita unicamente pelo processo anammox de 0,358 entre esses três íons. No eixo das ordenadas indica-se que T_Na_NiAm_N é a relação transformada por $\left(\left(\log _{10}\left(X_{i}+2\right)\right)\right.$ entre a formação de nitrato a partir da redução concomitante de nitrito e amônia em forma de nitrogênio em $\mathrm{mM}$. 
De forma contrária, interpreta-se que as bactérias heterotróficas desnitrificantes foram removidas dos demais sistemas biológicos principalmente para os sistemas Par A e B; AnF1 A; FaF1 B; FaF2 B; Cho A e B, uma vez que o nitrato acumulou nos sistemas. No entanto, o nitrato acumulado nesses sistemas é superior ao formado exclusivamente pelo processo anammox, indicando que os micro-organismos nitratantes como Nitrobacter foram os principais responsáveis para essa maior produção (Figura 5.24). A partir da análise dos valores médios, obtidos pela relação estequiométrica dada pela formação de nitrato a partir da redução concomitante de nitrito e amônia, reforça-se a capacidade de auto-organização dos sistemas biológicos visto que os sistemas AnF1B; FaF1A e FaF2B apresentaram uma menor produção de nitrato dada pela relação anammox.

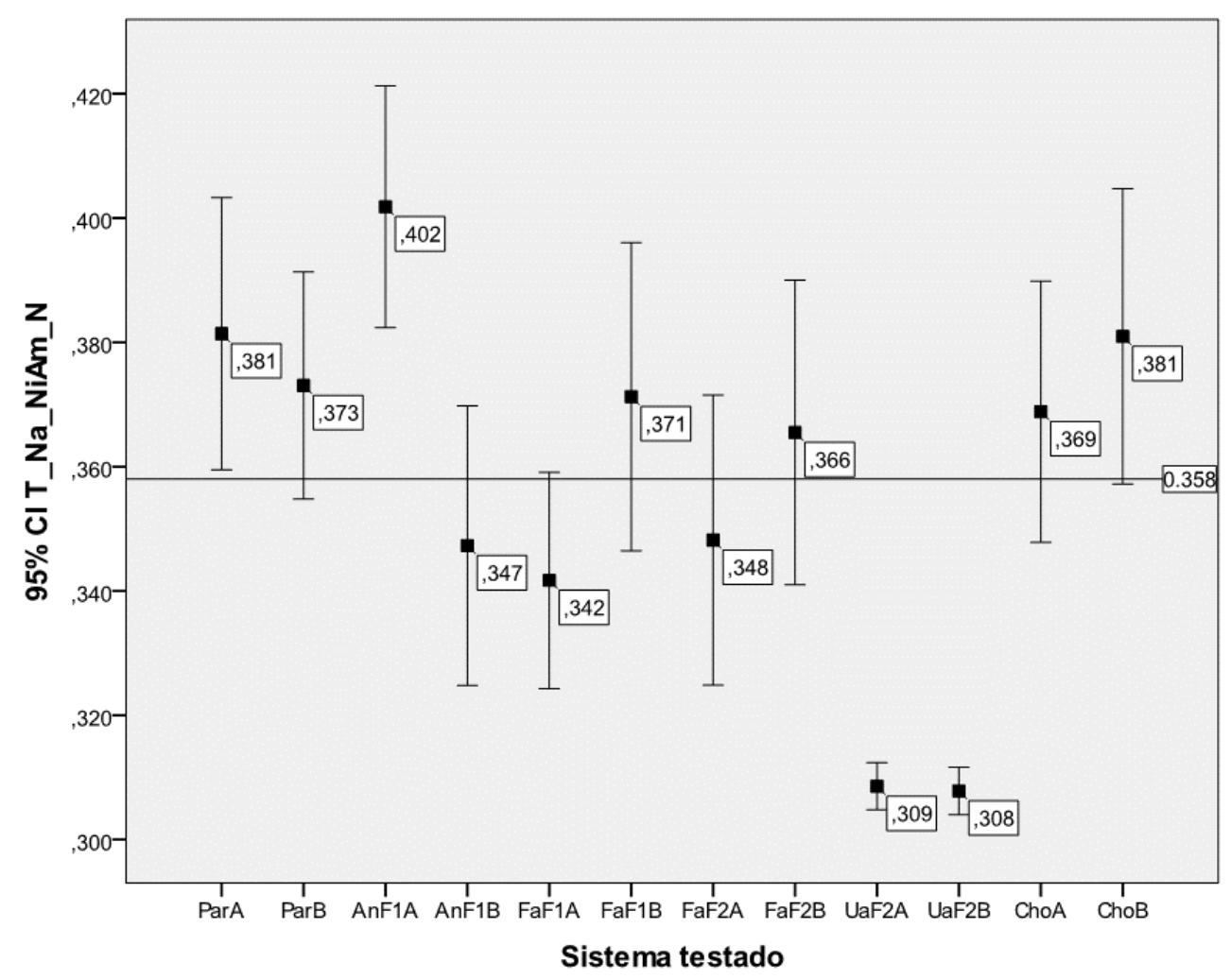

Figura 5.24: Relação estequiométrica entre a formação de nitrato a partir da redução concomitante dos íons nitrito e amônia comparada à relação estequiométrica dada pelo processo anammox, usando-se os dados de 10 bateladas e 5 diferentes intervalos de tempo

dentro de cada batelada. A linha traçada indica o valor obtido quando se obtém uma relação estequiométrica perfeita unicamente pelo processo anammox de 0,358 entre esses três íons. No eixo das ordenadas indica-se a média e o desvio padrão para T_Na_NiAm_N que é a relação transformada por $\left(\left(\log _{10}\left(X_{i}+2\right)\right)\right.$ entre a formação de nitrato a partir da redução concomitante de nitrito e amônia em forma de nitrogênio em mM com um intervalo de confiança de $95 \%$. 
As bactérias nitratantes como Nitrobacter permaneceram nos sistemas, ainda que as condições de anaerobiose não devessem favorecê-las, mas adaptaram-se a essas baixas concentrações de oxigênio. A oxidação química do nitrito, sem atuação biológica, é somente importante em ambientes com valores baixos de $\mathrm{pH}$ (Udert et al., 2005). O nitrito, em $\mathrm{pH}<$ 4, forma o $\mathrm{HNO}_{2}$ e combinando-se com o oxigênio livre, oxida-se a nitrato conforme: $\mathrm{HNO}_{2}$ $+0,5 \mathrm{O}_{2} \Rightarrow \mathrm{NO}_{3}{ }^{-}+\mathrm{H}^{+}$(Takenaka et al., 1998). Visto que os valores $\mathrm{pH}$ predominantes nos sistemas foram > 7, infere-se que a formação do nitrato nos sistemas deva-se à ação biológica.

Analisou-se a dispersão dos dados obtidos com as duas relações estequiométricas usadas para avaliação do processo anammox, sendo elas Ni_Am (Nitrito/Amônia) e Na_NiAm (Nitrato/Nitrito + Amônia), considerando-se os diferentes intervalos de tempo e não foram encontradas correlações significativas entre os índices estequiométricos da reação anammox com o tempo dentro das bateladas para todos os sistemas biológicos analisados (Apêndice VI - CD). Entende-se que os sistemas biológicos a cada nova batelada apresentaram comportamentos diferenciados dado às adaptações e estabelecimento das espécies dominantes nas comunidades biológicas de cada sistema.

A permanência do nitrito ao longo das bateladas foi avaliada uma vez que é o principal substrato limitante ao processo anammox. $\mathrm{O}$ nitrito pode ser consumido também pelas bactérias nitratantes como Nitrobacter e pelas desnitrificantes heterotróficas e, assim pode encontrar-se esgotado de acordo com a duração das bateladas. Inicialmente, nas duas primeiras bateladas, o nitrito tornou-se limitante após 24 horas apenas para os sistemas biológicos UaF2 A e B, enquanto nos demais sistemas suas concentrações permaneceram entre 30 a 50\% daquelas inicialmente inseridas, após 72 horas. Nas bateladas seguintes, os sistemas AnF1A e B; FaF1A e ChoB passaram a utilizar quase todo o nitrito até 24 horas. Nas últimas bateladas, em todos os sistemas biológicos, o nitrito permaneceu em concentrações não limitantes até as 72 horas.

As taxas de consumo horário do nitrito variaram entre os diferentes sistemas biológicos, sendo que as maiores taxas foram verificadas até 24 horas para os sistemas $\mathrm{PaA}\left(18 \mu \mathrm{M}^{-} \mathrm{h}^{-}\right.$ $\left.{ }^{1}\right), \operatorname{PaB}\left(25 \mu \mathrm{M} \cdot \mathrm{h}^{-1}\right)$, AnF1A $\left(31 \mu \mathrm{M} \cdot \mathrm{h}^{-1}\right)$, FaF2A $\left(21 \mu \mathrm{M} \cdot \mathrm{h}^{-1}\right)$; Cho A $\left(20 \mu \mathrm{M} \cdot \mathrm{h}^{-1}\right)$ e Cho B $\left(27 \mu \mathrm{M}^{-1} \mathrm{~h}^{-1}\right)$ tornando-se decrescentes nos próximos intervalos de tempo. Para o sistema FaF1B $\left(27 \mu \mathrm{M} . \mathrm{h}^{-1}\right)$, as taxas de consumo horário de nitrito foram crescentes entre os intervalos de 24 e 48 horas do início das bateladas e entre o intervalo de 48 e 72 horas para 
o sistema FaF2B $\left(26 \mu \mathrm{M} \cdot \mathrm{h}^{-1}\right)$. Para os sistemas UaF2 A $\left(90 \mu \mathrm{M} \cdot \mathrm{h}^{-1}\right)$ e UaF2B $\left(11 \mu \mathrm{M} \cdot \mathrm{h}^{-1}\right)$ as taxas foram constantes ao longo dos intervalos de tempo das bateladas.

Correspondentes às taxas de consumo de nitrito, as taxas de remoção de nitrogênio foram maiores para os sistemas biológicos Cho B (40,7 $\left.\mu \mathrm{M}^{-1}{ }^{-1}\right)$; PaB $\left(38,5 \mu \mathrm{M}^{-1}{ }^{-1}\right)$; AnF1A $(37,9$ $\left.\mu \mathrm{M} . \mathrm{h}^{-1}\right)$; PaA $\left(36,8 \mu \mathrm{M} . \mathrm{h}^{-1}\right)$; FaF2A $\left(36,3 \mu \mathrm{M} . \mathrm{h}^{-1}\right)$; Cho A $\left(35,2 \mu \mathrm{M} . \mathrm{h}^{-1}\right)$ respectivamente nas 24 horas iniciais das bateladas. Essas taxas foram iguais aquelas obtidas com cerca de 140-180 dias em sistemas operados e alimentados de maneira similar a este estudo, usando inóculo a partir de um reator com discos rotativos submersos (Tsushima et al., 2007). Taxas maiores de remoção de nitrogênio, em torno de $292 \mu \mathrm{M} . \mathrm{h}^{-1}$, só foram obtidas depois de 400 dias de operação dos sistemas (Tsushima et al., 2007).

As concentrações de nitrato presentes nos sistemas biológicos ao longo das bateladas foram decorrentes dos processos metabólicos anammox, nitratação e desnitrificação heterotrófica. Ao início dos experimentos na $2^{\mathrm{a}}$ etapa todos os sistemas biológicos apresentaram produções próximas ou inferiores àquelas esperadas pelo processo anammox. No entanto, nas bateladas seguintes ocorreram produções de nitrato superiores às registradas pelo processo anammox.

Devido às concentrações de nitrato não poderem ser atribuídas unicamente ao processo anammox, realizou-se uma avaliação para justificar a produção de nitrato com seu acúmulo nos diferentes intervalos de tempo dentro das bateladas a partir, exclusivamente, da oxidação aeróbia com a consequente redução das concentrações de nitrito no licor dos sistemas biológicos (Tabela 5.9) (Apêndice VI - CD).

No primeiro conjunto de sistemas avaliados ParA e ParB, pode-se supor que as concentrações de nitrato não podem ser explicadas somente pela oxidação aeróbia do nitrito, visto que intervalos com remoções altas de nitrito resultaram em concentrações baixas de nitrato. No sistema biológico ParA apenas para o intervalo T1_T2 (24 a 48 horas) foi que se observou uma maior relação entre as concentrações de nitrato produzido e nitrito consumido (Tabela 5.9). Nos demais intervalos de tempo dentro das bateladas ocorreram fracas correlações entre esses dois ânions. Numa avaliação total das bateladas, pode-se atribuir pelo menos $40 \%$ do nitrato formado à oxidação aeróbia do nitrito (Tabela 5.9). 
Tabela 5.9: Correlações entre produção de nitrato_N (mM) com a redução concomitante das concentrações de nitrito_N (mM) nos sistemas biológicos, dada pelo valor de $\mathrm{R}^{2}$ calculado.

\begin{tabular}{l|cccccc}
\hline \hline \multirow{2}{*}{ Sistema } & \multicolumn{7}{|c}{ Intervalos de tempo* } \\
\cline { 2 - 7 } & T0_T1 & T1-T2 & T0_T2 & T2_T3 & T0_T3 & Total \\
\hline Par A & 0,187 & 0,666 & 0,392 & 0,335 & 0,178 & $\mathbf{0 , 4 2 3}$ \\
\hline Par B & 0,593 & 0,327 & 0,485 & 0,510 & 0,157 & $\mathbf{0 , 5 3 3}$ \\
\hline AnF1 A & 0,849 & 0,254 & 0,525 & 0,449 & 0,112 & $\mathbf{0 , 6 0 6}$ \\
\hline AnF1 B & 0,831 & 0,055 & 0,687 & 0,433 & 0,298 & $\mathbf{0 , 5 9 0}$ \\
\hline FaF1 A & 0,801 & 0,065 & 0,580 & 0,783 & 0,319 & $\mathbf{0 , 5 6 6}$ \\
\hline FaF1 B & 0,078 & 0,411 & 0,287 & 0,401 & 0,305 & $\mathbf{0 , 3 7 4}$ \\
\hline FaF2 A & 0,366 & 0,667 & 0,508 & 0,055 & 0,113 & $\mathbf{0 , 3 6 8}$ \\
\hline FaF2 B & 0,091 & 0,416 & 0,338 & 0,504 & 0,487 & $\mathbf{0 , 4 2 0}$ \\
\hline UaF2 A & 0,259 & 0,600 & 0,560 & 0,335 & 0,837 & $\mathbf{0 , 1 4 5}$ \\
\hline UaF2 B & 0,063 & 0,134 & 0,002 & 0,241 & 0,044 & $\mathbf{0 , 0 3 3}$ \\
\hline Cho A & 0,115 & 0,605 & 0,247 & 0,001 & 0,148 & $\mathbf{0 , 1 8 1}$ \\
\hline Cho B & 0,535 & 0,299 & 0,161 & 0,924 & 0,055 & $\mathbf{0 , 3 3 9}$ \\
\hline \hline
\end{tabular}

* T0_T1: 0_24 hs; T1_T2: 24_48 hs; T0_T2: 0_48 hs; T2_T3: 48_72 hs; T0_T3: 0_72 hs; Total: dados de todos os intervalos (Apêndice VI - CD).

Para o sistema biológico $\mathrm{PaB}$, vários intervalos apresentaram correlações onde $50 \%$ do nitrato produzido pode ser explicado pela oxidação aeróbia do nitrito, sendo T0_T1 (0 a 24 horas); T0_T2 (0 a 48 horas); T2_T3 (48 a 72 horas), assim como quando se considera o intervalo total das bateladas (Tabela 5.9).

O nitrato acumulou-se nos sistemas ParA e ParB pois as bactérias heterotróficas desnitrificantes foram, provavelmente, removidas dos sistemas devido à ausência de carbono orgânico no licor uma vez que a alimentação dos sistemas foi realizada com água residuária sintética sem fonte de carbono orgânico.

Os sistemas biológicos formados pelos pares AnF1A e AnF2B apresentaram vários intervalos de tempos dentro das bateladas nos quais as concentrações de nitrato podem ser principalmente atribuídas à oxidação aeróbia do nitrito (Tabela 5.9). Para os dois sistemas AnF1A e AnF1B, nos intervalos T0_T1 (0 a 24 horas); T0_T2 (0 a 48 horas) e T2_T3 (48 a 72 horas) mais de $50 \%$ das conversões de nitrito podem ser explicadas pela oxidação aeróbia. Destaca-se que nesses sistemas biológicos nos intervalos T0_T1 (0 a 24 horas) pode-se atribuir quase $80 \%$ da produção de nitrato à oxidação aeróbia do nitrito. Com essa atuação das bactérias aeróbias nitratantes, a maior parte do nitrito foi convertido sem consideráveis conversões das concentrações de amônia e tornando-o um substrato limitante. 
Nos sistemas AnF1A e AnF1B, as correlações entre os íons nitrato e nitrito são mais fracas após as 24 horas iniciais das bateladas podendo os metabolismos anammox e de nitratação estarem ocorrendo concomitantemente. Contudo, as conversões iniciais de nitrito por bactérias nitratantes podem ter limitado as conversões por bactérias anammox.

Nesses sistemas também ocorreu o acúmulo de nitrato ao final das bateladas. A ausência de carbono orgânico no licor limitou o processo de desnitrificação heterotrófica. Ressalta-se que nas bateladas iniciais dessa $2^{\mathrm{a}}$ etapa experimental, até o final da $2^{\mathrm{a}}$ batelada para o sistema AnF1A e até o final da $4^{\mathrm{a}}$ batelada para o sistema $\mathrm{AnF} 1 \mathrm{~B}$, registraram concentrações baixas de nitrato devido ao consumo desse íon provavelmente por bactérias heterotróficas que utilizaram de concentrações residuais de carbono orgânico e/ou de lise de células de micro-organismos que não se adaptaram às condições estabelecidas nos sistemas.

Os sistemas FaF1A e FaF1B apresentaram comportamentos quanto à correlação entre os íons nitrito e nitrato diferenciados entre si (Tabela 5.9). No sistema FaF1A as concentrações de nitrato poderiam ser atribuídas principalmente à oxidação aeróbia do nitrito, durante os intervalos T0_T1 (0 a 24 horas); T0_T2 (0 a 48 horas) e T2_T3 (48 a 72 horas). Considerando-se todos os intervalos de tempos dentro das bateladas, a conversão do nitrito pelas bactérias nitratantes pode ter sido o processo de oxidação predominante no sistema, explicando em até $60 \%$ o nitrato formado.

No sistema FaF1B, as produções de nitrato pela oxidação aeróbia do nitrito estiveram correlacionadas mais fracamente, podendo-se esperar que nesse sistema as bactérias anaeróbias oxidadoras de amônia tenham conseguido utilizar o nitrito às taxas equivalentes às oxidadoras aeróbias. Nesse sistema as correlações maiores entre produção de nitrato pela redução das concentrações de nitrito ocorreram nos intervalos T1_T2 (24 a 48 horas) e T2_T3 (48 a 72 horas) (Tabela 5.9).

Até o final das 4 primeiras bateladas, o nitrato produzido nos sistemas FaF1A e FaF1B foi consumido por bactérias heterotróficas desnitrificantes devido às baixas concentrações no licor dos sistemas. As reduções nas concentrações de amônia e nitrito sejam por processos aeróbios e/ou anaeróbios resultariam em maiores concentrações de nitrato. Para esses sistemas, com biomassa da estação de tratamento de efluentes do frigorífico 1, as concentrações residuais de carbono orgânico permaneceram até cerca de 150 dias. Posteriormente, o nitrato passou acumular-se nos sistemas uma vez ocorrendo o esgotamento 
do carbono orgânico nos sistemas.

Foram registradas correlações parciais e totais fracas entre a produção de nitrato pela oxidação aeróbia do nitrito no sistema $\mathrm{FaF} 1 \mathrm{~B}$, indicando que outros processos metabólicos predominaram no sistema, em especial a oxidação anaeróbia da amônia usando o nitrito como aceptor final de elétrons (Tabela 5.9).

Nos sistemas biológicos FaF2A e FaF2B, pode-se atribuir em cerca de 50\% a produção de nitrato pela oxidação aeróbia do nitrito após as 24 horas do início das bateladas. Nesses sistemas, as correlações entre produção de nitrato e consumo de nitrito foram relativamente fracas, podendo supor que outros processos metabólicos foram atuantes nos sistemas contribuindo para as conversões do nitrito e amônia presentes. Também para esses sistemas biológicos, ocorreu o acúmulo do nitrato ao final das bateladas decorrente da ausência do metabolismo de desnitrificantes heterotróficos.

Nos sistemas biológicos FaF2A e FaF2B, após conversão da maior parte do nitrito nos intervalos iniciais, ou seja, entre T0_T1, T1_T2, T0_T2 que representam 48 horas das bateladas, ocorreram correlações baixas entre os íons nitrito e nitrato, indicando que o nitrito se tornou limitante no licor (Tabela 5.9).

Da mesma maneira que em outros sistemas biológicos, também para os sistemas FaF2A e FaF2B, o nitrato permaneceu acumulado nos sistemas, uma vez que o metabolismo das bactérias heterotróficas desnitrificantes não foi favorecido dado a ausência de carbono orgânico no meio.

Os sistemas biológicos com biomassa oriunda do reator UASB tratando efluente de frigorífico 2, Uberlândia, $\mathrm{MG}$ (UaF2 A e UaF2 B), apresentaram correlações baixas entre aumento e redução das concentrações de nitrato e nitrito, respectivamente, provavelmente devido à ação das bactérias heterotróficas desnitrificantes que os consumiram (Tabela 5.9). Ainda que para o sistema UaF2A tenha-se obtido correlações elevadas entre as concentrações de nitrato com a redução concomitante daquelas de nitrito em alguns intervalos de tempos analisados, deve-se considerar que a redução das concentrações de nitrito pode ser atribuída também ao consumo pelas bactérias desnitrificantes (Tabela 5.9). No entanto, dado as reduções nas concentrações de amônia e baixas concentrações de nitrato indicam que sua formação seja pelo processo anammox e ou de nitratação. 
Considerando-se todos os intervalos de tempos dentro de cada batelada e também todas bateladas realizadas para avaliação do comportamento da biomassa nas conversões dos íons amônia, nitrito e nitrato ocorre correlação fraca entre produção de nitrato por oxidação exclusiva por nitrito $\left(\mathrm{R}^{2}=0,145\right)$ (Tabela 5.9).

No sistema biológico UaF2B, as concentrações de nitrato correlacionaram fracamente com as oxidações concomitantes do nitrito (Tabela 5.9). Da mesma maneira, a participação contínua das bactérias heterotróficas desnitrificantes foram responsáveis pelas baixas concentrações de nitrato, assim como, podem ter sido responsáveis pela remoção do nitrito dos sistemas biológicos. Considerando-se as reduções nas concentrações de amônia devida unicamente ao processo anammox faltaria nitrito que permitissem tais reduções, devendo considerar que o processo de nitritação tenha ocorrido concomitantemente. Realizando-se os cálculos para atribuir as conversões de amônia ao processo anammox, esperar-se-ia maiores concentrações de nitrato do que as registradas. No entanto, reforça-se a ação das bactérias desnitrificantes reduzindo nitrito, nitrato e sulfato para conversão do carbono orgânico.

Os sistemas biológicos com biomassa a partir dos sedimentos da lagoa de acumulação de chorume do aterro controlado Jóckey Clube de Brasília, DF (ChoA e ChoB) acumularam significativas concentrações de nitrato ao final das bateladas. Correlacionando-se as concentrações de nitrato pela oxidação aeróbia do nitrito não foi possível atribuir a produção do nitrato unicamente ao processo de nitratação (Tabela 5.9). No sistema biológico ChoA a maior produção de nitrato ocorreu após 24 horas do início das bateladas, sendo que entre o intervalo T1_T2 pelo menos $60 \%$ do nitrato pode ter sido meio da conversão direta do nitrito presente (Tabela 5.9). A ausência de fontes de carbono orgânico nos sistemas limitou o processo de desnitrificação heterotrófica dado as concentrações altas de nitrato ao final das bateladas. Apenas nas duas primeiras bateladas foi que se obteve baixas concentrações de nitrato ao fim das 72 horas do ciclo. Nesse sistema, verifica-se que as concentrações convertidas de amônia e nitrito e produzidas de nitrato deveu-se à concomitância dos processos anammox, nitritação e nitratação.

No sistema ChoB os comportamentos de conversões de amônia e nitrito com consequente produção de nitrato não foram diferentes do sistema biológico ChoA, mudando-se apenas com relação à maior produção de nitrato ocorrer após 48 horas do início das bateladas, entre o intervalo T2_T3 pelo menos $90 \%$ do nitrato produzido pode ser a partir da conversão direta do nitrito presente (Tabela 5.9). Contudo, considerando-se que nesse intervalo a maior parte 
do nitrito já havia sido convertido, a prevalência do processo de nitratação não contribuiu para aumento significativo das concentrações de nitrato. As concentrações altas de nitrato, ao final das bateladas, também podem ser associadas a ausência de fontes de carbono orgânico para favorecer o processo de desnitrificação heterotrófica. Nas duas primeiras bateladas registrou-se baixas concentrações de nitrato ao fim das 72 horas do ciclo. Nesse sistema, considerando-se as concentrações convertidas de amônia e nitrito e produzidas de nitrato, os processos anammox, nitritação e nitratação ocorreram concomitantemente.

Numa análise geral do comportamento dos sistemas biológicos constatou-se que a atividade anammox ficou reduzida devido à competição por substratos com os diferentes grupos de micro-organismos sendo os nitritantes, os nitratantes e os heterotróficos desnitrificantes. Provavelmente, o nitrito foi a substância mais limitante. O acúmulo de nitrato em vários dos sistemas biológicos deveu-se à falta de matéria orgânica para o acoplamento da desnitrificação heterotrófica que seria condutora da redução do nitrato a nitrito que permitiria a reversão do nitrato ao substrato necessário à reação anammox (Jetten et al., 2005; Kalyuzhnyi et al., 2006).

Quando o carbono orgânico dissolvido está presente e não pode ser aproveitado pelos microorganismos anammox, as bactérias heterotróficas desnitrificantes podem vencer as anammox e, rapidamente, consumir o nitrito presente (Jenni et al., 2014). De acordo com Tao et al. (2013), as bactérias anammox apresentam desvantagens competitivas com as bactérias heterotróficas, pois a reação anammox é termodinamicamente menos viável do que a reação de desnitrificação heterotrófica. Também, a síntese celular das bactérias heterotróficas é quase cinco (5) vezes maior do que das anammox sob as condições de anaerobiose (Shen et al., 2011).

Além do mais, períodos elevados de retenção de biomassa, como os que foram adotados nesse estudo, para a conservação dos micro-organismos anammox podem, também, favorecer a manutenção das bactérias aeróbias oxidadoras de nitrito e, portanto, de grupos competidores pelo substrato nitrito (Jenni et al., 2014).

A estratégia de operação dos sistemas biológicos para atividade anammox é um aspecto importante para a composição microbiológica da comunidade (Park et al., 2010). Diferenças na composição inicial da comunidade dos inóculos podem resultar em performances diferenciadas dos sistemas biológicos após longos períodos de testes. 
5.3.2.3 - Teste de Kruskal-Wallis comparando as relações estequiométricas anammox obtidas nos sistemas biológicos

O teste não-paramétrico de Kruskal-Wallis permitiu comparar os sistemas biológicos frente às diferenças nas conversões das formas nitrogenadas amônia, nitrito e nitrato utilizando-se as relações estequiométricas esperadas para o processo anammox nos diferentes intervalos de tempo ao longo da duração das bateladas. Ressalta-se que o teste de Kruskal-Wallis apenas apontou a existência de diferenças nas conversões entre os sistemas biológicos testados. As relações estequiométricas utilizadas foram aquelas transformadas para consumo concomitante de nitrito e amônia (T_Ni/Am) e para produção de nitrato pela conversão conjunta de nitrito e amônia ( $\left.\mathrm{T}_{-} \mathrm{Na} / \mathrm{Ni}+\mathrm{Am}\right)$. Os índices estequiométricos pelo processo anammox, dada as relações transformadas, entre T_Ni/Am igual a 0,521 e T_Na/Ni+Am igual a 0,358. Considerou-se para realização dos testes comparativos os intervalos T0_T1 (entre 0 e 24 horas); T0_T2 (0 e 48 horas) e T0_T3 (0 e 72 horas) (Apêndice VII - CD).

Assim, com base na relação estequiométrica entre nitrito e amônia verificou-se que os sistemas biológicos variaram significativamente nas conversões desses dois íons para o intervalo entre T0_T2 $(\mathrm{H}(11)=22,99$ e $\mathrm{p}<0,05)$. Quando comparados os sistemas para os intervalos entre T0_T1 e T0_T3 não se pode atribuir diferenças significativas no comportamento das biomassas entre os sistemas $(\mathrm{p}>0,05)$. Como já observado entre outras análises das conversões, o período entre 24 e 48 horas é determinante para o sucesso de um dado comportamento metabólico prevalecer nos sistemas, devido principalmente à limitação de substratos.

Mesmo tendo usado o resultado da relação entre o consumo concomitante de nitrito e amônia como parâmetro de comparações entre os sistemas inoculados com diferentes fontes de biomassa, não se obtém pelo teste de Kruskal-Wallis qual sistema apresentou melhor performance pela reação anammox. No entanto, a análise de diagramas auxilia na identificação das diferenças entre os sistemas e, ao mesmo tempo, a leitura do comportamento metabólico dado pela relação entre nitrito e amônia aproximando-a do índice estequiométrico ideal anammox (Figura 5.25). 

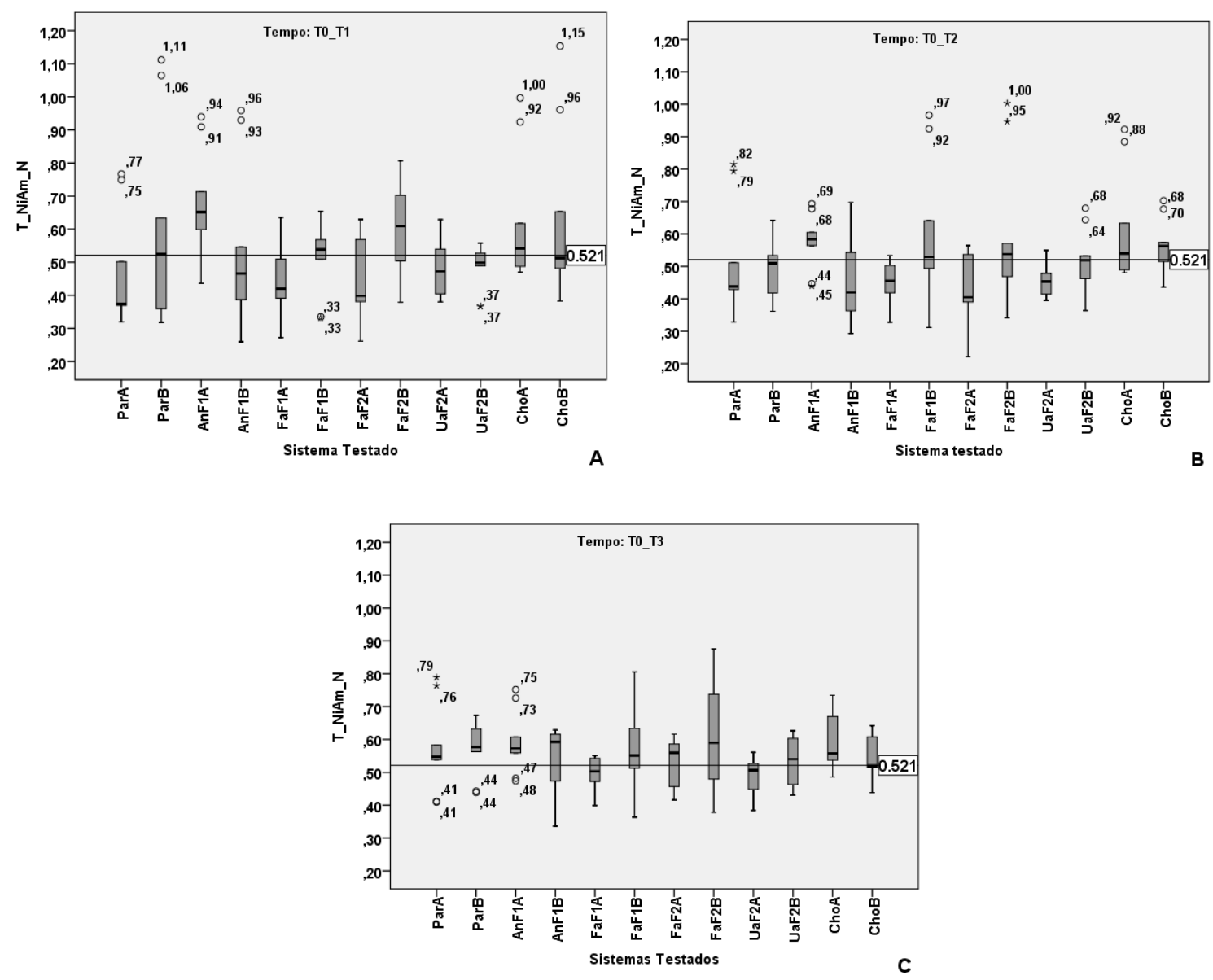

Figura 5.25: Relações estequiométricas entre as reduções concomitantes de nitrito e amônia nos intervalos de tempo A) T0_T1 ( 0 a 24 horas), B) T0_T2 (0 a 48 horas) e C) T0_T3 (0 a 72 horas) durante as 10 bateladas conduzidas na etapa 2 visando a atividade anammox. Os resultados encontram-se apresentados por indicadores descritivos que tratam-se da mediana, $1^{\circ}$ e $2^{\circ}$ quartis, desvio padrão, valores atípicos e extremos. A linha traçada indica o valor obtido quando se obtém uma relação estequiométrica perfeita unicamente pelo processo anammox de 0,521 . No eixo das ordenadas indica-se que T_NiAm_N é a relação transformada por $\left(\left(\log _{10}\left(X_{i}+2\right)\right)\right)$ entre nitrito e amônia em forma de nitrogênio em mM.

Os sistemas biológicos apresentaram comportamentos variantes nas conversões do nitrito e amônia. Como não se obteve variações aceitáveis, próximas ao índice estequiométrico anammox $(0,521)$ desejado, considera-se que aqueles sistemas com a maior parte das relações inferiores ao índice apresentaram melhor performance anammox. Quando se obtém relações maiores que o índice anammox significam que maiores concentrações de nitrito foram convertidas sem que conversões correspondentes de amônia tenham ocorrido, tendo sobressaído o metabolismo das bactérias nitratantes. Considerando-se as conversões de nitrito e amônia avaliadas por meio das relações estequiométricas, verifica-se que entre os 
intervalos T0_T2, os sistemas AnF1A, FaF1B, ChoA e ChoB já resultavam em conversões maiores de nitrito do que amônia (Figura 5.25B). Ao final das bateladas de 72 horas, apenas nos sistemas FaF1A, UaF2A e UaF2B que se registraram relações entre nitrito e amônia inferiores à estipulada para o metabolismo anammox (Figura 5.25 C).

Da mesma forma, com base na relação estequiométrica entre produção de nitrato com redução concomitante das concentrações de nitrito e amônia verificou-se que os sistemas biológicos variaram significativamente quanto às concentrações desses três íons para os todos os intervalos de tempos considerados, sendo os resultados calculados pelo teste de Kruskal-Walis iguais a T0_T1 $(\mathrm{H}(11)=29,58$ e p < 0,01); T0_T2 $(\mathrm{H}(11)=42,93$ e p < 0,01) e T0_T3 $(\mathrm{H}(11)=36,66$ e p < 0,01). Esses resultados indicam que a produção de nitrato ocorre nos diferentes intervalos de tempo e que diferentes processos metabólicos influenciaram nas suas concentrações dissolvidas no licor dos sistemas biológicos ao longo das bateladas. Deve-se considerar também que a biomassa em cada sistema reage diferentemente à cada nova batelada, dependendo das espécies da comunidade microbiológica predominantes nos sistemas.

Como discutido anteriormente, não se obtém os sistemas com melhor performance anammox realizando comparações pelo teste de Kruskal-Wallis usando os resultados das relações entre a produção de nitrato com o consumo concomitante de nitrito e amônia como parâmetro comparativo. No entanto, a análise de diagramas auxilia na identificação das diferenças entre os sistemas e, ao mesmo tempo, a leitura do comportamento metabólico dado pela relação entre produção de nitrato com consumo de nitrito e amônia aproximando-a do índice estequiométrico ideal anammox (0,358) (Figura 5.26).

Considerando-se o intervalo T0_T1 ( 0 a 24 horas), as quantidades de nitrato formado a partir de conversões diretas pela oxidação aeróbia do nitrito ou indiretas pela oxidação anaeróbia da amônia usando o nitrito como aceptor final de elétrons foram baixas nos sistemas biológicos ParB, AnF1B, FaF1A, FaF2A e FaF2B, UaF2A e UaF2B, indicando a permanência do substrato nitrito no licor dos sistemas (Figura 5.26 A). 

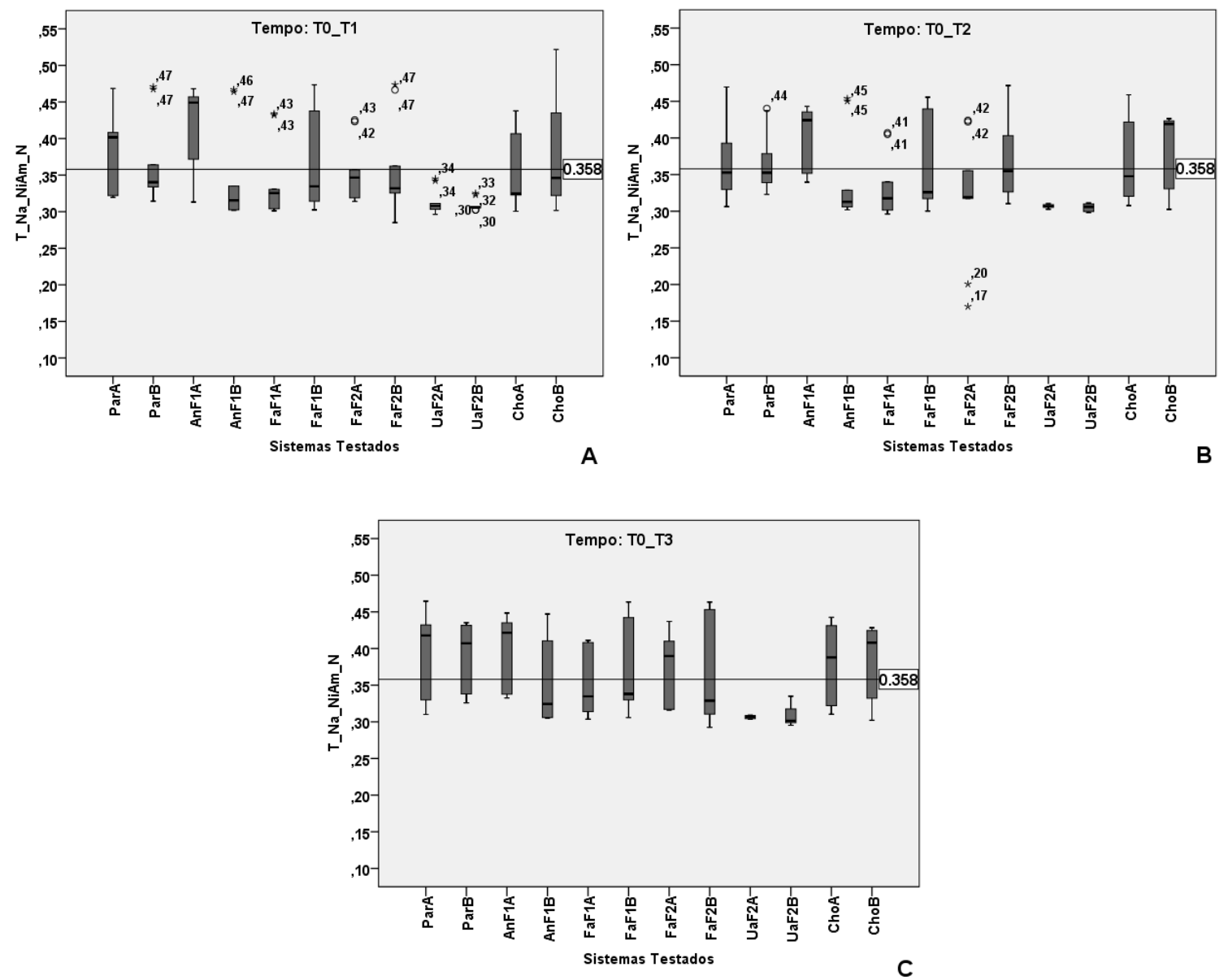

Figura 5.26: Relações estequiométricas entre a produção de nitrato com reduções concomitantes de nitrito e amônia nos intervalos de tempo A) T0_T1 (0 a 24 horas), B) T0_T2 (0 a 48 horas) e C) T0_T3 ( 0 a 72 horas) durante as 10 bateladas conduzidas na etapa 2 visando a atividade anammox. Os resultados encontram-se apresentados por indicadores descritivos que tratam-se da mediana, $1^{\circ}$ e $2^{\circ}$ quartis, desvio padrão, valores atípicos e extremos. A linha traçada indica o valor obtido quando se obtém uma relação estequiométrica perfeita unicamente pelo processo anammox de 0,358. No eixo das ordenadas indica-se que T_Na_NiAm_N é a relação transformada por $\left(\left(\log _{10}\left(X_{i}+2\right)\right)\right)$ entre nitrato, nitrito e amônia em forma de nitrogênio em $\mathrm{mM}$.

Avaliando-se as relações estequiométricas entre a produção de nitrato com reduções concomitantes das concentrações de nitrito e amônia no intervalo de tempo T0_T2 (0 a 48 horas) das bateladas realizadas, apenas nos sistemas AnF1B, FaF1A, FaF2A, UaF2A e UaF2B que se registraram baixas concentrações de nitrato resultando em relações estequiométricas inferiores à esperada pelo processo anammox (Figura 5.26 B). No entanto, quanto maiores os valores encontrados para a relação entre as concentrações de nitrato com redução de nitrito e amônia, pressupõe-se que o metabolismo de nitratação tenha sido predominante. Também, baixas concentrações de nitrato no licor podem indicar a atividade 
do metabolismo por desnitrificação heterotrófica.

Considerando todo o intervalo das bateladas, ou seja, T0_T3 (0 a 72 horas), apenas os sistemas biológicos que foram utilizados biomassa oriunda do lodo do reator UASB tratando efluente do frigorífico 2, Uberlândia (UaF2A e UaF2B) foram que registraram relações entre produção de nitrato com as concomitantes reduções das concentrações de nitrito e amônia inferiores à esperada pela estequiometria anammox (Figura 5.26 C). Nesses sistemas, interpreta-se que as bactérias desnitrificantes heterotróficas possam ter atuado como competidoras por nitrito com as bactérias anammox. No entanto, dadas as concentrações residuais de nitrato não se pode desprezar que a associação na comunidade microbiológica entre bactérias anammox e desnitrificantes heterotróficas possam ser preferíveis à associação entre bactérias anammox e nitratantes.

\subsubsection{4 - Variações do $\mathrm{pH}$ do licor misto na etapa 2}

$\mathrm{O}$ aumento no valor do $\mathrm{pH}$ do licor de sistemas biológicos, acima dos valores ajustados no início das bateladas, tem sido atribuído à ocorrência do metabolismo anammox em sistemas biológicos. A contínua variação positiva do $\mathrm{pH}$ ao longo das bateladas pode indicar que o processo anammox consegue compensar o consumo da alcalinidade devido ao processo de nitrificação, seja por nitritação e/ou nitratação (Li et al., 2012).

Em todos os sistemas biológicos testados, ao longo da $2^{\text {a }}$ etapa, ocorreram variações positivas do valor do $\mathrm{pH}$ indicando que o processo anammox, conduzido por microorganismos capazes de oxidar a amônia usando o nitrito como aceptor de elétrons, foi o responsável pelas variações do pH por produzir alcalinidade (Figuras 5.27 e 5.28).

A variação do $\mathrm{pH}$ foi positiva para todos os sistemas biológicos até as primeiras 24 horas do início das bateladas (Figura 5.27). Em todos os sistemas biológicos, à exceção de UaF2A e UaF2B, continuou-se a elevação dos valores do $\mathrm{pH}$ após as primeiras 24 horas, provavelmente devido à produção de alcalinidade, porém de forma menos acentuada. A partir das 24 horas ocorre limitação do substrato nitrito devido tanto ao consumo por bactérias anammox quanto pelas nitratantes fazendo com que as alterações do $\mathrm{pH}$ sejam menos acentuadas (Figura 5.27). Nos sistemas UaF2A e UaF2B, após as primeiras 24 horas, 
devido às reduções dos valores do $\mathrm{pH}$ pressupõe-se que outros processos metabólicos, que não o anammox, predominaram nos sistemas. Provavelmente, nos sistemas UaF2A e UaF2B, a competição por nitrito por organismos nitratantes, desnitrificantes heterotróficos e anammox comprometeram a estabilidade dos sistemas (Figura 5.27). A possível redução do sulfato nesses sistemas também poderia responder pela formação de ácidos como o $\mathrm{H}_{2} \mathrm{~S}$ (ácido sulfídrico) quando em solução, reduzindo os valores do pH no licor.

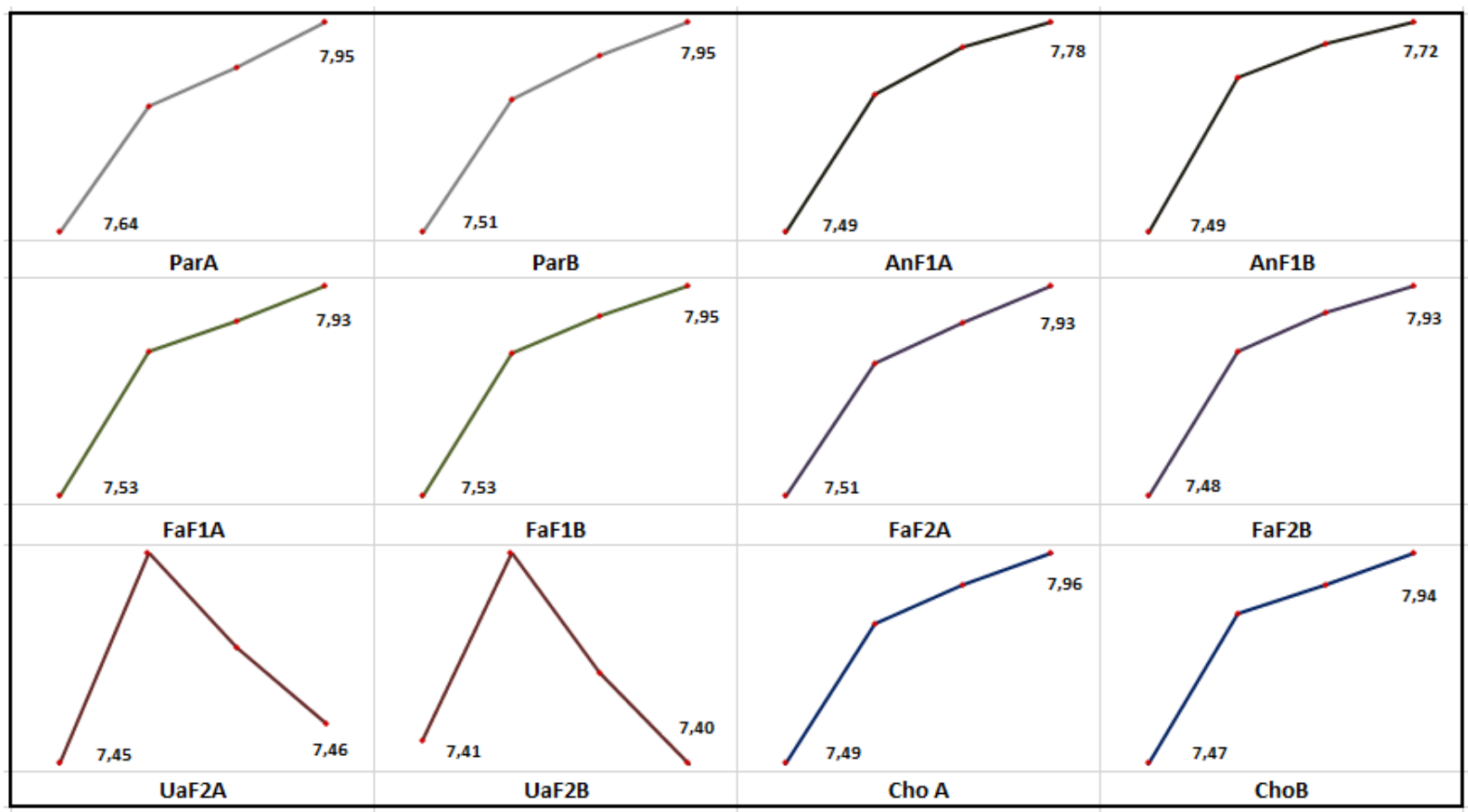

Figura 5.27: Variação do $\mathrm{pH}$ (em valores médios, $\mathrm{n}=10$ ) nos sistemas biológicos ao longo das bateladas de 72 horas durante a $2^{\mathrm{a}}$ etapa experimental. Sendo: Par A e ParB - biomassa do sedimento do lago Paranoá de Brasília, DF; AnF1A e AnF1B - biomassa lagoa anaeróbia tratando efluente do frigorífico 1, Araguari, MG; FaF1A e FaF1B - biomassa lagoa facultativa tratando efluente do frigorífico 1, Araguari, MG; FaF2A e FaF2B - biomassa lagoa facultativa tratando efluente do frigorífico 2, Uberlândia, MG; UaF2A e UaF2B - biomassa reator UASB tratando efluente do frigorífico 2, Uberlândia, MG; ChoA e ChoB - biomassa lagoa de acumulação de chorume do aterro controlado JC de Brasília, DF. Cada marcador nas linhas indica: $0,24,48$ e 72 horas consecutivamente.

$\mathrm{O} \mathrm{pH}$ foi ajustado ao início de cada batelada para valores dentro da faixa de $\mathrm{pH}$ determinada para ocorrência do processo anammox, tendo iniciado pouco abaixo do valor considerado ótimo, visto que, esperava-se a elevação do $\mathrm{pH}$ do licor dos sistemas biológicos ao longo da duração das bateladas (Figura 5.28). Ao final das bateladas, os valores do $\mathrm{pH}$ permaneceram dentro da faixa ótima de pH para a ocorrência do processo anammox, à exceção dos sistemas com inóculos provenientes do reator UASB tratando efluente do frigorífico 2, Uberlândia, 
MG (UaF2A e UaF2B) (Figura 5.28).

Atribui-se a variação positiva do $\mathrm{pH}$ no licor dos sistemas biológicos ao processo anammox, uma vez que o outro processo que também resultaria em elevação do $\mathrm{pH}$ seria a desnitrificação heterotrófica. No entanto, pressupõe-se que esse processo metabólico foi pouco ocorrente nos sistemas visto que a ausência de fonte de carbono orgânico fez com que ocorresse o acúmulo de nitrato ao final das bateladas. Exceção aos sistemas biológicos com biomassa proveniente do reator UASB tratando efluentes do Frigorífico 2, Uberlândia (UaF2A e UaF2B), cuja presença de matéria orgânica poderia ser devida à lise de células de micro-organismos que não se mantiveram nos sistemas.

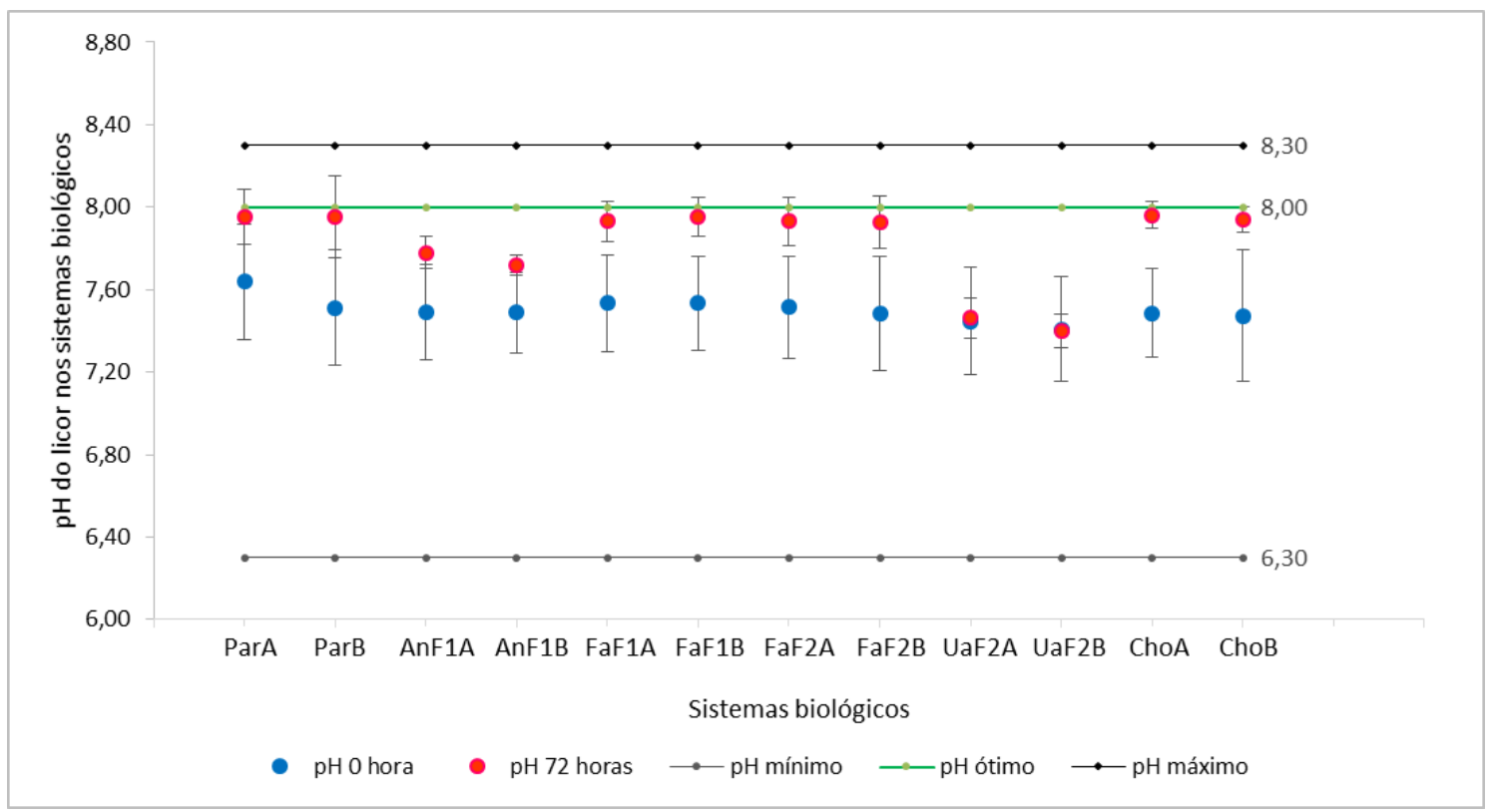

Figura 5.28: Valores médios do $\mathrm{pH}$ inicial (0 hora) e final (72 horas) do licor dos sistemas biológicos ao longo das bateladas de 72 horas durante a $2^{\mathrm{a}}$ etapa experimental. Sendo: Par A e ParB - biomassa do sedimento do lago Paranoá de Brasília, DF; AnF1A e AnF1B - biomassa lagoa anaeróbia tratando efluente do frigorífico 1, Araguari, MG; FaF1A e FaF1B - biomassa lagoa facultativa tratando efluente do frigorífico 1, Araguari, MG; FaF2A e FaF2B - biomassa lagoa facultativa tratando efluente do frigorífico 2, Uberlândia, MG; UaF2A e UaF2B - biomassa reator UASB tratando efluente do frigorífico 2, Uberlândia, MG; ChoA e ChoB - biomassa lagoa de acumulação de chorume do aterro controlado JC de Brasília, DF. 
5.3.2.5 - Análises da biomassa nos sistemas biológicos após 180 dias (final da $2^{\mathrm{a}}$ etapa)

Após 180 dias de operação dos sistemas biológicos e os mesmos terem sido submetidos às condições de operação estabelecidos nas etapas 1 e 2 , foi feita a verificação dos microorganismos pela detecção de fragmentos amplificados por PCR convencional e pela quantificação do número de cópias dos genes que codificam o RNAr 16S por PCR quantitativa utilizando primers específicos ao grupo de micro-organismos anammox. Da mesma forma, avaliou-se a participação dos grupos de micro-organismos nitrificantes aeróbios por análise de PCR convencional e quantitativa para entendimento dos processos metabólicos predominantes nos sistemas biológicos testados.

Após extração do DNA das biomassas, a realização de eletroforese, em gel de agarose 1\% corado com brometo de etídeo $\left(1 \mu \mathrm{g} . \mathrm{mL}^{-1}\right)$ usando-se o marcador molecular High Mass Ladder (Invitrogen, USA) permitiu uma estimativa da concentração total do DNA genômico para cada sistema biológico da biomassa presente em $1 \mathrm{~mL}$ do licor misto, tendo-se um volume final de $100 \mu \mathrm{L}$ às diferentes concentrações entre $2,5 \eta \mathrm{g} \cdot \mu \mathrm{L}^{-1}$ a $6,5 \eta \mathrm{g} \cdot \mu \mathrm{L}^{-1}$ para cada sistema (Apêndice VIII - CD).

Após o período destinado à avaliação dos comportamentos de conversões das formas nitrogenadas pelas biomassas presentes nos sistemas biológicos, ajustados para a atividade anammox em culturas em bateladas, por meio de PCR convencional, usando primers e condições de amplificação anteriormente testadas na biomassa dos inóculos e dos sistemas após 120 dias, foi possível registrar amplificações positivas para fragmentos de aproximadamente 774 pb para todos os sistemas, à exceção dos sistemas AnF1B e UaF2A (Tabela 5.11) (Apêndice VIII).

Verificou-se amplificação positiva para fragmentos de DNAr relacionados ao RNAr 16S dos organismos anammox no sistema UaF2B. Nesse sistema não havia verificado amplificação de fragmentos após os 120 dias da etapa 1. No sistema UaF2A não houve amplificação como ocorrido nas análises de PCR aos 120 dias ajustados para ocorrência de enriquecimento. Comparando-se os resultados de conversão dos compostos nitrogenados amônia e nitrito e formação de nitrato entre esses dois sistemas biológicos, constata-se uma melhor performance anammox do sistema $\mathrm{UaF} 2 \mathrm{~B}$ dado as concentrações de nitrato presente ao longo das bateladas, que podem ter sido devido à oxidação anaeróbia da amônia usando o nitrito como aceptor final de elétrons. 
A princípio, a ausência de amplificações positivas para os sistemas AnF1B e UaF2A não excluiu a presença de bactérias anammox nos sistemas, visto que as conversões dos compostos nitrogenados ocorridas nesses sistemas permitem inferir a participação do metabolismo anammox.

As amplificações de fragmentos do gene RNAr 16S para os micro-organismos anammox sugerem a ocorrência do metabolismo anammox nos sistemas biológicos, ainda que se possa atribuir remoções de amônia e nitrito com consequente produção de nitrato aos processos de nitritação e nitratação.

Portanto, tendo-se destacado a participação dos micro-organismos nitritantes e nitratantes no metabolismo dos sistemas biológicos, realizou-se a análise de PCR convencional avaliando as amplificações de genes específicos amoA para as bactérias nitritantes e genes relacionado aos RNAr 16S para as bactérias nitratantes (Tabela 5.10).

Tabela 5.10: Resultados das amplificações para fragmentos de DNA por PCR para bactérias anammox, nitritantes como Nitrosomonas e nitratantes como Nitrobacter.

\begin{tabular}{l|ccc}
\hline \hline \multirow{2}{*}{ Sistema } & \multicolumn{3}{|c}{ Resultados das amplificações* $^{*}$} \\
\cline { 2 - 4 } & Anammox $^{1}$ & Nitrosomonas $^{2}$ & Nitrobacter $^{3}$ \\
\hline Par A & + & - & + \\
\hline Par B & + & - & + \\
\hline AnF1 A & + & - & + \\
\hline AnF1 B & - & - & + \\
\hline FaF1 A & + & - & + \\
\hline FaF1 B & + & - & + \\
\hline FaF2 A & + & - & + \\
\hline FaF2 B & + & - & + \\
\hline UaF2 A & - & - & + \\
\hline UaF2 B & + & - & + \\
\hline Cho A & + & + & + \\
\hline Cho B & + & + & + \\
\hline \hline
\end{tabular}

1 Anammox: usando os primers Pla 46F e Amx 820R para amplificação de fragmentos do gene para o RNAr 16S. ${ }^{2}$ Nitrosomonas: usando os primers AmoA direto e reverso para amplificação de fragmentos do gene funcional da enzima amônia mono-oxigenase. ${ }^{3}$ Nitrobacter: usando os primers Nitro 1198F e Nitro 1423R para amplificação de fragmentos do gene para o RNAr 16S (Apêndice VIII).

$\mathrm{Na}$ análise dos géis de agarose com os resultados das amplificações para o gene amoA das biomassas a partir dos sistemas biológicos verificou-se fragmentos formados de 
aproximadamente $650 \mathrm{pb}$ apenas para os DNAs extraídos das biomassas dos sistemas ChoA e B.

O segundo grupo analisado foram as bactérias oxidadoras aeróbias de nitrito, representadas por bactérias como Nitrobacter, por meio da utilização dos primers Nitro 1198 direto e Nitro 1423 reverso (Graham et al., 2007), formando fragmentos de aproximadamente $225 \mathrm{pb}$ (Tabela 5.10).

Com relação ao grupo de bactérias oxidadoras aeróbias do nitrito como Nitrobacter, supõe que estavam presentes em todos os sistemas biológicos testados, ainda que as condições estabelecidas não devessem favorecer esse grupo, elas mantiveram-se ao longo dos períodos para enriquecimento e atividade anammox e, provavelmente, atuaram como competidoras pelo substrato nitrito com as bactérias anammox (Tabela 5.10) (Apendice VIII).

A avaliação dos resultados da PCR quantitativa (PCRq) permitiu, por meio da abundância de cópias de DNA inferidas pelo ciclo de quantificação $(\mathrm{Cq})$, indicar a representatividade relativa dos grupos de micro-organismos anammox, nitrificantes aeróbios de amônia (como Nitrosomonas) e nitrificantes aeróbios de nitrito (como Nitrobacter) no total do DNA genômico extraído da biomassa de cada um dos sistemas biológicos. Infere-se que quanto menor o Cq resultante pela análise de PCRq, maior o número de cópias do gene alvo.

Os resultados obtidos pela avaliação da biomassa dos sistemas biológicos após o período de 180 dias destinados ao enriquecimento e atividade de micro-organismos anammox demonstraram que do total de DNA genômico os organismos nitratantes são aqueles com maior abundância em todos os sistemas, tendo sido registrados os menores valores de $\mathrm{Cq}$ para as amplificações dos genes RNAr $16 \mathrm{~S}$ específicos às bactérias como Nitrobacter. Sequencialmente, obteve-se menores valores de Cq para as amplificações devidas aos genes RNAr 16S específicos à micro-organismos anammox do que aquelas devidas à amplificação dos genes amoA para as bactérias como Nitrosomonas (Tabela 5.11).

A implicação direta da representatividade dos grupos de micro-organismos na biomassa dos sistemas biológicos, entendida pelas concentrações de fragmentos de DNA amplificados, foi o resultado dos comportamentos metabólicos ao longo das bateladas. Dessa forma, explicase a maior produção de nitrato ocorrentes no licor dos sistemas possa ser atribuída à maior abundância dos micro-organismos nitratantes comparadas à abundância dos microorganismos anammox. A presença de organismos como anammox e nitritantes como 
Nitrosomonas explicam as reduções das concentrações de amônia dos sistemas.

Comparando-se a representatividade de cada grupo de micro-organismo ao final da etapa 2 (180 dias) com aqueles obtidos após a etapa 1 (120 dias), tem-se aumento na densidade de cópias de DNA de bactérias anammox dado pela redução do valor de $\mathrm{Cq}$ apenas para os sistemas ParA e ChoB (Tabela 5.11). Registra-se também um aumento das densidades de cópias dos organismos nitratantes para os sistemas ParA, ParB, AnF1A e de forma menos significante para os sistemas UaF2A e UaF2B e ChoA. Nos sistemas ParB, AnF1A e AnF1B, FaF2A e FaF2B ocorreu reduções dos valores de $\mathrm{Cq}$ para organismos como Nitrosomonas, indicando um aumento da representatividade desse grupo após 180 dias quando comparados aos 120 dias (Tabela 5.11).

Tabela 5.11: Ciclos de quantificação obtidos por PCR quantitativa para os sistemas biológicos aos 120 dias relativos às condições de operação da etapa 1 e aos 180 dias relativos às condições de operação da etapa 2 , destinadas ao enriquecimento e atividade dos organismos anammox.

\begin{tabular}{|c|c|c|c|c|c|c|c|c|}
\hline \multirow{3}{*}{$\begin{array}{l}\text { Sistemas } \\
\text { Biológicos }\end{array}$} & \multicolumn{8}{|c|}{ Ciclo de quantificação } \\
\hline & \multicolumn{2}{|c|}{ Anammox } & \multicolumn{2}{|c|}{ Nitrosomonas $^{3}$} & \multicolumn{2}{|c|}{ Nitrobacter $^{4}$} & \multicolumn{2}{|c|}{ Bacteria } \\
\hline & $120^{1}$ & $180^{2}$ & $120^{1}$ & $180^{2}$ & $120^{1}$ & $180^{2}$ & $120^{1}$ & $180^{2}$ \\
\hline \multirow[t]{2}{*}{ Par } & 32,0 & $\mathrm{~A}=29,83$ & 31,3 & $\mathrm{~A}=34,43$ & 28,2 & $\mathrm{~A}=23,27$ & 18,4 & $\mathrm{~A}=17,42$ \\
\hline & & $\mathrm{B}=34,01$ & & $\mathrm{~B}=30,10$ & & $\mathrm{~B}=25,16$ & & $\mathrm{~B}=18,04$ \\
\hline \multirow[t]{2}{*}{ AnF1 } & 31,0 & $\mathrm{~A}=32,19$ & 35,0 & $A=32,85$ & 23,2 & $A=22,18$ & 18,5 & $A=17,52$ \\
\hline & & $\mathrm{B}=33,05$ & & $\mathrm{~B}=33,22$ & & $B=25,31$ & & $\mathrm{~B}=18,20$ \\
\hline \multirow[t]{2}{*}{ FaF1 } & 30,7 & $A=35,65$ & 33,9 & $\mathrm{~A}=34,07$ & 22,2 & $A=23,33$ & 16,8 & $\mathrm{~A}=19,42$ \\
\hline & & $B=35,49$ & & $\mathrm{~B}=33,77$ & & $B=25,25$ & & $\mathrm{~B}=18,85$ \\
\hline \multirow[t]{2}{*}{ FaF2 } & 31,6 & $\mathrm{~A}=33,09$ & 35,1 & $\mathrm{~A}=34,41$ & 22,2 & $\mathrm{~A}=22,37$ & 18,8 & $\mathrm{~A}=18,67$ \\
\hline & & $\mathrm{B}=33,13$ & & $\underline{B}=33,92$ & & $\mathrm{~B}=21,73$ & & $\mathrm{~B}=18,89$ \\
\hline \multirow[t]{2}{*}{ UaF2 } & 34,1 & $\mathrm{~A}=35,83$ & 33,1 & $\mathrm{~A}=34,12$ & 23,0 & $\mathrm{~A}=22,31$ & 16,3 & $\mathrm{~A}=17,95$ \\
\hline & & $\mathrm{B}=36,58$ & & $\mathrm{~B}=34,80$ & & $\mathrm{~B}=22,32$ & & $\mathrm{~B}=18,02$ \\
\hline \multirow[t]{2}{*}{ Cho } & 34,4 & $A=35,86$ & 34,6 & $A=33,70$ & 22,7 & $\mathrm{~A}=21,17$ & 17,2 & $A=18,45$ \\
\hline & & $\mathrm{B}=32,67$ & & $\mathrm{~B}=31,45$ & & $\mathrm{~B}=23,68$ & & $\mathrm{~B}=18,32$ \\
\hline
\end{tabular}

${ }^{1}$ Avaliação após 120 dias; ${ }^{2}$ Avaliação após 180 dias; ${ }^{3}$ Micro-organismos como Nitrosomonas; ${ }^{4}$ Microorganismos como Nitrobacter. Os sistemas destacados em cinza indicam significativas diferenças entre os sistemas A e B após 180 dias. As interações sublinhadas indicam que ocorreu aumento da biomassa após 180 dia comparados àquelas aos 120 dias.

Numa análise global, utilizando-se de primers universais para os genes que codificam o RNAr 16S para o Domínio Bacteria, observa-se que não ocorreram variações significantes na concentração de cópias de DNA entre as análises aos 120 dias de enriquecimento e após 180 dias testando-se a atividade anammox, interpretadas pelos valores dos ciclos de 
quantificação $(\mathrm{Cq})$ (Tabela 5.11). Dessa maneira, verifica-se a existência contínua de uma comunidade microbiana atuante nos sistemas biológicos, sendo a responsável pelas modificações das concentrações das espécies químicas analisadas.

$\mathrm{Na}$ análise dos resultados obtidos pela PCRq, percebe-se muito frágil a estabilidade das comunidades biológicos dos sistemas. A modificação no modo de operação, ainda que ajustados para promover o crescimento das concentrações dos micro-organismos do grupo anammox, no período avaliado, a abundância de cópias dos genes relacionados ao RNAr $16 \mathrm{~S}$ foram expressivamente insignificantes frente às densidades dos grupos relacionados às bactérias como Nitrobacter e Nitrosomonas, bem como aos outros grupos de bactérias nos sistemas (Figura 5.29).

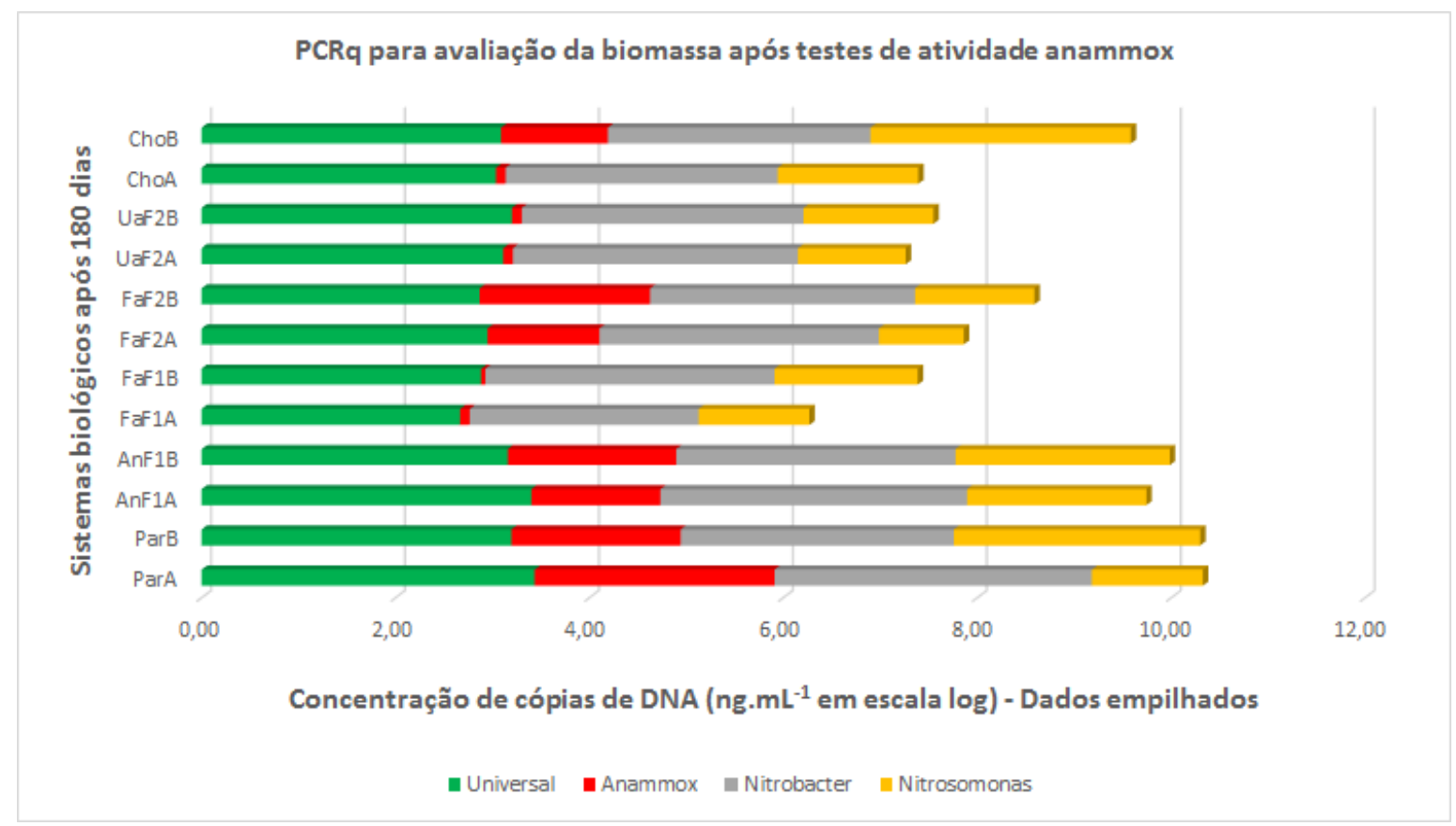

Figura 5.29: Abundância de cópias dos genes de micro-organismos de interesse na biomassa dos sistemas biológicos ajustados para permitir o enriquecimento e atividade de bactérias anammox.

As condições estabelecidas para operação dos sistemas biológicos, em modo de culturas em bateladas ajustadas para o enriquecimento e atividade de organismos anammox, selecionou os grupos de bactérias nos sistemas biológicos. Limitações dos substratos e, portanto, competições entre as bactérias foram provavelmente a principal força seletiva para o 
estabelecimento da comunidade microbiológica nos sistemas biológicos. O ajuste de condições, tais como anaerobiose, temperatura em torno $30^{\circ} \mathrm{C}$, água residuária sintética com concentrações altas de cloretos, modo de operação, não necessariamente excluíram bactérias nitrificantes dos sistemas.

Conforme resultados já obtidos pela interpretação dos ciclos de quantificação $(\mathrm{Cq})$, as avaliações das concentrações de cópias de DNA dos genes dos micro-organismos de interesse confirmam que ocorreu aumento na abundância de cópias das bactérias capazes de oxidar anaerobicamente a amônia após o período de 180 dias nos sistemas ParA, FaF2B e ChoB quando comparados aos 120 dias destinados ao enriquecimento promovido na etapa 1 (Figura 5.30). As reduções nas concentrações de cópias de DNA nos demais sistemas biológicos podem ser explicadas pelas substituições de dominância das espécies anammox originalmente presentes nos inóculos por outras espécies dadas as condições estabelecidas para os sistemas e pelas interações competitivas. O modo operacional estabelecido para os sistemas biológicos, na etapa 2, pode também ter levado à uma nova estrutura da comunidade e onde as bactérias anammox provavelmente passam novo período de adaptação.

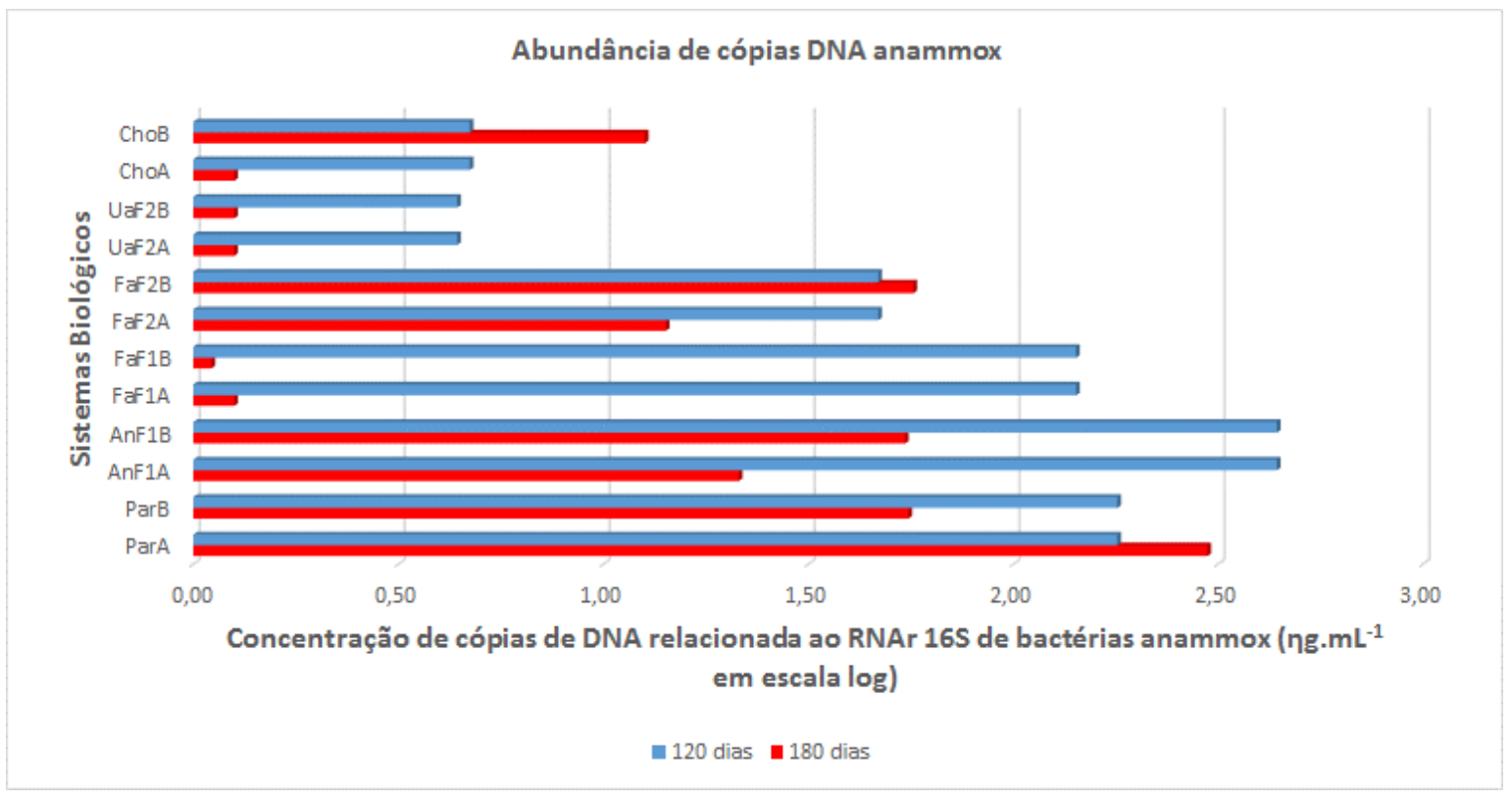

Figura 5.30: Concentrações de cópias de DNA relacionadas ao RNAr 16S de bactérias anammox nos sistemas biológicos aos 120 dias destinados ao enriquecimento e após o período de 180 dias destinados à atividade de micro-organismos anammox. 


\section{6 - CONCLUSÕES E RECOMENDAÇÕES}

× Sugere-se a presença de micro-organismos anammox, verificadas por analise de PCR convencional utilizando primers para amplificação dos genes relacionados ao RNAr 16S e por sequenciamento dos fragmentos amplificados, nas biomassas provenientes do sedimento do lago Paranoá, Brasília, DF (Par), dos lodos das lagoas anaeróbia e facultativa tratando efluente do frigorífico 1, Araguari, $\mathrm{MG}(\mathrm{AnF1}$ e FaF1) e no lodo da lagoa facultativa tratando efluente do frigorífico 2, Uberlândia, $\mathrm{MG}(\mathrm{FaF} 2 \mathrm{~A})$.

× Os resultados obtidos no alinhamento e comparação das sequências de nucleotídeos dos fragmentos de DNA amplificados por PCR, usando o conjunto de primers Pla46F e Amx820R, indicam haver substituição de dominância dos grupos de bactérias anammox inicialmente presentes nos inóculos quando estabelecidos os sistemas e as condições de operação.

× A aproximação filogenética das sequências de nucleotídeos dos fragmentos de DNA amplificados por PCR, usando o conjunto de primers Pla46F e Amx820R, com às sequências das candidatas espécies anammox depositadas no Genbank utilizando o Basic Local Alignment Search Tool (BLAST) foi baixa. No entanto, os índices de similaridades calculados para essa comparação indicam que os fragmentos amplificados a partir da biomassa nos sistemas pertençam a Ordem Brocadiales.

× Independentemente da origem do inóculo, as condições estabelecidas para os sistemas biológicas parecem selecionar o mesmo grupo de bactérias anammox nos sistemas, tendo-se concluído a partir da similaridade entre as sequências de bases dos fragmentos amplificados por PCR usando primers Pla46F e Amx820R específicos para o gene RNAr 16S de bactérias anammox.

× O tipo de inóculo provavelmente influencia o start-up dos sistemas anammox de acordo com a abundância original da bactéria anammox que tornará dominantes nos sistemas biológicos, definidos os tipos de reatores e condições de operação. As características físicoquímicas e da comunidade microbiana dos inóculos podem interferir no estabelecimento da atividade anammox dadas sua potencialidade de substâncias inibitórias e grupos de microorganismos competidores por substratos. 
× O tempo de partida de sistemas para atividade anammox são provavelmente longos devido à provável substituição de dominância entre as espécies anammox nos sistemas biológicos e o tempo requerido para o crescimento da densidade das bactérias anammox.

× A limitação de nitrito interferiu no sucesso do processo anammox, uma vez que as bactérias anammox tem menor afinidade por esse substrato e as bactérias nitratantes e heterotróficas desnitrificantes o consumiram mais rapidamente.

× Em todos os sistemas biológicos o metabolismo anammox não foi exclusivo, uma vez que não foram atendidos os índices estequiométricos esperados pelo metabolismo anammox. As conversões das formas nitrogenadas nos sistemas biológicos foram associadas à concomitância dos processos metabólicos anammox, nitritação, nitratação e desnitrificação heterotrófica.

* A partida dos sistemas biológicos para atividade anammox ficou sujeita às densidades iniciais dos micro-organismos anammox que, por sua vez, apresentam baixas afinidades pelos substratos, podem ser inibidos por várias substâncias, apresentam taxas lentas de crescimento e à competição por substrato com outras bactérias.

× Os sistemas biológicos que foram inoculados com biomassas provenientes do sedimento do lago Paranoá, Brasília/DF e do lodo da lagoa facultativa tratando efluente do Frigorífico 2, Uberlândia/MG apresentaram melhor performance da atividade anammox durante a etapa 1, correspondente a 120 dias de operação dos sistemas.

x Os inóculos utilizados e/ou as condições estabelecidas nesse estudo não favoreceram a redução do tempo de partida anammox nos sistemas biológicos. Como também verificado em outras pesquisas, o tempo de partida e estabilidade do processo pode ser superior a 200 dias de operação dos sistemas. 


\section{RECOMENDAÇÕES}

* Realizar a identificação filogenética dos grupos de bactérias anammox por meio de clonagem e posterior sequenciamento dos fragmentos obtidos a partir dos clones. Assim, construir a relação filogenética entre as sequências obtidas e aquelas depositadas no Genbank para as candidatas espécies anammox utilizando BLAST (Basic Local Alignment Search Tool).

* Avaliar a dinâmica populacional das bactérias relacionadas ao ciclo do nitrogênio ao longo das etapas experimentais e avaliar a estrutura das comunidades microbiológicas, utilizando das ferramentas de biologia molecular como a PCR quantitativa e do DGGE (Denaturing Gradient Gel Eletrophoresis).

× Avaliar as conversões das formas nitrogenadas por perfis temporais horários para uma melhor definição dos processos metabólicos predominantes ao longo das bateladas. 


\section{REFERÊNCIAS BIBLIOGRÁFICAS}

Abma, W.R; Driessen W.; Haarhuis R.; Loodrecht M.C.M. (2010). “Upgrading of sewage treatment plant by sustainable and cost-effective separate treatment of industrial wastewater". In: Water Science and Technology 61 (7): 1715-1722.

Ahn, Y. Ho. (2006). "Sustainable nitrogen elimination biotechnologies: a review". In: Process Biochemistry, 41: 1709-1721.

Aiyuk S.; Forrez I.; Lieren D. K.; van Haandel A.; Verstraete W. (2006). “Anaerobic and complementary treatment of domestic sewage in regions with hot climates. A review". In: Bioresource Technology, 97 (17): 2225-2241.

Alvarez-Vasquez, H.; Jefferson, B.; Judd, S. J. (2004). "Membrane bioreactors vs conventional biological treatment of landfill leachate: a brief review". In: Journal of Chemical Technology and Biotechnology, 79: 1043-1049.

APHA. (2005). Standard Methods for the examination of water and of wastewater. By Eaton, A.D.; Clesceri, L.S.; Rice, E.W.; Greenberg, A.E.; Frason, M.A.H. (eds). American Public Health Association, American Water Works Association, Water Environmental Federation. $21^{\text {th }}$ ed. USA.

Anthoniesen, A. C.; Loehr, R. C. Prakasam, T. B. S.; Srinath, E. G. (1976). "Inhibition of nitrification by ammonia and nitrous acid”. In: Journal of the Water Pollution Control Federation, 48 (5): 835-851.

Araújo, J. C.; Campos, A. P.; Correa, M. M. S.; Silva, E. C., Von Sperling, M.; Chernicharo, C. A. L. (2010). "Enriquecimento de bactérias anaeróbias oxidadoras de amônia Anammox”. In: Engenharia Sanitária e Ambiental, 15 (2): 205-212.

Araújo, J.C.; Campos, A.C.; Correa, M.M.; Silva, E.C.; Matte, M.H.; Matte, G.R.; Von Sperling, M.; Chernicharo, C.A. (2011). "Anammox bacteria enrichment and 
characterization from municipal activated sludge”. In: Water Science Technology, 64 (7): $1428-1434$.

Aslan, S.; Miller, L.; Dahab, M. (2009). "Ammonium oxidation via nitrite accumulation under limited oxygen concentration in sequencing batch reactors". In: Bioresouce Technology, 100: 659-664.

Bae, H.; Park, K-Soon.; Chung, Yun-Chul; Jung, Jin-Young. (2010). "Distribution of anammox bacteria in domestic WWTPs and their enrichments evaluated by real-time quantitative PCR”. In: Process Biochemistry, 45: 323-334.

Bagchi, S.; Biswas, R.; Nandy, T. (2012). “Autotrophic Ammonia Removal Processes: Ecology to Technology". In: Critical Reviews in Environmental Science and Technology, 42 (13): 1353-1418.

Barbosa, J. S. B. (2010). Remoção biológica de nitrogênio de lixiviado de aterro de resíduos sólidos urbanos por nitrificação e desnitrificação via nitrito. Dissertação de Mestrado em Tecnologia Ambiental e Recursos Hídricos, Departamento de Engenharia Civil e Ambiental, Universidade de Brasília. Brasília. 105p.

Bitton, G. (2005). Wastewater Microbiology, Wiley Liss Pub., New York, 449 p.

Boardman, G. D; Starbuck, S. M.; Hudgins, D. B; Li, X.; Kuhn, D. D. (2004). "Toxicity ammonia to three marine fish and three marine invertebrates". In: Environmental Toxicology, 19 (2): 134-142.

Brandsma, J.; van de Vossenberg, J.; Risgaard-Petersen, N.; Schmid, M. C.; Engstrom, P.; Eurenius, K.; Hulth, S.; Jaeschke, A.; Abbas, B.; Hopmans, E. C.; Strous, M.; Schouten, S.; Jetten, M. S. and Damste, J. S. (2011). “A multi-proxy study of anaerobic ammonium oxidation in marine sediments of the Gullmar Fjord, Sweden”. In: Environ Microbiol Rep. 3 (3), 360-366.

Brasil. Resolução Conama n ${ }^{\circ} 430$ de 13 de maio de 2011. Dispõe sobre condições e padrões de lançamento de efluentes, complementa e altera a Resolução n ${ }^{\circ}$ 357, de 17 de março 
de 2005, do Conselho Nacional de Meio Ambiente - CONAMA. Diário Oficial da República Federativa do Brasil, Brasília, DF, 16 de maio de 2011. Disponível em < http://www.mma.gov.br/port/conama/legiabre.cfm?codlegi=646 >. Acesso em 20 setembro de 2014.

Broda, E. (1977). "Two kinds of lithotrophs missing in nature”. In: Z. Allg. Mikrobiol., 17: 491-493.

Bustin, S.E; Benes, V.; Garson, J.A.; Hellemans, J.; Huggett, J. Kubista, M.; Mueller, R.; Nolan, T.; Pfaffl M.W.; Shipley, G. L.; Vandesompele, J.; Wittwer, C.T. (2009). “The MIQE Guidelines: "Minimum Information for Publication of Quantitative Real-Time PCR Experiments”. In: Clinical Chemistry 55 (4): 611-622.

Callado, N. H.; Foresti, E. (2000). "Tratamento de esgoto doméstico com remoção de nitrogênio e fósforo em reatores seqüenciais em batelada". In: Anais do XXVII Congresso Interamericano de Engenharia Sanitária e Ambiental. ABES - Associação Brasileira de Engenharia Sanitária e Ambiental.

Chamchoi, N.; Nitisoravut, S. (2007). “Anammox enrichment from different conventional sludges". In: Chemosphere, 66: 2225-2232.

Chen, H.; Liu, S.; Yang, F.; Xue, Y.; Wang, T. (2009). “The development of simultaneous partial nitrification, ANAMMOX and denitrification (SNAD) process in a single reactor for nitrogen removal”. In: Bioresource Technology, 100: 1548-1554.

Comeau, Yvès. (2008). “Microbial Metabolism”. In: Henze, M.; van Loosdrescht, M.C.M.; Ekama, G.A.; Brdjanovic, D. (eds.): Microbical Wastewater Treatment: Principles, Modelling and Design, IWA Publishing. London, UK.

Companhia de Saneamento Ambiental do Distrito Federal - CAESB, (2003). Plano de Gestão e Preservação do Lago Paranoá - Produto 01: Levantamento, Caracterização, Evolução e Situação Atual. Brasília - DF, 289p. 
Companhia Energética de Brasília - CEB, (2010). Usina do Paranoá - Dados Compilados. Brasília - DF, 10p.

Costa, M. C. M. S. (2013a). Impacto do tipo de inóculo e das condições operacionais sobre a estrutura da comunidade bacteriana e desempenho do processo ANAMMOX em biofiltros usando espuma de poliuretano como meio suporte dos microrganismos. Tese de Doutorado em Saneamento, Meio Ambiente e Recursos Hídricos da Universidade Federal de Minas Gerais, Belo Horizonte MG, 107 p.

Costa, M. E. L. (2013b). Monitoramento e modelagem das águas da drenagem urbana na bacia do lago Paranoá. Dissertação de Mestrado em Tecnologia Ambiental e Recursos Hídricos, Publicação PTARH.DM-148/2013, Departamento de Engenharia Civil e Ambiental, Universidade de Brasília, Brasília, DF, 179p.

Costa, M. C. M. S.; Carvalho, L.; Leal, C. D.; Dias, M. F.; Martins, K. L.; Garcia, G. B.; Mancuello, I.; Hipolito, T.; Abreu, E. F.; Okada, D.; Etchebehere, C.; Chernicharo, C. A._L.; Araújo, J. C. (2014). "Impact of inocula and operating conditions on the microbial community structure of two anammox reactors". In: Environmental Technology, p. 1-12.

Dapena-Mora, A.; Campos, J. L.; Mosquera-Corral, A.; Jetten, M. S. M.; Méndez, R. (2004). "Stability of the Anammox process in a gas-lift reactor and a SBR". In: Journal of Biotechnology, 110: 159-170.

Dang, H.; Zhou, H.; Zhang, Z., Yu, Z.; Hua, E.; Liu, X.; Jiao, N. (2013). "Molecular detection of Candidatus Scalindua pacifica and environmental responses of sediment Anammox bacterial community in the Bohai Sea, China”. In: PLoS One, 8 (4): e61330.

Date, Y.; Isaka, K.; Ikuta, H.; Sumino, T.; Kaneko, N.; Yoshie, S.; Tsuneda, S.; Inamorim Y. (2009). "Microbial diversity of anammox bactéria enriched from differente type of seed sludge in an anaerobic continuous-feeding cultivation reactors". In: Journal of Bioscience and Bioengineering, 107 (3): 281-286. 
Dijkman, H.; Strous, M. (1999). "Process for ammonium removal from wastewater". PCT/NL99/00446.

Egli, K.; Langer, C.; Siegrist, H-R.; Zehnder, A. J. B.; Wagner, M.; van der Meer, J. R. (2003). "Community Analysis of ammonia and nitrite oxidizers during start-up of nitritation reactors". In: Applied and Environmental Microbiology, 69: 3213-3222.

Egli, K.; Bosshard, F.; Werlen, C.; Lais, P.; Siegrist, H.; Zehnder, A. J.; van der Meer, J. R. (2003). "Microbial composition and structure of a rotating biological contactor biofilm treating ammonium-rich wastewater without organic carbon". In: Microbiology Ecology, 45: 419-432.

Fdz-polanco, F.; Fdz-polanco, M.; Fernandez, N.; Urueña, M.A.; Garcia, P.A.; Villaverde, S. (2001). "New process for simultaneous removal of nitrogen and sulphur under anaerobic conditions". In: Water Research, 35 (4): 1111-1114.

Field, Andy. (2009). Descobrindo a estatística usando o SPSS. $2^{\text {a }}$ Edição. Porto Alegre: Artmed, 688p.

Fuchsman, C.A.; Staley, J.T.; Oakley, B.B.; Kirkpatrick, J.B.; Murray, J.W. (2012). "Freeliving and aggregate-associated Planctomycetes in the Black Sea". In: FEMS Microbiol. Ecol., 80: 402-416.

Ganigué, R.; López, H.; Balaguer, M. D.; Colprim, J. (2007). "Partial ammonium oxidation to nitrite of high ammonium content urban landfill leachates”. In: Water Research, 41: 3317-3326.

Gao, D.; Tao, Y. (2011). "Versatility and application of anaerobic ammonium-oxidizing bacteria”. In: Applied Microbiology and Biotechnology, 91: 887-894.

Governo do Distrito Federal - GDF (2012a). Revisão e Atualização do Plano de Gerenciamento Integrado de Recursos Hídricos do Distrito Federal -Volume I Diagnóstico. Brasília - DF, 830. 
Governo do Distrito Federal - GDF (2012b). Revisão e Atualização do Plano de Gerenciamento Integrado de Recursos Hídricos do Distrito Federal -Volume II Prognóstico e Programas de Ação. Brasília - DF, 1094.

Hair, J.F.; Anderson, R.E.; Tatham, R.L.; Black, W.C. (2005). Análise multivariada de dados. $5^{\text {a }}$ edição. Porto Alegre: Bookman, 593p.

Hasler, A.D.; Swenson, M.E. (1967). “Eutrophication”. In: Science, 158 (3798): 278-283.

Hellinga, C.; Schellen, A.A.J.C.; Mulder, J.W.; van Loosdrecht, M.C.M.; Heijnen, J.J. (1998). "The Sharon process: an innovative method for nitrogen removal from ammonium-rich waste water". In: Water Science and Technology, 37 (9): 135-142.

Henze, Mogens. (2008). "Wastewater Treatment Development Biological”. In: Henze, Mogens; van Loosdrecht, Mark.C.M; Ekama, George.A.; Brdjanovic, Damir (eds). Wastewater Treatment: Principals, Modellind and Design. IWA Publishing. London, UK.

Hirsch, Matheus D.; Long, Zachery T.; Song, Bongkeun (2011). “Anammox Bacterial Diversity in Various Aquatic Ecosystems Based on the Detection of Hydrazine Oxidase Genes (hzoA/hzoB)". In: Microbial Ecology, 61: 264-276.

Hu, Ba-lan; Zheng, Ping; Tang, Chong-jian; Chen, Jian-wei; van der Biezen, Erwin; Zhang, Lei; Ni, Bing-jie; Jetten, Mike S.M.; Yan, Jia; Yu, Han-Qing; Kartal, Boran. (2010). "Identification and quantification of anammox bacteria in eight nitrogen removal reactors". In: Water Research, 44: 5014-5020.

IRAR (2008). Gestão e tratamento de lixiviados produzidos em aterros sanitários de resíduos sólidos. Relatório do Instituto Regulador de Águas e Resíduos, IRAR 03 2008. Departamento de Ciências e Engenharia do Ambiente, Faculdade de Ciências e Tecnologia da Universidade Nova de Lisboa, Portugal.

Isaka, K.; Sumino T. (2007). “Apparatus for removing nitrogen”. US 2007/7267764, $(11 / 09 / 2007)$. 
Isoldi, L. A.; Koetz, P. R.; Faria, O. L. V. (2003). "Remoção de carbono orgânico e nitrificação de águas residuárias da industrialização de arroz”. In: Revista Brasileira de Agrociência, 9: 273-277.

Jeison; D.; Chamy, R. (1998). "Novel technique for measuring the size distribution of granules from anaerobic reactores for wastewater treatment". In: Water Science and Biotechnology, 37: 135-142.

Jenni, S.; Vlaeminck, S.; Morgenroth, E.; Udert, K. M. (2014). "Successful application of nitritation/anammox to wastewater with elevated organic carbon to ammonia rations. In: Water Research, 49: 316-326.

Jetten, M.; Schmid, M.; van de Pas-Schoonen, K.; Sinningle, D.; Strous, M. (2005). "Anammox organisms: enrichment, cultivation and environmental analysis". In: Methods in Enzymology, 397: 34-57.

Jetten, M.; Strous, M. van de Pas-Schoonen, K.; Schalk, J.; van de Graaf, A. A.; Logemann, S.; Muyzer, G.; van Loosdrecht, M. C. C.; Kuenen, J. G. (1999). "The anaerobic oxidation of ammonium”. In: FEMS Microbiology Reviews, 22: 421-437.

Jetten, M. S. M.; Niftrik, L. V. V.; Strous, M.; Kartal, B.; Keltjens, J. T.; Op Den Camp, H. J. (2009). "Biochemistry and molecular biology of Anammox bacteria. Critical reviews". In: Biochemistry and Molecular Biology, 44: 65-84.

Jetten, J.S.M., Op den Camp, H.J.M., Kuenen, J.G., and Strous, M. "Family I. 'Candidatus Brocadiaceae' fam. nov." In: Bergey's Manual of Systematic Bacteriology, 2nd ed., vol. 4 (The Bacteroidetes, Spirochaetes, Tenericutes (Mollicutes), Acidobacteria, Fibrobacteres, Fusobacteria, Dictyglomi, Gemmatimonadetes, Lentisphaerae, Verrumicrobia, Chlamydiae, and Planctomycetes) (N.R. Krieg, J.T. Staley, D.R. Brown, B.P. Hedlund, B.J. Paster, N.L. Ward, W. Ludwig, and W.B. Whitman, eds.), Springer-Verlag, New York (2011). pp. 918-925.

Jin, Ren-Cun; Yang, Guang-Feng; Yu, Jin-Jin; Zheng, Ping. (2012). "The Inibition of the 
Anammox process: a Review". In: Chemical Engineering Journal, 197: 67-79.

Jogler, C.; Waldmann, J.; Huang, X.; Jogler, M.; Glöckner, Frank O.; Mascher, T.; Kolter, R. (2012). "Identification of Proteins Likely To Be Involved in Morphogenesis, Cell Division, and Signal Transduction in Planctomycetes by Comparative Genomics”. In: Journal of Bacteriology, 194 (23): 6419-6430.

Jordão, E. P.; Pessôa, C. A. (2005). Tratamento de Esgotos Domésticos. $4^{\mathrm{a}}$ edição. Rio de Janeiro: ABES - Depto de Recursos Hídricos e Meio Ambiente, Escola Politécnica, UFRJ. 932p.

Kartal, B.; Rattray, J.; van Niftrick, L. A.; van de Vossenberg, J. Schmid, M. C. Webb, R. J.; Schouten, S.; Fuerst, J. A. Damste, J. S. S.; Jetten, M. S. M.; Strous, M. (2007). "Candidatus Anammoxoglobus propionicus" a new propionate oxidizing species of anaerobic ammonium oxidizing bacteria”. In: Systematic and Applied Microbiology, 30 (1): 39-49.

Kartal, B.; Geerts, W.; Jetten, M. S. (2011). "Cultivation, detection and ecophysiology of anaerobic ammonium-oxidizing bacteria”. In: Methods in Enzymology, 486: 89-108.

Kartal, B.; van Niftrik, L.; Keltjens, J. T.; Op den Camp, H. J. M.; Jetten, M. S. M. (2012). Anammox-Growth Physiology, Cell Biology, and Metabolism. In: Robert K. Poole (editor): Advances in Microbial Physiology, Vol. 60, Burlington: Academic Press, pp. 211-262.

Kalyuzhnyi, S.V.; Gladchenko, M.; Mulder, A.; Versprile, B. (2009). "DEAMOX: New biological nitrogen removal process based on anaerobic ammonia oxidation coupled to suphide driven conversion of nitrate into nitrite". In: Water Resource, 40: 36373645 .

Kalyuzhnyi, S.V.; Gladchenko, M. (2009). "DEAMOX: New microbiological process of nitrogen removal from strong nitrogenous wastewater". In: Desalination, 248: 783793. 
Kayyuzhnyi, S.V.; Shestakova, N.M.; Tourova, T.P.; Poltaraus, A.B.; Gladchenko, M.A.; Trukhina, A.I.; Nazina, T.N. (2010) "Phylogenetic analysis of a microbial community involved in anaerobic oxidation of ammonium nitrogen". In: Mikrobiologia, 79 (2): 237-246.

Khin, T.; Annchhatre, A.P. (2004). "Novel microbial nitrogen removal process". In: Biotechnology Advances, 22 (7): 517-532.

Kim, D-J.; Lee, D-I; Keller, J. (2006). "Effect of temperature and free ammonia on nitrification and nitrite accumulation in landfill leachate and analysis of its nitrifying bacterial community by FISH”. In: Bioresources Technology, 97: 459-468. 2006.

Kuai, L.; Verstraete, W. (1998). "Ammonium removal by the oxigen-limited autotrophic nitrification-denitrification system”. In: Applied and Environmental Microbiology, 64 (11): 4500-4506.

Kunz, A.; Vanotti, M.; Szogi, A.; Gonzales, M. C. G.; Schierholt Neto, G. F.; Soares, H. M. (2007). "Development of Anammox process for animal waste treatment: Experiences in Brazil". In: International Symposium on Air Quality and Waste Management for Agriculture, 2007, Broomfield, Colorado. CD-Rom Proceedings: ASABE, Publication Number 701P0907cd.

Kuypers, M.M.; Sliekers, A.O.; Lavik, G.; Schmid, M.; Jorgensen, B. B.; Kuenen, J.G.; Sinninghe-Damste, J.S.; Strous, M.; Jetten, M.S.M. (2003). “Anaerobic ammonium oxidation by anammox bacteria in the Black Sea”. In: Nature 422 (6932): 608-611.

Lackner, S.; Gilbert, E.M.; Vlaeminck, S.E.; Joss, A.; Horn, H.; van Loosdrecht, M.C.M. (2014). "Full-scale partial nitritation/anammox experiences - An application survey". In: Water Research 55: 292-303.

Lackner, Susanne; Lindenblatt, Claus, Horn, Harald, Horn. (2012). "Swinging ORP as operation strategy for stable resject water treatment by nitritation-anammox in sequencing batch reactors”. In: Chemical Engineering Journal, 180: 190-196. 
Lan, Chien-Ju; Kumar, Mathava; Wang, Chih-Cheng; Lin, Jih-Gaw. (2011). "Development of simultaneous partial nitrification, anammox and denitrification (SNAD) process in a sequential batch reactor". In: Bioresource Technology, 102: 5514-5519.

Li, A.; Sun, G.; Xu, M. (2008). "Recent patents on anammox process". In: Recent Patents on Engineering 2: 189-194.

Li, H.; Zhou, S.; Ma, W.; Huang, G.; Xu, B. (2012). "Fast start-up of anammox reactor: operational strategy some characteristics as indicators of reactor performance". In: Desalination 286: 436-441.

Li, M.; Cao, H.; Hong, Y. Gu, Ji-D. (2011). "Spatial distribution and abundances of ammonia-oxidizing archaea (AOA) and ammonia-oxidizing bacteria (AOB) in mangrove sediments”. In: Applied Microbiology Biotechonology, 89 (4): 1243-2154.

Liang, Z.; Liu, J. (2007). "Control factor of partial nitrification for landfill leachate treatment”. In: Journal of Environmental Sciences, 19: 523-529.

Liang, Z.; Liu, J. (2008). "Landfill leachate treatment with a novel process: Anaerobic ammonium oxidation (Anammox) combined with soil infiltration system”. In: Journal of Hazardous Materials 151: 202-212.

Li-dong, Shen; An-hui, Hu; Ren-cun, Jin; Dong-qing, Cheng, Ping, Zheng; Xiang-yang, Xu; Bao-lan, Hu. (2012). "Enrichment of bacteria from three sludge sources for the startup of monosodium glutamate industrial wastewater treatment system". In: Journal of Hazardous Material, 199-200: 193-199.

Lindsay, M.R.; Webb, R.I.; Strous, M.; Jetten, M.S.; Butler, M.K.; Forde, R.J.; Fuerst, J.A. (2001). "Cell compartmentalisation in planctomycetes: novel types of structural organisation for the bacterial cell”. In: Archives Microbiology, 175: 413-429.

Liporoni, L. M. (2012). Estudo preliminar da qualidade da água do Lago Paranoá, Brasília - DF, utilizando um modelo de qualidade de água bidimensional. Dissertação de Mestrado em Tecnologia Ambiental e Recursos Hídricos, Publicação PTARH.DM- 
138/2012, Departamento de Engenharia Civil e Ambiental, Universidade de Brasília, Brasília, DF, 188p.

Liu, S.; Yang, F.; Gong, Z.; Meng, F.; Chen, H.; Xue, Y.; Furukawa, K. (2008). “Application of anaerobic ammonium-oxidizing consortium to achieve completely autotrophic ammonium and sulfate removal". In: Bioresource Technology, 99: 6817-6825.

Ludwig, W., Euzeby, J., and Whitman, W.B. In: N.R. Krieg, J.T. Staley, D.R. Brown, B.P. Hedlund, B.J. Paster, N.L. Ward, W. Ludwig, and W.B. Whitman (eds.). (2011) Road "Map of the Bacteroidetes, Spirochaetes, Tenericutes (Mollicutes), Acidobacteria, Fibrobacteres, Fusobacteria, Dictyoglomi, Gemmatimonadetes, Lentisphaerae, Verrucomicrobia, Chlamydiae, and Planctomycetes". In Bergey's Manual of Systematic Bacteriology 4, 2nd ed., Springer, New York, pp. 1-24.

Maier, R.M.; Pepper I. L.; Gerba, C. P. (2009). Environmental Microbiology. Academic Press/Elsevier. 2a edição. 598p.

Madigan, M. T.; Martinko, J. M.; Dunlap, P. V.; Clark, D. P. (2010). Microbiologia de Brock. $12^{\mathrm{a}}$ ed. Porto Alegre: Artmed, 1160p.

Maroco, J. (2007). Análise estatítica com utilização do SPSS. $3^{\text {a }}$ Edição, Lisboa: Edições Sílabo, Lda. 822p.

Martins, T. H. (2007). Enriquecimento de consórcios microbianos em quimiostato sob condições anammox. São Carlos, Dissertação (Mestrado) - Escola de Engenharia de São Carlos. Universidade de São Paulo. 58p.

Metcalf \& Eddy, Inc. (1991). Wastewater Engineering. Treatment, Disposal and Reuse. Inc. Revisado Tchobanoglous, G.; Burton, F. L. $3^{\text {a }}$ edição. McGraw-Hill, Inc. 1334p.

Mulder, A. (1992). “Anoxic Ammonia Oxidation”. US/1992/5078884, (07/01/1992).

Mulder, A.; van de Graaf, A. A.; Robertson, L. A.; Kuenen, J. G. (1995). "Anaerobic ammonium oxidation discovered in a denitrifying fluidized bed reactor". In: FEMS 
Microbiology Ecology, 16: 177-184.

Muñoz, J. C.L.; Babero, F. S.; Molist, J. S. (2007). “Anàlisi comparativa dels processos emergents sharon i anammox per al tractament d'aigües amb una alta càrrega de nitrogen”. In: Ciències Ambientals. Disponível em: http://hdl.handle.net/10256/76.

Ni, B.J.; Zeng, R.J.; Fang, F.; Xie, W.M.; Xu, J.; Sheng, G.P.; Sun, Y.J.; Yu, H.Q. (2011). "Evaluation on factors influencing the heterotrophic growth on the soluble microbial products of autotrophs". In: Biotechonology and Bioengineering 108: 804-812.

Ni, B.J.; Ruscalleda, M.; Smets, B. F (2012). "Evaluation on the microbial interactions of anaerobic ammonium oxidizers and heterotrophs in Anammox biofilm". In: Water Research, 46: 4645-4652.

Okabe, S.; Hiratia, K.; Ozawa, Y.; Watanabe, Y. (1996). "Spatial microbial distributions of nitrifiers and heterotrophs in mixed populations biofilms". In: Biotechonology and Bioengineering, 50: 24-35.

Oshiki, M., Shimokawa, M., Fujii, N., Satoh, H. and Okabe, S. (2011) "Physiological characteristics of the anaerobic ammonium-oxidizing bacterium 'Candidatus Brocadia sinica'. In: Microbiology 157 (6), 1706-1713.

Pacheco, J. W.; Yamanaka, H. T. (2006). Guia técnico ambiental de abates (suínos e bovinos). São Paulo: CETESB, 98p.

Park, H.; Rosenthal, A. Ramalingam, K.; Fillos, J. Chandran, K. (2010). "Linking community profiles, gene expression and $\mathrm{N}$-removal in anammox bioreactors treating municipal anaerobic digestion reject water". In: Environmental Science \& Technology, 44(16): 6110-6116.

Park, H.; Rosenthal, A.; Jesek, R.; Ramalingam, K.; Fillos, J.; Chandran, K. (2010). "Impact of inocula and growth mode on the molecular microbial ecology of anaerobic ammonia oxidation (anammox) bioreactor communities”. In: Water Research, 44: 5005-5013. 
Peng, Y.; Zhu, G. (2006). "Biological nitrogen removal with nitrification and denitrification via nitrite pathway". In: Applied Microbiology Biotechnology, 73: 15-26.

Porto, M. F. A. (1995). “Aspectos qualitativos do escoamento superficial em áreas urbana”. In: Tucci, C.E.M.; Porto, R. L. L.: Barros, M. T. (Eds). Drenagem Urbana. Porto Alegre: ABRH/Editora da Universidade/UFRS. 387-414. 228p.

Philomeno, M. G. 2007. A comunidade fitoplanctônica e a restauração do Lago Paranoá, Brasília-DF. Teses de Doutorado em Ecologia, Departamento de Ecologia, Universidade de Brasília, Brasília, DF, 223 p.

Quan, S. X.; Rhee, S. K.; Zuo, J. E.; Yang, Y.; Bae, J. W.; Park, J. R.; Lee, S. T. Park, Y. H. (2008). "Diversity of ammonium-oxidising bacteria in a granular sludge anaerobic ammonium-oxidizing (anammox) reactor”. In: Environmental Microbiology, 10 (11): 3130-3139.

Reginatto, V.; Teixeira, R. M.; Pereira, F.; Schmidell, W.; Furigo Jr. A.; Menes, R.; Etchebehere, C.; Soares, H.M. (2005). “Anaerobic ammonium oxidation in a bioreactor treating slaughterhouse wastewater". In: Brazilian J. of Chemical Engineering 22 (4): 593-600.

Rosselló-Mora, R.; Amann, R. (2001). The species concept for prokaryotes. In: FEMS Microbiology Reviews 25: 39-67.

Rothrock, M.J. Jr., Vanotti, M.B., Szogi, A.A., Garcia Gonzales, M.C., and Fuji, T. (2011). "Long-term preservation of anammox bacteria." In: Applied Microbiology Biotechnology 92:147-157.

Sánchez, J.; Sanabria, J.; Jetten, M. 2014. "Faster autotrophic growth of anaerobic ammonium oxidizing microorganisms in presence of nitrite, using inocula from Colombia”. In: Revista Colombina de Biotecnologia, XVI (1): 146-152.

Sànchez-Melsió, A.; Cáliz, J.; Balaguer, M. D.; Colprim, J.; Vila, X. (2009). “Development of batch-culture enrichment coupled to molecular detection for screening of natural 
and man-made environments in search of anammox bactéria for N-removal bioreactors systems". In: Chemosphere, 75: 169-179.

Sanz, Jose L; Kochling, Thorsten. (2007). "Molecular biology techniques used in wastewater treatment: An overview”. In: Process Biochemistry, 42 (2): 119-133.

Scheeren, M. B.; Kunz, A.; Steinmetz, R. L. R.; Dressler, V. L. (2011). “O processo ANAMMOX como alternativa para tratamento de águas residuárias, contendo alta concentração de nitrogênio". In: Revista Brasileira de Engenharia Agrícola e Ambiental, 15 (12): 1289-1297.

Schierholt Neto, G. F. (2007). Desenvolvimento de uma flora de micro-organismos oxidadores anaeróbios de amônia utilizando inóculos provenientes de dejeto suíno. Dissertação de Mestrado. Programa de Pós-Graduação em Engenharia Química da Universidade Federal de Santa Catarina. Florianópolis. 99p.

Schmid, M.C.; Hooper A.B; Klotz M.G., Woebken, D., Lam P., Kuypers, M.M.M, Pommerening-Roeser, A.; op den Camp, H.J.M.; Jetten M.S.M. (2008). "Environmental detection of octahaem cytochrome c, hydroxilamine/hydrazine oxidoreductase genes of aerobic and anaerobic ammonium-oxidizing bacteria”. In: Environmental Microbiology, 10: 3140-3149.

Schmid, M.C.; Maas, B.; Dapena, A.; van de Pas-Schoonen; K.; van de Vossenberg J.; Kartal, B.; van Niftrik, L.; Schmidt, I.; Cirpus, I.; Kuenen, J. G.; Wagner, M.; Damsté, J. S. S., Kuypers, M.; Revsbech, N. P.; Mendez, R., Jetten, M. S. M.; Strous, M. (2005). "Mini review - biomarker for in situ detection of anaerobic ammonium-oxidizing (Anammox) bacteria”. In: Applied Environmental Microbiology, 71: 1677-1684.

Schmid, M.C; Schimitz-Esser, S.; Jetten, M.; Wagner, M. (2001). "16S-23S rDNA intergenic spacer and 23S rDNA of anaerobic ammonium-oxidizing bactéria: implications for phylogeny and in sity detection". In: Environmental Microbiology 3 (7): 450-459. 
Schmid, M.C, Twachtmann, U., Klein, M., Strous, M., Juretschko, S., Jetten, M., Metzger, J.W., Schleifer, K.H., and Wagner, M. (2000). "Molecular evidence for genus level diversity of bacteria capable of catalyzing anaerobic ammonium oxidation." In: Syst. Appl. Microbiol., 23:93-106.

Schmid, M.C; Walsh, K.; Webb, R.; Rijpstra, W.I.; van de Pas-Schoonen, K.; Verbruggen, M.J.; Hill, T.; Moffett, B; Fuerst, J.; Schouten, S.; Damste, J.S.; Harris, J.; Shaw, P.; Jetten, M.; Strous, M. (2003). Candidatus Scalindua brodae, sp. nov., Candidatus Scalindua wagneri, sp. nov, two new species of anaerobic ammonium oxidizing bactéria”. In: Systematic Applied Microbiology, 26 (4): 529-538.

Schmidt, Ingo; Sliekers Olav; Schmid, Markus; Bock, Eberhard; Fuerst, John; Kuenen, J. Gijs; Jetten, Mike S.M.; Strous, Marc. (2003). "New concepts of microbial treatment processes for the nitrogen removal in wastewater". In: FEMS Microbiology Reviews, 27: 481-492.

Silva-Pereira, I. (2003). Amplificação de DNA por PCR. In. Azevedo, M. O.; Felipe, M. S. S.; Brigido, M. M.; Maranhão, A. Q.; Souza, M. T. (orgs). Técnicas básicas em Biologia Molecular. Editora Universidade de Brasília. Brasília. 212p.

Sliekers, A.O; Derwort, N., Campos Gomes, J.L.; Strous, M. Kuenen, J.G.; Jetten, M.S.M. (2002). "Completely autotrophic nitrogen removal over nitrite in one single reactor". In: Water Research, 36: 2475-2482.

Sliekers, A. O.; Haaijer, S. C. M.; Stafsnes, M. H. Kuenen J. G.; Jetten, M. S. M. (2005). "Competition and coexistence of aerobic ammonium-and nitrite-oxidizing bacteria at low oxygen concentrations”. In: Applied Microbiology Biotechnology, 68: 808-817.

Sonthiphand, P.; Hall, M.W.; Neufeld, J. D. (2014). "Biogeography of anaerobic ammoniaoxidizing (anammox) bacteria”. In: Frontiers in Microbiology, 5 (399): 1-14.

Souza, F.P. (2014). Monitoramento e modelagem hidrológica da sub-bacia do Lago Paranoá - Brasília/DF - e avaliação de bacias de detenção. Dissertação de Mestrado em Tecnologia Ambiental e Recursos Hídricos, Publicação PTARH.DM-165/2014, 
Departamento de Engenharia Civil e Ambiental, Universidade de Brasília, Brasília, DF, 139p.

Strous, M.; Fuerst, J.; Kramer, E.; Logemann, S.; Muyzer, G.; Van de Pas, K.; Webb, R.; Kuenen, J.; Jetten, M. S. M. (1999 a). "Missing lithotroph identified as new planctomycete". In: Nature, 400: 446 a 449.

Strous, M.; Heijnen, J.J.; Kuenen, J.G.; Jetten, M.S.M. (1998). "The sequencing batch reactor as a powerful tool for the study of slowly growing anaerobic ammoniumoxidizing microorganisms”. In: Applied Microbiology Biotechonology, 50 (5): 589596.

Strous, M.; Kuenen, J. G.; Jetten, M. S. M. (1999 b). "Key physiology of anaerobic ammonium oxidation”. In: Applied Microbiology Biotechonology, 65: 3248-3250.

Strous, M., Pelletier, E., Mangenot, S., Rattei, T., Lehner, A., Taylor, M.W., Horn, M., Daims, H., Bartol-Mavel, D., Wincker, P., Barbe, V., Fonknechten, N., Vallenet, D., Segurens, B., Schenowitz-Truong, C., Medigue, C., Collingro, A., Snel, B., Dutilh, B.E., Op den Camp, H.J., van der Drift, C., Cirpus, I., van de Pas-Schoonen, K.T., Harhangi, H.R., van Niftrik, L., Schmid, M., Keltjens, J., van de Vossenberg, J., Kartal, B., Meier, H., Frishman, D., Huynen, M.A., Mewes, H.W., Weissenbach, J., Jetten, M.S., Wagner, M., and Le Paslier, D. (2006). "Deciphering the evolution and metabolism of an anammox bacterium from a community genome." In: Nature 440:790-794.

Strous, M.; Van Gerven, E.; Ping, Z.; Kuenen, J. G.; Jetten, M.S.M. (1997). “Ammonium removal from concentrated waste streams with Anaerobic Ammonium Oxidation (Anammox) process in different reactor configuration”. In: Water Research, 31: 19551962.

Sun, W.; Banihani, Q.; Sierra-Alvarez, R.; Field, J.A. (2011). "Stoichiometric and molecular evidence for the enrichment of anaerobic ammonium oxidizing bacteria from wastewater treatment plant sludge samples”. In: Chemosphere, 84: 1262-1269. 
Suneethi, S.; Joseph, K. (2011). "Batch culture enrichment of anammox populations from anaerobic and aerobic seed cultures”. In: Bioresource Technology, 102: 585-591.

Takenaka, N.; Daimon, T.; Ueda, A.; Sato, K.; Kitano, M. Bandon, H.; Maeda, Y. (1998). "Fast oxidation reaction of nitrite by dissolved oxygen on the freezing process in the tropospheric aqueous phase. In: Journal of Atmospheric Chemistry 29, 135-150.

Tao, Y.; Gao, D.W.; Wang, H.Y.; Kreuk, M.; Ren, N.Q. (2013). "Ecological characteristics of seeding sludge triggering a prompt start-up of anammox". In: Bioresource Technology, 133: 475-481.

Tamura K, Dudley J, Nei M \& Kumar S. (2007). “MEGA4: Molecular Evolutionary Genetics Analysis (MEGA) software version 4.0”. In: Molecular Biology and Evolution, 24:1596-1599.

Terada, A.; Zhou, S.; Hosomi, M. (2011). "Presence and detection of anaerobic ammoniumoxidizing (anammox) bacteria and appraisal of anammox process for high-strength nitrogenous wastewater treatment: a review". In: Clean Technologies and Environmental Policy, publicação online.

Third, K. A.; Olav Sliekers, A.; Kuenen, J. G.; Jetten, M. S. M. (2001). “The CANON system (Completely Autotrophic Nitrogen-removal Over Nitrite) under ammonium limitation: Interaction and Competition between three groups of Bacteria”. In: Systematic Applied Microbiology 24: 588-596.

Tomaz, P. 2011. Remoção de sedimentos em BMPs (Best Management Practices). 278 p. disponível em: <http://www.pliniotomaz.com.br/downloads/livros/livro_remocao/ livro_re mocao_sedimentos.pdf> Acesso em 25 de janeiro de 2015.

Tortora, G. J.; Funke, B. R.; Case, C.L. (2005). Microbiologia. $8^{\mathrm{a}}$ ed. Porto Alegre: Artmed, $894 p$.

Tsushima, I.; Kindaichi, T.; Okabe, S. (2007a). "Quantification of anaerobic ammoniumoxidizing bacteria in enrichment cultures by real-time PCR”. In: Water Research, 41: 
785-794.

Tsushima, I.; Ogasawara, Y.; Kindaichi, T.; Satoh, H.; Okabe, S. (2007b). “Development of high-rate anaerobic ammonium-oxidizing (anammox) biofilm reactors". In: Water Research, 41: 1623-1634.

Udert, K. M.; Larsen, T.A.; Gujer, N. (2005). "Chemical nitrite oxidation in acid solutions as a consequence of microbial ammonium oxidation. In: Environmental Science \& Technology, 39: 4066-4075.

van de Graaf, A.A.; De Bruijin, P.; Robertson, L.A.; Jetten, M.S.M.; Kuenen, J.G. (1996). "Autotrophic growth of anaerobic ammonium-oxidizing micro-organisms in fluidized bed reactor". In: Microbiology, 142: 2187-2196.

van der Star, W.; Abma, W.R.; Blommers, D.; Mulder J.W.; Tokutomi, T.; Strous, M.; Picioreanu, C.; van Loosdrescht, M.C.M.; 2007. "Startup of reactor for anoxic ammonium oxidation: experiences from the first full-scale anammox in Rotterdam". In: Water Research, 41 (18): 4149-4163.

van de Vossenberg, J.; Rattray, J.E.; Geerts, W.; Kartal, B.; van Niftrik, L.; van Donselaar, E.G.; Jaap, S.; Damsté, S.; Strous, M.; Jetten, M.S.M. (2008). Enrichment and characterization of marine anammox bacteria associated with global nitrogen gas production. In: Environ.Microbiol., 10: 3120-3129.

van Hulle, S.W.H.; Vandeweyer, H.J.P.; Meesschaert, B.D.; Vanrolleghem, P.A.; Dejans, P. and Dumoulin, A. 2010. "Engineering aspects and practical application of autotrophic nitrogen removal from nitrogen rich streams". In: Chemical Engineering Journal, 162:1-20.

van Loosdresch, M.C.M; Jetten, M.S.M. (1997). "Method of treating ammonia comprising wastewater". PCT/NL97/00482 (25/08/1997).

Vanotti, M.B., Szogi, A., and Rothrock, M.J. Jr. "Novel anammox bacterium isolate." US Patent Application S/N 13/013,874, filed 1/26/2011."US Patent and Trademark Office, 
Washington, DC. (2011)

Vives, M. T.; Gonzáles, E.; Lópes, H.; Ganigué, R.; Rusculleda, M.; Balaguer, M.D.; Colprim, J.; Jiméne; Elorduy, M. (2007). “Clonic: Closing the nitrogen cycle from landfill leachates. A biological process with partial nitritation and anammox followed by thermal dry treatment”. In: Proceedings Sardinia 2007, Eleventh Internacional Waste Management and landfill Symposium.

Vlaeminck, S.E.; Hay, A.G.; Maignien, L.; Verstraete, W. (2011). "In quest of the nitrogen prokaryotes of the early Earth". In: Environmental Microbiology, 13 (2): 283-295.

Wang, C-C.; Lee, P-H.; Kumar, M.; Huang, Y-T.; Sung, S.; Lin, J-G. (2010). "Simultaneous partial nitrification, anaerobic ammonium oxidation and denitrification (SNAD) in a full-scale landfill-leachate treatment plant”. In: Journal of Hazardous Materials, 175: 622-628.

Windey, K.; De Bo, I.; Verstraete, W. (2005). “Oxygen-limited autotrophic nitrificationdenitrification (OLAND) in a rotating biological contactor treating high-salinity wastewater". In: Water Research 39: 4512-4520.

Woebken, D.; Lam, P.; Kuypers, M.M.; Naqvi, S.W.; Kartal, B.; Strous, M.; Jetten, M.S.M.; Fuchs, B.M.; Amann, R. (2008). “A microdiversity study of anammox bactéria reveals a novel Candidatus Scalindua phylotype in marine oxygen minimum zones". In: Environmental Microbiology 10 (11): 3106-3119.

World Health Organization, WHO. (2011). Nitrate and Nitrite in Drinking-water. WHO/SDE/WSH/07.01/16/REV/1. 23p. disponível em: < http://www.who.int/water_ sanitation_health/dwq/chemicals/nitratenitrite2ndadd.pdf>.

Yossef, N. H.; Couger, M. B.; Mccully, A. L.; Guerrero Criado, A. E.; Elshahed, M.S. (2014). "Assessing the global phylum level diversity within the bacterial domain: a Review". In: Journal of advanced Research disponível em <http://dx.doi.org/10.1016/j.jare. 2014.10.005. 


\section{APENDICE I}

Análise de PCR e avaliação do sucesso de extração de DNA e das amplificações em eletroforeses em gel de agarose a $1 \%$ corado com brometo de etídeo $\left(1 \mu \mathrm{g} \cdot \mathrm{mL}^{-1}\right)$.

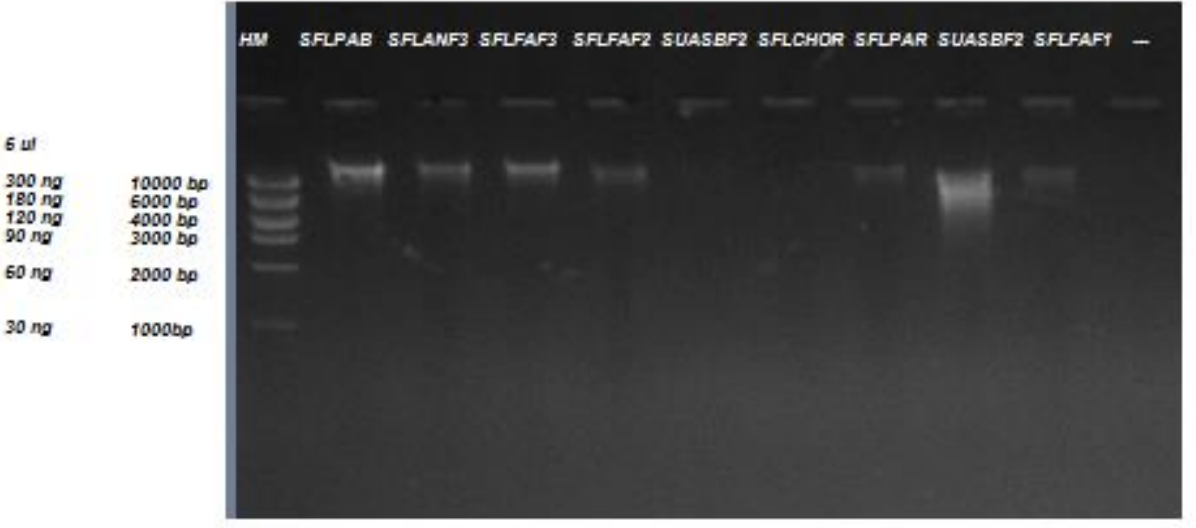

Figura 5.1: Eletroforese em gel de agarose a $1 \%$ corado com brometo de etídeo $\left(1 \mu \mathrm{g} \cdot \mathrm{mL}^{-1}\right)$ para avaliação do DNA genômico extraído dos seis inóculos utilizados nos experimentos em bateladas para enriquecimento anammox. Par: sedimento do lago Paranoá, Brasília/DF (SFLPAB); AnF1: lodo da lagoa anaeróbia tratando efluente do Frigorífico 1, Araguari/MG (SFLANF3); FaF1: lodo da lagoa facultativa tratando efluente do Frigorífico 1, Araguari/MG (SFLFAF3); FaF2: lodo de lagoa facultativa tratando efluente do Frigorífico 2,

Uberlândia, MG (SFLFAF2); UaF2: lodo de reator UASB tratanto efluente do Frigorífico 2, Uberlândia/MG (SUASBF2); CHOR: sedimento da lagoa de acumulação de chorume do aterro controlado Jockey Clube, Brasília, DF (SFLCHOR).

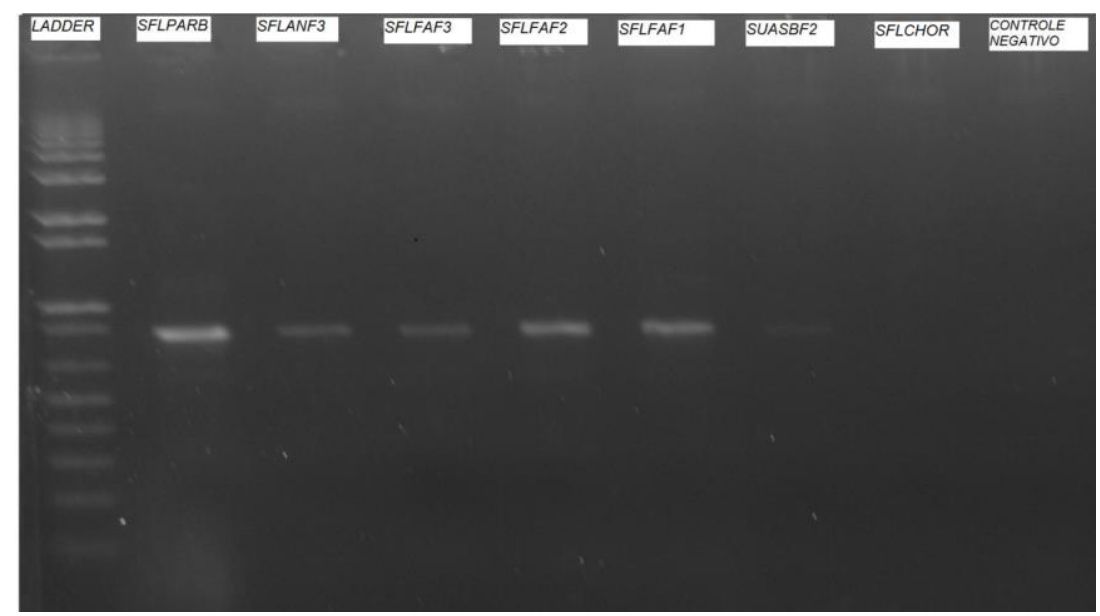

Legenda: SFLPAB: sedimento do lago Paranoá, Brasília/DF (Par); SFLANF3: lodo da lagoa anaeróbia tratando efluente do Frigorífico 1, Araguari/MG (AnF1); SFLFAF3: lodo da lagoa facultativa tratando efluente do Frigorífico 1, Araguari/MG (FaF1); SFLFAF2: lodo de lagoa facultativa tratando efluente do Frigorífico 2, Uberlândia, MG (FaF2); SUASBF2: lodo de reator UASB tratanto efluente do Frigorífico 2, Uberlândia/MG (UaF2); SFLCHOR: sedimento da lagoa de acumulação de chorume do aterro controlado Jockey Clube, Brasília, DF (Cho).

Figura 5.2: Eletroforese em gel de agarose a $1 \%$ corado com brometo de etídeo $\left(1 \mu \mathrm{g} \cdot \mathrm{mL}^{-1}\right)$ para avaliação de fragmentos amplificados de aproximadamente $774 \mathrm{pb}$, a partir da biomassa dos inóculos testados nos experimentos em bateladas para enriquecimento anammox, com os pares de primers Pla 46F e Amx 820R. 


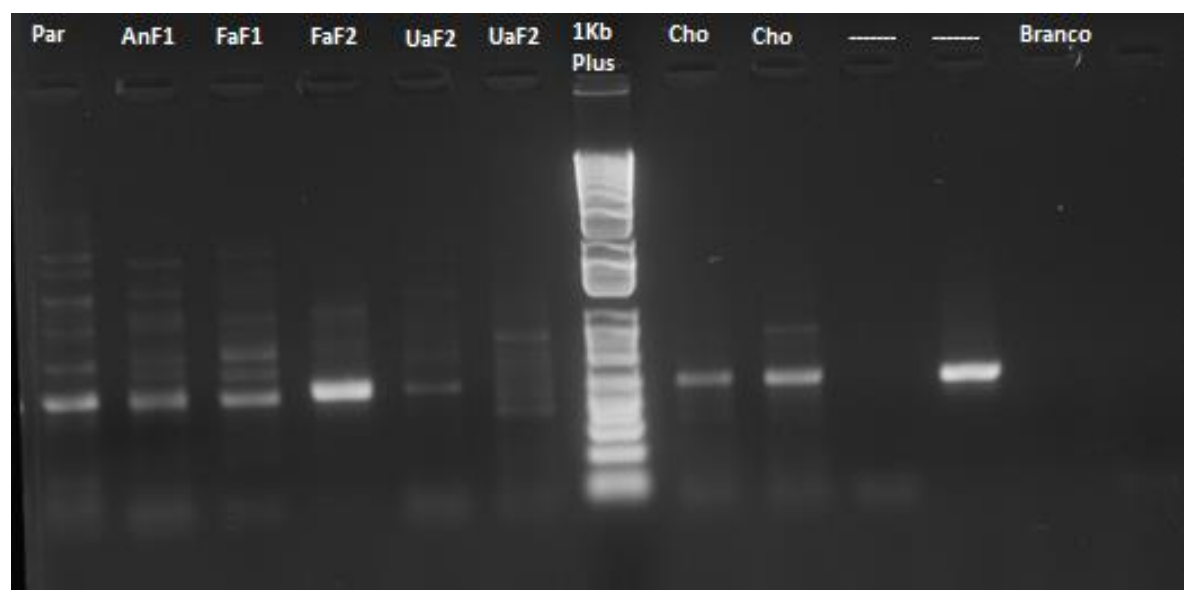

Legenda: Par: sedimento do lago Paranoá, Brasília/DF; AnF1: lodo da lagoa anaeróbia tratando efluente do Frigorífico 1, Araguari/MG; FaF1: lodo da lagoa facultativa tratando efluente do Frigorífico 1, Araguari/MG; FaF2: lodo de lagoa facultativa tratando efluente do Frigorífico 2, Uberlândia, MG; UaF2: lodo de reator UASB tratanto efluente do Frigorífico 2, Uberlândia/MG; CHOR: sedimento da lagoa de acumulação de chorume do aterro controlado Jockey Clube, Brasília, DF.

Figura 5.3: Eletroforese em gel de agarose a $1 \%$ corado com brometo de etídeo $\left(1 \mu \mathrm{g} \cdot \mathrm{mL}^{-1}\right)$ para avaliação de fragmentos de DNA amplificados de aproximadamente $650 \mathrm{pb}$, a partir das biomassas dos inóculos testados nos experimentos em bateladas para enriquecimento anammox, com os pares de primers AmoAF e AmoAR, para micro-organismos como Nitrossomonas.

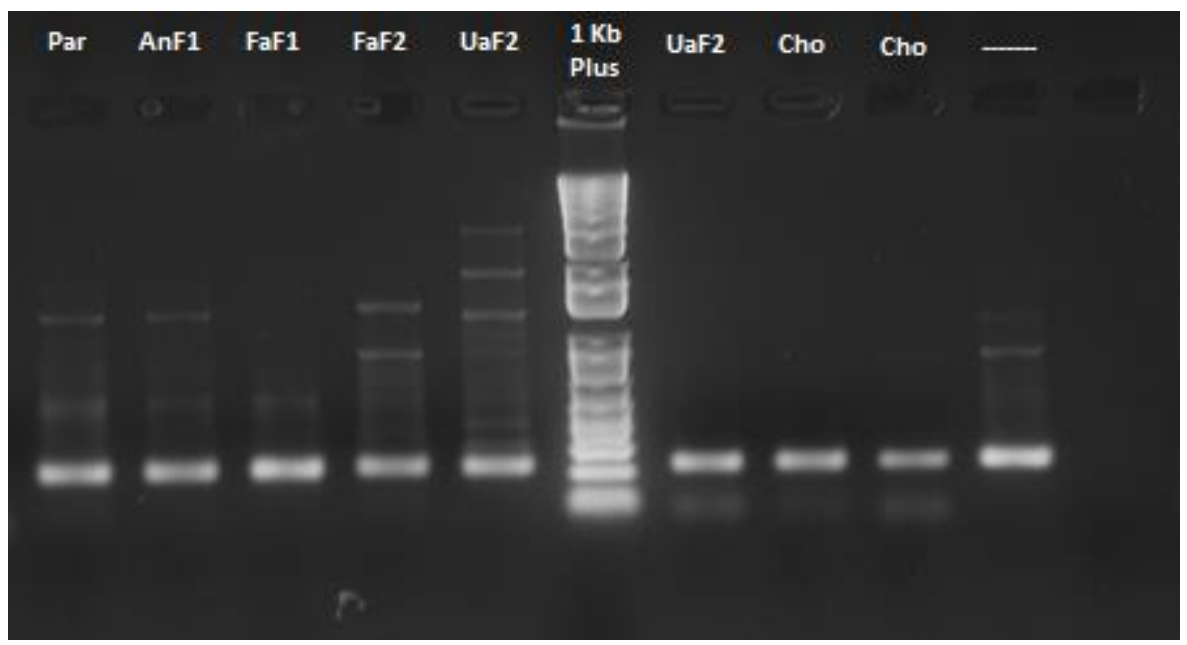

Legenda: Par: sedimento do lago Paranoá, Brasília/DF; AnF1: lodo da lagoa anaeróbia tratando efluente do Frigorífico 1, Araguari/MG; FaF1: lodo da lagoa facultativa tratando efluente do Frigorífico 1, Araguari/MG; FaF2: lodo de lagoa facultativa tratando efluente do Frigorífico 2, Uberlândia, MG; UaF2: lodo de reator UASB tratanto efluente do Frigorífico 2, Uberlândia/MG; CHOR: sedimento da lagoa de acumulação de chorume do aterro controlado Jockey Clube, Brasília, DF

Figura 5.4: Eletroforese em gel de agarose a $1 \%$ corado com brometo de etídeo $\left(1 \mu \mathrm{g} . \mathrm{mL}^{-1}\right)$ para avaliação de fragmentos de DNA amplificados de aproximadamente de $225 \mathrm{pb}$, a partir das biomassas dos inóculos testados nos experimentos em bateladas para enriquecimento anammox, com os pares de primers Nitro 1198Fe Nitro 1423R para micro-organismos como Nitrobacter. 


\section{APENDICE II}

Testes de Kolmogorov-Smirnov e Shapiro-Wilk para testar a distribuição dos dados obtidos nas conversões dos íons amônia, nitrito e nitrato para a etapa 1.

\section{Sistemas Biológicos ParA e ParB}

Testes de Normalidade

\begin{tabular}{|ll|r|r|r|r|r|r|}
\hline & & \multicolumn{3}{|c|}{ Kolmogorov-Smirnov $^{\mathrm{a}}$} & \multicolumn{3}{|c|}{ Shapiro-Wilk } \\
\cline { 3 - 8 } & Lodo & Estatística & \multicolumn{1}{c|}{$\mathrm{df}$} & \multicolumn{1}{c|}{ Sig. } & Estatística & \multicolumn{1}{c|}{$\mathrm{df}$} & \multicolumn{1}{c|}{ Sig. } \\
\hline Amônia & $\mathrm{PaA}$ &, 268 & 12 &, 018 &, 874 & 12 &, 073 \\
& $\mathrm{PaB}$ &, 173 & 12 &, $200^{*}$ &, 942 & 12 &, 518 \\
\hline Nitrito & $\mathrm{PaA}$ &, 241 & 12 &, 053 &, 911 & 12 &, 220 \\
& $\mathrm{PaB}$ &, 242 & 12 &, 051 &, 916 & 12 &, 252 \\
\hline Nitrato & $\mathrm{PaA}$ &, 155 & 12 &, $200^{*}$ &, 929 & 12 &, 369 \\
& $\mathrm{PaB}$ &, 163 & 12 &, $200^{*}$ &, 918 & 12 &, 271 \\
\hline
\end{tabular}

*. Este é um limite inferior da significância verdadeira.

a. Correlação de Significância de Lilliefors

\section{Sistemas Biológicos AnF1A e AnF1B}

\section{Testes de Normalidade}

\begin{tabular}{|ll|r|r|r|r|r|r|}
\hline & & \multicolumn{3}{|c|}{ Kolmogorov-Smirnov $^{2}$} & \multicolumn{3}{c|}{ Shapiro-Wilk } \\
\cline { 3 - 8 } & Lodo & Estatística & \multicolumn{1}{c|}{$\mathrm{df}$} & \multicolumn{1}{c|}{ Sig. } & \multicolumn{1}{c|}{ Estatística } & \multicolumn{1}{c|}{ df } & \multicolumn{1}{c|}{ Sig. } \\
\hline \multirow{2}{*}{ Amônia } & AnF1A &, 245 & 12 &, 045 &, 770 & 12 &, 004 \\
& AnF1B &, 272 & 12 &, 015 &, 822 & 12 &, 017 \\
\hline \multirow{2}{*}{ Nitrito } & AnF1A &, 121 & 12 &, $200^{*}$ &, 952 & 12 &, 661 \\
& AnF1B &, 165 & 12 &, $200^{*}$ &, 929 & 12 &, 368 \\
\hline \multirow{2}{*}{ Nitrato } & AnF1A &, 296 & 12 &, 005 &, 791 & 12 &, 007 \\
& AnF1B &, 368 & 12 &, 000 &, 727 & 12 &, 002 \\
\hline
\end{tabular}

*. Este é um limite inferior da significância verdadeira.

a. Correlação de Significância de Lilliefors

\section{Sistemas Biológicos FaF1A e FaF1B}

Testes de Normalidade

\begin{tabular}{|ll|r|r|r|r|r|r|}
\hline & & \multicolumn{3}{|c|}{ Kolmogorov-Smirnov $^{\mathrm{a}}$} & \multicolumn{3}{|c|}{ Shapiro-Wilk } \\
\cline { 3 - 8 } & Lodo & Estatística & \multicolumn{1}{c|}{$\mathrm{df}$} & \multicolumn{1}{c|}{ Sig. } & \multicolumn{1}{c|}{ Estatística } & \multicolumn{1}{c|}{ df } & \multicolumn{1}{c|}{ Sig. } \\
\hline Amônia & FaF1A &, 163 & 12 &, $200^{*}$ &, 957 & 12 &, 735 \\
& FaF1B &, 242 & 12 &, 051 &, 779 & 12 &, 005 \\
\hline \multirow{2}{*}{ Nitrito } & FaF1A &, 160 & 12 &, $200^{*}$ &, 938 & 12 &, 473 \\
& FaF1B &, 178 & 12 &, $200^{*}$ &, 940 & 12 &, 501 \\
\hline \multirow{2}{*}{ Nitrato } & FaF1A &, 246 & 12 &, 043 &, 874 & 12 &, 073 \\
& FaF1B &, 160 & 12 &, $200^{*}$ &, 927 & 12 &, 345 \\
\hline
\end{tabular}

*. Este é um limite inferior da significância verdadeira.

a. Correlação de Significância de Lilliefors 


\section{Sistemas Biológicos FaF2A e FaF2B}

Testes de Normalidade

\begin{tabular}{|ll|r|r|r|r|r|r|}
\hline & & \multicolumn{3}{|c|}{ Kolmogorov-Smirnov $^{\mathrm{a}}$} & \multicolumn{3}{|c|}{ Shapiro-Wilk } \\
\cline { 3 - 8 } & Lodo & Estatística & \multicolumn{1}{c|}{$\mathrm{df}$} & \multicolumn{1}{c|}{ Sig. } & Estatística & \multicolumn{1}{c|}{ df } & \multicolumn{1}{c|}{ Sig. } \\
\hline Amônia & FaF2A &, 187 & 12 &, $200^{*}$ &, 934 & 12 &, 427 \\
& FaF2B &, 155 & 12 &, $200^{*}$ &, 934 & 12 &, 427 \\
\hline Nitrito & FaF2A &, 175 & 12 &, $200^{*}$ &, 952 & 12 &, 668 \\
& FaF2B &, 184 & 12 &, $200^{*}$ &, 931 & 12 &, 391 \\
\hline \multirow{2}{*}{ Nitrato } & FaF2A &, 122 & 12 &, $200^{*}$ &, 971 & 12 &, 922 \\
& FaF2B &, 170 & 12 &, $200^{*}$ &, 938 & 12 &, 476 \\
\hline
\end{tabular}

*. Este é um limite inferior da significância verdadeira.

a. Correlação de Significância de Lilliefors

\section{Sistemas Biológicos UaF2A e UaF2B}

Testes de Normalidade

\begin{tabular}{|ll|r|r|r|r|r|r|}
\hline & & \multicolumn{3}{|c|}{ Kolmogorov-Smirnov $^{\mathrm{a}}$} & \multicolumn{3}{c|}{ Shapiro-Wilk } \\
\cline { 3 - 8 } & Lodo & Estatística & $\mathrm{df}$ & \multicolumn{1}{c|}{ Sig. } & \multicolumn{1}{c|}{ Estatística } & \multicolumn{1}{c|}{ df } & \multicolumn{1}{c|}{ Sig. } \\
\hline \multirow{2}{*}{ Amônia } & UaF2A &, 246 & 12 &, 044 &, 906 & 12 &, 191 \\
& UaF2B &, 135 & 12 &, $200^{*}$ &, 963 & 12 &, 832 \\
\hline \multirow{2}{*}{ Nitrito } & UaF2A &, 165 & 12 &, $200^{*}$ &, 901 & 12 &, 165 \\
& UaF2B &, 154 & 12 &, $200^{*}$ &, 930 & 12 &, 385 \\
\hline \multirow{2}{*}{ Nitrato } & UaF2A &, 225 & 12 &, 094 &, 874 & 12 &, 073 \\
& UaF2B &, 252 & 12 &, 034 &, 850 & 12 &, 037 \\
\hline
\end{tabular}

*. Este é um limite inferior da significância verdadeira.

a. Correlação de Significância de Lilliefors

\section{Sistemas Biológicos ChoA e ChoB}

Testes de Normalidade

\begin{tabular}{|ll|r|r|r|r|r|r|}
\hline & & \multicolumn{3}{|c|}{ Kolmogorov-Smirnov $^{\mathrm{a}}$} & \multicolumn{3}{|c|}{ Shapiro-Wilk $^{*}$} \\
\cline { 3 - 8 } & Lodo & Estatística & \multicolumn{1}{c|}{$\mathrm{df}$} & \multicolumn{1}{c|}{ Sig. } & \multicolumn{1}{c|}{ Estatística } & \multicolumn{1}{c|}{ df } & \multicolumn{1}{c|}{ Sig. } \\
\hline \multirow{2}{*}{ Amônia } & ChoA &, 183 & 12 &, $200^{*}$ &, 967 & 12 &, 874 \\
& ChoB &, 120 & 12 &, $200^{*}$ &, 987 & 12 &, 999 \\
\hline \multirow{2}{*}{ Nitrito } & ChoA &, 185 & 12 &, $200^{*}$ &, 919 & 12 &, 280 \\
& ChoB &, 171 & 12 &, $200^{*}$ &, 899 & 12 &, 155 \\
\hline \multirow{2}{*}{ Nitrato } & ChoA &, 141 & 12 &, $200^{*}$ &, 956 & 12 &, 718 \\
& ChoB &, 158 & 12 &, $200^{*}$ &, 969 & 12 &, 898 \\
\hline
\end{tabular}

*. Este é um limite inferior da significância verdadeira.

a. Correlação de Significância de Lilliefors 
Teste de Levene para testar a homogeneidade entre as variâncias dos dados entre as duplicatas A e B dos sistemas biológicos obtidos nas conversões dos íons amônia, nitrito e nitrato para a etapa 1.

\section{Sistemas Biológicos ParA e ParB}

Teste de Homogeneidade de Variância

\begin{tabular}{|c|c|c|c|c|c|}
\hline & & $\begin{array}{l}\text { Estatística de } \\
\text { Levene }\end{array}$ & df1 & $\mathrm{df2}$ & Sig. \\
\hline \multirow[t]{4}{*}{ Amônia } & Com base em média & ,567 & 1 & 22 & ,460 \\
\hline & Com base em mediana & ,103 & 1 & 22 & ,751 \\
\hline & $\begin{array}{l}\text { Com base em mediana e } \\
\text { com df ajustado }\end{array}$ & , 103 & 1 & 20,110 & ,751 \\
\hline & $\begin{array}{l}\text { Com base em média } \\
\text { aparada }\end{array}$ & ,414 & 1 & 22 & ,527 \\
\hline \multirow[t]{4}{*}{ Nitrito } & Com base em média &, 001 & 1 & 22 & 970, \\
\hline & Com base em mediana &, 000 & 1 & 22 & ,998 \\
\hline & $\begin{array}{l}\text { Com base em mediana e } \\
\text { com df ajustado }\end{array}$ & ,000 & 1 & 21,949 & ,998 \\
\hline & $\begin{array}{l}\text { Com base em média } \\
\text { aparada }\end{array}$ & 001, & 1 & 22 & ,971 \\
\hline \multirow[t]{4}{*}{ Nitrato } & Com base em média & ,046 & 1 & 22 & 832 \\
\hline & Com base em mediana & ,083 & 1 & 22 & ,776 \\
\hline & $\begin{array}{l}\text { Com base em mediana e } \\
\text { com df ajustado }\end{array}$ & ,083 & 1 & 20,642 & ,776 \\
\hline & $\begin{array}{l}\text { Com base em média } \\
\text { aparada }\end{array}$ & 062, & 1 & 22 & 806, \\
\hline
\end{tabular}

\section{Sistemas Biológicos AnF1A e AnF1B}

Teste de Homogeneidade de Variância

\begin{tabular}{|c|c|c|c|c|c|}
\hline & & $\begin{array}{l}\text { Estatística de } \\
\text { Levene }\end{array}$ & df1 & df2 & Sig. \\
\hline \multirow[t]{4}{*}{ Amônia } & Com base em média & ,003 & 1 & 22 & ,960 \\
\hline & Com base em mediana & ,034 & 1 & 22 & ,856 \\
\hline & $\begin{array}{l}\text { Com base em mediana e } \\
\text { com df ajustado }\end{array}$ & ,034 & 1 & 21,502 & ,856 \\
\hline & $\begin{array}{l}\text { Com base em média } \\
\text { aparada }\end{array}$ &, 010 & 1 & 22 & ,922 \\
\hline \multirow[t]{4}{*}{ Nitrito } & Com base em média & ,217 & 1 & 22 & ,646 \\
\hline & Com base em mediana & ,230 & 1 & 22 & ,636 \\
\hline & $\begin{array}{l}\text { Com base em mediana e } \\
\text { com df ajustado }\end{array}$ & ,230 & 1 & 21,742 & ,636 \\
\hline & $\begin{array}{l}\text { Com base em média } \\
\text { aparada }\end{array}$ & ,235 & 1 & 22 & 633 \\
\hline \multirow[t]{4}{*}{ Nitrato } & Com base em média & ,044 & 1 & 22 & ,836 \\
\hline & Com base em mediana & ,006 & 1 & 22 & ,940 \\
\hline & $\begin{array}{l}\text { Com base em mediana e } \\
\text { com df ajustado }\end{array}$ &, 006 & 1 & 21,444 & ,940 \\
\hline & $\begin{array}{l}\text { Com base em média } \\
\text { aparada }\end{array}$ &, 033 & 1 & 22 & ,858 \\
\hline
\end{tabular}




\section{Sistemas Biológicos FaF1A e FaF1B}

Teste de Homogeneidade de Variância

\begin{tabular}{|c|c|c|c|c|c|}
\hline & & $\begin{array}{l}\text { Estatística de } \\
\text { Levene }\end{array}$ & df1 & df2 & Sig. \\
\hline \multirow[t]{4}{*}{ Amônia } & Com base em média & 011 & 1 & 22 & ,916 \\
\hline & Com base em mediana & 022 & 1 & 22 & ,884 \\
\hline & $\begin{array}{l}\text { Com base em mediana e } \\
\text { com df ajustado }\end{array}$ & ,022 & 1 & 18,984 & ,884 \\
\hline & $\begin{array}{l}\text { Com base em média } \\
\text { aparada }\end{array}$ & 000, & 1 & 22 & ,990 \\
\hline \multirow[t]{4}{*}{ Nitrito } & Com base em média & 023 & 1 & 22 & 881 \\
\hline & Com base em mediana & ,008 & 1 & 22 & ,930 \\
\hline & $\begin{array}{l}\text { Com base em mediana e } \\
\text { com df ajustado }\end{array}$ &, 008 & 1 & 21,984 & ,930 \\
\hline & $\begin{array}{l}\text { Com base em média } \\
\text { aparada }\end{array}$ & ,032 & 1 & 22 & ,860 \\
\hline \multirow[t]{4}{*}{ Nitrato } & Com base em média &, 563 & 1 & 22 & ,461 \\
\hline & Com base em mediana & ,471 & 1 & 22 & 500, \\
\hline & $\begin{array}{l}\text { Com base em mediana e } \\
\text { com df ajustado }\end{array}$ & 471, & 1 & 21,999 & ,500 \\
\hline & $\begin{array}{l}\text { Com base em média } \\
\text { aparada }\end{array}$ & 507, & 1 & 22 & ,484 \\
\hline
\end{tabular}

\section{Sistemas Biológicos FaF2A e FaF2B}

Teste de Homogeneidade de Variância

\begin{tabular}{|c|c|c|c|c|c|}
\hline & & $\begin{array}{c}\text { Estatística de } \\
\text { Levene }\end{array}$ & df1 & df2 & Sig. \\
\hline \multirow[t]{4}{*}{ Amônia } & Com base em média & ,002 & 1 & 22 & ,964 \\
\hline & Com base em mediana & ,005 & 1 & 22 & ,942 \\
\hline & $\begin{array}{l}\text { Com base em mediana e } \\
\text { com df ajustado }\end{array}$ & ,005 & 1 & 18,386 & ,942 \\
\hline & $\begin{array}{l}\text { Com base em média } \\
\text { aparada }\end{array}$ & ,001 & 1 & 22 & ,982 \\
\hline \multirow[t]{4}{*}{ Nitrito } & Com base em média & ,065 & 1 & 22 & ,802 \\
\hline & Com base em mediana &, 044 & 1 & 22 & ,836 \\
\hline & $\begin{array}{l}\text { Com base em mediana e } \\
\text { com df ajustado }\end{array}$ & ,044 & 1 & 21,997 & ,836 \\
\hline & $\begin{array}{l}\text { Com base em média } \\
\text { aparada }\end{array}$ & ,061 & 1 & 22 & ,807 \\
\hline \multirow[t]{4}{*}{ Nitrato } & Com base em média & ,049 & 1 & 22 & ,827 \\
\hline & Com base em mediana & ,079 & 1 & 22 & ,782 \\
\hline & $\begin{array}{l}\text { Com base em mediana e } \\
\text { com df ajustado }\end{array}$ & 079 & 1 & 21,642 & ,782 \\
\hline & $\begin{array}{l}\text { Com base em média } \\
\text { aparada }\end{array}$ & ,060 & 1 & 22 & ,810 \\
\hline
\end{tabular}




\section{Sistemas Biológicos UaF2A e UaF2B}

Teste de Homogeneidade de Variância

\begin{tabular}{|c|c|c|c|c|c|}
\hline & & $\begin{array}{l}\text { Estatística de } \\
\text { Levene }\end{array}$ & df1 & df2 & Sig. \\
\hline \multirow[t]{4}{*}{ Amônia } & Com base em média & ,265 & 1 & 22 & 612 \\
\hline & Com base em mediana &, 504 & 1 & 22 & ,485 \\
\hline & $\begin{array}{l}\text { Com base em mediana e } \\
\text { com df ajustado }\end{array}$ &, 504 & 1 & 21,566 & ,485 \\
\hline & $\begin{array}{l}\text { Com base em média } \\
\text { aparada }\end{array}$ & ,291 & 1 & 22 &, 595 \\
\hline \multirow[t]{4}{*}{ Nitrito } & Com base em média & 025 & 1 & 22 & 876 \\
\hline & Com base em mediana & ,072 & 1 & 22 & ,791 \\
\hline & $\begin{array}{l}\text { Com base em mediana e } \\
\text { com df ajustado }\end{array}$ & 072 & 1 & 21,248 & ,791 \\
\hline & $\begin{array}{l}\text { Com base em média } \\
\text { aparada }\end{array}$ &, 029 & 1 & 22 & ,865 \\
\hline \multirow[t]{4}{*}{ Nitrato } & Com base em média &, 001 & 1 & 22 & ,980 \\
\hline & Com base em mediana & ,002 & 1 & 22 & ,966 \\
\hline & $\begin{array}{l}\text { Com base em mediana e } \\
\text { com df ajustado }\end{array}$ & ,002 & 1 & 21,898 & ,966 \\
\hline & $\begin{array}{l}\text { Com base em média } \\
\text { aparada }\end{array}$ &, 000 & 1 & 22 & ,986 \\
\hline
\end{tabular}

\section{Sistemas Biológicos ChoA e ChoB}

Teste de Homogeneidade de Variância

\begin{tabular}{|c|c|c|c|c|c|}
\hline & & $\begin{array}{l}\text { Estatística de } \\
\text { Levene }\end{array}$ & df1 & df2 & Sig. \\
\hline \multirow[t]{4}{*}{ Amônia } & Com base em média & ,217 & 1 & 22 & ,646 \\
\hline & Com base em mediana & 097 & 1 & 22 & ,758 \\
\hline & $\begin{array}{l}\text { Com base em mediana e } \\
\text { com df ajustado }\end{array}$ &, 097 & 1 & 20,938 & ,758 \\
\hline & $\begin{array}{l}\text { Com base em média } \\
\text { aparada }\end{array}$ & , 199 & 1 & 22 & ,660 \\
\hline \multirow[t]{4}{*}{ Nitrito } & Com base em média &, 013 & 1 & 22 & ,912 \\
\hline & Com base em mediana &, 012 & 1 & 22 & ,915 \\
\hline & $\begin{array}{l}\text { Com base em mediana e } \\
\text { com df ajustado }\end{array}$ & 012 & 1 & 21,959 & ,915 \\
\hline & $\begin{array}{l}\text { Com base em média } \\
\text { aparada }\end{array}$ & 013 & 1 & 22 & ,910 \\
\hline \multirow[t]{4}{*}{ Nitrato } & Com base em média &, 000 & 1 & 22 & ,984 \\
\hline & Com base em mediana &, 012 & 1 & 22 & ,915 \\
\hline & $\begin{array}{l}\text { Com base em mediana e } \\
\text { com df ajustado }\end{array}$ & 012 & 1 & 21,840 & ,915 \\
\hline & $\begin{array}{l}\text { Com base em média } \\
\text { aparada }\end{array}$ & 001 & 1 & 22 & ,978 \\
\hline
\end{tabular}


Diferença entre médias pelo teste $t$ com amostras dependentes para avaliar a igualdade estatísticas entre as duplicatas A e B dos sistemas biológicos obtidos nas conversões dos íons amônia, nitrito e nitrato para a etapa 1 .

\section{Quanto à conversão de Amônia}

\begin{tabular}{|c|c|c|c|c|c|c|c|c|c|}
\hline & & \multicolumn{5}{|c|}{ Diferenças emparelhadas } & \multirow[b]{3}{*}{$\mathrm{t}$} & \multirow[b]{3}{*}{ df } & \multirow{3}{*}{$\begin{array}{c}\text { Sig. (2 } \\
\text { extremidades } \\
\text { ) }\end{array}$} \\
\hline & & \multirow[b]{2}{*}{ Média } & \multirow{2}{*}{$\begin{array}{l}\text { Desvio } \\
\text { Padrão }\end{array}$} & \multirow{2}{*}{$\begin{array}{l}\text { Erro padrão } \\
\text { da média }\end{array}$} & \multicolumn{2}{|c|}{$\begin{array}{l}\text { 95\% Intervalo de Confiança da } \\
\text { Diferença }\end{array}$} & & & \\
\hline & & & & & Inferior & Superior & & & \\
\hline Par 1 & ParA-ParB &,- 046917 & ,310439 & ,089616 &,- 244160 & ,150327 &,- 524 & 11 & 611 \\
\hline Par 2 & AnF1A- AnF1B &,- 020750 & ,303718 & 087676 &,- 213723 & ,172223 &,- 237 & 11 & 817 \\
\hline Par 3 & FaF1A - FaF1B &,- 060750 & ,427196 & 123321 &,- 332177 & ,210677 &,- 493 & 11 & ,632 \\
\hline Par 4 & $\mathrm{FaF} 2 \mathrm{~A}-\mathrm{FaF} 2 \mathrm{~B}$ &, 043250 & ,210180 &, 060674 &,- 090292 & ,176792 &, 713 & 11 & ,491 \\
\hline Par 5 & $\mathrm{UaF} 2 \mathrm{~A}-\mathrm{UaF} 2 \mathrm{~B}$ & 073917 & ,240765 & 069503 &,- 079058 & ,226892 & 1,064 & 11 &, 310 \\
\hline Par 6 & ChoA-ChoB &, 001000 & , 145402 & ,041974 &,- 091384 & 093384 & 024 & 11 & ,981 \\
\hline
\end{tabular}

a. lons = Amônia

\section{Quanto à conversão de Nitrito}

Teste de amostras emparelhadas ${ }^{a}$

\begin{tabular}{|c|c|c|c|c|c|c|c|c|c|}
\hline & & \multicolumn{5}{|c|}{ Diferenças emparelhadas } & \multirow[b]{3}{*}{$\mathrm{t}$} & \multirow[b]{3}{*}{ df } & \multirow{3}{*}{$\begin{array}{c}\text { Sig. (2 } \\
\text { extremidades } \\
\text { ) }\end{array}$} \\
\hline & & \multirow[b]{2}{*}{ Média } & \multirow{2}{*}{$\begin{array}{l}\text { Desvio } \\
\text { Padrão } \\
\end{array}$} & \multirow{2}{*}{$\begin{array}{l}\text { Erro padrão } \\
\text { da média }\end{array}$} & \multicolumn{2}{|c|}{$\begin{array}{l}\text { 95\% Intervalo de Confiança da } \\
\text { Diferença }\end{array}$} & & & \\
\hline & & & & & Inferior & Superior & & & \\
\hline Par 1 & ParA-ParB &, 000083 &, 015000 &, 004330 &,- 009447 & 009614 & ,019 & 11 & ,985 \\
\hline Par 2 & AnF1A-AnF1B &, 005250 &, 063959 &, 018463 &,- 035388 & ,045888 & ,284 & 11 & ,781 \\
\hline Par 3 & FaF1A- FaF1B & ,007667 & ,055672 &, 016071 &,- 027705 & ,043039 &, 477 & 11 & ,643 \\
\hline Par 4 & $\mathrm{FaF} 2 \mathrm{~A}-\mathrm{FaF} 2 \mathrm{~B}$ &,- 000250 &, 024853 &, 007174 &,- 016041 & 015541 &,- 035 & 11 & ,973 \\
\hline Par 5 & UaF2A- UaF2B &, 003333 & , 140660 &, 040605 &,- 086038 & 092704 &, 082 & 11 & ,936 \\
\hline Par 6 & ChoA-ChoB &, 001500 & ,034595 & ,009987 &,- 020481 & ,023481 & 150 & 11 & ,883 \\
\hline
\end{tabular}

a. lons $=$ Nitrito

\section{Quanto à conversão de Nitrato}

\begin{tabular}{|c|c|c|c|c|c|c|c|c|c|}
\hline \multicolumn{10}{|c|}{ Teste de amostras emparelhadas ${ }^{a}$} \\
\hline & & \multicolumn{5}{|c|}{ Diferenças emparelhadas } & \multirow[b]{3}{*}{$\mathrm{t}$} & \multirow[b]{3}{*}{ df } & \multirow{3}{*}{$\begin{array}{c}\text { Sig. (2 } \\
\text { extremidades } \\
\text { ) }\end{array}$} \\
\hline & & \multirow[b]{2}{*}{ Média } & \multirow{2}{*}{$\begin{array}{l}\text { Desvio } \\
\text { Padrão }\end{array}$} & \multirow{2}{*}{$\begin{array}{l}\text { Erro padrão } \\
\text { da média }\end{array}$} & \multicolumn{2}{|c|}{$\begin{array}{l}95 \% \text { Intervalo de Confiança da } \\
\text { Diferença }\end{array}$} & & & \\
\hline & & & & & Inferior & Superior & & & \\
\hline Par 1 & ParA-ParB &,- 027333 &, 076295 & 022025 &,- 075809 &, 021142 & $-1,241$ & 11 & ,240 \\
\hline Par 2 & AnF1A-AnF1B &,- 008667 &, 028535 &, 008237 &,- 026797 &, 009464 & $-1,052$ & 11 & ,315 \\
\hline Par 3 & FaF1A-FaF1B &, 043250 & ,175523 &, 050669 &,- 068272 & ,154772 & 854 & 11 & ,412 \\
\hline Par 4 & FaF2A- FaF2B &,- 059667 & , 105510 & 030458 &,- 126705 & ,007371 & $-1,959$ & 11 & ,076 \\
\hline Par 5 & UaF2A- UaF2B &,- 000417 &, 013944 &, 004025 &,- 009277 &, 008443 &,- 104 & 11 & ,919 \\
\hline Par 6 & ChoA-ChoB & ,001500 &, 025033 &, 007226 &,- 014405 & ,017405 & ,208 & 11 & ,839 \\
\hline
\end{tabular}

a. lons $=$ Nitrato 
Teste de Wilcoxon de Postos com Sinais avaliar a igualdade estatísticas entre as duplicatas A e B dos sistemas biológicos obtidos nas conversões dos íons amônia, nitrito e nitrato para a etapa 1. Realizado para os íons e sistemas biológicos com dados não paramétricos.

\section{Quanto à conversão de Amônia}

Estatísticas de teste ${ }^{a, b}$

\begin{tabular}{|l|r|r|r|}
\hline & \multicolumn{1}{|c|}{$\begin{array}{c}\text { AnF1B - } \\
\text { AnF1A }\end{array}$} & $\begin{array}{r}\text { FaF1B - } \\
\text { FaF1A }\end{array}$ & \multicolumn{1}{c|}{$\begin{array}{c}\text { UaF2B - } \\
\text { UaF2A }\end{array}$} \\
\hline Z &,$- 392^{\mathrm{C}}$ &,$- 942^{\mathrm{c}}$ &,$- 314^{\mathrm{d}}$ \\
$\begin{array}{l}\text { Significância Sig. (2 } \\
\text { extremidades) }\end{array}$ &, 695 &, 346 &, 754 \\
$\begin{array}{l}\text { Sig exata (2 } \\
\text { extremidades) }\end{array}$ &, 718 &, 369 &, 778 \\
$\begin{array}{l}\text { Sig exata (1 extremidade) } \\
\text { Probabilidade de ponto }\end{array}$ &, 359 &, 184 &, 389 \\
\end{tabular}
a. lons = Amônia
b. Teste de Classificações Assinadas por Wilcoxon
c. Com base em postos negativos.
d. Com base em postos positivos.

\section{Quanto à conversão de Nitrato}

Estatísticas de teste ${ }^{a, b}$

\begin{tabular}{|l|r|r|r|}
\hline & \multicolumn{1}{|c|}{$\begin{array}{c}\text { AnF1B - } \\
\text { AnF1A }\end{array}$} & $\begin{array}{r}\text { FaF1B }- \\
\text { FaF1A }\end{array}$ & \multicolumn{1}{|c|}{$\begin{array}{c}\text { UaF2B }- \\
\text { UaF2A }\end{array}$} \\
\hline Z &,$- 830^{\mathrm{C}}$ &,$- 663^{\mathrm{d}}$ &,$- 060^{\mathrm{C}}$ \\
$\begin{array}{l}\text { Significância Sig. (2 } \\
\text { extremidades) }\end{array}$ &, 407 &, 507 &, 952 \\
$\begin{array}{l}\text { Sig exata (2 } \\
\text { extremidades) }\end{array}$ &, 441 &, 545 & 1,000 \\
$\begin{array}{l}\text { Sig exata (1 extremidade) } \\
\text { Probabilidade de ponto }\end{array}$ &, 221 &, 272 &, 500 \\
\end{tabular}
a. lons $=$ Nitrato
b. Teste de Classificações Assinadas por Wilcoxon
c. Com base em postos negativos.
d. Com base em postos positivos. 


\section{APENDICE III}

Análise de PCR e avaliação do sucesso de extração de DNA e das amplificações em eletroforeses em gel de agarose a $1 \%$ corado com brometo de etídeo $\left(1 \mu \mathrm{g} . \mathrm{mL}^{-1}\right)$ para os sistemas biológicos após 120 de operação visando o enriquecimento dos micro-organismos anammox.

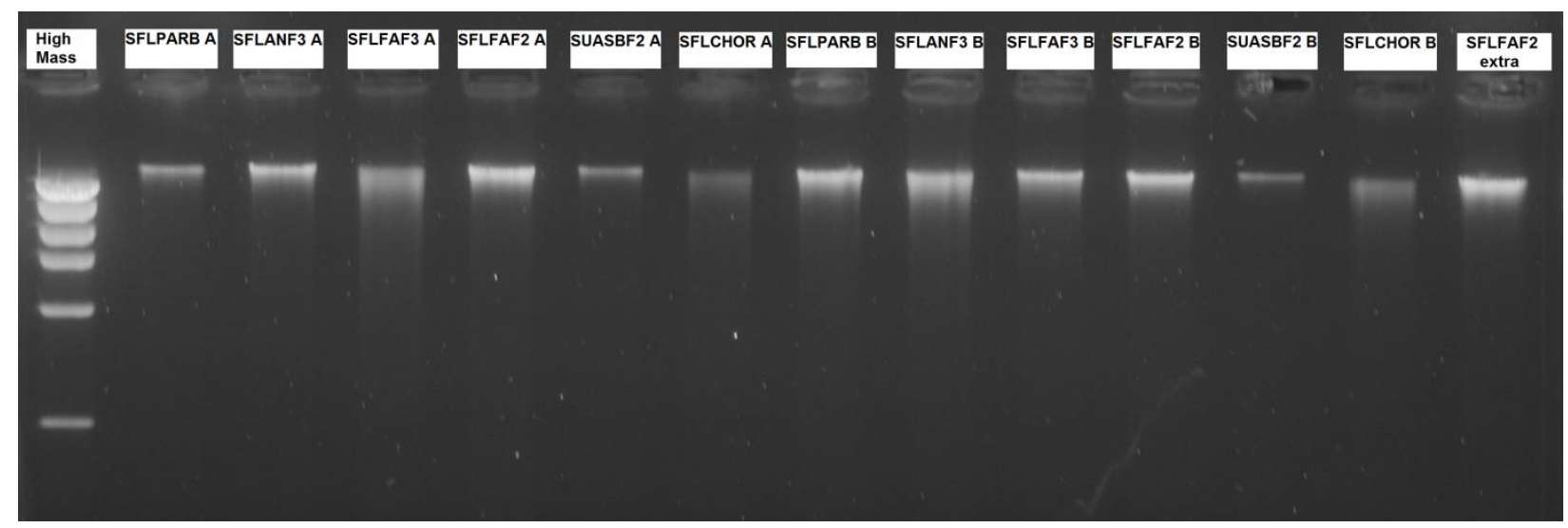

Figura III.1: Eletroforese em gel de agarose a $1 \%$ corado com brometo de etídeo $\left(1 \mu \mathrm{g} \cdot \mathrm{mL}^{-1}\right)$ para avaliação do DNA genômico extraído das biomassas dos sistemas biológicos após 120 dias para enriquecimento anammox. SFLPARB: sedimento do lago Paranoá, Brasília/DF (Par A e B); SFLANF3: lagoa anaeróbia tratando efluente do Frigorífico 3, Araguari/MG (AnF1 A e B); SFLFAF3: lagoa facultativa tratando efluente do Frigorífico 3, Araguari/MG (FaF1 A e B); SFLFAF2: lagoa facultativa tratando efluente do Frigorífico 2,

Uberlândia, MG (FaF2 Ae B); SUASBF2: lodo de reator UASB tratando efluente do Frigorífico 2, Uberlândia/MG (UaF2 Ae B); SFLCHOR: lagoa de acumulação de chorume do aterro controlado Jockey Clube de Brasília/DF (Cho A e B). (A e B se referem aos sistemas em duplicatas).

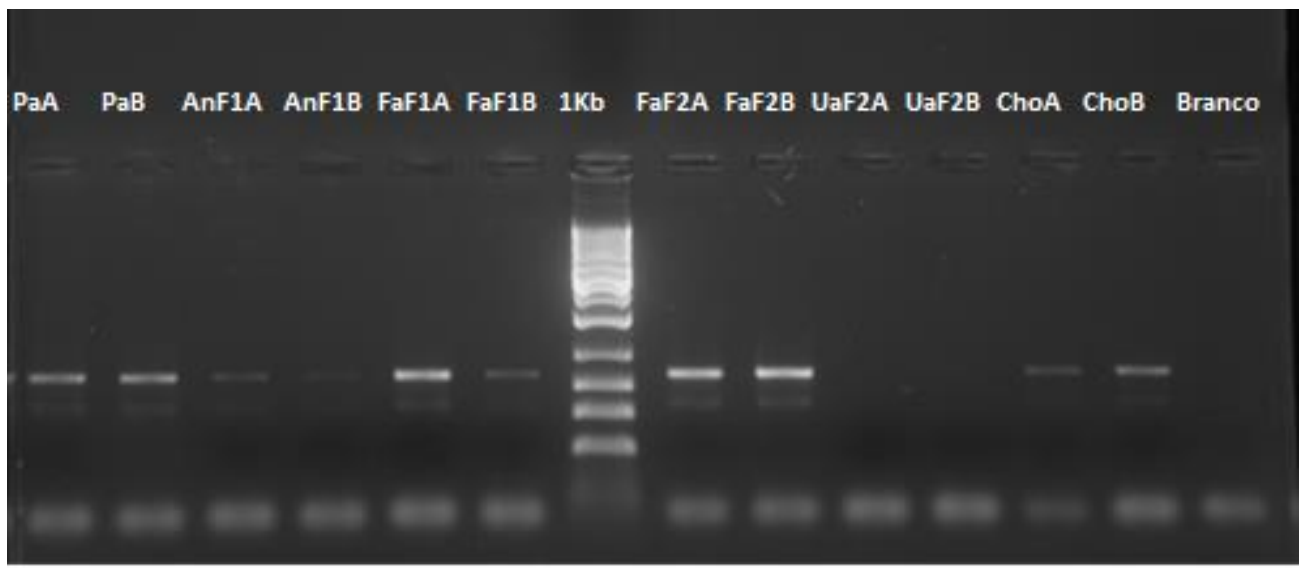

Figura III.2: Eletroforese em gel de agarose a $1 \%$ corado com brometo de etídeo $\left(1 \mu \mathrm{g} . \mathrm{mL}^{-1}\right)$ para avaliação de fragmentos amplificados de 774 pb, dos seis inóculos após 120 dias para enriquecimento anammox nas culturas bateladas com os pares de primers Pla 46F e Amx 820R. Par: sedimento do lago Paranoá, Brasília/DF; AnF1: lagoa anaeróbia tratando efluente do Frigorífico 1, Araguari/MG; FaF1: lagoa facultativa tratando efluente do Frigorífico 1, Araguari/MG; FaF2: lagoa facultativa tratando efluente do Frigorífico 2, Uberlândia, MG; UaF2: lodo de reator UASB tratando efluente do Frigorífico 2, Uberlândia/MG; Cho: lagoa de acumulação de chorume do aterro controlado Jockey Clube de Brasília/DF. (A e B refere-se aos sistemas em duplicatas). 


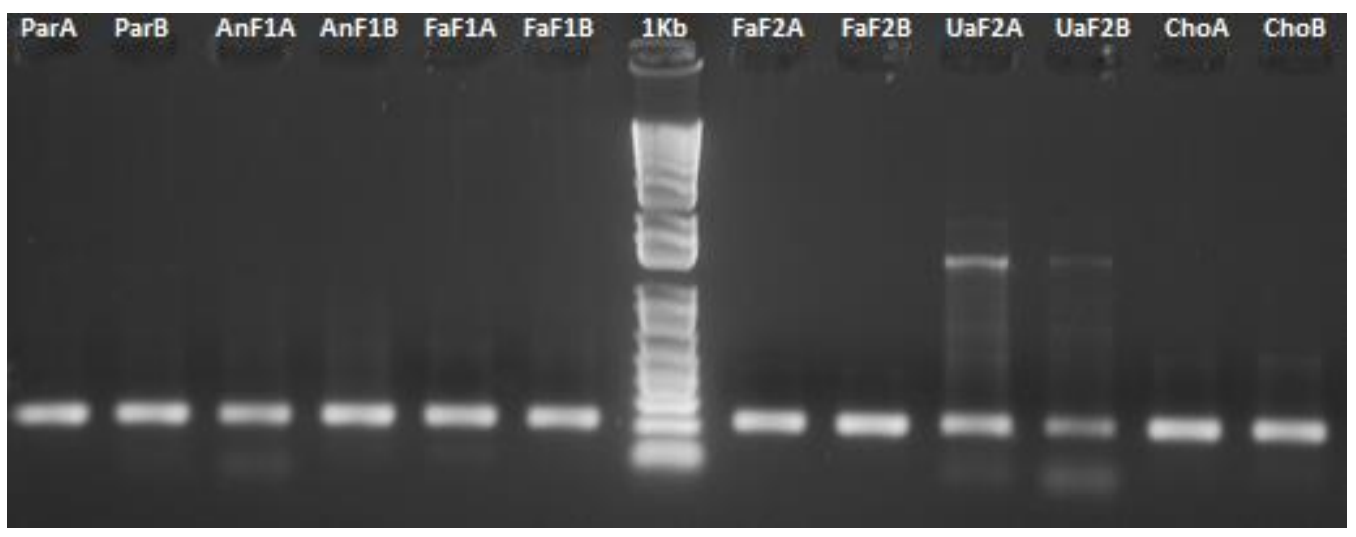

Figura III.3: Eletroforese em gel de agarose a $1 \%$ corado com brometo de etídeo $\left(1 \mu \mathrm{g} \cdot \mathrm{mL}^{-1}\right)$ para avaliação de fragmentos amplificados de $225 \mathrm{pb}$, a partir dos inóculos testados nos experimentos em bateladas para enriquecimento anammox, com os pares de primers Nitro 1198Fe Nitro 1423R para micro-organismos como Nitrobacter. Legenda: Par: sedimento do lago Paranoá, Brasília/DF; AnF1: lodo da lagoa anaeróbia tratando efluente do Frigorífico 1, Araguari/MG; FaF1: lodo da lagoa facultativa tratando efluente do Frigorífico 1, Araguari/MG; FaF2: lodo de lagoa facultativa tratando efluente do Frigorífico 2, Uberlândia, MG;

UaF2: lodo de reator UASB tratanto efluente do Frigorífico 2, Uberlândia/MG; CHOR: sedimento da lagoa de acumulação de chorume do aterro controlado Jockey Clube, Brasília, DF. 


\section{APENDICE IV}

Avaliação da qualidade das sequências dos fragmentos de DNA para o RNAr 16S obtidas pela análise do sequenciamento realizado pela Macrogen (Seul, Coréia do Sul), contratando-se o serviço EZseq, utilizando o software Sequence Scanner.

Sendo a qualidade dos sinal dos picos para cada base nitrogenada: cinza: duvidoso; amarelo: bom ; vermelho: ruim ; azul: excelente

$$
\begin{aligned}
& \text { Pure Base QV } \\
& \text { High } \square \text { Medium } \square \text { Low }
\end{aligned}
$$

Sequência obtida a partir da biomassa do sedimento do Paranoá (Pa inicial) - Primer Pla46F - selecionada para comparações filogenéticas

\begin{tabular}{|c|c|c|c|c|c|c|c|c|c|c|c|c|c|}
\hline 1 & GGGGGGCTCG & CAGAGACAGA & GATAAGTGGC & GGAAGGGCGA & GTAATGCATA & GATAACCTAC & CCCCGAGATG & GGAATAACCA & TTCGAAAGGA & TAGCTAATAC & CCAATGAGAC & CACGGATCGC & 120 \\
\hline 121 & ATGATCTGTG & CITAAAGATG & GGGACCCGCA & AGGGCCTTTC & GCTCGGGGAG & GGGTTTATGT & CCTATCAGCT & AGTTGGTGAG & GTAACGGCCC & ACCAAGGCTA & TGACGGGTAG & CCGACCTGAG & 240 \\
\hline 241 & AGGGTGACCG & GCCGCACTGG & GACTGAGACA & CTGCCCAGAC & TCCTACGGGA & GGCTGCAGTC & GAGGATCTTC & CGCAATGCGC & GAAAGCGTGA & CGGAGCGACG & CCGCGTGGGT & GATGAAGGCC & 360 \\
\hline 361 & TTCGGGTTGT & AAAGCCCTGI & СACCTGGAA & GAATGGCGGG & AGGTGAATAG & CCATCTCGTC & TGACGCTACC & AGGAAAGGAA & GCACCGGCTA & AATACGTGCC & AGCAGCCGCG & GTAATACGTA & 480 \\
\hline 481 & TGGTGCGAAC & GTTGTTCGGA & ATCACTGGGC & ATAAAGAGCA & CGTAGGCGGT & TGAGCAAGTC & CATTGTGAAA & TCCCCCGGCT & TAACCGGGGA & ACTGCAGTGG & ATACTACTTG & ACTTGAGTGC & 600 \\
\hline 601 & AGGAGGGGAG & AGTGGAATTC & CAGGTGGAGC & GGTGAAATGC & GTAGATATCT & GGAGGAACGC & CGGTGGCGAA & AGCGACTCTC & TGGTCTGTAA & CTGACGCTGA & GGTGCGAAAG & CTAGGGGAGC & 720 \\
\hline 721 & AAACGGGATT & AGATACCCCG & GTAGTCCTAG & СCCTAACGAT & GGCTAGAAAG & GGGGGTTTTT & TTTTAAAAAAA & GGG & & & & & 793 \\
\hline
\end{tabular}
C: \Users\GenildaMaria\Documents\Samsung\DOUTORADO 2014\COMPARAÇOES FILOGENETICAS SEQUENCIAMENTO MARÇO 2014\Resultados Korea\Genilda\PAinF_13DBZAC_004_PLA46F.ab1

Sequência obtida a partir da biomassa do sedimento do Paranoá (Pa inicial) - Primer Amx820R - utilizada para complementação da sequência obtida com o primer Pla46F.

\begin{tabular}{|c|c|c|c|c|c|c|c|c|c|c|c|c|c|}
\hline 1 & A.AAAATCTTA & GCAGGACACC & GAGGGTATCT & AATCCCGTTT & GCTCCCCTAG & CTTTCGCACC & TCAGCGTCAG & TTACAGACCA & GAGAGTCGCT & TTCGCCACCG & GCGTTCCTCC & TGATATCTAC & 120 \\
\hline 121 & GCATTTCACC & GCTCCACCAG & GAATTCCACT & СтсссстCст & GCACTCAAGT & CAAGTAGTAT & CCACTGCAGT & TCCCCGGTTA & AGCCGGGGGA & TTTCACAATG & GACTTGCTCA & ACCGCCTACG & 240 \\
\hline 241 & TGCTCTTTAT & GCCCAGTGAT & TCCGAACAAC & GTTCGCACCA & TACGTATTAC & CGCGGCTGCT & GGCACGTATT & TAGCCGGTGC & ТтсстстсCT & GGTAGCGTCA & AACGAGATGG & СTATTCACCT & 360 \\
\hline 361 & CCCGCCATTC & TTCCCAGGTG & ACAGGGCTTT & ACAACCCGAA & GGCCTTCATC & ACCCACGCGG & CGTCGCTCCG & TCACGCTTTC & GCGCATTGCG & GAAGATCCTC & GACTGCAGCC & TCCCGTAGGA & 480 \\
\hline 481 & GTCTGGGCAG & TGTCTCAGTC & CCAGTGCGGC & CGGTCACCCT & CTCAGGTCGG & CTACCCGTCA & TAACCTTGGT & GAGCCGTTAC & СТCCCCCACT & AGCTGATAGG & ACATAAACCC & CTCTCCGAGC & 600 \\
\hline 601 & GAARAGCCCCG & TGCGGATCCC & TTTTTTTAAT & CTCTAATCAT & GTTACTCATG & ATCTAATTAG & GTATTATCTA & СССTTTICAА & TAGITTTTCC & CATTTCGAAG & GTAGTAATCT & ATGCATTACA & 720 \\
\hline 721 & CGTCCTTAAT & ATACCTGATT & GATTICCTGA & AАAATCTTTT & TCTATTAGTT & GGTTTTCTAA & TATAATTTTA & TTA & & & & & 793 \\
\hline
\end{tabular}

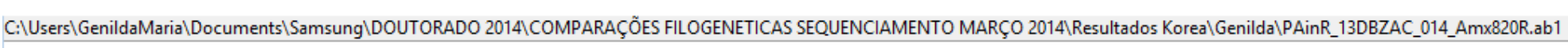


Sequencia obtida a partir da biomassa do sistema biológico com sedimento do Paranoá (PaA) - Primer Pla46F - não selecionada

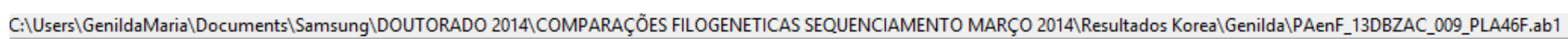

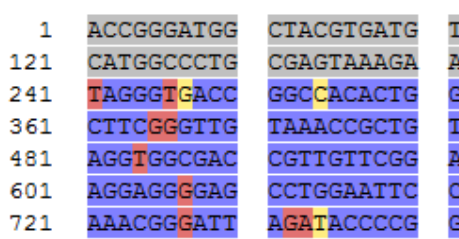

721 AAACGGGATT AGATACCCCG

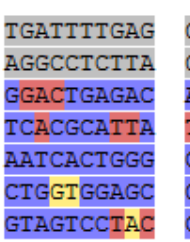

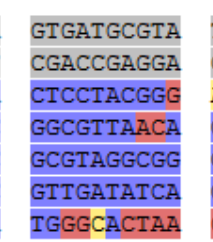

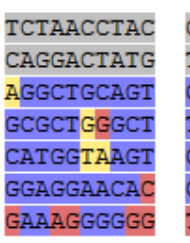

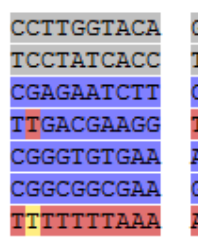

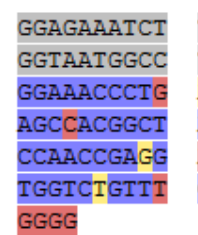

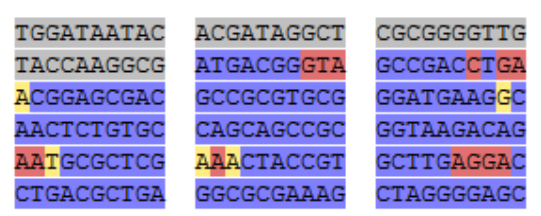

Sequencia obtida a partir da biomassa do sistema biológico com sedimento do Paranoá (PaB) - Primer Amx820 R - selecionada para comparações filogenéticas.

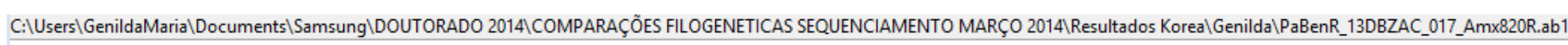
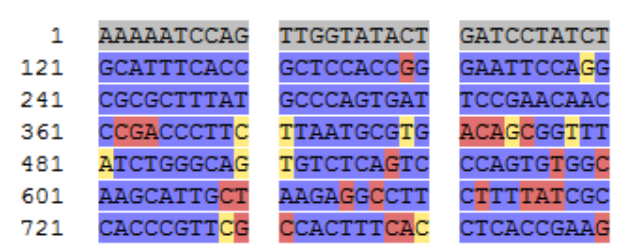

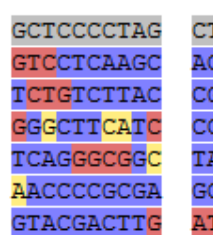

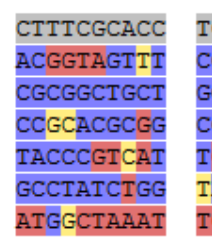

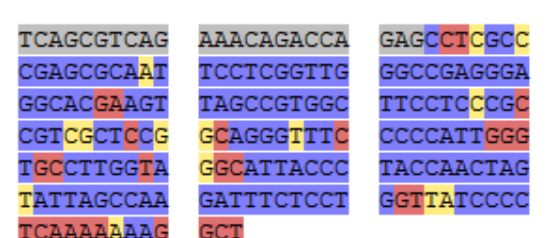

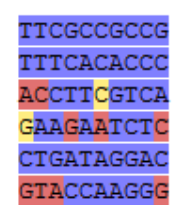

\begin{tabular}{lll} 
GTGTTCCTCC & TGATATCAAC \\
\hline GACTTACCAT & GCCGCCTACG \\
\hline AAACCCAACG & CTGTTAACGC \\
\hline GACTGGAGCC & TCCCGTAAGA \\
\hline ATAGTCCCGT & CCTCGGACGA \\
\hline GAGGTTAGCT & ATGCATTACT
\end{tabular}

20 CGAGGATCAC 
Sequencia obtida a partir da biomassa dos sistemas biológicos com lodo da lagoa anaeróbia do frigorífico 1, Araguari/MG (AnF1B) - Primer Pla46 $\mathrm{F}$ - selecionada para comparações filogenéticas.

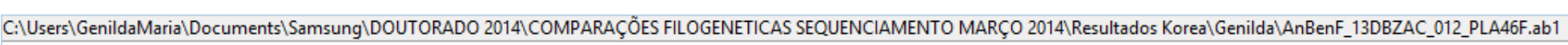

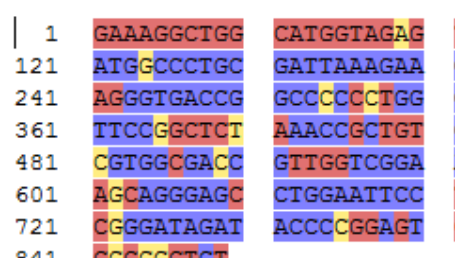

841 CGCGGCTCT
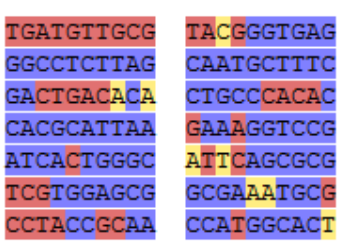
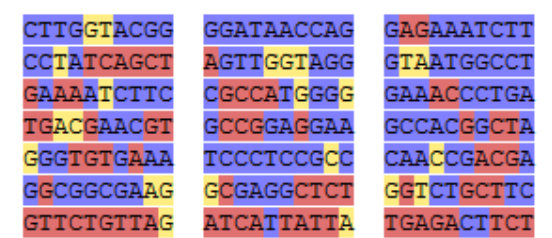

Sequencia obtida a partir da biomassa do lodo da lagoa facultativa do frigorífico 1, Araguari/MG (FaF2 inicial) - Primer Pla46 F - selecionada para comparações filogenéticas.

G:Users\GenildaMaria\Documents\Samsung \DOUTORADO 2014\COMPARAÇÕES FILOGENETICAS SEQUENCIAMENTO MARÇO 2014\Resultados KorealGenildalF3inF_13DBZAC_006_PLA46F.ab1

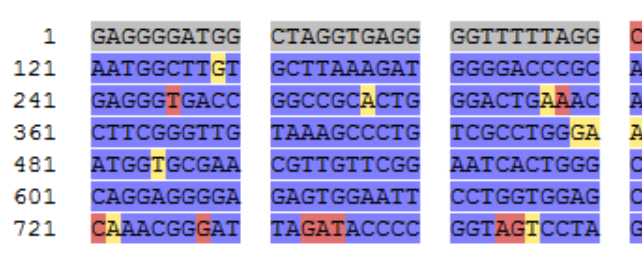

721 CAAACGGGAT

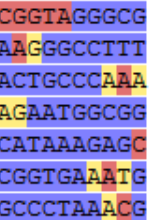

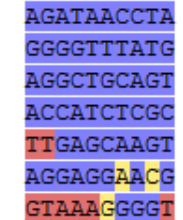

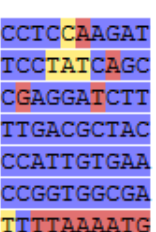

CCGGTGGCG

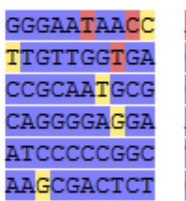

ATCCCCCGGC

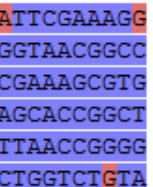

TAACCGGG

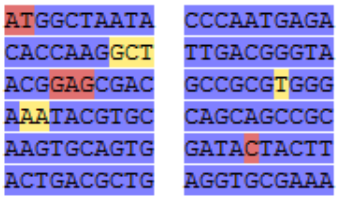

ACGGAGCGAC
AAATACGTGC
AAGTGCAGTG
ACTGACGCTG

\begin{tabular}{ll} 
CGATAGGCTC & GCGGGGTTGC \\
TGACGGGTAG & CCGACCTCAG \\
\hline CCGCGCGCGG & GATGAACGCC \\
\hline AGCAGCCGCC & GTCAGACAGA \\
\hline AAACTACCGT & GCTTGAGGAC \\
\hline GCGCGAAACT & ACGGGAAAAA \\
CATCTAGACA & AGAGTAGCGC
\end{tabular}

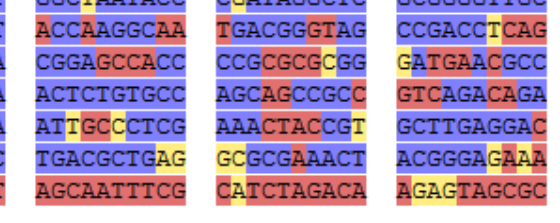

120
240
360
480
600
720
840

Pure Base QV

High $\square$ Medium Low


Sequencia obtida a partir da biomassa do lodo da lagoa facultativa do frigorífico 2, Uberlândia/MG (FaF2 inicial) - Primer Pla46 F - não selecionada

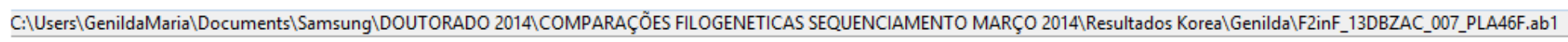

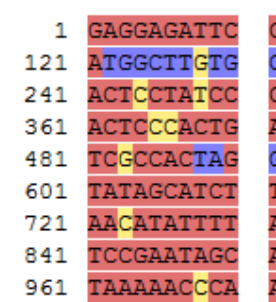

961 TAMAMACCC

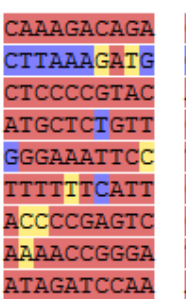

ATAGATCCA

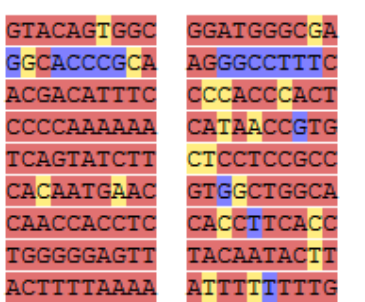

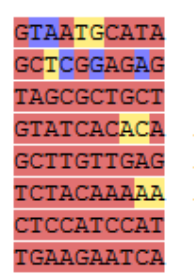

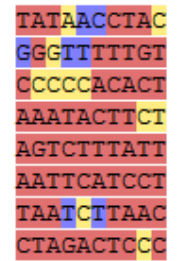

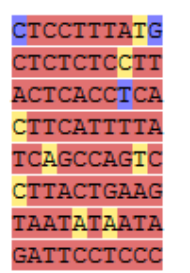

GGAATAACCA GCTGGTGACG TAGACACTCG CGACGCACTC CCCCCACCT GaCAATATA ATTTCTCTTC
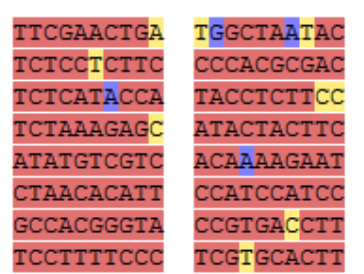

Sequencia obtida a partir da biomassa do lodo da lagoa facultativa do frigorífico 2, Uberlândia/MG (FaF2 inicial) - Primer Amx 820 R - selecionada para comparações filogenéticas.

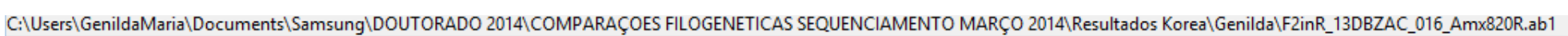

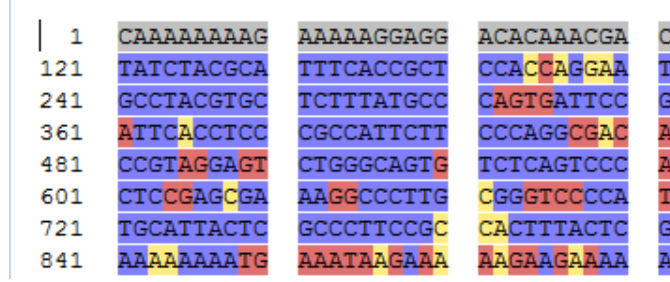

841 AAAAAAAATG
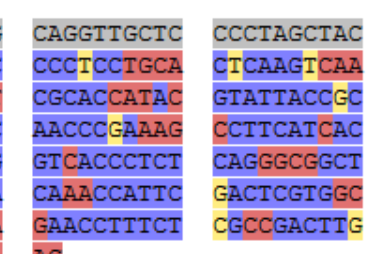

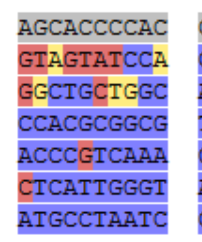

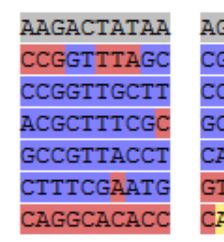

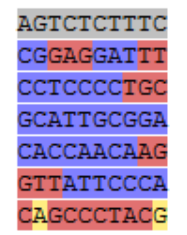

\begin{tabular}{ll} 
GGCGCCGGCG & TTCCTTCTGA \\
CACAATGGAC & TTGGTCGACC \\
\hline TAACGTCAAA & CGAGATGATT \\
\hline AGATCCTCGA & CTGCAGCCTC \\
\hline CTGATAGGAC & ATAAACCCCI \\
\hline TCTTGGAGGT & AGGTTATCTA \\
\hline CGGGCCTTAA & AAAAAAACAAA
\end{tabular}

Sequencia obtida a partir da biomassa do sistema biológico com lodo da lagoa facultativa do frigorífico 2, Uberlândia/MG (FaF2A) - Primer Pla 46F - selecionada para comparações filogenéticas.

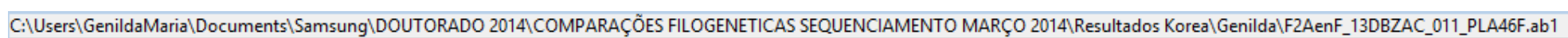

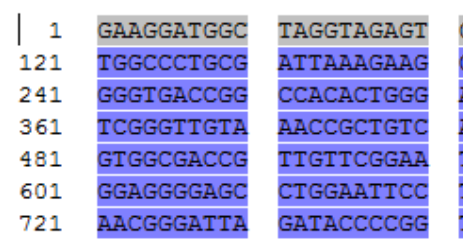

721 AACGGGATTA
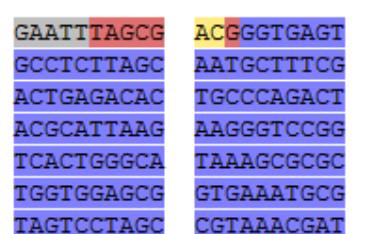

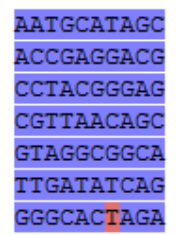

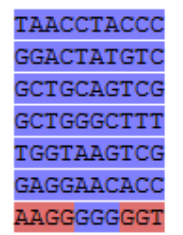

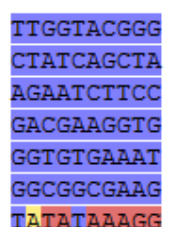

TATATAAAGG
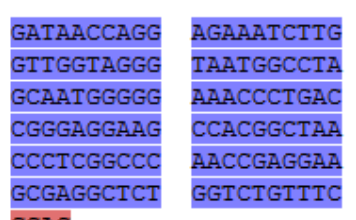

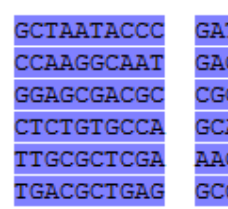

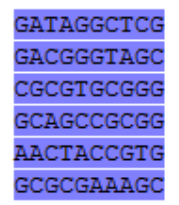

CGGGGTTGCA

CGACCTGAGA

ATGAAGGCCT

TAAGACAGAG

CTTGAGGACA

TAGGGGAGCA 
Sequencia obtida a partir da biomassa do sistema biológico com lodo da lagoa facultativa do frigorífico 2, Uberlândia/MG (FaF2A) - Primer Amx820R - não selecionada

:Users\GenildaMaria\Documents\Samsung\DOUTORADO 2014\COMPARAÇõES FILOGENETICAS SEQUENCIAMENTO MARÇO 2014\Resultados Korea\Genilda\F2AenR_13DBZAC_018_Amx820R.ab1
1 AAAAAAAACC
1 AaAaAaAacca ctaAaAagg gaAatcactc
GTGTICTAT
TTGGGCTCA
ACTCTTTTI AGTTTCGCCC

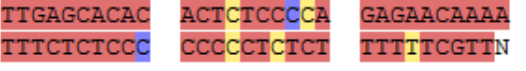
GATTTGATTI CTCACAGGCG GCGGAGagTC GTTATATCAC GACATCTCAC 130

Sequencia obtida a partir da biomassa do sistema biológico com lodo da lagoa facultativa do frigorífico 2, Uberlândia/MG (FaF2B) - Primer Pla 46F - selecionada para comparações filogenéticas.

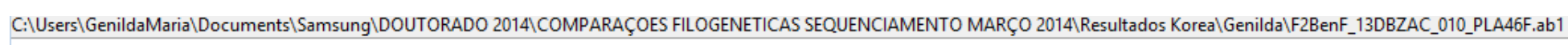

\begin{tabular}{|c|c|c|c|c|c|c|c|c|c|c|c|c|c|}
\hline 1 & GGAAAAAATGG & CTAGTTGAGG & GGTTTTAGCG & ACTAGGTGAG & TAATGCATAG & CTAACCTACC & CITGGTACGG & GGATAACCAG & GTAGAAATCT & TGGCTAATAC & CCGATAGGCT & CGCGGGGITG & 120 \\
\hline 121 & CATGGCCCTG & CGATTAAAGA & AGGCCTCTTA & GCAATGCTTT & CGACCGAGGA & CGGGACTATG & TCCTATCAGC & TAGTTGGTAG & GGTAATGGCC & TACCAAGGCA & ATGACGGGTA & GCCGACCTGA & 240 \\
\hline 241 & GAGGGTGACC & GGCCACACTG & GGACTGAGAC & ACTGCCCAGA & CTCCTACGGG & AGGCTGCAGT & CGAGAATCTT & CCGCAATGGG & GGAAACCCTG & ACGGAGCGAC & GCCGCGTGCG & GGATGAAGGC & 360 \\
\hline 361 & CTTCGGGTTG & TAAACCGCTG & TCACGCATTA & AGAAGGGTCC & GGCGTTAACA & GCGCTGGGCT & TTGACGAAGG & TGCGGGAGGA & AGCCACGGCT & AACTCTGTGC & CAGCAGCCGC & GGTAAGACAG & 480 \\
\hline 481 & AGGTGGCGAC & CGTTGTTCGG & AATCACTGGG & CATAAAGCGC & GCGTAGGCGG & CATGGTAAGT & CGGGTGTGAA & ATCCCTCGGC & CCAACCGAGG & AATTGCGCTC & GAAACTACCG & TGCTTGAGGA & 600 \\
\hline 601 & CAGGAGGGGA & GCCTGGAATT & CCTGGTGGAG & CGGTGAAATG & CGTTGATATC & AGGAGGAACA & CCGGCGGCGA & AGGCGAGGCT & CTGGTCTGTT & TCTGACGCTG & AGGCGCGAAA & GCTAGGGGAG & 720 \\
\hline 721 & CAAACGGGAT & TAGATACCCC & GGTAGTCCTA & GCCGTAAACG & ATGGGCACTA & AAAAAGGGGG & GITTTAAAAA & AGGAAAAAGG & AGCCCCGGAA & $\mathrm{AA}$ & & & 812 \\
\hline
\end{tabular}

Sequencia obtida a partir da biomassa do sistema biológico com lodo da lagoa facultativa do frigorífico 2, Uberlândia/MG (FaF2B) - Primer Amx 820R - selecionada para comparações filogenéticas.

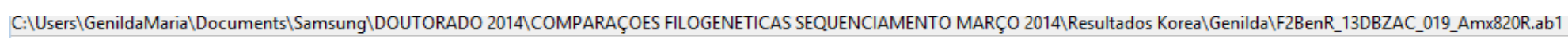

\begin{tabular}{|c|c|c|c|c|}
\hline 1 & AACATTCACC & TGACTAGTCT & AGTCATATCT & AATCACGTTT \\
\hline & GCATTTCACC & GCTCCACCAG & GAATTCCAGG & СтсссстсСТ \\
\hline & $\mathrm{CGCGC}$ & $\mathrm{GCCCP}$ & TCCGI & GGTC \\
\hline & & & & \\
\hline 18 & GTCTGGGC & TGTC? & CCAGTGI & CGGTCACCCT \\
\hline & GAAAGCAT & CTAAGAGGCC & TTCTTTA & GCAGGGCCAT \\
\hline & CACCCE & $\mathrm{CC}$ & $\mathrm{ACCT}$ & GCGAC \\
\hline
\end{tabular}

GCTCCCCTAG
GTCCTCAAGC
TCTGICTTAC
GGCCTTCATC
CTCAGGTCGG
GCAACCCCGC
ACGTACGACI

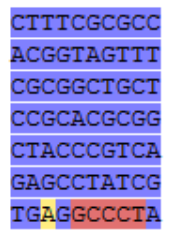

TCAGCGTCAG
CGAGCGCAAT
GGCACAGAGT
CGTCGCTCCG
TIGCCTTGGT
GGTATTAGCC
AATCCAAAAAA

\begin{tabular}{l} 
AAACAGACCA \\
TCCTCGGTTG \\
TAGCCGIGGC \\
\hline TCAGGGTTTC \\
\hline AGGCCATTAC \\
\hline AAGATTICTC \\
\hline AAAATTTTTT
\end{tabular}

\begin{tabular}{|c|c|}
\hline A $\mathrm{AGCTCGCC}$ & TTCGCCGCCG \\
\hline GGCCGAGC & TTTCACACCC \\
\hline TTCCTCCCGC & ACCTTCGTCA \\
\hline CCCCATT & GAAGATTCTC \\
\hline CCTACCAACT & AGCTGATAGG \\
\hline CTGGTTATCC & CCGTACCAAG \\
\hline ;GTTTTT & A \\
\hline
\end{tabular}

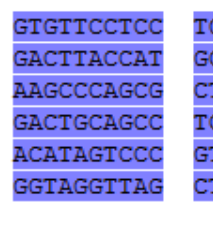

\begin{tabular}{l} 
TGATATCAAC \\
GCCGCCTACG \\
CIGTTAACGC \\
TCCCGTAGGA \\
GTCCTCGGTC \\
CTATGCATTA \\
\hline
\end{tabular}

- Pure Base QV

High Medium Low 
Sequencia obtida a partir da biomassa do lodo do Uasb frigorífico 2, Uberlândia/MG (UaF2 inicial) - Primer Pla46F - não selecionada.

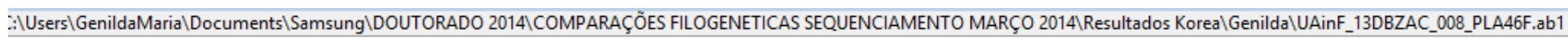

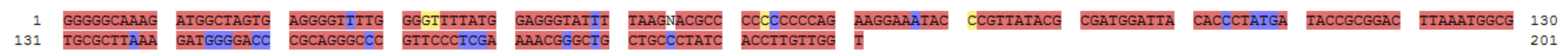

Sequencia obtida a partir da biomassa do sistema biológico com sedimento da lagoa de chorume, Brasília/DF (ChoA) - Primer Pla 46F - selecionada para comparações filogenéticas.

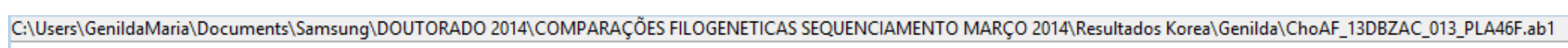

\begin{tabular}{|c|c|c|c|c|c|c|c|c|c|c|c|c|c|}
\hline 1 & GGAGGGATGC & ATCAGTAGAG & TGGATTTGAG & CGACGGGTGA & GTAATGCATA & GCTAACCTAC & CCTTGGTACG & GGGATAACCA & GGAGAAATCT & TGGCTAATAC & CCGATAGGCT & CGCGGGGTTG & 120 \\
\hline 121 & CATGGCCCTG & CGATTAAAGA & AGGCCTCTTA & GCAATGCTTT & CGACCGAGGA & CGGGACTATG & TCCTATCAGC & TAGTTGGTAG & GGTAATGGCC & TACCAAGGCA & ATGACGGGTA & GCCGACCTGA & 240 \\
\hline 241 & GAGGGTGACC & GGCCACACTG & GGACTGAGAC & ACTGCCCAGA & CTCCTACGGG & AGGCTGCAGT & CGAGAATCTT & CCGCAATGGG & GGAAACCCTG & ACGGAGCGAC & GCCGCGTGCG & GGATGAAGGC & 360 \\
\hline 361 & CTTCGGGTTG & TAAACCGCTG & TCACGCATTA & AGAAGGGTCC & GGCGTTAACA & GCGCTGGGCT & TTGACGAAGG & TGCGGGAGGA & AGCCACGGCT & AACTCTGTGC & CAGCAGCCGC & GGTAAGACAG & 480 \\
\hline 481 & AGGTGGCGAC & CGTTGTTCGG & AATCACTGGG & CATAAAGCGC & GCGTAGGCGG & CATGGTAAGT & CGGGTGTGAA & ATCCCTCGGC & CCAACCGAGG & AATTGCGCTC & GAAACTACCG & TGCTTGAGGA & 600 \\
\hline 601 & CAGGAGGGGA & GCCTGGAATT & CCTGGTGGAG & CGGTGAAATG & CGTTGATATC & AGGAGGAACA & CCGGCGGCGA & AGGCGAGGCT & CTGGTCTGTT & TCTGACGCTG & AGGCGCGAAA & GCTAGGGGAG & 720 \\
\hline 721 & CAAACGGGAT & TAGATACCCC & GGTAGTCCTA & GCCGTAAACG & ATGGGCATAT & AAAGGGGGG & TTTTAAAAGG & GGGG & & & & & 794 \\
\hline
\end{tabular}

Sequencia obtida a partir da biomassa do sistema biológico com sedimento da lagoa de chorume, Brasília/DF (ChoA) - Primer Amx 820R selecionada para comparações filogenéticas.

C:IUsers\GenildaMaria\Documents\Samsung\DOUTORADO 2014\COMPARAÇõES FILOGENETICAS SEQUENCIAMENTO MARÇO 2014\Resultados Korea\Genilda\ChoAenR_13DBZAC_020_Amx820R.ab1

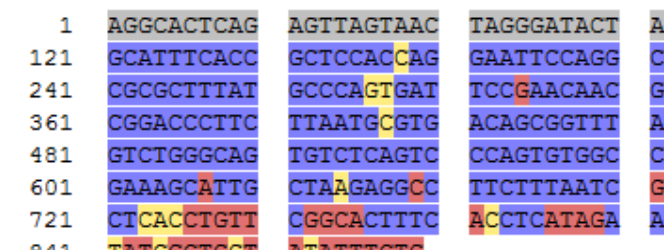

841 TATCGCTGGI ATATTTCTG

\begin{tabular}{lll} 
AATCCCGTTT & GCTCCCCTAG \\
CTCCCCTCCT & GTCCTCAAGC \\
\hline GGTCGCCACC & TCTGTCTTAC \\
\hline ACAACCCGAA & GGCCTTCATC \\
\hline CGGTCACCCT & CTCAGGTCGG \\
\hline GCAGGGCCAT & GCAACCCCGC \\
\hline AGGGAGGATT & ACGTAAGACT \\
\hline
\end{tabular}

CTTTCGCGCC
ACGGTAGTTT
CGCGGCTGCT
CCGCACGCGG
CTACCCGTCA
GAGCCTATCG
TGCTTGCCTA

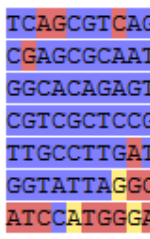

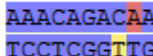

TCCTCGGTT

TAGCCGTGG

ACAGGGTTTC

AAGATTICT

TGGTTTTCTT

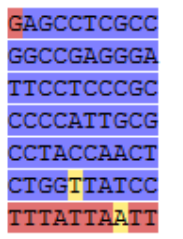

\begin{tabular}{llll}
\hline TTCGCCGCCG & GTGTTCCTCC & TGATATCAAC \\
\hline TTTCACACCC & GACTTACCAT & GCCGCCTACG \\
\hline ACCTTCGTCA & AAGCCCAGCG & CTGTTAACGC \\
\hline GAAGATTCTC & GACTGCAGCC & TCCCGTAGGA \\
\hline AGCTGATAGG & ACATAGTCCC & GTCCTCGGTC \\
\hline CCGTACCATG & GGTAGGTTAA & CTATGCATTA \\
\hline AAACATAACACA & AAACGAAGTT & CATAAAGTAG
\end{tabular}




\section{APENDICE V}

\section{VERIFICAÇÃO DOS SISTEMAS A E B PARA AVALIAÇÃO DA NORMALIDADE E HOMOGENEIDADE DAS AMOSTRAS COM RELAÇÃO ÀS VARIÁVEIS REDUÇÃO DE AMÔNIA, REDUÇÃO DE NITRITO E FORMAÇÃO DE NITRATO}

Duas premissas para uso de testes paramétrico é que as amostras coletadas para uma dada variável apresentem uma distribuição normal e tenham variâncias homogêneas. A discordância com apenas uma dessas premissas já invalida o uso de testes paramétricos.

Para testar se a distribuição dos dados se desvia de uma distribuição normal utilizou-se os testes de Kolmogorov-Smirnov e de Shapiro-Wilk, que comparam escores de uma amostra a uma distribuição normal modelo de mesma média e variância dos valores encontrados nas amostras. Nessa primeira etapa da análise da normalidade considerou-se as amostras coletadas ao longo dos testes e intervalos de tempos como independentes. Uma vez que, para o objetivo de comparar se os sistemas A e B montados com cada tipo de inóculo representavam duplicatas, essa análise de normalidade se aplica.

Lembrando que para esses testes foram utilizados os dados brutos de redução de amônia e nitrito e acréscimo de nitrato em $\mathrm{mM}$.

Numa primeira análise utilizou-se a comparação de normalidade e homogeneidade considerando-se o comportamento dos íons (amônia, nitrito, nitrato), tendo os dados para cada sistema componente da duplicata (A e B). Dessa maneira, considerou-se a concentração dos íons independentemente dos intervalos em que eles foram coletados. A homogeneidade foi avaliada usando a comparação da variância de um dado íon, se igual ou diferente entre os sistemas A e B.

Dessa maneira, com relação à redução na concentração de amônia tem-se:

Testes de Normalidade

\begin{tabular}{|l|r|r|r|r|r|r|}
\hline & \multicolumn{4}{|c|}{ Kolmogorov-Smirnova } & \multicolumn{3}{c|}{ Shapiro-Wilk } \\
\cline { 2 - 7 } & Estatística & Df & \multicolumn{1}{c|}{ Sig. } & Estatística & \multicolumn{1}{c|}{ df } & \multicolumn{1}{c|}{ Sig. } \\
\hline Am_ParA &, 138 & 50 &, 018 &, 909 & 50 &, 001 \\
Am_ParB &, 107 & 50 &, $200^{*}$ &, 942 & 50 &, 016 \\
\hline
\end{tabular}




\begin{tabular}{|l|l|r|r|r|r|r|} 
Am_AnF1A &, 135 & 50 &, 023 &, 943 & 50 &, 018 \\
Am_AnF1B &, 093 & 50 &, 200 &, 955 & 50 &, 055 \\
Am_FaF1A &, 163 & 50 &, 002 &, 919 & 50 &, 002 \\
Am_FaF1B &, 147 & 50 &, 009 &, 901 & 50 &, 001 \\
Am_FaF2A &, 161 & 50 &, 002 &, 925 & 50 &, 004 \\
Am_FaF2B &, 179 & 50 &, 000 &, 867 & 50 &, 000 \\
Am_UaF2A &, 271 & 50 &, 000 &, 751 & 50 &, 000 \\
Am_UaF2B &, 205 & 50 &, 000 &, 860 & 50 &, 000 \\
Am_ChoA &, 135 & 50 &, 024 &, 909 & 50 &, 001 \\
Am_ChoB &, 117 & 50 &, 087 &, 899 & 50 &, 000 \\
\hline
\end{tabular}

*. Este é um limite inferior da significância verdadeira.

a. Correlação de Significância de Lilliefors

Para todos os sistemas, com exceção dos sistemas Am_ParB e Am_AnF1B, diferiram significativamente da distribuição normal $\operatorname{com} p<0,01$ pelo teste de Shapiro Wilk que é mais robusto para amostra pequenas $(n=50)$ do que o teste de Kolmogorov-Smirnov. Os dados de concentração de amônia sistema Am_ParB foi diferente da distribuição normal com $\mathrm{p}<0,05$ pelo teste de Shapiro-Wilk, enquanto o Am_AnF1B não diferiu significativamente da distribuição normal pelo teste de Shapiro Wilk, com $p>0,05$. Com relação aos resultados obtidos pelo teste de Kolmogorov-Smirnov, todos os sistemas, à exceção dos pares de sistema Am_ParA e Am_ParB; Am_AnF1A e Am_AnF1B; Am_ChoA e Am_ChoB, também diferiram significativamente da distribuição normal com $p<0,01$ ). Por esse teste os sistemas Am_PaB; Am_AnF1B; Am_ChoB não diferiram significativamente da distribuição normal com $p>0,05$.

Dessa maneira, com relação à redução na concentração de nitrito tem-se:

Testes de Normalidade

\begin{tabular}{|l|r|r|r|r|r|r|}
\hline & \multicolumn{4}{|c|}{ Kolmogorov-Smirnova } & \multicolumn{3}{|c|}{ Shapiro-Wilk } \\
\cline { 2 - 7 } & Estatística & Df & Sig. & Estatística & df & \multicolumn{1}{c|}{ Sig. } \\
\hline Ni_ParA &, 148 & 50 &, 008 &, 896 & 50 &, 000 \\
Ni_ParB &, 145 & 50 &, 011 &, 912 & 50 &, 001 \\
Ni_AnF1A &, 133 & 50 &, 027 &, 902 & 50 &, 001 \\
Ni_AnF1B &, 214 & 50 &, 000 &, 801 & 50 &, 000 \\
Ni_FaF1A &, 214 & 50 &, 000 &, 851 & 50 &, 000 \\
Ni_FaF1B &, 151 & 50 &, 006 &, 904 & 50 &, 001 \\
Ni_FaF2A &, 126 & 50 &, 046 &, 884 & 50 &, 000
\end{tabular}




\begin{tabular}{|l|r|r|r|r|r|r|} 
Ni_FaF2B &, 159 & 50 &, 003 &, 908 & 50 &, 001 \\
Ni_UaF2A &, 240 & 50 &, 000 &, 779 & 50 &, 000 \\
Ni_UaF2B &, 159 & 50 &, 003 &, 864 & 50 &, 000 \\
Ni_ChoA &, 169 & 50 &, 001 &, 923 & 50 &, 003 \\
Ni_ChoB &, 111 & 50 &, 170 &, 931 & 50 &, 006 \\
\hline
\end{tabular}

a. Correlação de Significância de Lilliefors

Para todos os sistemas os dados coletados para a concentração de nitrito diferiram significativamente da distribuição normal com $p<0,01$ pelo teste de Shapiro Wilk que é mais robusto para amostra pequenas $(n \leq 50)$ do que o teste de KolmogorovSmirnov.Com relação ao teste de Kolmorov-Sminorv todos os sistemas, a exceção do Ni_ChoB, também apresentaram distribuição diferente da normal com $p<0,01$ e ou a $p$ $<0,05$.

Dessa maneira, com relação ao aumento na concentração de nitrato tem-se:

Testes de Normalidade

\begin{tabular}{|c|c|c|c|c|c|c|}
\hline & \multicolumn{3}{|c|}{ Kolmogorov-Smirnova } & \multicolumn{3}{|c|}{ Shapiro-Wilk } \\
\hline & Estatística & Df & Sig. & Estatística & df & Sig. \\
\hline $\mathrm{Na}$ _ParA & ,206 & 50 &, 000 & ,806 & 50 &, 000 \\
\hline $\mathrm{Na}$ _ParB & ,249 & 50 &, 000 & ,793 & 50 & ,000 \\
\hline $\mathrm{Na} \_$AnF1A & ,257 & 50 &, 000 & ,776 & 50 & ,000 \\
\hline $\mathrm{Na} \_$AnF1B & ,343 & 50 &, 000 &, 580 & 50 & ,000 \\
\hline $\mathrm{Na}$ _FaF1A & ,349 & 50 & ,000 & ,624 & 50 & ,000 \\
\hline $\mathrm{Na}$ _FaF1B & ,241 & 50 & ,000 & ,765 & 50 & ,000 \\
\hline $\mathrm{Na}$ _FaF2A & ,269 & 50 & ,000 & ,693 & 50 & ,000 \\
\hline $\mathrm{Na}$ _FaF2B & ,264 & 50 &, 000 & ,790 & 50 & ,000 \\
\hline $\mathrm{Na}$ _UaF2A & ,259 & 50 &, 000 & ,823 & 50 & ,000 \\
\hline $\mathrm{Na} \_$UaF2B & 273 & 50 &, 000 & ,778 & 50 & ,000 \\
\hline Na_ChoA & 200 & 50 & ,000 & ,788 & 50 & ,000 \\
\hline $\mathrm{Na}$ _ChoB & ,183 & 50 &, 000 & ,872 & 50 & ,000 \\
\hline
\end{tabular}

a. Correlação de Significância de Lilliefors

Para todos os sistemas os dados coletados para a concentração de nitrato diferiram significativamente da distribuição normal com $p<0,01$ tanto pelo teste de Shapiro Wilk quanto o teste de Kolmogorov-Smirnov. 
Com relação à homogeneidade das variâncias pelo teste de Levene tem-se:

\section{Entre o par ParA e ParB}

Teste de Homogeneidade de Variância

\begin{tabular}{|c|c|c|c|c|c|}
\hline & & $\begin{array}{l}\text { Estatística de } \\
\text { Levene }\end{array}$ & df1 & df2 & Sig. \\
\hline \multirow[t]{4}{*}{ Amônia } & Com base em média & 1,855 & 1 & 98 & ,176 \\
\hline & Com base em mediana & ,751 & 1 & 98 & ,388 \\
\hline & $\begin{array}{l}\text { Com base em mediana e } \\
\text { com df ajustado }\end{array}$ & 751 & 1 & 83,264 & ,389 \\
\hline & $\begin{array}{l}\text { Com base em média } \\
\text { aparada }\end{array}$ & 1,499 & 1 & 98 & ,224 \\
\hline \multirow[t]{4}{*}{ Nitrito } & Com base em média & , 191 & 1 & 98 & ,663 \\
\hline & Com base em mediana & , 166 & 1 & 98 & ,685 \\
\hline & $\begin{array}{l}\text { Com base em mediana e } \\
\text { com df ajustado }\end{array}$ & ,166 & 1 & 96,701 & ,685 \\
\hline & $\begin{array}{l}\text { Com base em média } \\
\text { aparada }\end{array}$ & ,171 & 1 & 98 & ,680 \\
\hline \multirow[t]{4}{*}{ Nitrato } & Com base em média & 027 & 1 & 98 & ,869 \\
\hline & Com base em mediana & , 138 & 1 & 98 & ,711 \\
\hline & $\begin{array}{l}\text { Com base em mediana e } \\
\text { com df ajustado }\end{array}$ & 138 & 1 & 97,634 & ,711 \\
\hline & $\begin{array}{l}\text { Com base em média } \\
\text { aparada }\end{array}$ & ,032 & 1 & 98 & ,859 \\
\hline
\end{tabular}

Entre o par AnF1A e AnF1B

Teste de Homogeneidade de Variância

\begin{tabular}{|c|c|c|c|c|c|}
\hline & & $\begin{array}{c}\text { Estatística de } \\
\text { Levene }\end{array}$ & df1 & $\mathrm{df2}$ & Sig. \\
\hline \multirow[t]{4}{*}{ Amônia } & Com base em média & 1,120 & 1 & 98 & ,292 \\
\hline & Com base em mediana & ,975 & 1 & 98 & ,326 \\
\hline & $\begin{array}{l}\text { Com base em mediana e } \\
\text { com df ajustado }\end{array}$ &, 975 & 1 & 93,122 & ,326 \\
\hline & $\begin{array}{l}\text { Com base em média } \\
\text { aparada }\end{array}$ & 1,020 & 1 & 98 & ,315 \\
\hline \multirow[t]{4}{*}{ Nitrito } & Com base em média & ,128 & 1 & 98 & ,721 \\
\hline & Com base em mediana & 459 & 1 & 98 &, 500 \\
\hline & $\begin{array}{l}\text { Com base em mediana e } \\
\text { com df ajustado }\end{array}$ & ,459 & 1 & 83,418 &, 500 \\
\hline & $\begin{array}{l}\text { Com base em média } \\
\text { aparada }\end{array}$ & ,204 & 1 & 98 & ,652 \\
\hline \multirow[t]{4}{*}{ Nitrato } & Com base em média & 4,084 & 1 & 98 & 046 \\
\hline & Com base em mediana & 2,862 & 1 & 98 & 094 \\
\hline & $\begin{array}{l}\text { Com base em mediana e } \\
\text { com df ajustado }\end{array}$ & 2,862 & 1 & 96,748 & 094 \\
\hline & $\begin{array}{l}\text { Com base em média } \\
\text { aparada }\end{array}$ & 5,096 & 1 & 98 &, 026 \\
\hline
\end{tabular}




\section{Entre o par FaF1A e FaF1B}

Teste de Homogeneidade de Variância

\begin{tabular}{|c|c|c|c|c|c|}
\hline & & $\begin{array}{l}\text { Estatística de } \\
\text { Levene }\end{array}$ & df1 & $\mathrm{df} 2$ & Sig. \\
\hline \multirow[t]{4}{*}{ Amônia } & Com base em média & 5,915 & 1 & 98 &, 017 \\
\hline & Com base em mediana & 4,636 & 1 & 98 & 034 \\
\hline & $\begin{array}{l}\text { Com base em mediana e } \\
\text { com df ajustado }\end{array}$ & 4,636 & 1 & 95,171 & ,034 \\
\hline & $\begin{array}{l}\text { Com base em média } \\
\text { aparada }\end{array}$ & 5,808 & 1 & 98 &, 018 \\
\hline \multirow[t]{4}{*}{ Nitrito } & Com base em média &, 580 & 1 & 98 & ,448 \\
\hline & Com base em mediana & ,200 & 1 & 98 & ,656 \\
\hline & $\begin{array}{l}\text { Com base em mediana e } \\
\text { com df ajustado }\end{array}$ & 200 & 1 & 91,026 & 656 \\
\hline & $\begin{array}{l}\text { Com base em média } \\
\text { aparada }\end{array}$ &, 512 & 1 & 98 & ,476 \\
\hline \multirow[t]{4}{*}{ Nitrato } & Com base em média & ,030 & 1 & 98 & ,864 \\
\hline & Com base em mediana & , 199 & 1 & 98 & ,656 \\
\hline & $\begin{array}{l}\text { Com base em mediana e } \\
\text { com df ajustado }\end{array}$ & ,199 & 1 & 93,267 & 656 \\
\hline & $\begin{array}{l}\text { Com base em média } \\
\text { aparada }\end{array}$ & ,002 & 1 & 98 & 967 \\
\hline
\end{tabular}

\section{Entre o par FaF2A e FaF2B}

Teste de Homogeneidade de Variância

\begin{tabular}{|c|c|c|c|c|c|}
\hline & & $\begin{array}{l}\text { Estatística de } \\
\text { Levene }\end{array}$ & df1 & df2 & Sig. \\
\hline \multirow[t]{4}{*}{ Amônia } & Com base em média & , 116 & 1 & 98 & ,734 \\
\hline & Com base em mediana & ,023 & 1 & 98 & ,881 \\
\hline & $\begin{array}{l}\text { Com base em mediana e } \\
\text { com df ajustado }\end{array}$ & ,023 & 1 & 96,248 & ,881 \\
\hline & $\begin{array}{l}\text { Com base em média } \\
\text { aparada }\end{array}$ & ,054 & 1 & 98 & ,817 \\
\hline \multirow[t]{4}{*}{ Nitrito } & Com base em média & ,002 & 1 & 98 & ,967 \\
\hline & Com base em mediana &, 073 & 1 & 98 &, 787 \\
\hline & $\begin{array}{l}\text { Com base em mediana e } \\
\text { com df ajustado }\end{array}$ &, 073 & 1 & 97,932 &, 787 \\
\hline & $\begin{array}{l}\text { Com base em média } \\
\text { aparada }\end{array}$ & ,001 & 1 & 98 & ,972 \\
\hline \multirow[t]{4}{*}{ Nitrato } & Com base em média & 2,811 & 1 & 98 & ,097 \\
\hline & Com base em mediana & 1,487 & 1 & 98 & ,226 \\
\hline & $\begin{array}{l}\text { Com base em mediana e } \\
\text { com df ajustado }\end{array}$ & 1,487 & 1 & 95,767 & ,226 \\
\hline & $\begin{array}{l}\text { Com base em média } \\
\text { aparada }\end{array}$ & 2,859 & 1 & 98 & ,094 \\
\hline
\end{tabular}




\section{Entre o par UaF2A e UaF2B}

Teste de Homogeneidade de Variância

\begin{tabular}{|c|c|c|c|c|c|}
\hline & & $\begin{array}{c}\text { Estatística de } \\
\text { Levene }\end{array}$ & df1 & df2 & Sig. \\
\hline \multirow[t]{4}{*}{ Amônia } & Com base em média & 017 & 1 & 98 & 895 \\
\hline & Com base em mediana & ,070 & 1 & 98 & ,791 \\
\hline & $\begin{array}{l}\text { Com base em mediana e } \\
\text { com df ajustado }\end{array}$ & ,070 & 1 & 93,745 & 791 \\
\hline & $\begin{array}{l}\text { Com base em média } \\
\text { aparada }\end{array}$ & ,007 & 1 & 98 & ,935 \\
\hline \multirow[t]{4}{*}{ Nitrito } & Com base em média & 2,143 & 1 & 98 & , 146 \\
\hline & Com base em mediana & ,320 & 1 & 98 &, 573 \\
\hline & $\begin{array}{l}\text { Com base em mediana e } \\
\text { com df ajustado }\end{array}$ & ,320 & 1 & 85,252 & ,573 \\
\hline & $\begin{array}{l}\text { Com base em média } \\
\text { aparada }\end{array}$ & 1,347 & 1 & 98 & ,249 \\
\hline \multirow[t]{4}{*}{ Nitrato } & Com base em média & 17,559 & 1 & 98 & 000 \\
\hline & Com base em mediana & 6,870 & 1 & 98 &, 010 \\
\hline & $\begin{array}{l}\text { Com base em mediana e } \\
\text { com df ajustado }\end{array}$ & 6,870 & 1 & 67,017 & 011, \\
\hline & $\begin{array}{l}\text { Com base em média } \\
\text { aparada }\end{array}$ & 14,226 & 1 & 98 & ,000 \\
\hline
\end{tabular}

\section{Entre o par ChoA e ChoB}

Teste de Homogeneidade de Variância

\begin{tabular}{|c|c|c|c|c|c|}
\hline & & $\begin{array}{l}\text { Estatística de } \\
\text { Levene }\end{array}$ & df1 & $\mathrm{df} 2$ & Sig. \\
\hline \multirow[t]{4}{*}{ Amônia } & Com base em média & 8,717 & 1 & 98 & ,004 \\
\hline & Com base em mediana & 7,056 & 1 & 98 & 009 \\
\hline & $\begin{array}{l}\text { Com base em mediana e } \\
\text { com df ajustado }\end{array}$ & 7,056 & 1 & 75,435 & , 010 \\
\hline & $\begin{array}{l}\text { Com base em média } \\
\text { aparada }\end{array}$ & 7,977 & 1 & 98 & ,006 \\
\hline \multirow[t]{4}{*}{ Nitrito } & Com base em média & 1,256 & 1 & 98 & ,265 \\
\hline & Com base em mediana & 1,322 & 1 & 98 & ,253 \\
\hline & $\begin{array}{l}\text { Com base em mediana e } \\
\text { com df ajustado }\end{array}$ & 1,322 & 1 & 97,357 & ,253 \\
\hline & $\begin{array}{l}\text { Com base em média } \\
\text { aparada }\end{array}$ & 1,333 & 1 & 98 & ,251 \\
\hline \multirow[t]{4}{*}{ Nitrato } & Com base em média & 2,759 & 1 & 98 & 100 \\
\hline & Com base em mediana & 1,844 & 1 & 98 & , 178 \\
\hline & $\begin{array}{l}\text { Com base em mediana e } \\
\text { com df ajustado }\end{array}$ & 1,844 & 1 & 95,433 & , 178 \\
\hline & $\begin{array}{l}\text { Com base em média } \\
\text { aparada }\end{array}$ & 2,687 & 1 & 98 & , 104 \\
\hline
\end{tabular}




\section{COMPARAÇÃO ENTRE OS SISTEMAS A E B DURANTE A ETAPA 2}

Os dados obtidos de conversão das formas nitrogenadas presentes na amostras, ao longo dos tempos de cada teste e também com o número do teste, que irá refletir numa variável tempo, visto que o teste sucessor ao anterior representa maior tempo que a biomassa encontra-se dentro do sistema e com isso maior aclimatação e enriquecimento dos grupos de microorganismos que melhor se desenvolveram dadas as condições estabelecidas, são considerados não paramétricos visto que não correspondem aos pressupostos de normalidade $\mathrm{e}$ homogeneidade. A não normalidade e homogeneidade dos dados eram esperados dado as características das informações coletadas, visto que, a conversão das formas nitrogenadas dependia das densidades dos grupos de micro-organismos presentes nos inóculos bem como das concentrações dos substratos limitantes e das concentrações de substâncias inibitórias a cada grupo de micro-organismos. Dessa maneira torna-se necessário a adoção de testes não paramétricos para interpretação dos resultados obtidos.

Comparação entre os sistemas A e B de cada inóculo da etapa 2 para verificar se os mesmos continuaram a agir como duplicatas na conversão dos compostos nitrogenados. Para tanto realizou-se testes de hipóteses, sendo $H 0=F($ Sistema $A)=F($ Sistema $B) ; H 1=F($ Sistema $A) \neq$ $\mathrm{F}($ Sistema B);

Nesse teste não existe uma previsão de qual sistema apresentou maior ou menor conversão, então considera-se apenas a igualdade e desigualdade entre os valores lidos de conversão para amônia, nitrito e nitrato e, portanto, busca-se uma análise bilateral.

Para esse teste os sistemas foram considerados como variáveis dependentes, visto que as mesmas estavam sendo avaliadas para checar a igualdade ou não, ou seja considerou elas como emparelhadas, como se fossem provenientes de um único sistema.

\section{Nesse caso utilizou-se o teste dos postos com sinais de Wilcoxon.}

Nesse teste calcula-se a diferença entre as observações de cada amostra (teste e tempo) das duas variáveis dependentes, nesse caso sistema A e sistema B, e depois essas diferenças são transformadas em postos, mas o sinal da diferença (se positiva ou negativa) é atribuído a cada posto. Ao final separa-se os postos com sinais negativos e positivos, e obtém-se a soma dos postos com mesmos sinais. A estatística desse teste $(T)$ é utilizar o menor dos dois valores obtidos na soma dos postos com sinais diferentes (que será o valor T). 
A significância do teste é obtida com o cálculo da média $\bar{T}$ e do erro padrão do teste $\left(E P_{T}\right)$ do teste para cálculo de $Z$, de acordo com as equações:

$$
\begin{gathered}
\bar{T}=\frac{n(n+1)}{4} \\
E P_{T}=\sqrt{\frac{n(n+1)(2 n+1)}{24}} \\
Z=\frac{T-\bar{T}}{E P_{T}}
\end{gathered}
$$

\section{1) Dessa maneira tem-se para as conversões de amônia para os sistemas A e B:}

Para os sistemas com inóculo proveniente da Lago Paranoá de Brasília (Par), as reduções nas concentrações de amônia, ao longo dos perfis temporais de cada teste e ao longo do conjunto de teste, foram significativamente mais altas para o sistema denominado de ParA (Média =0,300; Mediana =0,232) do que para o sistema denominado de ParB (Média =0,274; Mediana $=0,256)$, com $T=447,0$ e $Z=-1,839 p<0,05$. Dessa maneira, esses sistemas A e B com relação à redução de amônia não podem ser utilizados como duplicatas.

Para os sistemas com inóculo proveniente da Lagoa Anaeróbia do Frigorífico 1 (AnF1), as reduções nas concentrações de amônia, ao longo dos perfis temporais de cada teste e ao longo do conjunto de teste, foram significativamente mais altas para o sistema denominado de AnF1A (Média = 0,248; Mediana $=0,23$ ) do que para o sistema denominado de AnF1B (Média = 0,195; Mediana =0,171), com T = 267,0 e Z = -3,577 p <0,01. Dessa maneira, esses sistemas A e $\mathrm{B}$ com relação à redução de amônia não podem ser utilizados como duplicatas.

Para os sistemas com inóculo proveniente da Lagoa Facultativa do Frigorífico 1 (FaF1), as reduções nas concentrações de amônia, ao longo dos perfis temporais de cada teste e ao longo do conjunto de teste, foram significativamente mais altas para o sistema denominado de FaF1A (Média = 0,359; Mediana = 0,293) do que para o sistema denominado de FaF1B (Média = 0,261; Mediana = 0,208), com T = 299,5 e Z = -3,263 p < 0,01. Dessa maneira, esses sistemas A e B com relação à redução de amônia não podem ser utilizados como duplicatas.

Para os sistemas com inóculo proveniente da Lagoa de Acumulação de Chorume do Aterro Controlado Jockey Club, de Brasília (Cho), as reduções nas concentrações de amônia, ao longo dos perfis temporais de cada teste e ao longo do conjunto de teste, foram significativamente mais altas para o sistema denominado de ChoB (Média =0,326; Mediana = 0,341 ) do que para o sistema denominado de ChoA (Média =0,257; Mediana =0,228), com T = 
264,0 e Z = -3,606 p < 0,01. Dessa maneira, esses sistemas A e B com relação à redução de amônia não podem ser utilizados como duplicatas.

Para todos os demais pares de sistemas, com relação a redução de amônia, FaF2A e FaF2B; UaF2A e UaF2B, não diferiram entre si quando comparados aplicando o teste dos postos com sinais de Wilcoxon, utilizando $p<0,05$ (Os resultados dos testes podem ser verificados no Apêndice I-Resultados dos Testes Estatísticos).

Estatísticas descritivas

\begin{tabular}{|c|c|c|c|c|c|c|c|c|}
\hline & \multirow[b]{2}{*}{$\mathrm{N}$} & \multirow[b]{2}{*}{ Média } & \multirow[b]{2}{*}{ Erro Desvio } & \multirow[b]{2}{*}{ Mínimo } & \multirow[b]{2}{*}{ Máximo } & \multicolumn{3}{|c|}{ Percentis } \\
\hline & & & & & & 250. & $50^{\circ}$ (Mediana) & $75^{\circ}$ \\
\hline Am_ParA & 50 & ,30058 & 233764 & ,013 &, 860 &, 09275 & ,23250 & ,46350 \\
\hline Am_AnF1A & 50 & 24892 & ,151988 & ,022 &, 606 & ,14200 & ,23000 & ,32700 \\
\hline Am_FaF1A & 50 & ,35900 & ,267474 &,- 010 & ,899 & ,14125 & 29300 & ,51800 \\
\hline Am_FaF2A & 50 & ,28872 & ,243593 &,- 123 & ,845 & ,10975 & ,20850 & ,51400 \\
\hline Am_UaF2A & 50 & 29256 & ,316311 & ,006 & 1,048 &, 07525 & , 18300 & ,34475 \\
\hline Am_ChoA & 50 & ,25758 & ,195518 & ,015 & ,735 & ,09575 & ,22850 & ,37425 \\
\hline Am_ParB & 50 & ,27418 & ,190449 & ,001 & ,700 &, 09650 & ,25650 & 38900 \\
\hline Am_AnF1B & 50 & ,19570 & ,123512 & ,005 & ,483 & ,11325 & ,17050 & ,28225 \\
\hline Am_FaF1B & 50 & ,26076 & ,203511 &,- 001 &, 677 &, 08950 & ,20800 & ,42625 \\
\hline Am_FaF2B & 50 & ,30874 & ,263279 & ,010 & 1,124 &, 11400 & ,22050 & ,53650 \\
\hline Am_UaF2B & 50 & ,31474 & ,284831 & ,004 & ,949 & ,07900 & 20150 & ,57700 \\
\hline Am_ChoB & 50 & ,39528 & ,326492 & ,006 & 1,199 & ,14225 & ,34100 &, 53100 \\
\hline
\end{tabular}

\section{Teste de Classificações Assinadas por Wilcoxon}

\begin{tabular}{|ll|r|r|r|}
\hline \multicolumn{1}{|c|}{ Classificações } \\
& & \multicolumn{1}{c|}{$\begin{array}{c}\text { Postos de } \\
\text { média }\end{array}$} & $\begin{array}{c}\text { Soma de } \\
\text { Classificações }\end{array}$ \\
\hline Am_ParB - Am_ParA & Classificações Negativas & $32^{\mathrm{a}}$ & 25,88 & 828,00 \\
& Classificações Positivas & $18^{\mathrm{b}}$ & 24,83 & 447,00 \\
& Vínculos & $0^{\mathrm{c}}$ & & \\
& Total & 50 & & 1008,00 \\
& Classificações Negativas & $32^{\mathrm{d}}$ & 31,50 & 267,00 \\
& Classificações Positivas & $18^{\mathrm{e}}$ & 14,83 & \\
& Vínculos & $0^{\mathrm{f}}$ & & \\
& Total & 50 & & \\
\hline
\end{tabular}




\begin{tabular}{|c|c|c|c|c|}
\hline \multirow[t]{4}{*}{ Am_FaF1B - Am_FaF1A } & Classificações Negativas & $32^{\mathrm{g}}$ & 30,48 & 975,50 \\
\hline & Classificações Positivas & $18^{\mathrm{h}}$ & 16,64 & 299,50 \\
\hline & Vínculos & $0^{i}$ & & \\
\hline & Total & 50 & & \\
\hline \multirow[t]{4}{*}{ Am_FaF2B - Am_FaF2A } & Classificações Negativas & $34^{j}$ & 22,44 & 763,00 \\
\hline & Classificações Positivas & $16^{\mathrm{k}}$ & 32,00 & 512,00 \\
\hline & Vínculos & $0^{1}$ & & \\
\hline & Total & 50 & & \\
\hline \multirow[t]{4}{*}{ Am_UaF2B - Am_UaF2A } & Classificações Negativas & $32^{m}$ & 22,14 & 708,50 \\
\hline & Classificações Positivas & $18^{n}$ & 31,47 & 566,50 \\
\hline & Vínculos & $0^{\circ}$ & & \\
\hline & Total & 50 & & \\
\hline \multirow[t]{4}{*}{ Am_ChoB - Am_ChoA } & Classificações Negativas & $16^{p}$ & 16,50 & 264,00 \\
\hline & Classificações Positivas & 349 & 29,74 & 1011,00 \\
\hline & Vínculos & $0^{r}$ & & \\
\hline & Total & 50 & & \\
\hline
\end{tabular}
a. Am_ParB $<$ Am_ParA
b. Am_ParB > Am_ParA
c. Am_ParB $=$ Am_ParA
d. Am_AnF1B $<$ Am_AnF1A
e. Am_AnF1B > Am_AnF1A
f. Am_AnF1B $=A m \_A n F 1 A$
g. Am_FaF1B $<$ Am_FaF1A
h. Am_FaF1B $>$ Am_FaF1A
i. Am_FaF1B $=A m \_F a F 1 A$
j. Am_FaF2B $<$ Am_FaF2A
k. Am_FaF2B $>$ Am_FaF2A
I. Am_FaF2B $=$ Am_FaF2A
m. Am_UaF2B $<$ Am_UaF2A
n. Am_UaF2B $>$ Am_UaF2A
o. Am_UaF2B $=$ Am_UaF2A
p. Am_ChoB $<$ Am_ChoA
q. Am_ChoB $>$ Am_ChoA
r. Am_ChoB $=$ Am_ChoA

Estatísticas de teste ${ }^{a}$

\begin{tabular}{|c|c|c|c|c|c|c|}
\hline & $\begin{array}{l}\text { Am_ParB - } \\
\text { Am_ParA }\end{array}$ & $\begin{array}{l}\text { Am_AnF1B - } \\
\text { Am_AnF1A }\end{array}$ & $\begin{array}{l}\text { Am_FaF1B - } \\
\text { Am_FaF1A }\end{array}$ & $\begin{array}{l}\text { Am_FaF2B - } \\
\text { Am_FaF2A }\end{array}$ & $\begin{array}{l}\text { Am_UaF2B - } \\
\text { Am_UaF2A }\end{array}$ & $\begin{array}{l}\text { Am_ChoB - } \\
\text { Am_ChoA }\end{array}$ \\
\hline Z & $-1,839^{b}$ & $-3,577^{b}$ & $-3,263^{b}$ & $-1,212^{b}$ &,$- 685^{b}$ & $-3,606^{c}$ \\
\hline $\begin{array}{l}\text { Significância Sig. (2 } \\
\text { extremidades) }\end{array}$ & ,066 &, 000 &, 001 & ,226 & ,493 &, 000 \\
\hline
\end{tabular}




\begin{tabular}{|c|c|c|c|c|c|c|}
\hline $\begin{array}{l}\text { Sig exata (2 } \\
\text { extremidades) }\end{array}$ & ,066 & ,000 & ,001 & 229 & 498 & 000 \\
\hline $\begin{array}{l}\text { Sig exata (1 } \\
\text { extremidade) }\end{array}$ & & ,000 & ,000 & 114 & 249 & ,000 \\
\hline Probabilidade de ponto &, 000 &, 000 &, 000 & ,001 & ,002 & 000 \\
\hline
\end{tabular}
a. Teste de Classificações Assinadas por Wilcoxon
b. Com base em postos positivos.
c. Com base em postos negativos.

\section{2) Dessa maneira tem-se para as conversões de nitrito para os sistema A e B:}

Para os sistemas com inóculo proveniente da Lagoa Anaeróbia do Frigorífico 1 (AnF1), as reduções nas concentrações de nitrito, ao longo dos perfis temporais de cada teste e ao longo do conjunto de teste, foram significativamente mais altas para o sistema denominado de AnF1A (Média =0,459; Mediana =0,379) do que para o sistema denominado de AnF1B (Média =0,298; Mediana $=0,111)$, com $T=201,5$ e $Z=-3,965 p<0,01$. Dessa maneira, esses sistemas A e B com relação à redução de nitrito não podem ser utilizados como duplicatas.

Para os sistemas com inóculo proveniente da Lagoa Facultativa do Frigorífico 1 (FaF1), as reduções nas concentrações de nitrito, ao longo dos perfis temporais de cada teste e ao longo do conjunto de teste, foram significativamente mais altas para o sistema denominado de FaF1B (Média = 0,449; Mediana =0,349) do que para o sistema denominado de FaF1A (Média = 0,404; Mediana $=0,241)$, com $T=456,5$ e $Z=-1,747 p<0,05$. Dessa maneira, esses sistemas A e B com relação à redução de nitrito não podem ser utilizados como duplicatas.

Para os sistemas com inóculo proveniente do Reator Uasb do Frigorífico 2(UaF2), as reduções nas concentrações de nitrito, ao longo dos perfis temporais de cada teste e ao longo do conjunto de teste, foram significativamente mais altas para o sistema denominado de UaF2B (Média = 0,356; Mediana $=0,279$ ) do que para o sistema denominado de UaF2A (Média =0,311; Mediana $=0,136)$, com $T=376,0$ e $Z=-2,525 p<0,01$. Dessa maneira, esses sistemas A e B com relação à redução de nitrito não podem ser utilizados como duplicatas.

Para todos os demais pares de sistemas, com relação a redução de nitrito, PaA e PaB; FaF2A e FaF2B; ChoA e ChoB, não diferiram entre si quando comparados aplicando o teste dos postos 
com sinais de Wilcoxon, utilizando $p<0,05$ (Os resultados dos testes podem ser verificados no Apêndice I-Resultados dos Testes Estatísticos).

Estatísticas descritivas

\begin{tabular}{|c|c|c|c|c|c|c|c|c|}
\hline & \multirow[b]{2}{*}{$\mathrm{N}$} & \multirow[b]{2}{*}{ Média } & \multirow[b]{2}{*}{ Erro Desvio } & \multirow[b]{2}{*}{ Mínimo } & \multirow[b]{2}{*}{ Máximo } & \multicolumn{3}{|c|}{ Percentis } \\
\hline & & & & & & 250. & $50^{\circ}$ (Mediana) & $75^{\circ}$ \\
\hline Ni_ParA & 50 & ,40216 & ,310076 & ,030 & 1,040 & , 10925 & ,40050 & ,51375 \\
\hline Ni_AnF1A & 50 & , 45864 & ,359754 & ,000 & 1,062 & , 15000 & , 37850 & ,78925 \\
\hline Ni_FaF1A & 50 & ,40354 & ,389756 &,- 038 & 1,047 & ,06275 & ,24100 &, 79350 \\
\hline Ni_FaF2A & 50 & ,35596 & ,345140 &,- 047 & 1,218 & ,07750 & ,29850 & ,49925 \\
\hline Ni_UaF2A & 50 & ,31134 & ,353124 & ,004 & 1,354 & ,06550 & , 13650 & ,44025 \\
\hline Ni_ChoA & 50 & , 46548 & ,302471 &,- 008 & 1,065 & ,23675 & ,41000 &, 78500 \\
\hline Ni_ParB & 50 & ,40948 & ,309168 & ,009 & ,990 & ,13475 & ,38450 & ,61875 \\
\hline Ni_AnF1B & 50 & 29824 & ,363992 &,- 065 & 1,028 & ,02450 & , 11100 & ,52925 \\
\hline Ni_FaF1B & 50 & ,44920 & ,356255 &,- 020 & 1,057 & ,09950 & ,34950 & ,78125 \\
\hline Ni_FaF2B & 50 & , 44786 & ,318491 & ,014 & 1,066 & ,24425 & , 33950 & ,66050 \\
\hline Ni_UaF2B & 50 & , 35582 & ,286394 & ,015 & 1,150 & , 14475 & ,27950 & ,44225 \\
\hline Ni_ChoB & 50 & ,52582 & ,333138 & ,005 & 1,031 & 20425 & ,50250 &, 85250 \\
\hline
\end{tabular}

Classificações

\begin{tabular}{|c|c|c|c|c|}
\hline & & $\mathrm{N}$ & $\begin{array}{c}\text { Postos de } \\
\text { média }\end{array}$ & $\begin{array}{c}\text { Soma de } \\
\text { Classificações }\end{array}$ \\
\hline \multirow[t]{4}{*}{ Ni_ParB - Ni_ParA } & Classificações Negativas & $28^{\mathrm{a}}$ & 22,18 & 621,00 \\
\hline & Classificações Positivas & $22^{\mathrm{b}}$ & 29,73 & 654,00 \\
\hline & Vínculos & $0^{c}$ & & \\
\hline & Total & 50 & & \\
\hline \multirow[t]{4}{*}{ Ni_AnF1B - Ni_AnF1A } & Classificações Negativas & $38^{d}$ & 25,64 & 974,50 \\
\hline & Classificações Positivas & $10^{\mathrm{e}}$ & 20,15 & 201,50 \\
\hline & Vínculos & $2^{f}$ & & \\
\hline & Total & 50 & & \\
\hline \multirow[t]{4}{*}{ Ni_FaF1B - Ni_FaF1A } & Classificações Negativas & $22^{g}$ & 20,75 & 456,50 \\
\hline & Classificações Positivas & $28^{\mathrm{h}}$ & 29,23 & 818,50 \\
\hline & Vínculos & $0^{i}$ & & \\
\hline & Total & 50 & & \\
\hline \multirow[t]{4}{*}{ Ni_FaF2B - Ni_FaF2A } & Classificações Negativas & $20^{\mathrm{j}}$ & 23,43 & 468,50 \\
\hline & Classificações Positivas & $30^{k}$ & 26,88 & 806,50 \\
\hline & Vínculos & $0^{\prime}$ & & \\
\hline & Total & 50 & & \\
\hline Ni_UaF2B - Ni_UaF2A & Classificações Negativas & $14^{\mathrm{m}}$ & 26,86 & 376,00 \\
\hline
\end{tabular}




\begin{tabular}{|ll|r|r|r|} 
& Classificações Positivas & $36^{n}$ & 24,97 & 899,00 \\
& Vínculos & $0^{\circ}$ & & \\
& Total & 50 & & \\
\hline Ni_ChoB - Ni_ChoA & Classificações Negativas & $26^{p}$ & 19,94 & 518,50 \\
& Classificações Positivas & $2^{\mathrm{r}}$ & 31,52 & 756,50 \\
& Vínculos & 50 & & \\
& Total & & \\
\hline
\end{tabular}
a. Ni_ParB < Ni_ParA
b. Ni_ParB > Ni_ParA
C. Ni_ParB $=$ Ni_ParA
d. Ni_AnF1B $<$ Ni_AnF1A
e. Ni_AnF1B > Ni_AnF1A
f. Ni_AnF1B $=$ Ni_AnF1A
g. Ni_FaF1B $<$ Ni_FaF1A
h. Ni_FaF1B $>$ Ni_FaF1A
i. Ni_FaF1B $=$ Ni_FaF1A
j. Ni_FaF2B $<$ Ni_FaF2A
k. Ni_FaF2B > Ni_FaF2A
I. Ni_FaF2B $=\mathrm{Ni}$ _FaF2A
m. Ni_UaF2B $<$ Ni_UaF2A
n. Ni_UaF2B > Ni_UaF2A
o. Ni_UaF2B $=$ Ni_UaF2A
p. Ni_ChoB $<$ Ni_ChoA
q. Ni_ChoB $>$ Ni_ChoA
r. Ni_ChoB $=$ Ni_ChoA

Estatísticas de teste ${ }^{a}$

\begin{tabular}{|c|c|c|c|c|c|c|}
\hline & $\begin{array}{l}\text { Ni_ParB - } \\
\text { Ni_ParA }\end{array}$ & $\begin{array}{l}\text { Ni_AnF1B - } \\
\text { Ni_AnF1A }\end{array}$ & $\begin{array}{l}\text { Ni_FaF1B - } \\
\text { Ni_FaF1A } \\
\end{array}$ & $\begin{array}{l}\text { Ni_FaF2B - } \\
\text { Ni_FaF2A } \\
\end{array}$ & $\begin{array}{c}\text { Ni_UaF2B - } \\
\text { Ni_UaF2A } \\
\end{array}$ & $\begin{array}{l}\text { Ni_ChoB - } \\
\text { Ni_ChoA }\end{array}$ \\
\hline Z &,$- 159^{b}$ & $-3,965^{c}$ & $-1,747^{b}$ & $-1,631^{b}$ & $-2,525^{b}$ & $-1,149^{b}$ \\
\hline $\begin{array}{l}\text { Significância Sig. (2 } \\
\text { extremidades) }\end{array}$ & 873, & ,000 & ,081 & 103, & 012 & 251 \\
\hline $\begin{array}{l}\text { Sig exata ( } 2 \\
\text { extremidades) }\end{array}$ & 876, & ,000 & ,081 & 104 & ,011 & 254, \\
\hline $\begin{array}{l}\text { Sig exata (1 } \\
\text { extremidade) }\end{array}$ & ,438 & ,000 & ,040 & 052, & 005, & 127, \\
\hline $\begin{array}{l}\text { Probabilidade de } \\
\text { ponto }\end{array}$ & ,002 & ,000 & ,000 & ,001 & ,000 & ,001 \\
\hline
\end{tabular}
a. Teste de Classificações Assinadas por Wilcoxon
b. Com base em postos negativos.
c. Com base em postos positivos. 


\section{3) Dessa maneira tem-se para as conversões de nitrato para os sistemas A e B:}

Para os sistemas com inóculo proveniente da Lagoa Anaeróbia do Frigorífico 1 (AnF1), as produções de nitrato, ao longo dos perfis temporais de cada teste e ao longo do conjunto de teste, foram significativamente mais altas para o sistema denominado de AnF1A (Média = 0,365; Mediana $=0,163$ ) do que para o sistema denominado de AnF1B (Média =0,190; Mediana = $0,013)$, com $T=252,0$ e $Z=-3,586 p<0,01$. Dessa maneira, esses sistemas $A$ e $B$ com relação à formação de nitrato não podem ser utilizados como duplicatas.

Para todos os demais pares de sistemas, com relação a produção de nitrato, $\mathrm{PaA}$ e $\mathrm{PaB}$; FaF1A e FaF1; FaF2A e FaF2B; UaF2A e UaF2B; ChoA e ChoB, não diferiram entre si quando comparados aplicando o teste dos postos com sinais de Wilcoxon, utilizando $p<0,05$ (Os resultados dos testes podem ser verificados no Apêndice I-Resultados dos Testes Estatísticos).

Estatísticas descritivas

\begin{tabular}{|c|c|c|c|c|c|c|c|c|}
\hline & \multirow[b]{2}{*}{$\mathrm{N}$} & \multirow[b]{2}{*}{ Média } & \multirow[b]{2}{*}{ Erro Desvio } & \multirow[b]{2}{*}{ Mínimo } & \multirow[b]{2}{*}{ Máximo } & \multicolumn{3}{|c|}{ Percentis } \\
\hline & & & & & & 250. & $50^{\circ}$ (Mediana) & $75^{\circ}$ \\
\hline $\mathrm{Na}$ _ParA & 50 & ,30448 & 341393 &,- 027 & 1,121 & ,05175 & , 18900 & ,45750 \\
\hline $\mathrm{Na} \_$AnF1A & 50 & ,36572 & 392693 &,- 013 & 1,023 & ,06925 & , 16300 & ,86850 \\
\hline $\mathrm{Na} \_\mathrm{FaF} 1 \mathrm{~A}$ & 50 & ,23000 & ,387236 &,- 012 & 1,102 & ,00150 & ,02000 & 22100 \\
\hline $\mathrm{Na}$ _FaF2A & 50 & ,20142 & ,304359 &,- 077 & 1,119 & ,03175 & ,07050 & 24925 \\
\hline $\mathrm{Na}$ _UaF2A & 50 & ,01450 & ,024215 &,- 049 &, 075 & ,00450 & ,01000 & ,01625 \\
\hline Na_ChoA & 50 & ,27520 & ,305350 &,- 001 & 1,017 & ,04225 & , 13050 & ,36075 \\
\hline $\mathrm{Na}$-ParB & 50 & ,30112 & ,324668 &,- 010 & 1,067 & ,07200 & , 14850 & ,42625 \\
\hline $\mathrm{Na}$ _AnF1B & 50 & ,19040 & ,363872 &,- 046 & 1,150 & ,00175 & ,01300 & ,12600 \\
\hline $\mathrm{Na}$ _FaF1B & 50 & ,28736 & 365754 &,- 007 & 1,170 & ,02500 & , 13450 & ,45375 \\
\hline $\mathrm{Na}$ _FaF2B & 50 & ,26412 & ,377476 &,- 242 & 1,145 & ,04000 & ,09800 & ,34025 \\
\hline $\mathrm{Na}$ _UaF2B & 50 & ,02554 & ,051688 &,- 026 & ,162 &,- 00275 &, 00450 & ,03475 \\
\hline Na_ChoB & 50 & ,33286 & ,339992 &,- 049 & 1,037 & ,02175 & ,21700 & ,59375 \\
\hline
\end{tabular}

Classificações

\begin{tabular}{|ll|r|r|r|}
\hline & & N & \multicolumn{1}{|c|}{$\begin{array}{c}\text { Postos de } \\
\text { média }\end{array}$} & \multicolumn{1}{c|}{$\begin{array}{c}\text { Soma de } \\
\text { Classificações }\end{array}$} \\
\hline Na_ParB - Na_ParA & Classificações Negativas & $22^{\mathrm{a}}$ & 28,14 & 619,00 \\
& Classificações Positivas & $28^{\mathrm{b}}$ & 23,43 & 656,00 \\
& Vínculos & $0^{\mathrm{c}}$ & & \\
& Total & 50 & & \\
& & & \\
& & & \\
\end{tabular}




\begin{tabular}{|c|c|c|c|c|}
\hline \multirow[t]{4}{*}{$\mathrm{Na} \_\mathrm{AnF} 1 \mathrm{~B}-\mathrm{Na} \_\mathrm{AnF} 1 \mathrm{~A}$} & Classificações Negativas & $38^{d}$ & 25,61 & 973,00 \\
\hline & Classificações Positivas & $11^{\mathrm{e}}$ & 22,91 & 252,00 \\
\hline & Vínculos & $1^{f}$ & & \\
\hline & Total & 50 & & \\
\hline \multirow[t]{4}{*}{ Na_FaF1B - Na_FaF1A } & Classificações Negativas & 249 & 18,92 & 454,00 \\
\hline & Classificações Positivas & $24^{\mathrm{h}}$ & 30,08 & 722,00 \\
\hline & Vínculos & $2^{i}$ & & \\
\hline & Total & 50 & & \\
\hline \multirow[t]{4}{*}{ Na_FaF2B - Na_FaF2A } & Classificações Negativas & $26^{\mathrm{j}}$ & 22,06 & 573,50 \\
\hline & Classificações Positivas & $24^{\mathrm{k}}$ & 29,23 & 701,50 \\
\hline & Vínculos & $0^{\prime}$ & & \\
\hline & Total & 50 & & \\
\hline \multirow[t]{4}{*}{$\mathrm{Na}$ _UaF2B - Na_UaF2A } & Classificações Negativas & $27^{\mathrm{m}}$ & 21,28 & 574,50 \\
\hline & Classificações Positivas & $22^{n}$ & 29,57 & 650,50 \\
\hline & Vínculos & $1^{\circ}$ & & \\
\hline & Total & 50 & & \\
\hline \multirow[t]{4}{*}{$\mathrm{Na}$ _ChoB - Na_ChoA } & Classificações Negativas & $22^{p}$ & 22,50 & 495,00 \\
\hline & Classificações Positivas & 289 & 27,86 & 780,00 \\
\hline & Vínculos & $0^{r}$ & & \\
\hline & Total & 50 & & \\
\hline
\end{tabular}
a. Na_ParB $<\mathrm{Na}$ _ParA
b. Na_ParB > Na_ParA
c. Na_ParB $=\mathrm{Na} \_\mathrm{ParA}$
d. $\mathrm{Na} \_A n F 1 B<\mathrm{Na} \_A n F 1 A$
e. Na_AnF1B $>\mathrm{Na} \_A n F 1 A$
f. Na_AnF1B $=\mathrm{Na} \_\mathrm{AnF} 1 \mathrm{~A}$
g. $\mathrm{Na} \_\mathrm{FaF} 1 \mathrm{~B}<\mathrm{Na}$-FaF1A
h. Na_FaF1B $>\mathrm{Na} \_$FaF1A
i. $\mathrm{Na} \_\mathrm{FaF} 1 \mathrm{~B}=\mathrm{Na} \_\mathrm{FaF} 1 \mathrm{~A}$
j. $\mathrm{Na} \_\mathrm{FaF} 2 \mathrm{~B}<\mathrm{Na} \_\mathrm{FaF} 2 \mathrm{~A}$
k. $\mathrm{Na} \_F a F 2 B>N a \_F a F 2 A$
I. $\mathrm{Na} \_\mathrm{FaF} 2 \mathrm{~B}=\mathrm{Na} \_\mathrm{FaF} 2 \mathrm{~A}$
m. Na_UaF2B $<\mathrm{Na}$ _UaF2A
n. Na_UaF2B $>\mathrm{Na}$ _UaF2A
o. Na_UaF2B $=\mathrm{Na} \_U a F 2 A$
p. Na_ChoB $<\mathrm{Na}$ _ChoA
q. Na_ChoB > Na_ChoA
r. Na_ChoB $=\mathrm{Na} \_\mathrm{ChoA}$ 
Estatísticas de teste ${ }^{a}$

\begin{tabular}{|c|c|c|c|c|c|c|}
\hline & $\begin{array}{l}\mathrm{Na} \text { _ParB - } \\
\mathrm{Na} \text { _ParA }\end{array}$ & $\begin{array}{l}\mathrm{Na} \_\mathrm{AnF} 1 \mathrm{~B}- \\
\mathrm{Na} \text { _AnF1A }\end{array}$ & $\begin{array}{l}\mathrm{Na} \text { _FaF1B - } \\
\mathrm{Na} F \mathrm{FaF} 1 \mathrm{~A}\end{array}$ & $\begin{array}{l}\mathrm{Na} \text { _FaF2B - } \\
\mathrm{Na} F \mathrm{FaF} 2 \mathrm{~A}\end{array}$ & $\begin{array}{c}\mathrm{Na} \_U a F 2 B- \\
\mathrm{Na} \text { _UaF2A }\end{array}$ & $\begin{array}{l}\mathrm{Na} \_\mathrm{ChoB} \text { - } \\
\mathrm{Na} \text { _ChoA }\end{array}$ \\
\hline Z &,$- 179^{b}$ & $-3,586^{c}$ & $-1,375^{b}$ &,$- 618^{b}$ &,$- 378^{b}$ & $-1,376^{b}$ \\
\hline $\begin{array}{l}\text { Significância Sig. (2 } \\
\text { extremidades) }\end{array}$ & ,858 &, 000 & ,169 &, 537 & ,705 & 169 \\
\hline $\begin{array}{l}\text { Sig exata ( } 2 \\
\text { extremidades) }\end{array}$ & ,861 & ,000 & ,172 &, 541 & ,710 & ,171 \\
\hline $\begin{array}{l}\text { Sig exata ( } 1 \\
\text { extremidade) }\end{array}$ & ,431 & ,000 & ,086 & ,271 & ,355 & ,086 \\
\hline $\begin{array}{l}\text { Probabilidade de } \\
\text { ponto }\end{array}$ &, 002 &, 000 &, 001 & ,002 & ,002 & ,001 \\
\hline
\end{tabular}
a. Teste de Classificações Assinadas por Wilcoxon
b. Com base em postos negativos.
c. Com base em postos positivos.

A tabela XX, apresenta os resultados sintetizados com relação às conversões ocorridas nas formas nitrogenadas dos sistemas operados com o mesmo tipo de inóculo, com a finalidade de avaliar se os sistemas permaneciam como representantes de duplicatas. $\mathrm{O}$ teste aplicado foi o dos postos com sinais de Wilcoxon.

\begin{tabular}{|l|c|c|c|c|}
\hline \multicolumn{1}{|c|}{ Sistema } & Amônia & Nitrito & Nitrato & $\begin{array}{c}\text { Representam } \\
\text { duplicatas }\end{array}$ \\
\hline ParA & Não & Sim & Sim & Não \\
\hline ParB & Não & Sim & Sim & Não \\
\hline AnF1A & Não & Não & Não & Não \\
\hline AnF1B & Não & Não & Não & Não \\
\hline FaF1A & Não & Não & Sim & Não \\
\hline FaF1B & Não & Não & Sim & Não \\
\hline FaF2A & Sim & Sim & Sim & Sim \\
\hline FaF2B & Sim & Sim & Sim & Sim \\
\hline UaF2A & Sim & Não & Sim & Não \\
\hline UaF2B & Sim & Não & Sim & Não \\
\hline ChoA & Não & Sim & Sim & Não \\
\hline ChoB & Não & Sim & Sim & Não \\
\hline
\end{tabular}

Acrescentar comentários do Livro sobre organização dos sistemas biológicos 


\section{OUTRA FORMA EM QUE FORAM TESTADOS A NORMALIDADE E HOMOGENEIDADE DOS DADOS DA DUPLICATAS.}

Lembrando que para esses testes foram utilizados os dados brutos de redução de amônia e nitrito e acréscimo de nitrato em $\mathrm{mM}$, obtidas pela diferença entre os tempos de coleta de amostras dentro de cada batelada. Dessa maneira, como os intervalos de tempo se configuram como variáveis interferindo nas concentrações dos íons em análise, fez também uma avaliação da distribuição normal e homogeneidade entre as duplicatas considerando esse fator.

Numa segunda análise utilizou-se a comparação de normalidade e homogeneidade considerando-se o comportamento dos íons (amônia, nitrito, nitrato) obtidas para cada intervalo de tempo dado o início de cada bateladas, sendo eles (T0_T1 $\Leftrightarrow 0 \_24$ horas; T1_T2 $\Leftrightarrow$ 24_48 horas; T1_T2 $\Leftrightarrow 0$ 0_48 horas; T2_T3 $\Leftrightarrow 48$ 72 horas; T0_T3 $\Leftrightarrow 0$ 0_72 horas), consistindo em 10 bateladas para cada sistema componente da duplicata ( $\mathrm{e}$ e B). A homogeneidade foi avaliada usando a comparação da variância de um dado íon, se igual ou diferente entre os sistemas A e B, mas tendo a observância de analisar se a variância dentro de cada intervalo foi homogênea ou heterogênea para cada sistema componente da duplicata.

\section{Sistemas Par A e ParB}

Testes de Normalidade

\begin{tabular}{|lll|r|r|r|r|r|r|}
\hline & & & \multicolumn{3}{|c|}{ Kolmogorov-Smirnov $^{\text {a }}$} & \multicolumn{3}{|c|}{ Shapiro-Wilk } \\
\cline { 4 - 9 } Tempo & & Lodo & Estatística & df & \multicolumn{1}{c|}{ Sig. } & Estatística & \multicolumn{1}{c|}{ df } & \multicolumn{1}{c|}{ Sig. } \\
\hline T0_T1 & Amônia & ParA &, 253 & 10 &, 068 &, 818 & 10 &, 024 \\
& & ParB &, 292 & 10 &, 015 &, 744 & 10 &, 003 \\
\hline T0_T2 & Amônia & ParA &, 273 & 10 &, 033 &, 759 & 10 &, 005 \\
& & ParB &, 153 & 10 &, $200^{*}$ &, 940 & 10 &, 553 \\
\hline T0_T3 & Amônia & ParA &, 255 & 10 &, 064 &, 827 & 10 &, 031 \\
& & ParB &, 225 & 10 &, 166 &, 926 & 10 &, 408 \\
\hline T1_T2 & Amônia & ParA &, 311 & 10 &, 007 &, 798 & 10 &, 014 \\
& & ParB &, 200 & 10 &, $200^{*}$ &, 918 & 10 &, 338 \\
\hline T2_T3 & Amônia & ParA &, 314 & 10 &, 006 &, 682 & 10 &, 001 \\
& & ParB &, 386 & 10 &, 000 &, 684 & 10 &, 001 \\
\hline
\end{tabular}

*. Este é um limite inferior da significância verdadeira.

a. Correlação de Significância de Lilliefors 
Teste de Homogeneidade de Variância

\begin{tabular}{|c|c|c|c|c|c|c|}
\hline Tempo & & & $\begin{array}{l}\text { Estatística de } \\
\text { Levene }\end{array}$ & df1 & df2 & Sig. \\
\hline \multirow[t]{4}{*}{ T0_T1 } & \multirow[t]{4}{*}{ Amônia } & Com base em média & ,004 & 1 & 18 & ,948 \\
\hline & & Com base em mediana & 018 & 1 & 18 & ,896 \\
\hline & & $\begin{array}{l}\text { Com base em mediana e } \\
\text { com df ajustado }\end{array}$ & ,018 & 1 & 16,548 & ,896 \\
\hline & & $\begin{array}{l}\text { Com base em média } \\
\text { aparada }\end{array}$ & ,001 & 1 & 18 & ,970 \\
\hline \multirow[t]{4}{*}{ T0_T2 } & \multirow[t]{4}{*}{ Amônia } & Com base em média & 5,137 & 1 & 18 & ,036 \\
\hline & & Com base em mediana & ,889 & 1 & 18 & ,358 \\
\hline & & $\begin{array}{l}\text { Com base em mediana e } \\
\text { com df ajustado }\end{array}$ & ,889 & 1 & 13,860 & ,362 \\
\hline & & $\begin{array}{l}\text { Com base em média } \\
\text { aparada }\end{array}$ & 4,906 & 1 & 18 &, 040 \\
\hline \multirow[t]{4}{*}{ T0_T3 } & \multirow[t]{4}{*}{ Amônia } & Com base em média & 8,108 & 1 & 18 & 011 \\
\hline & & Com base em mediana & 2,345 & 1 & 18 & 143 \\
\hline & & $\begin{array}{l}\text { Com base em mediana e } \\
\text { com df ajustado }\end{array}$ & 2,345 & 1 & 15,162 & , 146 \\
\hline & & $\begin{array}{l}\text { Com base em média } \\
\text { aparada }\end{array}$ & 8,197 & 1 & 18 & 010 \\
\hline \multirow[t]{4}{*}{ T1_T2 } & \multirow[t]{4}{*}{ Amônia } & Com base em média & 2,365 & 1 & 18 & , 141 \\
\hline & & Com base em mediana & ,349 & 1 & 18 &, 562 \\
\hline & & $\begin{array}{l}\text { Com base em mediana e } \\
\text { com df ajustado }\end{array}$ & ,349 & 1 & 14,917 &, 564 \\
\hline & & $\begin{array}{l}\text { Com base em média } \\
\text { aparada }\end{array}$ & 2,177 & 1 & 18 & ,157 \\
\hline \multirow[t]{4}{*}{ T2_T3 } & \multirow[t]{4}{*}{ Amônia } & Com base em média & ,237 & 1 & 18 & ,632 \\
\hline & & Com base em mediana & 047 & 1 & 18 & 831 \\
\hline & & $\begin{array}{l}\text { Com base em mediana e } \\
\text { com df ajustado }\end{array}$ &, 047 & 1 & 17,919 & ,831 \\
\hline & & $\begin{array}{l}\text { Com base em média } \\
\text { aparada }\end{array}$ & , 175 & 1 & 18 & 680 \\
\hline
\end{tabular}

\section{Testes de Normalidade}

\begin{tabular}{|lll|r|r|r|r|r|r|}
\hline \multirow{2}{*}{ Tempo } & & \multicolumn{4}{|c|}{ Kolmogorov-Smirnov $^{\text {a }}$} & \multicolumn{3}{|c|}{ Shapiro-Wilk } \\
\cline { 4 - 9 } & & Lodo & Estatística & \multicolumn{1}{c|}{$\mathrm{df}$} & \multicolumn{1}{c|}{ Sig. } & Estatística & \multicolumn{1}{c|}{ df } & Sig. \\
\hline T0_T1 & Nitrito & ParA &, 309 & 10 &, 008 &, 745 & 10 &, 003 \\
& & ParB &, 273 & 10 &, 033 &, 844 & 10 &, 050 \\
\hline T0_T2 & Nitrito & ParA &, 214 & 10 &, $200^{*}$ &, 868 & 10 &, 094 \\
& & ParB &, 216 & 10 &, $200^{*}$ &, 895 & 10 &, 193 \\
\hline T0_T3 & Nitrito & ParA &, 328 & 10 &, 003 &, 758 & 10 &, 004 \\
& & ParB &, 309 & 10 &, 007 &, 808 & 10 &, 018 \\
\hline T1_T2 & Nitrito & ParA &, 252 & 10 &, 071 &, 856 & 10 &, 068 \\
& & ParB &, 222 & 10 &, 175 &, 832 & 10 &, 036 \\
\hline T2_T3 & Nitrito & ParA &, 206 & 10 &, $200^{*}$ &, 897 & 10 &, 205 \\
& & ParB &, 329 & 10 &, 003 &, 803 & 10 &, 016 \\
\hline
\end{tabular}

*. Este é um limite inferior da significância verdadeira.

a. Correlação de Significância de Lilliefors 
Teste de Homogeneidade de Variância

\begin{tabular}{|c|c|c|c|c|c|c|}
\hline Tempo & & & $\begin{array}{c}\text { Estatística de } \\
\text { Levene }\end{array}$ & df1 & df2 & Sig. \\
\hline \multirow[t]{4}{*}{ T0_T1 } & \multirow[t]{4}{*}{ Nitrito } & Com base em média & 1,020 & 1 & 18 & ,326 \\
\hline & & Com base em mediana & ,223 & 1 & 18 & ,643 \\
\hline & & $\begin{array}{l}\text { Com base em mediana e } \\
\text { com df ajustado }\end{array}$ & ,223 & 1 & 17,094 & ,643 \\
\hline & & $\begin{array}{l}\text { Com base em média } \\
\text { aparada }\end{array}$ & ,896 & 1 & 18 & ,356 \\
\hline \multirow[t]{4}{*}{ T0_T2 } & \multirow[t]{4}{*}{ Nitrito } & Com base em média & ,415 & 1 & 18 & ,528 \\
\hline & & Com base em mediana & ,497 & 1 & 18 & ,490 \\
\hline & & $\begin{array}{l}\text { Com base em mediana e } \\
\text { com df ajustado }\end{array}$ & ,497 & 1 & 17,472 & ,490 \\
\hline & & $\begin{array}{l}\text { Com base em média } \\
\text { aparada }\end{array}$ & ,420 & 1 & 18 &, 525 \\
\hline \multirow[t]{4}{*}{ T0_T3 } & \multirow[t]{4}{*}{ Nitrito } & Com base em média & 7,638 & 1 & 18 & 013 \\
\hline & & Com base em mediana & ,604 & 1 & 18 & ,447 \\
\hline & & $\begin{array}{l}\text { Com base em mediana e } \\
\text { com df ajustado }\end{array}$ & ,604 & 1 & 15,822 & ,449 \\
\hline & & $\begin{array}{l}\text { Com base em média } \\
\text { aparada }\end{array}$ & 6,864 & 1 & 18 & ,017 \\
\hline \multirow[t]{4}{*}{ T1_T2 } & \multirow[t]{4}{*}{ Nitrito } & Com base em média & 16,988 & 1 & 18 & 001 \\
\hline & & Com base em mediana & 4,743 & 1 & 18 & 043 \\
\hline & & $\begin{array}{l}\text { Com base em mediana e } \\
\text { com df ajustado }\end{array}$ & 4,743 & 1 & 11,776 & ,051 \\
\hline & & $\begin{array}{l}\text { Com base em média } \\
\text { aparada }\end{array}$ & 16,358 & 1 & 18 & 001 \\
\hline \multirow[t]{4}{*}{ T2_T3 } & \multirow[t]{4}{*}{ Nitrito } & Com base em média & 016 & 1 & 18 & 901 \\
\hline & & Com base em mediana &, 004 & 1 & 18 & ,951 \\
\hline & & $\begin{array}{l}\text { Com base em mediana e } \\
\text { com df ajustado }\end{array}$ & ,004 & 1 & 16,151 & ,951 \\
\hline & & $\begin{array}{l}\text { Com base em média } \\
\text { aparada }\end{array}$ & ,002 & 1 & 18 & ,965 \\
\hline
\end{tabular}

Testes de Normalidade

\begin{tabular}{|lll|r|r|r|r|r|r|}
\hline & & & \multicolumn{3}{|c|}{ Kolmogorov-Smirnov $^{2}$} & \multicolumn{3}{|c|}{ Shapiro-Wilk } \\
\cline { 5 - 9 } Tempo & & Lodo & Estatís tica & \multicolumn{1}{c|}{ df } & \multicolumn{1}{c|}{ Sig. } & Estatística & \multicolumn{1}{c|}{ df } & \multicolumn{1}{c|}{ Sig. } \\
\hline T0_T1 & Nitrato & ParA &, 297 & 10 &, 013 &, 743 & 10 &, 003 \\
& & ParB &, 408 & 10 &, 000 &, 654 & 10 &, 000 \\
\hline T0_T2 & Nitrato & ParA &, 272 & 10 &, 034 &, 802 & 10 &, 015 \\
& & ParB &, 281 & 10 &, 024 &, 760 & 10 &, 005 \\
\hline T0_T3 & Nitrato & ParA &, 253 & 10 &, 070 &, 816 & 10 &, 023 \\
& & ParB &, 222 & 10 &, 177 &, 858 & 10 &, 072 \\
\hline T1_T2 & Nitrato & ParA &, 205 & 10 &, 200 &, 849 & 10 &, 056 \\
& & ParB &, 274 & 10 &, 032 &, 834 & 10 &, 037 \\
\hline T2_T3 & Nitrato & ParA &, 333 & 10 &, 002 &, 760 & 10 &, 005 \\
& & ParB &, 307 & 10 &, 008 &, 817 & 10 &, 023 \\
\hline
\end{tabular}

*. Este é um limite inferior da significância verdadeira.

a. Correlação de Significância de Lilliefors 
Teste de Homogeneidade de Variância

\begin{tabular}{|c|c|c|c|c|c|c|}
\hline Tempo & & & $\begin{array}{l}\text { Estatística de } \\
\text { Levene }\end{array}$ & df1 & df2 & Sig. \\
\hline \multirow[t]{4}{*}{ T0_T1 } & \multirow[t]{4}{*}{ Nitrato } & Com base em média & 684 & 1 & 18 & ,419 \\
\hline & & Com base em mediana & 082 & 1 & 18 & ,778 \\
\hline & & $\begin{array}{l}\text { Com base em mediana e } \\
\text { com df ajustado }\end{array}$ & ,082 & 1 & 16,751 & ,779 \\
\hline & & $\begin{array}{l}\text { Com base em média } \\
\text { aparada }\end{array}$ & ,425 & 1 & 18 &, 523 \\
\hline \multirow[t]{4}{*}{ T0_T2 } & \multirow[t]{4}{*}{ Nitrato } & Com base em média & ,485 & 1 & 18 & ,495 \\
\hline & & Com base em mediana & ,171 & 1 & 18 & ,684 \\
\hline & & $\begin{array}{l}\text { Com base em mediana e } \\
\text { com df ajustado }\end{array}$ & ,171 & 1 & 17,673 & 684 \\
\hline & & $\begin{array}{l}\text { Com base em média } \\
\text { aparada }\end{array}$ & ,458 & 1 & 18 & ,507 \\
\hline \multirow[t]{4}{*}{ T0_T3 } & \multirow[t]{4}{*}{ Nitrato } & Com base em média & 1,368 & 1 & 18 & ,257 \\
\hline & & Com base em mediana & ,288 & 1 & 18 & ,598 \\
\hline & & $\begin{array}{l}\text { Com base em mediana e } \\
\text { com df ajustado }\end{array}$ & ,288 & 1 & 16,085 & ,599 \\
\hline & & $\begin{array}{l}\text { Com base em média } \\
\text { aparada }\end{array}$ & 1,357 & 1 & 18 & ,259 \\
\hline \multirow[t]{4}{*}{ T1_T2 } & \multirow[t]{4}{*}{ Nitrato } & Com base em média & 10,026 & 1 & 18 & ,005 \\
\hline & & Com base em mediana & 4,643 & 1 & 18 & ,045 \\
\hline & & $\begin{array}{l}\text { Com base em mediana e } \\
\text { com df ajustado }\end{array}$ & 4,643 & 1 & 12,315 & ,052 \\
\hline & & $\begin{array}{l}\text { Com base em média } \\
\text { aparada }\end{array}$ & 9,200 & 1 & 18 & ,007 \\
\hline \multirow[t]{4}{*}{ T2_T3 } & \multirow[t]{4}{*}{ Nitrato } & Com base em média & ,365 & 1 & 18 & ,553 \\
\hline & & Com base em mediana & ,095 & 1 & 18 & ,761 \\
\hline & & $\begin{array}{l}\text { Com base em mediana e } \\
\text { com df ajustado }\end{array}$ & ,095 & 1 & 17,975 & ,761 \\
\hline & & $\begin{array}{l}\text { Com base em média } \\
\text { aparada }\end{array}$ & ,341 & 1 & 18 & ,567 \\
\hline
\end{tabular}


SISTEMA AnF1A e AnF1B

Testes de Normalidade

\begin{tabular}{|c|c|c|c|c|c|c|c|c|}
\hline \multirow[b]{2}{*}{ Tempo } & & \multirow[b]{2}{*}{ Lodo } & \multicolumn{3}{|c|}{ Kolmogorov-Smirnov ${ }^{a}$} & \multicolumn{3}{|c|}{ Shapiro-Wilk } \\
\hline & & & Estatística & df & Sig. & Estatística & df & Sig. \\
\hline \multirow[t]{2}{*}{ T0_T1 } & Amônia & AnF1A & ,209 & 10 &, $200^{*}$ & 869 & 10 & ,097 \\
\hline & & AnF1B &, 189 & 10 &, $200^{*}$ & ,873 & 10 & ,108 \\
\hline \multirow[t]{2}{*}{ T0_T2 } & Amônia & $A n F 1 A$ &, 105 & 10 &, $200^{*}$ &, 967 & 10 & ,857 \\
\hline & & AnF1B &, 230 & 10 &, 143 &, 827 & 10 &, 031 \\
\hline \multirow[t]{2}{*}{ T0_T3 } & Amônia & $A n F 1 A$ & ,209 & 10 &, $200^{*}$ &, 902 & 10 & ,228 \\
\hline & & AnF1B & ,274 & 10 & ,032 & ,827 & 10 & ,031 \\
\hline \multirow[t]{2}{*}{ T1_T2 } & Amônia & $A n F 1 A$ & ,205 & 10 &, $200^{*}$ & ,890 & 10 & , 170 \\
\hline & & AnF1B & ,236 & 10 & ,121 & ,861 & 10 &, 078 \\
\hline \multirow[t]{2}{*}{ T2_T3 } & Amônia & $\mathrm{AnF} 1 \mathrm{~A}$ & ,317 & 10 & ,005 & ,826 & 10 & ,030 \\
\hline & & AnF1B & , 170 & 10 &, $200^{*}$ & ,878 & 10 & ,122 \\
\hline
\end{tabular}

*. Este é um limite inferior da significância verdadeira.

a. Correlação de Significância de Lilliefors

Teste de Homogeneidade de Variância

\begin{tabular}{|c|c|c|c|c|c|c|}
\hline Tempo & & & $\begin{array}{c}\text { Estatística de } \\
\text { Levene }\end{array}$ & df1 & $\mathrm{df2}$ & Sig. \\
\hline \multirow[t]{4}{*}{ T0_T1 } & \multirow[t]{4}{*}{ Amônia } & Com base em média & 1,899 & 1 & 18 & , 185 \\
\hline & & Com base em mediana & 1,894 & 1 & 18 & , 186 \\
\hline & & $\begin{array}{l}\text { Com base em mediana e } \\
\text { com df ajustado }\end{array}$ & 1,894 & 1 & 17,923 & ,186 \\
\hline & & $\begin{array}{l}\text { Com base em média } \\
\text { aparada }\end{array}$ & 1,895 & 1 & 18 & ,186 \\
\hline \multirow[t]{4}{*}{ T0_T2 } & \multirow[t]{4}{*}{ Amônia } & Com base em média & ,609 & 1 & 18 & ,445 \\
\hline & & Com base em mediana & , 162 & 1 & 18 & ,692 \\
\hline & & $\begin{array}{l}\text { Com base em mediana e } \\
\text { com df ajustado }\end{array}$ & ,162 & 1 & 17,944 & ,692 \\
\hline & & $\begin{array}{l}\text { Com base em média } \\
\text { aparada }\end{array}$ &, 583 & 1 & 18 & ,455 \\
\hline \multirow[t]{4}{*}{ T0_T3 } & \multirow[t]{4}{*}{ Amônia } & Com base em média &, 005 & 1 & 18 & ,943 \\
\hline & & Com base em mediana & ,091 & 1 & 18 & ,766 \\
\hline & & $\begin{array}{l}\text { Com base em mediana e } \\
\text { com df ajustado }\end{array}$ & ,091 & 1 & 17,509 & ,766 \\
\hline & & $\begin{array}{l}\text { Com base em média } \\
\text { aparada }\end{array}$ & ,005 & 1 & 18 & ,942 \\
\hline \multirow[t]{4}{*}{ T1_T2 } & \multirow[t]{4}{*}{ Amônia } & Com base em média &, 584 & 1 & 18 & ,455 \\
\hline & & Com base em mediana & ,308 & 1 & 18 & ,586 \\
\hline & & $\begin{array}{l}\text { Com base em mediana e } \\
\text { com df ajustado }\end{array}$ & ,308 & 1 & 17,923 & ,586 \\
\hline & & $\begin{array}{l}\text { Com base em média } \\
\text { aparada }\end{array}$ & ,638 & 1 & 18 & ,435 \\
\hline \multirow[t]{4}{*}{ T2_T3 } & \multirow[t]{4}{*}{ Amônia } & Com base em média & 26,735 & 1 & 18 &, 000 \\
\hline & & Com base em mediana & 3,815 & 1 & 18 &, 067 \\
\hline & & $\begin{array}{l}\text { Com base em mediana e } \\
\text { com df ajustado }\end{array}$ & 3,815 & 1 & 10,277 & ,079 \\
\hline & & $\begin{array}{l}\text { Com base em média } \\
\text { aparada }\end{array}$ & 24,459 & 1 & 18 &, 000 \\
\hline
\end{tabular}


Testes de Normalidade

\begin{tabular}{|c|c|c|c|c|c|c|c|c|}
\hline \multirow[b]{2}{*}{ Tempo } & & \multirow[b]{2}{*}{ Lodo } & \multicolumn{3}{|c|}{ Kolmogorov-Smirnov ${ }^{a}$} & \multicolumn{3}{|c|}{ Shapiro-Wilk } \\
\hline & & & Estatística & df & Sig. & Estatística & $\mathrm{df}$ & Sig. \\
\hline \multirow[t]{2}{*}{ T0_T1 } & Nitrito & $\mathrm{AnF} 1 \mathrm{~A}$ & ,359 & 10 & ,001 & ,735 & 10 & ,002 \\
\hline & & AnF1B & ,299 & 10 & ,012 &, 740 & 10 & ,003 \\
\hline \multirow[t]{2}{*}{ T0_T2 } & Nitrito & $A n F 1 A$ & , 163 & 10 & $200^{*}$ & ,909 & 10 & ,276 \\
\hline & & AnF1B & ,312 & 10 &, 007 & ,787 & 10 & 010 \\
\hline \multirow[t]{2}{*}{ T0_T3 } & Nitrito & $\mathrm{AnF} 1 \mathrm{~A}$ & ,297 & 10 & ,012 & ,804 & 10 & 016 \\
\hline & & AnF1B & ,234 & 10 &, 129 & ,867 & 10 & 092 \\
\hline \multirow[t]{2}{*}{ T1_T2 } & Nitrito & AnF1A & ,353 & 10 & ,001 & ,743 & 10 &, 003 \\
\hline & & AnF1B & ,378 & 10 &, 000 & ,679 & 10 &, 000 \\
\hline \multirow[t]{2}{*}{ T2_T3 } & Nitrito & $\mathrm{AnF} 1 \mathrm{~A}$ & ,253 & 10 & ,068 & ,813 & 10 & 021 \\
\hline & & AnF1B & ,245 & 10 & ,090 & ,823 & 10 & ,028 \\
\hline
\end{tabular}

*. Este é um limite inferior da significância verdadeira.

a. Correlação de Significância de Lilliefors

Teste de Homogeneidade de Variância

\begin{tabular}{|c|c|c|c|c|c|c|}
\hline Tempo & & & $\begin{array}{l}\text { Estatística de } \\
\text { Levene }\end{array}$ & df1 & $\mathrm{df2}$ & Sig. \\
\hline \multirow[t]{4}{*}{ T0_T1 } & \multirow[t]{4}{*}{ Nitrito } & Com base em média & ,119 & 1 & 18 & ,734 \\
\hline & & Com base em mediana & 014 & 1 & 18 & ,908 \\
\hline & & $\begin{array}{l}\text { Com base em mediana e } \\
\text { com df ajustado }\end{array}$ & 014 & 1 & 17,936 & ,908 \\
\hline & & $\begin{array}{l}\text { Com base em média } \\
\text { aparada }\end{array}$ &, 128 & 1 & 18 &, 725 \\
\hline \multirow[t]{4}{*}{ T0_T2 } & \multirow[t]{4}{*}{ Nitrito } & Com base em média & 1,852 & 1 & 18 & 190 \\
\hline & & Com base em mediana & ,243 & 1 & 18 & ,628 \\
\hline & & $\begin{array}{l}\text { Com base em mediana e } \\
\text { com df ajustado }\end{array}$ & ,243 & 1 & 12,337 & ,630 \\
\hline & & $\begin{array}{l}\text { Com base em média } \\
\text { aparada }\end{array}$ & 1,626 & 1 & 18 & ,219 \\
\hline \multirow[t]{4}{*}{ T0_T3 } & \multirow[t]{4}{*}{ Nitrito } & Com base em média & 5,703 & 1 & 18 & 028 \\
\hline & & Com base em mediana & 3,984 & 1 & 18 & 061 \\
\hline & & $\begin{array}{l}\text { Com base em mediana e } \\
\text { com df ajustado }\end{array}$ & 3,984 & 1 & 17,962 & 061 \\
\hline & & $\begin{array}{l}\text { Com base em média } \\
\text { aparada }\end{array}$ & 5,860 & 1 & 18 & ,026 \\
\hline \multirow[t]{4}{*}{ T1_T2 } & \multirow[t]{4}{*}{ Nitrito } & Com base em média & 11,889 & 1 & 18 & ,003 \\
\hline & & Com base em mediana & 1,839 & 1 & 18 & ,192 \\
\hline & & $\begin{array}{l}\text { Com base em mediana e } \\
\text { com df ajustado }\end{array}$ & 1,839 & 1 & 12,256 & , 199 \\
\hline & & $\begin{array}{l}\text { Com base em média } \\
\text { aparada }\end{array}$ & 10,668 & 1 & 18 & ,004 \\
\hline \multirow[t]{4}{*}{ T2_T3 } & \multirow[t]{4}{*}{ Nitrito } & Com base em média & ,002 & 1 & 18 & ,969 \\
\hline & & Com base em mediana & ,008 & 1 & 18 & ,931 \\
\hline & & $\begin{array}{l}\text { Com base em mediana e } \\
\text { com df ajustado }\end{array}$ & ,008 & 1 & 17,971 & ,931 \\
\hline & & $\begin{array}{l}\text { Com base em média } \\
\text { aparada }\end{array}$ & ,002 & 1 & 18 & ,963 \\
\hline
\end{tabular}


Testes de Normalidade

\begin{tabular}{|c|c|c|c|c|c|c|c|c|}
\hline \multirow[b]{2}{*}{ Tempo } & & \multirow[b]{2}{*}{ Lodo } & \multicolumn{3}{|c|}{ Kolmogorov-Smirnov ${ }^{a}$} & \multicolumn{3}{|c|}{ Shapiro-Wilk } \\
\hline & & & Estatística & $\mathrm{df}$ & Sig. & Estatística & df & Sig. \\
\hline \multirow[t]{2}{*}{ T0_T1 } & Nitrato & AnF1A & ,337 & 10 &, 002 & ,749 & 10 &, 003 \\
\hline & & AnF1B & ,430 & 10 & ,000 &, 563 & 10 & ,000 \\
\hline \multirow[t]{2}{*}{ T0_T2 } & Nitrato & $A n F 1 A$ & 241 & 10 & ,105 & ,806 & 10 & 017 \\
\hline & & AnF1B & ,418 & 10 & ,000 &, 573 & 10 & ,000 \\
\hline \multirow[t]{2}{*}{ T0_T3 } & Nitrato & $A n F 1 A$ & ,311 & 10 & ,007 & ,735 & 10 & ,002 \\
\hline & & AnF1B & ,262 & 10 & ,051 & ,771 & 10 & ,006 \\
\hline \multirow[t]{2}{*}{ T1_T2 } & Nitrato & $A n F 1 A$ & ,205 & 10 & ,200* &, 860 & 10 & 076 \\
\hline & & AnF1B & ,303 & 10 & ,010 & ,742 & 10 & ,003 \\
\hline \multirow[t]{2}{*}{ T2_T3 } & Nitrato & $A n F 1 A$ & ,409 & 10 & ,000 & 624 & 10 & ,000 \\
\hline & & AnF1B & ,383 & 10 & ,000 & ,665 & 10 & ,000 \\
\hline
\end{tabular}

*. Este é um limite inferior da significância verdadeira.

a. Correlação de Significância de Lilliefors

Teste de Homogeneidade de Variância

\begin{tabular}{|c|c|c|c|c|c|c|}
\hline Tempo & & & $\begin{array}{c}\text { Estatística de } \\
\text { Levene }\end{array}$ & df1 & df2 & Sig. \\
\hline \multirow[t]{4}{*}{ T0_T1 } & \multirow[t]{4}{*}{ Nitrato } & Com base em média &, 664 & 1 & 18 & ,426 \\
\hline & & Com base em mediana & ,433 & 1 & 18 & ,519 \\
\hline & & $\begin{array}{l}\text { Com base em mediana e } \\
\text { com df ajustado }\end{array}$ & ,433 & 1 & 17,717 & ,519 \\
\hline & & $\begin{array}{l}\text { Com base em média } \\
\text { aparada }\end{array}$ & 846 & 1 & 18 & ,370 \\
\hline \multirow[t]{4}{*}{ T0_T2 } & \multirow[t]{4}{*}{ Nitrato } & Com base em média &, 007 & 1 & 18 & ,932 \\
\hline & & Com base em mediana & , 175 & 1 & 18 & ,681 \\
\hline & & $\begin{array}{l}\text { Com base em mediana e } \\
\text { com df ajustado }\end{array}$ & , 175 & 1 & 13,462 & ,682 \\
\hline & & $\begin{array}{l}\text { Com base em média } \\
\text { aparada }\end{array}$ &, 011 & 1 & 18 & ,916 \\
\hline \multirow[t]{4}{*}{ T0_T3 } & \multirow[t]{4}{*}{ Nitrato } & Com base em média &, 047 & 1 & 18 & ,831 \\
\hline & & Com base em mediana & ,005 & 1 & 18 & ,947 \\
\hline & & $\begin{array}{l}\text { Com base em mediana e } \\
\text { com df ajustado }\end{array}$ & ,005 & 1 & 17,808 & ,947 \\
\hline & & $\begin{array}{l}\text { Com base em média } \\
\text { aparada }\end{array}$ & 061 & 1 & 18 & ,808 \\
\hline \multirow[t]{4}{*}{ T1_T2 } & \multirow[t]{4}{*}{ Nitrato } & Com base em média & 6,716 & 1 & 18 & 018 \\
\hline & & Com base em mediana & 6,585 & 1 & 18 & ,019 \\
\hline & & $\begin{array}{l}\text { Com base em mediana e } \\
\text { com df ajustado }\end{array}$ & 6,585 & 1 & 12,242 & ,024 \\
\hline & & $\begin{array}{l}\text { Com base em média } \\
\text { aparada }\end{array}$ & 6,522 & 1 & 18 & ,020 \\
\hline \multirow[t]{4}{*}{ T2_T3 } & \multirow[t]{4}{*}{ Nitrato } & Com base em média & ,695 & 1 & 18 & ,415 \\
\hline & & Com base em mediana & 141 & 1 & 18 & ,711 \\
\hline & & $\begin{array}{l}\text { Com base em mediana e } \\
\text { com df ajustado }\end{array}$ & ,141 & 1 & 16,592 & ,712 \\
\hline & & $\begin{array}{l}\text { Com base em média } \\
\text { aparada }\end{array}$ & ,505 & 1 & 18 & ,486 \\
\hline
\end{tabular}




\section{Sistemas FaF1A e FaF1B}

Testes de Normalidade

\begin{tabular}{|lll|r|r|r|r|r|r|}
\hline & & & \multicolumn{3}{|c|}{ Kolmogorov-Smirnov $^{\text {a }}$} & \multicolumn{3}{|c|}{ Shapiro-Wilk } \\
\cline { 5 - 9 } Tempo & & Lodo & Estatística & \multicolumn{1}{c|}{ df } & \multicolumn{1}{c|}{ Sig. } & Estatística & \multicolumn{1}{c|}{ df } & Sig. \\
\hline T0_T1 & Amônia & FaF1A &, 183 & 10 &, $200^{*}$ &, 914 & 10 &, 311 \\
& & FaF1B &, 210 & 10 &, $200^{*}$ &, 864 & 10 &, 084 \\
\hline T0_T2 & Amônia & FaF1A &, 176 & 10 &, $200^{*}$ &, 925 & 10 &, 404 \\
& & FaF1B &, 202 & 10 &, $200^{*}$ &, 876 & 10 &, 117 \\
\hline T0_T3 & Amônia & FaF1A &, 208 & 10 &, $200^{*}$ &, 862 & 10 &, 080 \\
& & FaF1B &, 211 & 10 &, $200^{*}$ &, 866 & 10 &, 090 \\
\hline T1_T2 & Amônia & FaF1A &, 241 & 10 &, 103 &, 839 & 10 &, 043 \\
& & FaF1B &, 193 & 10 &, $200^{*}$ &, 873 & 10 &, 109 \\
\hline T2_T3 & Amônia & FaF1A &, 145 & 10 &, $200^{*}$ &, 928 & 10 &, 432 \\
& & FaF1B &, 168 & 10 &, $200^{*}$ &, 938 & 10 &, 531 \\
\hline
\end{tabular}

*. Este é um limite inferior da significância verdadeira.

a. Correlação de Significância de Lilliefors

Teste de Homogeneidade de Variância

\begin{tabular}{|c|c|c|c|c|c|c|}
\hline Tempo & & & $\begin{array}{c}\text { Estatística de } \\
\text { Levene }\end{array}$ & df1 & $\mathrm{df2}$ & Sig. \\
\hline \multirow[t]{4}{*}{ T0_T1 } & \multirow[t]{4}{*}{ Amônia } & Com base em média &, 713 & 1 & 18 & ,410 \\
\hline & & Com base em mediana & ,456 & 1 & 18 & ,508 \\
\hline & & $\begin{array}{l}\text { Com base em mediana e } \\
\text { com df ajustado }\end{array}$ & ,456 & 1 & 17,699 & ,508 \\
\hline & & $\begin{array}{l}\text { Com base em média } \\
\text { aparada }\end{array}$ &, 703 & 1 & 18 & ,413 \\
\hline \multirow[t]{4}{*}{ T0_T2 } & \multirow[t]{4}{*}{ Amônia } & Com base em média & ,064 & 1 & 18 & 804 \\
\hline & & Com base em mediana & ,035 & 1 & 18 & ,854 \\
\hline & & $\begin{array}{l}\text { Com base em mediana e } \\
\text { com df ajustado }\end{array}$ & ,035 & 1 & 14,602 & ,855 \\
\hline & & $\begin{array}{l}\text { Com base em média } \\
\text { aparada }\end{array}$ & ,068 & 1 & 18 & ,797 \\
\hline \multirow[t]{4}{*}{ T0_T3 } & \multirow[t]{4}{*}{ Amônia } & Com base em média & ,512 & 1 & 18 & ,483 \\
\hline & & Com base em mediana & 230 & 1 & 18 & 637 \\
\hline & & $\begin{array}{l}\text { Com base em mediana e } \\
\text { com df ajustado }\end{array}$ & ,230 & 1 & 12,404 & ,640 \\
\hline & & $\begin{array}{l}\text { Com base em média } \\
\text { aparada }\end{array}$ & ,445 & 1 & 18 &, 513 \\
\hline \multirow[t]{4}{*}{ T1_T2 } & \multirow[t]{4}{*}{ Amônia } & Com base em média & ,300 & 1 & 18 & ,591 \\
\hline & & Com base em mediana & ,029 & 1 & 18 & ,866 \\
\hline & & $\begin{array}{l}\text { Com base em mediana e } \\
\text { com df ajustado }\end{array}$ & ,029 & 1 & 17,970 & ,866 \\
\hline & & $\begin{array}{l}\text { Com base em média } \\
\text { aparada }\end{array}$ & ,274 & 1 & 18 & 607 \\
\hline \multirow[t]{4}{*}{ T2_T3 } & \multirow[t]{4}{*}{ Amônia } & Com base em média & 6,819 & 1 & 18 & 018 \\
\hline & & Com base em mediana & 5,572 & 1 & 18 & 030 \\
\hline & & $\begin{array}{l}\text { Com base em mediana e } \\
\text { com df ajustado }\end{array}$ & 5,572 & 1 & 13,337 & 034 \\
\hline & & $\begin{array}{l}\text { Com base em média } \\
\text { aparada }\end{array}$ & 6,675 & 1 & 18 & ,019 \\
\hline
\end{tabular}


Testes de Normalidade

\begin{tabular}{|lll|r|r|r|r|r|r|}
\hline & & & \multicolumn{3}{|c|}{ Kolmogorov-Smirnov $^{\text {a }}$} & \multicolumn{3}{|c|}{ Shapiro-Wilk } \\
\cline { 5 - 9 } Tempo & & Lodo & Estatística & \multicolumn{1}{c|}{$\mathrm{df}$} & \multicolumn{1}{c|}{ Sig. } & Estatística & \multicolumn{1}{c|}{ df } & \multicolumn{1}{c|}{ Sig. } \\
\hline T0_T1 & Nitrito & FaF1A &, 314 & 10 &, 006 &, 758 & 10 &, 005 \\
& & FaF1B &, 246 & 10 &, 086 &, 870 & 10 &, 100 \\
\hline T0_T2 & \multirow{2}{*}{ Nitrito } & FaF1A &, 234 & 10 &, 128 &, 860 & 10 &, 077 \\
& & FaF1B &, 296 & 10 &, 013 &, 769 & 10 &, 006 \\
\hline T0_T3 & \multirow{2}{*}{ Nitrito } & FaF1A &, 310 & 10 &, 007 &, 729 & 10 &, 002 \\
& & FaF1B &, 340 & 10 &, 002 &, 665 & 10 &, 000 \\
\hline T1_T2 & Nitrito & FaF1A &, 247 & 10 &, 084 &, 833 & 10 &, 037 \\
& & FaF1B &, 297 & 10 &, 012 &, 770 & 10 &, 006 \\
\hline T2_T3 & Nitrito & FaF1A &, 208 & 10 &, $200^{*}$ &, 817 & 10 &, 023 \\
& & FaF1B &, 207 & 10 &, $200^{*}$ &, 876 & 10 &, 116 \\
\hline
\end{tabular}

*. Este é um limite inferior da significância verdadeira.

a. Correlação de Significância de Lilliefors

Teste de Homogeneidade de Variância

\begin{tabular}{|c|c|c|c|c|c|c|}
\hline Tempo & & & $\begin{array}{l}\text { Estatística de } \\
\text { Levene }\end{array}$ & df1 & df2 & Sig. \\
\hline \multirow[t]{4}{*}{ T0_T1 } & \multirow[t]{4}{*}{ Nitrito } & Com base em média & 4,959 & 1 & 18 &, 039 \\
\hline & & Com base em mediana & 1,151 & 1 & 18 & ,297 \\
\hline & & $\begin{array}{l}\text { Com base em mediana e } \\
\text { com df ajustado }\end{array}$ & 1,151 & 1 & 11,036 & ,306 \\
\hline & & $\begin{array}{l}\text { Com base em média } \\
\text { aparada }\end{array}$ & 4,453 & 1 & 18 & ,049 \\
\hline \multirow[t]{4}{*}{ T0_T2 } & \multirow[t]{4}{*}{ Nitrito } & Com base em média &, 513 & 1 & 18 & ,483 \\
\hline & & Com base em mediana & ,474 & 1 & 18 &, 500 \\
\hline & & $\begin{array}{l}\text { Com base em mediana e } \\
\text { com df ajustado }\end{array}$ & ,474 & 1 & 17,040 &, 500 \\
\hline & & $\begin{array}{l}\text { Com base em média } \\
\text { aparada }\end{array}$ & ,594 & 1 & 18 & ,451 \\
\hline \multirow[t]{4}{*}{ T0_T3 } & \multirow[t]{4}{*}{ Nitrito } & Com base em média & 035 & 1 & 18 & ,853 \\
\hline & & Com base em mediana &, 000 & 1 & 18 & 983 \\
\hline & & $\begin{array}{l}\text { Com base em mediana e } \\
\text { com df ajustado }\end{array}$ &, 000 & 1 & 17,515 & ,983 \\
\hline & & $\begin{array}{l}\text { Com base em média } \\
\text { aparada }\end{array}$ & ,014 & 1 & 18 & ,908 \\
\hline \multirow[t]{4}{*}{ T1_T2 } & \multirow[t]{4}{*}{ Nitrito } & Com base em média & 1,459 & 1 & 18 & ,243 \\
\hline & & Com base em mediana & ,334 & 1 & 18 &, 570 \\
\hline & & $\begin{array}{l}\text { Com base em mediana e } \\
\text { com df ajustado }\end{array}$ & ,334 & 1 & 15,317 &, 572 \\
\hline & & $\begin{array}{l}\text { Com base em média } \\
\text { aparada }\end{array}$ & 1,300 & 1 & 18 & ,269 \\
\hline \multirow[t]{4}{*}{ T2_T3 } & \multirow[t]{4}{*}{ Nitrito } & Com base em média & 9,350 & 1 & 18 & ,007 \\
\hline & & Com base em mediana & 6,666 & 1 & 18 & 019 \\
\hline & & $\begin{array}{l}\text { Com base em mediana e } \\
\text { com df ajustado }\end{array}$ & 6,666 & 1 & 9,877 & ,028 \\
\hline & & $\begin{array}{l}\text { Com base em média } \\
\text { aparada }\end{array}$ & 8,654 & 1 & 18 & ,009 \\
\hline
\end{tabular}


Testes de Normalidade

\begin{tabular}{|c|c|c|c|c|c|c|c|c|}
\hline \multirow[b]{2}{*}{ Tempo } & & \multirow[b]{2}{*}{ Lodo } & \multicolumn{3}{|c|}{ Kolmogorov-Smirnov $^{a}$} & \multicolumn{3}{|c|}{ Shapiro-Wilk } \\
\hline & & & Estatística & df & Sig. & Estatística & df & Sig. \\
\hline \multirow[t]{2}{*}{ T0_T1 } & Nitrato & FaF1A & ,422 & 10 &, 000 &, 573 & 10 & ,000 \\
\hline & & FaF1B & ,216 & 10 & $200^{*}$ & ,852 & 10 &, 062 \\
\hline \multirow[t]{2}{*}{ T0_T2 } & Nitrato & FaF1A & ,346 & 10 & ,001 & 639 & 10 & ,000 \\
\hline & & FaF1B & ,289 & 10 &, 017 & ,793 & 10 & ,012 \\
\hline \multirow[t]{2}{*}{ T0_T3 } & Nitrato & FaF1A & ,243 & 10 & ,096 & ,808 & 10 & ,018 \\
\hline & & FaF1B & ,308 & 10 &, 008 & ,725 & 10 & ,002 \\
\hline \multirow[t]{2}{*}{ T1_T2 } & Nitrato & FaF1A & ,422 & 10 &, 000 & 621 & 10 &, 000 \\
\hline & & FaF1B &, 357 & 10 &, 001 & ,705 & 10 & ,001 \\
\hline \multirow[t]{2}{*}{ T2_T3 } & Nitrato & FaF1A & ,436 & 10 &, 000 & ,578 & 10 & ,000 \\
\hline & & FaF1B &, 312 & 10 & ,007 & 673 & 10 & ,000 \\
\hline
\end{tabular}

*. Este é um limite inferior da significância verdadeira.

a. Correlação de Significância de Lilliefors

Teste de Homogeneidade de Variância

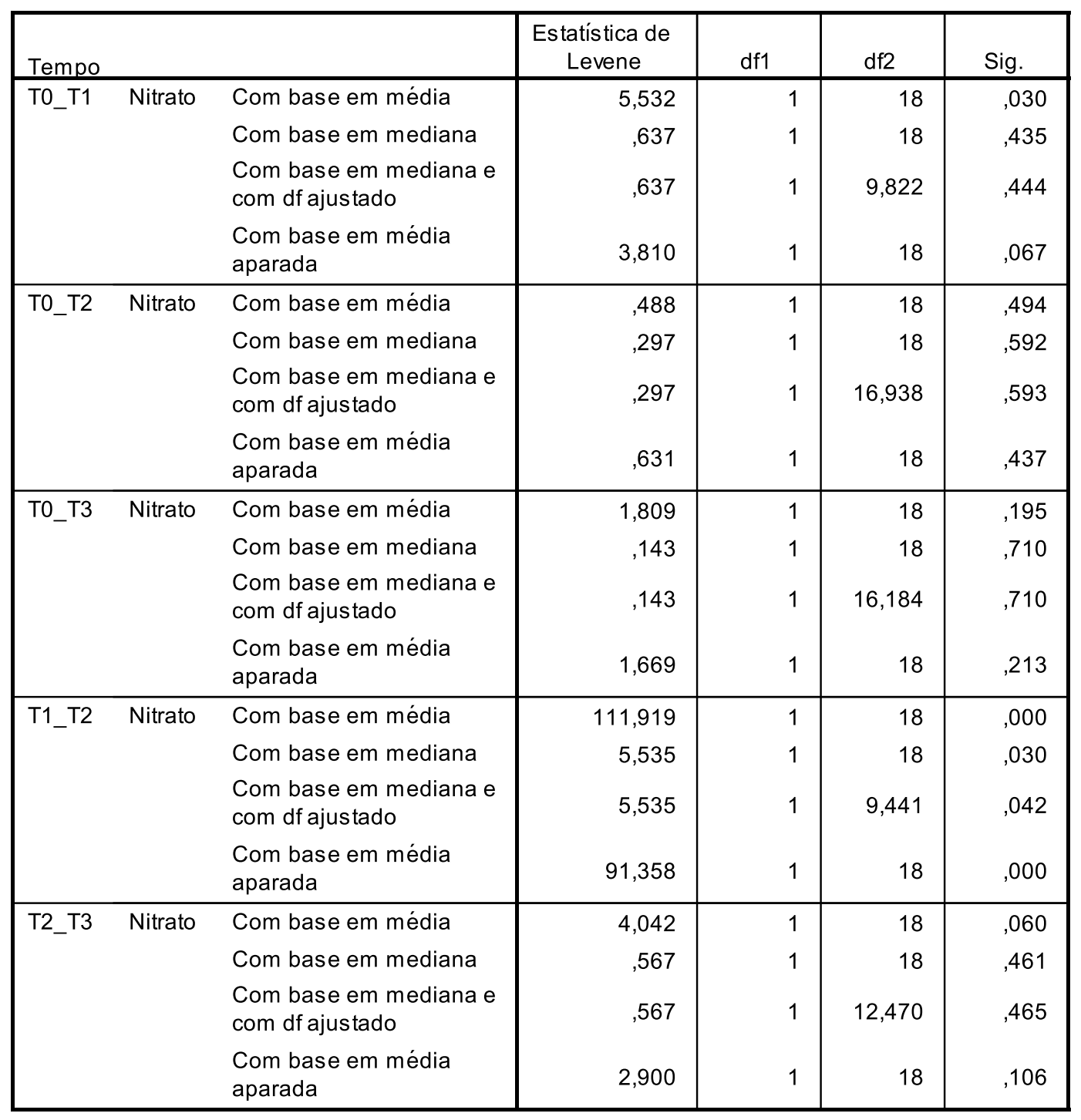




\section{Sistema FaF2A e FaF2B}

Testes de Normalidade

\begin{tabular}{|lll|r|r|r|r|r|r|}
\hline & & & \multicolumn{2}{|c|}{ Kolmogorov-Smirnov $^{2}$} & \multicolumn{3}{|c|}{ Shapiro-Wilk } \\
\cline { 5 - 9 } Tempo & & Lodo & Estatística & df & Sig. & Estatística & \multicolumn{1}{c|}{ df } & Sig. \\
\hline T0_T1 & Amônia & FaF2A &, 208 & 10 &, $200^{*}$ &, 875 & 10 &, 113 \\
& & FaF2B &, 181 & 10 &, $200^{*}$ &, 902 & 10 &, 229 \\
\hline T0_T2 & Amônia & FaF2A &, 290 & 10 &, 017 &, 773 & 10 &, 007 \\
& & FaF2B &, 234 & 10 &, 130 &, 876 & 10 &, 117 \\
\hline T0_T3 & Amônia & FaF2A &, 199 & 10 &, $200^{*}$ &, 882 & 10 &, 139 \\
& & FaF2B &, 168 & 10 &, $200^{*}$ &, 903 & 10 &, 235 \\
\hline T1_T2 & Amônia & FaF2A &, 252 & 10 &, 071 &, 886 & 10 &, 153 \\
& & FaF2B &, 203 & 10 &, $200^{*}$ &, 868 & 10 &, 094 \\
\hline T2_T3 & Amônia & FaF2A &, 207 & 10 &, $200^{*}$ &, 846 & 10 &, 052 \\
& & FaF2B &, 339 & 10 &, 002 &, 707 & 10 &, 001 \\
\hline
\end{tabular}

*. Este é um limite inferior da significância verdadeira.

a. Correlação de Significância de Lilliefors

Teste de Homogeneidade de Variância

\begin{tabular}{|c|c|c|c|c|c|c|}
\hline Tempo & & & $\begin{array}{c}\text { Estatística de } \\
\text { Levene }\end{array}$ & df1 & df2 & Sig. \\
\hline \multirow[t]{4}{*}{ T0_T1 } & \multirow[t]{4}{*}{ Amônia } & Com base em média & 2,653 & 1 & 18 & ,121 \\
\hline & & Com base em mediana & 2,671 & 1 & 18 & 120 \\
\hline & & $\begin{array}{l}\text { Com base em mediana e } \\
\text { com df ajustado }\end{array}$ & 2,671 & 1 & 11,324 & ,130 \\
\hline & & $\begin{array}{l}\text { Com base em média } \\
\text { aparada }\end{array}$ & 2,658 & 1 & 18 & 120 \\
\hline \multirow[t]{4}{*}{ T0_T2 } & \multirow[t]{4}{*}{ Amônia } & Com base em média & 1,839 & 1 & 18 & ,192 \\
\hline & & Com base em mediana &, 156 & 1 & 18 & 697 \\
\hline & & $\begin{array}{l}\text { Com base em mediana e } \\
\text { com df ajustado }\end{array}$ & ,156 & 1 & 14,276 & ,698 \\
\hline & & $\begin{array}{l}\text { Com base em média } \\
\text { aparada }\end{array}$ & 1,703 & 1 & 18 & ,208 \\
\hline \multirow[t]{4}{*}{ T0_T3 } & \multirow[t]{4}{*}{ Amônia } & Com base em média &, 753 & 1 & 18 & ,397 \\
\hline & & Com base em mediana & ,458 & 1 & 18 &, 507 \\
\hline & & $\begin{array}{l}\text { Com base em mediana e } \\
\text { com df ajustado }\end{array}$ &, 458 & 1 & 14,780 & ,509 \\
\hline & & $\begin{array}{l}\text { Com base em média } \\
\text { aparada }\end{array}$ & ,696 & 1 & 18 & ,415 \\
\hline \multirow[t]{4}{*}{ T1_T2 } & \multirow[t]{4}{*}{ Amônia } & Com base em média & 4,616 & 1 & 18 & ,046 \\
\hline & & Com base em mediana & 2,375 & 1 & 18 & 141 \\
\hline & & $\begin{array}{l}\text { Com base em mediana e } \\
\text { com df ajustado }\end{array}$ & 2,375 & 1 & 17,024 & ,142 \\
\hline & & $\begin{array}{l}\text { Com base em média } \\
\text { aparada }\end{array}$ & 4,357 & 1 & 18 & 051 \\
\hline \multirow[t]{4}{*}{ T2_T3 } & \multirow[t]{4}{*}{ Amônia } & Com base em média & 1,248 & 1 & 18 & ,279 \\
\hline & & Com base em mediana & ,326 & 1 & 18 & ,575 \\
\hline & & $\begin{array}{l}\text { Com base em mediana e } \\
\text { com df ajustado }\end{array}$ & ,326 & 1 & 12,824 &, 578 \\
\hline & & $\begin{array}{l}\text { Com base em média } \\
\text { aparada }\end{array}$ & ,823 & 1 & 18 & ,376 \\
\hline
\end{tabular}


Testes de Normalidade

\begin{tabular}{|c|c|c|c|c|c|c|c|c|}
\hline \multirow[b]{2}{*}{ Tempo } & & \multirow[b]{2}{*}{ Lodo } & \multicolumn{3}{|c|}{ Kolmogorov-Smirnov ${ }^{a}$} & \multicolumn{3}{|c|}{ Shapiro-Wilk } \\
\hline & & & Estatística & $\mathrm{df}$ & Sig. & Estatística & $\mathrm{df}$ & Sig. \\
\hline \multirow[t]{2}{*}{ T0_T1 } & Nitrito & FaF2A & ,217 & 10 & $200^{*}$ &, 850 & 10 & ,058 \\
\hline & & FaF2B & ,263 & 10 & ,049 &, 777 & 10 & ,008 \\
\hline \multirow[t]{2}{*}{ T0_T2 } & Nitrito & FaF2A & ,192 & 10 &, $200^{*}$ & ,872 & 10 & ,105 \\
\hline & & FaF2B & ,219 & 10 & , 190 & ,903 & 10 & ,234 \\
\hline \multirow[t]{2}{*}{ T0_T3 } & Nitrito & FaF2A &, 250 & 10 & ,076 & ,828 & 10 & ,032 \\
\hline & & FaF2B & ,304 & 10 & ,009 & ,782 & 10 & ,009 \\
\hline \multirow[t]{2}{*}{ T1_T2 } & Nitrito & FaF2A & ,211 & 10 &, $200^{*}$ & ,887 & 10 & ,156 \\
\hline & & FaF2B & ,283 & 10 &, 023 & ,846 & 10 &, 052 \\
\hline \multirow[t]{2}{*}{ T2_T3 } & Nitrito & FaF2A & ,262 & 10 &, 050 &, 847 & 10 &, 054 \\
\hline & & FaF2B & ,172 & 10 &, $200^{*}$ & ,912 & 10 & ,292 \\
\hline
\end{tabular}

*. Este é um limite inferior da significância verdadeira.

a. Correlação de Significância de Lilliefors

Teste de Homogeneidade de Variância

\begin{tabular}{|c|c|c|c|c|c|c|}
\hline Tempo & & & $\begin{array}{c}\text { Estatística de } \\
\text { Levene }\end{array}$ & df1 & $\mathrm{df2}$ & Sig. \\
\hline \multirow[t]{4}{*}{ T0_T1 } & \multirow[t]{4}{*}{ Nitrito } & Com base em média & 12,016 & 1 & 18 &, 003 \\
\hline & & Com base em mediana & 6,629 & 1 & 18 & 019 \\
\hline & & $\begin{array}{l}\text { Com base em mediana e } \\
\text { com df ajustado }\end{array}$ & 6,629 & 1 & 14,031 & ,022 \\
\hline & & $\begin{array}{l}\text { Com base em média } \\
\text { aparada }\end{array}$ & 11,737 & 1 & 18 & ,003 \\
\hline \multirow[t]{4}{*}{ T0_T2 } & \multirow[t]{4}{*}{ Nitrito } & Com base em média & 3,175 & 1 & 18 & 092 \\
\hline & & Com base em mediana & 1,890 & 1 & 18 & , 186 \\
\hline & & $\begin{array}{l}\text { Com base em mediana e } \\
\text { com df ajustado }\end{array}$ & 1,890 & 1 & 17,730 & ,186 \\
\hline & & $\begin{array}{l}\text { Com base em média } \\
\text { aparada }\end{array}$ & 3,077 & 1 & 18 & ,096 \\
\hline \multirow[t]{4}{*}{ T0_T3 } & \multirow[t]{4}{*}{ Nitrito } & Com base em média & 8,228 & 1 & 18 & 010 \\
\hline & & Com base em mediana & 2,157 & 1 & 18 & ,159 \\
\hline & & $\begin{array}{l}\text { Com base em mediana e } \\
\text { com df ajustado }\end{array}$ & 2,157 & 1 & 17,243 & , 160 \\
\hline & & $\begin{array}{l}\text { Com base em média } \\
\text { aparada }\end{array}$ & 7,767 & 1 & 18 & 012 \\
\hline \multirow[t]{4}{*}{ T1_T2 } & \multirow[t]{4}{*}{ Nitrito } & Com base em média &, 034 & 1 & 18 & 855 \\
\hline & & Com base em mediana &, 008 & 1 & 18 & 928 \\
\hline & & $\begin{array}{l}\text { Com base em mediana e } \\
\text { com df ajustado }\end{array}$ & ,008 & 1 & 15,863 & ,928 \\
\hline & & $\begin{array}{l}\text { Com base em média } \\
\text { aparada }\end{array}$ & ,034 & 1 & 18 & ,856 \\
\hline \multirow[t]{4}{*}{ T2_T3 } & \multirow[t]{4}{*}{ Nitrito } & Com base em média & ,589 & 1 & 18 & ,453 \\
\hline & & Com base em mediana & ,735 & 1 & 18 & ,402 \\
\hline & & $\begin{array}{l}\text { Com base em mediana e } \\
\text { com df ajustado }\end{array}$ & ,735 & 1 & 17,053 & ,403 \\
\hline & & $\begin{array}{l}\text { Com base em média } \\
\text { aparada }\end{array}$ &, 555 & 1 & 18 & ,466 \\
\hline
\end{tabular}


Testes de Normalidade

\begin{tabular}{|lll|r|r|r|r|r|r|}
\hline & & & \multicolumn{3}{|c|}{ Kolmogorov-Smirnov $^{\text {a }}$} & \multicolumn{3}{|c|}{ Shapiro-Wilk } \\
\cline { 5 - 9 } Tempo & & Lodo & Estatística & \multicolumn{1}{c|}{$\mathrm{df}$} & \multicolumn{1}{c|}{ Sig. } & Estatística & \multicolumn{1}{c|}{ df } & Sig. \\
\hline T0_T1 & Nitrato & FaF2A &, 438 & 10 &, 000 &, 571 & 10 &, 000 \\
& & FaF2B &, 368 & 10 &, 000 &, 722 & 10 &, 002 \\
\hline T0_T2 & Nitrato & FaF2A &, 431 & 10 &, 000 &, 625 & 10 &, 000 \\
& & FaF2B &, 327 & 10 &, 003 &, 709 & 10 &, 001 \\
\hline T0_T3 & Nitrato & FaF2A &, 381 & 10 &, 000 &, 666 & 10 &, 000 \\
& & FaF2B &, 298 & 10 &, 012 &, 762 & 10 &, 005 \\
\hline T1_T2 & Nitrato & FaF2A &, 390 & 10 &, 000 &, 705 & 10 &, 001 \\
& & FaF2B &, 300 & 10 &, 011 &, 793 & 10 &, 012 \\
\hline T2_T3 & Nitrato & FaF2A &, 301 & 10 &, 011 &, 762 & 10 &, 005 \\
& & FaF2B &, 357 & 10 &, 001 &, 756 & 10 &, 004 \\
\hline
\end{tabular}

a. Correlação de Significância de Lilliefors

Teste de Homogeneidade de Variância

\begin{tabular}{|c|c|c|c|c|c|c|}
\hline Tempo & & & $\begin{array}{l}\text { Estatística de } \\
\text { Levene }\end{array}$ & df1 & df2 & Sig. \\
\hline \multirow[t]{4}{*}{ T0_T1 } & \multirow[t]{4}{*}{ Nitrato } & Com base em média & 1,012 & 1 & 18 & ,328 \\
\hline & & Com base em mediana & 081 & 1 & 18 & ,779 \\
\hline & & $\begin{array}{l}\text { Com base em mediana e } \\
\text { com df ajustado }\end{array}$ & ,081 & 1 & 15,231 & ,779 \\
\hline & & $\begin{array}{l}\text { Com base em média } \\
\text { aparada }\end{array}$ & ,699 & 1 & 18 & ,414 \\
\hline \multirow[t]{4}{*}{ T0_T2 } & \multirow[t]{4}{*}{ Nitrato } & Com base em média & , 105 & 1 & 18 & ,749 \\
\hline & & Com base em mediana & ,005 & 1 & 18 & ,943 \\
\hline & & $\begin{array}{l}\text { Com base em mediana e } \\
\text { com df ajustado }\end{array}$ &, 005 & 1 & 17,566 & ,943 \\
\hline & & $\begin{array}{l}\text { Com base em média } \\
\text { aparada }\end{array}$ &, 077 & 1 & 18 & ,785 \\
\hline \multirow[t]{4}{*}{ T0_T3 } & \multirow[t]{4}{*}{ Nitrato } & Com base em média & 5,381 & 1 & 18 & ,032 \\
\hline & & Com base em mediana & 1,539 & 1 & 18 & ,231 \\
\hline & & $\begin{array}{l}\text { Com base em mediana e } \\
\text { com df ajustado }\end{array}$ & 1,539 & 1 & 17,439 & ,231 \\
\hline & & $\begin{array}{l}\text { Com base em média } \\
\text { aparada }\end{array}$ & 5,339 & 1 & 18 & ,033 \\
\hline \multirow[t]{4}{*}{ T1_T2 } & \multirow[t]{4}{*}{ Nitrato } & Com base em média & ,045 & 1 & 18 & 834 \\
\hline & & Com base em mediana & ,265 & 1 & 18 & ,613 \\
\hline & & $\begin{array}{l}\text { Com base em mediana e } \\
\text { com df ajustado }\end{array}$ & ,265 & 1 & 17,938 & ,613 \\
\hline & & $\begin{array}{l}\text { Com base em média } \\
\text { aparada }\end{array}$ & ,072 & 1 & 18 & ,792 \\
\hline \multirow[t]{4}{*}{ T2_T3 } & \multirow[t]{4}{*}{ Nitrato } & Com base em média & 4,395 & 1 & 18 & ,050 \\
\hline & & Com base em mediana & 1,653 & 1 & 18 & ,215 \\
\hline & & $\begin{array}{l}\text { Com base em mediana e } \\
\text { com df ajustado }\end{array}$ & 1,653 & 1 & 11,207 & ,224 \\
\hline & & $\begin{array}{l}\text { Com base em média } \\
\text { aparada }\end{array}$ & 3,587 & 1 & 18 & ,074 \\
\hline
\end{tabular}




\section{Sistema par UaF2A e UaF2B}

Testes de Normalidade

\begin{tabular}{|c|c|c|c|c|c|c|c|c|}
\hline \multirow[b]{2}{*}{ Tempo } & & \multirow[b]{2}{*}{ Lodo } & \multicolumn{3}{|c|}{ Kolmogorov-Smirnov ${ }^{a}$} & \multicolumn{3}{|c|}{ Shapiro-Wilk } \\
\hline & & & Estatística & df & Sig. & Estatística & $d f$ & Sig. \\
\hline \multirow[t]{2}{*}{ T0_T1 } & Amônia & UaF2B & , 198 & 10 & $200^{*}$ & ,855 & 10 & ,066 \\
\hline & & UaF2A & ,273 & 10 &, 033 & ,778 & 10 & ,008 \\
\hline \multirow[t]{2}{*}{ T0_T2 } & Amônia & UaF2B & ,234 & 10 & ,129 & ,866 & 10 & 089 \\
\hline & & UaF2A & ,296 & 10 & 013 & 811 & 10 & ,020 \\
\hline \multirow[t]{2}{*}{ T0_T3 } & Amônia & UaF2B & ,241 & 10 & 103 & ,856 & 10 & ,068 \\
\hline & & UaF2A & ,291 & 10 & ,016 & ,793 & 10 & 012 \\
\hline \multirow[t]{2}{*}{ T1_T2 } & Amônia & UaF2B & ,218 & 10 & ,196 & ,862 & 10 & 081 \\
\hline & & UaF2A & ,320 & 10 & ,005 & ,646 & 10 & ,000 \\
\hline \multirow[t]{2}{*}{ T2_T3 } & Amônia & UaF2B & ,244 & 10 & ,093 & ,877 & 10 & ,121 \\
\hline & & UaF2A & ,258 & 10 & ,058 & ,854 & 10 &, 065 \\
\hline
\end{tabular}

*. Este é um limite inferior da significância verdadeira.

a. Correlação de Significância de Lilliefors

Teste de Homogeneidade de Variância

\begin{tabular}{|c|c|c|c|c|c|c|}
\hline Tempo & & & $\begin{array}{c}\text { Estatística de } \\
\text { Levene }\end{array}$ & df1 & $\mathrm{df} 2$ & Sig. \\
\hline \multirow[t]{4}{*}{ T0_T1 } & \multirow[t]{4}{*}{ Amônia } & Com base em média & 1,049 & 1 & 18 & ,319 \\
\hline & & Com base em mediana & ,626 & 1 & 18 & ,439 \\
\hline & & $\begin{array}{l}\text { Com base em mediana e } \\
\text { com df ajustado }\end{array}$ & ,626 & 1 & 16,421 & ,440 \\
\hline & & $\begin{array}{l}\text { Com base em média } \\
\text { aparada }\end{array}$ & 1,055 & 1 & 18 & ,318 \\
\hline \multirow[t]{4}{*}{ T0_T2 } & \multirow[t]{4}{*}{ Amônia } & Com base em média & 219 & 1 & 18 & ,645 \\
\hline & & Com base em mediana & ,007 & 1 & 18 & ,933 \\
\hline & & $\begin{array}{l}\text { Com base em mediana e } \\
\text { com df ajustado }\end{array}$ &, 007 & 1 & 15,820 & ,933 \\
\hline & & $\begin{array}{l}\text { Com base em média } \\
\text { aparada }\end{array}$ & ,162 & 1 & 18 & ,692 \\
\hline \multirow[t]{4}{*}{ T0_T3 } & \multirow[t]{4}{*}{ Amônia } & Com base em média & 1,675 & 1 & 18 & ,212 \\
\hline & & Com base em mediana & 144 & 1 & 18 & ,708 \\
\hline & & $\begin{array}{l}\text { Com base em mediana e } \\
\text { com df ajustado }\end{array}$ & 144 & 1 & 13,670 & ,710 \\
\hline & & $\begin{array}{l}\text { Com base em média } \\
\text { aparada }\end{array}$ & 1,478 & 1 & 18 & ,240 \\
\hline \multirow[t]{4}{*}{ T1_T2 } & \multirow[t]{4}{*}{ Amônia } & Com base em média & ,956 & 1 & 18 & ,341 \\
\hline & & Com base em mediana & 081 & 1 & 18 & ,779 \\
\hline & & $\begin{array}{l}\text { Com base em mediana e } \\
\text { com df ajustado }\end{array}$ &, 081 & 1 & 11,210 & ,781 \\
\hline & & $\begin{array}{l}\text { Com base em média } \\
\text { aparada }\end{array}$ & ,591 & 1 & 18 & ,452 \\
\hline \multirow[t]{4}{*}{ T2_T3 } & \multirow[t]{4}{*}{ Amônia } & Com base em média & ,040 & 1 & 18 & 843 \\
\hline & & Com base em mediana &, 000 & 1 & 18 & ,984 \\
\hline & & $\begin{array}{l}\text { Com base em mediana e } \\
\text { com df ajustado }\end{array}$ &, 000 & 1 & 17,580 & ,984 \\
\hline & & $\begin{array}{l}\text { Com base em média } \\
\text { aparada }\end{array}$ & 047 & 1 & 18 & 831 \\
\hline
\end{tabular}


Testes de Normalidade

\begin{tabular}{|lll|r|r|r|r|r|r|}
\hline \multirow{2}{*}{ Tempo } & & \multicolumn{4}{|c|}{ Kolmogorov-Smirnov $^{\text {a }}$} & \multicolumn{3}{|c|}{ Shapiro-Wilk } \\
\cline { 4 - 9 } & & Lodo & Estatística & \multicolumn{1}{c|}{$\mathrm{df}$} & \multicolumn{1}{c|}{ Sig. } & Estatística & \multicolumn{1}{c|}{ df } & Sig. \\
\hline T0_T1 & \multirow{2}{*}{ Nitrito } & UaF2B &, 343 & 10 &, 002 &, 775 & 10 &, 007 \\
& & UaF2A &, 316 & 10 &, 005 &, 682 & 10 &, 001 \\
\hline T0_T2 & Nitrito & UaF2B &, 317 & 10 &, 005 &, 725 & 10 &, 002 \\
& & UaF2A &, 372 & 10 &, 000 &, 696 & 10 &, 001 \\
\hline T0_T3 & \multirow{2}{*}{ Nitrito } & UaF2B &, 361 & 10 &, 001 &, 734 & 10 &, 002 \\
& & UaF2A &, 332 & 10 &, 003 &, 786 & 10 &, 010 \\
\hline T1_T2 & \multirow{2}{*}{ Nitrito } & UaF2B &, 219 & 10 &, 191 &, 824 & 10 &, 028 \\
& & UaF2A &, 364 & 10 &, 001 &, 729 & 10 &, 002 \\
\hline T2_T3 & Nitrito & UaF2B &, 189 & 10 &, 200 &, 897 & 10 &, 201 \\
& & UaF2A &, 269 & 10 &, 038 &, 806 & 10 &, 017 \\
\hline
\end{tabular}

*. Este é um limite inferior da significância verdadeira.

a. Correlação de Significância de Lilliefors

Teste de Homogeneidade de Variância

\begin{tabular}{|c|c|c|c|c|c|c|}
\hline Tempo & & & $\begin{array}{l}\text { Estatística de } \\
\text { Levene }\end{array}$ & df1 & df2 & Sig. \\
\hline \multirow[t]{4}{*}{ T0_T1 } & \multirow[t]{4}{*}{ Nitrito } & Com base em média & ,330 & 1 & 18 &, 573 \\
\hline & & Com base em mediana & 073 & 1 & 18 & ,790 \\
\hline & & $\begin{array}{l}\text { Com base em mediana e } \\
\text { com df ajustado }\end{array}$ & ,073 & 1 & 17,905 & ,790 \\
\hline & & $\begin{array}{l}\text { Com base em média } \\
\text { aparada }\end{array}$ & ,333 & 1 & 18 &, 571 \\
\hline \multirow[t]{4}{*}{ T0_T2 } & \multirow[t]{4}{*}{ Nitrito } & Com base em média & 5,542 & 1 & 18 & 030 \\
\hline & & Com base em mediana & ,175 & 1 & 18 & 681 \\
\hline & & $\begin{array}{l}\text { Com base em mediana e } \\
\text { com df ajustado }\end{array}$ & , 175 & 1 & 15,223 & ,682 \\
\hline & & $\begin{array}{l}\text { Com base em média } \\
\text { aparada }\end{array}$ & 4,456 & 1 & 18 & ,049 \\
\hline \multirow[t]{4}{*}{ T0_T3 } & \multirow[t]{4}{*}{ Nitrito } & Com base em média & 4,318 & 1 & 18 & 052 \\
\hline & & Com base em mediana & ,618 & 1 & 18 & ,442 \\
\hline & & $\begin{array}{l}\text { Com base em mediana e } \\
\text { com df ajustado }\end{array}$ & ,618 & 1 & 15,977 & ,443 \\
\hline & & $\begin{array}{l}\text { Com base em média } \\
\text { aparada }\end{array}$ & 3,802 & 1 & 18 & ,067 \\
\hline \multirow[t]{4}{*}{ T1_T2 } & \multirow[t]{4}{*}{ Nitrito } & Com base em média & 9,737 & 1 & 18 & 006 \\
\hline & & Com base em mediana & 1,031 & 1 & 18 & ,323 \\
\hline & & $\begin{array}{l}\text { Com base em mediana e } \\
\text { com df ajustado }\end{array}$ & 1,031 & 1 & 11,512 & ,331 \\
\hline & & $\begin{array}{l}\text { Com base em média } \\
\text { aparada }\end{array}$ & 8,524 & 1 & 18 & ,009 \\
\hline \multirow[t]{4}{*}{ T2_T3 } & \multirow[t]{4}{*}{ Nitrito } & Com base em média & , 186 & 1 & 18 & 671 \\
\hline & & Com base em mediana & ,267 & 1 & 18 & ,612 \\
\hline & & $\begin{array}{l}\text { Com base em mediana e } \\
\text { com df ajustado }\end{array}$ & ,267 & 1 & 17,101 & ,612 \\
\hline & & $\begin{array}{l}\text { Com base em média } \\
\text { aparada }\end{array}$ & , 179 & 1 & 18 & ,678 \\
\hline
\end{tabular}


Testes de Normalidade

\begin{tabular}{|c|c|c|c|c|c|c|c|c|}
\hline \multirow[b]{2}{*}{ Tempo } & & \multirow[b]{2}{*}{ Lodo } & \multicolumn{3}{|c|}{ Kolmogorov-Smirnov $^{a}$} & \multicolumn{3}{|c|}{ Shapiro-Wilk } \\
\hline & & & Estatística & $\mathrm{df}$ & Sig. & Estatística & df & Sig. \\
\hline \multirow[t]{2}{*}{ T0_T1 } & Nitrato & UaF2B & ,356 & 10 &, 001 & ,702 & 10 & ,001 \\
\hline & & UaF2A & ,325 & 10 & ,004 & ,794 & 10 & ,012 \\
\hline \multirow[t]{2}{*}{ T0_T2 } & Nitrato & UaF2B &, 210 & 10 &, $200^{*}$ & ,891 & 10 & , 172 \\
\hline & & UaF2A & ,408 & 10 & ,000 & ,642 & 10 & ,000 \\
\hline \multirow[t]{2}{*}{ T0_T3 } & Nitrato & UaF2B & ,334 & 10 & ,002 & ,714 & 10 & ,001 \\
\hline & & UaF2A & ,354 & 10 & ,001 & ,693 & 10 & ,001 \\
\hline \multirow[t]{2}{*}{ T1_T2 } & Nitrato & UaF2B & ,284 & 10 & ,022 & ,860 & 10 & ,076 \\
\hline & & UaF2A & ,386 & 10 & ,000 & ,665 & 10 & ,000 \\
\hline \multirow[t]{2}{*}{ T2_T3 } & Nitrato & UaF2B & 315 & 10 & ,006 & ,833 & 10 & ,037 \\
\hline & & UaF2A & ,161 & 10 &, $200^{*}$ & ,882 & 10 & ,138 \\
\hline
\end{tabular}

*. Este é um limite inferior da significância verdadeira.

a. Correlação de Significância de Lilliefors

Teste de Homogeneidade de Variância

\begin{tabular}{|c|c|c|c|c|c|c|}
\hline Tempo & & & $\begin{array}{c}\text { Estatística de } \\
\text { Levene }\end{array}$ & $\mathrm{df1}$ & df2 & Sig. \\
\hline \multirow[t]{4}{*}{ T0_T1 } & \multirow[t]{4}{*}{ Nitrato } & Com base em média & 30,192 & 1 & 18 & 000 \\
\hline & & Com base em mediana & 2,870 & 1 & 18 & 108 \\
\hline & & $\begin{array}{l}\text { Com base em mediana e } \\
\text { com df ajustado }\end{array}$ & 2,870 & 1 & 11,831 & ,116 \\
\hline & & $\begin{array}{l}\text { Com base em média } \\
\text { aparada }\end{array}$ & 26,450 & 1 & 18 &, 000 \\
\hline \multirow[t]{4}{*}{ T0_T2 } & \multirow[t]{4}{*}{ Nitrato } & Com base em média & 2,826 & 1 & 18 & 110 \\
\hline & & Com base em mediana & 2,113 & 1 & 18 & 163 \\
\hline & & $\begin{array}{l}\text { Com base em mediana e } \\
\text { com df ajustado }\end{array}$ & 2,113 & 1 & 17,477 & ,164 \\
\hline & & $\begin{array}{l}\text { Com base em média } \\
\text { aparada }\end{array}$ & 2,896 & 1 & 18 & 106 \\
\hline \multirow[t]{4}{*}{ T0_T3 } & \multirow[t]{4}{*}{ Nitrato } & Com base em média & 56,767 & 1 & 18 &, 000 \\
\hline & & Com base em mediana & 4,728 & 1 & 18 &, 043 \\
\hline & & $\begin{array}{l}\text { Com base em mediana e } \\
\text { com df ajustado }\end{array}$ & 4,728 & 1 & 10,747 & ,053 \\
\hline & & $\begin{array}{l}\text { Com base em média } \\
\text { aparada }\end{array}$ & 48,891 & 1 & 18 & ,000 \\
\hline \multirow[t]{4}{*}{ T1_T2 } & \multirow[t]{4}{*}{ Nitrato } & Com base em média &, 063 & 1 & 18 & ,804 \\
\hline & & Com base em mediana &, 042 & 1 & 18 & 839 \\
\hline & & $\begin{array}{l}\text { Com base em mediana e } \\
\text { com df ajustado }\end{array}$ &, 042 & 1 & 17,289 & ,839 \\
\hline & & $\begin{array}{l}\text { Com base em média } \\
\text { aparada }\end{array}$ & ,016 & 1 & 18 & 899 \\
\hline \multirow[t]{4}{*}{ T2_T3 } & \multirow[t]{4}{*}{ Nitrato } & Com base em média & 36,981 & 1 & 18 &, 000 \\
\hline & & Com base em mediana & 6,280 & 1 & 18 & ,022 \\
\hline & & $\begin{array}{l}\text { Com base em mediana e } \\
\text { com df ajustado }\end{array}$ & 6,280 & 1 & 9,108 & ,033 \\
\hline & & $\begin{array}{l}\text { Com base em média } \\
\text { aparada }\end{array}$ & 33,959 & 1 & 18 &, 000 \\
\hline
\end{tabular}




\section{Sistemas par ChoA e ChoB}

Testes de Normalidade

\begin{tabular}{|lll|r|r|r|r|r|r|}
\hline & & & \multicolumn{3}{|c|}{ Kolmogorov-Smirnov $^{\text {a }}$} & \multicolumn{3}{|c|}{ Shapiro-Wilk } \\
\cline { 4 - 9 } Tempo & & Lodo & Estatística & \multicolumn{1}{c|}{$\mathrm{df}$} & \multicolumn{1}{c|}{ Sig. } & Estatística & \multicolumn{1}{c|}{$\mathrm{df}$} & \multicolumn{1}{c|}{ Sig. } \\
\hline T0_T1 & Amônia & ChoA &, 266 & 10 &, 043 &, 860 & 10 &, 076 \\
& & ChoB &, 282 & 10 &, 024 &, 841 & 10 &, 046 \\
\hline T0_T2 & Amônia & ChoA &, 205 & 10 &, $200^{*}$ &, 903 & 10 &, 238 \\
& & ChoB &, 213 & 10 &, $200^{*}$ &, 875 & 10 &, 115 \\
\hline T0_T3 & Amônia & ChoA &, 224 & 10 &, 169 &, 823 & 10 &, 027 \\
& & ChoB &, 262 & 10 &, 051 &, 810 & 10 &, 019 \\
\hline T1_T2 & Amônia & ChoA &, 279 & 10 &, 027 &, 816 & 10 &, 022 \\
& & ChoB &, 168 & 10 &, $200^{*}$ &, 900 & 10 &, 217 \\
\hline T2_T3 & Amônia & ChoA &, 207 & 10 &, $200^{*}$ &, 872 & 10 &, 105 \\
& & ChoB &, 211 & 10 &, $200^{*}$ &, 853 & 10 &, 064 \\
\hline
\end{tabular}

*. Este é um limite inferior da significância verdadeira.

a. Correlação de Significância de Lilliefors

Teste de Homogeneidade de Variância

\begin{tabular}{|c|c|c|c|c|c|c|}
\hline Tempo & & & $\begin{array}{c}\text { Estatística de } \\
\text { Levene }\end{array}$ & df1 & df2 & Sig. \\
\hline \multirow[t]{4}{*}{ T0_T1 } & Amônia & Com base em média & 1,658 & 1 & 18 & ,214 \\
\hline & & Com base em mediana & ,397 & 1 & 18 &, 536 \\
\hline & & $\begin{array}{l}\text { Com base em mediana e } \\
\text { com df ajustado }\end{array}$ & ,397 & 1 & 17,809 & ,537 \\
\hline & & $\begin{array}{l}\text { Com base em média } \\
\text { aparada }\end{array}$ & 1,662 & 1 & 18 & ,214 \\
\hline \multirow[t]{4}{*}{ T0_T2 } & Amônia & Com base em média & 2,744 & 1 & 18 & , 115 \\
\hline & & Com base em mediana & 1,516 & 1 & 18 & 234 \\
\hline & & $\begin{array}{l}\text { Com base em mediana e } \\
\text { com df ajustado }\end{array}$ & 1,516 & 1 & 10,944 & 244 \\
\hline & & $\begin{array}{l}\text { Com base em média } \\
\text { aparada }\end{array}$ & 2,580 & 1 & 18 & ,126 \\
\hline \multirow[t]{4}{*}{ T0_T3 } & Amônia & Com base em média & 807 & 1 & 18 & ,381 \\
\hline & & Com base em mediana & 182 & 1 & 18 & 675 \\
\hline & & $\begin{array}{l}\text { Com base em mediana e } \\
\text { com df ajustado }\end{array}$ & 182 & 1 & 13,044 & 676 \\
\hline & & $\begin{array}{l}\text { Com base em média } \\
\text { aparada }\end{array}$ & ,695 & 1 & 18 & ,415 \\
\hline \multirow[t]{4}{*}{ T1_T2 } & Amônia & Com base em média & 9,725 & 1 & 18 &, 006 \\
\hline & & Com base em mediana & 9,172 & 1 & 18 & ,007 \\
\hline & & $\begin{array}{l}\text { Com base em mediana e } \\
\text { com df ajustado }\end{array}$ & 9,172 & 1 & 10,817 & 012 \\
\hline & & $\begin{array}{l}\text { Com base em média } \\
\text { aparada }\end{array}$ & 9,445 & 1 & 18 & ,007 \\
\hline \multirow[t]{4}{*}{ T2_T3 } & Amônia & Com base em média & , 183 & 1 & 18 & 674 \\
\hline & & Com base em mediana & ,306 & 1 & 18 & ,587 \\
\hline & & $\begin{array}{l}\text { Com base em mediana e } \\
\text { com df ajustado }\end{array}$ & ,306 & 1 & 17,929 & ,587 \\
\hline & & $\begin{array}{l}\text { Com base em média } \\
\text { aparada }\end{array}$ & ,200 & 1 & 18 & ,660 \\
\hline
\end{tabular}


Testes de Normalidade

\begin{tabular}{|c|c|c|c|c|c|c|c|c|}
\hline \multirow[b]{2}{*}{ Tempo } & & \multirow[b]{2}{*}{ Lodo } & \multicolumn{3}{|c|}{ Kolmogorov-Smirnov $^{a}$} & \multicolumn{3}{|c|}{ Shapiro-Wilk } \\
\hline & & & Estatística & df & Sig. & Estatística & df & Sig. \\
\hline \multirow[t]{2}{*}{ T0_T1 } & Nitrito & ChoA & ,181 & 10 &, $200^{*}$ & ,921 & 10 & ,366 \\
\hline & & ChoB & ,234 & 10 & ,130 & ,891 & 10 & ,173 \\
\hline \multirow[t]{2}{*}{ T0_T2 } & Nitrito & ChoA & ,343 & 10 & ,002 & ,757 & 10 & ,004 \\
\hline & & ChoB & ,323 & 10 & ,004 & ,753 & 10 & ,004 \\
\hline \multirow[t]{2}{*}{ T0_T3 } & Nitrito & ChoA & 299 & 10 & ,012 & ,799 & 10 & ,014 \\
\hline & & ChoB &, 262 & 10 &, 049 & ,803 & 10 &, 016 \\
\hline \multirow[t]{2}{*}{ T1_T2 } & Nitrito & ChoA & ,231 & 10 & ,139 & ,828 & 10 & ,032 \\
\hline & & ChoB &, 373 & 10 &, 000 & ,741 & 10 & ,003 \\
\hline \multirow[t]{2}{*}{ T2_T3 } & Nitrito & ChoA & ,211 & 10 & $200^{*}$ & ,886 & 10 & ,154 \\
\hline & & ChoB & ,288 & 10 & ,019 & ,788 & 10 & ,010 \\
\hline
\end{tabular}

*. Este é um limite inferior da significância verdadeira.

a. Correlação de Significância de Lilliefors

Teste de Homogeneidade de Variância

\begin{tabular}{|c|c|c|c|c|c|c|}
\hline Tempo & & & $\begin{array}{l}\text { Estatística de } \\
\text { Levene }\end{array}$ & df1 & df2 & Sig. \\
\hline \multirow[t]{4}{*}{ T0_T1 } & \multirow[t]{4}{*}{ Nitrito } & Com base em média & 3,242 & 1 & 18 & 089 \\
\hline & & Com base em mediana & 3,139 & 1 & 18 & 093 \\
\hline & & $\begin{array}{l}\text { Com base em mediana e } \\
\text { com df ajustado }\end{array}$ & 3,139 & 1 & 12,115 & ,102 \\
\hline & & $\begin{array}{l}\text { Com base em média } \\
\text { aparada }\end{array}$ & 3,344 & 1 & 18 & 084 \\
\hline \multirow[t]{4}{*}{ T0_T2 } & \multirow[t]{4}{*}{ Nitrito } & Com base em média & 11,605 & 1 & 18 & ,003 \\
\hline & & Com base em mediana & 1,559 & 1 & 18 & ,228 \\
\hline & & $\begin{array}{l}\text { Com base em mediana e } \\
\text { com df ajustado }\end{array}$ & 1,559 & 1 & 12,769 & ,234 \\
\hline & & $\begin{array}{l}\text { Com base em média } \\
\text { aparada }\end{array}$ & 10,166 & 1 & 18 & ,005 \\
\hline \multirow[t]{4}{*}{ T0_T3 } & \multirow[t]{4}{*}{ Nitrito } & Com base em média & 4,754 & 1 & 18 & 043 \\
\hline & & Com base em mediana & 1,229 & 1 & 18 & ,282 \\
\hline & & $\begin{array}{l}\text { Com base em mediana e } \\
\text { com df ajustado }\end{array}$ & 1,229 & 1 & 12,571 & ,288 \\
\hline & & $\begin{array}{l}\text { Com base em média } \\
\text { aparada }\end{array}$ & 4,349 & 1 & 18 & 052 \\
\hline \multirow[t]{4}{*}{ T1_T2 } & \multirow[t]{4}{*}{ Nitrito } & Com base em média & ,345 & 1 & 18 &, 564 \\
\hline & & Com base em mediana & ,462 & 1 & 18 &, 505 \\
\hline & & $\begin{array}{l}\text { Com base em mediana e } \\
\text { com df ajustado }\end{array}$ & ,462 & 1 & 15,363 & ,507 \\
\hline & & $\begin{array}{l}\text { Com base em média } \\
\text { aparada }\end{array}$ & ,446 & 1 & 18 &, 513 \\
\hline \multirow[t]{4}{*}{ T2_T3 } & \multirow[t]{4}{*}{ Nitrito } & Com base em média & 3,385 & 1 & 18 & 082 \\
\hline & & Com base em mediana & 2,672 & 1 & 18 & 119 \\
\hline & & $\begin{array}{l}\text { Com base em mediana e } \\
\text { com df ajustado }\end{array}$ & 2,672 & 1 & 10,977 & 130 \\
\hline & & $\begin{array}{l}\text { Com base em média } \\
\text { aparada }\end{array}$ & 3,096 & 1 & 18 & ,095 \\
\hline
\end{tabular}


Testes de Normalidade

\begin{tabular}{|c|c|c|c|c|c|c|c|c|}
\hline \multirow[b]{2}{*}{ Tempo } & & \multirow[b]{2}{*}{ Lodo } & \multicolumn{3}{|c|}{ Kolmogorov-Smirnov ${ }^{a}$} & \multicolumn{3}{|c|}{ Shapiro-Wilk } \\
\hline & & & Estatística & $\mathrm{df}$ & Sig. & Estatística & $\mathrm{df}$ & Sig. \\
\hline \multirow[t]{2}{*}{ T0_T1 } & Nitrato & ChoA & ,265 & 10 &, 045 &, 831 & 10 &, 035 \\
\hline & & ChoB &, 227 & 10 & ,153 &, 803 & 10 & ,016 \\
\hline \multirow[t]{2}{*}{ T0_T2 } & Nitrato & ChoA & ,336 & 10 & ,002 &, 748 & 10 & ,003 \\
\hline & & ChoB & ,209 & 10 &, $200^{*}$ & ,882 & 10 & ,138 \\
\hline \multirow[t]{2}{*}{ T0_T3 } & Nitrato & ChoA & ,265 & 10 & ,045 & ,785 & 10 & ,010 \\
\hline & & ChoB & ,211 & 10 &, $200^{*}$ & ,849 & 10 & ,057 \\
\hline \multirow[t]{2}{*}{ T1_T2 } & Nitrato & ChoA & ,357 & 10 & ,001 &, 746 & 10 &, 003 \\
\hline & & ChoB & ,349 & 10 &, 001 &, 746 & 10 &, 003 \\
\hline \multirow[t]{2}{*}{ T2_T3 } & Nitrato & ChoA &, 234 & 10 &, 127 & ,827 & 10 &, 031 \\
\hline & & ChoB & ,253 & 10 &, 068 & ,797 & 10 & ,013 \\
\hline
\end{tabular}

*. Este é um limite inferior da significância verdadeira.

a. Correlação de Significância de Lilliefors

Teste de Homogeneidade de Variância

\begin{tabular}{|c|c|c|c|c|c|c|}
\hline Tempo & & & $\begin{array}{c}\text { Estatística de } \\
\text { Levene }\end{array}$ & df1 & df2 & Sig. \\
\hline \multirow[t]{4}{*}{ T0_T1 } & \multirow[t]{4}{*}{ Nitrato } & Com base em média & 2,896 & 1 & 18 & ,106 \\
\hline & & Com base em mediana & 1,279 & 1 & 18 & ,273 \\
\hline & & $\begin{array}{l}\text { Com base em mediana e } \\
\text { com df ajustado }\end{array}$ & 1,279 & 1 & 13,385 & ,278 \\
\hline & & $\begin{array}{l}\text { Com base em média } \\
\text { aparada }\end{array}$ & 2,594 & 1 & 18 & ,125 \\
\hline \multirow[t]{4}{*}{ T0_T2 } & \multirow[t]{4}{*}{ Nitrato } & Com base em média & ,884 & 1 & 18 & ,359 \\
\hline & & Com base em mediana & ,009 & 1 & 18 & ,927 \\
\hline & & $\begin{array}{l}\text { Com base em mediana e } \\
\text { com df ajustado }\end{array}$ & ,009 & 1 & 13,564 & ,927 \\
\hline & & $\begin{array}{l}\text { Com base em média } \\
\text { aparada }\end{array}$ & ,812 & 1 & 18 & ,380 \\
\hline \multirow[t]{4}{*}{ T0_T3 } & \multirow[t]{4}{*}{ Nitrato } & Com base em média & 069 & 1 & 18 & ,795 \\
\hline & & Com base em mediana & ,001 & 1 & 18 & ,972 \\
\hline & & $\begin{array}{l}\text { Com base em mediana e } \\
\text { com df ajustado }\end{array}$ & ,001 & 1 & 17,650 & ,972 \\
\hline & & $\begin{array}{l}\text { Com base em média } \\
\text { aparada }\end{array}$ & ,073 & 1 & 18 & ,790 \\
\hline \multirow[t]{4}{*}{ T1_T2 } & \multirow[t]{4}{*}{ Nitrato } & Com base em média & ,258 & 1 & 18 & 617 \\
\hline & & Com base em mediana & ,026 & 1 & 18 & 874 \\
\hline & & $\begin{array}{l}\text { Com base em mediana e } \\
\text { com df ajustado }\end{array}$ & ,026 & 1 & 17,999 & 874 \\
\hline & & $\begin{array}{l}\text { Com base em média } \\
\text { aparada }\end{array}$ & ,242 & 1 & 18 & ,629 \\
\hline \multirow[t]{4}{*}{ T2_T3 } & \multirow[t]{4}{*}{ Nitrato } & Com base em média & 2,672 & 1 & 18 & ,119 \\
\hline & & Com base em mediana & ,906 & 1 & 18 & ,354 \\
\hline & & $\begin{array}{l}\text { Com base em mediana e } \\
\text { com df ajustado }\end{array}$ & ,906 & 1 & 11,089 & ,361 \\
\hline & & $\begin{array}{l}\text { Com base em média } \\
\text { aparada }\end{array}$ & 2,398 & 1 & 18 & ,139 \\
\hline
\end{tabular}




\section{APENDICE V}

\section{VERIFICAÇÃO DOS SISTEMAS A E B PARA AVALIAÇÃO DA NORMALIDADE E HOMOGENEIDADE DAS AMOSTRAS COM RELAÇÃO ÀS VARIÁVEIS REDUÇÃO DE AMÔNIA, REDUÇÃO DE NITRITO E FORMAÇÃO DE NITRATO}

Duas premissas para uso de testes paramétrico é que as amostras coletadas para uma dada variável apresentem uma distribuição normal e tenham variâncias homogêneas. A discordância com apenas uma dessas premissas já invalida o uso de testes paramétricos.

Para testar se a distribuição dos dados se desvia de uma distribuição normal utilizou-se os testes de Kolmogorov-Smirnov (D) e de Shapiro-Wilk (D), que comparam escores de uma amostra a uma distribuição normal modelo de mesma média e variância dos valores encontrados na amostras. Devido ao pequeno número de amostras para cada condição testada ( $n=10)$, utilizou-se os resultados de conferência da distribuição da normal oferecida pelo teste de Shapiro-Wilk. Quando o teste é não significativo $(p>0,05)$, infere-se que os dados da amostra não diferem significativamente de uma distribuição normal. Por outro lado, quando o teste é significativo $(p<0,05)$ a distribuição em questão é significativamente diferente de uma distribuição normal. Exemplo de como relatar o resultados dos testes, sendo: D (10 que é o grau de liberdade) $=0,306$, $p<0,01$.

Para testar a homogeneidade das amostras entre os intervalos de tempos estudados, ou seja, verificar se as variâncias entre os intervalos T0_T1; T0_T2: T0_T3 (que são variáveis a serem comparadas) distorciam igualmente da média entre os intervalos para cada sistema utilizou-se o teste de Levene (F). Esse teste verifica a hipótese de que a variância nos grupos é a mesma (isto é, a diferença entre as variâncias é zero). Dessa forma, se o teste de Levene é significativo quando $p \leq 0,05$, conclui-se que a hipótese nula é incorreta e que as variâncias são significativamente diferentes. No entanto, se o teste de Levene é não significativo (isto é p>0,05), aceita-se a hipótese nula de que as diferenças entre as variâncias é zero, ou seja, as variâncias são estatisticamente iguais. Exemplo de como relatar o resultados dos testes, sendo: $F(2,27$ que são os dois graus de liberdade) $=0,655, p>0,05$ ou $n s$. 
Para testar se a distribuição dos dados se desvia de uma distribuição normal utilizou-se os testes de Kolmogorov-Smirnov e de Shapiro-Wilk, que comparam escores de uma amostra a uma distribuição normal modelo de mesma média e variância dos valores encontrados na amostras. Nessa primeira etapa da análise da normalidade considerou-se as amostras coletadas ao longo dos testes e intervalos de tempos como independentes. Uma vez que, para o objetivo de comparar se os sistemas A e B montados com cada tipo de inóculo representavam duplicatas, essa análise de normalidade se aplica.

Lembrando que para esses testes foram utilizados os dados brutos de redução de amônia e nitrito e acréscimo de nitrato em $\mathrm{mM}$, obtidas pela diferença entre os tempos de coleta de amostras dentro de cada batelada. Dessa maneira, como os intervalos de tempo se configuram como variáveis interferindo nas concentrações dos íons em análise, fez também uma avaliação da distribuição normal e homogeneidade entre as duplicatas considerando esse fator.

Numa segunda análise utilizou-se a comparação de normalidade e homogeneidade considerando-se o comportamento dos íons (amônia, nitrito, nitrato) obtidas para cada intervalo de tempo dado o início de cada bateladas, sendo eles (T0_T1 $\Leftrightarrow 0$ 24 horas; T1_T2 $\Leftrightarrow$ 24_48 horas; T1_T2 $\Leftrightarrow 0$ 048 horas; T2_T3 $\Leftrightarrow 48$ 72 horas; T0_T3 $\Leftrightarrow 0$ 0_72 horas), consistindo em 10 bateladas para cada sistema componente da duplicata ( $A$ e B). A homogeneidade foi avaliada usando a comparação da variância de um dado íon, se igual ou diferente entre os sistemas A e B, mas tendo a observância de analisar se a variância dentro de cada intervalo foram homogêneas ou heterogêneas para cada sistema componente da duplicata.

\section{Sistemas Par A e ParB}


Testes de Normalidade

\begin{tabular}{|lll|r|r|r|r|r|r|}
\hline & & & \multicolumn{3}{|c|}{ Kolmogorov-Smirnov $^{\text {a }}$} & \multicolumn{3}{|c|}{ Shapiro-Wilk } \\
\cline { 4 - 9 } Tempo & & Lodo & Estatística & df & \multicolumn{1}{c|}{ Sig. } & Estatística & \multicolumn{1}{c|}{ df } & \multicolumn{1}{c|}{ Sig. } \\
\hline T0_T1 & Amônia & ParA &, 253 & 10 &, 068 &, 818 & 10 &, 024 \\
& & ParB &, 292 & 10 &, 015 &, 744 & 10 &, 003 \\
\hline T0_T2 & Amônia & ParA &, 273 & 10 &, 033 &, 759 & 10 &, 005 \\
& & ParB &, 153 & 10 &, $200^{*}$ &, 940 & 10 &, 553 \\
\hline T0_T3 & Amônia & ParA &, 255 & 10 &, 064 &, 827 & 10 &, 031 \\
& & ParB &, 225 & 10 &, 166 &, 926 & 10 &, 408 \\
\hline T1_T2 & Amônia & ParA &, 311 & 10 &, 007 &, 798 & 10 &, 014 \\
& & ParB &, 200 & 10 &, $200^{*}$ &, 918 & 10 &, 338 \\
\hline T2_T3 & Amônia & ParA &, 314 & 10 &, 006 &, 682 & 10 &, 001 \\
& & ParB &, 386 & 10 &, 000 &, 684 & 10 &, 001 \\
\hline
\end{tabular}

*. Este é um limite inferior da significância verdadeira.

a. Correlação de Significância de Lilliefors

\section{Exemplo Relato dos Resultados para o par PaA e PaB:}

Para todos os intervalos de tempo, com exceção dos intervalos de tempo T0_T2; T0_T3;

T1_T2 de Am_ParB, diferiram significativamente da distribuição normal com $p<0,05$ pelo teste de Shapiro Wilk que é mais robusto para amostras pequenas $(n<50)$ do que o teste de Kolmogorov-Smirnov. Com relação a homogeneidade da variância 
Teste de Homogeneidade de Variância

\begin{tabular}{|c|c|c|c|c|c|c|}
\hline Tempo & & & $\begin{array}{l}\text { Estatística de } \\
\text { Levene }\end{array}$ & df1 & df2 & Sig. \\
\hline \multirow[t]{4}{*}{ T0_T1 } & \multirow[t]{4}{*}{ Amônia } & Com base em média & ,004 & 1 & 18 & ,948 \\
\hline & & Com base em mediana & 018 & 1 & 18 & ,896 \\
\hline & & $\begin{array}{l}\text { Com base em mediana e } \\
\text { com df ajustado }\end{array}$ & ,018 & 1 & 16,548 & ,896 \\
\hline & & $\begin{array}{l}\text { Com base em média } \\
\text { aparada }\end{array}$ & ,001 & 1 & 18 & ,970 \\
\hline \multirow[t]{4}{*}{ T0_T2 } & \multirow[t]{4}{*}{ Amônia } & Com base em média & 5,137 & 1 & 18 & ,036 \\
\hline & & Com base em mediana & ,889 & 1 & 18 & ,358 \\
\hline & & $\begin{array}{l}\text { Com base em mediana e } \\
\text { com df ajustado }\end{array}$ & ,889 & 1 & 13,860 & ,362 \\
\hline & & $\begin{array}{l}\text { Com base em média } \\
\text { aparada }\end{array}$ & 4,906 & 1 & 18 &, 040 \\
\hline \multirow[t]{4}{*}{ T0_T3 } & \multirow[t]{4}{*}{ Amônia } & Com base em média & 8,108 & 1 & 18 & 011 \\
\hline & & Com base em mediana & 2,345 & 1 & 18 & 143 \\
\hline & & $\begin{array}{l}\text { Com base em mediana e } \\
\text { com df ajustado }\end{array}$ & 2,345 & 1 & 15,162 & , 146 \\
\hline & & $\begin{array}{l}\text { Com base em média } \\
\text { aparada }\end{array}$ & 8,197 & 1 & 18 & 010 \\
\hline \multirow[t]{4}{*}{ T1_T2 } & \multirow[t]{4}{*}{ Amônia } & Com base em média & 2,365 & 1 & 18 & , 141 \\
\hline & & Com base em mediana & ,349 & 1 & 18 &, 562 \\
\hline & & $\begin{array}{l}\text { Com base em mediana e } \\
\text { com df ajustado }\end{array}$ & ,349 & 1 & 14,917 &, 564 \\
\hline & & $\begin{array}{l}\text { Com base em média } \\
\text { aparada }\end{array}$ & 2,177 & 1 & 18 & ,157 \\
\hline \multirow[t]{4}{*}{ T2_T3 } & \multirow[t]{4}{*}{ Amônia } & Com base em média & ,237 & 1 & 18 & ,632 \\
\hline & & Com base em mediana & 047 & 1 & 18 & 831 \\
\hline & & $\begin{array}{l}\text { Com base em mediana e } \\
\text { com df ajustado }\end{array}$ &, 047 & 1 & 17,919 & ,831 \\
\hline & & $\begin{array}{l}\text { Com base em média } \\
\text { aparada }\end{array}$ & , 175 & 1 & 18 & 680 \\
\hline
\end{tabular}

\section{Testes de Normalidade}

\begin{tabular}{|lll|r|r|r|r|r|r|}
\hline \multirow{2}{*}{ Tempo } & & \multicolumn{4}{|c|}{ Kolmogorov-Smirnov $^{\text {a }}$} & \multicolumn{3}{|c|}{ Shapiro-Wilk } \\
\cline { 4 - 9 } & & Lodo & Estatística & \multicolumn{1}{c|}{$\mathrm{df}$} & \multicolumn{1}{c|}{ Sig. } & Estatística & \multicolumn{1}{c|}{ df } & Sig. \\
\hline T0_T1 & Nitrito & ParA &, 309 & 10 &, 008 &, 745 & 10 &, 003 \\
& & ParB &, 273 & 10 &, 033 &, 844 & 10 &, 050 \\
\hline T0_T2 & Nitrito & ParA &, 214 & 10 &, $200^{*}$ &, 868 & 10 &, 094 \\
& & ParB &, 216 & 10 &, $200^{*}$ &, 895 & 10 &, 193 \\
\hline T0_T3 & Nitrito & ParA &, 328 & 10 &, 003 &, 758 & 10 &, 004 \\
& & ParB &, 309 & 10 &, 007 &, 808 & 10 &, 018 \\
\hline T1_T2 & Nitrito & ParA &, 252 & 10 &, 071 &, 856 & 10 &, 068 \\
& & ParB &, 222 & 10 &, 175 &, 832 & 10 &, 036 \\
\hline T2_T3 & Nitrito & ParA &, 206 & 10 &, $200^{*}$ &, 897 & 10 &, 205 \\
& & ParB &, 329 & 10 &, 003 &, 803 & 10 &, 016 \\
\hline
\end{tabular}

*. Este é um limite inferior da significância verdadeira.

a. Correlação de Significância de Lilliefors 
Teste de Homogeneidade de Variância

\begin{tabular}{|c|c|c|c|c|c|c|}
\hline Tempo & & & $\begin{array}{c}\text { Estatística de } \\
\text { Levene }\end{array}$ & df1 & df2 & Sig. \\
\hline \multirow[t]{4}{*}{ T0_T1 } & \multirow[t]{4}{*}{ Nitrito } & Com base em média & 1,020 & 1 & 18 & ,326 \\
\hline & & Com base em mediana & ,223 & 1 & 18 & ,643 \\
\hline & & $\begin{array}{l}\text { Com base em mediana e } \\
\text { com df ajustado }\end{array}$ & ,223 & 1 & 17,094 & ,643 \\
\hline & & $\begin{array}{l}\text { Com base em média } \\
\text { aparada }\end{array}$ & ,896 & 1 & 18 & ,356 \\
\hline \multirow[t]{4}{*}{ T0_T2 } & \multirow[t]{4}{*}{ Nitrito } & Com base em média & ,415 & 1 & 18 & ,528 \\
\hline & & Com base em mediana & ,497 & 1 & 18 & ,490 \\
\hline & & $\begin{array}{l}\text { Com base em mediana e } \\
\text { com df ajustado }\end{array}$ & ,497 & 1 & 17,472 & ,490 \\
\hline & & $\begin{array}{l}\text { Com base em média } \\
\text { aparada }\end{array}$ & ,420 & 1 & 18 &, 525 \\
\hline \multirow[t]{4}{*}{ T0_T3 } & \multirow[t]{4}{*}{ Nitrito } & Com base em média & 7,638 & 1 & 18 & 013 \\
\hline & & Com base em mediana & ,604 & 1 & 18 & ,447 \\
\hline & & $\begin{array}{l}\text { Com base em mediana e } \\
\text { com df ajustado }\end{array}$ & ,604 & 1 & 15,822 & ,449 \\
\hline & & $\begin{array}{l}\text { Com base em média } \\
\text { aparada }\end{array}$ & 6,864 & 1 & 18 & ,017 \\
\hline \multirow[t]{4}{*}{ T1_T2 } & \multirow[t]{4}{*}{ Nitrito } & Com base em média & 16,988 & 1 & 18 & 001 \\
\hline & & Com base em mediana & 4,743 & 1 & 18 & 043 \\
\hline & & $\begin{array}{l}\text { Com base em mediana e } \\
\text { com df ajustado }\end{array}$ & 4,743 & 1 & 11,776 & ,051 \\
\hline & & $\begin{array}{l}\text { Com base em média } \\
\text { aparada }\end{array}$ & 16,358 & 1 & 18 & 001 \\
\hline \multirow[t]{4}{*}{ T2_T3 } & \multirow[t]{4}{*}{ Nitrito } & Com base em média & 016 & 1 & 18 & 901 \\
\hline & & Com base em mediana &, 004 & 1 & 18 & ,951 \\
\hline & & $\begin{array}{l}\text { Com base em mediana e } \\
\text { com df ajustado }\end{array}$ & ,004 & 1 & 16,151 & ,951 \\
\hline & & $\begin{array}{l}\text { Com base em média } \\
\text { aparada }\end{array}$ & ,002 & 1 & 18 & ,965 \\
\hline
\end{tabular}

Testes de Normalidade

\begin{tabular}{|lll|r|r|r|r|r|r|}
\hline & & & \multicolumn{3}{|c|}{ Kolmogorov-Smirnov $^{2}$} & \multicolumn{3}{|c|}{ Shapiro-Wilk } \\
\cline { 5 - 9 } Tempo & & Lodo & Estatís tica & \multicolumn{1}{c|}{ df } & \multicolumn{1}{c|}{ Sig. } & Estatística & \multicolumn{1}{c|}{ df } & \multicolumn{1}{c|}{ Sig. } \\
\hline T0_T1 & Nitrato & ParA &, 297 & 10 &, 013 &, 743 & 10 &, 003 \\
& & ParB &, 408 & 10 &, 000 &, 654 & 10 &, 000 \\
\hline T0_T2 & Nitrato & ParA &, 272 & 10 &, 034 &, 802 & 10 &, 015 \\
& & ParB &, 281 & 10 &, 024 &, 760 & 10 &, 005 \\
\hline T0_T3 & Nitrato & ParA &, 253 & 10 &, 070 &, 816 & 10 &, 023 \\
& & ParB &, 222 & 10 &, 177 &, 858 & 10 &, 072 \\
\hline T1_T2 & Nitrato & ParA &, 205 & 10 &, 200 &, 849 & 10 &, 056 \\
& & ParB &, 274 & 10 &, 032 &, 834 & 10 &, 037 \\
\hline T2_T3 & Nitrato & ParA &, 333 & 10 &, 002 &, 760 & 10 &, 005 \\
& & ParB &, 307 & 10 &, 008 &, 817 & 10 &, 023 \\
\hline
\end{tabular}

*. Este é um limite inferior da significância verdadeira.

a. Correlação de Significância de Lilliefors 
Teste de Homogeneidade de Variância

\begin{tabular}{|c|c|c|c|c|c|c|}
\hline Tempo & & & $\begin{array}{l}\text { Estatística de } \\
\text { Levene }\end{array}$ & df1 & df2 & Sig. \\
\hline \multirow[t]{4}{*}{ T0_T1 } & \multirow[t]{4}{*}{ Nitrato } & Com base em média & 684 & 1 & 18 & ,419 \\
\hline & & Com base em mediana & 082 & 1 & 18 & ,778 \\
\hline & & $\begin{array}{l}\text { Com base em mediana e } \\
\text { com df ajustado }\end{array}$ & ,082 & 1 & 16,751 & ,779 \\
\hline & & $\begin{array}{l}\text { Com base em média } \\
\text { aparada }\end{array}$ & ,425 & 1 & 18 &, 523 \\
\hline \multirow[t]{4}{*}{ T0_T2 } & \multirow[t]{4}{*}{ Nitrato } & Com base em média & ,485 & 1 & 18 & ,495 \\
\hline & & Com base em mediana & ,171 & 1 & 18 & ,684 \\
\hline & & $\begin{array}{l}\text { Com base em mediana e } \\
\text { com df ajustado }\end{array}$ & ,171 & 1 & 17,673 & 684 \\
\hline & & $\begin{array}{l}\text { Com base em média } \\
\text { aparada }\end{array}$ & ,458 & 1 & 18 & ,507 \\
\hline \multirow[t]{4}{*}{ T0_T3 } & \multirow[t]{4}{*}{ Nitrato } & Com base em média & 1,368 & 1 & 18 & ,257 \\
\hline & & Com base em mediana & ,288 & 1 & 18 & ,598 \\
\hline & & $\begin{array}{l}\text { Com base em mediana e } \\
\text { com df ajustado }\end{array}$ & ,288 & 1 & 16,085 & ,599 \\
\hline & & $\begin{array}{l}\text { Com base em média } \\
\text { aparada }\end{array}$ & 1,357 & 1 & 18 & ,259 \\
\hline \multirow[t]{4}{*}{ T1_T2 } & \multirow[t]{4}{*}{ Nitrato } & Com base em média & 10,026 & 1 & 18 & ,005 \\
\hline & & Com base em mediana & 4,643 & 1 & 18 & ,045 \\
\hline & & $\begin{array}{l}\text { Com base em mediana e } \\
\text { com df ajustado }\end{array}$ & 4,643 & 1 & 12,315 & ,052 \\
\hline & & $\begin{array}{l}\text { Com base em média } \\
\text { aparada }\end{array}$ & 9,200 & 1 & 18 & ,007 \\
\hline \multirow[t]{4}{*}{ T2_T3 } & \multirow[t]{4}{*}{ Nitrato } & Com base em média & ,365 & 1 & 18 & ,553 \\
\hline & & Com base em mediana & ,095 & 1 & 18 & ,761 \\
\hline & & $\begin{array}{l}\text { Com base em mediana e } \\
\text { com df ajustado }\end{array}$ & ,095 & 1 & 17,975 & ,761 \\
\hline & & $\begin{array}{l}\text { Com base em média } \\
\text { aparada }\end{array}$ & ,341 & 1 & 18 & ,567 \\
\hline
\end{tabular}


SISTEMA AnF1A e AnF1B

Testes de Normalidade

\begin{tabular}{|c|c|c|c|c|c|c|c|c|}
\hline \multirow[b]{2}{*}{ Tempo } & & \multirow[b]{2}{*}{ Lodo } & \multicolumn{3}{|c|}{ Kolmogorov-Smirnov ${ }^{a}$} & \multicolumn{3}{|c|}{ Shapiro-Wilk } \\
\hline & & & Estatística & df & Sig. & Estatística & df & Sig. \\
\hline \multirow[t]{2}{*}{ T0_T1 } & Amônia & AnF1A & ,209 & 10 &, $200^{*}$ & 869 & 10 & ,097 \\
\hline & & AnF1B &, 189 & 10 &, $200^{*}$ & ,873 & 10 & ,108 \\
\hline \multirow[t]{2}{*}{ T0_T2 } & Amônia & $A n F 1 A$ &, 105 & 10 &, $200^{*}$ &, 967 & 10 & ,857 \\
\hline & & AnF1B &, 230 & 10 &, 143 &, 827 & 10 &, 031 \\
\hline \multirow[t]{2}{*}{ T0_T3 } & Amônia & $A n F 1 A$ & ,209 & 10 &, $200^{*}$ &, 902 & 10 & ,228 \\
\hline & & AnF1B & ,274 & 10 & ,032 & ,827 & 10 & ,031 \\
\hline \multirow[t]{2}{*}{ T1_T2 } & Amônia & $A n F 1 A$ & ,205 & 10 &, $200^{*}$ & ,890 & 10 & , 170 \\
\hline & & AnF1B & ,236 & 10 & ,121 & ,861 & 10 &, 078 \\
\hline \multirow[t]{2}{*}{ T2_T3 } & Amônia & $\mathrm{AnF} 1 \mathrm{~A}$ & ,317 & 10 & ,005 & ,826 & 10 & ,030 \\
\hline & & AnF1B & , 170 & 10 &, $200^{*}$ & ,878 & 10 & ,122 \\
\hline
\end{tabular}

*. Este é um limite inferior da significância verdadeira.

a. Correlação de Significância de Lilliefors

Teste de Homogeneidade de Variância

\begin{tabular}{|c|c|c|c|c|c|c|}
\hline Tempo & & & $\begin{array}{c}\text { Estatística de } \\
\text { Levene }\end{array}$ & df1 & $\mathrm{df2}$ & Sig. \\
\hline \multirow[t]{4}{*}{ T0_T1 } & \multirow[t]{4}{*}{ Amônia } & Com base em média & 1,899 & 1 & 18 & , 185 \\
\hline & & Com base em mediana & 1,894 & 1 & 18 & , 186 \\
\hline & & $\begin{array}{l}\text { Com base em mediana e } \\
\text { com df ajustado }\end{array}$ & 1,894 & 1 & 17,923 & ,186 \\
\hline & & $\begin{array}{l}\text { Com base em média } \\
\text { aparada }\end{array}$ & 1,895 & 1 & 18 & ,186 \\
\hline \multirow[t]{4}{*}{ T0_T2 } & \multirow[t]{4}{*}{ Amônia } & Com base em média & ,609 & 1 & 18 & ,445 \\
\hline & & Com base em mediana & , 162 & 1 & 18 & ,692 \\
\hline & & $\begin{array}{l}\text { Com base em mediana e } \\
\text { com df ajustado }\end{array}$ & ,162 & 1 & 17,944 & ,692 \\
\hline & & $\begin{array}{l}\text { Com base em média } \\
\text { aparada }\end{array}$ &, 583 & 1 & 18 & ,455 \\
\hline \multirow[t]{4}{*}{ T0_T3 } & \multirow[t]{4}{*}{ Amônia } & Com base em média &, 005 & 1 & 18 & ,943 \\
\hline & & Com base em mediana & ,091 & 1 & 18 & ,766 \\
\hline & & $\begin{array}{l}\text { Com base em mediana e } \\
\text { com df ajustado }\end{array}$ & ,091 & 1 & 17,509 & ,766 \\
\hline & & $\begin{array}{l}\text { Com base em média } \\
\text { aparada }\end{array}$ & ,005 & 1 & 18 & ,942 \\
\hline \multirow[t]{4}{*}{ T1_T2 } & \multirow[t]{4}{*}{ Amônia } & Com base em média &, 584 & 1 & 18 & ,455 \\
\hline & & Com base em mediana & ,308 & 1 & 18 & ,586 \\
\hline & & $\begin{array}{l}\text { Com base em mediana e } \\
\text { com df ajustado }\end{array}$ & ,308 & 1 & 17,923 & ,586 \\
\hline & & $\begin{array}{l}\text { Com base em média } \\
\text { aparada }\end{array}$ & ,638 & 1 & 18 & ,435 \\
\hline \multirow[t]{4}{*}{ T2_T3 } & \multirow[t]{4}{*}{ Amônia } & Com base em média & 26,735 & 1 & 18 &, 000 \\
\hline & & Com base em mediana & 3,815 & 1 & 18 &, 067 \\
\hline & & $\begin{array}{l}\text { Com base em mediana e } \\
\text { com df ajustado }\end{array}$ & 3,815 & 1 & 10,277 & ,079 \\
\hline & & $\begin{array}{l}\text { Com base em média } \\
\text { aparada }\end{array}$ & 24,459 & 1 & 18 &, 000 \\
\hline
\end{tabular}


Testes de Normalidade

\begin{tabular}{|c|c|c|c|c|c|c|c|c|}
\hline \multirow[b]{2}{*}{ Tempo } & & \multirow[b]{2}{*}{ Lodo } & \multicolumn{3}{|c|}{ Kolmogorov-Smirnov ${ }^{a}$} & \multicolumn{3}{|c|}{ Shapiro-Wilk } \\
\hline & & & Estatística & df & Sig. & Estatística & $\mathrm{df}$ & Sig. \\
\hline \multirow[t]{2}{*}{ T0_T1 } & Nitrito & $\mathrm{AnF} 1 \mathrm{~A}$ & ,359 & 10 & ,001 & ,735 & 10 & ,002 \\
\hline & & AnF1B & ,299 & 10 & ,012 &, 740 & 10 & ,003 \\
\hline \multirow[t]{2}{*}{ T0_T2 } & Nitrito & $A n F 1 A$ & , 163 & 10 & $200^{*}$ & ,909 & 10 & ,276 \\
\hline & & AnF1B & ,312 & 10 &, 007 & ,787 & 10 & 010 \\
\hline \multirow[t]{2}{*}{ T0_T3 } & Nitrito & $\mathrm{AnF} 1 \mathrm{~A}$ & ,297 & 10 & ,012 & ,804 & 10 & 016 \\
\hline & & AnF1B & ,234 & 10 &, 129 & ,867 & 10 & 092 \\
\hline \multirow[t]{2}{*}{ T1_T2 } & Nitrito & AnF1A & ,353 & 10 & ,001 & ,743 & 10 &, 003 \\
\hline & & AnF1B & ,378 & 10 &, 000 & ,679 & 10 &, 000 \\
\hline \multirow[t]{2}{*}{ T2_T3 } & Nitrito & $\mathrm{AnF} 1 \mathrm{~A}$ & ,253 & 10 & ,068 & ,813 & 10 & 021 \\
\hline & & AnF1B & ,245 & 10 & ,090 & ,823 & 10 & ,028 \\
\hline
\end{tabular}

*. Este é um limite inferior da significância verdadeira.

a. Correlação de Significância de Lilliefors

Teste de Homogeneidade de Variância

\begin{tabular}{|c|c|c|c|c|c|c|}
\hline Tempo & & & $\begin{array}{l}\text { Estatística de } \\
\text { Levene }\end{array}$ & df1 & $\mathrm{df2}$ & Sig. \\
\hline \multirow[t]{4}{*}{ T0_T1 } & \multirow[t]{4}{*}{ Nitrito } & Com base em média & ,119 & 1 & 18 & ,734 \\
\hline & & Com base em mediana & 014 & 1 & 18 & ,908 \\
\hline & & $\begin{array}{l}\text { Com base em mediana e } \\
\text { com df ajustado }\end{array}$ & 014 & 1 & 17,936 & ,908 \\
\hline & & $\begin{array}{l}\text { Com base em média } \\
\text { aparada }\end{array}$ &, 128 & 1 & 18 &, 725 \\
\hline \multirow[t]{4}{*}{ T0_T2 } & \multirow[t]{4}{*}{ Nitrito } & Com base em média & 1,852 & 1 & 18 & 190 \\
\hline & & Com base em mediana & ,243 & 1 & 18 & ,628 \\
\hline & & $\begin{array}{l}\text { Com base em mediana e } \\
\text { com df ajustado }\end{array}$ & ,243 & 1 & 12,337 & ,630 \\
\hline & & $\begin{array}{l}\text { Com base em média } \\
\text { aparada }\end{array}$ & 1,626 & 1 & 18 & ,219 \\
\hline \multirow[t]{4}{*}{ T0_T3 } & \multirow[t]{4}{*}{ Nitrito } & Com base em média & 5,703 & 1 & 18 & 028 \\
\hline & & Com base em mediana & 3,984 & 1 & 18 & 061 \\
\hline & & $\begin{array}{l}\text { Com base em mediana e } \\
\text { com df ajustado }\end{array}$ & 3,984 & 1 & 17,962 & 061 \\
\hline & & $\begin{array}{l}\text { Com base em média } \\
\text { aparada }\end{array}$ & 5,860 & 1 & 18 & ,026 \\
\hline \multirow[t]{4}{*}{ T1_T2 } & \multirow[t]{4}{*}{ Nitrito } & Com base em média & 11,889 & 1 & 18 & ,003 \\
\hline & & Com base em mediana & 1,839 & 1 & 18 & ,192 \\
\hline & & $\begin{array}{l}\text { Com base em mediana e } \\
\text { com df ajustado }\end{array}$ & 1,839 & 1 & 12,256 & , 199 \\
\hline & & $\begin{array}{l}\text { Com base em média } \\
\text { aparada }\end{array}$ & 10,668 & 1 & 18 & ,004 \\
\hline \multirow[t]{4}{*}{ T2_T3 } & \multirow[t]{4}{*}{ Nitrito } & Com base em média & ,002 & 1 & 18 & ,969 \\
\hline & & Com base em mediana & ,008 & 1 & 18 & ,931 \\
\hline & & $\begin{array}{l}\text { Com base em mediana e } \\
\text { com df ajustado }\end{array}$ & ,008 & 1 & 17,971 & ,931 \\
\hline & & $\begin{array}{l}\text { Com base em média } \\
\text { aparada }\end{array}$ & ,002 & 1 & 18 & ,963 \\
\hline
\end{tabular}


Testes de Normalidade

\begin{tabular}{|c|c|c|c|c|c|c|c|c|}
\hline \multirow[b]{2}{*}{ Tempo } & & \multirow[b]{2}{*}{ Lodo } & \multicolumn{3}{|c|}{ Kolmogorov-Smirnov ${ }^{a}$} & \multicolumn{3}{|c|}{ Shapiro-Wilk } \\
\hline & & & Estatística & $\mathrm{df}$ & Sig. & Estatística & df & Sig. \\
\hline \multirow[t]{2}{*}{ T0_T1 } & Nitrato & AnF1A & ,337 & 10 &, 002 & ,749 & 10 &, 003 \\
\hline & & AnF1B & ,430 & 10 & ,000 &, 563 & 10 & ,000 \\
\hline \multirow[t]{2}{*}{ T0_T2 } & Nitrato & $A n F 1 A$ & 241 & 10 & ,105 & ,806 & 10 & 017 \\
\hline & & AnF1B & ,418 & 10 & ,000 &, 573 & 10 & ,000 \\
\hline \multirow[t]{2}{*}{ T0_T3 } & Nitrato & $A n F 1 A$ & ,311 & 10 & ,007 & ,735 & 10 & ,002 \\
\hline & & AnF1B & ,262 & 10 & ,051 & ,771 & 10 & ,006 \\
\hline \multirow[t]{2}{*}{ T1_T2 } & Nitrato & $A n F 1 A$ & ,205 & 10 & ,200* &, 860 & 10 & 076 \\
\hline & & AnF1B & ,303 & 10 & ,010 & ,742 & 10 & ,003 \\
\hline \multirow[t]{2}{*}{ T2_T3 } & Nitrato & $A n F 1 A$ & ,409 & 10 & ,000 & 624 & 10 & ,000 \\
\hline & & AnF1B & ,383 & 10 & ,000 & ,665 & 10 & ,000 \\
\hline
\end{tabular}

*. Este é um limite inferior da significância verdadeira.

a. Correlação de Significância de Lilliefors

Teste de Homogeneidade de Variância

\begin{tabular}{|c|c|c|c|c|c|c|}
\hline Tempo & & & $\begin{array}{c}\text { Estatística de } \\
\text { Levene }\end{array}$ & df1 & df2 & Sig. \\
\hline \multirow[t]{4}{*}{ T0_T1 } & \multirow[t]{4}{*}{ Nitrato } & Com base em média &, 664 & 1 & 18 & ,426 \\
\hline & & Com base em mediana & ,433 & 1 & 18 & ,519 \\
\hline & & $\begin{array}{l}\text { Com base em mediana e } \\
\text { com df ajustado }\end{array}$ & ,433 & 1 & 17,717 & ,519 \\
\hline & & $\begin{array}{l}\text { Com base em média } \\
\text { aparada }\end{array}$ & 846 & 1 & 18 & ,370 \\
\hline \multirow[t]{4}{*}{ T0_T2 } & \multirow[t]{4}{*}{ Nitrato } & Com base em média &, 007 & 1 & 18 & ,932 \\
\hline & & Com base em mediana & , 175 & 1 & 18 & ,681 \\
\hline & & $\begin{array}{l}\text { Com base em mediana e } \\
\text { com df ajustado }\end{array}$ & , 175 & 1 & 13,462 & ,682 \\
\hline & & $\begin{array}{l}\text { Com base em média } \\
\text { aparada }\end{array}$ &, 011 & 1 & 18 & ,916 \\
\hline \multirow[t]{4}{*}{ T0_T3 } & \multirow[t]{4}{*}{ Nitrato } & Com base em média &, 047 & 1 & 18 & ,831 \\
\hline & & Com base em mediana & ,005 & 1 & 18 & ,947 \\
\hline & & $\begin{array}{l}\text { Com base em mediana e } \\
\text { com df ajustado }\end{array}$ & ,005 & 1 & 17,808 & ,947 \\
\hline & & $\begin{array}{l}\text { Com base em média } \\
\text { aparada }\end{array}$ & 061 & 1 & 18 & ,808 \\
\hline \multirow[t]{4}{*}{ T1_T2 } & \multirow[t]{4}{*}{ Nitrato } & Com base em média & 6,716 & 1 & 18 & 018 \\
\hline & & Com base em mediana & 6,585 & 1 & 18 & ,019 \\
\hline & & $\begin{array}{l}\text { Com base em mediana e } \\
\text { com df ajustado }\end{array}$ & 6,585 & 1 & 12,242 & ,024 \\
\hline & & $\begin{array}{l}\text { Com base em média } \\
\text { aparada }\end{array}$ & 6,522 & 1 & 18 & ,020 \\
\hline \multirow[t]{4}{*}{ T2_T3 } & \multirow[t]{4}{*}{ Nitrato } & Com base em média & ,695 & 1 & 18 & ,415 \\
\hline & & Com base em mediana & 141 & 1 & 18 & ,711 \\
\hline & & $\begin{array}{l}\text { Com base em mediana e } \\
\text { com df ajustado }\end{array}$ & ,141 & 1 & 16,592 & ,712 \\
\hline & & $\begin{array}{l}\text { Com base em média } \\
\text { aparada }\end{array}$ & ,505 & 1 & 18 & ,486 \\
\hline
\end{tabular}




\section{Sistemas FaF1A e FaF1B}

Testes de Normalidade

\begin{tabular}{|lll|r|r|r|r|r|r|}
\hline & & & \multicolumn{3}{|c|}{ Kolmogorov-Smirnov $^{\text {a }}$} & \multicolumn{3}{|c|}{ Shapiro-Wilk } \\
\cline { 5 - 9 } Tempo & & Lodo & Estatística & \multicolumn{1}{c|}{ df } & \multicolumn{1}{c|}{ Sig. } & Estatística & \multicolumn{1}{c|}{ df } & Sig. \\
\hline T0_T1 & Amônia & FaF1A &, 183 & 10 &, $200^{*}$ &, 914 & 10 &, 311 \\
& & FaF1B &, 210 & 10 &, $200^{*}$ &, 864 & 10 &, 084 \\
\hline T0_T2 & Amônia & FaF1A &, 176 & 10 &, $200^{*}$ &, 925 & 10 &, 404 \\
& & FaF1B &, 202 & 10 &, $200^{*}$ &, 876 & 10 &, 117 \\
\hline T0_T3 & Amônia & FaF1A &, 208 & 10 &, $200^{*}$ &, 862 & 10 &, 080 \\
& & FaF1B &, 211 & 10 &, $200^{*}$ &, 866 & 10 &, 090 \\
\hline T1_T2 & Amônia & FaF1A &, 241 & 10 &, 103 &, 839 & 10 &, 043 \\
& & FaF1B &, 193 & 10 &, $200^{*}$ &, 873 & 10 &, 109 \\
\hline T2_T3 & Amônia & FaF1A &, 145 & 10 &, $200^{*}$ &, 928 & 10 &, 432 \\
& & FaF1B &, 168 & 10 &, $200^{*}$ &, 938 & 10 &, 531 \\
\hline
\end{tabular}

*. Este é um limite inferior da significância verdadeira.

a. Correlação de Significância de Lilliefors

Teste de Homogeneidade de Variância

\begin{tabular}{|c|c|c|c|c|c|c|}
\hline Tempo & & & $\begin{array}{c}\text { Estatística de } \\
\text { Levene }\end{array}$ & df1 & $\mathrm{df2}$ & Sig. \\
\hline \multirow[t]{4}{*}{ T0_T1 } & \multirow[t]{4}{*}{ Amônia } & Com base em média &, 713 & 1 & 18 & ,410 \\
\hline & & Com base em mediana & ,456 & 1 & 18 & ,508 \\
\hline & & $\begin{array}{l}\text { Com base em mediana e } \\
\text { com df ajustado }\end{array}$ & ,456 & 1 & 17,699 & ,508 \\
\hline & & $\begin{array}{l}\text { Com base em média } \\
\text { aparada }\end{array}$ &, 703 & 1 & 18 & ,413 \\
\hline \multirow[t]{4}{*}{ T0_T2 } & \multirow[t]{4}{*}{ Amônia } & Com base em média & ,064 & 1 & 18 & 804 \\
\hline & & Com base em mediana & ,035 & 1 & 18 & ,854 \\
\hline & & $\begin{array}{l}\text { Com base em mediana e } \\
\text { com df ajustado }\end{array}$ & ,035 & 1 & 14,602 & ,855 \\
\hline & & $\begin{array}{l}\text { Com base em média } \\
\text { aparada }\end{array}$ & ,068 & 1 & 18 & ,797 \\
\hline \multirow[t]{4}{*}{ T0_T3 } & \multirow[t]{4}{*}{ Amônia } & Com base em média & ,512 & 1 & 18 & ,483 \\
\hline & & Com base em mediana & 230 & 1 & 18 & 637 \\
\hline & & $\begin{array}{l}\text { Com base em mediana e } \\
\text { com df ajustado }\end{array}$ & ,230 & 1 & 12,404 & ,640 \\
\hline & & $\begin{array}{l}\text { Com base em média } \\
\text { aparada }\end{array}$ & ,445 & 1 & 18 &, 513 \\
\hline \multirow[t]{4}{*}{ T1_T2 } & \multirow[t]{4}{*}{ Amônia } & Com base em média & ,300 & 1 & 18 & ,591 \\
\hline & & Com base em mediana & ,029 & 1 & 18 & ,866 \\
\hline & & $\begin{array}{l}\text { Com base em mediana e } \\
\text { com df ajustado }\end{array}$ & ,029 & 1 & 17,970 & ,866 \\
\hline & & $\begin{array}{l}\text { Com base em média } \\
\text { aparada }\end{array}$ & ,274 & 1 & 18 & 607 \\
\hline \multirow[t]{4}{*}{ T2_T3 } & \multirow[t]{4}{*}{ Amônia } & Com base em média & 6,819 & 1 & 18 & 018 \\
\hline & & Com base em mediana & 5,572 & 1 & 18 & 030 \\
\hline & & $\begin{array}{l}\text { Com base em mediana e } \\
\text { com df ajustado }\end{array}$ & 5,572 & 1 & 13,337 & 034 \\
\hline & & $\begin{array}{l}\text { Com base em média } \\
\text { aparada }\end{array}$ & 6,675 & 1 & 18 & ,019 \\
\hline
\end{tabular}


Testes de Normalidade

\begin{tabular}{|lll|r|r|r|r|r|r|}
\hline & & & \multicolumn{3}{|c|}{ Kolmogorov-Smirnov $^{\text {a }}$} & \multicolumn{3}{|c|}{ Shapiro-Wilk } \\
\cline { 5 - 9 } Tempo & & Lodo & Estatística & \multicolumn{1}{c|}{$\mathrm{df}$} & \multicolumn{1}{c|}{ Sig. } & Estatística & \multicolumn{1}{c|}{ df } & \multicolumn{1}{c|}{ Sig. } \\
\hline T0_T1 & Nitrito & FaF1A &, 314 & 10 &, 006 &, 758 & 10 &, 005 \\
& & FaF1B &, 246 & 10 &, 086 &, 870 & 10 &, 100 \\
\hline T0_T2 & \multirow{2}{*}{ Nitrito } & FaF1A &, 234 & 10 &, 128 &, 860 & 10 &, 077 \\
& & FaF1B &, 296 & 10 &, 013 &, 769 & 10 &, 006 \\
\hline T0_T3 & \multirow{2}{*}{ Nitrito } & FaF1A &, 310 & 10 &, 007 &, 729 & 10 &, 002 \\
& & FaF1B &, 340 & 10 &, 002 &, 665 & 10 &, 000 \\
\hline T1_T2 & Nitrito & FaF1A &, 247 & 10 &, 084 &, 833 & 10 &, 037 \\
& & FaF1B &, 297 & 10 &, 012 &, 770 & 10 &, 006 \\
\hline T2_T3 & Nitrito & FaF1A &, 208 & 10 &, $200^{*}$ &, 817 & 10 &, 023 \\
& & FaF1B &, 207 & 10 &, $200^{*}$ &, 876 & 10 &, 116 \\
\hline
\end{tabular}

*. Este é um limite inferior da significância verdadeira.

a. Correlação de Significância de Lilliefors

Teste de Homogeneidade de Variância

\begin{tabular}{|c|c|c|c|c|c|c|}
\hline Tempo & & & $\begin{array}{l}\text { Estatística de } \\
\text { Levene }\end{array}$ & df1 & df2 & Sig. \\
\hline \multirow[t]{4}{*}{ T0_T1 } & \multirow[t]{4}{*}{ Nitrito } & Com base em média & 4,959 & 1 & 18 &, 039 \\
\hline & & Com base em mediana & 1,151 & 1 & 18 & ,297 \\
\hline & & $\begin{array}{l}\text { Com base em mediana e } \\
\text { com df ajustado }\end{array}$ & 1,151 & 1 & 11,036 & ,306 \\
\hline & & $\begin{array}{l}\text { Com base em média } \\
\text { aparada }\end{array}$ & 4,453 & 1 & 18 & ,049 \\
\hline \multirow[t]{4}{*}{ T0_T2 } & \multirow[t]{4}{*}{ Nitrito } & Com base em média &, 513 & 1 & 18 & ,483 \\
\hline & & Com base em mediana & ,474 & 1 & 18 &, 500 \\
\hline & & $\begin{array}{l}\text { Com base em mediana e } \\
\text { com df ajustado }\end{array}$ & ,474 & 1 & 17,040 &, 500 \\
\hline & & $\begin{array}{l}\text { Com base em média } \\
\text { aparada }\end{array}$ & ,594 & 1 & 18 & ,451 \\
\hline \multirow[t]{4}{*}{ T0_T3 } & \multirow[t]{4}{*}{ Nitrito } & Com base em média & 035 & 1 & 18 & ,853 \\
\hline & & Com base em mediana &, 000 & 1 & 18 & 983 \\
\hline & & $\begin{array}{l}\text { Com base em mediana e } \\
\text { com df ajustado }\end{array}$ &, 000 & 1 & 17,515 & ,983 \\
\hline & & $\begin{array}{l}\text { Com base em média } \\
\text { aparada }\end{array}$ & ,014 & 1 & 18 & ,908 \\
\hline \multirow[t]{4}{*}{ T1_T2 } & \multirow[t]{4}{*}{ Nitrito } & Com base em média & 1,459 & 1 & 18 & ,243 \\
\hline & & Com base em mediana & ,334 & 1 & 18 &, 570 \\
\hline & & $\begin{array}{l}\text { Com base em mediana e } \\
\text { com df ajustado }\end{array}$ & ,334 & 1 & 15,317 &, 572 \\
\hline & & $\begin{array}{l}\text { Com base em média } \\
\text { aparada }\end{array}$ & 1,300 & 1 & 18 & ,269 \\
\hline \multirow[t]{4}{*}{ T2_T3 } & \multirow[t]{4}{*}{ Nitrito } & Com base em média & 9,350 & 1 & 18 & ,007 \\
\hline & & Com base em mediana & 6,666 & 1 & 18 & 019 \\
\hline & & $\begin{array}{l}\text { Com base em mediana e } \\
\text { com df ajustado }\end{array}$ & 6,666 & 1 & 9,877 & ,028 \\
\hline & & $\begin{array}{l}\text { Com base em média } \\
\text { aparada }\end{array}$ & 8,654 & 1 & 18 & ,009 \\
\hline
\end{tabular}


Testes de Normalidade

\begin{tabular}{|c|c|c|c|c|c|c|c|c|}
\hline \multirow[b]{2}{*}{ Tempo } & & \multirow[b]{2}{*}{ Lodo } & \multicolumn{3}{|c|}{ Kolmogorov-Smirnov $^{a}$} & \multicolumn{3}{|c|}{ Shapiro-Wilk } \\
\hline & & & Estatística & df & Sig. & Estatística & df & Sig. \\
\hline \multirow[t]{2}{*}{ T0_T1 } & Nitrato & FaF1A & ,422 & 10 &, 000 &, 573 & 10 & ,000 \\
\hline & & FaF1B & ,216 & 10 & $200^{*}$ & ,852 & 10 &, 062 \\
\hline \multirow[t]{2}{*}{ T0_T2 } & Nitrato & FaF1A & ,346 & 10 & ,001 & 639 & 10 & ,000 \\
\hline & & FaF1B & ,289 & 10 &, 017 & ,793 & 10 & ,012 \\
\hline \multirow[t]{2}{*}{ T0_T3 } & Nitrato & FaF1A & ,243 & 10 & ,096 & ,808 & 10 & ,018 \\
\hline & & FaF1B & ,308 & 10 &, 008 & ,725 & 10 & ,002 \\
\hline \multirow[t]{2}{*}{ T1_T2 } & Nitrato & FaF1A & ,422 & 10 &, 000 & 621 & 10 &, 000 \\
\hline & & FaF1B &, 357 & 10 &, 001 & ,705 & 10 & ,001 \\
\hline \multirow[t]{2}{*}{ T2_T3 } & Nitrato & FaF1A & ,436 & 10 &, 000 & ,578 & 10 & ,000 \\
\hline & & FaF1B &, 312 & 10 & ,007 & 673 & 10 & ,000 \\
\hline
\end{tabular}

*. Este é um limite inferior da significância verdadeira.

a. Correlação de Significância de Lilliefors

Teste de Homogeneidade de Variância

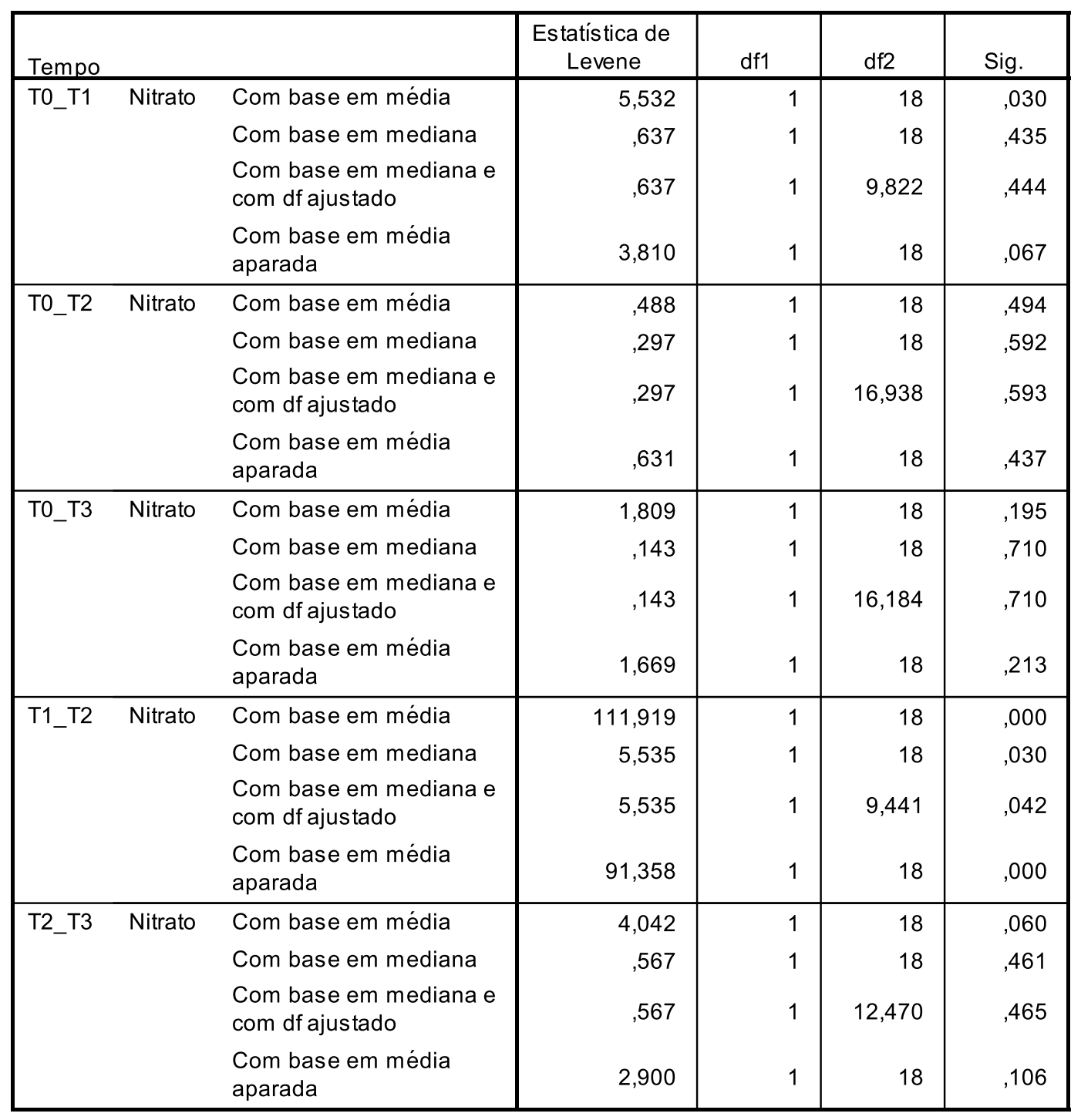




\section{Sistema FaF2A e FaF2B}

Testes de Normalidade

\begin{tabular}{|lll|r|r|r|r|r|r|}
\hline & & & \multicolumn{2}{|c|}{ Kolmogorov-Smirnov $^{2}$} & \multicolumn{3}{|c|}{ Shapiro-Wilk } \\
\cline { 5 - 9 } Tempo & & Lodo & Estatística & df & Sig. & Estatística & \multicolumn{1}{c|}{ df } & Sig. \\
\hline T0_T1 & Amônia & FaF2A &, 208 & 10 &, $200^{*}$ &, 875 & 10 &, 113 \\
& & FaF2B &, 181 & 10 &, $200^{*}$ &, 902 & 10 &, 229 \\
\hline T0_T2 & Amônia & FaF2A &, 290 & 10 &, 017 &, 773 & 10 &, 007 \\
& & FaF2B &, 234 & 10 &, 130 &, 876 & 10 &, 117 \\
\hline T0_T3 & Amônia & FaF2A &, 199 & 10 &, $200^{*}$ &, 882 & 10 &, 139 \\
& & FaF2B &, 168 & 10 &, $200^{*}$ &, 903 & 10 &, 235 \\
\hline T1_T2 & Amônia & FaF2A &, 252 & 10 &, 071 &, 886 & 10 &, 153 \\
& & FaF2B &, 203 & 10 &, $200^{*}$ &, 868 & 10 &, 094 \\
\hline T2_T3 & Amônia & FaF2A &, 207 & 10 &, $200^{*}$ &, 846 & 10 &, 052 \\
& & FaF2B &, 339 & 10 &, 002 &, 707 & 10 &, 001 \\
\hline
\end{tabular}

*. Este é um limite inferior da significância verdadeira.

a. Correlação de Significância de Lilliefors

Teste de Homogeneidade de Variância

\begin{tabular}{|c|c|c|c|c|c|c|}
\hline Tempo & & & $\begin{array}{c}\text { Estatística de } \\
\text { Levene }\end{array}$ & df1 & df2 & Sig. \\
\hline \multirow[t]{4}{*}{ T0_T1 } & \multirow[t]{4}{*}{ Amônia } & Com base em média & 2,653 & 1 & 18 & ,121 \\
\hline & & Com base em mediana & 2,671 & 1 & 18 & 120 \\
\hline & & $\begin{array}{l}\text { Com base em mediana e } \\
\text { com df ajustado }\end{array}$ & 2,671 & 1 & 11,324 & ,130 \\
\hline & & $\begin{array}{l}\text { Com base em média } \\
\text { aparada }\end{array}$ & 2,658 & 1 & 18 & 120 \\
\hline \multirow[t]{4}{*}{ T0_T2 } & \multirow[t]{4}{*}{ Amônia } & Com base em média & 1,839 & 1 & 18 & ,192 \\
\hline & & Com base em mediana &, 156 & 1 & 18 & 697 \\
\hline & & $\begin{array}{l}\text { Com base em mediana e } \\
\text { com df ajustado }\end{array}$ & ,156 & 1 & 14,276 & ,698 \\
\hline & & $\begin{array}{l}\text { Com base em média } \\
\text { aparada }\end{array}$ & 1,703 & 1 & 18 & ,208 \\
\hline \multirow[t]{4}{*}{ T0_T3 } & \multirow[t]{4}{*}{ Amônia } & Com base em média &, 753 & 1 & 18 & ,397 \\
\hline & & Com base em mediana & ,458 & 1 & 18 &, 507 \\
\hline & & $\begin{array}{l}\text { Com base em mediana e } \\
\text { com df ajustado }\end{array}$ &, 458 & 1 & 14,780 & ,509 \\
\hline & & $\begin{array}{l}\text { Com base em média } \\
\text { aparada }\end{array}$ & ,696 & 1 & 18 & ,415 \\
\hline \multirow[t]{4}{*}{ T1_T2 } & \multirow[t]{4}{*}{ Amônia } & Com base em média & 4,616 & 1 & 18 & ,046 \\
\hline & & Com base em mediana & 2,375 & 1 & 18 & 141 \\
\hline & & $\begin{array}{l}\text { Com base em mediana e } \\
\text { com df ajustado }\end{array}$ & 2,375 & 1 & 17,024 & ,142 \\
\hline & & $\begin{array}{l}\text { Com base em média } \\
\text { aparada }\end{array}$ & 4,357 & 1 & 18 & 051 \\
\hline \multirow[t]{4}{*}{ T2_T3 } & \multirow[t]{4}{*}{ Amônia } & Com base em média & 1,248 & 1 & 18 & ,279 \\
\hline & & Com base em mediana & ,326 & 1 & 18 & ,575 \\
\hline & & $\begin{array}{l}\text { Com base em mediana e } \\
\text { com df ajustado }\end{array}$ & ,326 & 1 & 12,824 &, 578 \\
\hline & & $\begin{array}{l}\text { Com base em média } \\
\text { aparada }\end{array}$ & ,823 & 1 & 18 & ,376 \\
\hline
\end{tabular}


Testes de Normalidade

\begin{tabular}{|c|c|c|c|c|c|c|c|c|}
\hline \multirow[b]{2}{*}{ Tempo } & & \multirow[b]{2}{*}{ Lodo } & \multicolumn{3}{|c|}{ Kolmogorov-Smirnov ${ }^{a}$} & \multicolumn{3}{|c|}{ Shapiro-Wilk } \\
\hline & & & Estatística & $\mathrm{df}$ & Sig. & Estatística & $\mathrm{df}$ & Sig. \\
\hline \multirow[t]{2}{*}{ T0_T1 } & Nitrito & FaF2A & ,217 & 10 & $200^{*}$ &, 850 & 10 & ,058 \\
\hline & & FaF2B & ,263 & 10 & ,049 &, 777 & 10 & ,008 \\
\hline \multirow[t]{2}{*}{ T0_T2 } & Nitrito & FaF2A & ,192 & 10 &, $200^{*}$ & ,872 & 10 & ,105 \\
\hline & & FaF2B & ,219 & 10 & , 190 & ,903 & 10 & ,234 \\
\hline \multirow[t]{2}{*}{ T0_T3 } & Nitrito & FaF2A &, 250 & 10 & ,076 & ,828 & 10 & ,032 \\
\hline & & FaF2B & ,304 & 10 & ,009 & ,782 & 10 & ,009 \\
\hline \multirow[t]{2}{*}{ T1_T2 } & Nitrito & FaF2A & ,211 & 10 &, $200^{*}$ & ,887 & 10 & ,156 \\
\hline & & FaF2B & ,283 & 10 &, 023 & ,846 & 10 &, 052 \\
\hline \multirow[t]{2}{*}{ T2_T3 } & Nitrito & FaF2A & ,262 & 10 &, 050 &, 847 & 10 &, 054 \\
\hline & & FaF2B & ,172 & 10 &, $200^{*}$ & ,912 & 10 & ,292 \\
\hline
\end{tabular}

*. Este é um limite inferior da significância verdadeira.

a. Correlação de Significância de Lilliefors

Teste de Homogeneidade de Variância

\begin{tabular}{|c|c|c|c|c|c|c|}
\hline Tempo & & & $\begin{array}{c}\text { Estatística de } \\
\text { Levene }\end{array}$ & df1 & $\mathrm{df2}$ & Sig. \\
\hline \multirow[t]{4}{*}{ T0_T1 } & \multirow[t]{4}{*}{ Nitrito } & Com base em média & 12,016 & 1 & 18 &, 003 \\
\hline & & Com base em mediana & 6,629 & 1 & 18 & 019 \\
\hline & & $\begin{array}{l}\text { Com base em mediana e } \\
\text { com df ajustado }\end{array}$ & 6,629 & 1 & 14,031 & ,022 \\
\hline & & $\begin{array}{l}\text { Com base em média } \\
\text { aparada }\end{array}$ & 11,737 & 1 & 18 & ,003 \\
\hline \multirow[t]{4}{*}{ T0_T2 } & \multirow[t]{4}{*}{ Nitrito } & Com base em média & 3,175 & 1 & 18 & 092 \\
\hline & & Com base em mediana & 1,890 & 1 & 18 & , 186 \\
\hline & & $\begin{array}{l}\text { Com base em mediana e } \\
\text { com df ajustado }\end{array}$ & 1,890 & 1 & 17,730 & ,186 \\
\hline & & $\begin{array}{l}\text { Com base em média } \\
\text { aparada }\end{array}$ & 3,077 & 1 & 18 & ,096 \\
\hline \multirow[t]{4}{*}{ T0_T3 } & \multirow[t]{4}{*}{ Nitrito } & Com base em média & 8,228 & 1 & 18 & 010 \\
\hline & & Com base em mediana & 2,157 & 1 & 18 & ,159 \\
\hline & & $\begin{array}{l}\text { Com base em mediana e } \\
\text { com df ajustado }\end{array}$ & 2,157 & 1 & 17,243 & , 160 \\
\hline & & $\begin{array}{l}\text { Com base em média } \\
\text { aparada }\end{array}$ & 7,767 & 1 & 18 & 012 \\
\hline \multirow[t]{4}{*}{ T1_T2 } & \multirow[t]{4}{*}{ Nitrito } & Com base em média &, 034 & 1 & 18 & 855 \\
\hline & & Com base em mediana &, 008 & 1 & 18 & 928 \\
\hline & & $\begin{array}{l}\text { Com base em mediana e } \\
\text { com df ajustado }\end{array}$ & ,008 & 1 & 15,863 & ,928 \\
\hline & & $\begin{array}{l}\text { Com base em média } \\
\text { aparada }\end{array}$ & ,034 & 1 & 18 & ,856 \\
\hline \multirow[t]{4}{*}{ T2_T3 } & \multirow[t]{4}{*}{ Nitrito } & Com base em média & ,589 & 1 & 18 & ,453 \\
\hline & & Com base em mediana & ,735 & 1 & 18 & ,402 \\
\hline & & $\begin{array}{l}\text { Com base em mediana e } \\
\text { com df ajustado }\end{array}$ & ,735 & 1 & 17,053 & ,403 \\
\hline & & $\begin{array}{l}\text { Com base em média } \\
\text { aparada }\end{array}$ &, 555 & 1 & 18 & ,466 \\
\hline
\end{tabular}


Testes de Normalidade

\begin{tabular}{|lll|r|r|r|r|r|r|}
\hline & & & \multicolumn{3}{|c|}{ Kolmogorov-Smirnov $^{\text {a }}$} & \multicolumn{3}{|c|}{ Shapiro-Wilk } \\
\cline { 5 - 9 } Tempo & & Lodo & Estatística & \multicolumn{1}{c|}{$\mathrm{df}$} & \multicolumn{1}{c|}{ Sig. } & Estatística & \multicolumn{1}{c|}{ df } & Sig. \\
\hline T0_T1 & Nitrato & FaF2A &, 438 & 10 &, 000 &, 571 & 10 &, 000 \\
& & FaF2B &, 368 & 10 &, 000 &, 722 & 10 &, 002 \\
\hline T0_T2 & Nitrato & FaF2A &, 431 & 10 &, 000 &, 625 & 10 &, 000 \\
& & FaF2B &, 327 & 10 &, 003 &, 709 & 10 &, 001 \\
\hline T0_T3 & Nitrato & FaF2A &, 381 & 10 &, 000 &, 666 & 10 &, 000 \\
& & FaF2B &, 298 & 10 &, 012 &, 762 & 10 &, 005 \\
\hline T1_T2 & Nitrato & FaF2A &, 390 & 10 &, 000 &, 705 & 10 &, 001 \\
& & FaF2B &, 300 & 10 &, 011 &, 793 & 10 &, 012 \\
\hline T2_T3 & Nitrato & FaF2A &, 301 & 10 &, 011 &, 762 & 10 &, 005 \\
& & FaF2B &, 357 & 10 &, 001 &, 756 & 10 &, 004 \\
\hline
\end{tabular}

a. Correlação de Significância de Lilliefors

Teste de Homogeneidade de Variância

\begin{tabular}{|c|c|c|c|c|c|c|}
\hline Tempo & & & $\begin{array}{l}\text { Estatística de } \\
\text { Levene }\end{array}$ & df1 & df2 & Sig. \\
\hline \multirow[t]{4}{*}{ T0_T1 } & \multirow[t]{4}{*}{ Nitrato } & Com base em média & 1,012 & 1 & 18 & ,328 \\
\hline & & Com base em mediana & 081 & 1 & 18 & ,779 \\
\hline & & $\begin{array}{l}\text { Com base em mediana e } \\
\text { com df ajustado }\end{array}$ & ,081 & 1 & 15,231 & ,779 \\
\hline & & $\begin{array}{l}\text { Com base em média } \\
\text { aparada }\end{array}$ & ,699 & 1 & 18 & ,414 \\
\hline \multirow[t]{4}{*}{ T0_T2 } & \multirow[t]{4}{*}{ Nitrato } & Com base em média & , 105 & 1 & 18 & ,749 \\
\hline & & Com base em mediana & ,005 & 1 & 18 & ,943 \\
\hline & & $\begin{array}{l}\text { Com base em mediana e } \\
\text { com df ajustado }\end{array}$ &, 005 & 1 & 17,566 & ,943 \\
\hline & & $\begin{array}{l}\text { Com base em média } \\
\text { aparada }\end{array}$ &, 077 & 1 & 18 & ,785 \\
\hline \multirow[t]{4}{*}{ T0_T3 } & \multirow[t]{4}{*}{ Nitrato } & Com base em média & 5,381 & 1 & 18 & ,032 \\
\hline & & Com base em mediana & 1,539 & 1 & 18 & ,231 \\
\hline & & $\begin{array}{l}\text { Com base em mediana e } \\
\text { com df ajustado }\end{array}$ & 1,539 & 1 & 17,439 & ,231 \\
\hline & & $\begin{array}{l}\text { Com base em média } \\
\text { aparada }\end{array}$ & 5,339 & 1 & 18 & ,033 \\
\hline \multirow[t]{4}{*}{ T1_T2 } & \multirow[t]{4}{*}{ Nitrato } & Com base em média & ,045 & 1 & 18 & 834 \\
\hline & & Com base em mediana & ,265 & 1 & 18 & ,613 \\
\hline & & $\begin{array}{l}\text { Com base em mediana e } \\
\text { com df ajustado }\end{array}$ & ,265 & 1 & 17,938 & ,613 \\
\hline & & $\begin{array}{l}\text { Com base em média } \\
\text { aparada }\end{array}$ & ,072 & 1 & 18 & ,792 \\
\hline \multirow[t]{4}{*}{ T2_T3 } & \multirow[t]{4}{*}{ Nitrato } & Com base em média & 4,395 & 1 & 18 & ,050 \\
\hline & & Com base em mediana & 1,653 & 1 & 18 & ,215 \\
\hline & & $\begin{array}{l}\text { Com base em mediana e } \\
\text { com df ajustado }\end{array}$ & 1,653 & 1 & 11,207 & ,224 \\
\hline & & $\begin{array}{l}\text { Com base em média } \\
\text { aparada }\end{array}$ & 3,587 & 1 & 18 & ,074 \\
\hline
\end{tabular}




\section{Sistema par UaF2A e UaF2B}

Testes de Normalidade

\begin{tabular}{|c|c|c|c|c|c|c|c|c|}
\hline \multirow[b]{2}{*}{ Tempo } & & \multirow[b]{2}{*}{ Lodo } & \multicolumn{3}{|c|}{ Kolmogorov-Smirnov ${ }^{a}$} & \multicolumn{3}{|c|}{ Shapiro-Wilk } \\
\hline & & & Estatística & df & Sig. & Estatística & $d f$ & Sig. \\
\hline \multirow[t]{2}{*}{ T0_T1 } & Amônia & UaF2B & , 198 & 10 & $200^{*}$ & ,855 & 10 & ,066 \\
\hline & & UaF2A & ,273 & 10 &, 033 & ,778 & 10 & ,008 \\
\hline \multirow[t]{2}{*}{ T0_T2 } & Amônia & UaF2B & ,234 & 10 & ,129 & ,866 & 10 & 089 \\
\hline & & UaF2A & ,296 & 10 & 013 & 811 & 10 & ,020 \\
\hline \multirow[t]{2}{*}{ T0_T3 } & Amônia & UaF2B & ,241 & 10 & 103 & ,856 & 10 & ,068 \\
\hline & & UaF2A & ,291 & 10 & ,016 & ,793 & 10 & 012 \\
\hline \multirow[t]{2}{*}{ T1_T2 } & Amônia & UaF2B & ,218 & 10 & ,196 & ,862 & 10 & 081 \\
\hline & & UaF2A & ,320 & 10 & ,005 & ,646 & 10 & ,000 \\
\hline \multirow[t]{2}{*}{ T2_T3 } & Amônia & UaF2B & ,244 & 10 & ,093 & ,877 & 10 & ,121 \\
\hline & & UaF2A & ,258 & 10 & ,058 & ,854 & 10 &, 065 \\
\hline
\end{tabular}

*. Este é um limite inferior da significância verdadeira.

a. Correlação de Significância de Lilliefors

Teste de Homogeneidade de Variância

\begin{tabular}{|c|c|c|c|c|c|c|}
\hline Tempo & & & $\begin{array}{c}\text { Estatística de } \\
\text { Levene }\end{array}$ & df1 & $\mathrm{df} 2$ & Sig. \\
\hline \multirow[t]{4}{*}{ T0_T1 } & \multirow[t]{4}{*}{ Amônia } & Com base em média & 1,049 & 1 & 18 & ,319 \\
\hline & & Com base em mediana & ,626 & 1 & 18 & ,439 \\
\hline & & $\begin{array}{l}\text { Com base em mediana e } \\
\text { com df ajustado }\end{array}$ & ,626 & 1 & 16,421 & ,440 \\
\hline & & $\begin{array}{l}\text { Com base em média } \\
\text { aparada }\end{array}$ & 1,055 & 1 & 18 & ,318 \\
\hline \multirow[t]{4}{*}{ T0_T2 } & \multirow[t]{4}{*}{ Amônia } & Com base em média & 219 & 1 & 18 & ,645 \\
\hline & & Com base em mediana & ,007 & 1 & 18 & ,933 \\
\hline & & $\begin{array}{l}\text { Com base em mediana e } \\
\text { com df ajustado }\end{array}$ &, 007 & 1 & 15,820 & ,933 \\
\hline & & $\begin{array}{l}\text { Com base em média } \\
\text { aparada }\end{array}$ & ,162 & 1 & 18 & ,692 \\
\hline \multirow[t]{4}{*}{ T0_T3 } & \multirow[t]{4}{*}{ Amônia } & Com base em média & 1,675 & 1 & 18 & ,212 \\
\hline & & Com base em mediana & 144 & 1 & 18 & ,708 \\
\hline & & $\begin{array}{l}\text { Com base em mediana e } \\
\text { com df ajustado }\end{array}$ & 144 & 1 & 13,670 & ,710 \\
\hline & & $\begin{array}{l}\text { Com base em média } \\
\text { aparada }\end{array}$ & 1,478 & 1 & 18 & ,240 \\
\hline \multirow[t]{4}{*}{ T1_T2 } & \multirow[t]{4}{*}{ Amônia } & Com base em média & ,956 & 1 & 18 & ,341 \\
\hline & & Com base em mediana & 081 & 1 & 18 & ,779 \\
\hline & & $\begin{array}{l}\text { Com base em mediana e } \\
\text { com df ajustado }\end{array}$ &, 081 & 1 & 11,210 & ,781 \\
\hline & & $\begin{array}{l}\text { Com base em média } \\
\text { aparada }\end{array}$ & ,591 & 1 & 18 & ,452 \\
\hline \multirow[t]{4}{*}{ T2_T3 } & \multirow[t]{4}{*}{ Amônia } & Com base em média & ,040 & 1 & 18 & 843 \\
\hline & & Com base em mediana &, 000 & 1 & 18 & ,984 \\
\hline & & $\begin{array}{l}\text { Com base em mediana e } \\
\text { com df ajustado }\end{array}$ &, 000 & 1 & 17,580 & ,984 \\
\hline & & $\begin{array}{l}\text { Com base em média } \\
\text { aparada }\end{array}$ & 047 & 1 & 18 & 831 \\
\hline
\end{tabular}


Testes de Normalidade

\begin{tabular}{|lll|r|r|r|r|r|r|}
\hline \multirow{2}{*}{ Tempo } & & \multicolumn{4}{|c|}{ Kolmogorov-Smirnov $^{\text {a }}$} & \multicolumn{3}{|c|}{ Shapiro-Wilk } \\
\cline { 4 - 9 } & & Lodo & Estatística & \multicolumn{1}{c|}{$\mathrm{df}$} & \multicolumn{1}{c|}{ Sig. } & Estatística & \multicolumn{1}{c|}{ df } & Sig. \\
\hline T0_T1 & \multirow{2}{*}{ Nitrito } & UaF2B &, 343 & 10 &, 002 &, 775 & 10 &, 007 \\
& & UaF2A &, 316 & 10 &, 005 &, 682 & 10 &, 001 \\
\hline T0_T2 & Nitrito & UaF2B &, 317 & 10 &, 005 &, 725 & 10 &, 002 \\
& & UaF2A &, 372 & 10 &, 000 &, 696 & 10 &, 001 \\
\hline T0_T3 & \multirow{2}{*}{ Nitrito } & UaF2B &, 361 & 10 &, 001 &, 734 & 10 &, 002 \\
& & UaF2A &, 332 & 10 &, 003 &, 786 & 10 &, 010 \\
\hline T1_T2 & \multirow{2}{*}{ Nitrito } & UaF2B &, 219 & 10 &, 191 &, 824 & 10 &, 028 \\
& & UaF2A &, 364 & 10 &, 001 &, 729 & 10 &, 002 \\
\hline T2_T3 & Nitrito & UaF2B &, 189 & 10 &, 200 &, 897 & 10 &, 201 \\
& & UaF2A &, 269 & 10 &, 038 &, 806 & 10 &, 017 \\
\hline
\end{tabular}

*. Este é um limite inferior da significância verdadeira.

a. Correlação de Significância de Lilliefors

Teste de Homogeneidade de Variância

\begin{tabular}{|c|c|c|c|c|c|c|}
\hline Tempo & & & $\begin{array}{l}\text { Estatística de } \\
\text { Levene }\end{array}$ & df1 & df2 & Sig. \\
\hline \multirow[t]{4}{*}{ T0_T1 } & \multirow[t]{4}{*}{ Nitrito } & Com base em média & ,330 & 1 & 18 &, 573 \\
\hline & & Com base em mediana & 073 & 1 & 18 & ,790 \\
\hline & & $\begin{array}{l}\text { Com base em mediana e } \\
\text { com df ajustado }\end{array}$ & ,073 & 1 & 17,905 & ,790 \\
\hline & & $\begin{array}{l}\text { Com base em média } \\
\text { aparada }\end{array}$ & ,333 & 1 & 18 &, 571 \\
\hline \multirow[t]{4}{*}{ T0_T2 } & \multirow[t]{4}{*}{ Nitrito } & Com base em média & 5,542 & 1 & 18 & 030 \\
\hline & & Com base em mediana & ,175 & 1 & 18 & 681 \\
\hline & & $\begin{array}{l}\text { Com base em mediana e } \\
\text { com df ajustado }\end{array}$ & , 175 & 1 & 15,223 & ,682 \\
\hline & & $\begin{array}{l}\text { Com base em média } \\
\text { aparada }\end{array}$ & 4,456 & 1 & 18 & ,049 \\
\hline \multirow[t]{4}{*}{ T0_T3 } & \multirow[t]{4}{*}{ Nitrito } & Com base em média & 4,318 & 1 & 18 & 052 \\
\hline & & Com base em mediana & ,618 & 1 & 18 & ,442 \\
\hline & & $\begin{array}{l}\text { Com base em mediana e } \\
\text { com df ajustado }\end{array}$ & ,618 & 1 & 15,977 & ,443 \\
\hline & & $\begin{array}{l}\text { Com base em média } \\
\text { aparada }\end{array}$ & 3,802 & 1 & 18 & ,067 \\
\hline \multirow[t]{4}{*}{ T1_T2 } & \multirow[t]{4}{*}{ Nitrito } & Com base em média & 9,737 & 1 & 18 & 006 \\
\hline & & Com base em mediana & 1,031 & 1 & 18 & ,323 \\
\hline & & $\begin{array}{l}\text { Com base em mediana e } \\
\text { com df ajustado }\end{array}$ & 1,031 & 1 & 11,512 & ,331 \\
\hline & & $\begin{array}{l}\text { Com base em média } \\
\text { aparada }\end{array}$ & 8,524 & 1 & 18 & ,009 \\
\hline \multirow[t]{4}{*}{ T2_T3 } & \multirow[t]{4}{*}{ Nitrito } & Com base em média & , 186 & 1 & 18 & 671 \\
\hline & & Com base em mediana & ,267 & 1 & 18 & ,612 \\
\hline & & $\begin{array}{l}\text { Com base em mediana e } \\
\text { com df ajustado }\end{array}$ & ,267 & 1 & 17,101 & ,612 \\
\hline & & $\begin{array}{l}\text { Com base em média } \\
\text { aparada }\end{array}$ & , 179 & 1 & 18 & ,678 \\
\hline
\end{tabular}


Testes de Normalidade

\begin{tabular}{|c|c|c|c|c|c|c|c|c|}
\hline \multirow[b]{2}{*}{ Tempo } & & \multirow[b]{2}{*}{ Lodo } & \multicolumn{3}{|c|}{ Kolmogorov-Smirnov $^{a}$} & \multicolumn{3}{|c|}{ Shapiro-Wilk } \\
\hline & & & Estatística & $\mathrm{df}$ & Sig. & Estatística & df & Sig. \\
\hline \multirow[t]{2}{*}{ T0_T1 } & Nitrato & UaF2B & ,356 & 10 &, 001 & ,702 & 10 & ,001 \\
\hline & & UaF2A & ,325 & 10 & ,004 & ,794 & 10 & ,012 \\
\hline \multirow[t]{2}{*}{ T0_T2 } & Nitrato & UaF2B &, 210 & 10 &, $200^{*}$ & ,891 & 10 & , 172 \\
\hline & & UaF2A & ,408 & 10 & ,000 & ,642 & 10 & ,000 \\
\hline \multirow[t]{2}{*}{ T0_T3 } & Nitrato & UaF2B & ,334 & 10 & ,002 & ,714 & 10 & ,001 \\
\hline & & UaF2A & ,354 & 10 & ,001 & ,693 & 10 & ,001 \\
\hline \multirow[t]{2}{*}{ T1_T2 } & Nitrato & UaF2B & ,284 & 10 & ,022 & ,860 & 10 & ,076 \\
\hline & & UaF2A & ,386 & 10 & ,000 & ,665 & 10 & ,000 \\
\hline \multirow[t]{2}{*}{ T2_T3 } & Nitrato & UaF2B & 315 & 10 & ,006 & ,833 & 10 & ,037 \\
\hline & & UaF2A & ,161 & 10 &, $200^{*}$ & ,882 & 10 & ,138 \\
\hline
\end{tabular}

*. Este é um limite inferior da significância verdadeira.

a. Correlação de Significância de Lilliefors

Teste de Homogeneidade de Variância

\begin{tabular}{|c|c|c|c|c|c|c|}
\hline Tempo & & & $\begin{array}{c}\text { Estatística de } \\
\text { Levene }\end{array}$ & $\mathrm{df1}$ & df2 & Sig. \\
\hline \multirow[t]{4}{*}{ T0_T1 } & \multirow[t]{4}{*}{ Nitrato } & Com base em média & 30,192 & 1 & 18 & 000 \\
\hline & & Com base em mediana & 2,870 & 1 & 18 & 108 \\
\hline & & $\begin{array}{l}\text { Com base em mediana e } \\
\text { com df ajustado }\end{array}$ & 2,870 & 1 & 11,831 & ,116 \\
\hline & & $\begin{array}{l}\text { Com base em média } \\
\text { aparada }\end{array}$ & 26,450 & 1 & 18 &, 000 \\
\hline \multirow[t]{4}{*}{ T0_T2 } & \multirow[t]{4}{*}{ Nitrato } & Com base em média & 2,826 & 1 & 18 & 110 \\
\hline & & Com base em mediana & 2,113 & 1 & 18 & 163 \\
\hline & & $\begin{array}{l}\text { Com base em mediana e } \\
\text { com df ajustado }\end{array}$ & 2,113 & 1 & 17,477 & ,164 \\
\hline & & $\begin{array}{l}\text { Com base em média } \\
\text { aparada }\end{array}$ & 2,896 & 1 & 18 & 106 \\
\hline \multirow[t]{4}{*}{ T0_T3 } & \multirow[t]{4}{*}{ Nitrato } & Com base em média & 56,767 & 1 & 18 &, 000 \\
\hline & & Com base em mediana & 4,728 & 1 & 18 &, 043 \\
\hline & & $\begin{array}{l}\text { Com base em mediana e } \\
\text { com df ajustado }\end{array}$ & 4,728 & 1 & 10,747 & ,053 \\
\hline & & $\begin{array}{l}\text { Com base em média } \\
\text { aparada }\end{array}$ & 48,891 & 1 & 18 & ,000 \\
\hline \multirow[t]{4}{*}{ T1_T2 } & \multirow[t]{4}{*}{ Nitrato } & Com base em média &, 063 & 1 & 18 & ,804 \\
\hline & & Com base em mediana &, 042 & 1 & 18 & 839 \\
\hline & & $\begin{array}{l}\text { Com base em mediana e } \\
\text { com df ajustado }\end{array}$ &, 042 & 1 & 17,289 & ,839 \\
\hline & & $\begin{array}{l}\text { Com base em média } \\
\text { aparada }\end{array}$ & ,016 & 1 & 18 & 899 \\
\hline \multirow[t]{4}{*}{ T2_T3 } & \multirow[t]{4}{*}{ Nitrato } & Com base em média & 36,981 & 1 & 18 &, 000 \\
\hline & & Com base em mediana & 6,280 & 1 & 18 & ,022 \\
\hline & & $\begin{array}{l}\text { Com base em mediana e } \\
\text { com df ajustado }\end{array}$ & 6,280 & 1 & 9,108 & ,033 \\
\hline & & $\begin{array}{l}\text { Com base em média } \\
\text { aparada }\end{array}$ & 33,959 & 1 & 18 &, 000 \\
\hline
\end{tabular}




\section{Sistemas par ChoA e ChoB}

Testes de Normalidade

\begin{tabular}{|lll|r|r|r|r|r|r|}
\hline & & & \multicolumn{3}{|c|}{ Kolmogorov-Smirnov $^{\text {a }}$} & \multicolumn{3}{|c|}{ Shapiro-Wilk } \\
\cline { 4 - 9 } Tempo & & Lodo & Estatística & \multicolumn{1}{c|}{$\mathrm{df}$} & \multicolumn{1}{c|}{ Sig. } & Estatística & \multicolumn{1}{c|}{$\mathrm{df}$} & \multicolumn{1}{c|}{ Sig. } \\
\hline T0_T1 & Amônia & ChoA &, 266 & 10 &, 043 &, 860 & 10 &, 076 \\
& & ChoB &, 282 & 10 &, 024 &, 841 & 10 &, 046 \\
\hline T0_T2 & Amônia & ChoA &, 205 & 10 &, $200^{*}$ &, 903 & 10 &, 238 \\
& & ChoB &, 213 & 10 &, $200^{*}$ &, 875 & 10 &, 115 \\
\hline T0_T3 & Amônia & ChoA &, 224 & 10 &, 169 &, 823 & 10 &, 027 \\
& & ChoB &, 262 & 10 &, 051 &, 810 & 10 &, 019 \\
\hline T1_T2 & Amônia & ChoA &, 279 & 10 &, 027 &, 816 & 10 &, 022 \\
& & ChoB &, 168 & 10 &, $200^{*}$ &, 900 & 10 &, 217 \\
\hline T2_T3 & Amônia & ChoA &, 207 & 10 &, $200^{*}$ &, 872 & 10 &, 105 \\
& & ChoB &, 211 & 10 &, $200^{*}$ &, 853 & 10 &, 064 \\
\hline
\end{tabular}

*. Este é um limite inferior da significância verdadeira.

a. Correlação de Significância de Lilliefors

Teste de Homogeneidade de Variância

\begin{tabular}{|c|c|c|c|c|c|c|}
\hline Tempo & & & $\begin{array}{c}\text { Estatística de } \\
\text { Levene }\end{array}$ & df1 & df2 & Sig. \\
\hline \multirow[t]{4}{*}{ T0_T1 } & Amônia & Com base em média & 1,658 & 1 & 18 & ,214 \\
\hline & & Com base em mediana & ,397 & 1 & 18 &, 536 \\
\hline & & $\begin{array}{l}\text { Com base em mediana e } \\
\text { com df ajustado }\end{array}$ & ,397 & 1 & 17,809 & ,537 \\
\hline & & $\begin{array}{l}\text { Com base em média } \\
\text { aparada }\end{array}$ & 1,662 & 1 & 18 & ,214 \\
\hline \multirow[t]{4}{*}{ T0_T2 } & Amônia & Com base em média & 2,744 & 1 & 18 & , 115 \\
\hline & & Com base em mediana & 1,516 & 1 & 18 & 234 \\
\hline & & $\begin{array}{l}\text { Com base em mediana e } \\
\text { com df ajustado }\end{array}$ & 1,516 & 1 & 10,944 & 244 \\
\hline & & $\begin{array}{l}\text { Com base em média } \\
\text { aparada }\end{array}$ & 2,580 & 1 & 18 & ,126 \\
\hline \multirow[t]{4}{*}{ T0_T3 } & Amônia & Com base em média & 807 & 1 & 18 & ,381 \\
\hline & & Com base em mediana & 182 & 1 & 18 & 675 \\
\hline & & $\begin{array}{l}\text { Com base em mediana e } \\
\text { com df ajustado }\end{array}$ & 182 & 1 & 13,044 & 676 \\
\hline & & $\begin{array}{l}\text { Com base em média } \\
\text { aparada }\end{array}$ & ,695 & 1 & 18 & ,415 \\
\hline \multirow[t]{4}{*}{ T1_T2 } & Amônia & Com base em média & 9,725 & 1 & 18 &, 006 \\
\hline & & Com base em mediana & 9,172 & 1 & 18 & ,007 \\
\hline & & $\begin{array}{l}\text { Com base em mediana e } \\
\text { com df ajustado }\end{array}$ & 9,172 & 1 & 10,817 & 012 \\
\hline & & $\begin{array}{l}\text { Com base em média } \\
\text { aparada }\end{array}$ & 9,445 & 1 & 18 & ,007 \\
\hline \multirow[t]{4}{*}{ T2_T3 } & Amônia & Com base em média & , 183 & 1 & 18 & 674 \\
\hline & & Com base em mediana & ,306 & 1 & 18 & ,587 \\
\hline & & $\begin{array}{l}\text { Com base em mediana e } \\
\text { com df ajustado }\end{array}$ & ,306 & 1 & 17,929 & ,587 \\
\hline & & $\begin{array}{l}\text { Com base em média } \\
\text { aparada }\end{array}$ & ,200 & 1 & 18 & ,660 \\
\hline
\end{tabular}


Testes de Normalidade

\begin{tabular}{|c|c|c|c|c|c|c|c|c|}
\hline \multirow[b]{2}{*}{ Tempo } & & \multirow[b]{2}{*}{ Lodo } & \multicolumn{3}{|c|}{ Kolmogorov-Smirnov $^{a}$} & \multicolumn{3}{|c|}{ Shapiro-Wilk } \\
\hline & & & Estatística & df & Sig. & Estatística & df & Sig. \\
\hline \multirow[t]{2}{*}{ T0_T1 } & Nitrito & ChoA & ,181 & 10 &, $200^{*}$ & ,921 & 10 & ,366 \\
\hline & & ChoB & ,234 & 10 & ,130 & ,891 & 10 & ,173 \\
\hline \multirow[t]{2}{*}{ T0_T2 } & Nitrito & ChoA & ,343 & 10 & ,002 & ,757 & 10 & ,004 \\
\hline & & ChoB & ,323 & 10 & ,004 & ,753 & 10 & ,004 \\
\hline \multirow[t]{2}{*}{ T0_T3 } & Nitrito & ChoA & 299 & 10 & ,012 & ,799 & 10 & ,014 \\
\hline & & ChoB &, 262 & 10 &, 049 & ,803 & 10 &, 016 \\
\hline \multirow[t]{2}{*}{ T1_T2 } & Nitrito & ChoA & ,231 & 10 & ,139 & ,828 & 10 & ,032 \\
\hline & & ChoB &, 373 & 10 &, 000 & ,741 & 10 & ,003 \\
\hline \multirow[t]{2}{*}{ T2_T3 } & Nitrito & ChoA & ,211 & 10 & $200^{*}$ & ,886 & 10 & ,154 \\
\hline & & ChoB & ,288 & 10 & ,019 & ,788 & 10 & ,010 \\
\hline
\end{tabular}

*. Este é um limite inferior da significância verdadeira.

a. Correlação de Significância de Lilliefors

Teste de Homogeneidade de Variância

\begin{tabular}{|c|c|c|c|c|c|c|}
\hline Tempo & & & $\begin{array}{l}\text { Estatística de } \\
\text { Levene }\end{array}$ & df1 & df2 & Sig. \\
\hline \multirow[t]{4}{*}{ T0_T1 } & \multirow[t]{4}{*}{ Nitrito } & Com base em média & 3,242 & 1 & 18 & 089 \\
\hline & & Com base em mediana & 3,139 & 1 & 18 & 093 \\
\hline & & $\begin{array}{l}\text { Com base em mediana e } \\
\text { com df ajustado }\end{array}$ & 3,139 & 1 & 12,115 & ,102 \\
\hline & & $\begin{array}{l}\text { Com base em média } \\
\text { aparada }\end{array}$ & 3,344 & 1 & 18 & 084 \\
\hline \multirow[t]{4}{*}{ T0_T2 } & \multirow[t]{4}{*}{ Nitrito } & Com base em média & 11,605 & 1 & 18 & ,003 \\
\hline & & Com base em mediana & 1,559 & 1 & 18 & ,228 \\
\hline & & $\begin{array}{l}\text { Com base em mediana e } \\
\text { com df ajustado }\end{array}$ & 1,559 & 1 & 12,769 & ,234 \\
\hline & & $\begin{array}{l}\text { Com base em média } \\
\text { aparada }\end{array}$ & 10,166 & 1 & 18 & ,005 \\
\hline \multirow[t]{4}{*}{ T0_T3 } & \multirow[t]{4}{*}{ Nitrito } & Com base em média & 4,754 & 1 & 18 & 043 \\
\hline & & Com base em mediana & 1,229 & 1 & 18 & ,282 \\
\hline & & $\begin{array}{l}\text { Com base em mediana e } \\
\text { com df ajustado }\end{array}$ & 1,229 & 1 & 12,571 & ,288 \\
\hline & & $\begin{array}{l}\text { Com base em média } \\
\text { aparada }\end{array}$ & 4,349 & 1 & 18 & 052 \\
\hline \multirow[t]{4}{*}{ T1_T2 } & \multirow[t]{4}{*}{ Nitrito } & Com base em média & ,345 & 1 & 18 &, 564 \\
\hline & & Com base em mediana & ,462 & 1 & 18 &, 505 \\
\hline & & $\begin{array}{l}\text { Com base em mediana e } \\
\text { com df ajustado }\end{array}$ & ,462 & 1 & 15,363 & ,507 \\
\hline & & $\begin{array}{l}\text { Com base em média } \\
\text { aparada }\end{array}$ & ,446 & 1 & 18 &, 513 \\
\hline \multirow[t]{4}{*}{ T2_T3 } & \multirow[t]{4}{*}{ Nitrito } & Com base em média & 3,385 & 1 & 18 & 082 \\
\hline & & Com base em mediana & 2,672 & 1 & 18 & 119 \\
\hline & & $\begin{array}{l}\text { Com base em mediana e } \\
\text { com df ajustado }\end{array}$ & 2,672 & 1 & 10,977 & 130 \\
\hline & & $\begin{array}{l}\text { Com base em média } \\
\text { aparada }\end{array}$ & 3,096 & 1 & 18 & ,095 \\
\hline
\end{tabular}


Testes de Normalidade

\begin{tabular}{|c|c|c|c|c|c|c|c|c|}
\hline \multirow[b]{2}{*}{ Tempo } & & \multirow[b]{2}{*}{ Lodo } & \multicolumn{3}{|c|}{ Kolmogorov-Smirnov ${ }^{a}$} & \multicolumn{3}{|c|}{ Shapiro-Wilk } \\
\hline & & & Estatística & $\mathrm{df}$ & Sig. & Estatística & $\mathrm{df}$ & Sig. \\
\hline \multirow[t]{2}{*}{ T0_T1 } & Nitrato & ChoA & ,265 & 10 &, 045 &, 831 & 10 &, 035 \\
\hline & & ChoB &, 227 & 10 & ,153 &, 803 & 10 & ,016 \\
\hline \multirow[t]{2}{*}{ T0_T2 } & Nitrato & ChoA & ,336 & 10 & ,002 &, 748 & 10 & ,003 \\
\hline & & ChoB & ,209 & 10 &, $200^{*}$ & ,882 & 10 & ,138 \\
\hline \multirow[t]{2}{*}{ T0_T3 } & Nitrato & ChoA & ,265 & 10 & ,045 & ,785 & 10 & ,010 \\
\hline & & ChoB & ,211 & 10 &, $200^{*}$ & ,849 & 10 & ,057 \\
\hline \multirow[t]{2}{*}{ T1_T2 } & Nitrato & ChoA & ,357 & 10 & ,001 &, 746 & 10 &, 003 \\
\hline & & ChoB & ,349 & 10 &, 001 &, 746 & 10 &, 003 \\
\hline \multirow[t]{2}{*}{ T2_T3 } & Nitrato & ChoA &, 234 & 10 &, 127 & ,827 & 10 &, 031 \\
\hline & & ChoB & ,253 & 10 &, 068 & ,797 & 10 & ,013 \\
\hline
\end{tabular}

*. Este é um limite inferior da significância verdadeira.

a. Correlação de Significância de Lilliefors

Teste de Homogeneidade de Variância

\begin{tabular}{|c|c|c|c|c|c|c|}
\hline Tempo & & & $\begin{array}{c}\text { Estatística de } \\
\text { Levene }\end{array}$ & df1 & df2 & Sig. \\
\hline \multirow[t]{4}{*}{ T0_T1 } & \multirow[t]{4}{*}{ Nitrato } & Com base em média & 2,896 & 1 & 18 & ,106 \\
\hline & & Com base em mediana & 1,279 & 1 & 18 & ,273 \\
\hline & & $\begin{array}{l}\text { Com base em mediana e } \\
\text { com df ajustado }\end{array}$ & 1,279 & 1 & 13,385 & ,278 \\
\hline & & $\begin{array}{l}\text { Com base em média } \\
\text { aparada }\end{array}$ & 2,594 & 1 & 18 & ,125 \\
\hline \multirow[t]{4}{*}{ T0_T2 } & \multirow[t]{4}{*}{ Nitrato } & Com base em média & ,884 & 1 & 18 & ,359 \\
\hline & & Com base em mediana & ,009 & 1 & 18 & ,927 \\
\hline & & $\begin{array}{l}\text { Com base em mediana e } \\
\text { com df ajustado }\end{array}$ & ,009 & 1 & 13,564 & ,927 \\
\hline & & $\begin{array}{l}\text { Com base em média } \\
\text { aparada }\end{array}$ & ,812 & 1 & 18 & ,380 \\
\hline \multirow[t]{4}{*}{ T0_T3 } & \multirow[t]{4}{*}{ Nitrato } & Com base em média & 069 & 1 & 18 & ,795 \\
\hline & & Com base em mediana & ,001 & 1 & 18 & ,972 \\
\hline & & $\begin{array}{l}\text { Com base em mediana e } \\
\text { com df ajustado }\end{array}$ & ,001 & 1 & 17,650 & ,972 \\
\hline & & $\begin{array}{l}\text { Com base em média } \\
\text { aparada }\end{array}$ & ,073 & 1 & 18 & ,790 \\
\hline \multirow[t]{4}{*}{ T1_T2 } & \multirow[t]{4}{*}{ Nitrato } & Com base em média & ,258 & 1 & 18 & 617 \\
\hline & & Com base em mediana & ,026 & 1 & 18 & 874 \\
\hline & & $\begin{array}{l}\text { Com base em mediana e } \\
\text { com df ajustado }\end{array}$ & ,026 & 1 & 17,999 & 874 \\
\hline & & $\begin{array}{l}\text { Com base em média } \\
\text { aparada }\end{array}$ & ,242 & 1 & 18 & ,629 \\
\hline \multirow[t]{4}{*}{ T2_T3 } & \multirow[t]{4}{*}{ Nitrato } & Com base em média & 2,672 & 1 & 18 & ,119 \\
\hline & & Com base em mediana & ,906 & 1 & 18 & ,354 \\
\hline & & $\begin{array}{l}\text { Com base em mediana e } \\
\text { com df ajustado }\end{array}$ & ,906 & 1 & 11,089 & ,361 \\
\hline & & $\begin{array}{l}\text { Com base em média } \\
\text { aparada }\end{array}$ & 2,398 & 1 & 18 & ,139 \\
\hline
\end{tabular}


Os dados obtidos de conversão das formas nitrogenadas presentes na amostras, ao longo dos tempos de cada teste e também com o número do teste, que irá refletir numa variável tempo, visto que o teste sucessor ao anterior representa maior tempo que a biomassa encontra-se dentro do sistema e com isso maior aclimatação e enriquecimento dos grupos de microorganismos que melhor se desenvolveram dadas as condições estabelecidas, são considerados não paramétricos visto que não correspondem aos pressupostos de normalidade e homogeneidade. A não normalidade e homogeneidade dos dados eram esperados dado as características das informações coletadas, visto que a conversão das formas nitrogenadas dependiam das densidades dos grupos de micro-organismos presentes nos inóculos bem como das concentrações dos substratos limitantes e das concentrações de substâncias inibitórias a cada grupo de micro-organismos. Dessa maneira torna-se necessário a adoção de testes não paramétricos para interpretação dos resultados obtidos.

Comparação entre os sistemas A e B de cada inóculo da etapa 2 para verificar se os mesmos continuaram a agir como duplicatas na conversão dos compostos nitrogenados. Para tanto realizou-se testes de hipóteses, sendo $H O=F($ Sistema $A)=F($ Sistema $B) ; H 1=F($ Sistema $A) \neq$ $\mathrm{F}($ Sistema B);

Nesse teste não existe uma previsão de qual sistema apresentou maior ou menor conversão, então considera-se apenas a igualdade e desigualdade entre os valores lidos de conversão para amônia, nitrito e nitrato, e portanto busca-se uma análise bilateral.

Para esse teste os sistemas foram considerados como variáveis dependentes, visto que as mesmas estavam sendo avaliadas para checar a igualdade ou não, ou seja considerou elas como emparelhadas, como se fossem provenientes de um único sistema.

\section{Nesse caso utilizou-se o teste dos postos com sinais de Wilcoxon.}

Nesse teste calcula-se a diferença entre as observações de cada amostra (teste e tempo) das duas variáveis dependentes, nesse caso sistema A e sistema B, e depois essas diferenças são transformadas em postos, mas o sinal da diferença (se positiva ou negativa) é atribuído a cada posto. Ao final separa-se os postos com sinais negativos e positivos, e obtém-se a soma dos postos com mesmos sinais. A estatística desse teste $(T)$ é utilizar o menor dos dois valores obtidos na soma dos postos com sinais diferentes (que será o valor T). 
A significância do teste é obtida com o cálculo da média $\bar{T}$ e do erro padrão do teste $\left(E P_{T}\right)$ do teste para cálculo de $Z$, de acordo com as equações:

$$
\begin{gathered}
\bar{T}=\frac{n(n+1)}{4} \\
E P_{T}=\sqrt{\frac{n(n+1)(2 n+1)}{24}} \\
Z=\frac{T-\bar{T}}{E P_{T}}
\end{gathered}
$$

1) Dessa maneira tem-se para as conversões de amônia para os sistema A e B:

Para os sistemas com inóculo proveniente da Lago Paranoá de Brasília (Par), as reduções nas concentrações de amônia, ao longo dos perfis temporais de cada teste e ao longo do conjunto de teste, foram significativamente mais altos para o sistema denominado de ParA (Média =0,300; Mediana =0,232) do que para o sistema denominado de ParB (Média =0,274; Mediana $=0,256)$, com $T=447,0$ e $Z=-1,839 p<0,05$. Dessa maneira, esses sistema A e B com relação à redução de amônia não podem ser utilizados como duplicatas.

A tabela XX, apresenta os resultados sintetizados com relação às conversões ocorridas nas formas nitrogenadas dos sistemas operados com o mesmo tipo de inóculo, com a finalidade de

\begin{tabular}{|c|c|c|c|c|c|c|c|}
\hline & \multirow{2}{*}{$\begin{array}{c}\text { IONS (mM) } \\
\text { Intervalo tempo }\end{array}$} & \multicolumn{6}{|c|}{ SISTEMAS TESTADOS } \\
\hline & & $\begin{array}{c}\text { ParA e } \\
\text { ParB }\end{array}$ & $\begin{array}{c}\text { Anf1A e } \\
\text { AnF1B }\end{array}$ & $\begin{array}{c}\text { FaF1A e } \\
\text { FaF1B }\end{array}$ & $\begin{array}{c}\text { FaF2A e } \\
\text { FaF2B }\end{array}$ & $\begin{array}{c}\text { UaF2A e } \\
\text { UaF2B }\end{array}$ & $\begin{array}{c}\text { ChoA e } \\
\text { ChoB }\end{array}$ \\
\hline \multirow{5}{*}{$\begin{array}{l}\nwarrow \\
\sum \\
\sum\end{array}$} & T0_T1 (0 a 24 horas) & Não & $\checkmark$ & Não & $\checkmark$ & $\checkmark$ & $\checkmark$ \\
\hline & T1_T2 (24 a 48 horas) & $\checkmark$ & Não & Não & $\checkmark$ & $\checkmark$ & Não \\
\hline & T0_T2 (0 a 48 horas) & $\checkmark$ & $\checkmark$ & $\checkmark$ & $\checkmark$ & $\checkmark$ & Não \\
\hline & T2_T3 (48 a 72 horas) & $\checkmark$ & Não & $\checkmark$ & $\checkmark$ & $\checkmark$ & $\checkmark$ \\
\hline & T0_T3 (0 a 72 horas) & $\checkmark$ & Não & Não & $\checkmark$ & $\checkmark$ & Não \\
\hline
\end{tabular}
avaliar se os sistemas permaneciam como representantes de duplicatas. $O$ teste aplicado foi 0 dos postos com sinais de Wilcoxon. 


\begin{tabular}{|c|c|c|c|c|c|c|c|}
\hline \multirow{5}{*}{$\begin{array}{l}\stackrel{ }{E} \\
\text { 믈 } \\
\text { 三 }\end{array}$} & T0_T1 (0 a 24 horas) & $\checkmark$ & $\checkmark$ & $\checkmark$ & $\checkmark$ & $\checkmark$ & $\sqrt{ }$ \\
\hline & T1_T2 (24 a 48 horas) & Não & Não & $\checkmark$ & Não & $\checkmark$ & $\checkmark$ \\
\hline & T0_T2 (0 a 48 horas) & $\checkmark$ & Não & $\checkmark$ & $\checkmark$ & $\checkmark$ & Não \\
\hline & T2_T3 (48 a 72 horas) & Não & $\sqrt{ }$ & $\checkmark$ & $\checkmark$ & $\checkmark$ & $\checkmark$ \\
\hline & T0_T3 (0 a 72 horas) & $\checkmark$ & Não & $\checkmark$ & $\checkmark$ & $\checkmark$ & $\checkmark$ \\
\hline \multirow{7}{*}{ 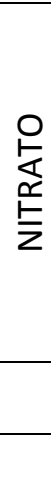 } & T0_T1 (0 a 24 horas) & $\checkmark$ & $\checkmark$ & $\checkmark$ & $\checkmark$ & $\checkmark$ & $\checkmark$ \\
\hline & T1_T2 (24 a 48 horas) & $\checkmark$ & $\checkmark$ & $\checkmark$ & $\checkmark$ & $\checkmark$ & $\checkmark$ \\
\hline & T0_T2 (0 a 48 horas) & $\checkmark$ & $\sqrt{ }$ & $\checkmark$ & $\sqrt{ }$ & $\checkmark$ & Não \\
\hline & T2_T3 (48 a 72 horas) & Não & $\checkmark$ & $\checkmark$ & $\checkmark$ & $\checkmark$ & $\checkmark$ \\
\hline & T0_T3 (0 a 72 horas) & $\checkmark$ & Não & Não & $\checkmark$ & $\checkmark$ & $\checkmark$ \\
\hline & Desigualdades & 4 & 7 & 4 & 1 & 0 & 5 \\
\hline & Julgamento se iguais & & & & SIM & SIM & \\
\hline
\end{tabular}

Acrescentar comentários do Livro sobre organização dos sistemas biológicos 


\section{APENDICE VI}

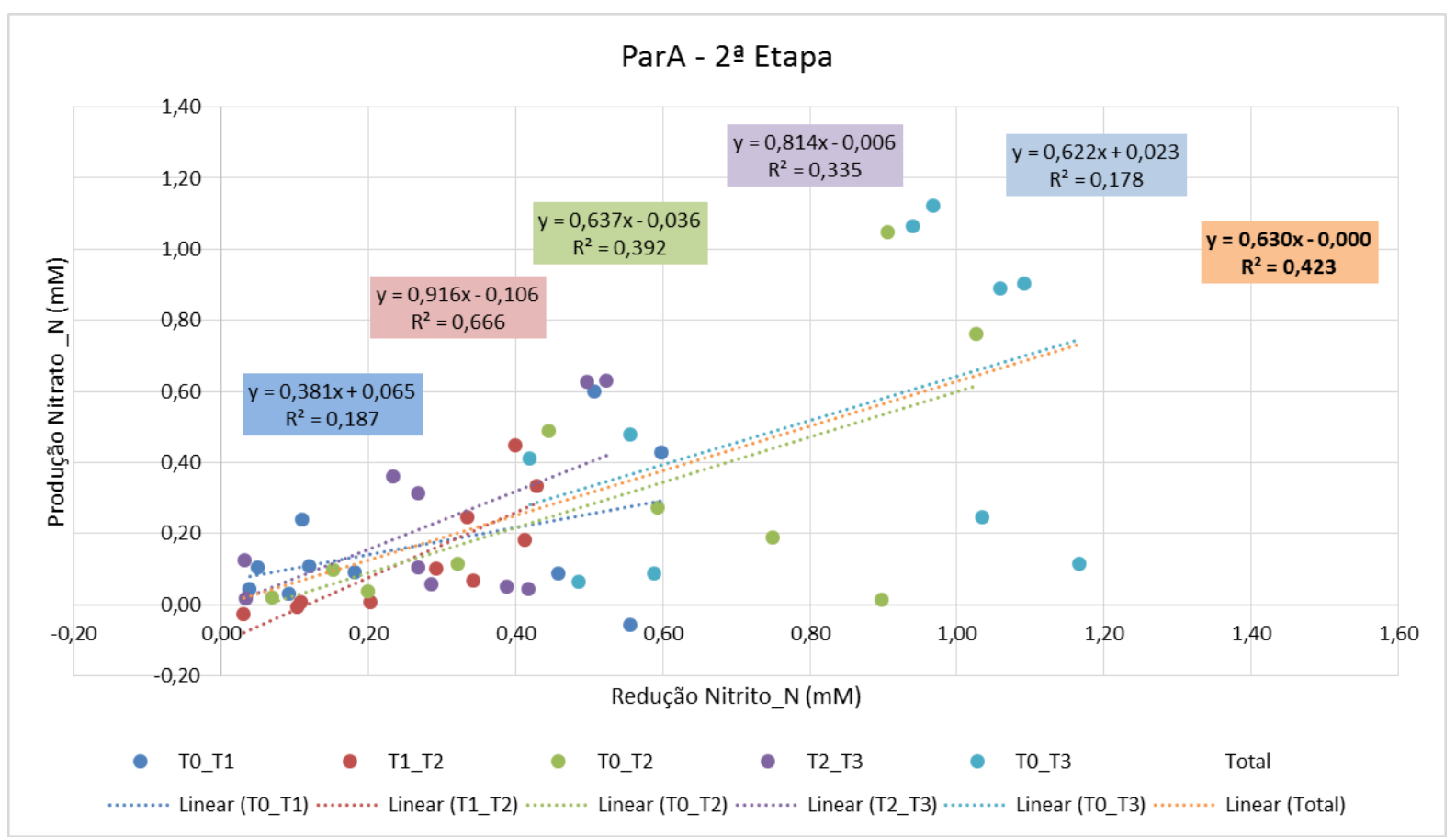

Figura VI.1: Correlações entre produção de nitrato_N (mM) com a redução concomitante das concentrações de nitrito_N (mM) no sistema biológico com inóculo proveniente do sedimento do lago Paranoá Brasília, DF (ParA). Cada equação representa a correlação para um dado intervalo de tempo. Na legenda, total - representa a correlação entre os dados de todos intervalos de tempo.

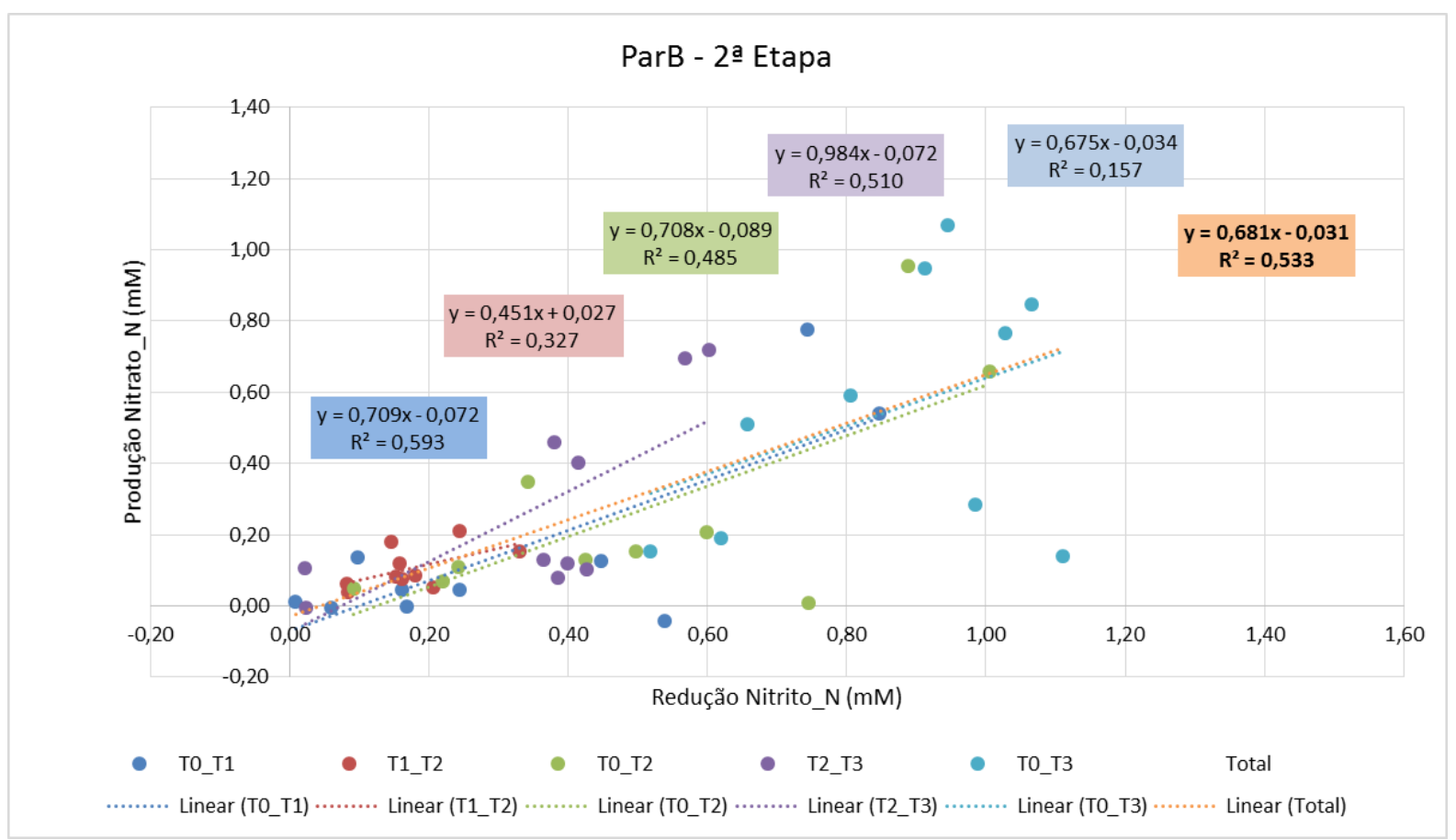

Figura VI.2: Correlações entre produção de nitrato_N (mM) com a redução concomitante das concentrações de nitrito_N (mM) no sistema biológico com inóculo proveniente do sedimento do lago Paranoá Brasília, DF (ParB). Cada equação representa a correlação para um dado intervalo de tempo. Na legenda, total - representa a correlação entre os dados de todos intervalos de tempo. 


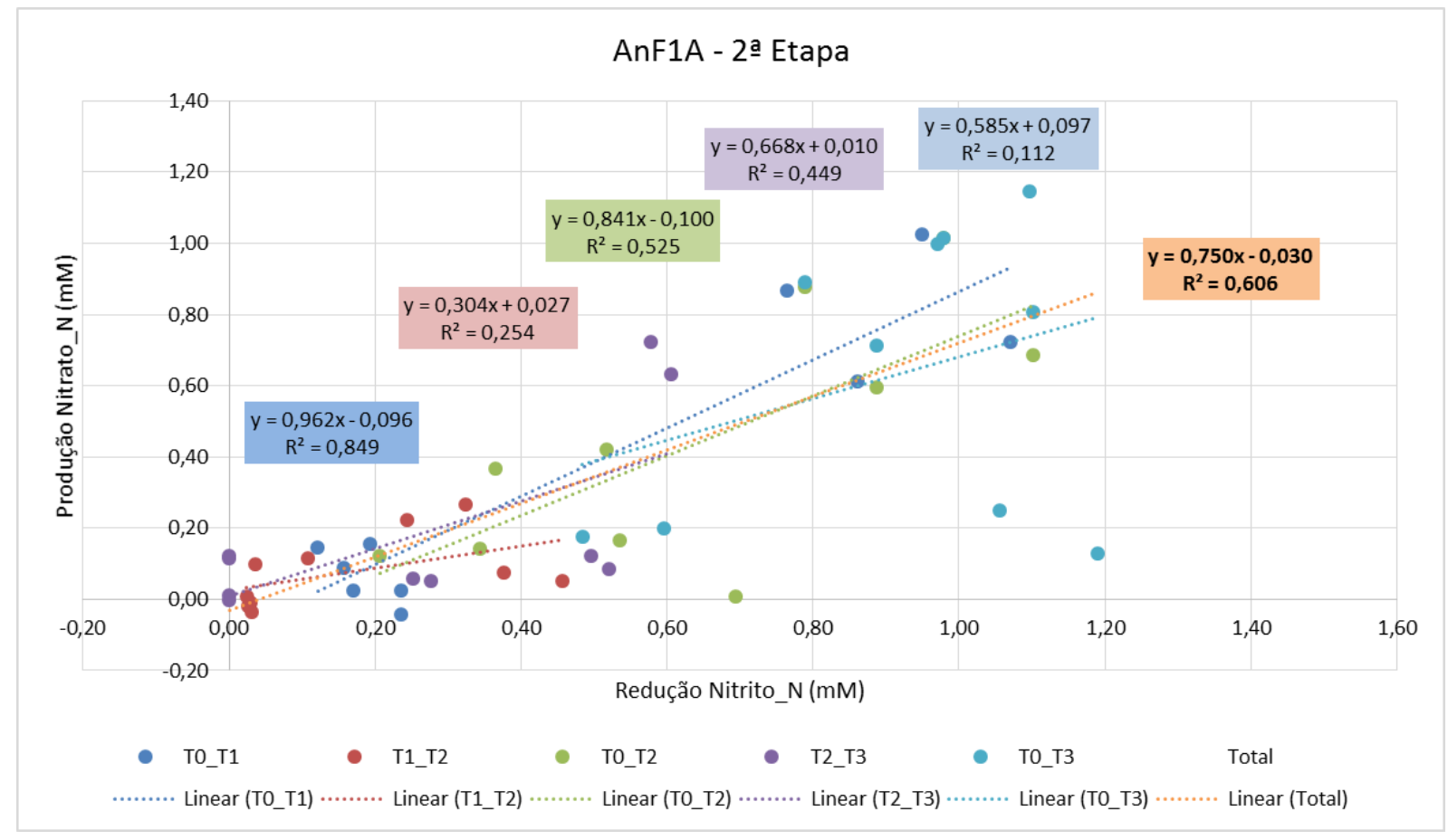

Figura VI.3: Correlações entre produção de nitrato_N (mM) com a redução concomitante das concentrações de nitrito_N (mM) no sistema biológico com inóculo proveniente do lodo da lagoa anaeróbia tratando efluente do Frigorífico 1, Araguari, MG (AnF1A). Cada equação representa a correlação para um dado intervalo de tempo. Na legenda, total - representa a correlação entre os dados de todos intervalos de tempo.

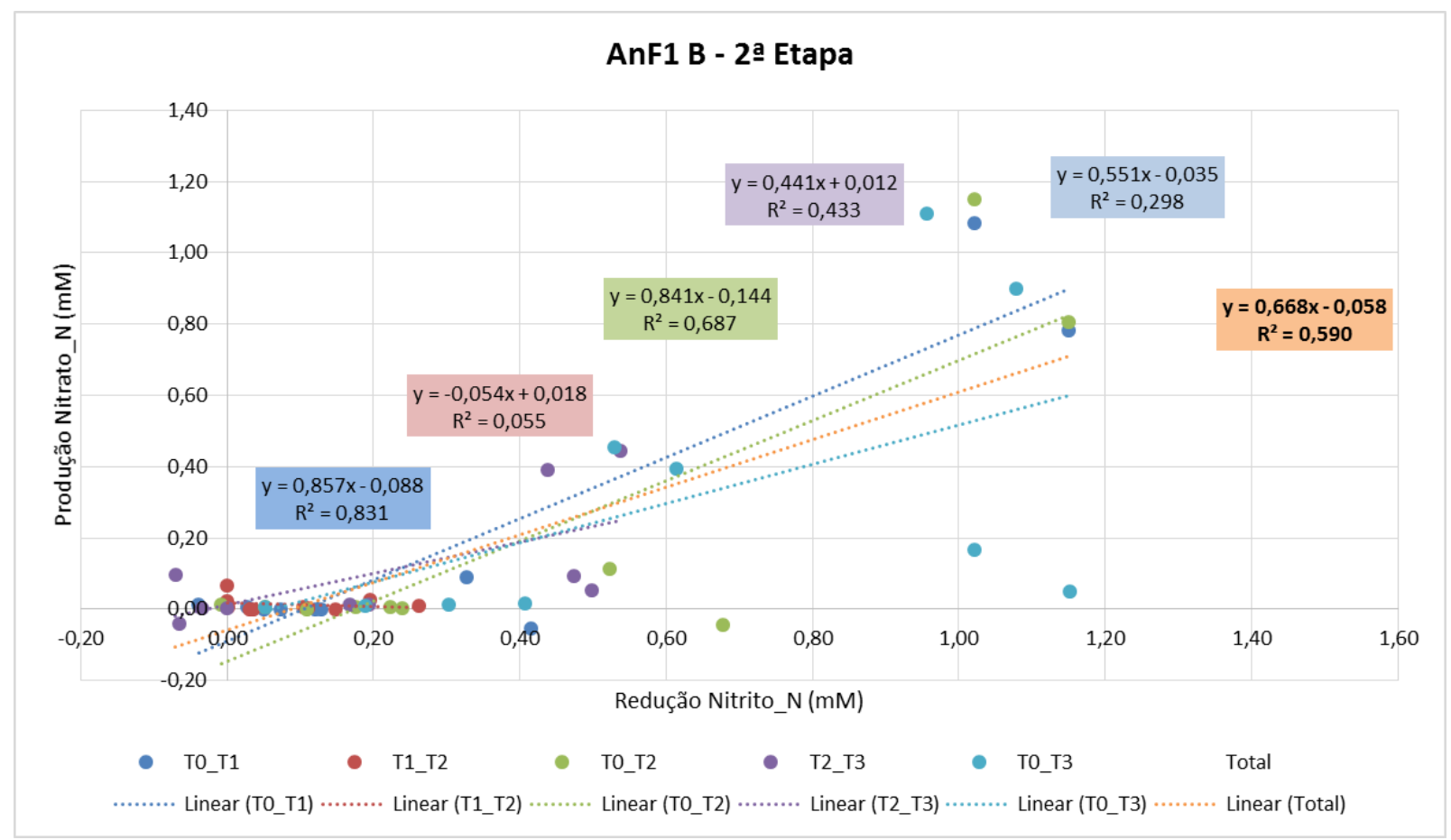

Figura VI.4: Correlações entre produção de nitrato_N (mM) com a redução concomitante das concentrações de nitrito_N (mM) no sistema biológico com inóculo proveniente do lodo da lagoa anaeróbia tratando efluente do Frigorífico 1, Araguari, MG (AnF1B). Cada equação representa a correlação para um dado intervalo de tempo. Na legenda, total - representa a correlação entre os dados de todos intervalos de tempo. 


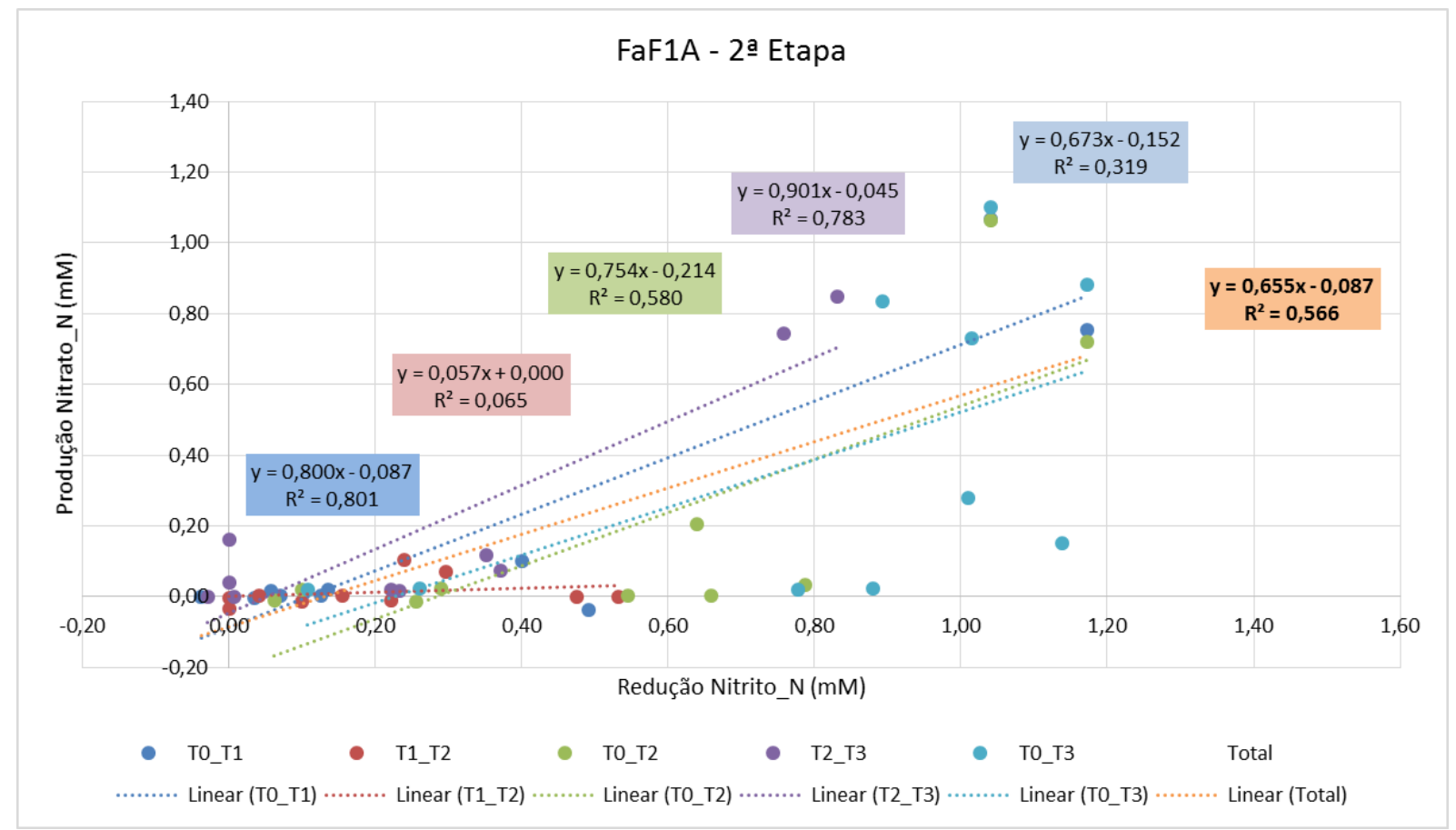

Figura VI.5: Correlações entre produção de nitrato_N (mM) com a redução concomitante das concentrações de nitrito_N (mM) no sistema biológico com inóculo proveniente do lodo da lagoa facultativa tratando efluente do Frigorífico 1, Araguari, MG (FaF1A). Cada equação representa a correlação para um dado intervalo de tempo. Na legenda, total - representa a correlação entre os dados de todos intervalos de tempo.

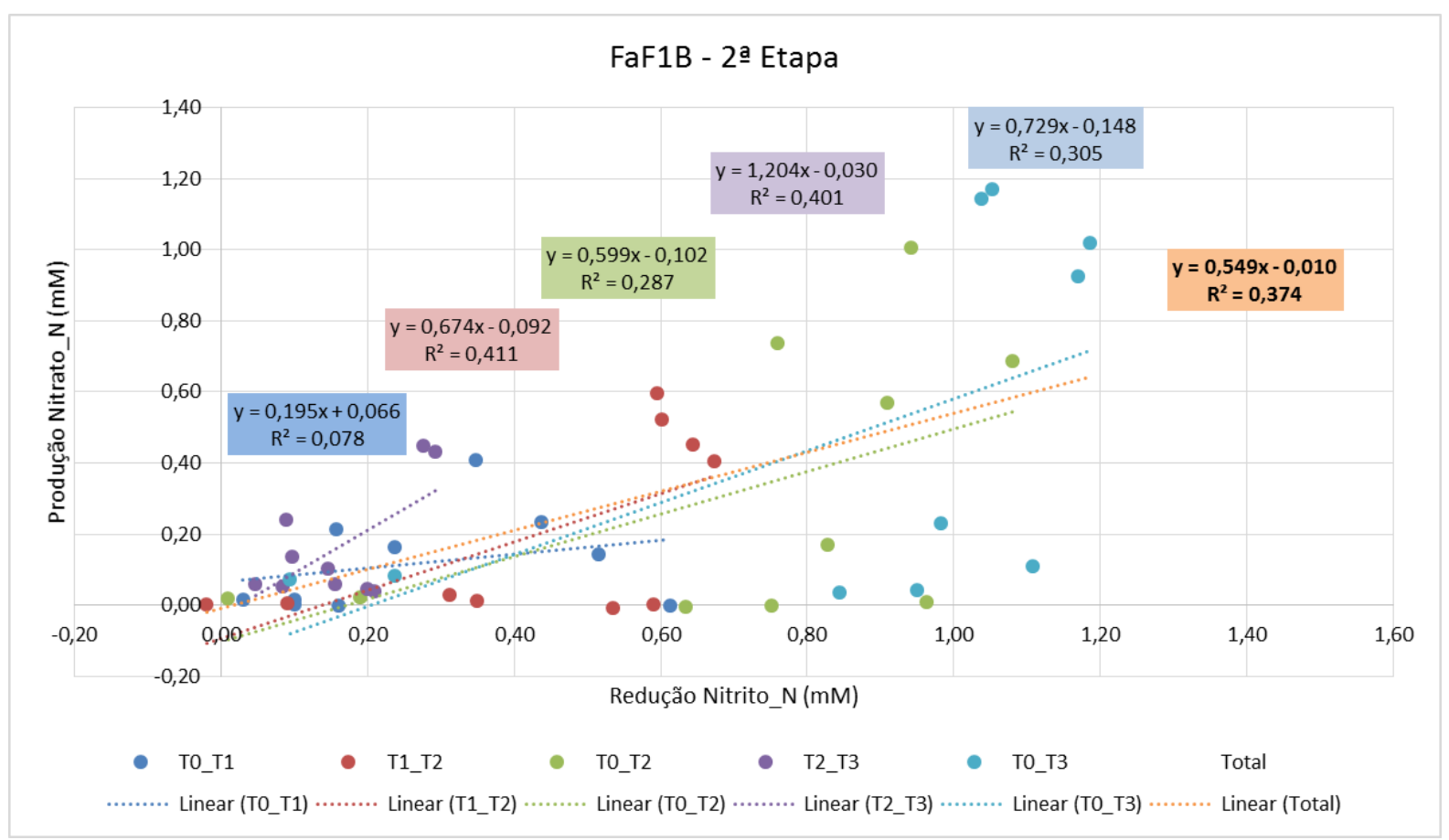

Figura VI.6: Correlações entre produção de nitrato_N (mM) com a redução concomitante das concentrações de nitrito_N (mM) no sistema biológico com inóculo proveniente do lodo da lagoa facultativa tratando efluente do Frigorífico 1, Araguari, MG (FaF1B). Cada equação representa a correlação para um dado intervalo de tempo. Na legenda, total - representa a correlação entre os dados de todos intervalos de tempo. 


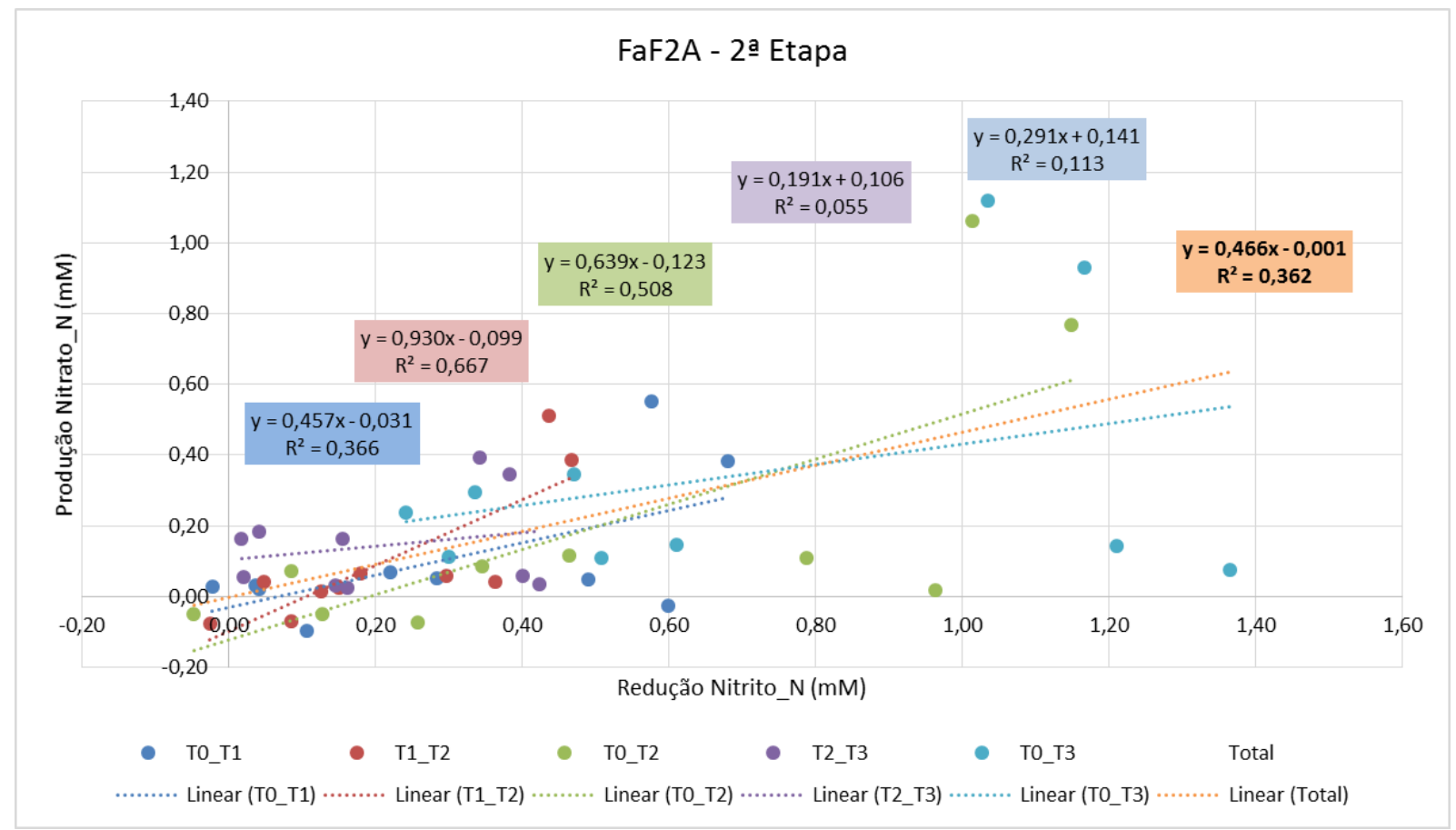

Figura VI.7: Correlações entre produção de nitrato_N (mM) com a redução concomitante das concentrações de nitrito_N (mM) no sistema biológico com inóculo proveniente do lodo da lagoa facultativa tratando efluente do Frigorífico 2, Uberlândia, MG (FaF2A). Cada equação representa a correlação para um dado intervalo de tempo. Na legenda, total - representa a correlação entre os dados de todos intervalos de tempo.

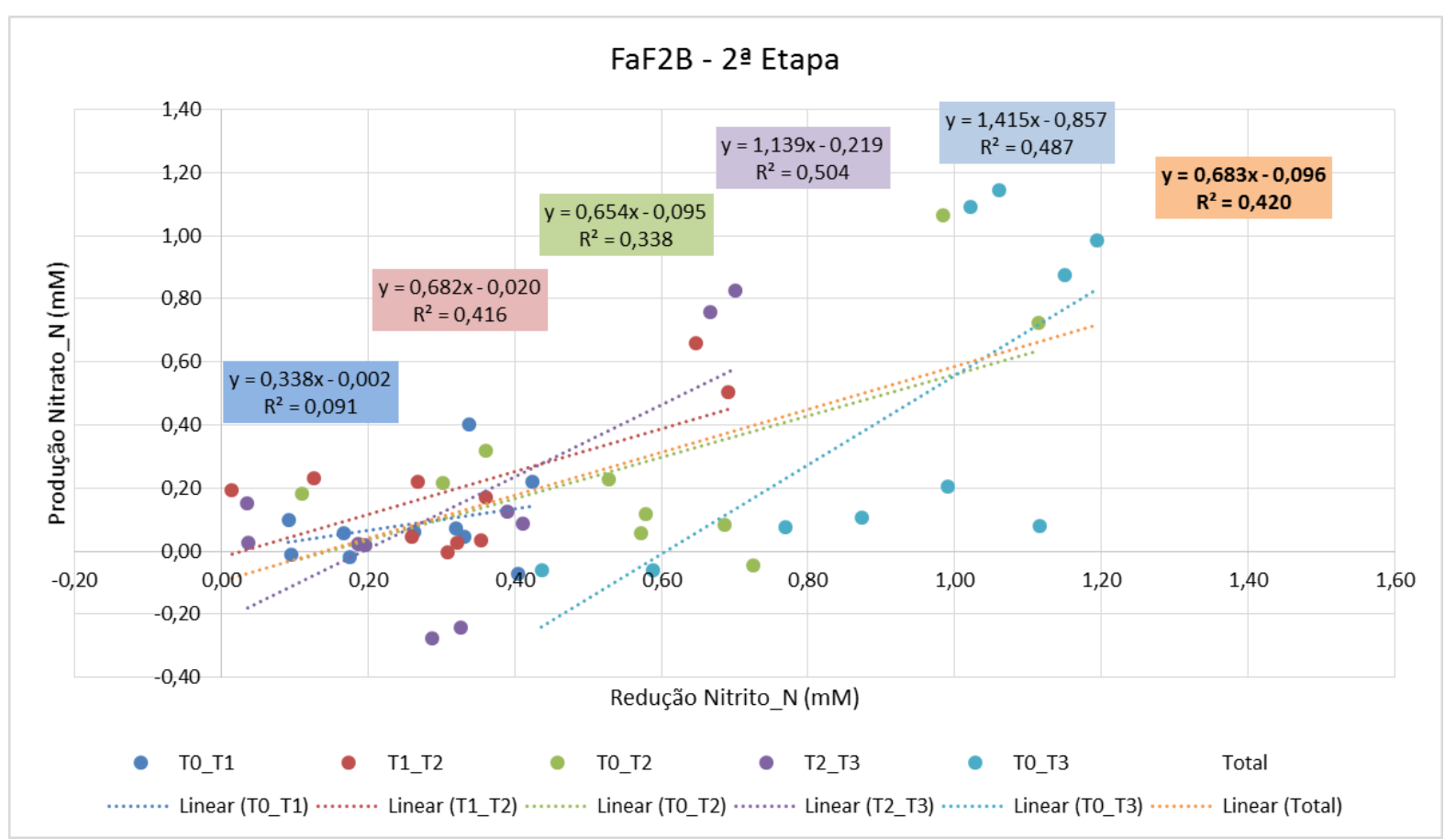

Figura VI.8: Correlações entre produção de nitrato_N (mM) com a redução concomitante das concentrações de nitrito_N (mM) no sistema biológico com inóculo proveniente do lodo da lagoa facultativa tratando efluente do Frigorífico 2, Uberlândia, MG (FaF2B). Cada equação representa a correlação para um dado intervalo de tempo. Na legenda, total - representa a correlação entre os dados de todos intervalos de tempo. 


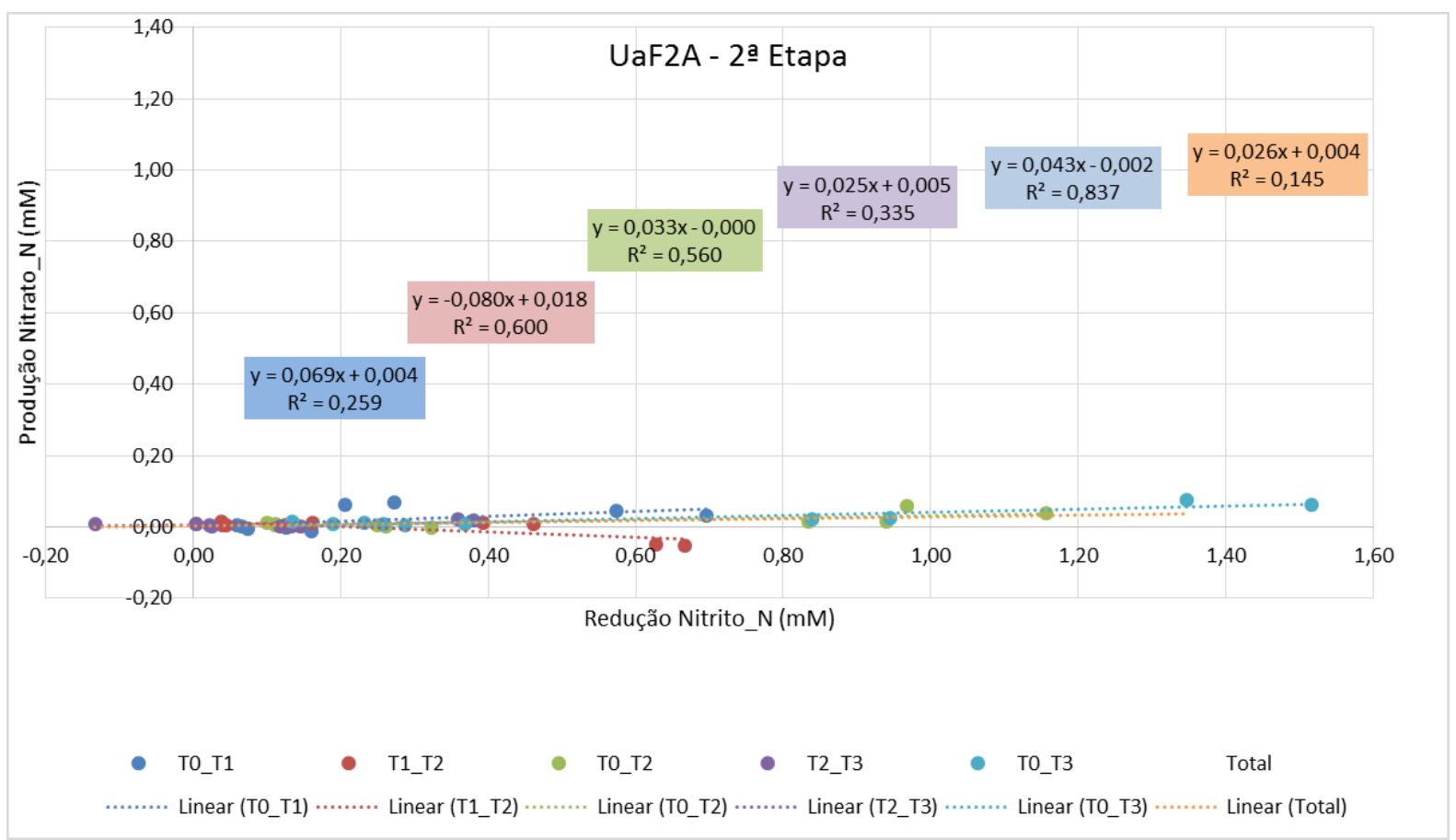

Figura VI.9: Correlações entre produção de nitrato_N (mM) com a redução concomitante das concentrações de nitrito_N (mM) no sistema biológico com inóculo proveniente do lodo do reator

UASB tratando efluente do Frigorífico 2, Uberlândia, MG (UaF2A). Cada equação representa a correlação para um dado intervalo de tempo. Na legenda, total - representa a correlação entre os dados de todos intervalos de tempo.

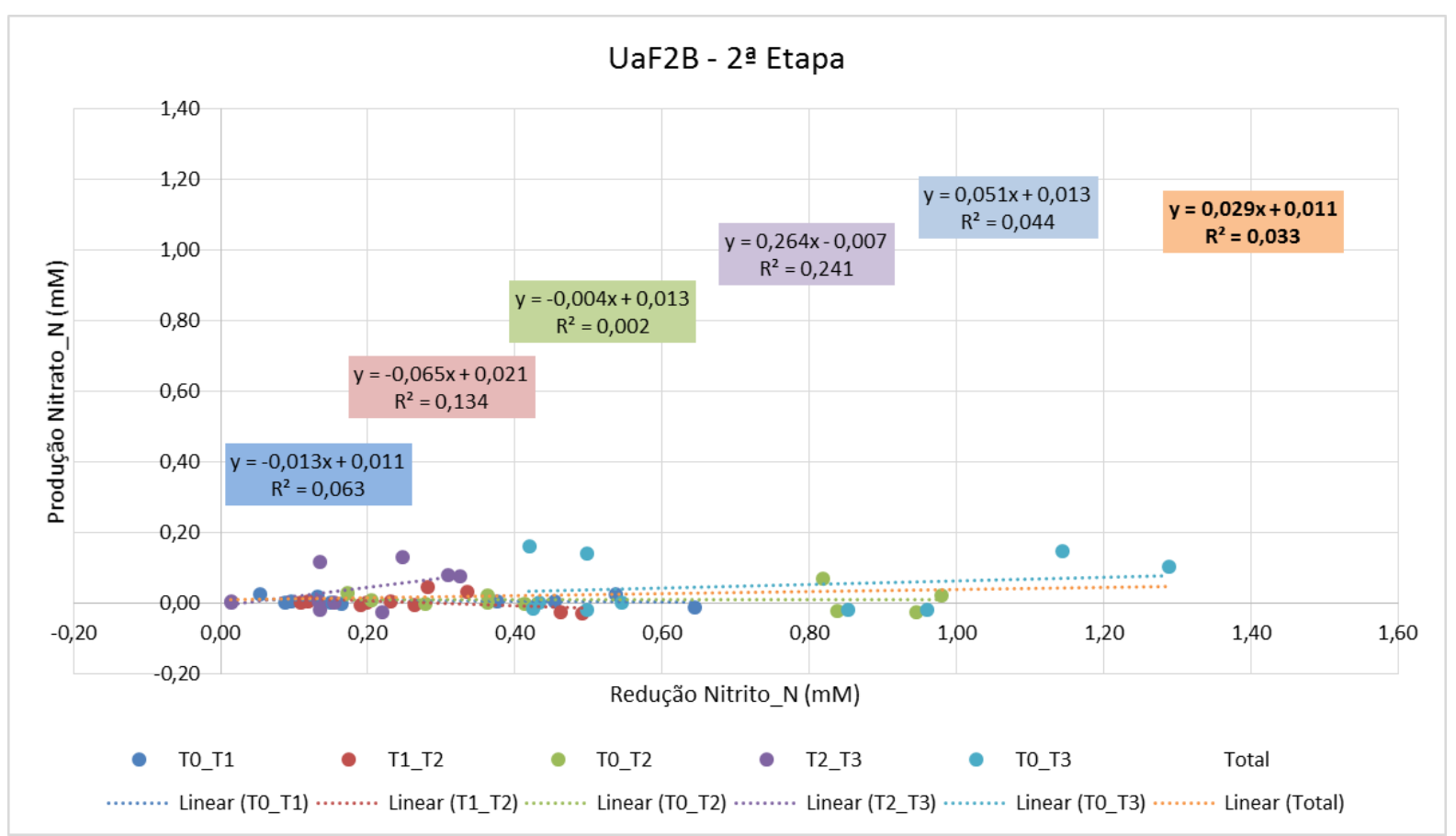

Figura VI.10: Correlações entre produção de nitrato_N (mM) com a redução concomitante das concentrações de nitrito_N (mM) no sistema biológico com inóculo proveniente do lodo do reator Uasb tratando efluente do Frigorífico 2, Uberlândia, MG (UaF2B). Cada equação representa a correlação para um dado intervalo de tempo. Na legenda, total - representa a correlação entre os dados de todos intervalos de tempo. 


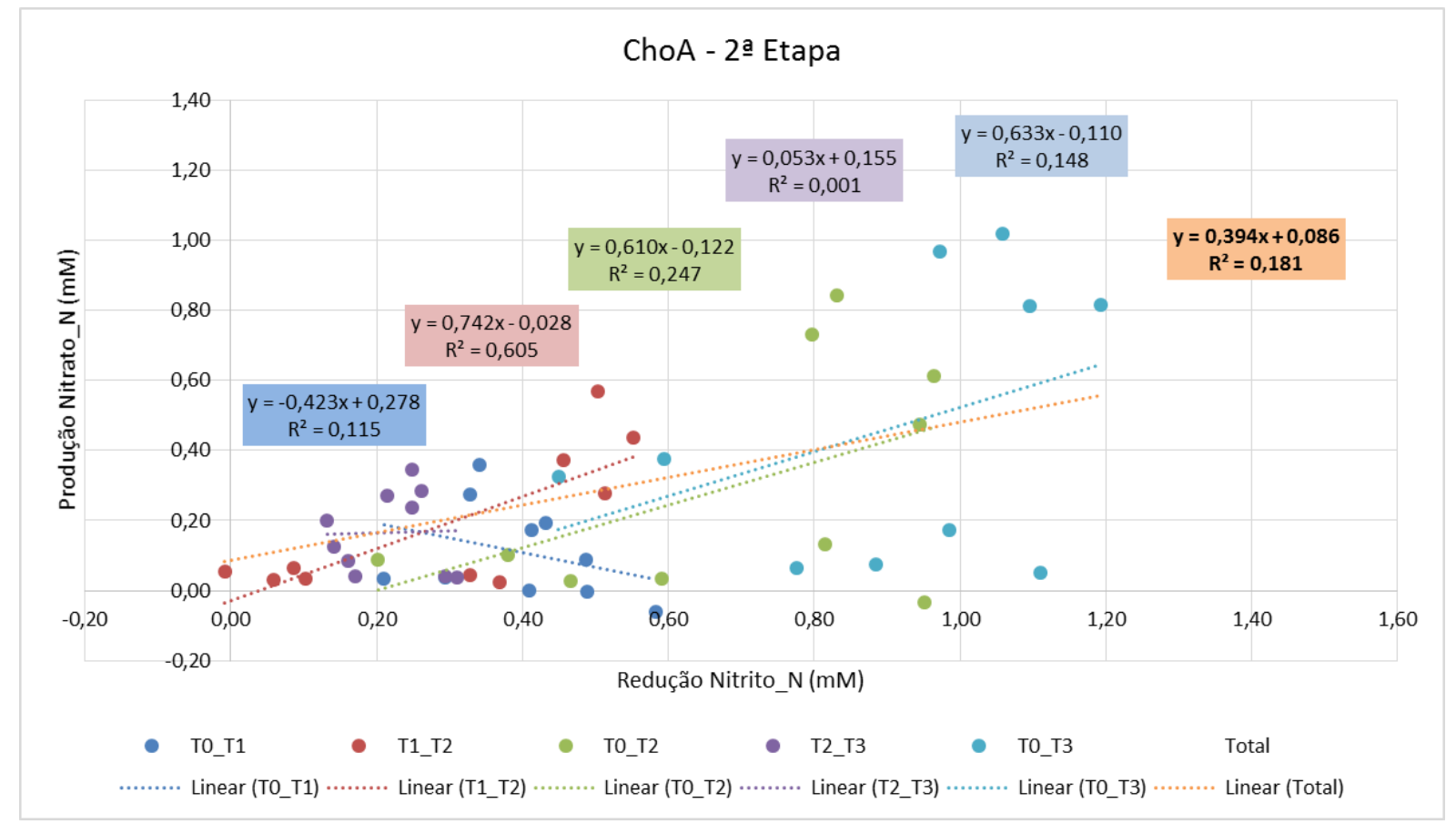

Figura VI.11: Correlações entre produção de nitrato_N (mM) com a redução concomitante das concentrações de nitrito_N (mM) no sistema biológico com inóculo proveniente do sedimento da lagoa de acumulação de chorume do aterro controlado Jockey Clube de Brasília, DF (ChoA). Cada equação representa a correlação para um dado intervalo de tempo. Na legenda, total - representa a correlação entre os dados de todos intervalos de tempo.

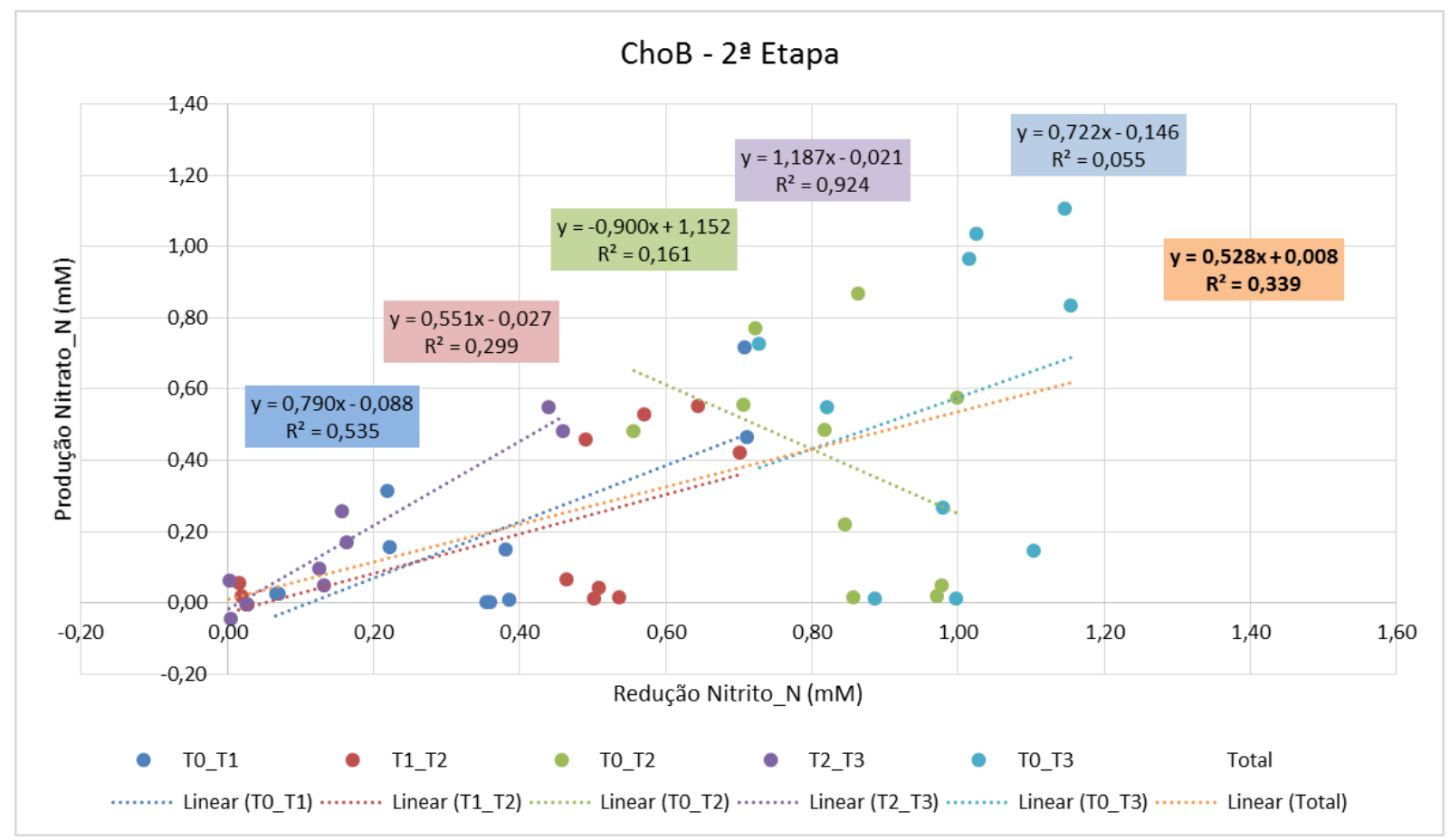

Figura VI.12: Correlações entre produção de nitrato_N (mM) com a redução concomitante das concentrações de nitrito_N (mM) no sistema biológico com inóculo proveniente do sedimento da lagoa de acumulação de chorume do aterro controlado Jockey Clube de Brasília, DF (ChoB). Cada equação representa a correlação para um dado intervalo de tempo. Na legenda, total - representa a correlação entre os dados de todos intervalos de tempo. 


\section{APENDICE VII \\ COMPARAÇÃO ENTRE LODOS 2a ETAPA}

Foi verificado a existência de diferença das relações T_NiAm_N e T_Na_NiAm_N entre os diferentes sistemas componentes da etapa 2.

Verificou-se os valores calculados para essas variáveis quanto à sua distribuição normal e homogeneidade entre as variâncias entre os grupos comparados para definição dos testes de estatísticos afim de testar hipóteses do efeito da origem do inóculo em cada sistema sobre o comportamento metabólico ocorrentes nos sistemas biológicos.

Os dados calculados seguem uma distribuição livre e a variância das observações em torno da média entre os grupos comparados é heterogênea.

Diante desses resultados, optou-se pela realização do teste de Kruskal-Wallis que permite avaliar se há diferenças entre vários grupos independentes. O Teste de KruskalWallis é uma alternativa a ANOVA independente de um fator, para quando os dados são não paramétricos.

O Teste de Kruskall_Wallis $(\mathrm{H})$ tem como base os postos de valores. Inicia-se ordenando os escores do menor para o maior, ignorando o grupo ao qual o escore pertence. Após a ordenação, retorna-se os escores aos grupos as quais eles pertenciam inicialmente e soma-se os postos atribuídos a cada escores para cada grupo. A soma dos postos de cada grupo é representada por $R_{i}$ (i representa cada um dos grupo testados). A estatística H é calculada usando a equação:

$$
H=\frac{12}{N(N+1)} \sum_{i=1}^{k} \frac{R_{i}^{2}}{n_{i}}-3(N-1)
$$

Onde:

$\mathrm{R}_{\mathrm{i}}=$ soma dos postos para cada grupo

$\mathrm{N}=$ total da amostra (somatório de $\mathrm{n}_{\mathrm{i}}$ de cada grupo testado)

$\mathrm{n}_{\mathrm{i}}=$ tamanho amostral de cada um dos grupos testados

$\mathrm{k}=$ graus de liberdade (número de grupos menos um) 
Essa estatística teste tem um tipo especial de distribuição conhecida como QuiQuadrado e para isso essa distribuição possui um parâmetro denominado graus de liberdade, que é o número de grupos menos um (K-1).

Dessa maneira tem-se como resultados se os lodos diferem ou não quanto a relação de T_NiAm_N, para os intervalos de tempo do início de cada batelada (T0_T1; T0_T2; T0_T3).

Classificações $^{a}$

\begin{tabular}{|rl|r|r|}
\hline & Lodo & N & $\begin{array}{c}\text { Postos de } \\
\text { média }\end{array}$ \\
\hline T_NiAm_N & ParA & 10 & 41,70 \\
& ParB & 10 & 59,60 \\
& AnF1A & 10 & 89,00 \\
& AnF1B & 10 & 52,50 \\
& FaF1A & 10 & 46,15 \\
FaF1B & 10 & 65,05 \\
FaF2A & 10 & 47,10 \\
FaF2B & 10 & 75,40 \\
UaF2A & 10 & 52,75 \\
UaF2B & 10 & 52,00 \\
ChoA & 10 & 73,70 \\
ChoB & 10 & 71,05 \\
Total & 120 & \\
\hline
\end{tabular}

a. Tempo $=$ TO_T1

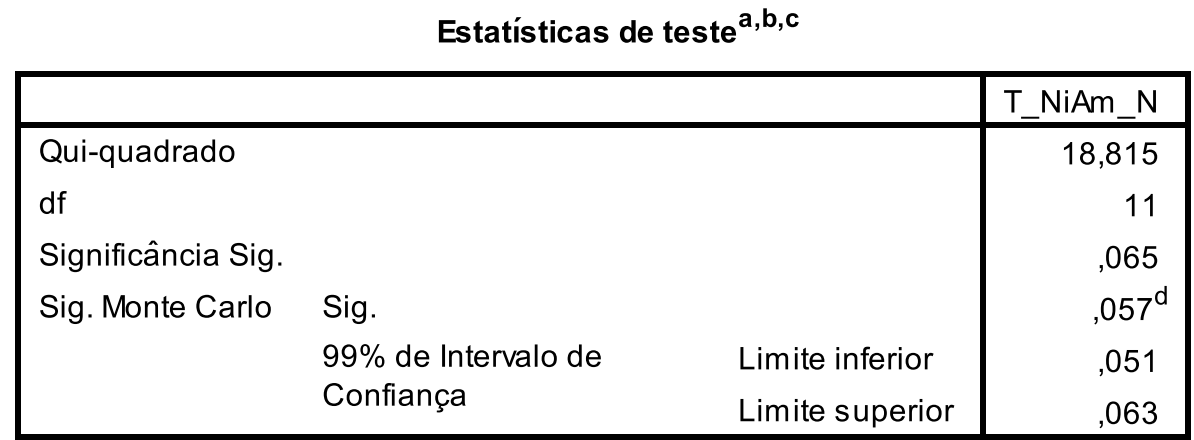
a. Tempo $=$ TO_T1
b. Teste Kruskal Wallis
c. Variável de Agrupamento: Lodo
d. Baseado em 10000 tabelas de amostra com o valor inicial 1502173562. 
Classificações ${ }^{a}$

\begin{tabular}{|rl|r|r|}
\hline & Lodo & $\mathrm{N}$ & $\begin{array}{c}\text { Postos de } \\
\text { média }\end{array}$ \\
\hline T_NiAm_N & ParA & 10 & 50,60 \\
& ParB & 10 & 55,40 \\
& AnF1A & 10 & 86,50 \\
& AnF1B & 10 & 47,70 \\
FaF1A & 10 & 42,15 \\
FaF1B & 10 & 69,90 \\
FaF2A & 10 & 41,40 \\
FaF2B & 10 & 69,15 \\
UaF2A & 10 & 44,20 \\
UaF2B & 10 & 61,00 \\
ChoA & 10 & 80,30 \\
ChoB & 10 & 77,70 \\
Total & 120 & \\
\hline
\end{tabular}

a. Tempo $=$ TO_T2

Estatísticas de teste ${ }^{a, b, c}$

\begin{tabular}{|c|c|c|c|}
\hline & & & T_NiAm_N \\
\hline \multirow{6}{*}{$\begin{array}{l}\text { Qui-quadrado } \\
\text { df } \\
\text { Significância Sig. } \\
\text { Sig. Monte Carlo }\end{array}$} & & & 22,995 \\
\hline & & & 11 \\
\hline & & & ,018 \\
\hline & Sig. & &, $013^{d}$ \\
\hline & $99 \%$ de Intervalo de & Limite inferior & 010 \\
\hline & Confiança & Limite superior &, 016 \\
\hline
\end{tabular}
a. Tempo $=$ T0_T2
b. Teste Kruskal Wallis
c. Variável de Agrupamento: Lodo
d. Baseado em 10000 tabelas de amostra com o valor inicial 1502173562. 
Classificações $^{a}$

\begin{tabular}{|rl|r|r|}
\hline & Lodo & N & \multicolumn{1}{c|}{$\begin{array}{c}\text { Postos de } \\
\text { média }\end{array}$} \\
\hline T_NiAm_N & ParA & 10 & 63,10 \\
& ParB & 10 & 74,80 \\
& AnF1A & 10 & 75,10 \\
& AnF1B & 10 & 61,90 \\
FaF1A & 10 & 37,30 \\
FaF1B & 10 & 64,70 \\
FaF2A & 10 & 55,00 \\
FaF2B & 10 & 70,30 \\
UaF2A & 10 & 36,30 \\
UaF2B & 10 & 54,00 \\
ChoA & 10 & 74,10 \\
ChoB & 10 & 59,40 \\
Total & 120 & \\
\hline
\end{tabular}

a. Tempo $=$ TO_T3

Estatísticas de teste $e^{a, b, c}$

\begin{tabular}{|lll|r|}
\hline & & & T_NiAm_N \\
\hline Qui-quadrado & & 15,889 \\
df & & 11 \\
Significância Sig. & &, 145 \\
Sig. Monte Carlo & Sig. & &, $139^{\mathrm{d}}$ \\
& $99 \%$ de Intervalo de &, 130 \\
& Confiança & Limite inferior &, 148 \\
\hline
\end{tabular}

a. Tempo = T0_T3

b. Teste Kruskal Wallis

c. Variável de Agrupamento: Lodo

d. Baseado em 10000 tabelas de amostra com o valor inicial 1502173562.

As análises post hoc para o teste de Kruskal-wallis, que busca quais os sistema que foram responsáveis pela diferença entre as relações nos tempos testados, não foram realizadas pois a opção seriam os testes de Mann-Witney que faz comparação em pares e com tal tratamento estatísticos, visto que são 12 sistemas a serem comparados em duplas, aumentaria a possibilidade de incorrer no erro tipo I (quando aceita um efeito que na verdade não existe). Para reduzir as chances de cometer o erro tipo I, deve-se aplicar a correção de Bonferroni que divide o valor crítico de significância de 0,05 pelo número de comparações a serem feitas. Na situação em estudo equivaleria a serem 
realizadas 132 comparações, que para serem significativamente diferentes teriam que apresentar $p<3,788 \times 10^{-4}$. Outra opção de teste post hoc tem semelhanças com o de Mann-Witney, por fazer comparações entre duplas da fator de grupo em estudo, no entanto envolve tomar a diferença entre as médias dos postos dos diferentes grupos comparadas com um valor $Z$ (corrigido pelo número de comparações sendo feitas) e uma constante baseada no tamanho amostral total e as dos tamanhos amostras dos dois grupos sendo comparados, dada pela equação:

$$
\left|\bar{R}_{u}-\bar{R}_{v}\right| \geq \sqrt[z_{\alpha} / k(k-1)]{\frac{N(N-1)}{12}}\left(\frac{1}{n_{u}}+\frac{1}{n_{v}}\right)
$$

Onde:

$\left|\bar{R}_{u}-\bar{R}_{v}\right|=$ diferença em módulos entre a média dos postos para os dois grupos comparados

$\mathrm{k}=$ número de grupos

$\mathrm{N}=$ tamanho total da amostra

$\mathrm{n}_{\mathrm{u}}=$ tamanho da amostra no grupo 1

$\mathrm{n}_{\mathrm{v}}=$ tamanho da amostra no grupo 2

$Z_{\alpha / k(k-1)}=$ valor da curva normal para o qual somente $\alpha / k(k-1)$, dos demais valores $Z$ são maiores. 
Dessa maneira tem-se como resultados se os lodos diferem ou não quanto a relação de T_Na_NiAm_N, para os intervalos de tempo do início de cada batelada (T0_T1; TO_T2; T0_T3).

Classificações $^{a}$

\begin{tabular}{|rl|r|r|}
\hline & Lodo & $\mathrm{N}$ & $\begin{array}{c}\text { Postos de } \\
\text { média }\end{array}$ \\
\hline T_Na_NiAm_N & ParA & 10 & 76,90 \\
& ParB & 10 & 75,55 \\
& AnF1A & 10 & 88,00 \\
& AnF1B & 10 & 48,50 \\
& FaF1A & 10 & 48,90 \\
FaF1B & 10 & 67,05 \\
FaF2A & 10 & 65,90 \\
FaF2B & 10 & 64,10 \\
UaF2A & 10 & 31,40 \\
UaF2B & 10 & 28,75 \\
ChoA & 10 & 60,00 \\
ChoB & 10 & 70,95 \\
Total & 120 & \\
\hline
\end{tabular}

a. Tempo $=$ T0_T1

Estatísticas de teste ${ }^{a, b, c}$

\begin{tabular}{|c|c|c|c|}
\hline & & & $\mathrm{T}_{-}{ }_{\mathrm{N}}^{\mathrm{Na} N i A m_{-}}$ \\
\hline \multirow{6}{*}{$\begin{array}{l}\text { Qui-quadrado } \\
\text { df } \\
\text { Significância Sig. } \\
\text { Sig. Monte Carlo }\end{array}$} & \multirow{4}{*}{\multicolumn{2}{|c|}{ Sig. }} & 29,586 \\
\hline & & & 11 \\
\hline & & & ,002 \\
\hline & & &, $001^{d}$ \\
\hline & \multirow{2}{*}{$\begin{array}{l}99 \% \text { de Intervalo de } \\
\text { Confiança }\end{array}$} & Limite inferior &, 000 \\
\hline & & Limite superior & ,001 \\
\hline
\end{tabular}
a. Tempo $=$ T0_T1
b. Teste Kruskal Wallis
c. Variável de Agrupamento: Lodo
d. Baseado em 10000 tabelas de amostra com o valor inicial 112562564 . 
Classificações $^{a}$

\begin{tabular}{|rl|r|r|}
\hline & Lodo & $\mathrm{N}$ & $\begin{array}{c}\text { Postos de } \\
\text { média }\end{array}$ \\
\hline T_Na_NiAm_N & ParA & 10 & 74,00 \\
& ParB & 10 & 78,00 \\
& AnF1A & 10 & 91,25 \\
& AnF1B & 10 & 49,85 \\
& FaF1A & 10 & 43,25 \\
FaF1B & 10 & 66,20 \\
FaF2A & 10 & 54,00 \\
FaF2B & 10 & 76,30 \\
UaF2A & 10 & 25,85 \\
UaF2B & 10 & 21,55 \\
ChoA & 10 & 72,10 \\
ChoB & 10 & 73,65 \\
Total & 120 & \\
\hline
\end{tabular}

a. Tempo $=$ T0_T2

Estatísticas de teste $e^{a, b, c}$

\begin{tabular}{|lll|r|}
\hline & & & $T_{-} \mathrm{Na}_{-} \mathrm{NiAm}$ \\
\hline Qui-quadrado & & & 42,933 \\
df & & & 11 \\
Significância Sig. & &, 000 \\
Sig. Monte Carlo & Sig. & &, $000^{\mathrm{d}}$ \\
& $99 \%$ de Intervalo de & Limite inferior &, 000 \\
& Confiança & Limite superior &, 000 \\
\hline
\end{tabular}
a. Tempo $=$ T0_T2
b. Teste Kruskal Wallis
c. Variável de Agrupamento: Lodo
d. Baseado em 10000 tabelas de amostra com o valor inicial 112562564. 


\begin{tabular}{|c|c|c|c|}
\hline \multicolumn{4}{|c|}{ Classificações $^{a}$} \\
\hline & Lodo & $\mathrm{N}$ & $\begin{array}{c}\text { Postos de } \\
\text { média }\end{array}$ \\
\hline \multirow[t]{13}{*}{ T_Na_NiAm_N } & ParA & 10 & 76,80 \\
\hline & ParB & 10 & 77,80 \\
\hline & AnF1A & 10 & 84,05 \\
\hline & AnF1B & 10 & 54,55 \\
\hline & FaF1A & 10 & 53,75 \\
\hline & FaF1B & 10 & 72,25 \\
\hline & FaF2A & 10 & 65,80 \\
\hline & FaF2B & 10 & 62,70 \\
\hline & UaF2A & 10 & 20,90 \\
\hline & UaF2B & 10 & 23,10 \\
\hline & ChoA & 10 & 69,25 \\
\hline & ChoB & 10 & 65,05 \\
\hline & Total & 120 & \\
\hline
\end{tabular}

a. Tempo $=$ T0_T3

\section{Estatísticas de teste $e^{a, b, c}$}

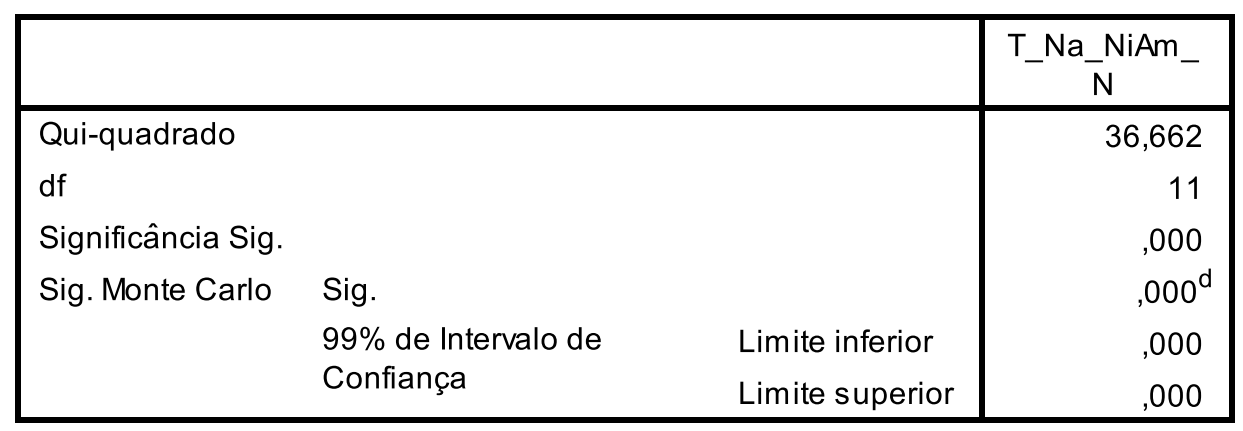
a. Tempo $=$ T0_T3
b. Teste Kruskal Wallis
c. Variável de Agrupamento: Lodo
d. Baseado em 10000 tabelas de amostra com o valor inicial 112562564 .

Exemplo de como relatar esses resultados:

A relação T_Na_NiAm_N foi significativamente afetada pelo tipo de inóculo nos sistemas testados comparando-se o início das bateladas até 72 horas (TO_T1) sendo $(H 11)=$ $36,662, p<0,001$.

Preciso relatar o tamanho do efeito, pois não fiz os testes pos hoc. 


\section{APENDICE VIII}

Análise de PCR e avaliação do sucesso de extração de DNA e das amplificações em eletroforeses em gel de agarose a $1 \%$ corado com brometo de etídeo $\left(1 \mu \mathrm{g} \cdot \mathrm{mL}^{-1}\right)$ para os sistemas biológicos após 120 de operação visando o enriquecimento dos micro-organismos anammox.

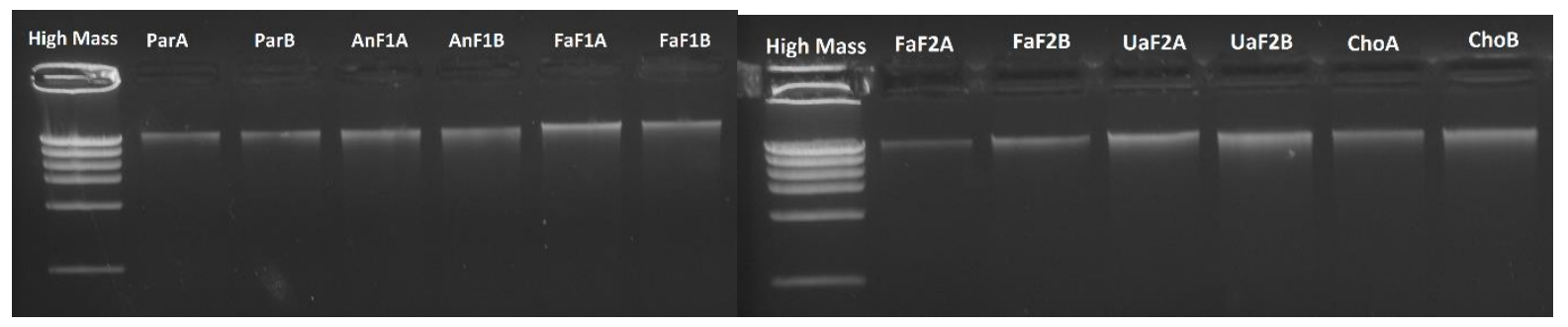

Figura VIII.1: Eletroforese em gel de agarose a $1 \%$ corado com brometo de etídeo $\left(1 \mu \mathrm{g} \cdot \mathrm{mL}^{-1}\right)$ para avaliação do DNA genômico extraído das biomassas nos sistemas biológicos após 180 dias para ocorrência de enriquecimento e atividade anammox em culturas bateladas. ParA e ParB: com inóculo proveniente do sedimento do lago Paranoá, Brasília/DF; AnF1A e AnF1B: com inóculo proveniente do

lodo de lagoa anaeróbia tratando efluente do Frigorífico 1, Araguari/MG; FaF1A e FaF1B: com inóculo proveniente do lodo de lagoa facultativa tratando efluente do Frigorífico 3, Araguari/MG; FaF2A e FaF2B: com inóculo proveniente do lagoa facultativa tratando efluente do Frigorífico 2, Uberlândia, MG ; UaF2A e UaF2B: com inóculo proveniente do lodo de reator UASB tratando efluente do Frigorífico 2, Uberlândia/MG; ChoA e ChoB: com inóculo proveniente do lagoa de acumulação de chorume do aterro controlado Jockey Clube de Brasília/DF.

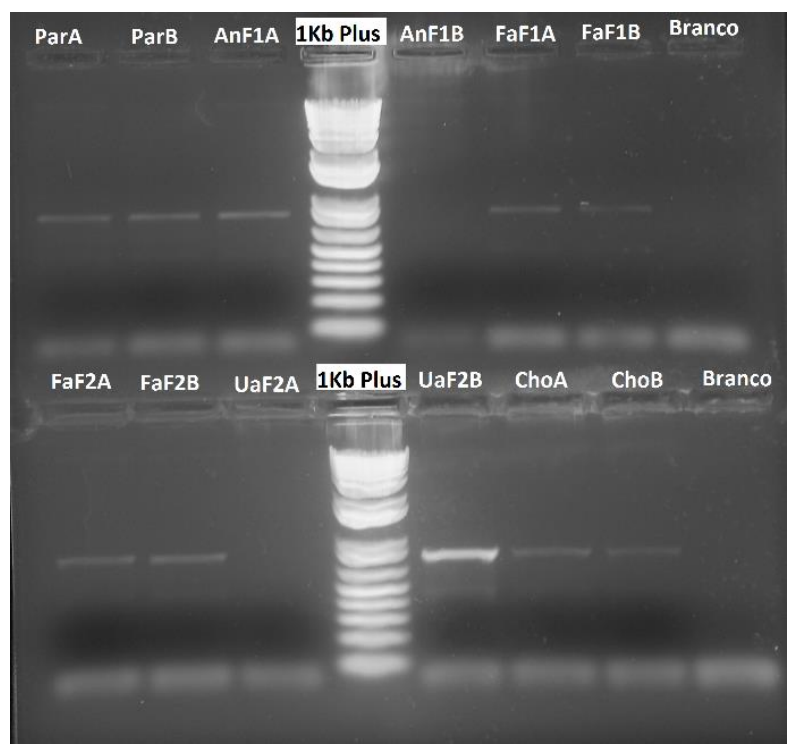

Figura VIII.2: Eletroforese em gel de agarose a $1 \%$ corado com brometo de etídeo $\left(1 \mu \mathrm{g} . \mathrm{mL}^{-1}\right)$ para avaliação dos fragmentos amplificados de $774 \mathrm{pb}$ a partir das biomassas dos sistemas biológicos após 180 dias para enriquecimento e atividade anammox em culturas bateladas com os pares de primers Pla 46F e Amx 820R. ParA e ParB: sedimento do lago Paranoá, Brasília/DF; AnF1A e AnF1B: lagoa anaeróbia tratando efluente do Frigorífico 1, Araguari/MG; FaF1A e FaF1B: lagoa facultativa tratando efluente do Frigorífico 1, Araguari/MG; FaF2A e FaF2B: lagoa facultativa tratando efluente do Frigorífico

2, Uberlândia, MG; UaF2A e UaF2B: lodo de reator UASB tratando efluente do Frigorífico 2, Uberlândia/MG;

ChoA e ChoB: lagoa de acumulação de chorume do aterro controlado Jockey Clube de Brasília/DF. 


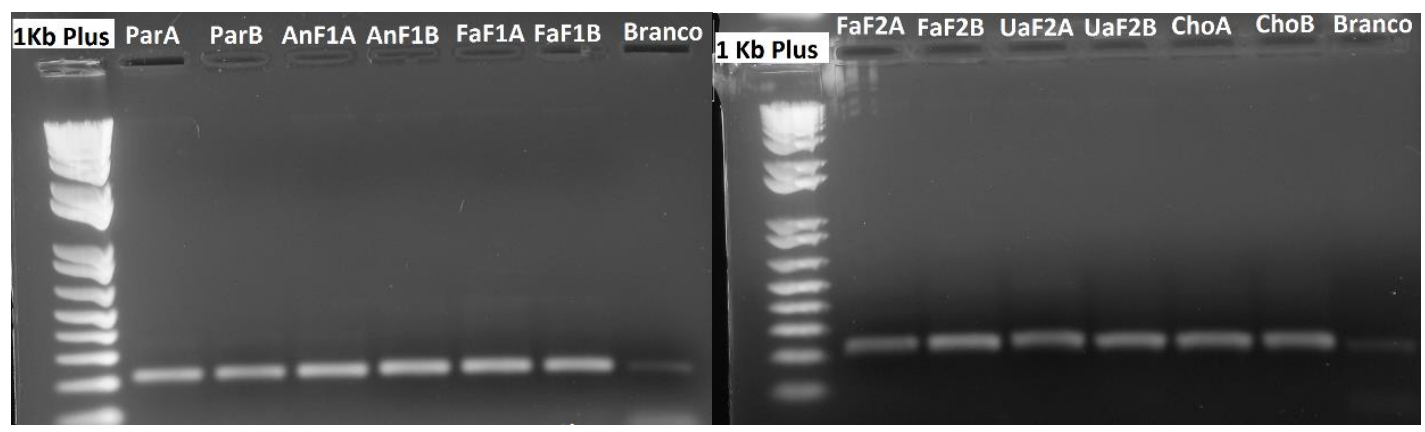

Figura VIII.3: Eletroforese em gel de agarose a $1 \%$ corado com brometo de etídeo $\left(1 \mu \mathrm{g} \cdot \mathrm{mL}^{-1}\right)$ para avaliação dos fragmentos amplificados de $225 \mathrm{pb}$, a partir dos inóculos testados nos experimentos em bateladas para atividade anammox após 180 dias, com os pares de primers Nitro 1198Fe Nitro 1423R para micro-organismos como Nitrobacter. Legenda: ParA e ParB: sedimento do lago Paranoá, Brasília/DF; AnF1A e AnF1B: lodo da lagoa anaeróbia tratando efluente do Frigorífico 1, Araguari/MG; FaF1A e FaF2B: lodo da lagoa facultativa tratando efluente do Frigorífico 1, Araguari/MG; FaF2A e FaF2B: lodo de lagoa facultativa tratando efluente do Frigorífico 2, Uberlândia, MG; UaF2A e UaF2B: lodo de reator UASB tratando efluente do Frigorífico 2, Uberlândia/MG; ChoA e ChoB: sedimento da lagoa de acumulação de chorume do aterro controlado Jockey Clube, Brasília, DF. 